\title{
MUSEU PAULISTA: UM EDIFÍCIO DE TÉCNICA TRADICIONAL DE CONSTRUÇÃO DE ALVENARIAS
}

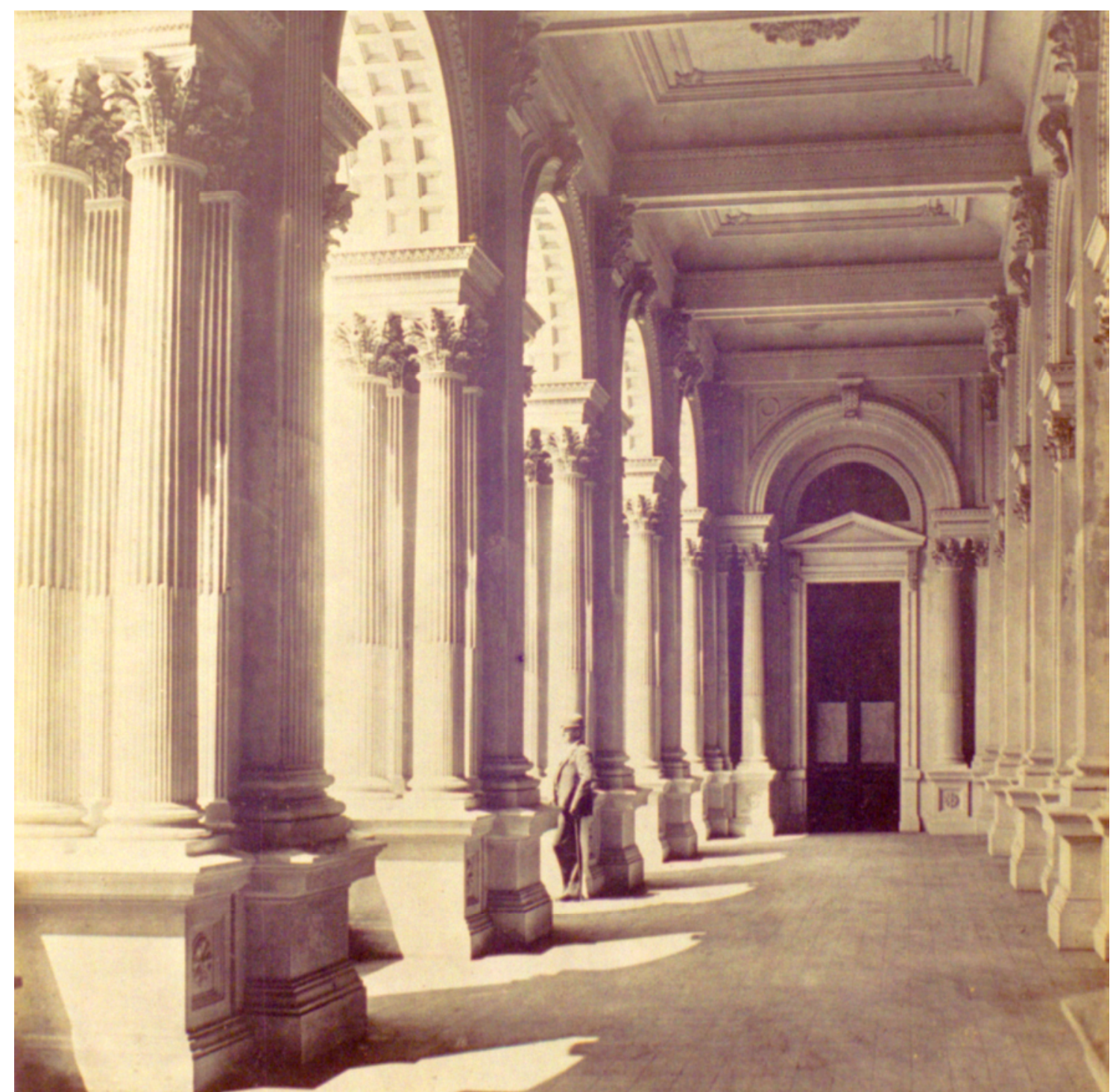

IC 13295 - Fundo Bezzi - Acervo Museu Paulista - ("Monumento D'lpiranga Commemorativo dell'Independenza del Brasile (ancora incompleto) Architeto I'Ingegnere", Tommaso Gaudenzio Bezzi)

YARA LÍGIA MELLO MOREIRA PETRELLA

ORIENTADORA: PROFA. DRA. MARIA LUCIA BRESSAN PINHEIRO

PROGRAMA DE PÓS-GRADUAÇÃO: DOUTORADO

ÁREA DE CONCENTRAÇÃO: HISTÓRIA E FUNDAMENTOS DA ARQUITETURA E URBANISMO LINHA DE PESQUISA: HISTÓRIA E PRESERVAÇÃO DA ARQUITETURA NO BRASIL

FACULDADE DE ARQUITETURA E URBANISMO DA UNIVERSIDADE DE SÃO PAULO FEVEREIRO 2008 


\section{AGRADECIMENTOS}

Desejo agradecer

A minha orientadora - Profa. Dra. Maria Lucia Bressan Pinheiro

A Profa. Dra. Beatriz Mugayar Kuhl - FAU / USP

A participação e apoio voluntário nos ensaios exploratórios de:

- Profa. Dra. Maria Alba Cincotto, que efetuou toda a coordenação - POLI

- Daniel Martins Aleixo, Fabiano Ferreira Chotoli, Eduardo Brandau Quitete, Mirian Cruxem Barros de Oliveira, Valdecir Ângelo Quarcioni - IPT

- Márcia Shirakawa - Laboratório de Microbiologia / POLI

- Profa. Dra. Dalva Lucia de Faria - Instituto de Química / USP

- Profa. Dra. Eliane Del Lama - Instituto de Geociências / USP

- Liz Zanchetta D’Agostino e Rui Barbosa de Souza - LCT- Laboratório de Caracterização Tecnológica / POLI

A especial participação de:

- Flavia Paes Lourenção,

- Eder Marques Loiola (COSEAS)

- Beatriz Ricardo

- Fotógrafo - Clemente Gauer (fotos Coliseu)

- José Rodrigues Paiva Neto

- Profa. Dra. Miyoko Makino, Shirley Ribeiro, Profa. Dra. Heloísa Barbuy

- Aos fotógrafos com os devidos créditos José Rosael, Hélio Nobre Museu Paulista / USP

DEDICO

A DEUS em primeiro lugar

Ao meu marido - Eros Rafael, pelo seu apoio

Ao meu pai Astério

Em memória de minha mãe, Alice 


\section{SUMÁRIO}

INTRODUÇÃO

\section{CARACTERIZAÇÃO FORMAL}

A inserção do edifício na cidade de São Paulo em meados do século XIX $\quad 07$

A estrutura geral do edifício e a articulação volumétrica dos três corpos 19

O emprego das Ordens Arquitetônicas 43

TÉCNICA TRADICIONAL DE CONSTRUÇ̃̃O DE ALVENARIAS

CÉCNICA TRADICIONAL DE CONSTRUÇÃO DE ALVENARIAS

CARACTERÍSTICAS ESTRUTURAIS

$\begin{array}{ll}\text { Paredes e Pés-direitos } & 57\end{array}$

Arcos e Abóbadas $\quad 76$

Pisos $\quad 117$

$\begin{array}{lr}\text { Colunas e Pilastras } & 128\end{array}$

$\begin{array}{lr}\text { Fundação } & 142\end{array}$

$\begin{array}{ll}\text { Estrutura Metálica } & 147\end{array}$

\section{ANÁLISE DO ESTADO DE CONSERVAÇÃO}

HISTÓRICO DA CONSTRUÇÃO E DAS INTERVENÇÕES POSTERIORES:

1823-1881 - Antecedentes históricos 166

1882-1893 - Período da atuação de Bezzi 168

1894-1924 - Inauguração do Museu Paulista e os primeiros Diretores 188

1931-1972 - Intervenções realizadas pela CPOS 192

1988-1993 - Arquivo Intermediário 206

1995-1997 - Diversas intervenções (livro) 213

$2002-$ Intervenções no Mirante (relatório) 221

TÉCNICA TRADICIONAL DE CONSTRUÇÃO DE ALVENARIAS

CARACTERÍSTICAS DOS MATERIAIS

Edifício Histórico - Umidade, Salinidade, Porosidade e Pintura 227

Patologia da Argamassa de Revestimento 236

Tintas para edifícios históricos $\quad 245$

ANÁLISE VISUAL - COLETA DE AMOSTRAS 248

$\begin{array}{ll}\text { Argamassas } & 251\end{array}$

Tijolos 259

Eflorescência 261

Camada de Tinta

Microrganismos

ENSAIOS EXPLORATÓRIOS

Análise Química e Reconstituição de Traço 262

$\begin{array}{ll}\text { DRX } & 275\end{array}$

EDS 282

MEV 283

Espectroscopia Raman 285

MEV $\quad 291$

Análise Microbiológica 296

CONCLUSÕES 313

BIBLIOGRAFIA 322 
RESUMO: Museu Paulista um edifício de técnica tradicional de construção de alvenarias

Esta tese se refere ao estudo do edifício do Museu Paulista, identificando as características da técnica construtiva tradicional de alvenarias, quanto ao sistema estrutural e os materiais empregados. Descreve as circunstâncias históricas, a evolução do emprego da taipa para o emprego do tijolo, e a inserção do edifício do Museu Paulista na cidade de São Paulo em meados do século XIX.

Analisa as características que diferenciam um edifício histórico de um edifício moderno relativo às soluções estruturais e a natureza dos materiais. O sistema estrutural tem como elementos principais paredes e pés-direitos, arcos e abóbadas, colunas e pilastras, pisos de assoalho e abobadilha, e fundações. Os materiais são analisados quanto à presença de umidade constante, devido à inexistência de impermeabilização das fundações, a presença de sais solúveis, a porosidade dos materiais, a presença de microrganismos, e a relação com o tipo de tinta utilizada na pintura.

Através do levantamento do histórico das intervenções, verifica-se que entre elas há aquelas que causaram danos ao edifício, pelo fato de não considerar as características específicas que o definem.

Através de ensaios exploratórios, se reconstitui os traços das argamassas e identificam processos de danos

\section{Abstract}

This thesis refers to the study of the building of Museu Paulista and identifies the characteristics of the traditional masonries constructions techniques that involves the structural systems and the materials used.

It describes the historical circumstances and of the evolution of taipa to brick and the inclusion of the building of Museu Paulista in the city of São Paulo in the middle of XIX ${ }^{\text {th }}$

Century. It also analyses the characteristics that differs one history and modern build structural solutions and the nature of materials.

The main structural systems are constituted by walls, right feet, arch and vault, pilaster and colums, wooden floor, abobadilha, and foundation. The materials are analysed in the several aspects such as the presence of constant humidity, that occurs when there isn't the impermeabilization of the foundations; presence of solubles salts; the porosity of materials; the presence of microorganism and the type of paint used in the painting.

Through the history intervations it is verified that amount them there are some generated caused damage to the building due the fact that the specified characteristics were not taken account of.

Through the exploratories essays it is reconstructed the composition of the mortars and the identification of the damages process. 


\section{INTRODUÇÃO}

A escolha deste tema de pesquisa surgiu em função da convivência diária com o edifício, que permitiu a observação de danos que se tornaram evidentes, e se manifestaram de diferentes formas.

Nos últimos 16 anos, as intervenções realizadas apresentaram conseqüências que foram positivas ou negativas. Em alguns casos, estas conseqüências eram de danos consumados, e, em outros, foi possível acompanhar o seu desenvolvimento que se agravaram no decorrer do tempo.

Assim, despertou-se o interesse em compreender as causas e os mecanismos pelos quais alguns danos ocorreram, e o que estes representam hoje para a preservação do edifício; buscar compreender como foram planejadas e executadas as intervenções.

Inicialmente, constatou-se que, entre os momentos de intervenções significativas, houve intervalos de alguns anos sem qualquer planejamento de atividades, bem como, de esforços de conservação preventiva que pudessem manter em bom estado, as realizadas ou, se fosse preciso, investir em pequenas correções.

Ainda observou-se que as intervenções realizadas, tiveram objetivos pontuais ou setoriais, resolvendo os problemas que se apresentavam e certamente introduziram alterações, que vieram a beneficiar o edifício de alguma forma. Entretanto, tais ações não demonstraram a adoção de critérios levando-se em conta o edifício como um todo, ou que se relacionavam uma à outra, como parte de um programa de intervenção coerente, composto por medidas complementares e baseadas em princípios comuns. Como resultado, muitas das intervenções promovidas no edifício do Museu Paulista, para resolverem problemas imediatos, adotaram procedimentos fragmentários e pragmáticos que trouxeram conseqüências prejudiciais para a sua conservação, contrariando seus objetivos primordiais.

Um programa comum e sistemático de conservação, sem dúvida garantiria que uma intervenção, que eventualmente obtivesse resultados satisfatórios no momento de sua realização, não viesse a se constituir numa causa de danos num futuro próximo ou distante. Na realidade, o ideal seria que as ações de conservação e restauração no geral, fossem embasadas numa Política de Conservação ampla, que estabelecesse parâmetros técnicos consensuais, quanto a natureza química e física dos materiais, do comportamento estrutural, e aos valores estéticos e históricos, de modo a adequar as intervenções às características do edifício a favor de sua durabilidade. Sabe-se que uma Política de Conservação envolve diferentes especialidades, e que se constitui numa área de conhecimento interdisciplinar e complexa. No entanto, pode ser implantada satisfatoriamente, desde que se estabeleçam de forma objetiva as metas a serem alcançadas. 
Assim, esta pesquisa estabeleceu como hipóteses:

- Que as diversas intervenções havidas no edifício do Museu Paulista, com raras exceções, não foram projetadas e executadas considerando-se as características específicas da técnica construtiva tradicional de alvenarias, a qual se diferencia substancialmente da dos edifícios modernos.

- Que as intervenções nem sempre foram antecedidas por uma ampla investigação da natureza física e química dos materiais, e das características estruturais,. para que pudesse embasar um projeto de conservação e restauração.

- Que os danos que se apresentam são conseqüências de intervenções inadequadas, introduzindo materiais incompatíveis que alteraram o comportamento dos materiais originais e das suas funções na estrutura do edifício.

A técnica tradicional com que se construiu o edifício do Museu Paulista foi empregada em São Paulo até aproximadamente a passagem do século XIX para o XX. Depois desse período foi substituída pela tecnologia do concreto, que possibilitou a criação e o desenvolvimento da linguagem da arquitetura moderna.

Desde então, a técnica construtiva tradicional passou a ser considerada obsoleta e ultrapassada, sendo este fato ainda mais acentuado pelo desenvolvimento fecundo que a arquitetura moderna brasileira experimentava, com projetos expressivos inseridos num contexto cultural mais amplo, e reconhecidos internacionalmente.

A técnica tradicional, assim, foi progressivamente colocada em desuso, e seu conhecimento deixou de ser transmitido às novas gerações, sendo retirado progressivamente do currículo das escolas de arquitetura e engenharia.

Além disso, foi desaparecendo do mercado da construção a oferta de mão-de-obra dos antigos artesãos, que eram indispensáveis na execução dessas construções tradicionais.

Considera-se neste trabalho que nas intervenções realizadas no Museu Paulista, anos atrás, foram utilizados materiais contemporâneos que, embora apresentavam maior qualidades em si próprio, eram incompatíveis com as características do edifício e assim causaram extensos danos. É muito provável que o conceito de edifício antigo e de "estilo", presentes nos diagnósticos que fundamentaram as intervenções, eram interpretados mais no âmbito da ornamentação desvinculada da técnica. Deste modo, o edifício foi tratado de forma semelhante aos edifícios contemporâneos, por falta mesmo de conhecimento desta técnica construtiva considerada obsoleta.

Em conseqüência, nas intervenções ocorridas no Museu Paulista, os efeitos deste desconhecimento da técnica construtiva tradicional, tornaram-se evidentes.

Tendo em vista os problemas decorrentes do emprego de procedimentos, e materiais agressivos à natureza peculiar do edifício do Museu Paulista, este estudo se propôs a focalizar as características que diferenciam os edifícios históricos, dos edifícios modernos, contribuindo assim com reflexões para futuras restaurações.

Tem-se a pretensão de promover a conscientização de que o conhecimento sobre esta técnica construtiva deve ser retomado de forma absolutamente indispensável para embasar toda e qualquer intervenção de conservação e restauração, para efetivamente promover a sua preservação.

A pesquisa foi organizada segundo a escolha de alguns princípios que levaram a compor uma metodologia de trabalho que, embora baseada num estudo de caso, pudesse estabelecer generalizações sobre a técnica construtiva tradicional. 
Assim, baseou-se a pesquisa em alguns tópicos, que foram inclusive tema dos Trabalhos Programados::

- Levantamento dos antecedentes históricos que influenciaram a escolha do projeto ou de suas alterações

- Pesquisa do Fundo Bezzi que reúne documentos arquivísticos e iconográficos, do próprio Bezzi, do empreiteiro Pucci e do presidente da Comissão da Construção do Monumento do Ipiranga, Barão de Ramalho, a respeito da construção do edifício, referindo-se aos materiais, alguns detalhes técnicos, cálculos de determinadas estruturas, orçamentos e especificações de materiais.

- As informações técnicas contidas no Fundo Bezzi, foram complementadas pelos textos e manuais técnicos sobre as construções deste período

- Levantamento documental da história das intervenções, logo após ter sido considerada terminada a construção, e as realizadas posteriormente, para a devida conservação ou execução de alterações.

- Análise detalhada do edifício identificando-se os principais elementos estruturais, e a sua relação com o repertório ornamental que caracterizam a técnica construtiva, embasada também nos textos e manuais técnicos.

- Levantamento bibliográfico quanto às características dos materiais dos edifícios históricos, em sua natureza física e química, e as patologias que apresentam, estabelecendo os conceitos e a linguagem técnica adotada.

O texto da pesquisa foi então estruturado em duas partes, que conduzem o tempo todo à investigação:

- A primeira parte tem como fim conhecer as características estruturais, através dos principais elementos, e como estes se articulam com o repertório ornamental. Intitula-se Caracterização Formal

- A segunda parte, a Análise do Estado de Conservação, identifica danos, seus mecanismos e suas possíveis causas, segundo a natureza física e química dos materiais empregados.

\section{CARACTERIZAÇÃO FORMAL}

O edifício do Museu Paulista se insere na cidade num momento histórico do final do século XIX, de profundas transformações sociais, econômicas, políticas e culturais, responsáveis pela valorização de nova linguagem arquitetônica, como símbolo de progresso e civilização, e concretizada através de uma técnica construtiva. Esta técnica, por sua vez, se tornou disponível devido à existência de profissionais formados em ensino superior, da oferta de mão-de-obra especializada e à melhor qualidade dos materiais.

Neste período, a cidade de São Paulo, conhecida durante os três primeiros séculos como a cidade de taipa, rompeu o isolamento cultural em que se encontrava, em função das novas perspectivas de intercâmbio com a Europa, geradas pela riqueza do café e a sua exportação para novos mercados.

O emprego do tijolo passa a se constituir num importante elemento construtivo, que na segunda metade do século XIX vem participar da reconstrução da fisionomia da cidade. Neste trabalho, as técnicas da taipa como da alvenaria de tijolos são consideradas no que se refere ao tipo de materiais empregados, à mão-de-obra e ao modo como o conhecimento foi transmitido. 
São importantes todas as observações a respeito da qualidade, dos vícios da fabricação, bem como da origem dos materiais, como a presença de sais e a conseqüente umidade. A linguagem arquitetônica expressada através do que foi convencionado como Neoclassicismo e Ecletismo neste período, é considerada aqui como estilo, enquanto uma técnica construtiva, ou seja, em referência aos recursos técnicos pelos quais se expressa. Não são neste estudo, portanto, discutidas as questões teóricas estilísticas e históricas, contidas naturalmente neste tema abrangente.

\section{ANÁLISE DO ESTADO DE CONSERVAÇÃO}

O Histórico da Construção, e das Intervenções Posteriores, foi elaborado a partir da pesquisa histórica, arquivística e iconográfica, em que foram levantadas as informações sobre fatos e circunstâncias, que vieram de alguma maneira a influenciar ou determinar a forma que o edifício tem hoje. De outro lado, a reconstituição da história das intervenções posteriores ao período de construção, tem uma grande importância nesta pesquisa, pois revela a origem de algumas causas de danos que ainda hoje interferem no estado de conservação do edifício.

Neste histórico, são elencadas diversas intervenções que foram documentadas. Em tal levantamento, contudo, não estão incluídas as não inventariadas, como as realizadas pelos próprios funcionários do museu, consideradas como rotina diária de trabalho e, por essa razão, não registradas sistematicamente.

Deve-se observar que as informações encontradas nos arquivos existentes no Museu não são propriamente projetos ou detalhes técnicos, mas geralmente registros destinados a calcular quantidades de material e orçamentos respectivos, e, mesmo assim, são devidamente valorizadas.

Neste item são abordadas as características do edifício histórico, como resultado de sua técnica construtiva, quanto ao estado de conservação do materiais, da natureza física e química, e suas reações às diversas intervenções realizadas, e às agressões do meio ambiente.

Levando em conta que nas intervenções realizadas, na sua maioria, não foram consideradas as características da estrutura e dos materiais, alterando o comportamento físico e químico dos mesmos, tal como foram concebidos e que deveriam permanecer ao longo dos anos. Como resultado, as patologias foram criadas devido às intervenções inadequadas e à incompatibilidade de materiais contemporâneos que foram introduzidos.

Pretende-se então que esta pesquisa seja uma contribuição, na medida em que se demonstra a importância da investigação, que deve necessariamente anteceder todo tipo de ação conservativa ou de restauração, apresentando uma parcela significativa dos conhecimentos, relativos à grande complexidade própria de um edifício desse porte.

Para tanto, foram planejados ensaios exploratórios para a caracterização dos materiais, e a investigação de possíveis causas dos danos, com a importante e indispensável contribuição de uma equipe de pesquisadores de caráter interdisciplinar. 


\section{CARACTERIZAÇÃO FORMAL DO EDIFÍCIO}

\section{A INSERÇÃO DO EDIFÍCIO DO MUSEU PAULISTA NA CIDADE DE SÃO PAULO EM MEADOS DO SÉCULO XIX}

Este estudo focaliza alguns fatos históricos que de alguma forma influenciaram a história do urbanismo e da arquitetura, configurando fases de ruptura ou de continuidade. Pretende-se assim fazer reflexões sobre a cidade de São Paulo, à época da construção do edifício do Museu Paulista, em relação à evolução da arquitetura, quanto às técnicas construtivas, aos materiais empregados, à mão-de-obra, e a transmissão do conhecimento.

Convencionou-se o dia 25 de janeiro de 1554, consagrado à conversão de São Paulo, como a data do início da história de São Paulo, erguendo-se uma simples casinha de paua-pique barreado para sediar o Colégio dos Jesuítas, com a finalidade de se constituir um núcleo de catequese voltado à conversão e educação do gentio. O local escolhido para a fundação de São Paulo foi o topo mais ou menos plano de uma colina, uma das mais estreitas e escarpadas elevações, por volta de $30 \mathrm{~m}$ acima da planície fluvial. Desta colina podia-se avistar um amplo horizonte, a várzea do Tamanduateí, onde o ribeiro dava sete voltas; alcançava a calha do Tietê e a colina onde se encontra a Penha; do lado oposto um declive mais abrupto e o vale do Anhangabaú. Consideravam os jesuítas que estas condições tornava mais segura a defesa de possíveis ataques indígenas.

Esse núcleo inicial era "um simples aglomerado de modestíssimas habitações de taipa, cobertas de sapé, cujo centro de vida social era o Colégio dos Jesuítas" (TAUNAY, in SILVA, 1955 p.66). A vila era toda coberta de sapé, a igreja, a cadeia, a casa do Conselho, sendo que esta caiu em 1580 passando a Câmara se reunir na casa de um vereador (MOTA, 1941, pp.9,8,11). Não havia telha a princípio, e muito menos tijolo. Nos sete primeiros volumes das Atas da Câmara I de São Paulo, por exemplo, em nenhuma só vez aparece a palavra "tijolo" (ATA DA CÂMARA I, p.67).

O casario coberto de sapé predominou até 1575 , quando teria aparecido na vila um fabricante de telhas, e foi então este material introduzido nas construções por ser mais seguro e duradouro: no dia 6 de março de 1575, então apareceu na vila e se apresentou Cristóvão Gonçalves, oferecendo seu trabalho "por razão desta vila estar coberta de palha e correr risco de fogo, queria fazer telhas para se cobrirem as moradas por necessidade e enobrecimento" (MOTA, 1941, p.9,8,11).

Desse modo, nos três primeiros séculos perdurou o emprego da taipa de mão e de pilão nas construções paulistanas e, com o emprego das telhas côncavas, surgiram os grandes beirais utilizados para afastar a água de chuva das paredes. O emprego destes beirais tornou-se uma característica das construções paulistanas.

A taipa de pilão se originou no Velho Mundo e foi trazida pelos colonizadores portugueses desde os primeiros tempos da colonização. Considera-se ter sido empregada pela primeira vez no Rio de Janeiro, quando a frota de Martim de Afonso, em abril de 1551, procurava um ponto na costa para estabelecer um núcleo colonizador. Construiu-se uma casa-forte em três meses, e neste tempo, não daria para construir senão com a taipa e cobrir com pindobas à moda do silvícola. Não era possível construir uma olaria para 
fabricar telhas ou empregar a alvenaria de pedra. (MARIANO FILHO in: SCHMIDT, 1949, p.9).

Em 1549, o padre Manoel da Nóbrega, de São Vicente, solicitou à metrópole que Ihe enviasse oficiais e carpinteiros, provavelmente para a execução da técnica do barro comprimido entre os taipais. Anos mais tarde, José de Anchieta construiu o Colégio da Companhia de Jesus, em Piratininga. (SCHMIDT,1949, p.9)

A taipa de pilão, se adaptou a esses núcleos coloniais, por ser uma técnica menos trabalhosa do que a alvenaria de pedra, tendo também se acomodado aos locais onde não havia pedra ou em que sua extração não fosse possível. Essa técnica levantava edifícios duráveis e ainda com bom isolamento térmico e incombustibilidade. Era executada com baixos custos, extraindo do seu entorno os materiais de que necessitava.

Os materiais empregados na construção de taipa eram ainda os disponíveis ao redor da vila, como a terra, o saibro, a tabatinga, a madeira, o barro, a areia. O saibro era uma areia grossa amarela pedregulhenta, usado na composição da taipa. A tabatinga consistia num barro branco usado na pintura das paredes. Ambos eram retirados do morro da Tabatinguera. Quanto à areia, há documentos municipais que apontam a sua extração num ponto entre a Glória e o Lavapés. Trata-se de areia de mina. (ou de cava). (CAMPOS,1997, p.369)

$\mathrm{Na}$ vila paulistana, a taipa foi amplamente utilizada, vindo a caracterizar a fisionomia da cidade. Ela chamava a atenção dos viajantes sobretudo por sua durabilidade. John Mawe, um dos viajantes estrangeiros que visitou a Província de São Paulo, afirmou que a taipa "é uma estrutura durável; vi casas assim construídas que resistiram duzentos anos e a maioria tem várias histórias. $\mathrm{Na}$ verdade a taipa é durável, eterna quase, se convenientemente protegida contra a intempérie, pelo reboco das paredes e pela cobertura sempre bem conservada". (MAWE in SCHMIDT, 1949, p.131)

SEGURADO (s/ data p. 100-101), indica os cuidados necessários a serem observados em relação à duração dos alicerces e paredes de taipa e à presença de umidade:

[A taipa é] "um sistema de construção muito antigo e ainda em uso em edificações rurais. Ela é constituída de terra úmida comprimida entre os taipais móveis de madeira e após a retirada destes, aparecem paredes monolíticas e homogêneas.[...]. A taipa não pode assentar diretamente no solo, porque a água facilmente a desagregaria; faz-se sempre um pequeno alicerce ou sapata de alvenaria ordinária de pedra ou de tijolo, erguendo-se do solo de 0,25 a $0,60 \mathrm{~cm}$. As paredes da taipa são quase sempre rebocadas com argamassa de cal e areia, para terem duração que pode atingir séculos. Dois operários em 12 horas podem construir 8 metros cúbicos de taipa se a terra ficar junto ao local da construção [...] A taipa é muito aplicada em construções rurais, por ser incombustível, má condutora de calor e econômica; é atacada por roedores e não pode ser empregada em grandes edifícios. A taipa é bastante empregada na nossa província de Algarve.”

Já no fim do período colonial, o poder municipal tentou melhorar a qualidade das construções de taipa paulistanas. Uma Postura de 1820, por exemplo, exigia que as paredes fossem executadas sobre fundação de pedra ou tijolo, mas não deve ter sido cumprida. Em 1830, foram elaboradas as primeiras Posturas em termos de lei, e este preceito foi abandonado. Mesmo assim, a partir de 1820, tem-se notícia até de muros divisórios de pilão, erguidos sobre baldrames de pedra. No casario paulista colonial, 
contudo, manteve-se o antigo costume de construir sobre rasa fundação de terra socada. Assim, como conseqüência da enchente de 1850, mais de oitenta prédios desabaram, e este acontecimento provocou a renovação da arquitetura da cidade, devido às reconstruções dessas casas. Outra tentativa bem menos ambiciosa do poder municipal se deu em 1852, ao tornar obrigatória a construção de alicerces de alvenaria, na parede frontal dos sobrados erguidos em ladeiras, pois eram os que mais se ressentiam das enxurradas. (CAMPOS, 1997, p.303-304)

A taipa utilizava a mão-de-obra escrava indígena, "pouco numerosa, precisando de um amassador, um carregador e dois apiloadores, e já existia desde os primórdios do povoamento em São Vicente.[...]" (PRADO in SILVA, 1955, p.70).

Esta mão-de-obra utilizada nas construções subsistiu na primeira metade do século XIX , sendo que a partir de 1840 igualmente os imigrantes italianos e alemães, começam a concorrer como força de trabalho livre. Por outro lado, começa a avolumar-se a introdução de escravos negros, incrementada desde os fins do século XVII, em conseqüência da exploração das minas (TAUNAY in SILVA,1955, p.77).

Os negros eram vendidos a preços mais altos, pois eram trabalhadores mais aptos do que o índio, razão pela qual em reduzida porcentagem se fixaram em São Paulo. (PRADO, BRUNO in SILVA, 1955, p.77)

Um fato dominante durante o século XVII foi a expansão das Bandeiras. Nesse período, o pequeno núcleo paulistano se torna o centro irradiador, das famosas partidas dos sertanistas, que foram marcantes para a formação territorial e política do Brasil. Mas este fato não influenciou o desenvolvimento urbano, demográfico e econômico desse núcleo. Já do ponto de vista político e administrativo, a vila tornou-se, em 1681, sede da Capitania de São Vicente e em 1711 foi elevada à categoria de cidade. Em 1748, no entanto, a Coroa extinguiu a Capitania de São Paulo, submetendo-a novamente ao governo do Rio de Janeiro. Em 1765, enfim, a Capitania foi restaurada e entrou na fase do governo dos capitães-generais, cuja administração era dirigida pelos interesses da Metrópole. (SILVA, 1955, p. 69-75)

Desde o final do século XVIII, a cidade conhece uma relativa prosperidade, embora permaneça como uma cidade provinciana e isolada culturalmente. $O$ crescimento urbano dá seus primeiros passos, graças ao comércio de animais provindos do sul, e à recente perspectiva econômica aberta pela lavoura canavieira. Muitas obras públicas são construídas no período pela atuação profissional dos engenheiros militares portugueses, que acompanharam a vinda dos capitães-generais. Mesmo apresentando insuficiências técnicas e aparência grosseira, essas obras permaneceram úteis até a segunda metade do século XIX. Obras como a Casa de Câmara, Cadeia e Quartel dos Voluntários Real, o Hospital Militar, pontes de pedra, do Lorena, do Marechal ou do Acu, a Pirâmide dos Piques, todas se tornaram símbolos da administração colonial. (CAMPOS, 2004, p.188)

A partir dos últimos do século XVIII, os edifícios públicos incorporam, nas características tradicionais da arquitetura, princípios estéticos e elementos compositivos próprios da arquitetura erudita, mesmo que timidamente: a simetria axial com a porta de entrada no centro; regularidade no ritmo dos vãos, com uma seqüência eqüidistante de portas e janelas, alinhadas uma sobre as outras, fachadas contidas num mesmo plano. (CAMPOS, 2004, p. 193) 
As ruas, por essa época, tinham um traçado irregular, pois se adaptavam às dificuldades da topografia, formando um conjunto desordenado de vias tortuosas e estreitas. A maior parte do casario era térreo, distribuído entre a vegetação dos quintais. Sobressaíam as torres das igrejas do Colégio, do Carmo, de São Francisco e de São Bento.

São Paulo ainda não havia ocupado inteiramente sua colina fundadora até no início do Império, em função de anos de estagnação econômica. Era constituída por três freguesias: Sé, Santa Ifigênia e Brás. Tinha como limite urbano, pontes sobre o Anhangabaú e Tamanduateí, grandes glebas dos conventos, Mosteiro de São Bento, Carmo e São Francisco, e ainda algumas chácaras dentro deste limite. Era difícil identificar o que era urbano ou rural. Entretanto, como São Paulo foi fundada num ponto elevado, cercada de vales de rios, surgiu a necessidade, no início do século XIX, de se construir viadutos para se expandir além do "triângulo" inicial, da Cidade Histórica para a chamada Cidade Nova. (MAWE, SAINT-HILAIRE in SILVA, 1955, p.81)

$\mathrm{Na}$ verdade, a preocupação com a expansão da cidade já era verificada desde fins do século XVIII. Por essa época, o governador Bernardo José de Lorena (1782-1797) propôs à Câmara Municipal o arruamento da margem esquerda do Anhangabaú, um "terreno montuoso e desigual" para criar um novo assentamento. Entre 1807 e 1808 o Marechal Arouche Toledo Rendon fez o arruamento e a Câmara se incumbiu de administrar os terrenos integrantes do patrimônio municipal, distribuindo datas e reservando áreas para logradouros públicos. Essa região era de difícil acesso, separada do núcleo pelo profundo Vale do Anhangabaú. Apesar das iniciativas, a Cidade Nova ainda ficaria desocupada por um longo tempo. (CAMPOS, 2004, p.188-189 e 193)

O ciclo agrícola e a atividade comercial iniciada desde as últimas décadas do século XVIII, em decorrência do desenvolvimento das plantações da cana e produção do açúcar, foram paulatinamente se ampliando até se constituírem no fator principal, da reabilitação econômica da região, que se manifestou nas primeiras décadas do século XIX. Assim, foram sendo criadas as condições mais favoráveis ao surpreendente desenvolvimento da cidade de São Paulo, com a produção do café. (MOMBEIG in SILVA, 1955, p. 81-82)

Na primeira metade do século XIX, a arquitetura da cidade paulista pouco diferia da vila dos tempos coloniais. Do mesmo modo, as condições geográficas ou as circunstâncias históricas, nesse momento, não tinham proporcionado crescimento urbano significativo. A cidade situava-se na mesma área da colina, no triângulo formado pelas ruas que hoje são a Rua Direita, Rua 15 de Novembro e Rua São Bento. O isolamento cultural em que ainda viviam os paulistas, pode ter contribuído para a manutenção dos hábitos construtivos, pois subsistia a mesma técnica construtiva, a taipa de pilão. (MATOS, 1955, pp. 89-90)

Porém, a partir da segunda metade do século XIX, a taipa começa a sofrer a concorrência de outras técnicas, como as estruturas autônomas de madeira preenchidas com diversos vedos, entre eles a alvenaria de tijolos. Assim, nas últimas décadas do século, a taipa vai sendo desprestigiada e gradativamente colocada em desuso. Inicialmente a alvenaria de tijolos tinha uma função secundária, sendo utilizada nas técnicas mistas, e que foram em seguida substituídas pela estrutura maciça de tijolos, passando a ser amplamente utilizada nas construções paulistanas. (CAMPOS,1997, pp. 369-370)

Segundo CAMPOS, a nova técnica de alvenaria de tijolos autoportante, ao que tudo indica, foi trazida do Rio de Janeiro, no final da primeira metade do século XIX, pelos 
engenheiros formados na escola militar da Corte, postos à disposição da Província pelo governo central. Foram os primeiros profissionais que apareceram para sugerir a adoção do desconhecido processo de construção, ainda nos anos de 1820, e que passaram a preponderar na construção civil paulistana, desde os anos de 1840 ou 1850. Esses engenheiros tiveram como aliados membros da classe abastada paulistana, e é desta classe que saíram alguns donos de olarias, sendo eles mesmos os profissionais que executavam as obras públicas. Com a inauguração da maior olaria em 1859, o uso de paredes maciças e autoportantes de tijolos difundiu-se. No período, utilizavam-se regularmente alicerces de alvenaria de pedra. Essa fase de 1850 a 1870, portanto, tem como principal característica o emprego da alvenaria de tijolos com função estrutural, em substituição gradativa à tradicional taipa.

A reconstrução da ponte do Acu entre 1851 e 1852, em particular, representou um momento importante para a aceitação e confiança da população, e do poder municipal em relação à técnica construtiva de alvenaria de tijolos. A ponte, construída originalmente em pedra, é então reconstruída com base na nova técnica após o desabamento provocado pelo temporal de 1850. Na concorrência para a reconstrução, o empreiteiro ganhador foi o engenheiro francês Martin d'Estadin. Para as obras, foi necessário realizar testes de resistência, já que os tijolos paulistanos não eram considerados de boa qualidade. Os tijolos foram então recozidos para aumentar a resistência por indicação do responsável pela obra.

A ponte enfim foi reconstruída, sendo que a Câmara ainda encomendou pareceres sobre a questão, como o do Dr. Rath, que observou que foi empregada a cal de marisco, como se usava em São Paulo, e que os tijolos eram na maior parte bons, outros mais ou menos cozidos.

Quanto à areia, há documentos municipais que apontam a sua extração num ponto entre a Glória e o Lavapés. Trata-se de areia de mina (ou de cava). Já a cal, era utilizada "a cal de ostras oriunda do litoral que seria o aglomerante mais acessível até o início da República". (RAFFARD in CAMPOS, 1997, p.301) ${ }^{1}$ embora a obtida de rochas calcárias em Parnaíba fosse conhecida desde o século anterior. (LEMOS in CAMPOS, 1997, p.301)

Dada a característica higroscópica conferida pela presença de cloreto de sódio nunca perfeitamente eliminado, a cal de marisco era considerada um produto de baixa qualidade. Com o tempo provocava a umidade das construções e por isso passou a ser condenada pelos higienistas da segunda metade do século XIX.

A areia retirada das margens do Tietê, também começa a disputar o mercado paulistano com o saibro e com a areia de mina. A esse respeito encontramos um anúncio interessante dirigido a "os donos de obras" que menciona especificamente o monumento do Ipiranga :

Chamo a atenção dos srs. donos de obras para o emprego da area branca ou amarela tirada debaixo da terra e empregada pelos srs. empreiteiros em muitas obras tomadas de

\footnotetext{
${ }^{1}$ CAMPOS cita um artigo da Revista de Engenharia, datado de 11 de agosto de 1879, descreve o processo seguido na fabricação de cal de marisco vendida no Rio de Janeiro.O autor, o engenheiro civil JOSÉ AMÉRICO DOS SANTOS, atribui a característica higrométrica dessa cal à presença de "chlorureto de magnesium”. Conclui que esta indústria caminhava para a decadência, à medida que se ia generalizando na região o uso do cimento Portland
} 
empreitadas; os donos de obras não devem consentir que se empregue essas areas em suas obras. O reboco feito com qualquer dessas áreas não dura mais de um a dois mezes na parede.

Nas obras [do monumento] do Ypiranga estão também empregando para o serviço as ditas areas, por economizar a cal, e também por ser mais barato.

Todos os que quizerem fazer uma obra sólida devem preferir a area do Tietê que é area lavada e de muito boa qualidade, portanto é que devem preferir esta. [sic]

São Paulo 7 de junho de 1886 Atilio Giannotti

Correio Paulistano, SP 8 de junho de 1886, p.3 (CAMPOS, 1997, pp. 298-301, 305, $306,308)$

Fatos semelhantes relacionados à qualidade dos materiais, à sua origem ou preparo, são relatados pelo engenheiro francês Vauthier, que esteve em Pernambuco no período de 1840 a 1846. O engenheiro registrou suas observações sobre a arquitetura doméstica pernambucana em suas cartas, publicadas em 1943 na revista do SPHAN. Quanto à técnica construtiva utilizada neste período, Vauthier, em sua peregrinação pelo litoral pernambucano, observa que a alvenaria de tijolos constituía mais ou menos toda construção. Mas, no caso da Província de São Paulo, encontra ainda casas de taipa e construções de pau-a-pique, de grande diversidade de espécies que caracterizam sua fisionomia.

Em 1839 chegaram em Pernambuco, uma companhia de 105 artistas mecânicos e operários, e um ano depois Vauthier e técnicos com estudos superiores, ambos através de contratações. Com a atuação desses profissionais europeus, novidades européias são introduzidas na arquitetura, segundo o cronista Pereira da Costa ${ }^{2}$ (PEREIRA DA COSTA in VAUTHIER, 1943) o emprego de pedras nas pesadas cornijas feitas à mão, nas vergas, dão lugar às novas construídas através de moldes ou simplices de alvenaria de tijolos, inclusive as vergas retas ou abatidas, semicirculares ou ogivais. Há outros melhoramentos como a ornamentação arquitetônica, as maiores dimensões de portas e janelas encimadas com cornijas, que deram um tom belo e agradável às construções. As obras de construção ficaram mais baratas, pela economia de salário sem a utilização da pedra e dos trabalhos menos complicados do pedreiro e carpinteiro.

Gilberto Freyre, ao se referir à fabricação do tijolo na cidade do Rio de Janeiro, cita o engenheiro Antonio de Paula Freitas, que em suas memórias sobre $O$ saneamento da Cidade do Rio de Janeiro, em 1884, dizia que "não era raro ao demolir prédios antigos, encontrar umidade até no alto das paredes". "No Rio de Janeiro, na primeira metade do século XIX, nem sempre havia escrúpulo no preparo dos materiais. O tijolo continuaria na segunda metade do século XIX, não só de má qualidade como mal feito. Paula Freitas considerava que era devido ao barro, que não era lavado e expurgado de matérias estranhas e prejudiciais à construção, como também empregavam na confecção da pasta, areia da água do mar".

Vauthier, por sua vez, considerava o barro encontrado em Pernambuco e no Rio de Janeiro como de boa qualidade, capaz de dar tijolos resistentes, se bem fabricados sem os vícios de se agregar areia da água do mar. Além disso, ele diz ainda que se abusou na construção de casas, do uso de areia de água salgada, de mais fácil extração, mesmo existindo os rios de água doce. No Rio de Janeiro, sabe-se que foi maior o uso de cal de

\footnotetext{
${ }^{2}$ COSTA. Estudo publicado no n.54 da "Revista do Instituto Arqueológico e Geográfico Pernambucano
} 
marisco, do que em Recife, contendo matérias deliqüescentes, que Paula Freitas responsabiliza pela umidade das paredes.

Em 1890 o tijolo continuava de má qualidade na região fluminense, cheio de numerosos vacúolos, porque a argila em certos lugares é ferruginosa, e adicionam areia tirada do mar, o que dá à alvenaria grandes inconvenientes, em virtude das propriedades deliquescentes dos sais que acompanham aquela areia. Opinião idêntica à do já citado Paula Freitas, para quem "os materiais empregados nas construções do Rio de Janeiro, por não serem escolhidos ou fabricados com matérias-primas de boa qualidade e conscienciosamente empregados", não satisfazem sempre "as condições necessárias contra a umidade", constituindo muitas vezes "o veículo pelo qual a água absorvida do solo ou da atmosfera" penetrava nas paredes e se elevava "até as suas partes mais altas" (IDEM in VAUTHIER, p.16)

Em São Paulo, sobre o assunto, também há um relatório de 1887 do inspetor de higiene Marcos Arruda. No texto, entre outras informações, o inspetor insiste na necessidade de se melhorar o sistema de construções em toda a cidade, particularmente nos bairros baixos e úmidos, "nunca consentindo aí se fazer casas térreas, e proibindo o emprego de cal de marisco que, pela sua natureza, conserva sempre a umidade, e pela capilaridade chama a umidade do solo e provoca diversos processos de fermentação" (NOGUEIRA DE SÁ, in BRUNO 1954 p.1192)

Observe-se que as citações sobre os hábitos construtivos, são semelhantes quanto à qualidade da fabricação e origem dos materiais em Recife, Pernambuco, e São Paulo. A presença de sais pelo uso da cal de marisco na argamassa e água ou areia de mar na fabricação de tijolos, é apontada pelos higienistas dessa época como causa da umidade nas paredes. Os higienistas, no entanto, não se referem às conseqüências destes sais solúveis, nas superfícies das paredes internas ou externas. Os sais, absorvendo a umidade no estado líquido ou na forma de vapor, dissolvem-se e caminham por capilaridade desses materiais porosos, até à superfície. A umidade se evapora e os sais se recristalizam; desse modo, aumentam de tamanho e desagregam a estrutura dos materiais, como o tijolo e a argamassa, causando danos nas paredes. Esse assunto será retomado quando for analisado o nosso estudo de caso.

A partir da segunda metade do século XIX, a fisionomia da cidade de São Paulo e de sua arquitetura, as técnicas e os materiais, passaram por grandes transformações devido a um conjunto de fatores que se articularam entre si, e promoveram um grande desenvolvimento de ordem social, cultural e econômico em direção à modernização, à importação e à mecanização. São considerados, entre os principais fatores de crescimento, a expansão cafeeira, a multiplicação das estradas de ferro e o surto da imigração européia. (MATOS, 1955, p.103-104).

No campo econômico, o café nessa época começou a suplantar a cultura do açúcar, e o seu desenvolvimento representou a principal fonte de riqueza da Província de São Paulo, como salientou Prado Junior (Prado Jr. in BRUNO, p.899-900). Inicialmente foi cultivado no litoral Norte e Vale do Paraíba, durante 60 anos. Posteriormente, estende-se para as regiões a oeste do estado. Com a marcha do café em direção a essa região, as estradas de ferro acompanharam em paralelo a ampliação da produção cafeeira, se multiplicando pela área. A primeira estrada de ferro paulista foi inaugurada já no final da década de 1860 , a São Paulo Railway, que ligava São Paulo ao porto de Santos, e a Santos- 
Jundiaí em 1867, cujas ramificações foram sendo adicionadas até por volta de 1875. (D'ALAMBERT, 1993, p.8)

Todas as estradas de ferro passavam por São Paulo, que com esta localização estratégica se beneficiou imensamente. Foi um grande feito, defendido pela cidade em 1875 através da Câmara Municipal, a conversão da cidade em pivô central das comunicações ferroviárias. E, assim como previu o viajante William Radfield em 1870, São Paulo estava destinada ao progresso e a ser a capital da Província. (BRUNO, 1954, p. 900).

As estradas de ferro vieram resolver as dificuldades de transporte, outrora praticado em lombo de animais, com segurança e rapidez. Elas favoreciam grandemente a circulação da produção ao impulsionar o comércio local, ligando-o ao porto de Santos e daí, através da exportação, à economia internacional. Desse modo, com a riqueza oriunda do café, São Paulo se insere no mercado capitalista mundial, não só exportando o café como também recebendo capital estrangeiro, principalmente inglês. (RAMALHO, 1989, p. 172)

Como conseqüência da economia de exportação, ganha força uma nova cultura orientada para a Europa, valorizada como modelo ideológico, bem como de padrões de consumo. Tal orientação era notada nas mudanças de moda e na culinária, nos estilos arquitetônicos e nos conceitos de higiene e conforto. Assim, o isolamento cultural em que outrora vivia o paulistano, agora se abre para novas perspectivas que vão se refletir amplamente na fisionomia da cidade. Em particular, o conceito de modernidade e progresso nos moldes das cidades européias, é tão acentuado à época, que para construir segundo esses novos padrões, os habitantes destroem construções anteriores para reconstruí-las no mesmo local. (GRAHAM in RAMALHO, 1973, p. 173)

De fato, em 1885, o viajante Lomônaco observava que a cidade de São Paulo estava sujeita a um trabalho de contínua demolição e transformação, que não podia ser logo completado: "uma cidade nova tende a substituir a antiga". Nesse período, em outras palavras, a tradicional taipa foi substituída pelo tijolo, e São Paulo foi reconstruída em alvenaria. No entanto, a cidade cresceu então sobre si mesma, de modo que, mesmo com aumento demográfico, não houve um significativo aumento da área urbanizada. (BRUNO, 1954, p.900)

\footnotetext{
"Poucas vezes na história do urbanismo terá ocorrido um fenômeno semelhante, uma cidade reconstruída duas vezes sobre o mesmo assentamento. A descoberta de uma cidade inteiramente construída de barro surpreendeu os viajantes no início do século XIX, como surpreendera anteriormente Morgado de Mateus (primeiro governador de São Paulo depois da restauração da Capitania - 1765-1775). Há um século, contava com trinta mil habitantes e, a partir do momento que a ferrovia chegou às novas terras produtoras de café, a cidade conheceu um crescimento incontrolado. Crises econômicas, revoluções, guerras, nada conseguiu infletir sua curva de crescimento. Com os imigrantes vieram novas técnicas de construir e a cidade foi reconstruída integralmente, disso resultando uma nova imagem: a Metrópole do Café". (TOLEDO, 2004, p.181)
}

A partir de 1870, a capital paulista rompeu com as barreiras da colina histórica, e avançou para a Cidade Nova, expandindo-se de maneira sempre crescente. Concomitantemente ao desenvolvimento urbano, há o crescimento populacional e o crescimento da demanda de novas edificações. Nesse momento, fazendeiros enriquecidos com o café e famílias abastadas de Campinas e Santos, vêm fixar residência em São Paulo, que também ganha importância como sede do governo, centro das comunicações, indústria e 
comércio, tendência que se acentuaria com a abolição da escravatura em 1888, como observa Raffard em 1890. (BRUNO, 1954, p.900-901).

Como já citado, um fator de enorme significado nas transformações, foi a introdução da mão-de-obra do imigrante europeu, não só nas fazendas de café como na cidade de São Paulo no geral. A partir de 1871 começaram a chegar as primeiras levas de imigrantes europeus, portugueses, espanhóis, eslavos e principalmente italianos, a qual foi intensificada em 1887. São Paulo foi a província que mais recebeu imigrantes. No período de 1877 a 1914, entraram aqui cerca de 1.728.620 imigrantes, dos quais 845.816 eram italianos. (HOMEM in D'ALAMBERT,1993, p.9,10).

Nesse contexto, veio para São Paulo, através da imigração subvencionada, organizada pelos cafeicultores, o artesão independente e o operário qualificado. Estes trabalhadores, apesar de analfabetos, possuíam nível técnico e cultural superior ao da média dos paulistas, pois vinham com experiência do seu país de origem. (MACAMBIRA in D'ALAMBERT, 1993, p.10)

Os imigrantes têm um destacado papel na arquitetura e construção civil paulista do período. Atuaram aqui tanto os arquitetos e engenheiros com formação em escolas de ensino superior na Europa, como mestres-de-obras, pedreiros, estucadores, fachadistas, que detinham o conhecimento e certas especialidades, adquiridos através da experiência prática nas obras do país de origem. Assim, contribuem para o emprego da alvenaria de tijolo auto-portante, e para a execução do repertório ornamental, integrantes da linguagem arquitetônica neoclássica ou eclética que vai se difundindo em São Paulo. Substituem, com vantagem, a mão-de-obra escrava, ao executarem obras caracterizadas por um acabamento requintado, bem superior às tradicionais construções de taipa. A atuação conjunta desses arquitetos e mestres-de-obras, em suma, concorre para a alteração da fisionomia da capital num período de 40 anos, transformando a cidade de taipa em cidade do tijolo, com novos valores de conforto e higiene, de modernização e progresso, tendo como modelo as cidades européias. (D'ALAMBERT, 1993, p.10-11)

O tijolo, na da segunda metade do século XIX, em São Paulo, torna-se símbolo das transformações das técnicas construtivas, expressas na arquitetura através da linguagem do neoclassicismo e do ecletismo. Contudo, no Brasil, há referências do uso do tijolo cozido em construções já poucos anos após seu descobrimento. Em uma carta sobre o primitivo Colégio de Olinda, em Pernambuco, José de Anchieta escreve que a obra "ainda que grande, está toda cercada de paredes de tijolos" e tem "duas ruas com pilares de tijolos com parreira". Lúcio Costa, por sua vez, informa que muitas igrejas jesuíticas do Espírito Santo e do Rio de Janeiro, possuíam a cobertura das torres executadas em tijolos, com acabamento externo de caiação, conforme a tradição árabe. Na Bahia, o tijolo também era comumente usado, e foi encontrado em ruínas de construções do século XVI. Não obstante, essa peça ganha significado moderno somente na segunda metade do século XIX.

CAMPOS, através de um levantamento dos "reclames" nos jornais, a partir de 1850, os quais ofereciam materiais de construção, revela a marcha cada vez mais acelerada da arquitetura rumo à modernização, à sofisticação das técnicas de fabricação e do aperfeiçoamento na preparação desses materiais. Nesses documentos é possível avaliar como a cidade se prepara para atender às demandas de consumo, moda, hábitos, costumes etc, demandas essas, que acabam por propiciar todos os meios para a concretização da nova linguagem arquitetônica, em função dos novos valores da 
organização urbana e da arquitetura paulistana. São Paulo vai assim ficando pronta para receber as linguagens neoclássica e eclética. Nesses anúncios, por exemplo, há referências a importantes aglutinantes, o cimento Portland e o cimento romano, cujo registro de uso data de 1875. Como o cimento Portland, outros materiais eram também importados, como a cal, a cantaria, o ferro e o vidro.

As modificações quanto ao uso de materiais e de técnicas construtivas não se resumem a este exemplo. Ainda na segunda metade do século XIX, a Câmara apressou-se em aprovar uma postura para obrigar os moradores a utilizar calhas e condutores, para as águas não danificarem as ruas com o novo sistema de pavimentação, abaulamento a pedregulho. Desse modo, logo apareceram as platibandas, em que o emprego de calhas e condutores são indispensáveis.

Igualmente, nos últimos anos de 1860, a primeira fundição é inaugurada, e posteriormente novas fundições ofereciam maquinismo, utensílios, ferramentas e alguns elementos construtivos, como grades, para os respiradouros dos porões, uma novidade nas construções paulistanas; colunas, escadas, latrinas. Artigos de artefatos de ferro e matérias-primas chegavam do porto de Santos através da recém-inaugurada ferrovia. $O$ maquinário importado melhora a fabricação de tijolos, telhas, tubos de barro. As inovações permitem melhor serrar e aparelhar madeiras mecanicamente, condições para a execução de forros, soalhos, sistemas de coberturas, portas e janelas; também se torna possível furar e cortar pedras.

Em 1868 surge a primeira marmoraria. Os ornatos de pedra artificial (feita com areia e cimento) eram utilizados na decoração eclética e havia diversas peças, tais como batente para portas e janelas, socos e soleiras, escadas, pilastras, colunas e capitéis, cimalhas com arquitrave e friso, platibandas com balaustrada, gradis para jardim, pilastras para portão, ladrilhos imitando mármore, ladrilhos brancos para terreiro de café, etc.

Abrem-se lojas de artigos para instalação de gás, água, luz telefone e eletricidade, esta avidamente consumida pela classe mais abastada, beneficiada pela inauguração de empresas de serviço público nos derradeiros anos do Império. Já se torna habitual o emprego da cal de pedra, que é abundante, embora nos edifícios públicos os empreiteiros teimem em empregar cal de ostras por ser mais barata ${ }^{3}$ e contra a qual se levantam os higienistas da Corte. Nesse momento, por fim, acentuam-se os propósitos de higiene e conforto quanto à umidade nas construções, o emprego das fundações de pedra e tijolo e à elevação do primeiro piso, distanciando-se do contato direto com o solo, que passa a ser amplamente utilizado. Surgem assim a "a caixa de ar" ou porão (CAMPOS, 1997, pp. 310-314)

As inovações construtivas inspiraram mudanças na legislação. No Código de Posturas do Município de São Paulo de 6 de outubro de 1886, Título II - Da edificação e reedificação do calçamento, no Artigo 11, que regulamenta a altura dos edifícios e dos seus diferentes pavimentos, afirma que o "soalho do primeiro pavimento deverá ficar pelo menos a 0,50m superior ao terreno". (p.4)

\footnotetext{
${ }^{3}$ Departamento do Arquivo do Estado. Obras públicas. Ordem 5169. Documentos relativos ao Palácio do Tesouro Provincial, 1876. Conta de João Lopes do Nascimento Nóbrega pelo fornecimento de sacos de cal proveniente de Santos., de maio de 1876.
} 
A esse respeito, SEGURADO cita que em 1903 ainda persiste o emprego do porão em Portugal e Rio de Janeiro, e que em Portugal, O Regulamento de Salubridade das Edificações Urbanas de 14 de fevereiro de 1903 estabelece, no seu artigo 9, a altura mínima para caixa de ar de $0,60 \mathrm{~m}$, sempre que não revista o solo com uma camada impermeável. No Rio de Janeiro, exige-se que toda superfície ocupada por uma edificação receba um revestimento de asfalto ou beton com $0,15 \mathrm{~m}$ de espessura. Quando se deixa caixa de ar, que no Brasil tem o nome de porão, a sua altura nunca será inferior a $0,60 m$, nem superior a $3 m$, podendo ser dividida desde que o pé direito seja de $2 m$ ou mais; a medida é tomada desde o nível do revestimento impermeável até à face inferior do vigamento. As caixas de ar serão convenientemente ventiladas por meio de aberturas em comunicação com o exterior, e protegidas por grades de ferro ou outras, além destas aberturas prescreve-se no regulamento brasileiro, em certos casos, a construção de chaminés de ventilação (SEGURADO, p.6)

Outra preocupação com a higiene, era referente à entrada de luz e ventilação nos interiores das casas brasileiras, preocupação essa, que se contrapunha aos antigos costumes das tradições do uso das alcovas, dos conhecidos dormitórios sem janelas. As clarabóias e lanternins não só atendem a este objetivo, como também passam a fazer parte dos edifícios como recurso estético.

O poder municipal participa destas transformações com uma parcela de grande importância, conduzindo as intervenções na cidade mediante esforço deliberado de administradores, como Antônio Prado, que tinha o objetivo de esconder ou apagar qualquer traço não-europeu ou caipira, que porventura perdurasse em suas ruas, em suas casas, em seus jardins, em seus costumes. (BRUNO, 1954, p.911) Todavia, não podemos deixar de considerar, por outro lado, que São Paulo, ao perder seus aspectos mais tradicionais e provincianos, perdia também a história de sua arquitetura colonial, seu patrimônio edificado, substituído com grande rapidez conforme se processava 0 crescimento da cidade.

Em linhas gerais, o Neoclassicismo caracteriza a linguagem arquitetônica dos primeiros tempos da Revolução Industrial européia, e em particular, do período napoleônico na França. Essa linguagem se configura no contexto de crise da estética classicista, abrangendo um complexo variado de experiências arquitetônicas. No Brasil, tais experiências são introduzidas pela Missão Francesa, trazida em 1816 ao Rio de Janeiro, então capital do Império português, como parte das medidas de modernização urbana e cultural implementadas por Dom João VI. A Missão, dirigida por Lebreton, contava com artistas e profissionais especializados, incumbidos de fundar uma escola voltada para a formação de artistas e artífices, na tradição neoclássica, projeto que se concretizará com a formação da Escola Imperial de Belas Artes, em 1826.

Diferentemente das circunstâncias de sua introdução no Rio de Janeiro, o estilo neoclássico se generaliza em São Paulo de modo não oficial e deliberado. Nessa região, sua manifestação, em meados do século XIX, é espontânea, resultado das experiências e práticas dos artesãos e artífices imigrantes, que passam a estabelecer residência na província, bem como da intensificação do intercâmbio econômico e cultural com as cidades européias, relacionada à integração da região à economia mundial. No entanto, tanto no Rio de Janeiro como em São Paulo, o novo estilo tinha a conotação de progressismo e modernidade.

Em São Paulo, dois exemplos do mais puro Neoclassicismo, como indica LEMOS, são a chácara da família Gavião e a primeira sede do Hospital da Real e Benemérita Sociedade 
Portuguesa. Tudo indica que esses prédios foram introduzidos pela colônia portuguesa. $\mathrm{Em}$ ata de reunião da diretoria da Beneficência Portuguesa, de 1886, encontra-se referência ao arquiteto Manoel Gonçalves da Silva Cantarino, como autor do projeto da Beneficência Portuguesa, em 17 de julho de 1866. A inauguração do hospital só se deu em 20 de agosto de 1876.

Formalmente, esse hospital apresenta um só corpo, definindo a entrada principal no seu eixo central, encimada por um frontão triangular. As paredes das fachadas são resolvidas num único plano vertical. A relação dos planos de parede fechada e as aberturas são compostas num ritmo constante, e as áreas das paredes são um pouco maiores do que as aberturas. É aqui empregado o porão de ventilação que eleva o primeiro pavimento; a platibanda, o gradil de ferro nas sacadas e nos muros fronteiriços.

Em 1886, os dois primeiros edifícios destinados à administração pública, as Secretarias da Fazenda e da Agricultura, de Ramos de Azevedo, são isolados e decorados com motivos renascentistas, mas a volumetria, o frontão e a colunata de uma delas são ainda de inspiração no Neoclassicismo histórico.

A partir de 1885, no entanto, se inicia uma nova fase na arquitetura paulista e o Monumento do Ypiranga de Tommaso Gaudenzio Bezzi introduz novos elementos expressivos da linguagem eclética, com maior liberdade criativa. Esses elementos se manifestam nos diferentes planos das fachadas, através das saliências e reentrâncias, da relação entre paredes e grandes aberturas, movimentos e ritmos variados, jogo de luz e sombra. Para comemorar o grande feito da Independência, buscou-se, antes de tudo, a grandiosidade, a grandiloqüência. As loggias do edifício de Bezzi, fizeram escola, pois começaram a surgir com mais freqüência em projetos diversos, principalmente nos grandes palacetes, inclusive nos concebidos sem compromisso algum com 0 renascimento italiano. (LEMOS, 1987, p.76-79)

É de se notar, que para a concretização deste edifício, como de outros na mesma época, seja na sua materialidade como na aceitação e valorização desta linguagem arquitetônica, a sociedade paulistana foi mobilizada em seus diversos segmentos e contribuiu de forma indispensável, tornando-a viável, adaptada ao ambiente sócio- econômico e cultural. 


\section{FACHADA NORTE}

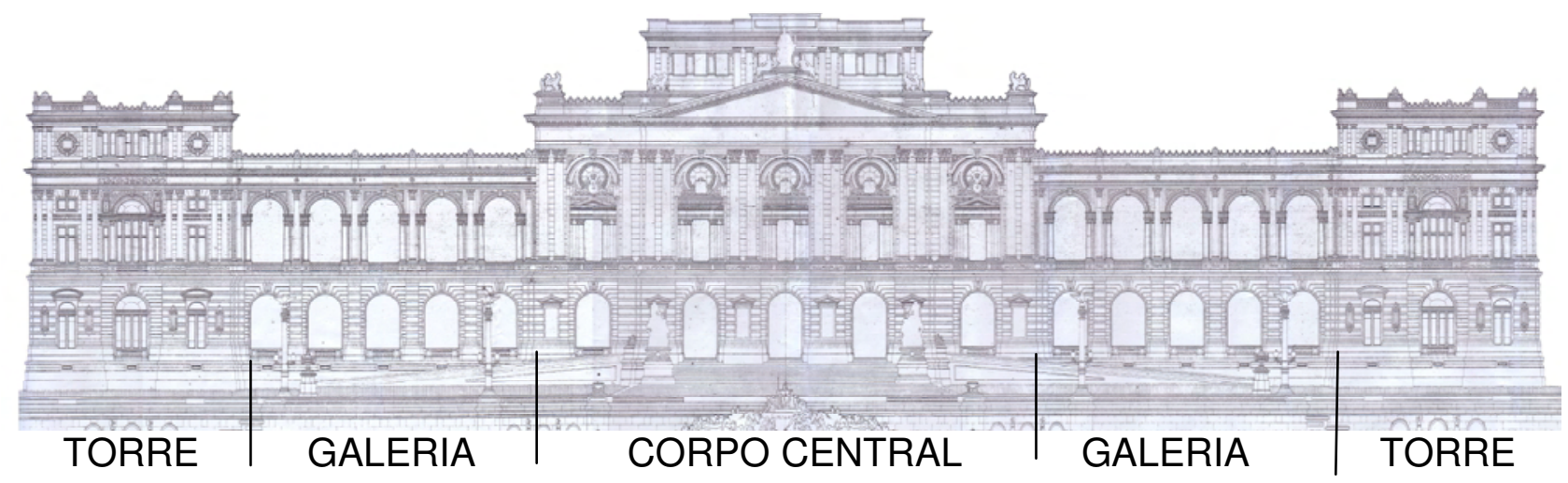

Fig.2 - Fachada e Planta

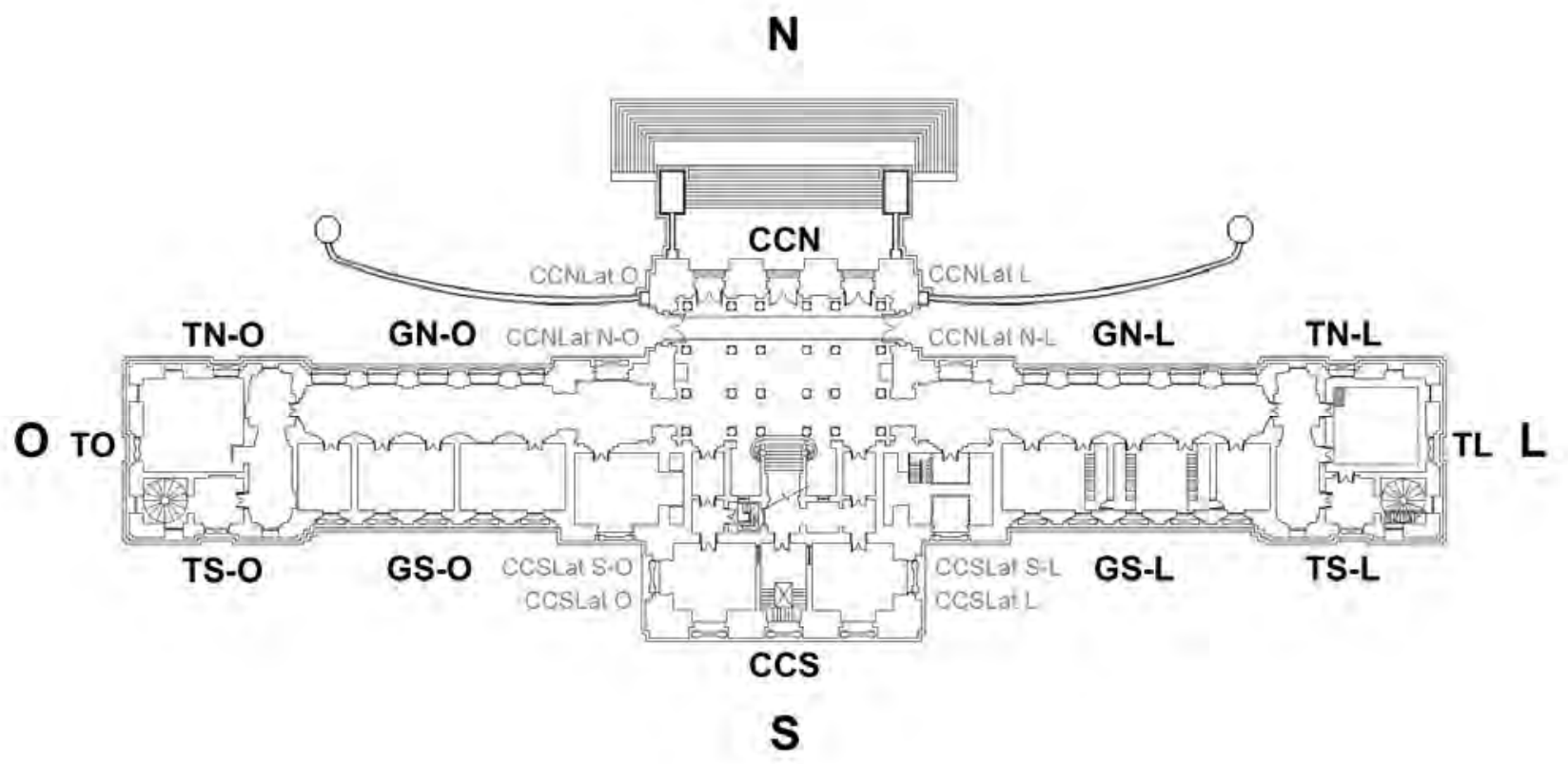

PLANTA TÉRREO

CCN: Corpo Central Norte CCS: Corpo Central Sul

GN-O: Galeria Norte- Oeste GN-L: Galeria Norte- Leste

GS-O: Galeria Sul- Oeste

GS-L: Galeria Sul- Leste
TN-O: Torre Norte- Oeste

TO: Torre Oeste

TS-O: Torre Sul -Oeste

TN-L: Torre Norte- Leste

TL: Torre Leste

TS-L: Torre Sul - Leste

NOMENCLATURA DE LOCALIZAÇÃO ADOTADA 


\section{ESTRUTURA GERAL DO EDIFÍCIO}

O edifício é constituído por três tipos de volumes formando cinco corpos.

O Corpo Central é ladeado simetricamente pelas Galerias e Torres.

Os volumes são definidos por recuos e saliências, larguras e alturas diferentes, e assim criam movimento, jogo de luz e sombra, acentuam os relevos e os planos verticais das paredes.

A composição formal das fachadas e o repertório ornamental de cada corpo se apresentam com soluções individualizadas e, ao mesmo tempo, há elementos de ligação entre eles participando da composição geral. Em planta é o Corpo Central que apresenta maior largura em relação aos demais.

Através da vista aérea, pode-se observar a composição geral dos volumes e, na cobertura, no Corpo Central, o coroamento do Ático.

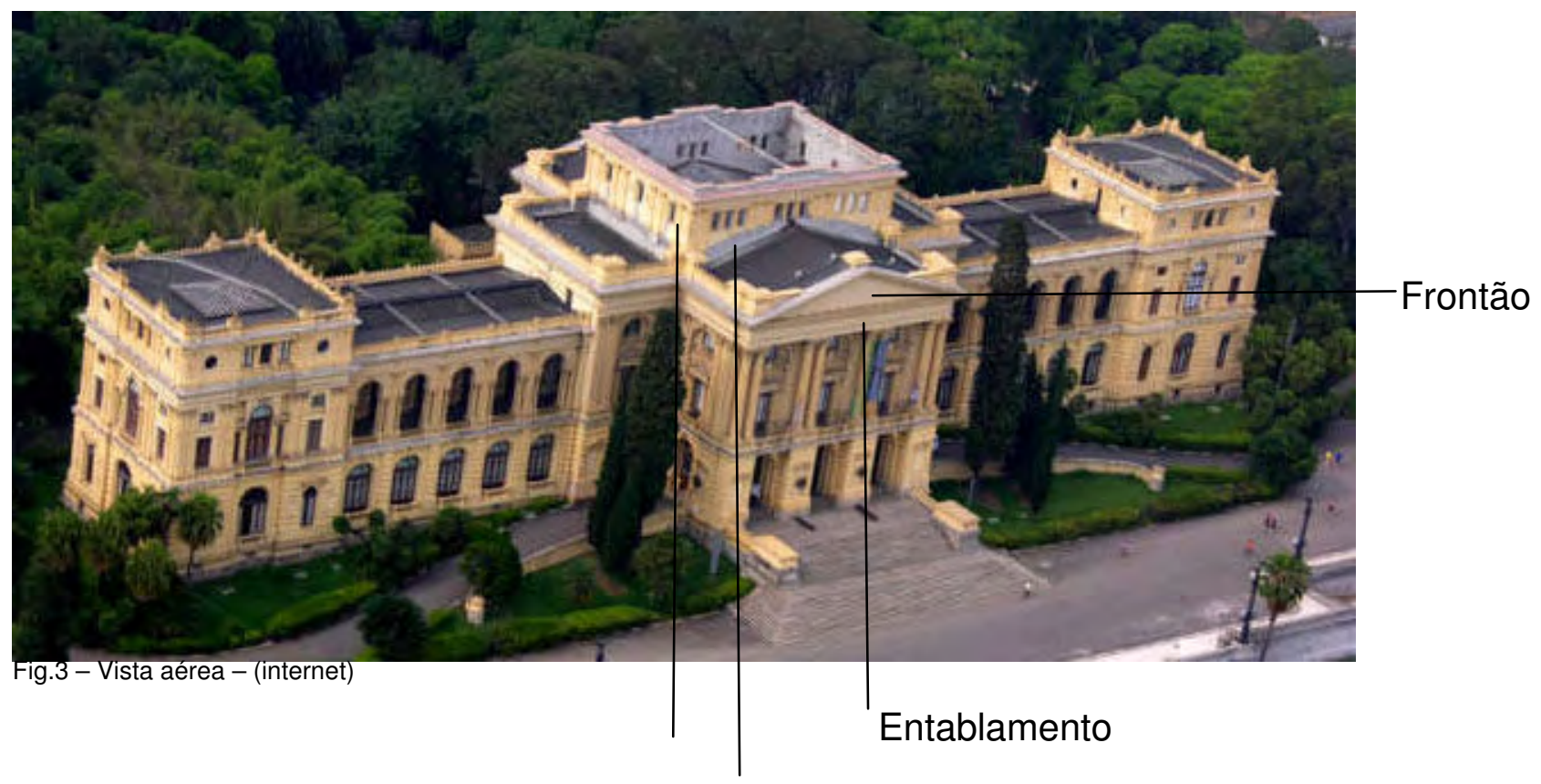

Paredes do Mirante - Ático Arco abatido do Ático

Em todo trabalho, procurou-se utilizar a nomenclatura empregada por Bezzi e dos manuais técnicos da época, da técnica construtiva do edifício, com os conceitos e significados próprios.

O ático é a parte mais elevada e que coroa o edifício. Neste caso, o ático é formado por quatro paredes, sem cobertura, que se convencionou chamar de Mirante, porque havia uma passarela ou passadiço de onde se avistava a paisagem do entorno.

O Mirante contorna uma parte do telhado central e do telhado de vidro sobre a clarabóia da escadaria central.

Bezzi se refere à região sob o telhado do Corpo Central, o que comumente chamamos de sótão, também como ático, ao descrever os dois grandes arcos abatidos bem visíveis sob o telhado, e, externamente, sua parte mais elevada que ultrapassa o telhado, observada na vista aérea acima. 
O frontão que destaca a fachada do Corpo Central, na face norte e sul, acompanha o telhado em duas águas e está acima do entablamento. O frontão é limitado em três lados do triângulo pela mesma cornija próxima à platibanda e que contorna o Corpo Central.

\section{CORPO CENTRAL}

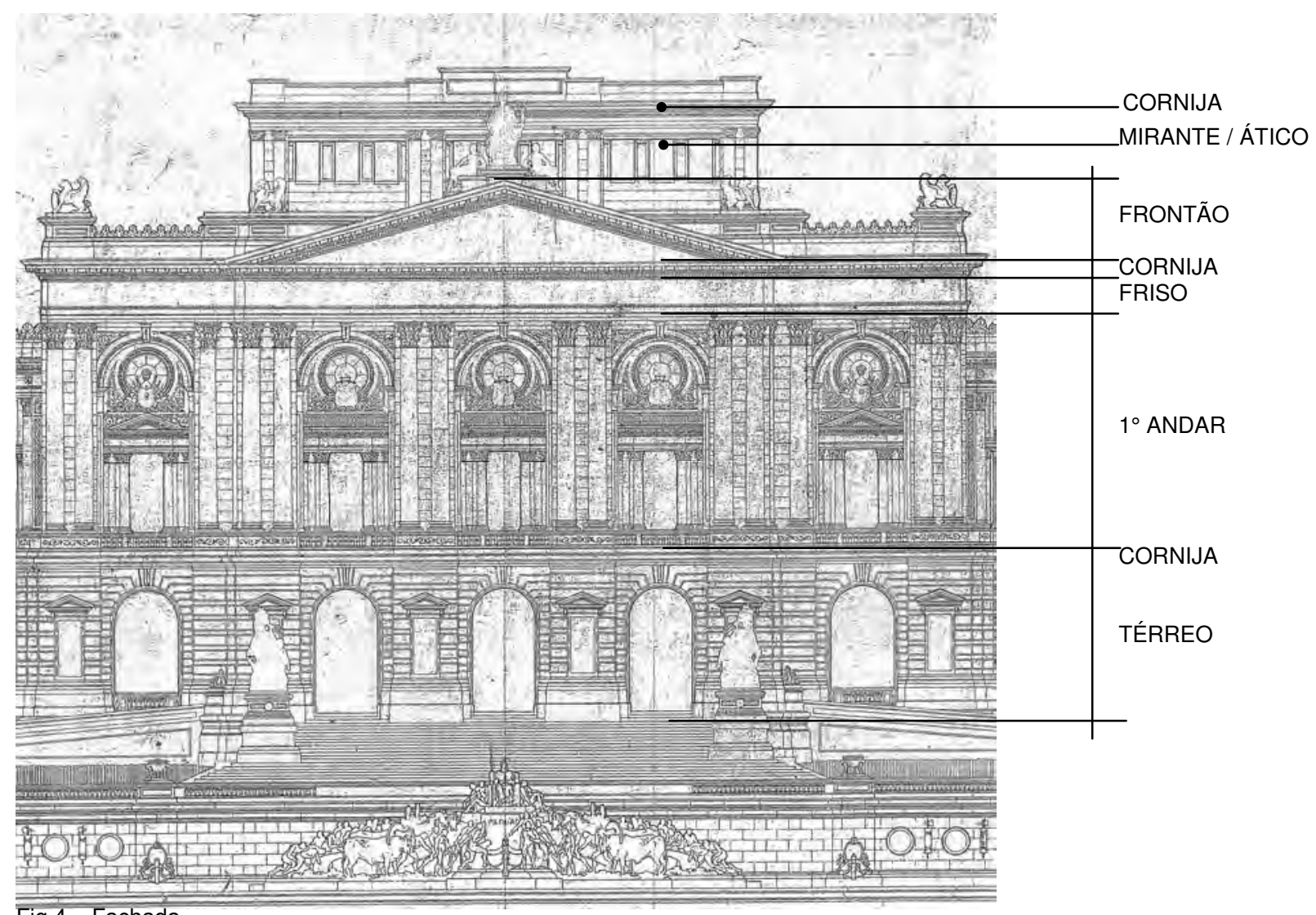

Fig.4-Fachada

\section{CORPO CENTRAL NORTE}

O Corpo Central, na face norte, é a parte de maior destaque, evidenciado pela altura, pelo coroamento do frontão e do ático; pela localização no centro do eixo da composição acentuada pela escadaria externa. Corresponde internamente à entrada principal que acessa o átrio e à escadaria de mármore, onde se comunicam os outros espaços. E ainda é marcado pelo caráter monumental, expresso através das grandes colunas isoladas e duplas.

A fachada norte e a sul são compostas por três elementos horizontais: o nível térreo, primeiro pavimento e o ático.

A parte interna do ático é chamada também de Mirante, como já foi referido. À altura total do pé-direito das grandes colunas, na face norte, corresponde o espaço interno mais importante do edifício, o Salão de Honra ou Salão Nobre, e à escadaria central, iluminada pela clarabóia.

Há algumas diferenças entre a face norte e a face sul. Na face norte, os maciços nas laterais dos arcos do pavimento térreo, são mais salientes do que na face sul, e as grandes colunas duplas são isoladas da parede, à frente das pilastras.

$\mathrm{Na}$ face sul, as saliências dos maciços são menores e as grandes colunas são adossadas à parede.

No pé-direito (altura interna) duplo interno, voltado à face norte é ocupado pelo Salão Nobre, na face sul, surge um outro pavimento intermediário situado na lateral inferior das aberturas cilíndricas ou óculos. 

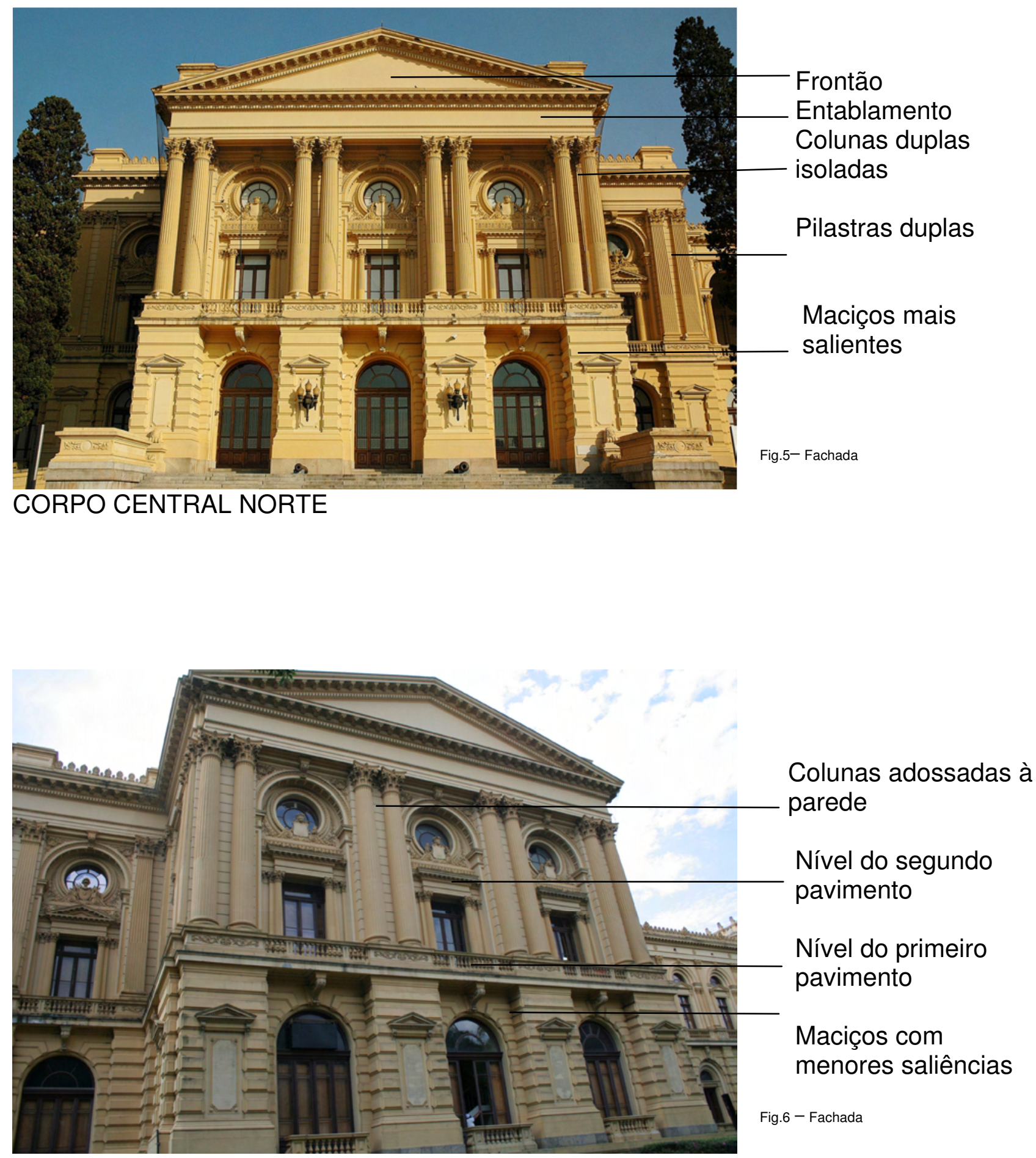

CORPO CENTRAL SUL 


\section{GALERIAS}

\section{COMPOSIÇÃO: ELEMENTOS HORIZONTAIS}

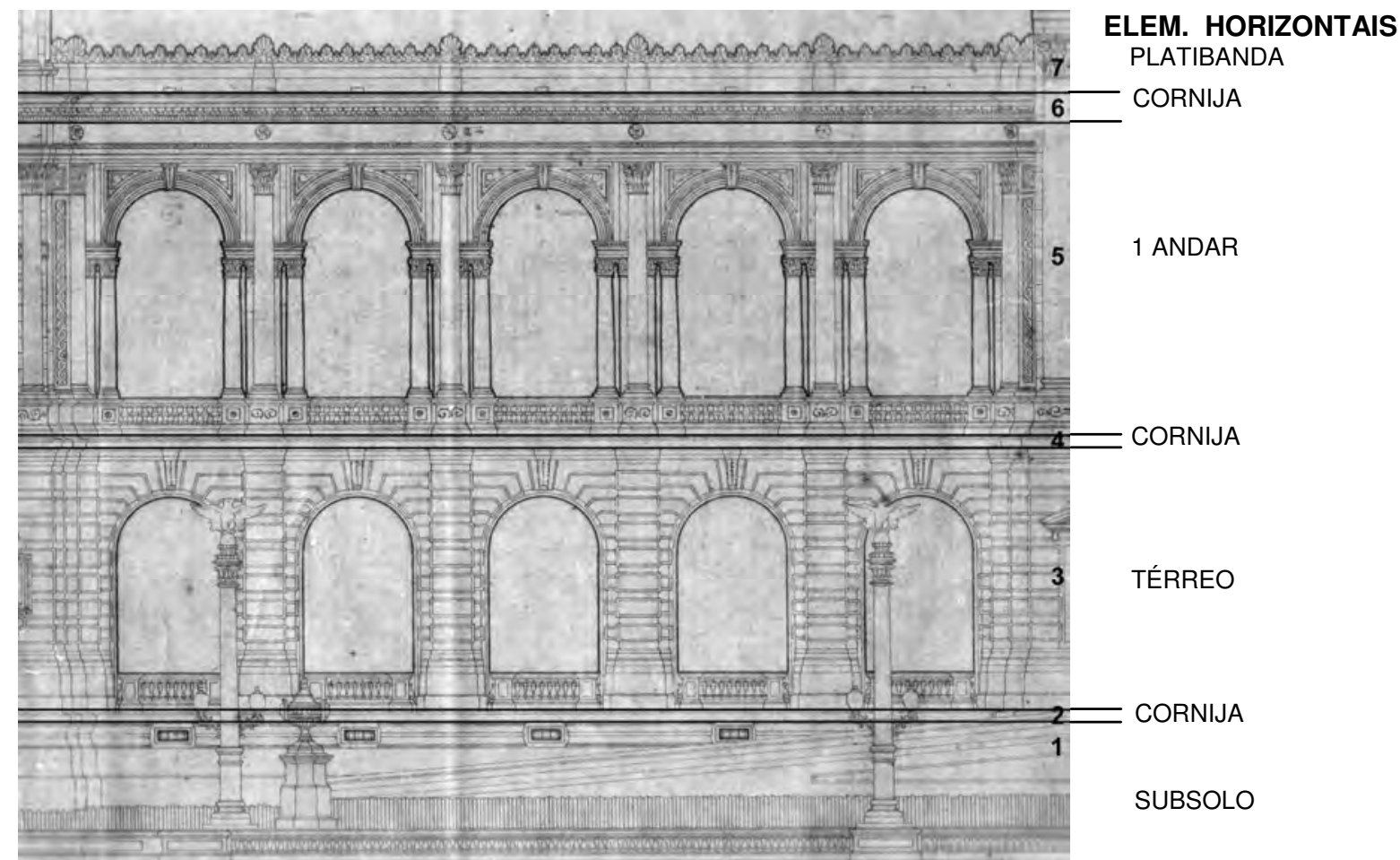

Fig.7 - Fachada Galeria Norte

Há duas GALERIAS, uma em cada lado do Corpo Central, sendo que as fachadas norte são diferentes das fachadas sul. As diferenças existentes se referem às aberturas e elementos arquitetônicos que as compõem, no térreo e no primeiro pavimento.

A diferença mais significativa aparece no primeiro andar da fachada norte, onde são empregadas as arcadas abertas também chamadas de loggias, que no passado eram mais comuns serem utilizadas no térreo, como lojas.

$\mathrm{Na}$ fachada sul, as aberturas são menores, são fechadas por portas e janelas e os maciços tem maior espessura.

Cada fachada é composta por 4 elementos horizontais, subsolo, térreo, $\quad 1^{\circ}$ andar e platibanda, e cada nível apresenta um repertório de ornamentos específicos. 


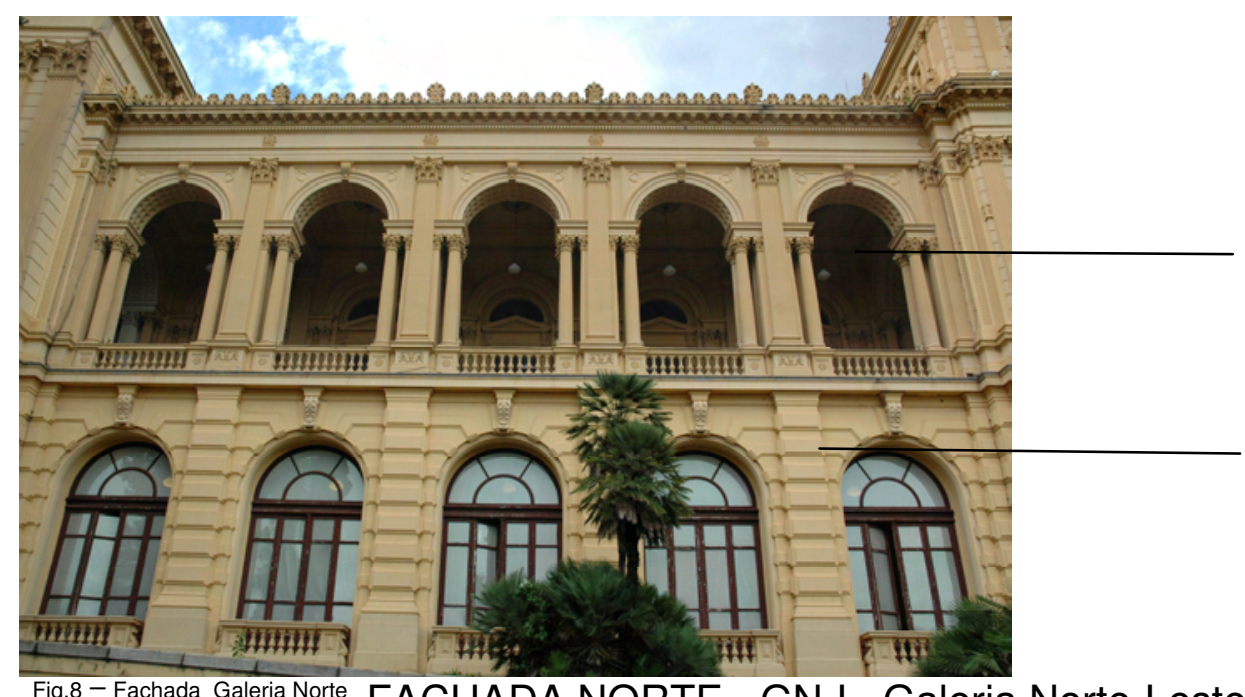

"Loggias" - Arcadas e Pórticos

Embossamento

Fig.8 - Fachada Galeria Norte FACHADA NORTE - GN-L Galeria Norte-Leste

Pilastras e Colunas

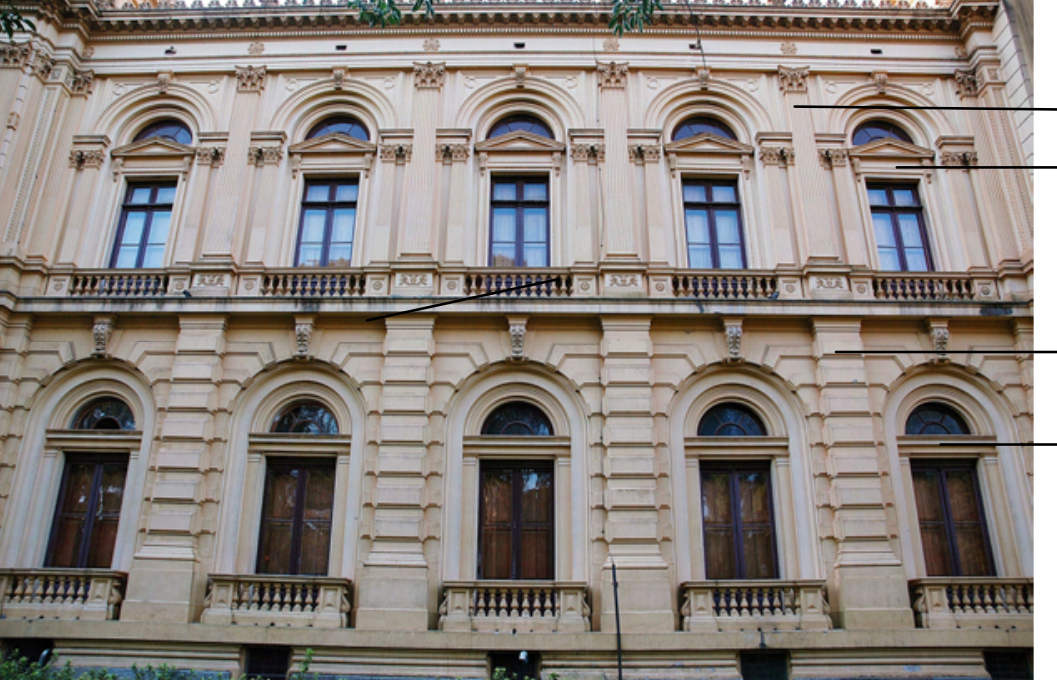

Adossadas

Arcos de Ressalva

FACHADA SUL - GS- L Galeria Sul-Leste 


\section{TORRES}

\section{COMPOSIÇÃO: ELEMENTOS HORIZONTAIS E VERTICAIS}

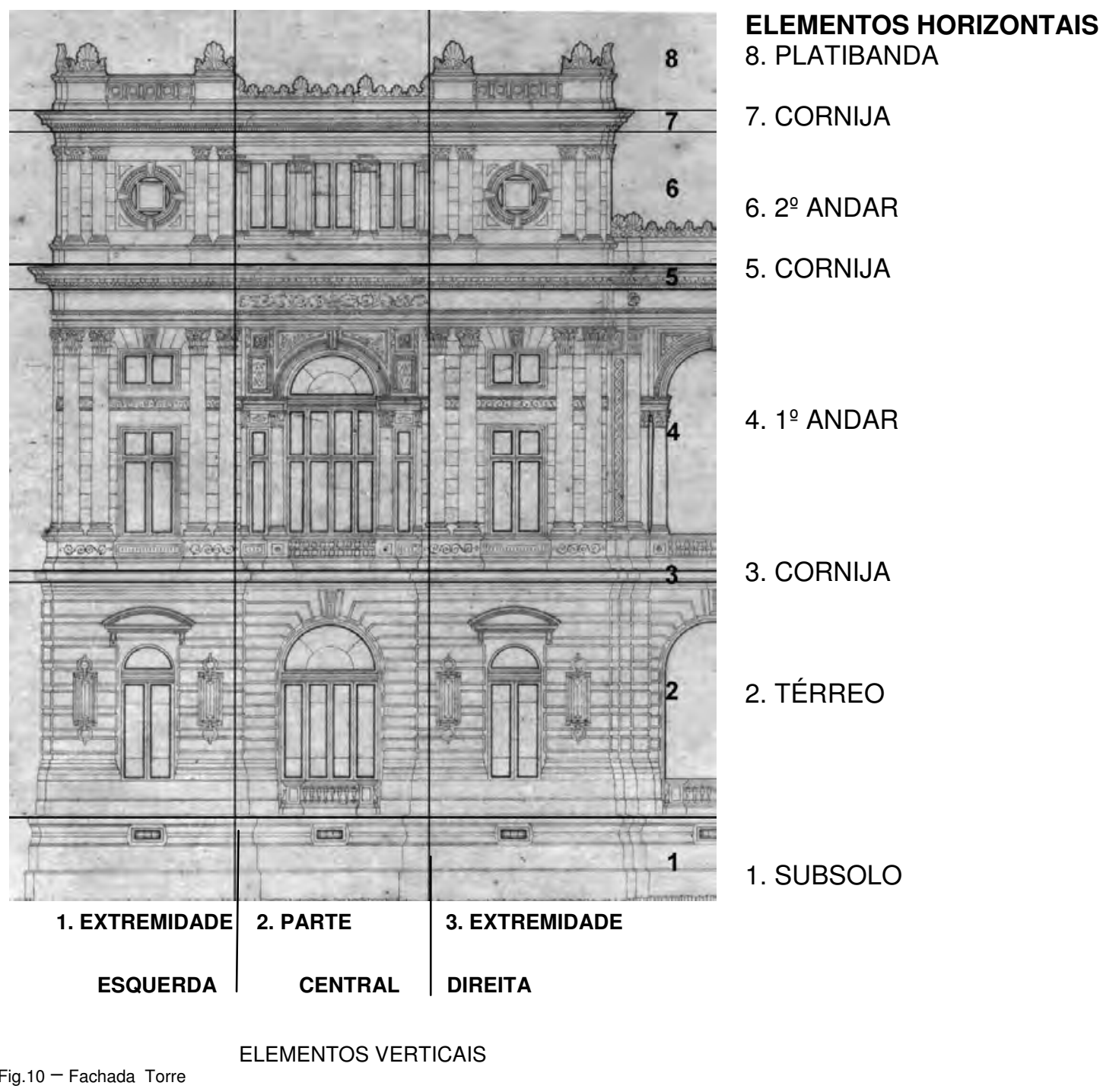

Há duas TORRES, ou TORREÕES, um em cada extremidade do edifício.

Cada Torre apresenta 3 faces ou fachadas idênticas, constituídas por 5 níveis: subsolo, térreo, primeiro e segundo andares e platibanda.

Há uma quarta fachada constituída somente pelo $2^{\circ}$ andar, nas faces que se ligam às Galerias (Torre Oeste Interna e Torre Leste Interna).

Cada um dos 4 níveis constituintes da fachada apresentam um repertório de ornamentos, aberturas e estrutura diferentes. O pé-direito (altura dos pavimentos) e as aberturas no Térreo e $1^{\circ}$ andar, são maiores, se comparadas com o $2^{\circ}$ andar. 


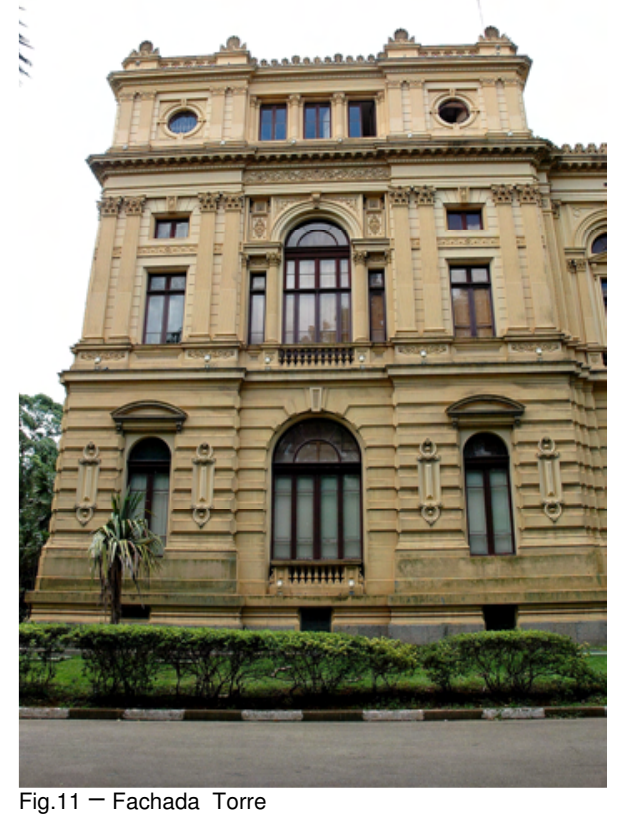

TN-L TORRE NORTE LESTE

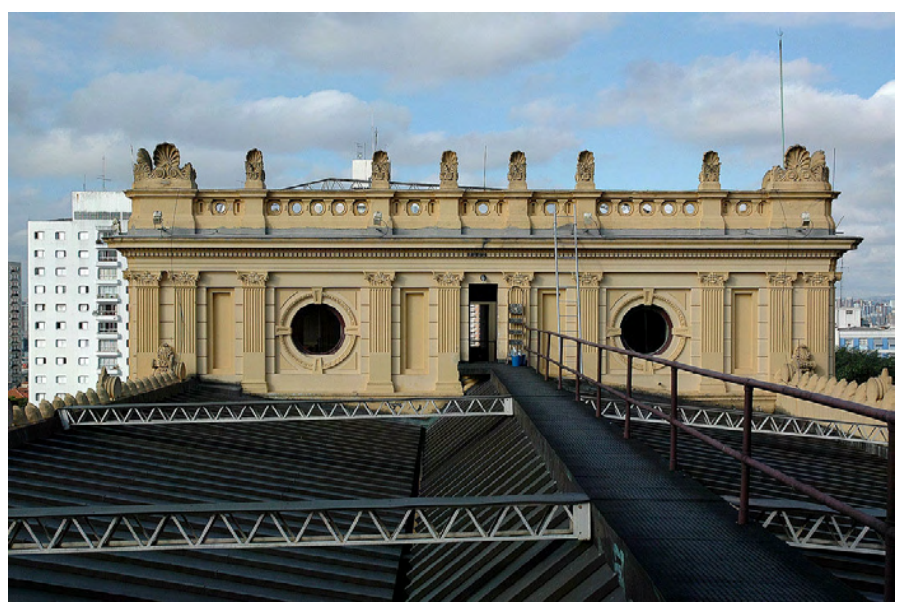

QUARTA FACHADA interna ligando-se à Galeria 


\section{ARTICULAÇÃO VOLUMÉTRICA DOS TRÊS CORPOS}

Considerando-se o conjunto, verifica-se que existem elementos ornamentais que individualizam cada corpo e, existem outros que articulam estes corpos entre si, repetindo-se através de grandes linhas horizontais, ou em toda altura de um pavimento. São eles: O embasamento, ou faixa externa do subsolo; $A$ bossagem no pavimento térreo; As balaustradas empregadas em todos pavimentos; As cornijas e molduras que delimitam os pavimentos. Todos estes elementos são indispensáveis nessa linguagem e são citados em detalhes nos manuais técnicos, nos tratados, com a mesma importância dos elementos estruturais.

\section{A FAIXA DO EMBASAMENTO}

A faixa do embasamento, com exceção da face norte do Corpo Central, recebe o mesmo tratamento ao redor do edifício, variando em altura, acompanhando o perfil do terreno, aparecendo ou não o socco ou envasamento, uma pequena saliência que a parede da fachada apresenta junto ao solo.

Assim, variam também as aberturas de ventilação do porão original, que ora ocupam a faixa do dado, ora só das molduras, conforme indicado na figura 12 e 13.

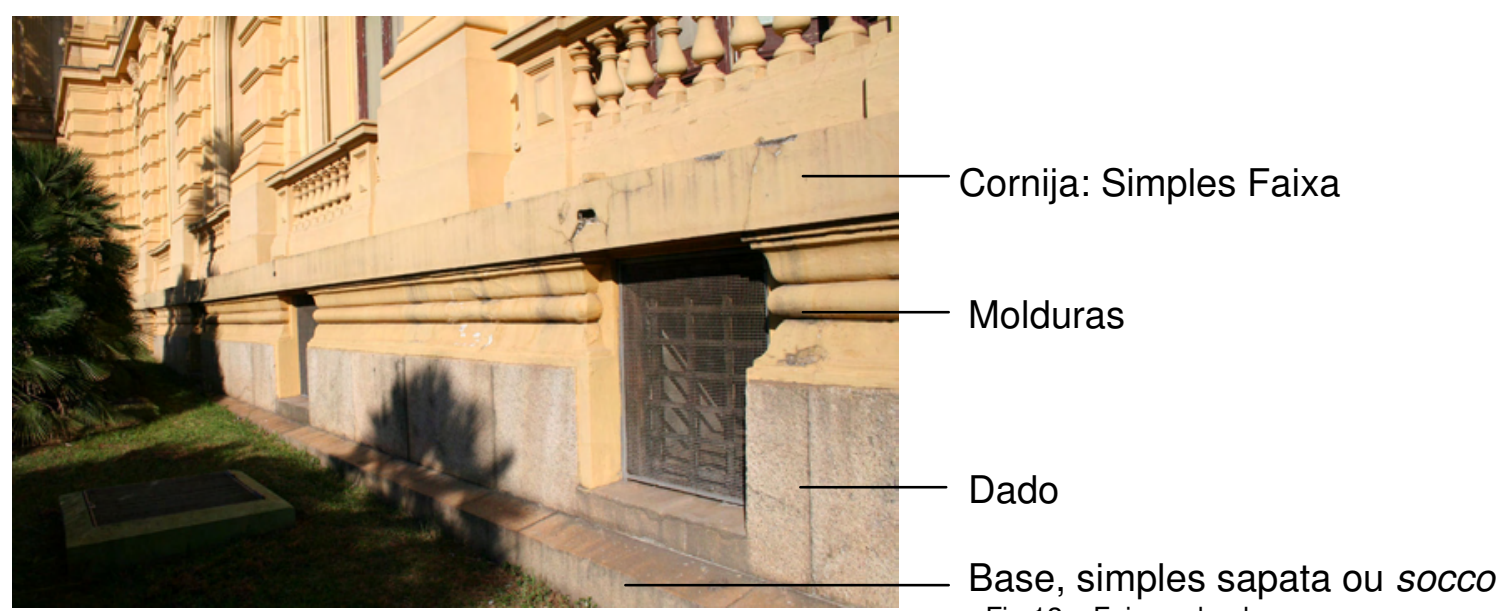

Abertura ocupando as faixas da moldura e do dado Fig.12 - Faixa subsolo

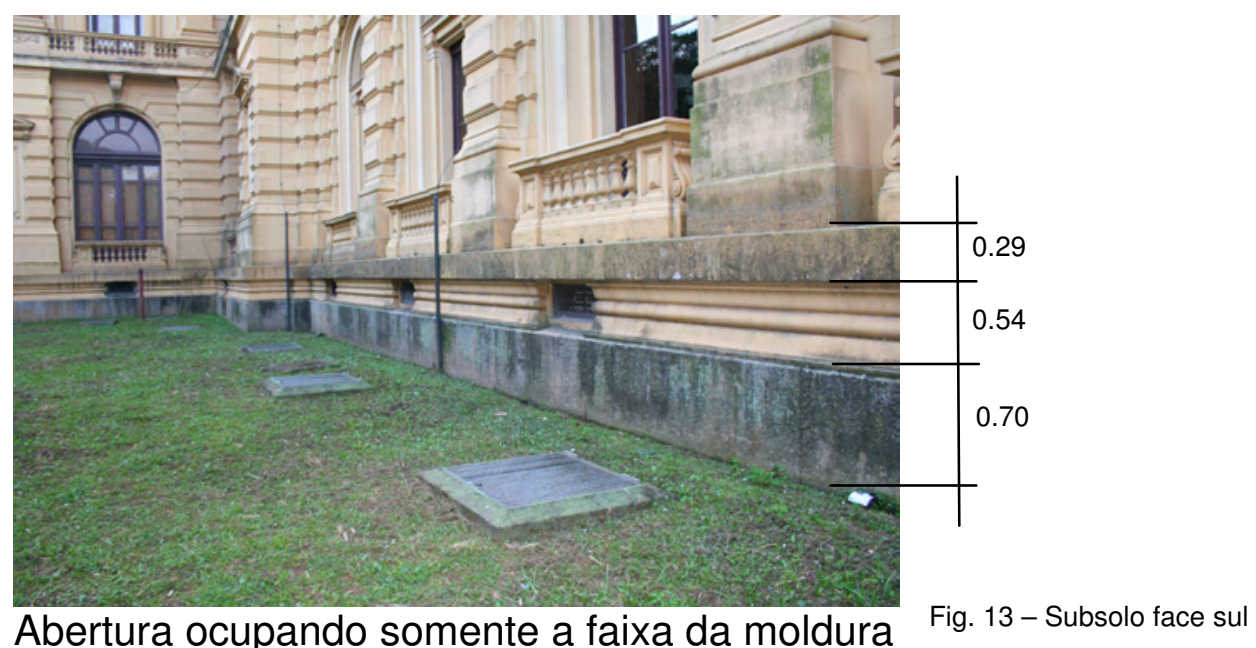




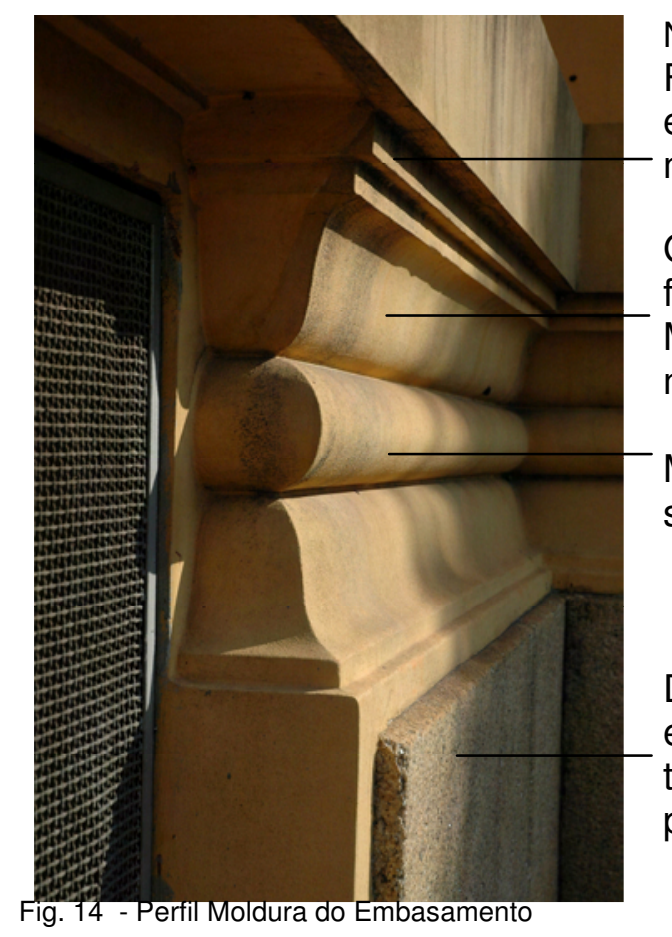

NOMENCLATURA DAS MOLDURAS:

Filete - Moldura ou área estreita e chata, projetada ou encovada, que se utiliza para separar molduras ou áreas maiores. ${ }^{1}$

Garganta - Moldura com perfil de uma curva dupla em forma de um $\mathrm{S}$ alongado. ${ }^{1}$

Moldura de perfil côncavo usado nos enquadramentos, mais larga e menos profunda que a escócia. ${ }^{2}$

Moldura semi-redonda - Moldura com um corte transversal semicircular. ${ }^{1}$

Dado - Face vertical de um pedestal isolado, entre a base e a cornija ou sobrebase. Por extensão: zona análoga de todos os elementos arquitectónicos parecidos com pedestais da arquitectura romana e italiana. ${ }^{2}$

\section{A BOSSAGEM NO PAVIMENTO TÉRREO}

As fachadas dos três corpos no pavimento térreo tem como acabamento a bossagem, que nos remete ao emprego da rusticação.

Rusticação é a arte de trabalhar a alvenaria (de pedra) de modo a dar ao edifício, ou a porções do edifício, um caráter de ênfase especial. O termo transmite a idéia de algo rústico ou irregular, como as pedras apenas saídas da pedreira, porém, a forma mais comum encontrada na Antiguidade é o sulco profundo nas juntas entre as pedras. [... $]^{3}$

Summerson cita as obras de Bramante, como a casa de Rafael de 1512, já demolida; de Sansovino, o Pallazo Córner, em Veneza de 1532; a Sommerset House de Sir William Chambers, em Londres de 1780 - como exemplos de rusticação no primeiro pavimento. E também se refere ao tratado de Serlio, que dedica uma página aos tipos de rusticação, a qual associa com a Ordem Toscana. ${ }^{3}$

O embossamento, neste edifício, é um elemento integrador no pavimento térreo e estabelece uma grande linha horizontal, unindo os três corpos. É realizado neste edifício em argamassa sobre tijolos salientes e observa-se que é muito bem executado, com mais detalhes do que a ponta de diamante.

\footnotetext{
${ }^{1}$ CHING, Francis D. K. Dicionário Visual de Arquitetura.

${ }^{2}$ SILVA, Jorge Henrique Pais da; CALADO, Margarida. Dicionário de Termos de Arte e Arquitectura.

${ }^{3}$ SUMMERSON, John A Linguagem clássica da Arquitetura fig. 48, 49, 50, 51.
} 


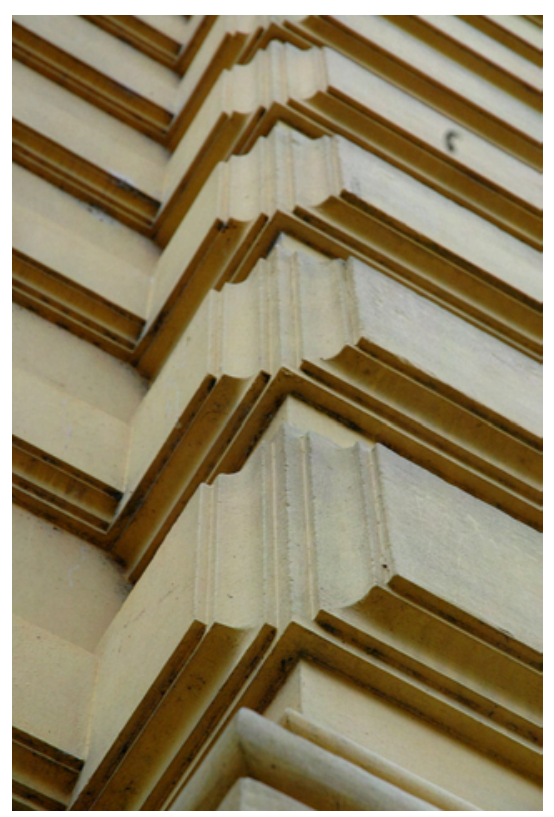

Fig. 15- Embossamento
Bossagem - Saliência sobre uma superfície. Almofada saliente. Pedra ou tijolo saliente numa parede. ${ }^{4}$

Almofadas salientes aplicadas às superfícies das paredes, sobretudo externas, em geral imitando o modo decorativo do aparelho de pedras de cantaria usado durante o período da Renascença ${ }^{5}$

Aparelho Rusticado - Tipo de aparelho em que o bloco de pedra é deixado com aspecto inacabado ou grosseiramente talhado, separado por juntas cavadas, usando normalmente nos pisos inferiores. Entre as variedades do rusticado, estão o ciclópico, que tem o aspecto da rocha em bruto; o de ponta de diamante, em que os blocos têm a forma de pirâmides de base quadrangular $[\ldots]^{6}$

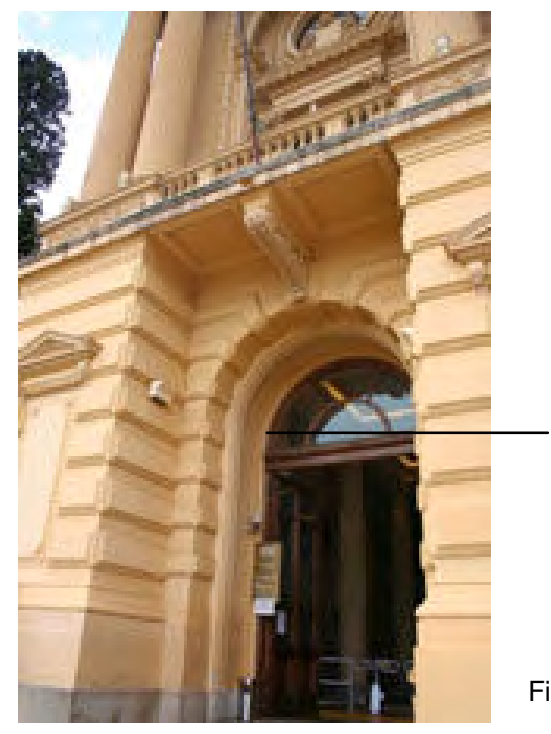

Segundo Bezzi, arcos com ornamentação rústica da Ordem Toscana

Fig. 16- Corpo Central Norte

\section{BALAUSTRADAS}

As balaustradas integram a ornamentação, também em linhas horizontais, de forma interrompida ou contínua.

No térreo e no primeiro pavimento, constituem-se de guarda-corpo corrido, sobre balaústres, dispostos regularmente que arrematam e servem de anteparo às portasbalcões, sacadas, e das loggias nas arcadas das galerias.

\footnotetext{
${ }^{4}$ CORONA, Eduardo; LEMOS, Carlos A. C. Dicionário da Arquitetura Brasileira.

${ }^{5}$ CAMPOS, Eudes. São Paulo: desenvolvimento urbano e arquitetura sob o Império. Em PORTA, Paula. (org.). História da Cidade de São Paulo v.2 - A cidade no Império 1823-1889.

${ }^{6}$ SILVA, Jorge Henrique Pais da; CALADO, Margarida. Dicionário de Termos de Arte e Arquitectura.
} 
São utilizadas na platibanda das Torres, em conjunto com as palmetas.

$\mathrm{Na}$ área interna, aparecem no corrimão da grande escada de mármore.

Os Balaústres acompanham em cada andar a ordem arquitetônica empregada, tendo no térreo uma forma simplificada, e no primeiro andar mais ornamentada.

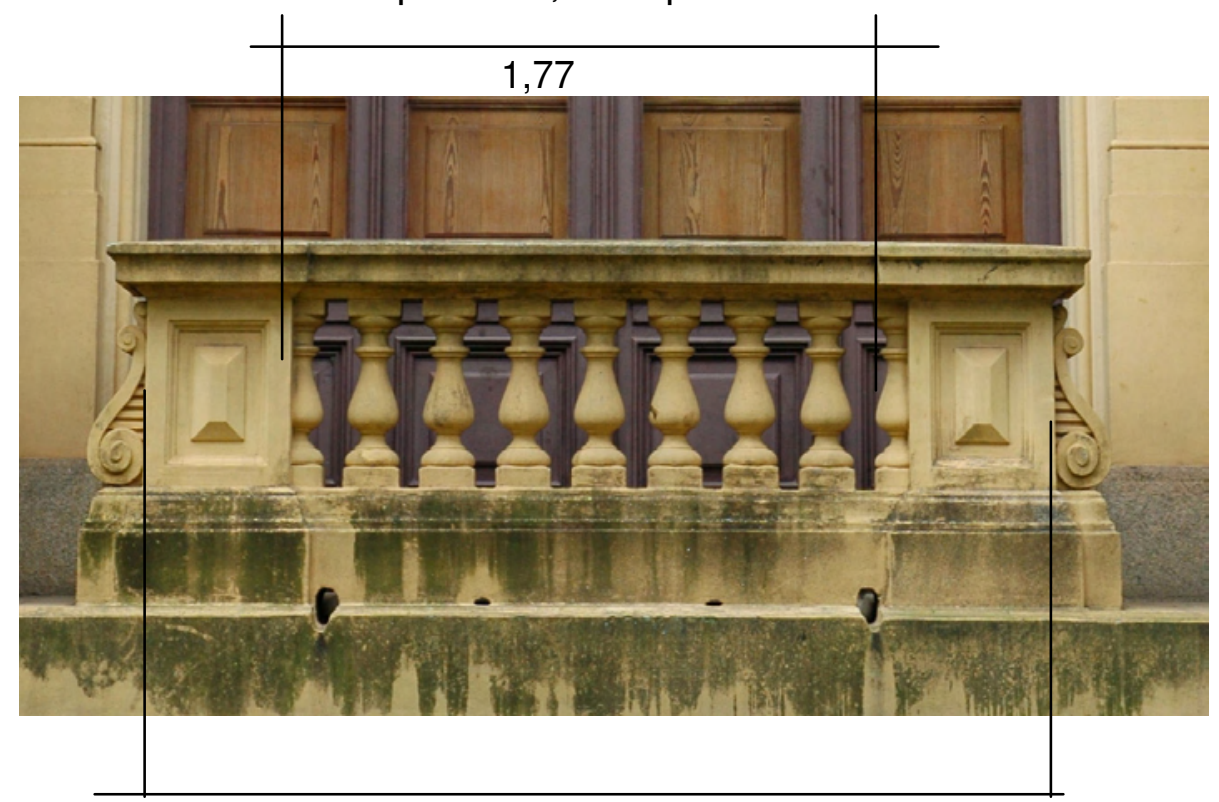

Balaústre Jônico

No pavimento térreo

7 balaustres e duas metades

2.82

No térreo, as balaustradas estão presentes nas Torres, Galerias e Corpo Central.

Ao longo de todo o térreo as balaustradas são arrematadas por um dado de cada lado, aos quais se encontram ladeados por uma mísula vertical.

Constitui-se num elemento independente da estrutura da parede.

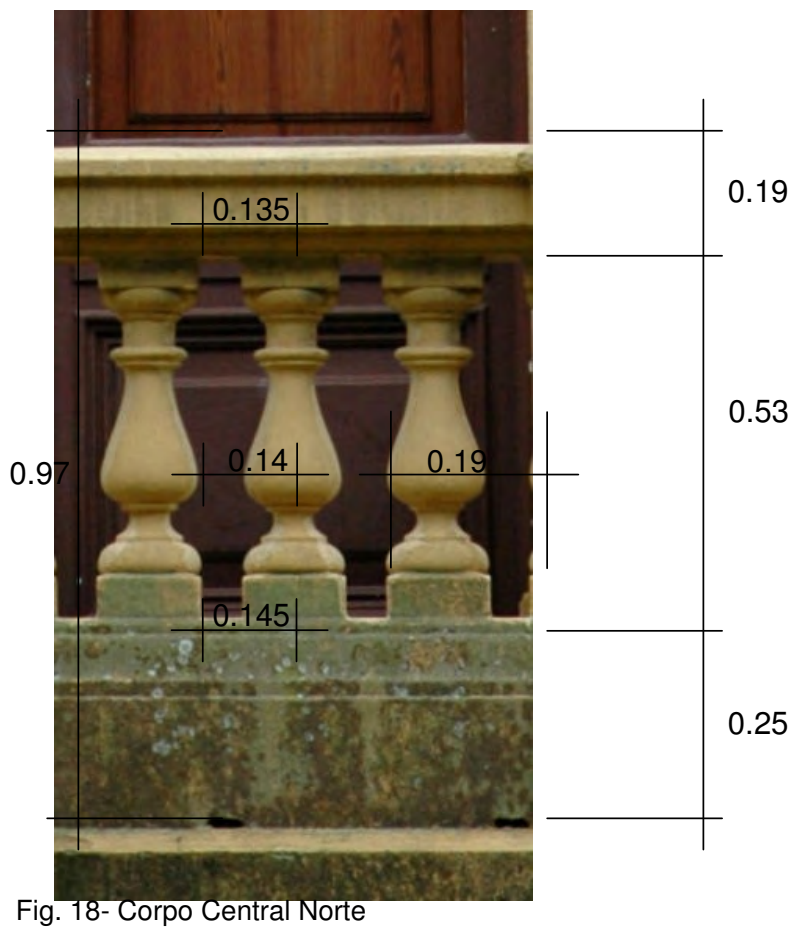

Balaustre - pequena coluna com base e capitel, dispostas em fila, ligadas em cima pelo corrimão.

Cornija ou Corrimão

Corpo ou Balaustre: formado por Base, Fuste e Capitel

Base - Soco 


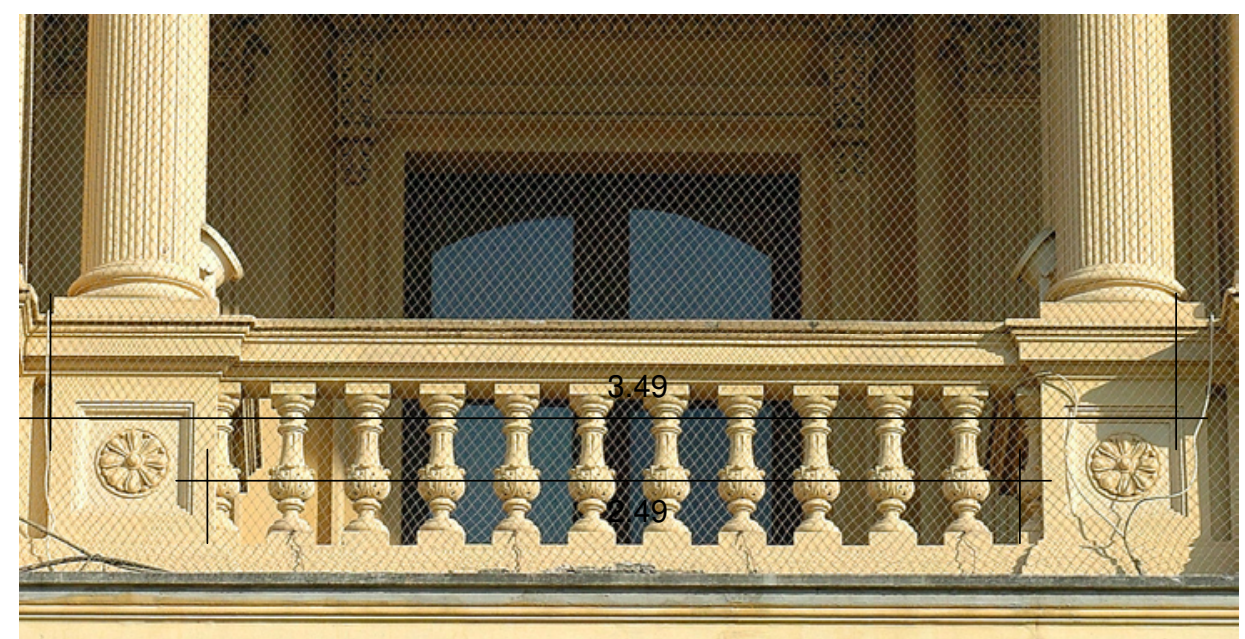

Balaústres Coríntios como guarda-corpo nas loggias das Galerias Norte.

No primeiro pavimento

10 balaustres

Fig. 19- Balaustrada Coríntia GN-O Galeria Norte - Oeste

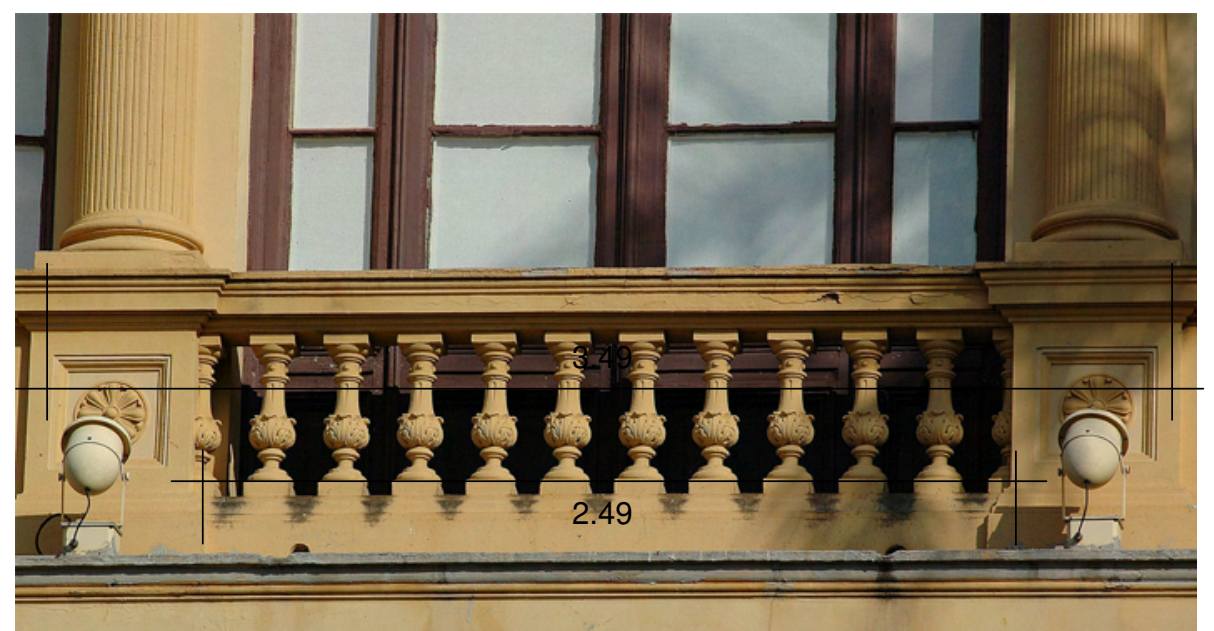

Balaústres Coríntios como guarda-corpo das portas -balcões das Torres.

10 balaústres

Fig. 20- Balaustrada Coríntia

TN-O Torre Norte-Oeste

Nas Torres e Galerias a balaustrada é contínua, apoiada lateralmente nas bases dos pedestais dos pórticos, decorados com uma roseta.

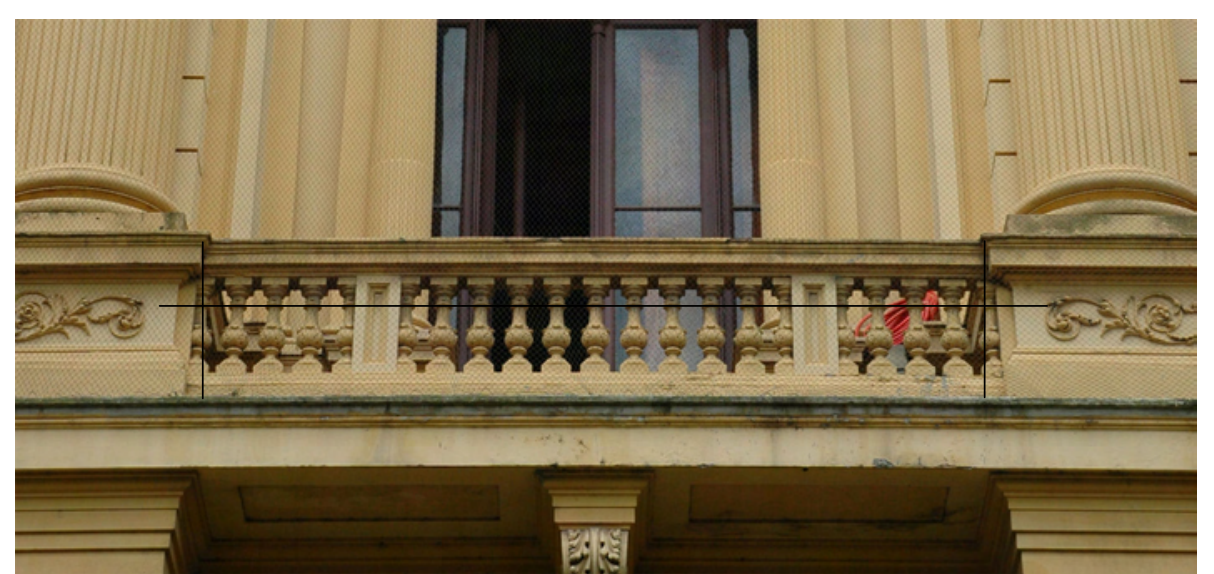

CCS - Corpo Central Sul
Balaustres Coríntios nos balcões do Corpo Central, Sul e Norte Maior extensão dos balcões

Fig. 21- Balaustrada 


\section{BALAUSTRADAS NA PLATIBANDA}

A balaustrada empregada na platibanda das Torres é de outro desenho, as quais Segurado chama de Econômica.

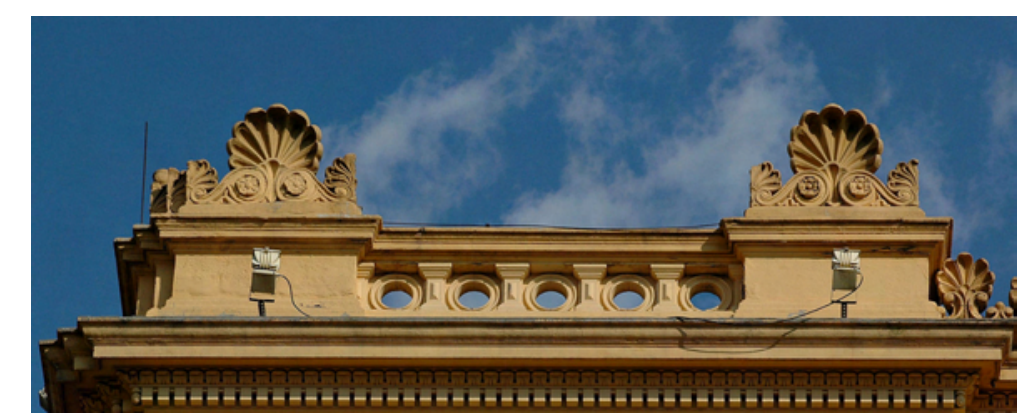

TS-O Torre Sul Oeste Balaustrada Econômica

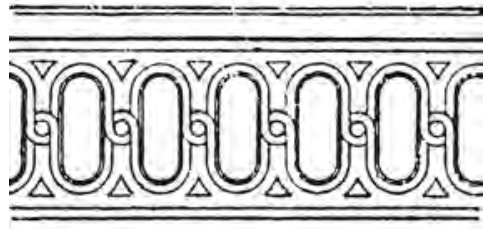

Fig. 22- Balaústre Platibanda

SEGURADO, João Emílio dos Santos.

Nas balaustradas denominadas Econômicas por Segurado, os balaústres são substituídos por lajes vazadas com desenhos diversos, o que apresenta uma economia quanto à construção individual das peças. Observa-se neste caso que o desenho é composto por círculos vazados, com uma moldura simples ao redor. Entre cada círculo, há uma pilastra quadrada com moldura central saliente retangular. As balaustradas são ladeadas por acrotérios com uma grande palmeta acima.

\section{ENTABLAMENTO: ARQUITRAVE, FRISO E CORNIJA}

O entablamento é o conjunto de elementos horizontais apoiados nas colunas, nas paredes e arcadas, e se divide em arquitrave, friso e cornija. É bem definido e em altura maior, em todas as faces do Corpo Central. Circunda também, em menor dimensão, a lateral inferior da platibanda nas Galerias, seguindo pelas Torres, na altura do piso do segundo pavimento. A faixa mais ornamentada do entablamento é a Cornija.

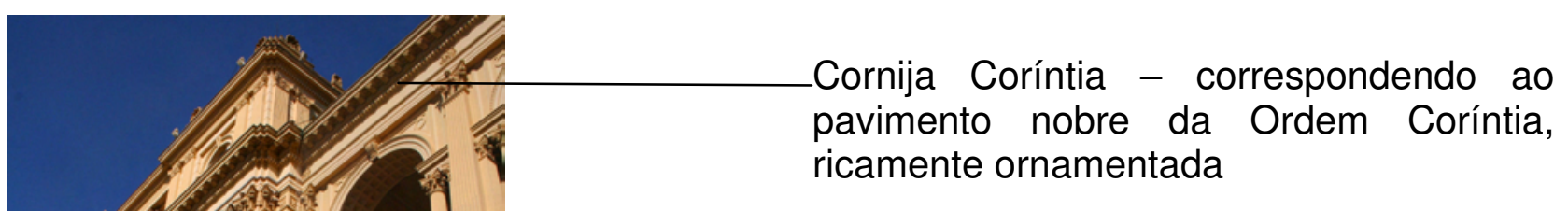

Friso liso

Fig. 23- Fachada Norte - Cornija e Friso

GN-L Galeria Norte Leste 


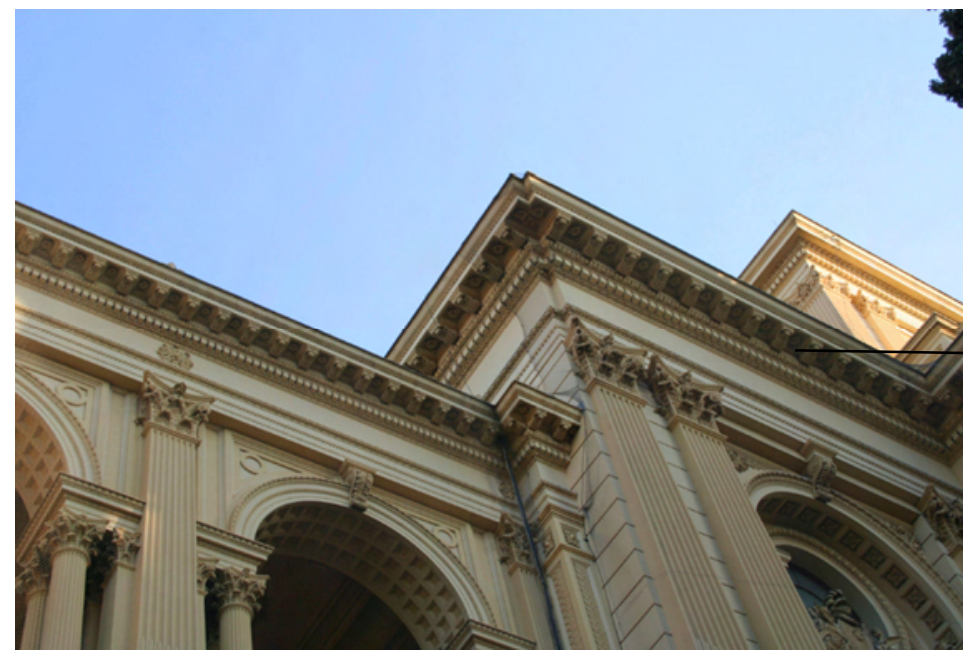

Entablamento com

Cornija Coríntia, no

Corpo Central em dimensão maior do que sobre a Galeria

Fig. 24- Entablamento

As cornijas são compostas de várias molduras e acompanham a ornamentação de cada pavimento. Nos tratados e manuais, há sempre um capítulo dedicado às molduras, apresentando suas formas mais conhecidas e sua nomenclatura.

Muitas vezes as molduras não são lisas, mas são ornamentadas de acordo com a riqueza do edifício.

Entre os ornamentos mais usados na arquitetura clássica contam-se: Óvulos, Palmas ou Palmetas, Entrelaçado, Gregas ou Meandros, Pérolas, Folhas de Acanto, Caneluras, Flores de Lódão, Ondas, Folhas de água.
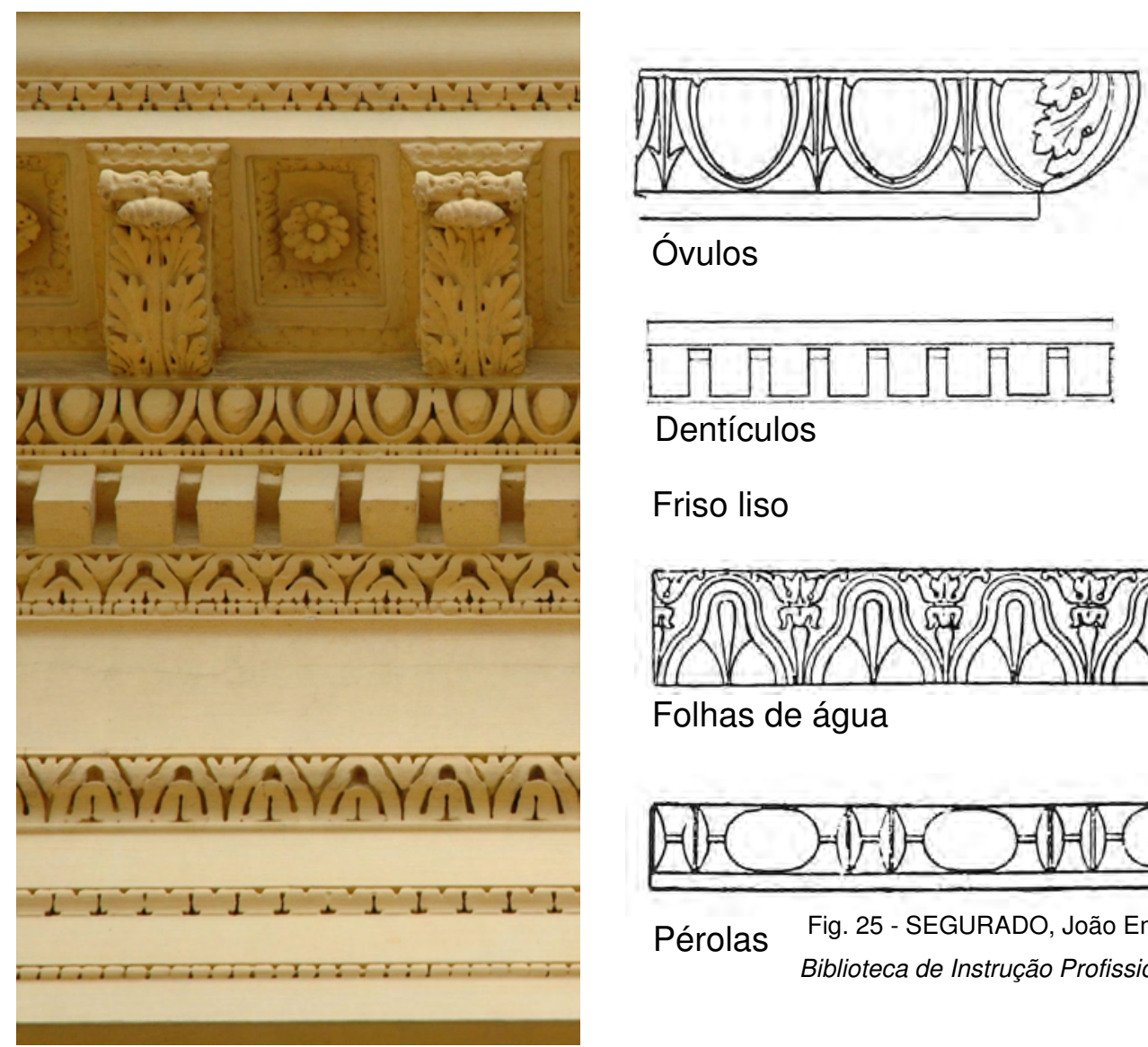

Dentículos

Friso liso

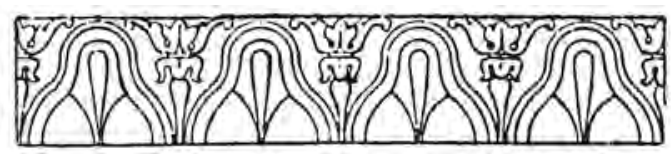

Folhas de água

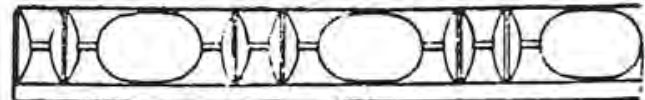

Pérolas

Fig. 25 - SEGURADO, João Emilio dos Santos.

Biblioteca de Instrução Profissional: Edificações. p. 73 
Óvulos são ornatos em forma de ovos, separados por nervuras ou dardos, de desenho variável; são muito usados na ornamentação dos óvalos. ${ }^{1}$

Dentículos Cada um dentre uma série de pequenos blocos retangulares pouco espaçados entre $\mathrm{si}$, que formam uma moldura ou que se projetam por sob as coroas das cornijas coríntias e compósitas. ${ }^{2}$

Pérolas são usadas para ornamentação dos astrágalos, etc. ${ }^{1}$

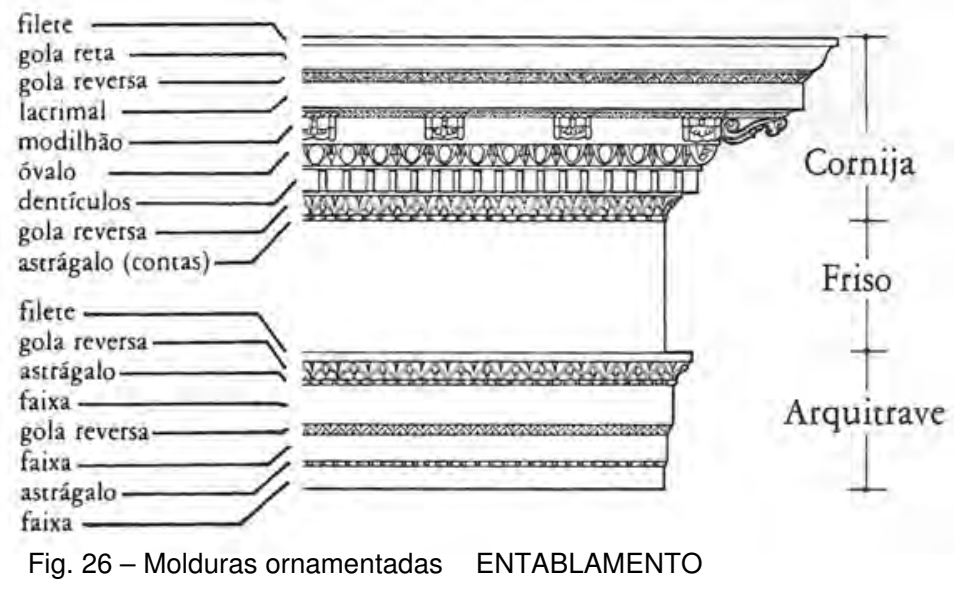

Os elementos acima citados fazem parte da cornija que está localizada no 1 - andar ao longo de todo o edifício. Esta segue a Ordem Coríntia presente no pavimento, sendo assim decorada com diversos tipos de molduras ornamentadas, e é muito próxima ao modelo desenhado por John Summerson no livro $A$ linguagem Clássica da Arquitetura, p.135.

O entablamento, juntamente com o frontão, são elementos que se originam da arquitetura arquitravada dos gregos, em que as colunas suportavam toda carga distribuída pela arquitrave e o entablamento. Neste, edifício as colunas, mesmo isoladas, recebem uma carga local e reduzida, e sua principal função é a ornamental. 


\section{FRONTÃO}

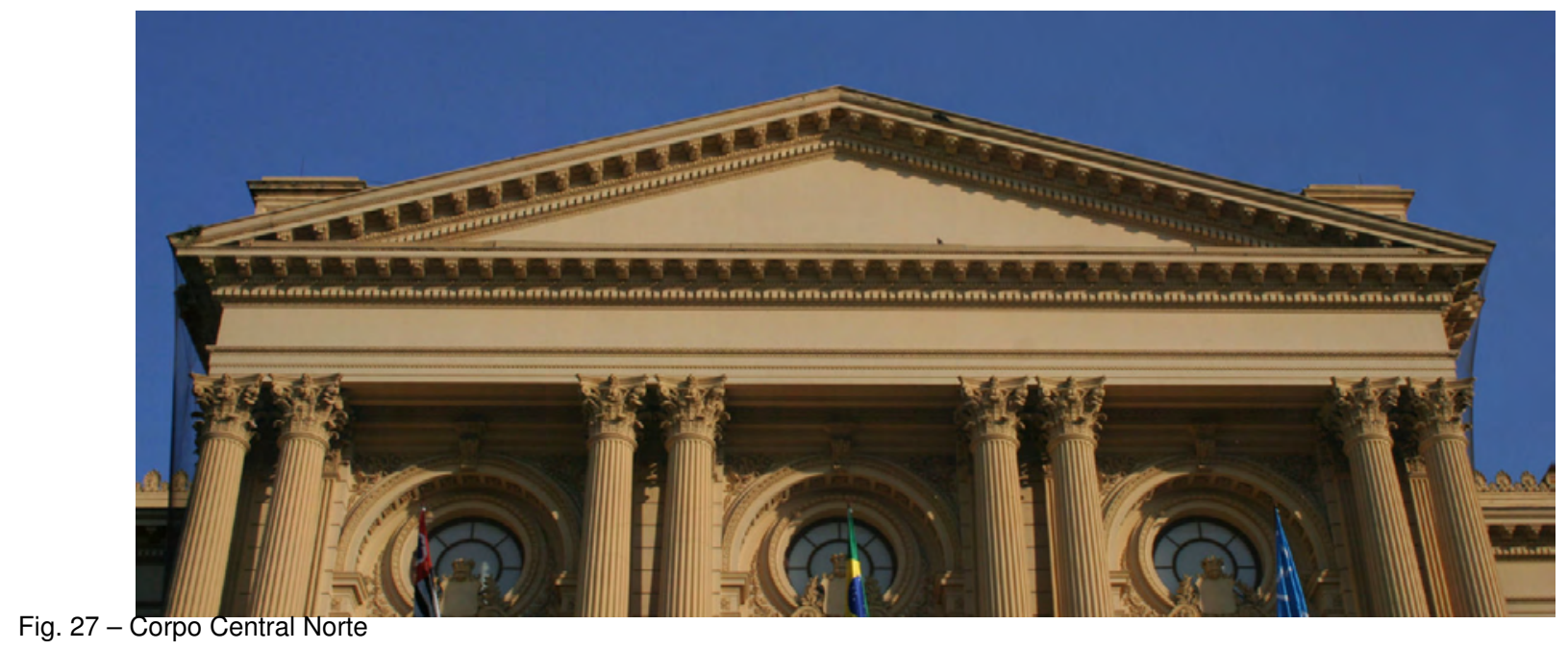

O frontão é um dos elementos que caracterizam esta linguagem.

Foram utilizados nos templos gregos, de bases retangulares, cujo telhado de duas águas era paralelo aos lados maiores da construção, fazendo assim com que a frente principal e a posterior apresentassem empenas triangulares, de pequena altura, que aquele povo ornamentava com frontões sobrepostos às colunas.

Os frontões são limitados inferiormente pela cornija do entablamento, reproduzindo-se esta, pelo menos em parte,nos outros dois lados do triângulo isósceles.

À parte central triangular dos frontões dá-se o nome de tímpano; a sua face está no mesmo plano da parede que Ihe fica inferior. Podem os tímpanos ser lisos ou apresentar baixos relevos. 


\section{MOLDURAS E PERFIS}

Todas as paredes das fachadas são ornamentadas, e as internas nas áreas nobres. A argamassa é aplicada sobre tijolos devidamente preparados, previamente recortados com os desenhos de cada local. São os ornamentos moldados in loco, como chamamos, para se diferenciar daqueles feitos em série de cimento romano.

Bezzi, no Documento 237 da Pasta 4, se refere no Parágrafo 5 à alvenaria de tijolos e à ornamentação das paredes

Alvenaria de Tijolos

Artigo 1 - Paredes: serão de tijolos chamados de primeira qualidade, como os que são empregados nos edifícios luxuosos da capital da província, tendo em média as dimensões de 7, 14 e 20 centímetros. Serão de argila homogênea, bem amassada e bem cozidos. [...]

A argamassa será composta com a proporção de 1/3 de cal e 2/3 de areia bem lavada. [...]

A ornamentação das paredes, menos os capitéis das pilastras e modilhões das cornijas, será toda feita com tijolos salientes, preparados expressamente para poder receber com toda segurança o emboço e reboco. [...]

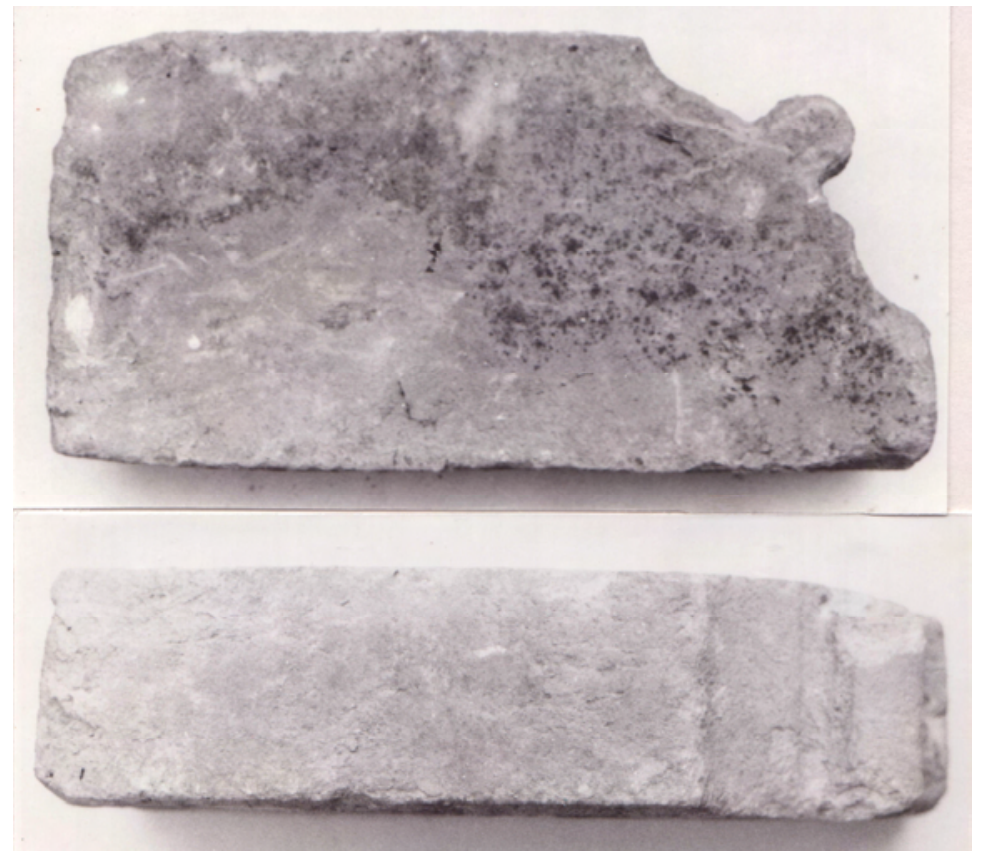

Fig. 28 - MY 01.15 - Acervo Museu Paulista

Este tijolo "preparado" é um importante exemplo, com desenho de uma moldura. Foi coletado nas escavações arqueológicas históricas realizadas no subsolo do Museu Paulista, em 1994, sob coordenação da Profa. Dra. Margarida Davina Andreatta.

Foi identificado como Tijolo do tipo Burro de barro cozido, sem marca e sem moldura

Os tratados e manuais descrevem em detalhes os tipos de molduras mais comuns. Apresentamos uma amostragem das existentes no edifício, constitutivas de parte indispensável de sua linguagem arquitetônica. 
As Molduras são um dos principais elementos decorativos usados em Arquitetura. São constituídas por superfícies planas ou curvas, limitadas entre arestas paralelas, mais ou menos salientes, servindo para destacar os diversos componentes de um edifício, para guarnecer os vãos das portas e janelas, etc. Podem ser ou não ornamentadas, segundo o grau de riqueza que se queira dar à construção.[...]

As Molduras simples, mais usadas em Arquitetura, são: Escapo, Filete, Facha, Astrágalo, Toro, Quarto de Círculo Convexo, Quarto de Círculo Côncavo, Meio Redondo Côncavo.

As Molduras compostas são as que resultam da combinação das molduras simples. As mais comuns são as seguintes: Gola, Garganta, Cimásio, Escócia, Escócia Profunda, Colarete, Lacrimal

SEGURADO, João Emilio dos Santos. Biblioteca de Instrução Profissional: Edificações. p. 65

As molduras estão aplicadas não somente ao plano das paredes, mas sobre bases das colunas, pilastras, seguindo um padrão da época. A seguir apresentamos uma amostragem e a nomenclatura respectiva.

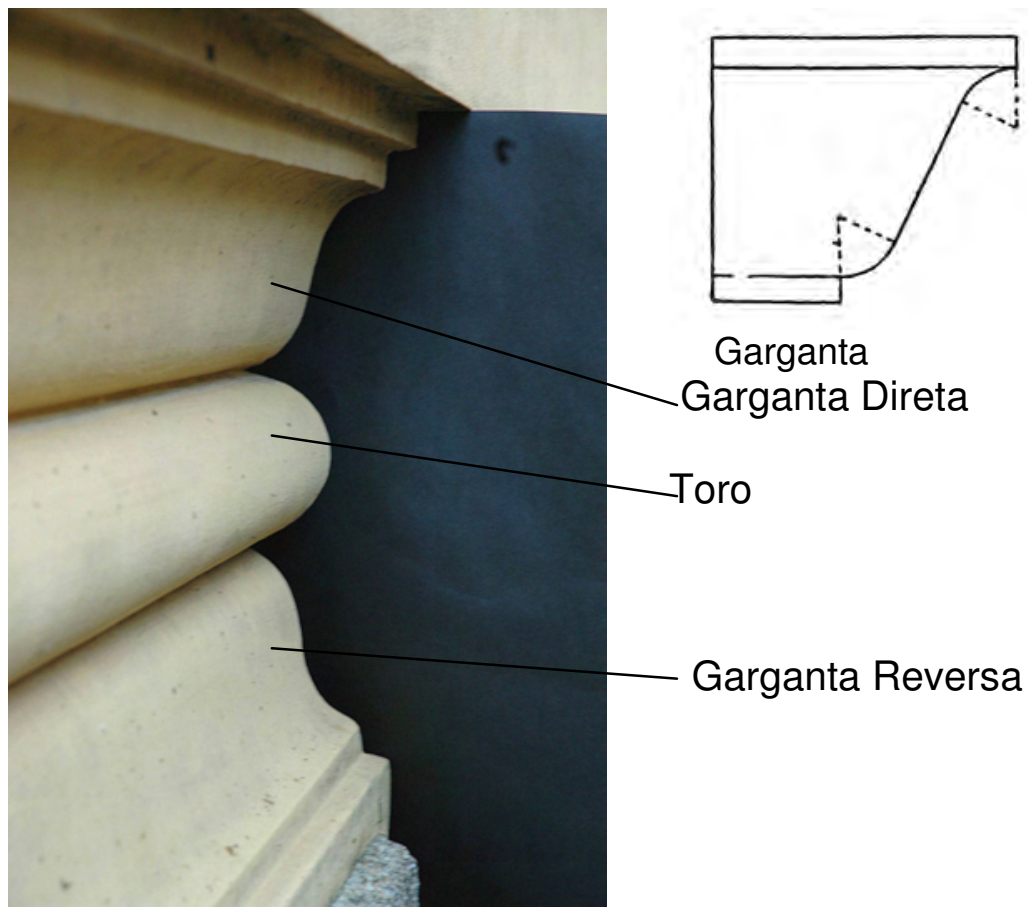

Garganta ou Papo de Rola é formada por dois quartos de círculo dispostos em sentido contrário. O quarto de círculo côncavo é a maior saliência da moldura. Quando este está na parte superior é chamada Garganta Direta. Quando está na parte inferior, é chamada Garganta Reversa. ${ }^{1}$

Toro moldura com perfil arredondado. $^{1}$

Altura correspondente ao Subsolo,Soco ou Envasamento 

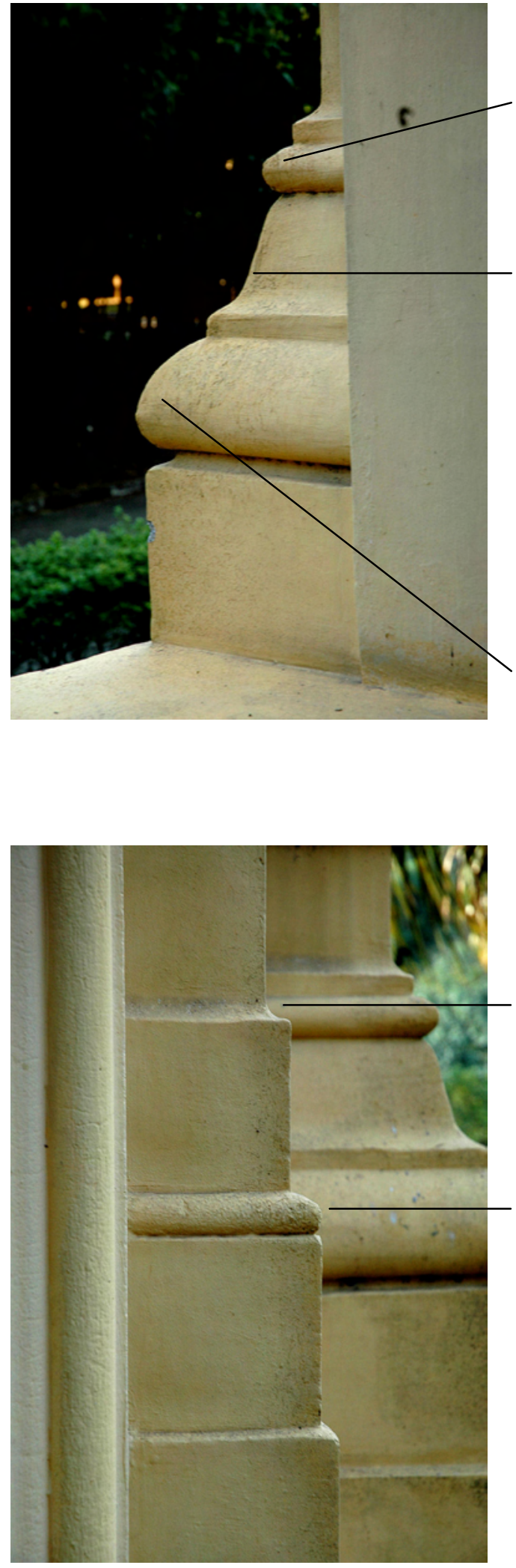

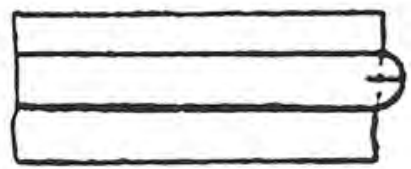

Astrágalo

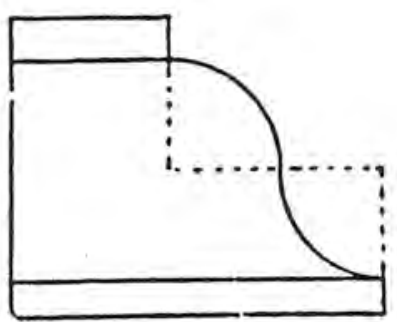

Garganta Reversa

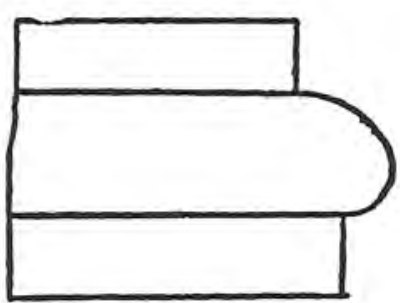

Bocel

Astrágalo ou Tondinho é uma moldura estreita, limitada entre duas retas horizontais e dois semi-círculos laterais, apresentando a convexidade para o lado de fora. Pode ainda ser chamado de cordão ou redondo. 1

Bocel geralmente não tem o perfil semicircular, mas é arredondado, formando bojo inferiormente. ${ }^{1}$

Fig. 30

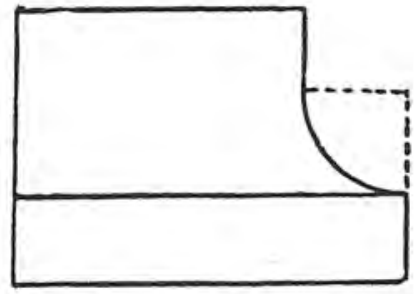

Escapo

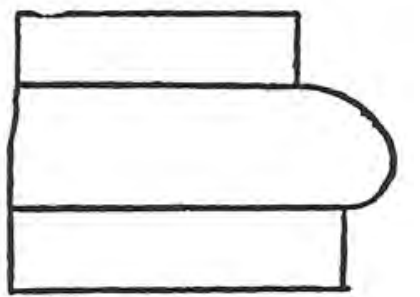

Bocel
Escapo é uma moldura côncava ligando entre si duas molduras ou corpos. Serve de transição entre uma moldura e um paramento, como acontece nas colunas, em que liga 0 fuste ao filete da base ou ao colarete superior. É muitas vezes um simples quarto de círculo. Pode ainda ser chamada de nacela ou meia-cana. ${ }^{1}$

Fig. 31 

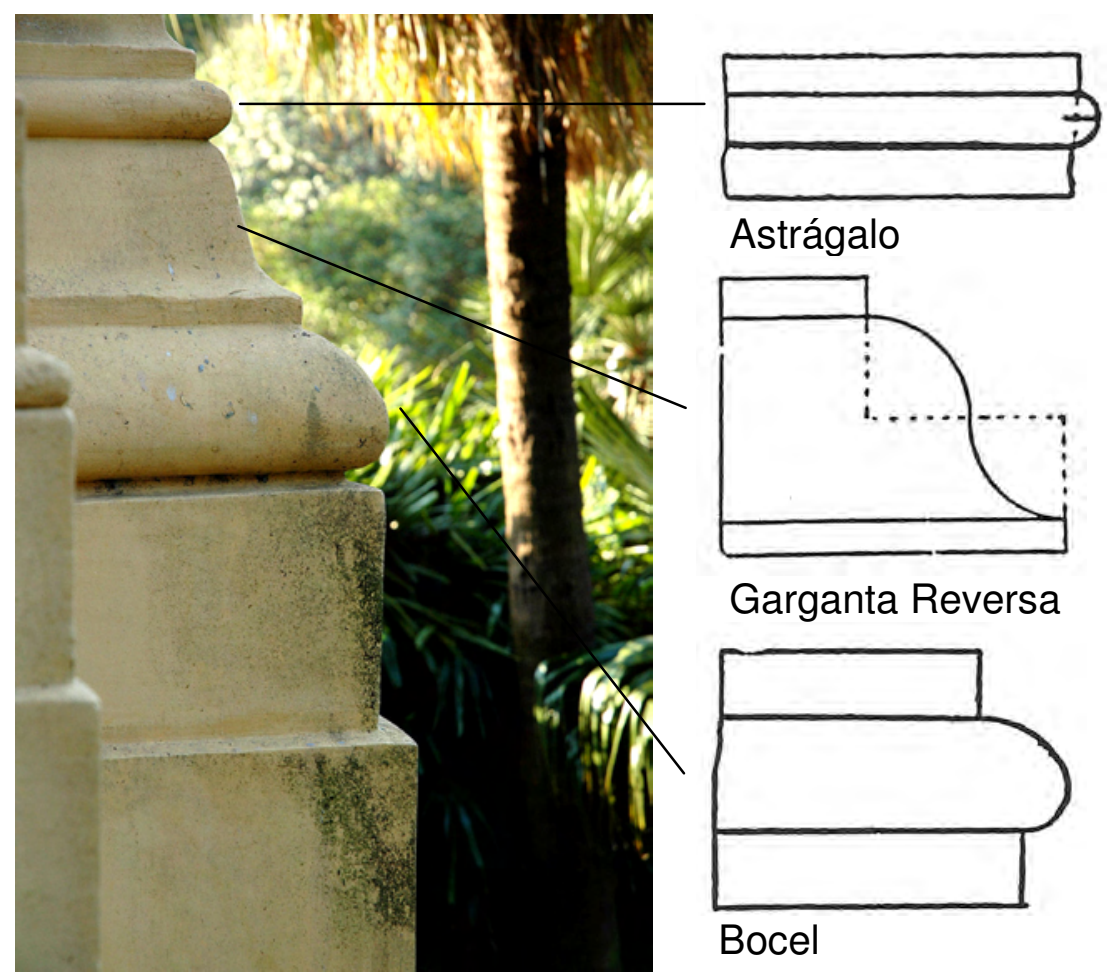

Astrágalo

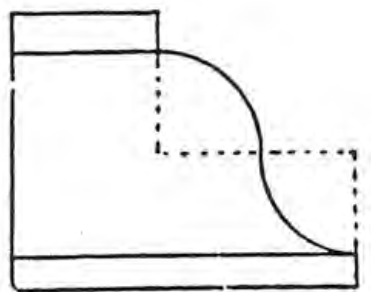

Garganta Reversa

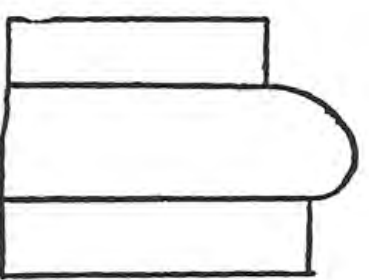

Bocel

Fig. 32

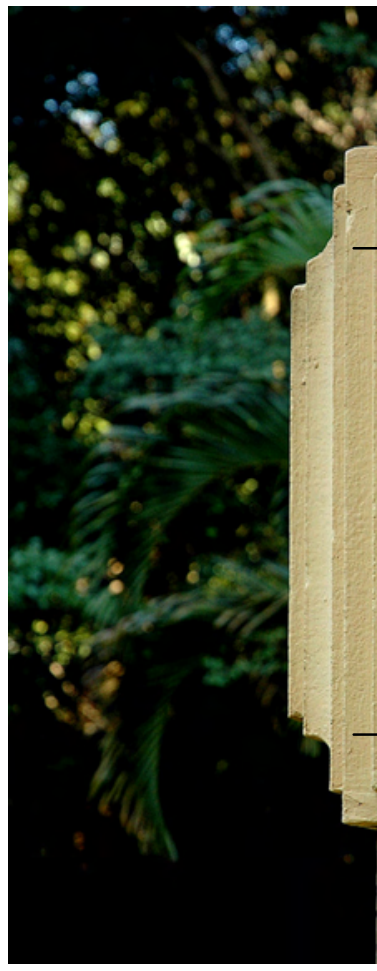

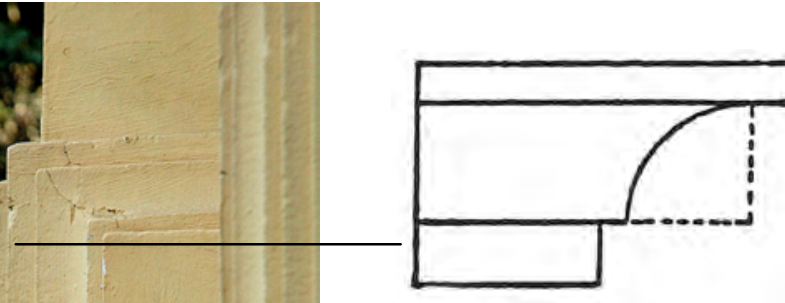

Quarto de círculo côncavo direto

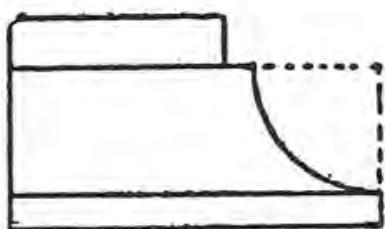

Quarto de círculo côncavo reverso
Quarto de Círculo Côncavo tem concavidade voltada para fora. Pode ser direto ou reverso, conforme a maior saliência esteja na parte superior ou inferior da moldura. Pode ser confundida esta moldura, quando tem pequenas dimensões, com o escapo Pode ser chamada ainda de cavado se as suas dimensões forem muito grandes. $^{1}$

Embossamento nas paredes do pavimento térreo 


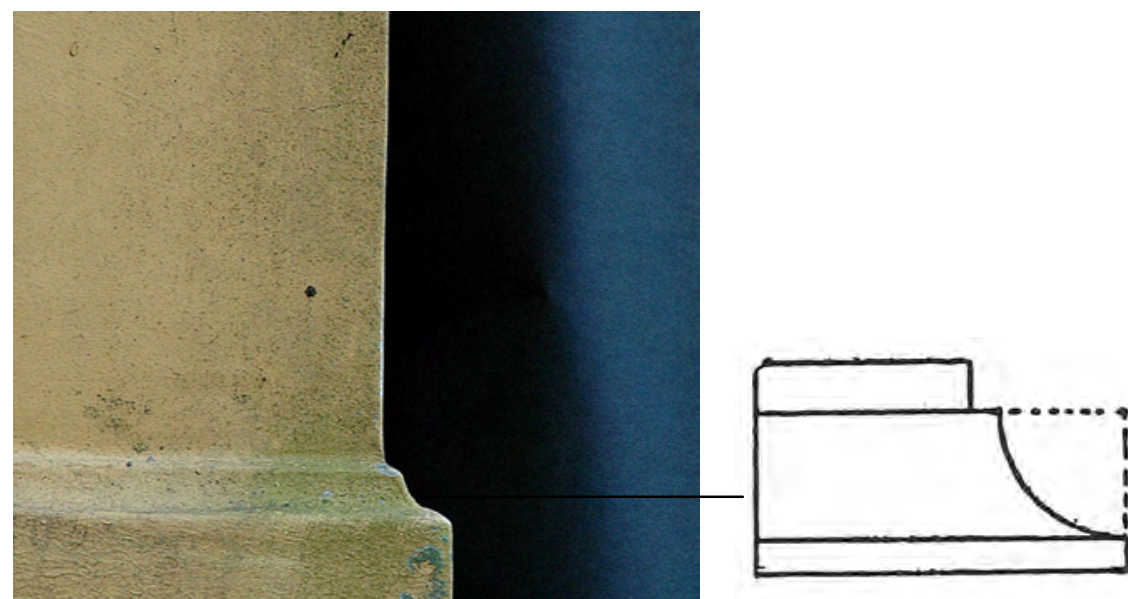

Quarto de círculo

côncavo reverso

Fig. 34

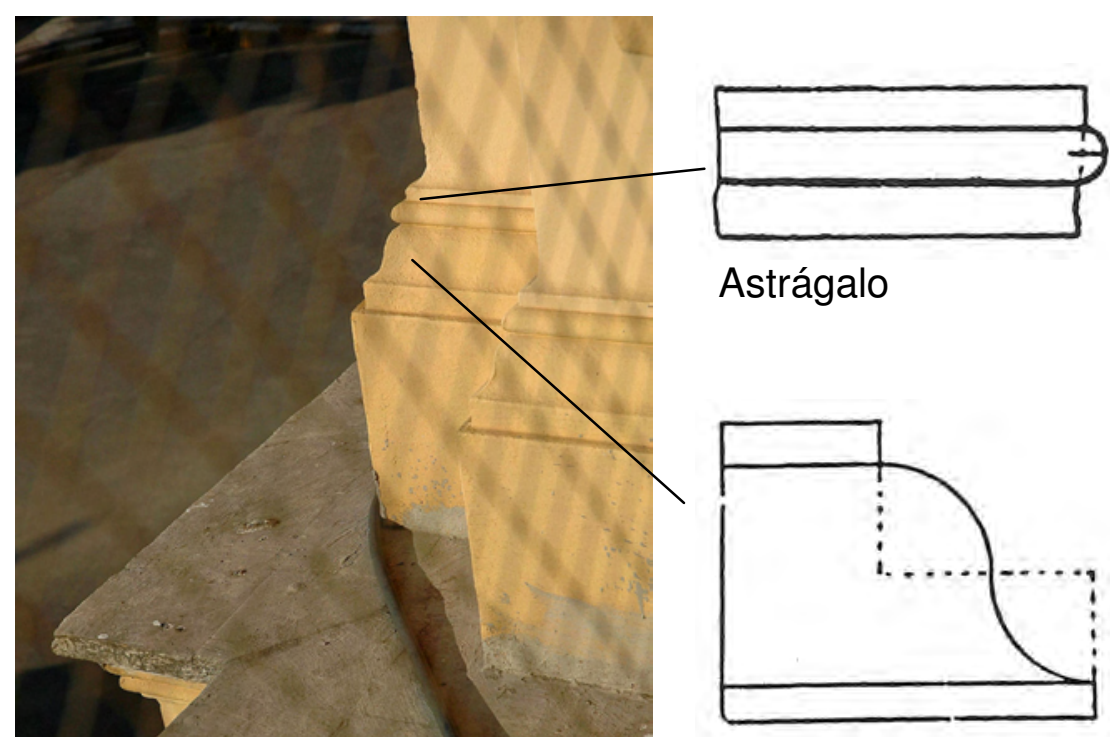

Garganta reversa

Fig. 35 


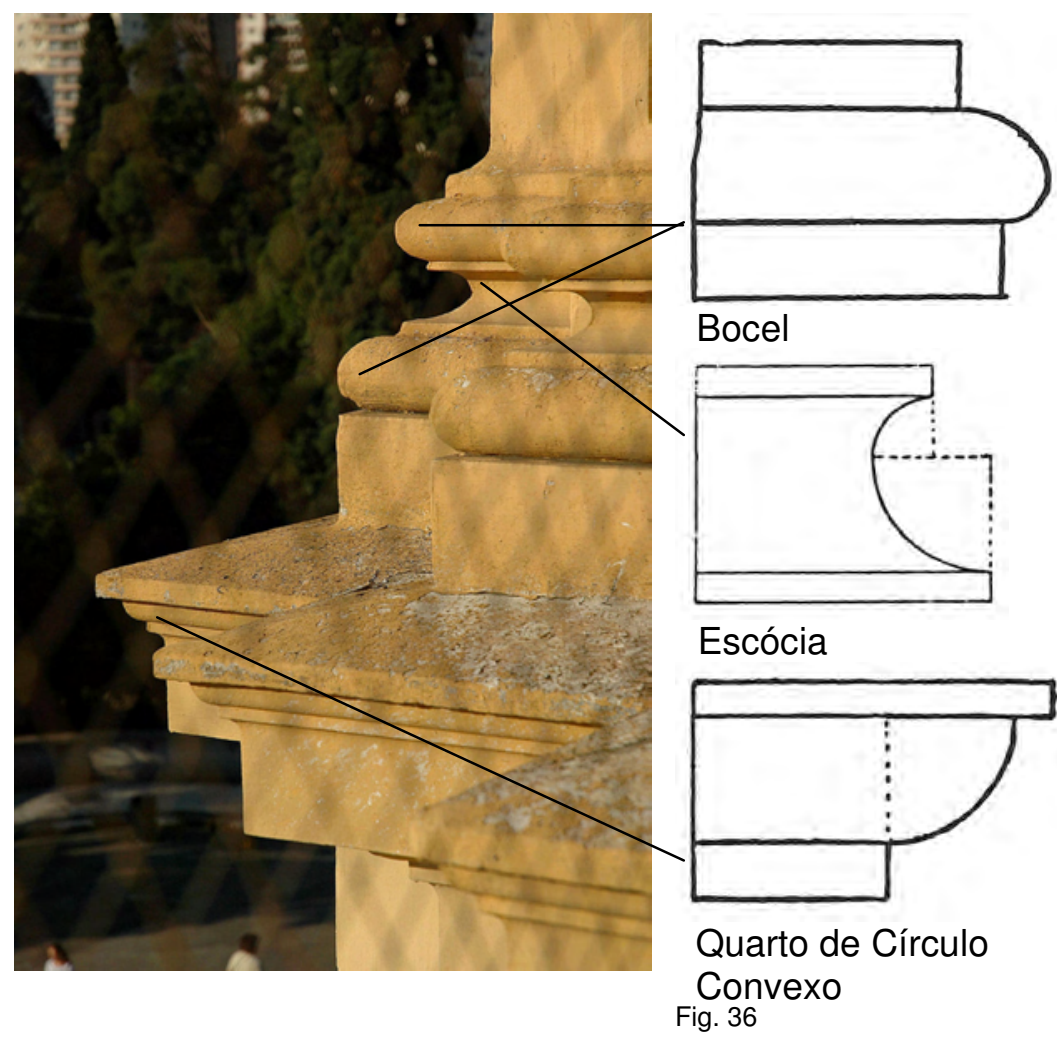

Escócia é uma moldura côncava, não simétrica, colocada geralmente entre dois filetes. Podem ser traçadas à mão ou por meio de arcos de círculo, tangentes às retas que limitam os filetes. ${ }^{1}$

Quarto de Círculo Convexo. Diz-se reverso quando a maior saliência fica na base da moldura. Pode do mesmo modo ser ou não um quarto de círculo perfeito. Ao quarto de círculo, de dimensões tais, que permita a sua decoração característica com óvulos separados por dardos, recebe o nome de óvalo. ${ }^{1}$

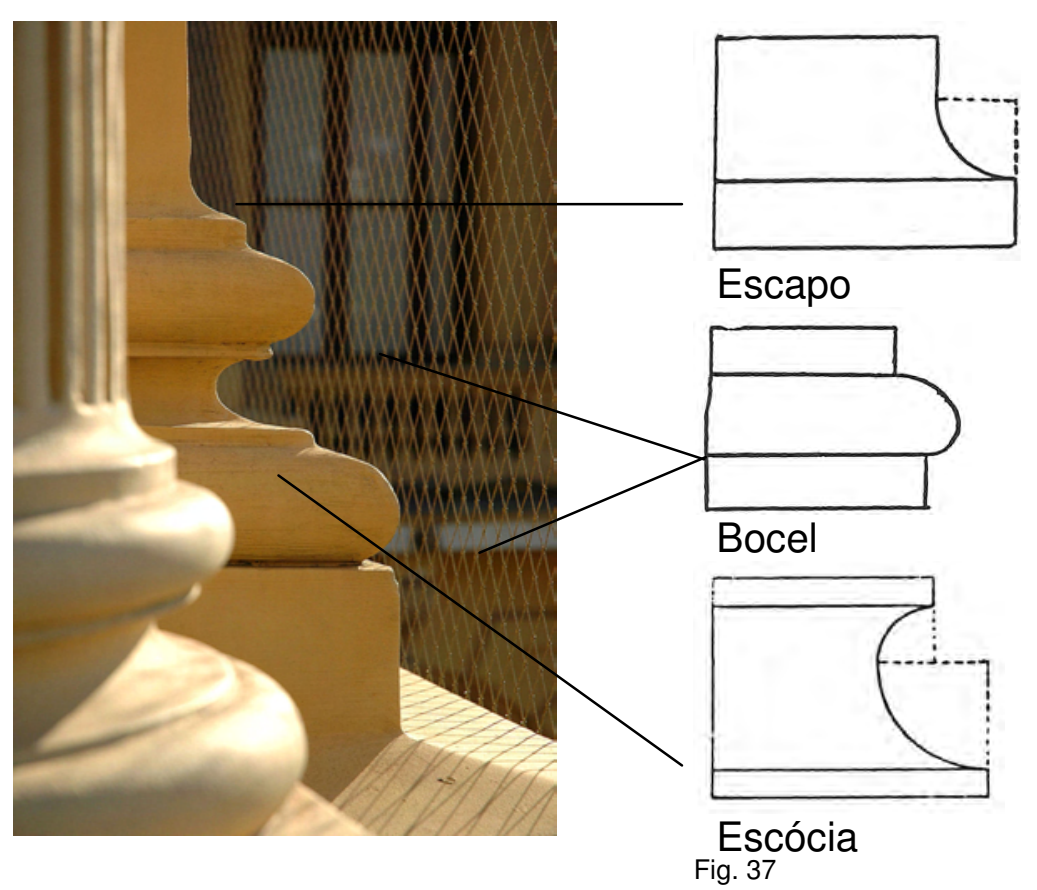




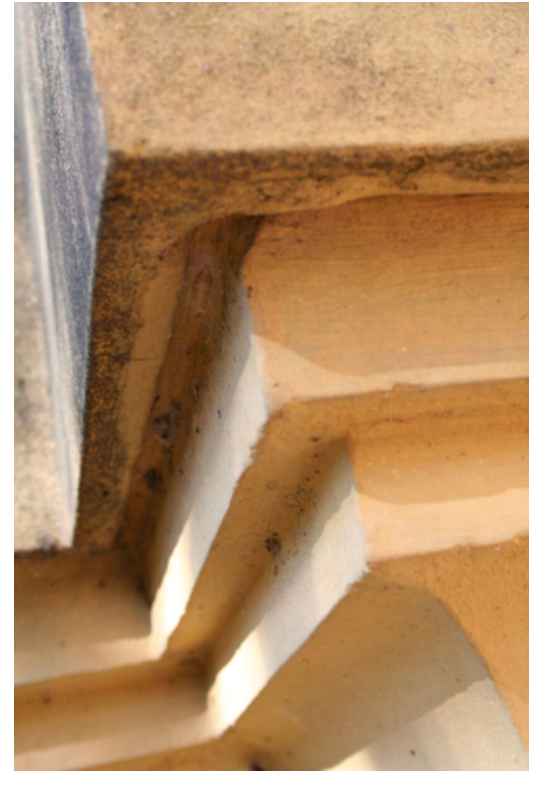

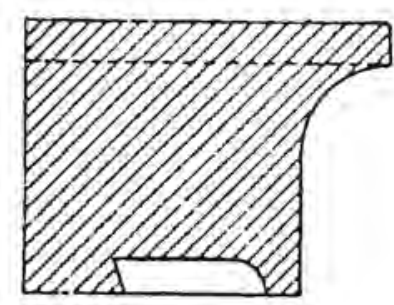

Lacrimal

Lacrimal ou pingadeira, é uma moldura apresentando uma faixa lisa, tendo inferiormente um cavado ou canal para fazer cair água da chuva, gota a gota, em vez de correr pelas molduras abaixo.

É indispensável em todas as cornijas e cimalhas. ${ }^{1}$

No edifício, os lacrimais ou pingadeiras são irregulares e algumas vezes inexistentes.

Fig. 38

1 SEGURADO, João Emílio dos Santos. Biblioteca de Instrução Profissional: Edificações. 


\section{O EMPREGO DAS ORDENS ARQUITETÔNICAS}

À primeira vista, o que se apreende deste edifício é uma profusão de ornamentos, cobrindo todas as superfícies de paredes externas e as internas nas áreas nobres. Mas assim que se iniciou o estudo, verificou-se que os elementos ornamentais e estruturais, estão relacionados entre si e se organizam de forma coerente e lógica. Esta coerência se baseia no emprego das Ordens Arquitetônicas, surgidas no mundo antigo ou "mundo clássico". Como foi descrito por SUMMERSON (1999, p.20,21), estas foram definidas através de cinco tipos padronizados de colunas, nos tratamentos também padronizados de aberturas, frontões e uma série de ornamentos. As Ordens foram desenvolvidas a partir da arquitetura dos templos, e assim constituem fundamentalmente o Sistema Arquitravado. A arquitetura clássica tinha como objetivo alcançar uma harmonia, e esta era obtida através de proporções aritméticas de todas as partes do edifício, relacionadas entre si.

SEGURADO (sem data, p.56 ) descreve ainda que Ordem é a disposição harmoniosa e regular das diversas partes de um edifício. É posta em evidência nas edificações com colunas, em que se torna fácil de apreciar a relação e a proporção entre os seus diversos elementos. A harmonia das formas e proporções aplicada aos suportes isolados, e mantida entre certos limites, levou à adoção de um certo número de tipos de colunas formando as Ordens Arquitetônicas.

A Antiguidade nos legou um certo número de ordens: a Toscana, a Dórica, a Jônica, a Coríntia e a Compósita. A primeira e a última são romanas e as três restantes gregas. A Toscana é a simplificação da Dórica e a Compósita uma variante da Coríntia, ou a soma da Coríntia com a Jônica.

\section{COMO O EMPREGO DAS ORDENS FOI TRANSMITIDO NO DECORRER DO TEMPO}

Apresentou SUMMERSON, (1999, p.7-9) a história dos tratados que se referem às ordens. Esse autor considera como tratado mais antigo o de Vitrúvio, arquiteto romano do século I d.C que, durante o reinado de Augusto, escreveu os cinco volumes $\mathrm{Da}$ Arquitetura. Esse tratado é, pelo menos, aquele mais antigo que sobreviveu até a Idade Média, tendo sido traduzido e legado à posteridade. Vitrúvio descreve três Ordens, a Jônica, a Dórica e a Coríntia, e faz algumas observações sobre a Toscana. Refere-se às origens delas, descrevendo os templos e a que Deus ou Deusa eram dedicadas. $O$ importante é que o autor não apresenta as ordens como um conjunto de fórmulas canônicas, que resumiriam em si toda a virtude arquitetônica. Isto só será feito pelos teóricos da Renascença.

Em meados do século XV, 1400 anos depois de Vitrúvio, Leon Battista Alberti oferece nova descrição das Ordens, considerando em parte Vitruvio e em parte suas próprias observações de ruínas romanas. Como resultado, acrescentou uma quinta ordem em sua descrição, a Compósita. Mas foi Sebastiano Serlio, homem da Alta Renascença, quase um século depois, quem legou às Ordens, agora cinco, uma autoridade canônica, simbólica, quase lendária. $O$ maior serviço que prestou à arquitetura foi a compilação da primeira gramática arquitetônica da Renascença.

Ao longo da história da arquitetura clássica, a especulação quanto aos tipos ideais de cada Ordem era uma constante, oscilando entre o respeito preciosista e a pura invenção pessoal. Entre estes extremos ficam as Ordens definidas e publicadas pelos grandes teóricos - Sérlio em 1537, seguido por Vignola em1562, Palladio em 1570 e Scamozzi em 1615. 
Os textos de autoria desses tratadistas têm uma característica em comum, pois se referem às ordens empregadas nas fachadas dos edifícios. Os edifícios romanos, por exemplo, foram alvo de interesse dos arquitetos renascentistas do século XVI. Neste momento, porém, eram poucos os edifícios que haviam se conservado intacto o seu interior. Em sua maioria apresentavam maior quantidade de elementos nas fachadas, e assim tiveram uma concepção incompleta. Tratava-se de edifícios construídos com arcos e colunas, apresentando diversas ordens, ou seja, diversas proporções entre seus elementos. Por isso, os tratados de Alberti, de Serlio, se referiam sobretudo, aos detalhes das fachadas, e, em particular as proporções das colunas, pedestais, entablamentos, as dimensões de pilastras, arquitraves, perfis das molduras, composição de arcadas, pórticos e frontões.

\section{AS ORDENS SOBREPOSTAS}

Também relata SUMMERSON (1999,p.19), que o Coliseu de Roma, do século I d.C., foi um dos edifícios com que os homens da Renascença mais aprenderam, pois permitiu introduzir o tema de arcos e Ordens combinados, e é o exemplo mais antigo de Ordens Sobrepostas ou seja, a Dórica no térreo, forte e simples; a Jônica, mais leve, no seguinte; a Coríntia, mais elegante no último andar aberto, e no andar superior, a Compósita, numa solução fechada.

A seqüência de arcos é emoldurada por colunas, adossadas ao maciço de parede, ou esculpidas em relevo, que, se tiver função estrutural, é muito pequena. Mesmo com o que sobrou da fachada, pode-se observar as Ordens Sobrepostas no Coliseu, e os espessos arcos que depositam sua carga nos maciços de alvenaria, conhecido por pé-direito. As colunas estão como esculpidas na parede, adossadas em $2 / 3$, e sob a saliência proporcional do entablamento.

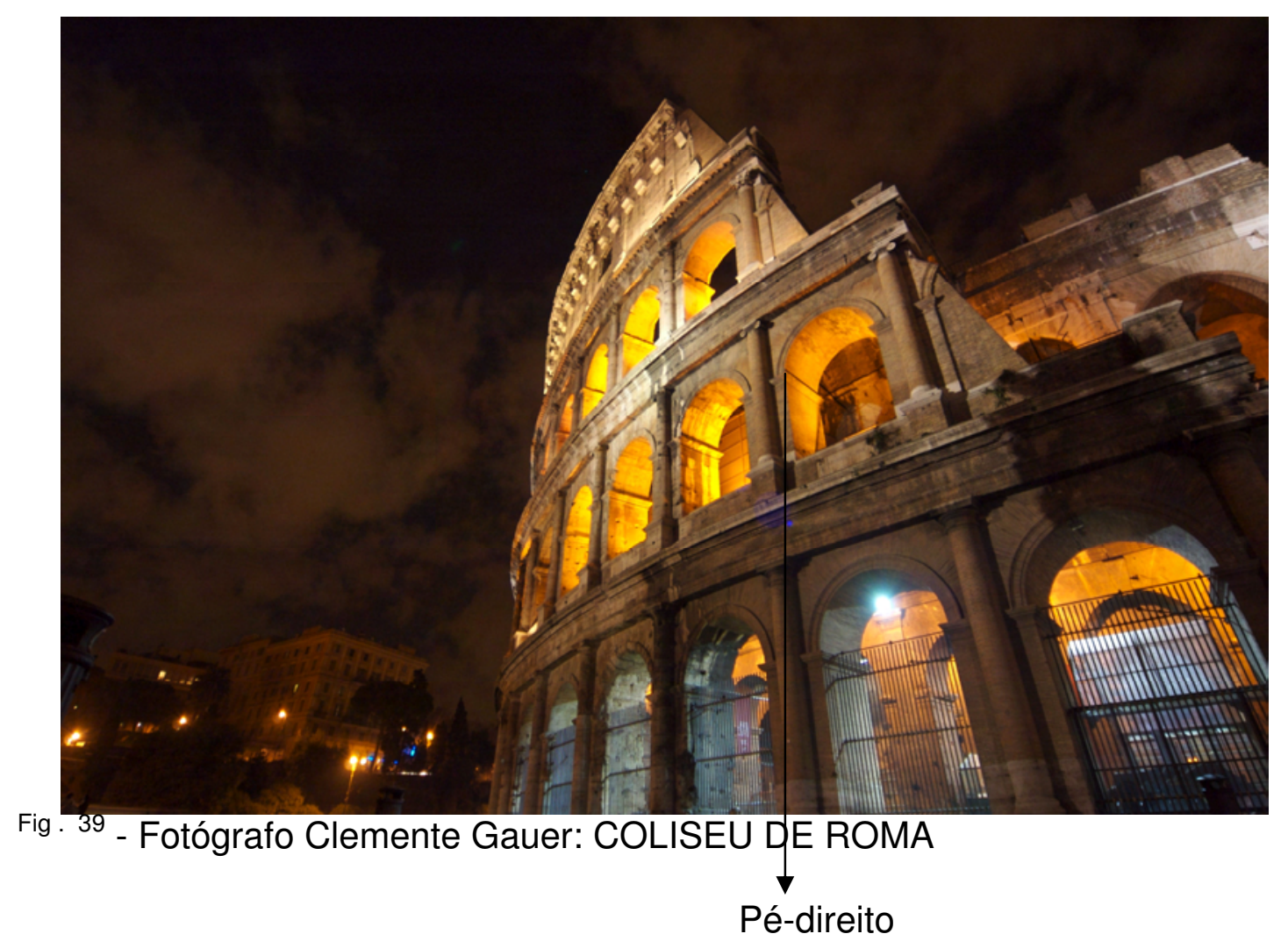


$\mathrm{Na}$ parte interna do Coliseu, houve grandes perdas. Devido às ruínas, não se pode observar se foram empregadas as ordens correspondentes à fachada. $\mathrm{O}$ que há em quantidade é o emprego de abóbadas cilíndricas, que, segundo MATEUS (2002, p.84), são as que têm o intradorso, uma superfície cilíndrica de revolução, e correspondem ao tipo de abóbadas, mais freqüentemente construídas a partir da Antiguidade, sendo as de mais fácil execução para a cobertura de espaços retangulares, uma vez que necessitavam apenas de duas paredes portantes.

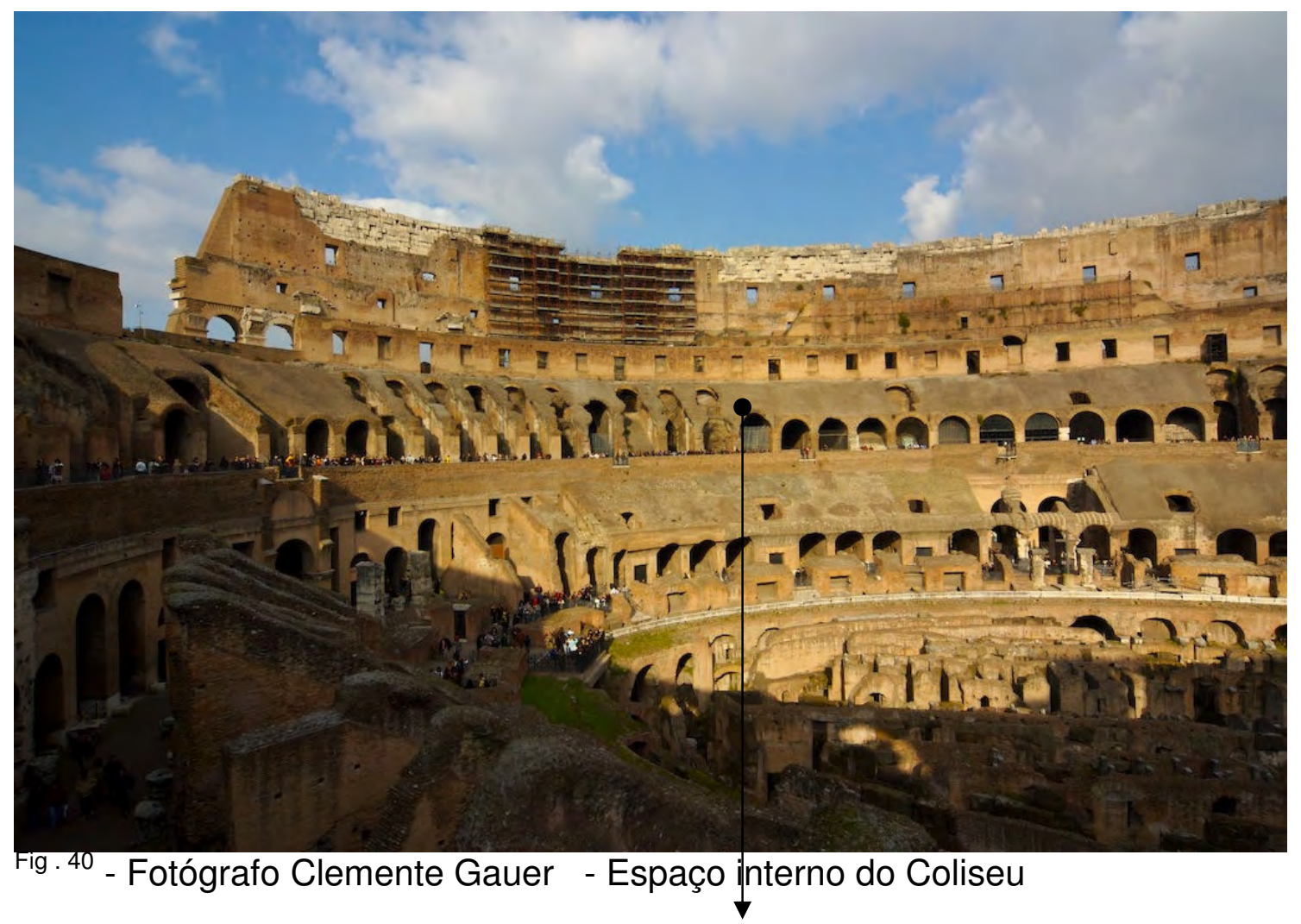

Abóbadas cilíndricas ou abóbada de berço

No edifício do Museu Paulista, Bezzi adotou este sistema, as Ordens Sobrepostas, utilizando em cada pavimento uma ordem diferente, com funções determinadas em relação à estrutura, à ornamentação, e segundo os espaços internos.

O primeiro pavimento, sobre o embasamento, externamente tem como acabamento das paredes, a bossagem em toda volta dos três corpos do edifício. Bezzi, ao se referir aos arcos das portas de entrada do Corpo Central, afirma que foram executados com uma ornamentação rústica toscana. Dessa forma, podemos considerar que esta é a ordem utilizada na face externa do pavimento térreo.

Neste pavimento, a ornamentação utilizada nos espaços internos, o átrio, galerias e torres, é da Ordem Jônica. No átrio há 12 colunas Jônicas, com "alma" de metal, que estruturam o piso do Salão Nobre. As paredes e pés-direitos são robustos, pois 
correspondem ao pavimento que suporta a carga de todo edifício, apoiado sobre o embasamento.

A escadaria central é trabalhada com a Ordem Coríntia, e assim introduz esta ordem no primeiro pavimento nas Galerias, nas Torres e no Salão Nobre.

À Ordem Coríntia correspondem os espaços mais nobres, pois é considerada a ordem mais elegante, a mais delicada e requintada, e geralmente não é utilizada no andar térreo. As colunas, pilastras e seus capitéis, entablamento, cornijas, molduras e frisos ornamentados, os balaústres do primeiro pavimento, são trabalhados com a Ordem Coríntia e se destacam no conjunto pela riqueza de formas e desenhos.

A Ordem Compósita, considerada pelos historiadores como resultado da união da Ordem Jônica com a Ordem Coríntia, é utilizada no segundo pavimento das Torres, em suas fachadas externas, e na região superior das paredes internas do Salão Nobre.

Neste estudo, mesmo relativo ao emprego das ordens, é considerado o edifício como um todo, não apenas no que se refere às suas fachadas. As soluções estruturais e o repertório ornamental estão profundamente relacionados, e não há nenhum sentido considerar apenas as paredes envoltórias. O estilo e a técnica construtiva são totalmente dependentes, um não existindo sem o outro. Se, por exemplo, as colunas não se encarregam de grandes cargas, outros elementos foram criados com esta finalidade. Não é possível separar a função estrutural da função ornamental, em seus principais elementos.

E sobre esta questão, SUMMERSON se refere ao que chama de gramática da Antiguidade, ou seja, ao fato de que para se realizar a linguagem clássica, não basta pendurar colunas, entablamentos e frontões em uma estrutura. A estrutura e a expressão arquitetônica devem estar integradas, formando um todo.

Ainda de acordo com esse autor, são importantes os conceitos sobre os sistemas arquitravado dos gregos, o de arcos e abóbadas dos romanos, quanto às diferenças que ambos apresentam nas funções estruturais. Os principais edifícios romanos, com exceção dos templos, eram construídos de arcos e abóbadas, e combinavam os dois sistemas. Os romanos tomaram as Ordens da arquitetura dos templos, e as manipularam para decorar e controlar seus monumentos seculares. Destaca-se, então, que o sistema arquitravado, em que as colunas sustentavam a carga da arquitrave, passou a ser apenas um meio de expressão. O sistema de arcos requeria maciços, para suportar as forças oblíquas dos arcos, e as colunas delgadas não poderiam ter esta função. Além disso, o sistema de arcos aumenta o intercolúnio, e as abóbadas permitem novo meio de cobertura de espaços. 


\section{A APLICAÇÃO DAS ORDENS NO EDIFÍCIO - FOTOS DA CONSTRUÇÃO}

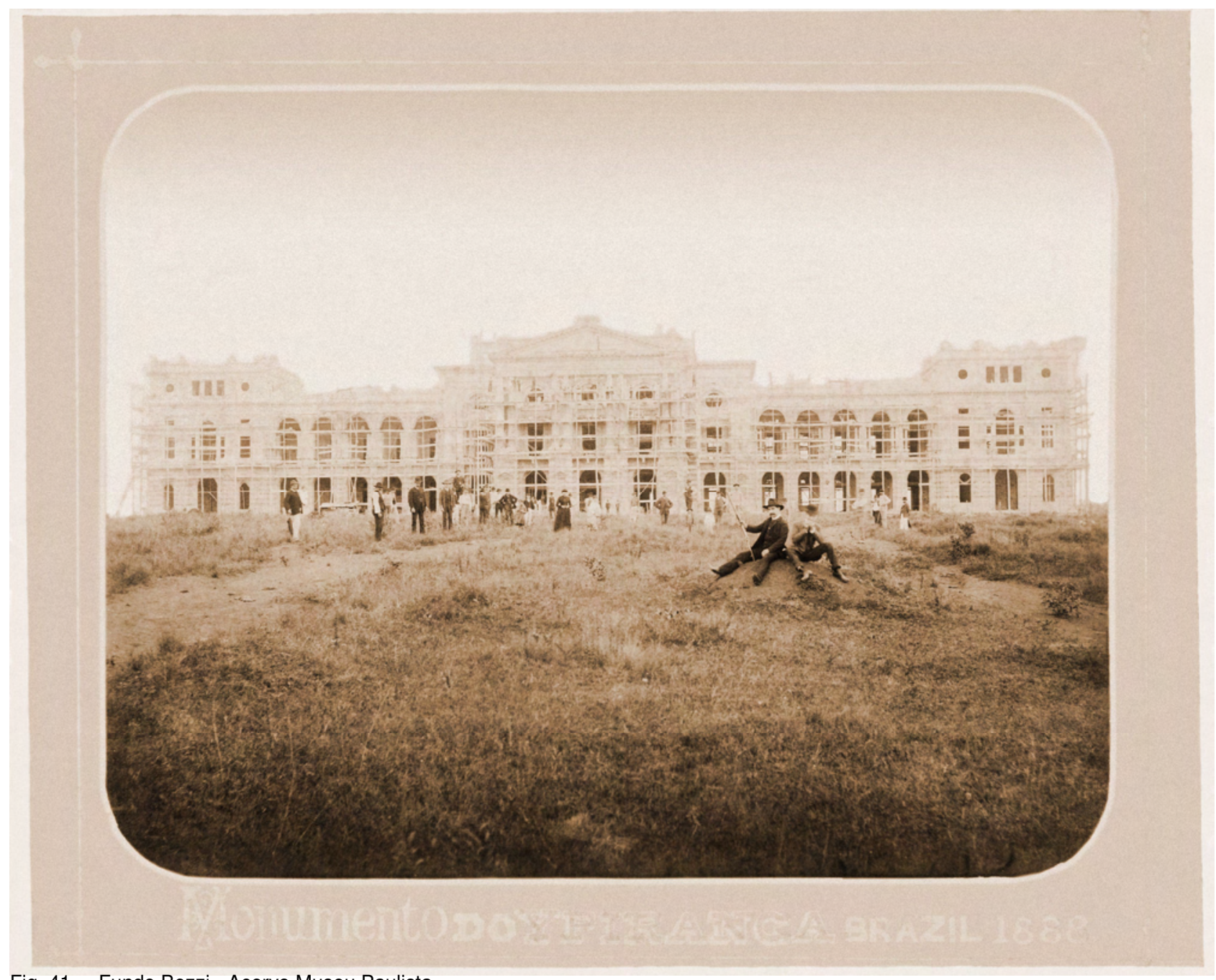

Fig. 41 - Fundo Bezzi - Acervo Museu Paulista

IC 13278 - Monumento do Ypiranga Brazil 1888

As fotografias de IC 13278 e 13280 são as mais antigas que foram utilizadas nesta pesquisa, pois apresentam o edifício ainda em construção, com os andaimes montados nas fachadas, para a execução de acabamentos nos revestimentos, e a execução de entablamento e colocação das colunas nas arcadas das galerias. As fotografias foram parcialmente restauradas.

Através de detalhes ampliados, pode-se constatar funções estruturais de colunas e arcos nas arcadas, que vieram a comprovar que os arcos das galerias são sustentados pelos pés-direitos, e as colunas, no máximo, recebem somente cargas localizadas, e não de toda arquitrave da galeria.

O edifício, no momento correspondente à imagem, apresenta a alvenaria construída até o ático, e a estrutura ainda desprovida das finalizações de revestimento, pisos, caixilhos, etc. 


\section{GALERIA OESTE}

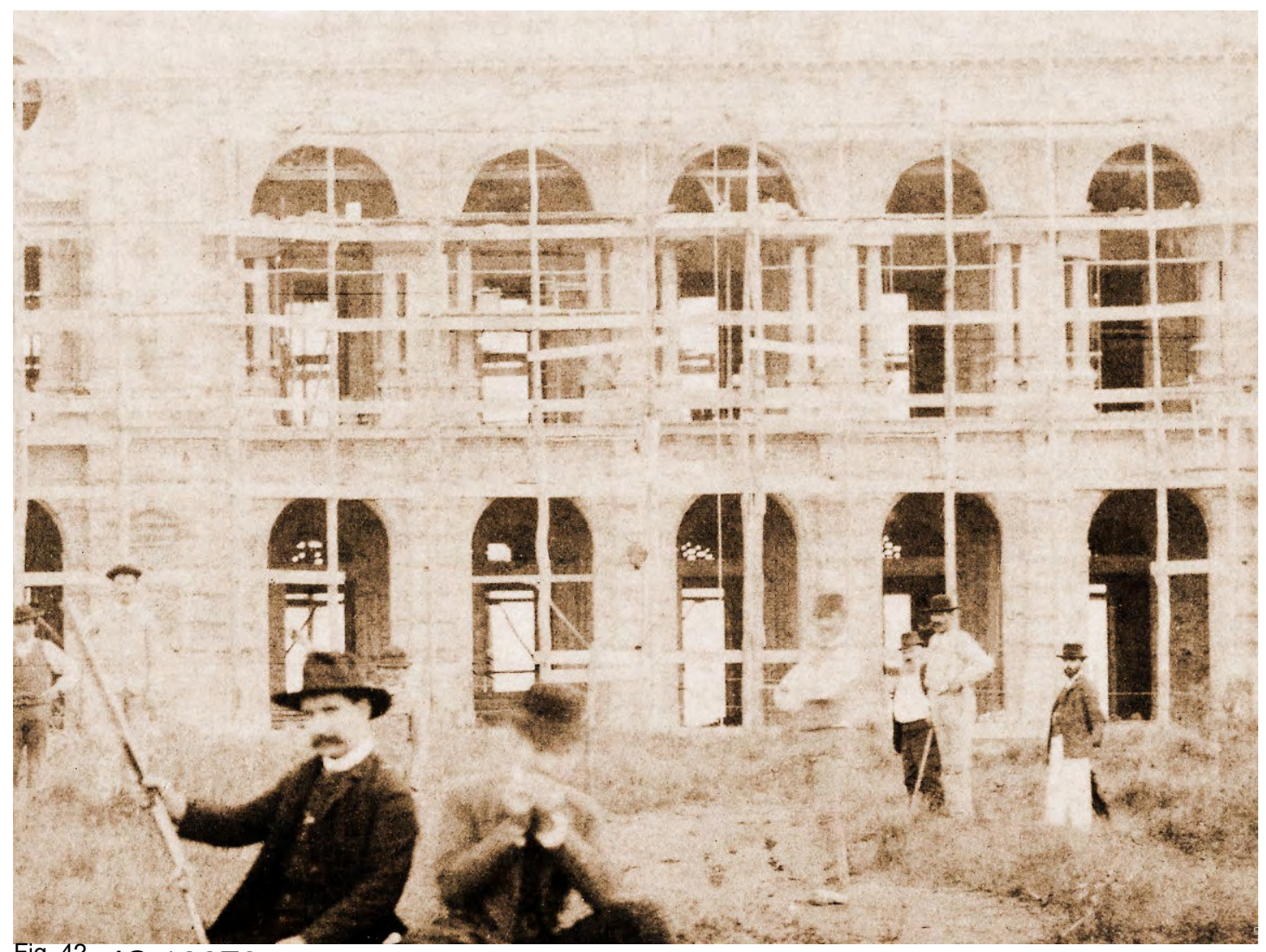

Fig. 42 - IC 13278

Os arcos da galeria do térreo estão sem o emprego das fôrmas (simples, símplices ou cimbramento) e, como tudo indica, estão concluídos. Os arcos do primeiro pavimento ainda estão com o cimbramento, e estes não aparentam ser muito robustos. 0 cimbramento está sendo utilizado no próprio arco e no entablamento das colunas. Estas obras com os arcos aparentam estar em fases diferentes. Alguns arcos ainda não têm a forma do entablamento, e algumas colunas não receberam o entablamento apoiado sobre elas.

Tudo indica que o procedimento construtivo foi o de levantar o pé-direito, o arco apoiado sobre este e o cimbramento. Foi executado o tímpano e daí por diante a arquitrave e o telhado.

Somente neste momento de acabamento estão sendo colocadas as colunas e o seu respectivo entablamento.

O acabamento da argamassa de revestimento está sendo executado de cima para baixo, e os elementos que realmente são estruturais, já foram executados pelo fato do edifício ter sido levantado até sua parte mais alta. 
GALERIA LESTE

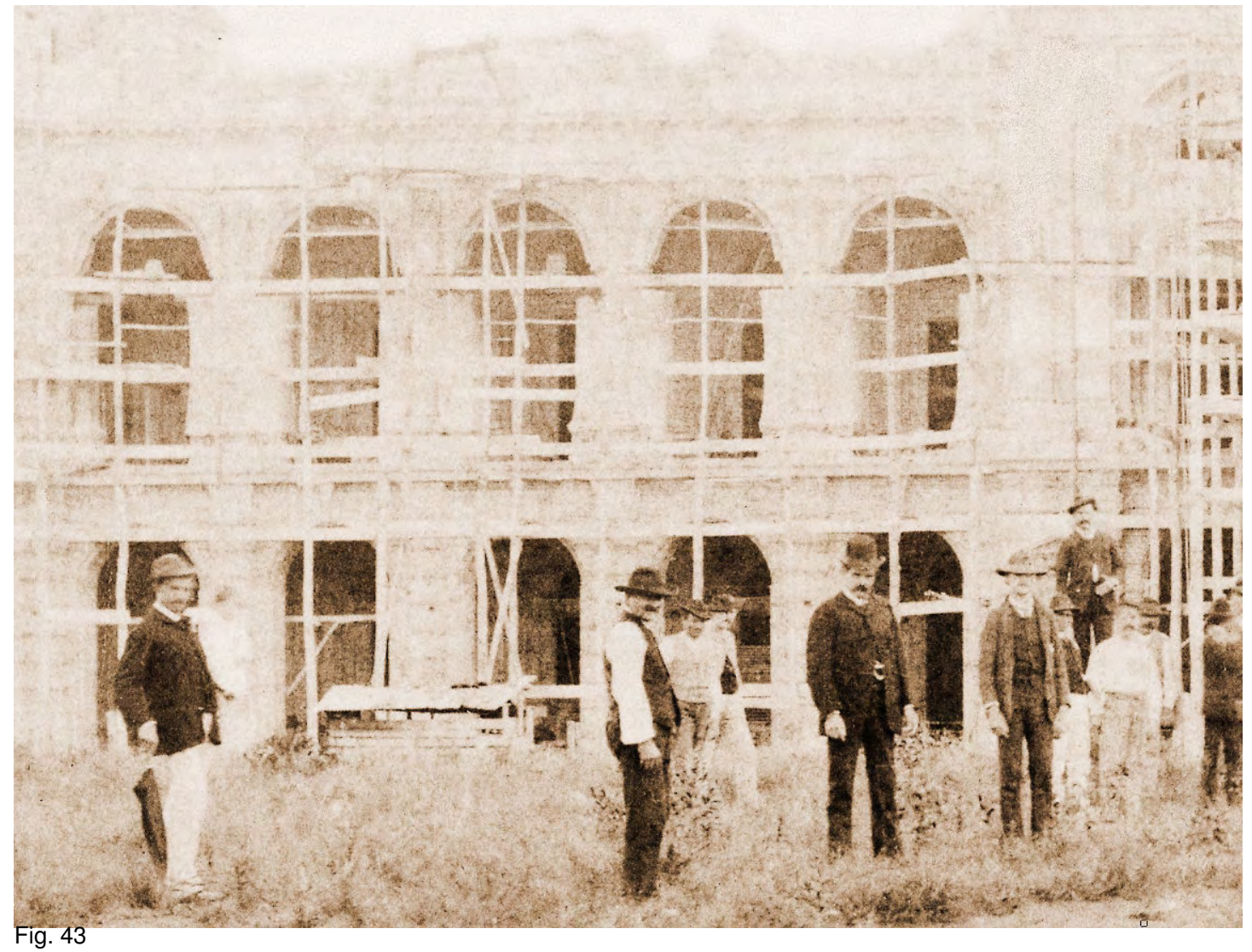

Nesta galeria, é provável que ainda não foram executadas as formas do entablamento. Podem também ser observadas as formas dos arcos.

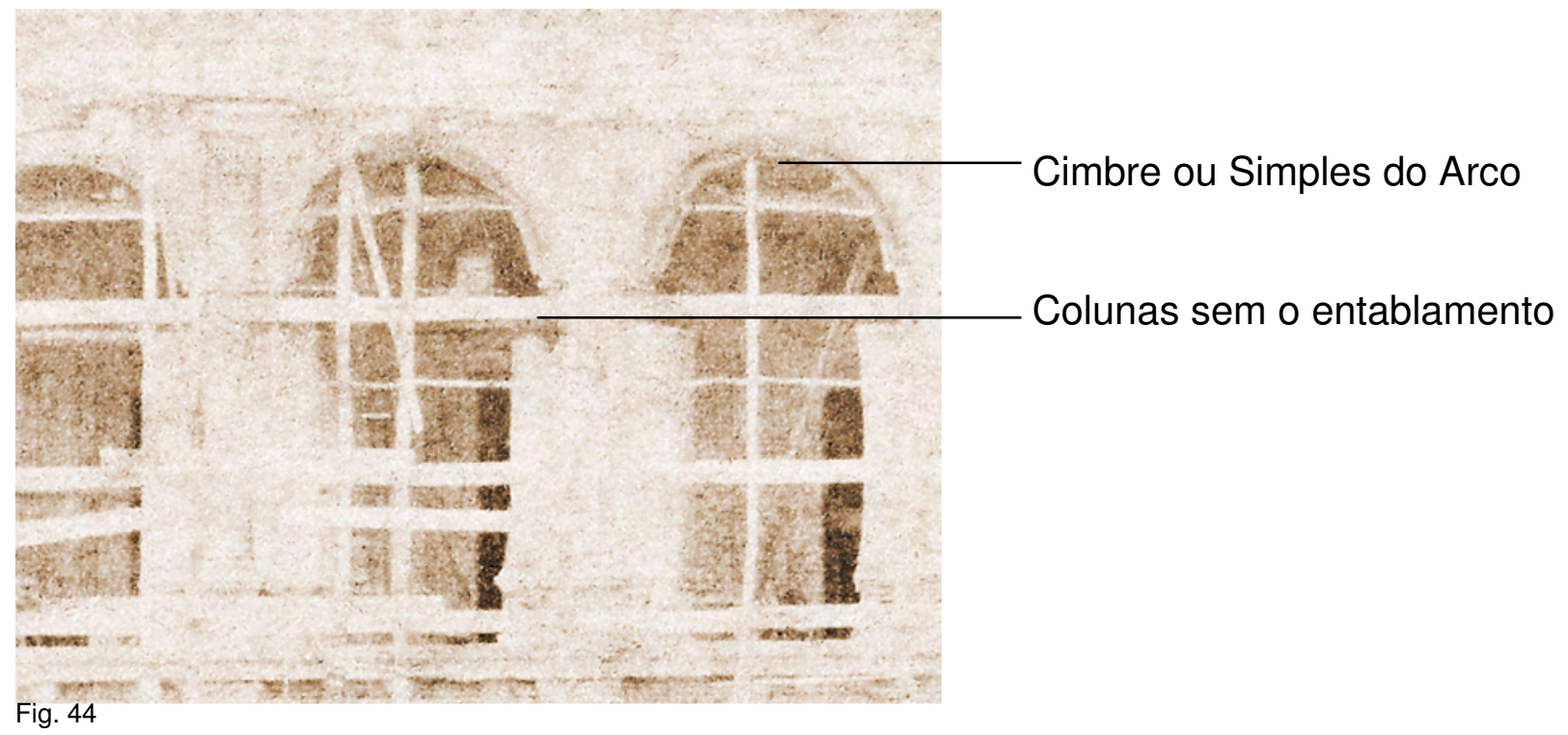




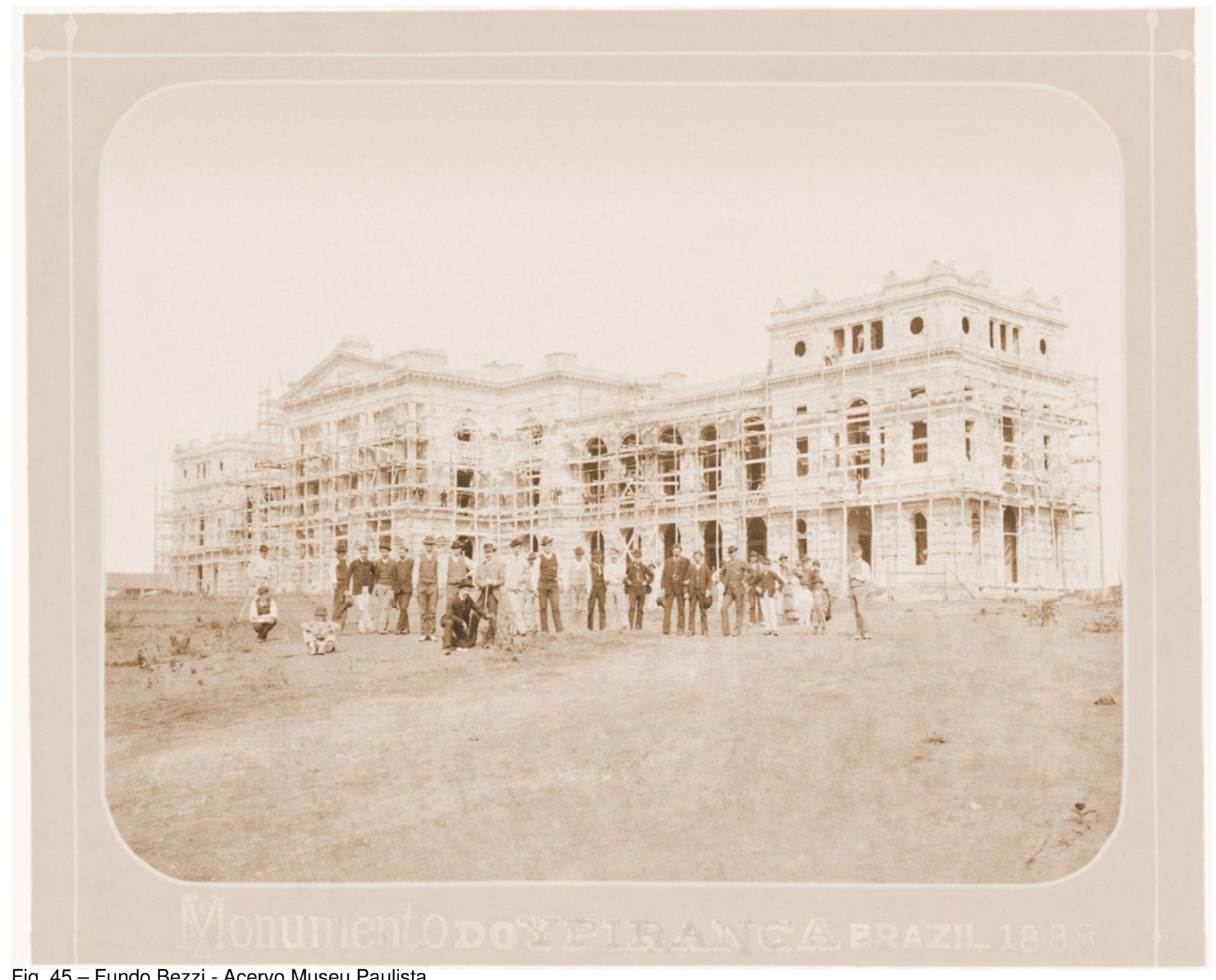

Fig. 45 - Fundo Bezzi - Acervo Museu Paulista

IC 13280 - Monumento do Ypiranga Brazil, 1888

No verso há o carimbo "doado ao Museu Paulista pela família de Tommaso Gaudenzio Bezzi"

Esta fotografia foi realizada no mesmo dia, mas a partir de outro ponto. Provavelmente tratava-se de um dia especial, a julgar pela presença de mulheres e crianças e pelas vestimentas dos homens. 


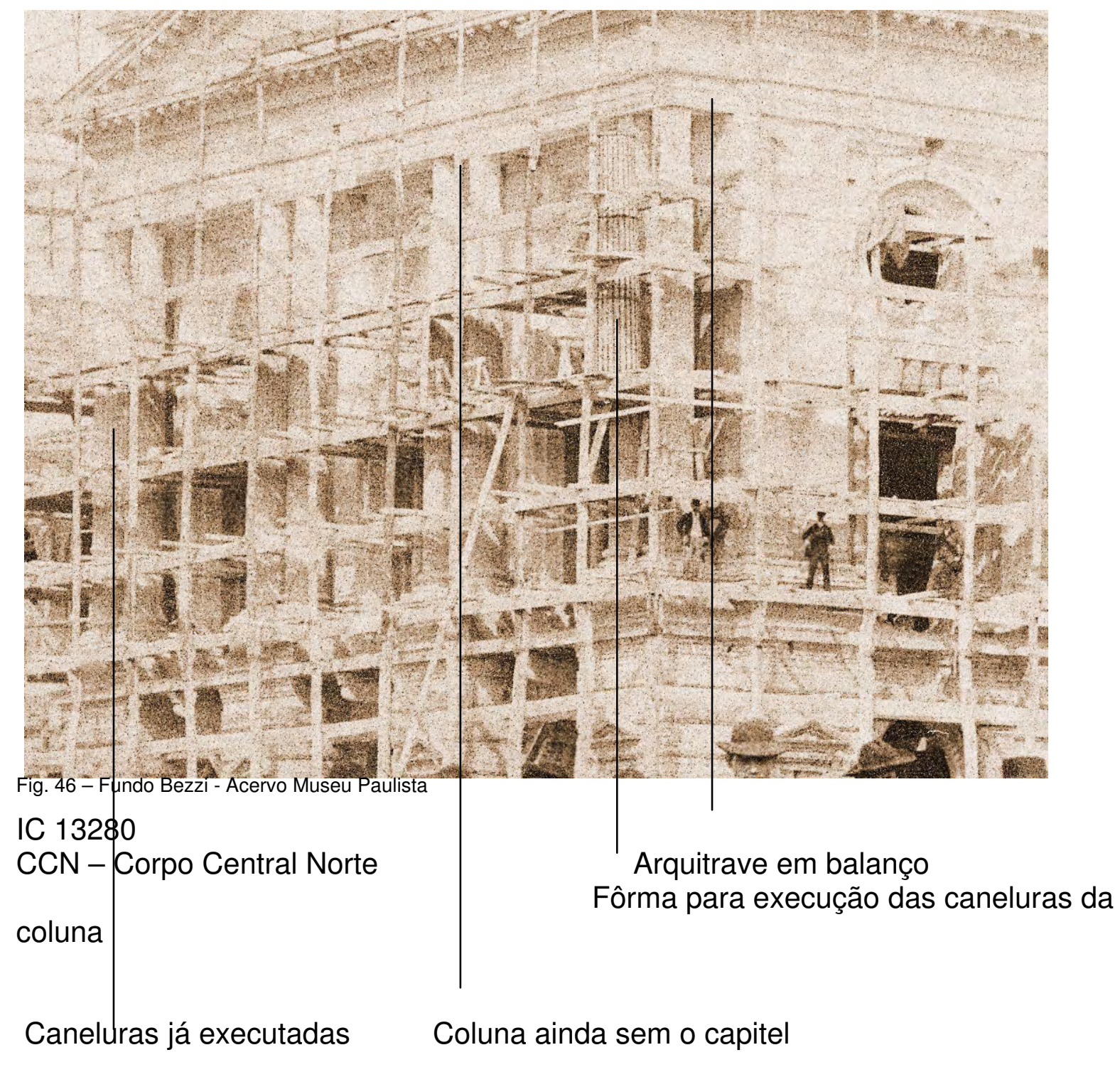

Segundo a documentação do Fundo Bezzi, a arquitrave sobre as colunas isoladas, recebem uma amarração horizontal com 3 perfis metálicos, ferros chatos, que contornam toda área do Corpo Central.

As colunas foram executadas com tijolos em forma circular e são ocas. Não foi encontrada nenhuma informação se foi utilizado algum ferro para sustentação vertical, tal como as 12 colunas do átrio.

Esta solução, com colunas de tijolos, também pode ser observada no edifício da Pinacoteca do Estado de São Paulo.

Tudo indica que estas colunas também não recebem toda carga da arquitrave e do ático, devido à competente amarração horizontal, as cargas podem estar sendo encaminhadas aos grandes maciços de alvenaria, da frente e das laterais do Corpo Central. 

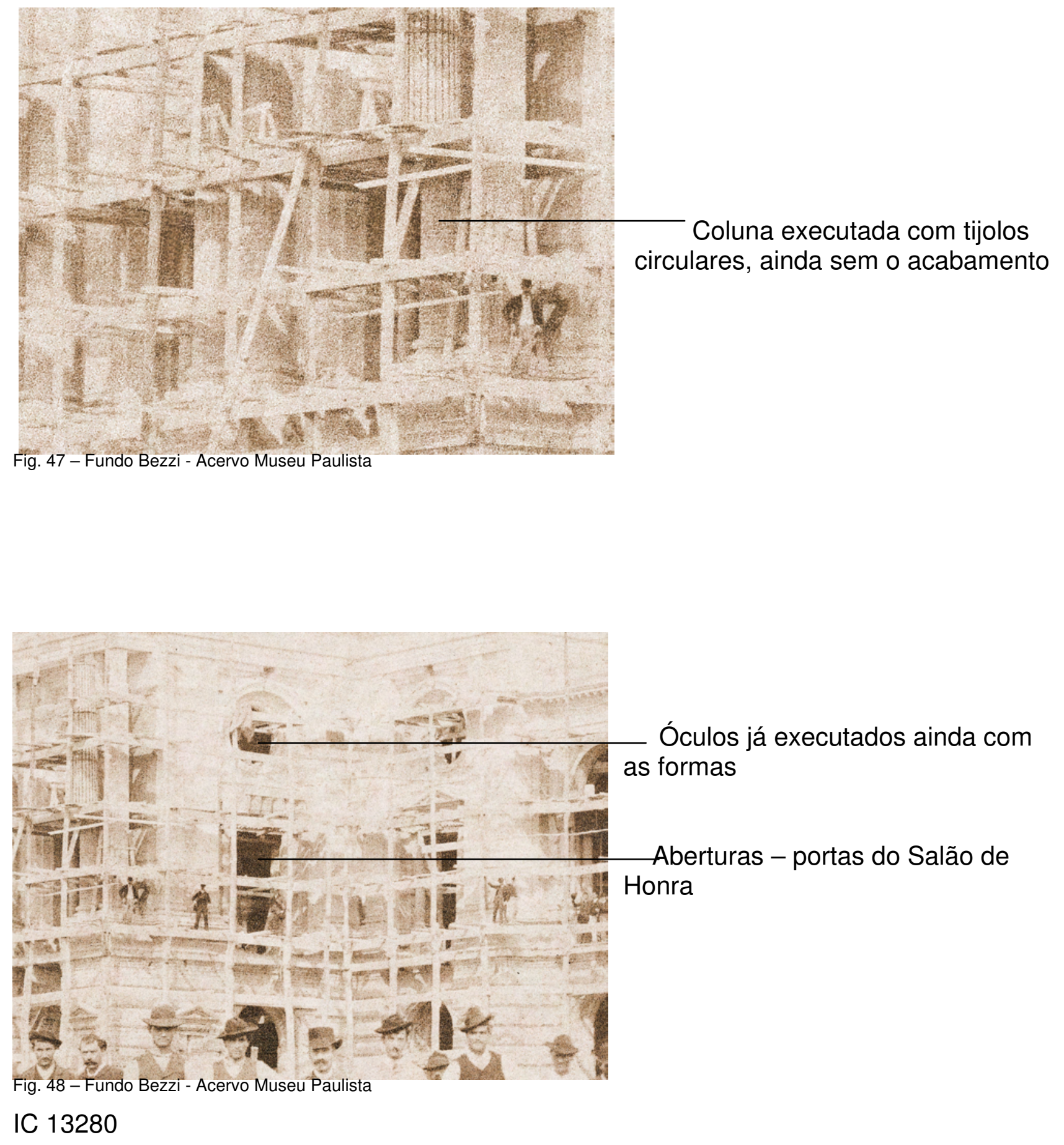


\section{GALERIA OESTE}

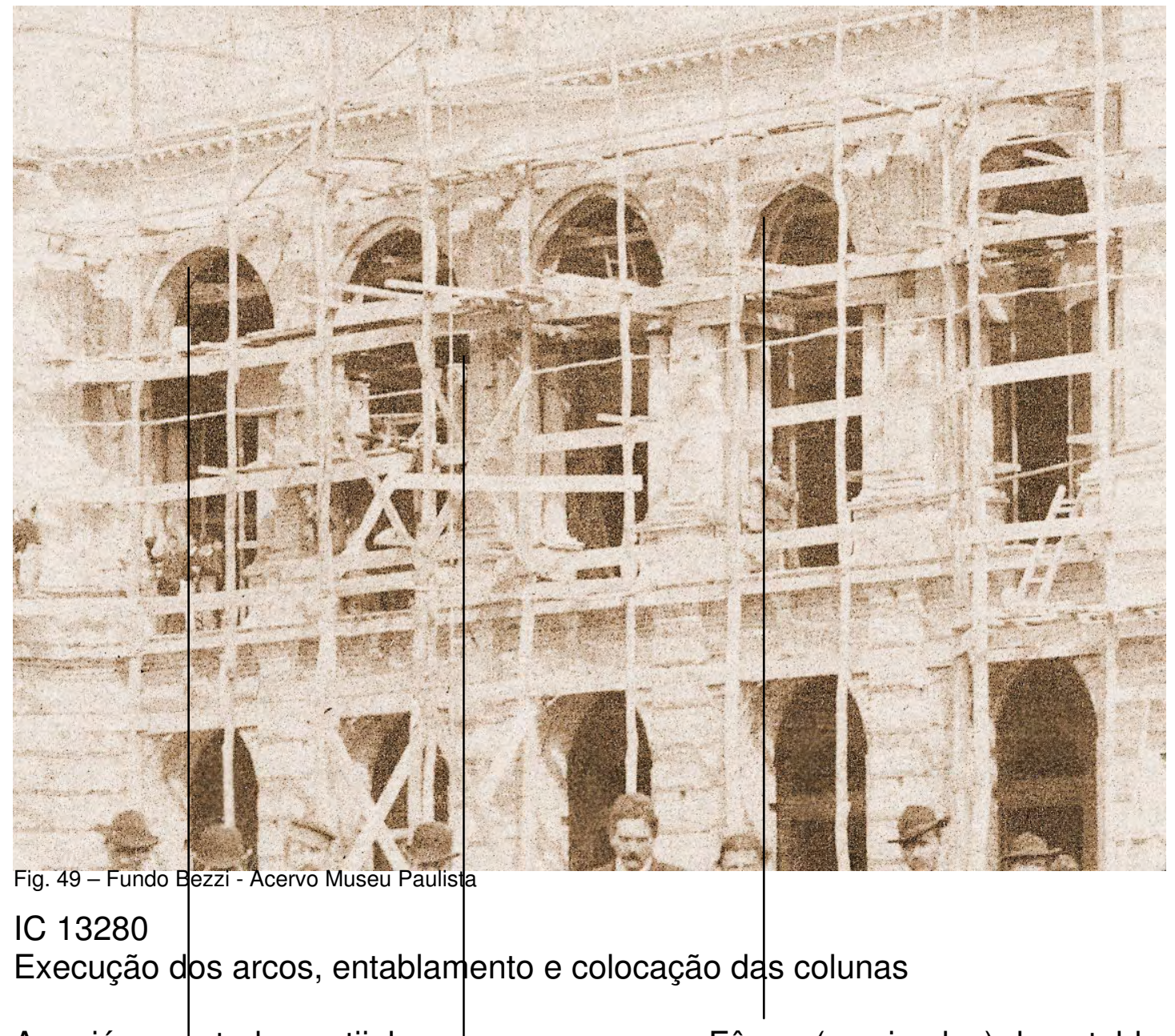

Arco já executado em tijolos

Fôrma (ou simples) do entablamento

Coluna ainda sem o entablamento

Pode-se observar que os arcos das galerias estão em fases diferentes de execução.

O primeiro arco da esquerda já está pronto e com as colunas e a forma do entablamento

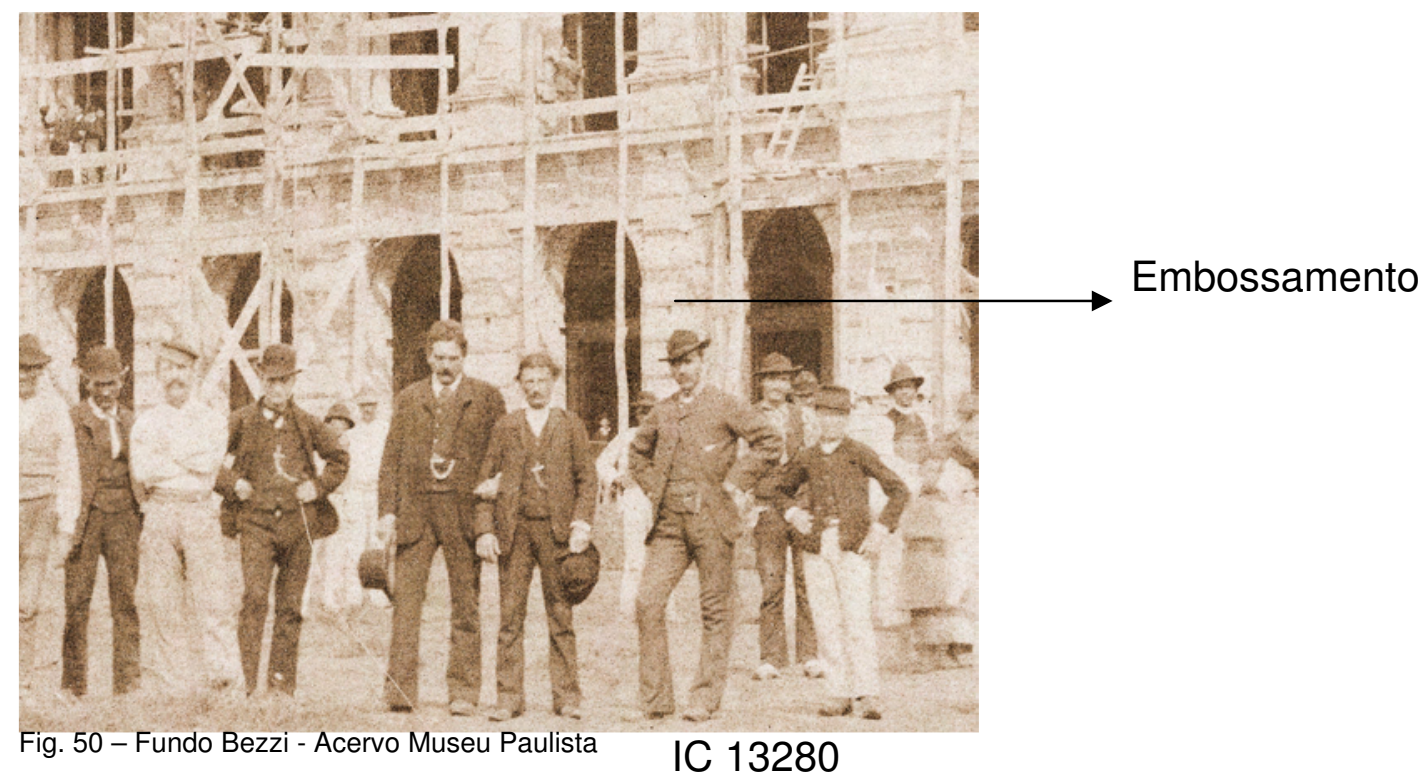




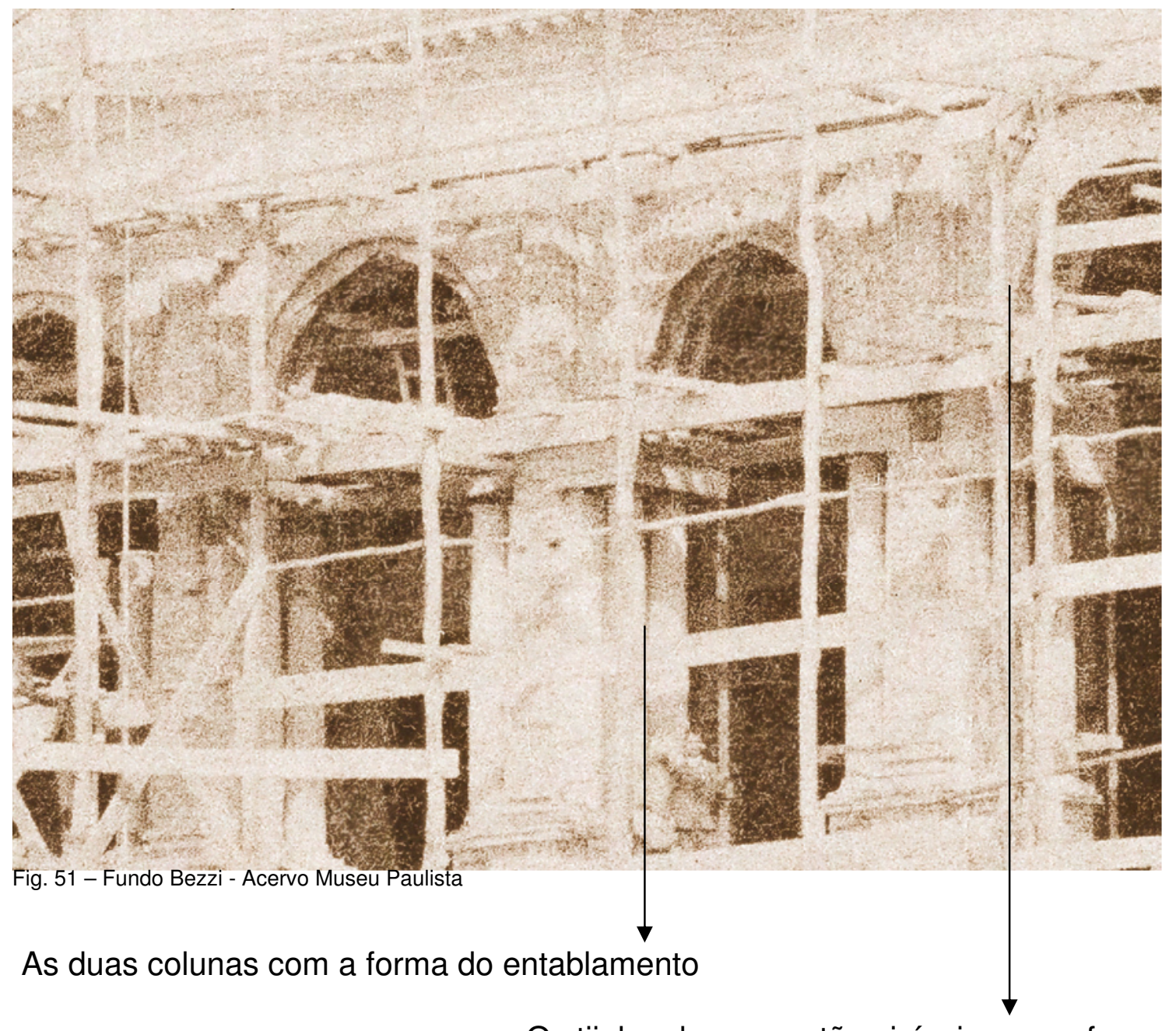

Os tijolos do arco estão visíveis sem a forma

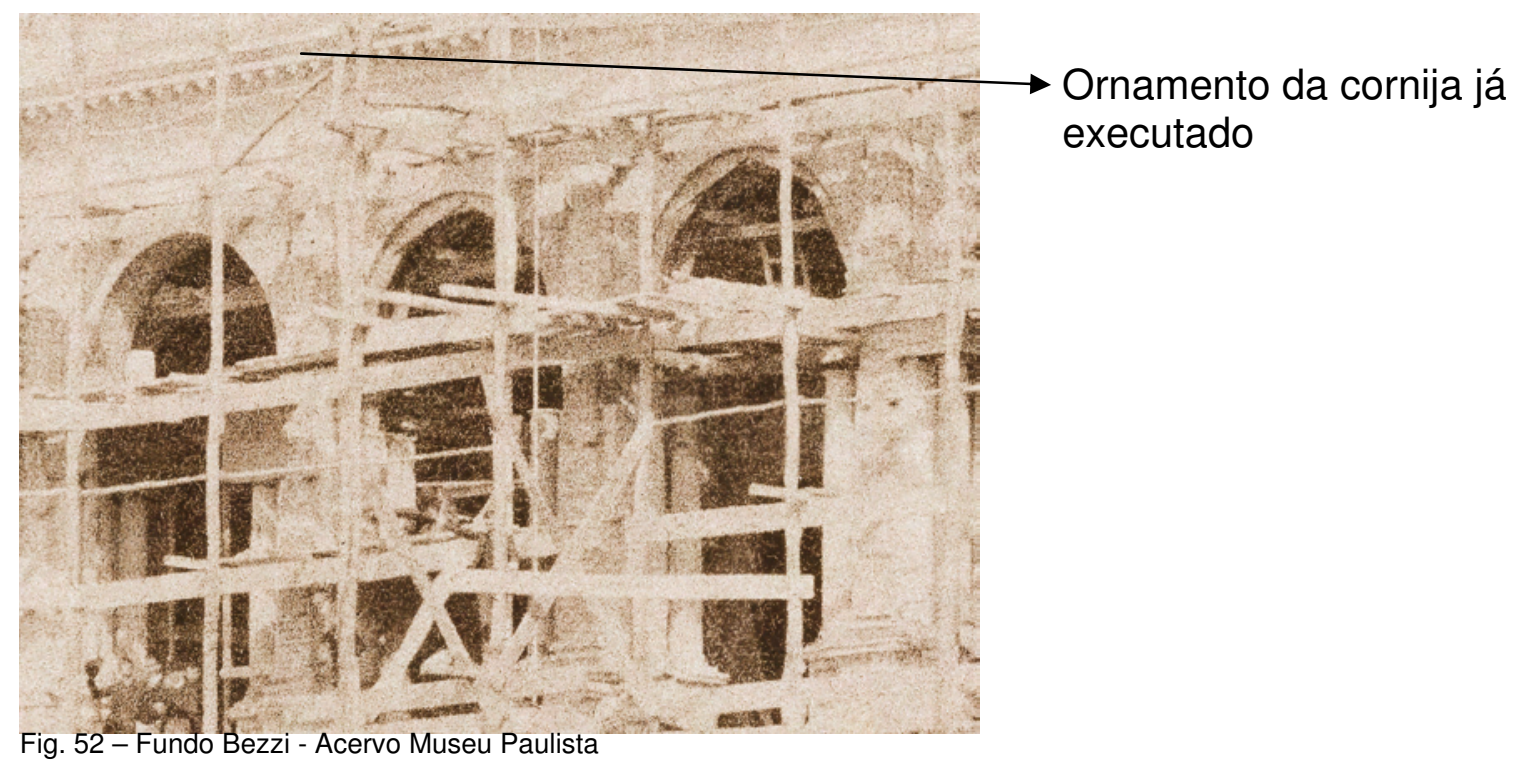




\section{TÉCNICA TRADICIONAL DE CONSTRUÇÃO DE ALVENARIA}

O edifício do Museu Paulista é um exemplo de técnica tradicional de construção de alvenarias, em que são empregadas as soluções estruturais, os materiais e a linguagem arquitetônica características desta técnica.

No texto anterior, pudemos constatar características do Sistema de Arcos e Abóbadas, em que as forças oblíquas dos arcos descarregam sobre os maciços de alvenaria, que são chamados de pé-direito. Assim, esta técnica tem como elementos estruturais principais as paredes e pés-direitos, as colunas e pilastras, os arcos e abóbadas, e as fundações.

Os materiais empregados são: A pedra, em alvenaria ordinária nas fundações. O tijolo, em todas paredes, pés-direitos, arcos e abóbadas. A madeira nos pisos, tetos, telhados, nas estruturas dos tabiques, nos caixilhos. $O$ ferro, nas amarrações horizontais, nos elementos em balanço, em elementos verticais, na abobadilha.

As paredes e pés-direitos são portantes empregados em maciços de grandes dimensões, sustentando as cargas de seu peso próprio, dos pisos, dos arcos e abóbadas.

Os arcos e as abóbadas são empregados desde o embasamento de alvenaria de tijolos nas fundações, no térreo, no primeiro pavimento, nas paredes internas e externas, e até no ático (sótão).

Esta técnica construtiva consiste num sistema estrutural que pode ser conceituado quanto:

- À transmissão de cargas da cobertura de vãos e espaços através dos arcos e abóbadas aos maciços de alvenaria, que resistem devido à massa do seu peso próprio.

Este sistema de arcos e abóbadas teve origem nas civilizações da Antiguidade, sendo iniciado por Assírios e Egípcios e difundiu-se durante o período romano..

Veio substituir o sistema arquitravado dos gregos, com a vantagem sobre este de aumentar a dimensão dos vãos, dos intercolúnios e dos espaços cobertos.

- Quanto à sua constituição interna ou esqueleto, é anelástico ou rígido, obtido por blocos de tijolos e argamassa (MATEUS, 2002, p.74,75)

O autor acima citado relata a evolução da técnica tradicional de alvenarias, através de um amplo levantamento sobre a "Bibliografia e a Transmissão do Saber aos Protagonistas da Construção" no Capítulo I, p. 21,23 do seu livro, estabelecendo importantes referências históricas para situar a técnica construtiva, objeto deste estudo:

Das antigas civilizações Assíria, Egípcia e Grega não sobreviveu nenhuma obra a que se possa chamar propriamente um tratado de construção. No entanto determinados textos, muitos deles não especificamente dedicados à Arquitetura, escritos durante o período Grego, influenciaram os autores Romanos e juntamente com estes últimos foram citados frequentemente na tratadística estudada dos séculos XVIII e XIX.

[...] a referência às práticas construtivas da Antiguidade constituirá a base e o modelo ideal de que resultaram os processos "modernos" de construção.

Estes textos clássicos chegaram até à época da invenção da imprensa através de cópias sucessivas executadas sobretudo por monges ao longo da Idade Média, a partir dos volumines dos pergaminhos manuscritos Romanos e Gregos, dos códices romanos que sobreviveram à queda do Império do Ocidente e à censura da Igreja. [...]

Os tratados escritos durante o período que vai do lluminismo ao início do século $\mathrm{XX}$, refletem a evolução de um campo do conhecimento que encontra a sua origem nas civilizações da Antiguidade, e se desenvolve ao longo de séculos de melhoramentos 
técnicos, que tiveram como conseqüência os processos otimizados da construção moderna de edifícios. Estas obras foram publicadas num período que se inicia com a consolidação e o estabelecimento das teorias construtivas de alvenarias, passa pela sua compreensão científica e otimização, e termina com o declínio do uso das alvenarias em detrimento das construções em aço e betão, materiais de "produção industrial controlada".

A primeira data, 1750 corresponde praticamente à edição do primeiro volume da Enciclopédia de Diderot e d'Alembert. O espírito iluminado que deu início à sistematização da grande "aventura" da pesquisa científica interessada em conhecer tudo pela experiência, começou por se preocupar com a compilação do saber relativo a todas as artes e ofícios. Este primeiro esforço foi feito associando a narração de métodos empíricos e ancestrais, garantidos por séculos de práxis, à preocupação da sua explicação racional à luz das diversas ciências. Esta visão na base do espírito científico moderno foi impulsionadora da publicação da grande literatura técnica ao longo de todo o século XVIII e XIX.

A última data, 1900, corresponde ao apogeu da investigação sobre a construção de alvenarias não armadas e ao mesmo tempo ao declínio do ensino destas técnicas nas escolas profissionais e nas universidades com o advento do cimento Portland, do betão e do aço.

O período definido por estas duas datas corresponde por isso ao período histórico durante o qual a prática tecnológica das alvenarias foi expressa da maneira mais completa e sistemática.

O edifício, portanto, apresenta traços desta tradição e, ao mesmo tempo, da evolução da tecnologia. Nele se notam tanto as características originais da técnica quanto novos conhecimentos e materiais industrializados (como os ferros) que foram sendo agregados em conseqüência do desenvolvimento da investigação e da transmissão do conhecimento de forma sistemática.

A seguir, pois a técnica referida será estudada no que se refere aos elementos estruturais principais e os ornamentais, buscando-se a conceituação da nomenclatura utilizada por Bezzi, e da teoria da época. 


\section{PAREDES E PÉS-DIREITOS}

As paredes e pés-direitos constituem-se na estrutura básica desta técnica construtiva, juntamente com os arcos e abóbadas. São autoportantes e empregados em grande maciços de alvenaria.

As paredes são destinadas a suportar o seu peso próprio, telhados e pavimentos de madeira.

Os pés-direitos são os maciços de alvenaria que suportam os arcos, abóbadas, e os respectivos pavimentos.

A edificação é limitada por paredes mestras, contornando seus limites e ligando-se às outras paredes secundárias, perpendiculares, formando células.

As paredes mestras devem se corresponder em todos os andares, obedecendo as soluções da planta, diferenciando-se apenas na altura conforme o uso a que se destina a edificação.

Estas paredes, delimitando espaços, criam células que se associam lateralmente ou se sobrepõe. Assim, pode-se definir:

O edifício de alvenaria como uma estrutura tridimensional, em que a combinação dos vários elementos estruturais delimitadores de um espaço, serve à constituição de células que se associam lateralmente, ou se sobrepõem. Esta associação de células constituem os complexos murais - os edifícios.

Estes vários aspectos foram sempre tidos em conta na concepção de edifícios em alvenaria, e nas soluções diretamente relacionadas com:

- A escolha do tipo de associação e de combinação de blocos rígidos e das argamassas, de forma a obter um determinado elemento estrutural

- A definição do tipo de combinação, e de ligação dos diversos elementos estruturais, para obter estruturas capazes de cobrir um ou vários espaços. (MATEUS, 2002, p.71)

As paredes devem ser bem travadas entre si, dispostas de modo que a distribuição das cargas se faça uniformemente sobre o terreno.

As distâncias entre as paredes devem ser planejadas, considerando-se os comprimentos dos vigamentos dos pisos e dos telhados.

Segundo MATEUS (2002, p 117) as paredes e os pés-direitos eram concebidos através de métodos de dimensionamento diferentes, sendo os das paredes mais simplificados.

As paredes destinadas a suportar o seu peso próprio, telhados e pavimentos de madeira, começaram a ser explicado sob a forma de regras, que não tinham nada a ver diretamente com o cálculo da resistência dos materiais, como hoje concebemos.

As primeiras "receitas" preocupavam-se sobretudo com a forma, o número, e a posição das aberturas nas paredes autoportantes, como responsáveis por uma diminuição da sua capacidade resistente. Segundo Leon Battista Alberti as aberturas não deveriam ultrapassar $1 / 7$ ou $1 / 9$ da superfície total da fachada.

Associadas a estas regras de proporção relativa, eram adotadas práticas de composição arquitetônica, que implicavam uma distribuição a mais possível equilibrada, de vãos e nembos autoportantes nas fachadas e nos cunhais.

( $N e m b o=$ maciço entre dois vãos seguidos de portas e janelas, de mesma altura que eles)

Estas práticas são bem resumidas por Giovanonni nos seus comentários à tradução do tratado do alemão Breymann, em 1911:

"É necessário que os cheios e vazios se correspondam verticalmente para todos os andares do edifício. Nos muros ordinários, as aberturas não devem ser próximas demais entre si, nem os vazios superarem em grandeza os cheios, e especialmente não deve a 
distância das aberturas do canto de um edifício, ser menor que a largura da mesma abertura". (BREYMANN, G.A. Trattato generale di costruzioni. Cap.I, p.81)

Além da distribuição dos vãos nas fachadas, era recomendada uma distribuição equilibrada da "rede" em planta constituída pelas paredes e pela vigas dos pavimentos.

Sobre este tema, Milani resume as considerações principais a se ter em conta na fase do projeto:

O conceito fundamental que naturalmente nos guia em tal disposição, é aquele de projetar a rede mural de modo que em todas as paredes autoportantes (sejam tanto externas quanto internas), trabalhem todos igualmente, ou seja, que todos tenham a carga do peso dos vários sistemas de cobertura (assoalho e teto);

A este fim, bastará distribuir as paredes autoportantes de modo a formar uma verdadeira rede resistente, cujas malhas não superem nas dimensões de comprimento e largura fixada por razão de economia, em 8,50.

Depois de fixado isto nos vários andares do edifício, nós podemos com uma disposição adequada das travas principais de um andar, dispostos em um sentido longitudinal ao invés do sentido transversal, distribuir normalmente a carga da cobertura para um andar sobre paredes longitudinais, tanto paredes externas de frente ou externas de espinha.

(MILANI, G.B. I'Ossatura Murale, Cp.II, p.38) (MATEUS, 2002, p.117)

A estas regras de bem construir, foram associados diversos métodos de cálculo desenvolvidos ao longo de todo século XIX, baseados em regras empíricas de prédimensionamento da secção das paredes, autoportantes e divisórias do edifício que se desejava construir, na verificação estática da estabilidade e da resistência das secções mais solicitadas, de uma parede ou de um pé-direito.

No que se refere ao pré-dimensionamento da espessura das paredes, a tratadística francesa, italiana, alemã, inglesa, portuguesa e espanhola são unânimes na referência às classes e fórmulas estabelecidas por Rondelet, no Livro IV Théorie des Constructions, da sua obra Traité Théorique et Pratique de l'Art de Bâtir, publicada entre 1812 e 1817.

Este conjunto de fórmulas aborda dois tipos de estruturas:

- Estruturas térreas com paredes autoportantes suportando essencialmente o seu peso próprio

- Estruturas de vários pisos, com pavimento de madeira (MATEUS, 2002, p.117)

Portanto, não é possível a todas estas causas múltiplas (resistência do material à pressão, a segurança e estabilidade contra a torção, a forma e configuração da parede, a qualidade e a forma dos materiais, o cuidado e a qualidade do trabalho, e o emprego justo do material e da argamassa,...) atribuir os coeficientes adequados e determinar com isso racionalmente as dimensões das paredes. Dessas, ao invés, convirá, caso a caso, segundo as suas varias importâncias fazer cálculo empiricamente. É com o mesmo critério do exame das circunstâncias especiais que são aplicadas também as várias fórmulas práticas, baseadas na experiência de numerosos edifícios. Grande importância têm ainda hoje as fórmulas estabelecidas do século passado por Rondelet, particularmente porque a partir delas são ainda baseadas as regras relativas às espessuras mínimas das paredes [..] (BREYMANN, G.A. Trattato Generale di Costruzioni. Cap.I, p.68-81) (MATEUS, 2002, p.117,118)

O peso suportado pela parede era estimado tendo em consideração o número total de pisos do edifício e a posição relativa da parede entre pisos, variando se fosse uma parede autoportante, exterior ou interior, ou simplesmente divisória, fosse maciça ou apresentasse aberturas, suportasse ou não escadas.

Associada a estas distinções, as fórmulas usadas partiam de premissas sobre a distribuição proporcionada de massa e rigidez ao longo do edifício [...] Segundo Rondelet e os outros autores mencionados, na elaboração das fórmulas, tinha sido considerado que na futura construção:

As vigas dos soalhos entre pisos seriam dispostas sempre na direção dos vãos menores. 
A distribuição dos espaços em planta seria simétrica e que a disposição em elevação dos diversos soalhos, arcos ou abóbadas, seria feita de forma regular e sistemática.

As vigas contribuíram por um lado para a ligação das paredes sujeitas a esforços horizontais e por outro seriam responsáveis por impulsos horizontais sobre as paredes de suporte, impulsos estes proporcionais aos seus vãos [...] (MATEUS,2002,p.121)

\section{OS ARCOS, AS ABÓBADAS E A RELAÇÃO COM OS PÉS-DIREITOS}

Os cálculos dos pés-direitos destinados a suportar arcos e abóbadas, exigiam métodos de dimensionamento mais complexos do que as paredes autoportantes.

$\mathrm{O}$ estudo relativo ao dimensionamento destas estruturas consistiu, essencialmente, em reunir compreender e apresentar de forma sintética, o conteúdo e os resultados dos construtores do século XVIII e XIX utilizados em edifícios de alvenaria.

Procurou-se identificar os métodos de cálculos mais comuns, e qual o tipo de informação que era fornecida a quem construía. Estes métodos e regras deveriam ser avaliados à luz das últimas teorias de cálculo das alvenarias

As regras e os métodos destinados ao dimensionamento de sistemas de arcos e abóbadas, e respectivos pés-direitos, classificam-se de forma resumida em quatro grupos:

1 o grupo - emprego de regras empíricas baseadas em proporções geométricas, que eram as únicas regras praticadas até o século XVII, e sucessivamente melhoradas até início do século $X X$

$2^{\circ}$ grupo - Algoritmos algébricos e geométricos, desenvolvidos entre o final do século XVII e a primeira metade do século XIX, baseados no cálculo estático de mecanismos de colapso em arcos circulares e em abóbadas cilíndricas retas, estudadas como um arco de comprimento unitário destinados ao dimensionamento de diversas secções, constituíram os primeiros métodos a ter em conta não só as proporções geométricas das estruturas, como as cargas a que elas estariam sujeitas.

$3^{\circ}$ grupo - Foram desenvolvidas no início do século XIX as fórmulas de Rondelet, com coeficientes calibrados por investigação experimental, que resultou em algoritmos algébricos e gráficos simplificados, baseados nos métodos do grupo 1 e 2 .

$4^{\circ}$ grupo - Os métodos gráficos, desenvolvidos durante a segunda metade do século XIX, baseados no funicular de pressões, e destinados à verificação da estabilidade dos sistemas pré-dimensionados pelos métodos 1,2 ou 3 . A estes métodos estava associado o cálculo do estado tensional a que as estruturas estariam sujeitas sob o sistema de carregamento previsto, e o controle da resistência dos materiais. (MATEUS 2002, p.130)

Os tres primeiros grupos metodológicos destinavam-se sobretudo a fornecer as primeiras dimensões para o traçado de novas estruturas.

O método da linha de pressões permitia:

- A confirmação ou eventual optimização dos resultados obtidos através de regras empíricas e destinadas a uma construção nova

- A análise da estabilidade de edifícios existentes. (MATEUS 2002, p.130)

MATEUS ainda esclarece, que para o dimensionamento de paredes destinadas a suportar seu peso próprio, telhados, etc existe na Europa normas estabelecidas no Eurocódigo 6, Parte 1. Para o dimensionamento de arcos e abóbadas não há de forma similar, regras disponíveis. Os métodos de cálculos de arcos e abóbadas são por isso discutidos à luz das mais recentes teorias de cálculo.

Ver o Capítulo II, Arcos, abóbadas e Pés-direitos, que o autor descreve os quatro grupos de tipos de dimensionamento e os métodos contemporâneos e os antigos, da p.130 a p.149. 


\section{ABERTURAS}

As aberturas são utilizadas em forma de portas-balcão, janelas e óculos
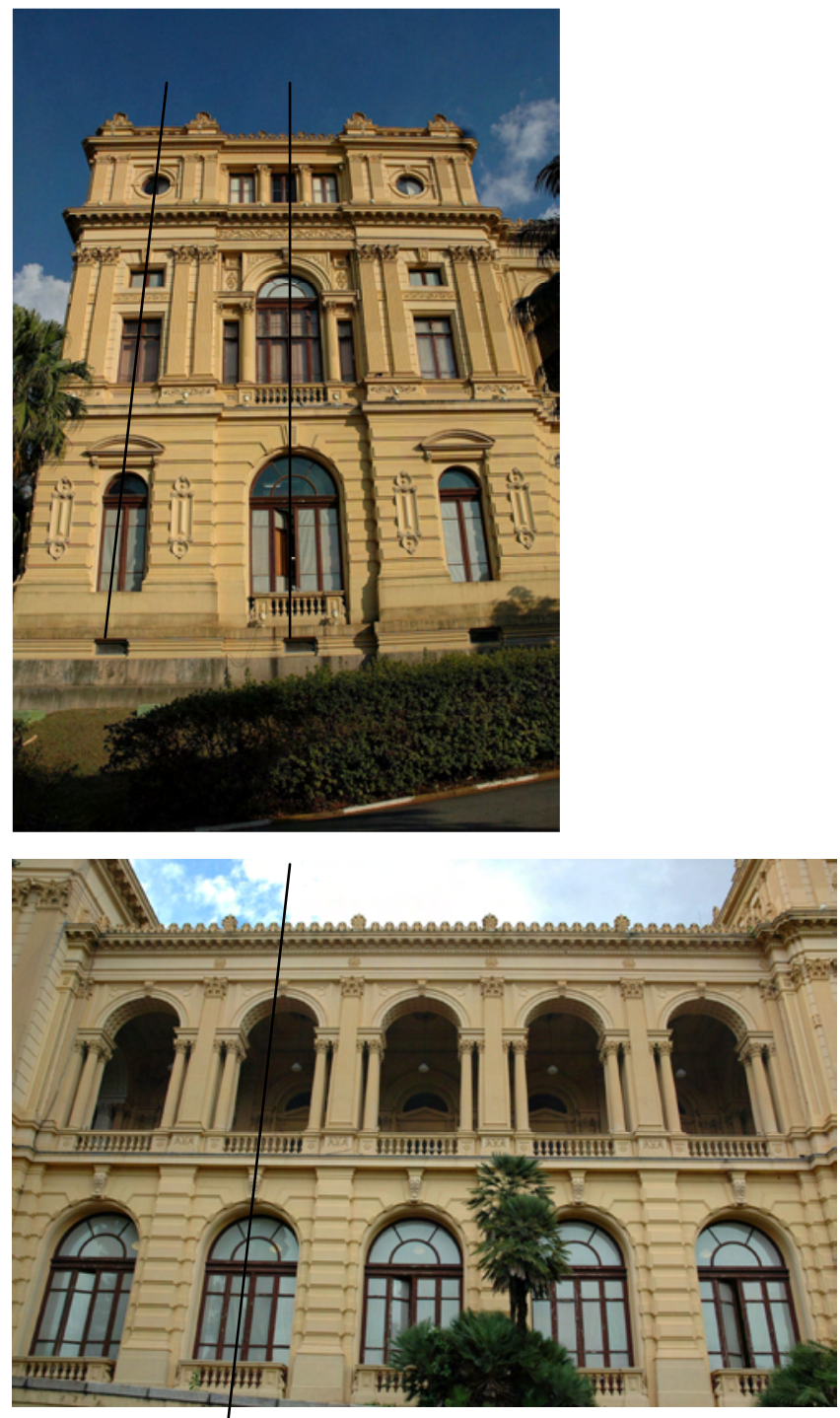

As aberturas são alinhadas verticalmente através de seu eixo central.

Nas Torres as aberturas em cada pavimento têm formas e dimensões diferentes, mas as larguras das paredes, e pés-direitos, se mantêm na mesma proporção.

Fig. 53

A relação entre pés-direitos e as aberturas no pavimento térreo, se mantém praticamente em todas as fachadas. Nas galerias da face norte, as aberturas que se apresentam com larguras maiores, estão nas arcadas do primeiro pavimento.

Fig. 54

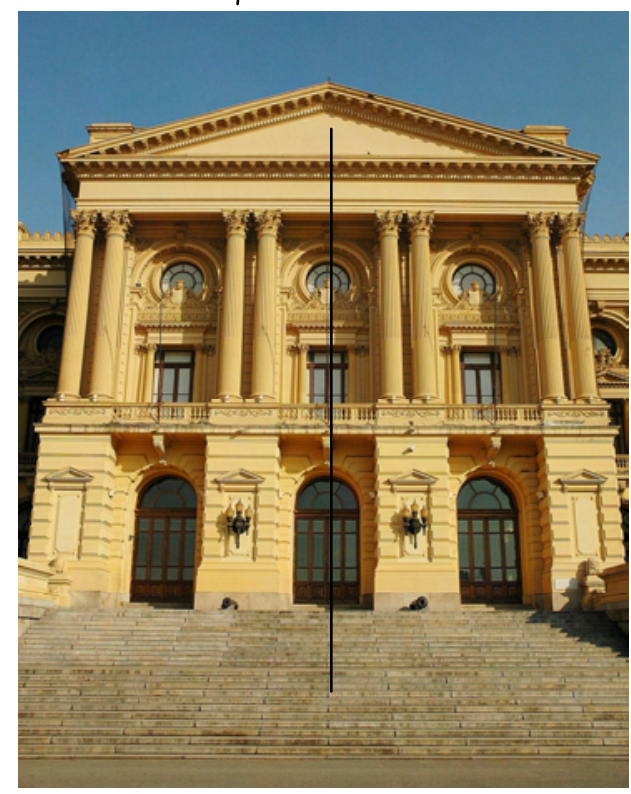

$\mathrm{Na}$ fachada principal, da face norte e da face sul, as aberturas são utilizadas de três tipos diferentes, nos três níveis horizontais.

As paredes e pés-direitos se apresentam em espessos maciços 


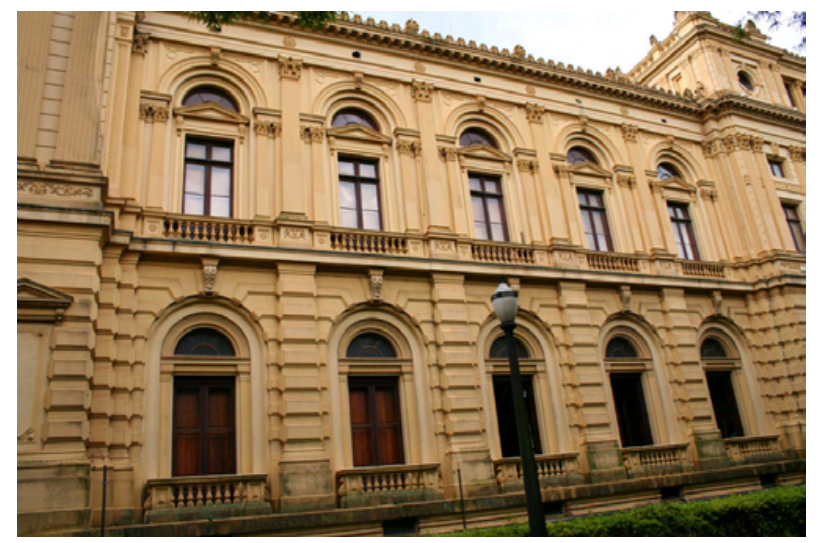

Nas galerias da face sul, no térreo e no primeiro pavimento, as aberturas são menores do que as da face norte, aumentando assim a largura dos pésdireitos.

São utilizados nas aberturas arcos de ressalva, proporcionando aos pésdireitos maior resistência às cargas.

Fig. 56

\section{PLANTAS DOS PAVIMENTOS (p.62 - Fig.57)}

As plantas a seguir, destacam as espessuras das paredes, pés-direitos, e as soluções espaciais.

As paredes mestras se correspondem em todos os pavimentos.

As alterações de planta aparecem nas paredes internas, mas observa-se que são previstas e preparadas desde o subsolo, confirmando o conceito estrutural de agregar células sobre células.

No Corpo Central há alterações em relação ao átrio, ao Salão de Honra e no espaço correspondente à face sul, a presença de outro pavimento.

As galerias se mantêm com a mesma solução dos espaços, embora a área da face sul seja mais robusta, com maiores pés-direitos do que a face norte, sem as arcadas e as loggias.

Somente no segundo pavimento das Torres, as paredes internas são alteradas, onde são utilizados tabiques, numa estrutura conhecida por viga Vierendeel.

Neste pavimento o pé-direito (altura interna) é bem menor, e supõe-se que foi planejado para atingir menor peso à estrutura. 

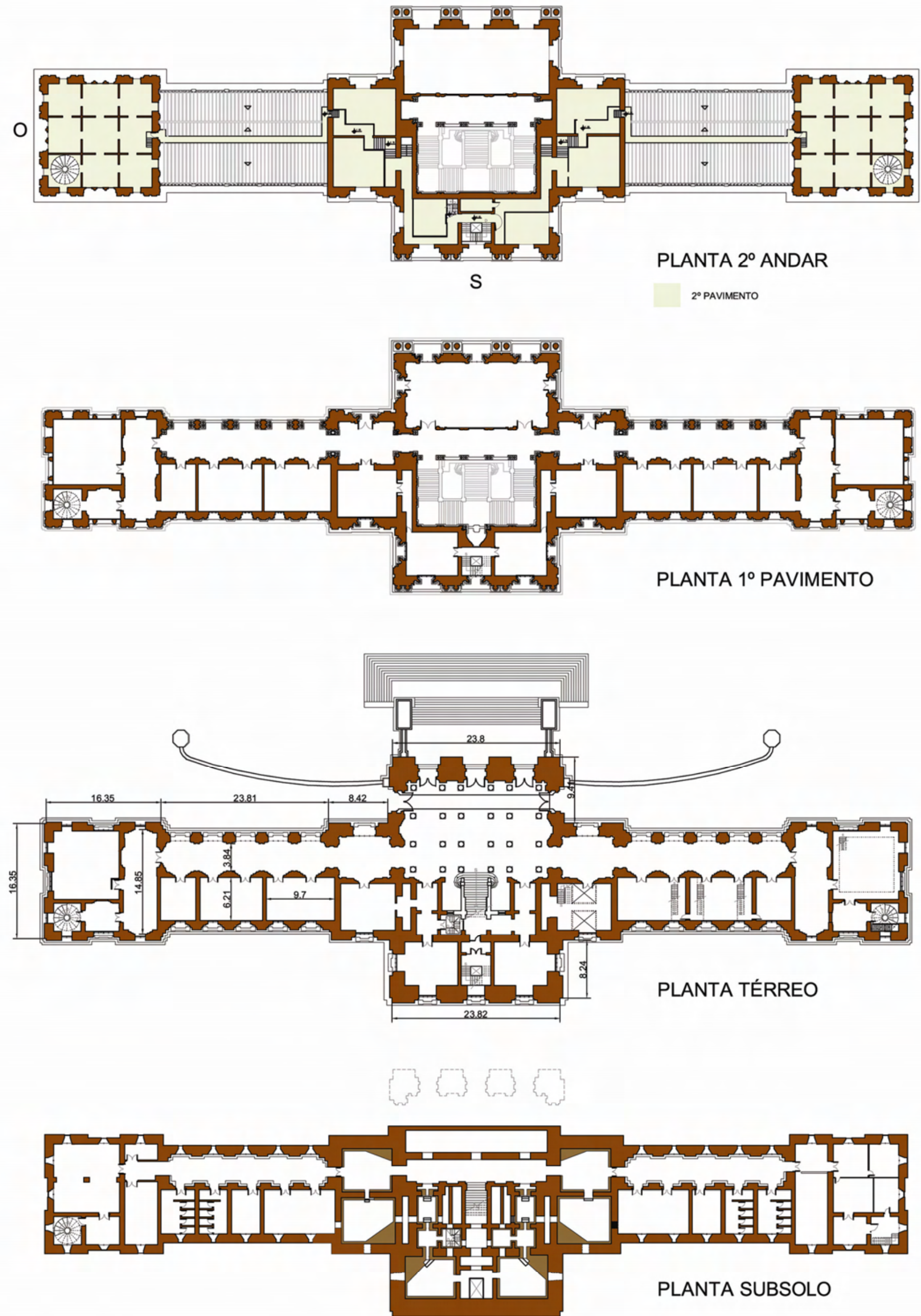


\section{SUBSOLO - CORPO CENTRAL}

Toda a área considerada como subsolo era apenas um porão de ventilação. Surgiu como espaço útil após o desaterro do solo original, de uma camada de entulho de obra, e como resultado de algumas alterações. Só restou o solo em estado original sob o Corpo Central, correspondente ao átrio (saguão) e parte da escadaria. As figuras abaixo apresentam a área sob o átrio (o saguão).

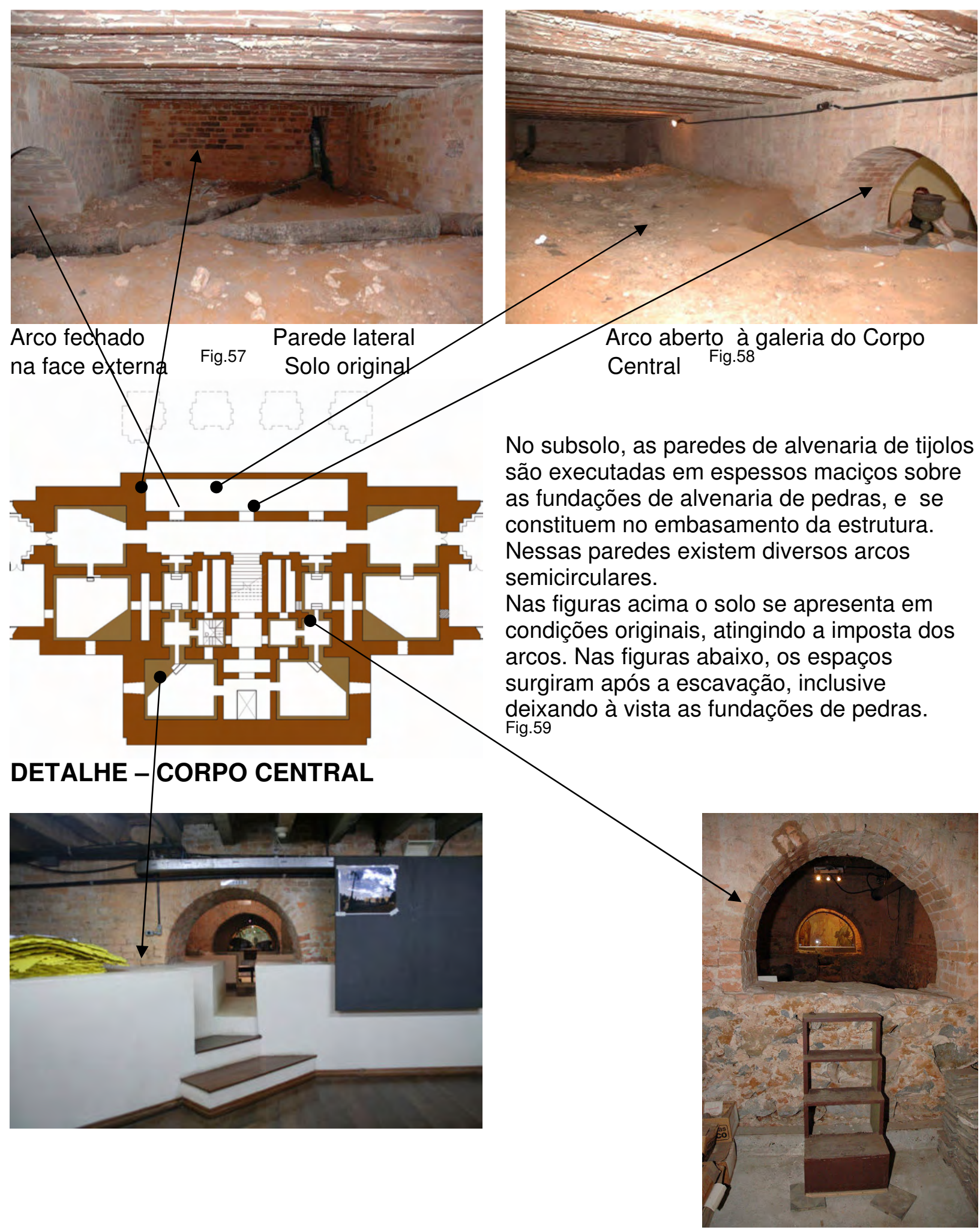

Nesta sala as fundações de pedras receberam revestimento em argamassa e pintura
Alvenaria de pedra à vista e o embasamento em alvenaria de tijolos. Fig. 60-61 


\section{SUBSOLO - GALERIA}

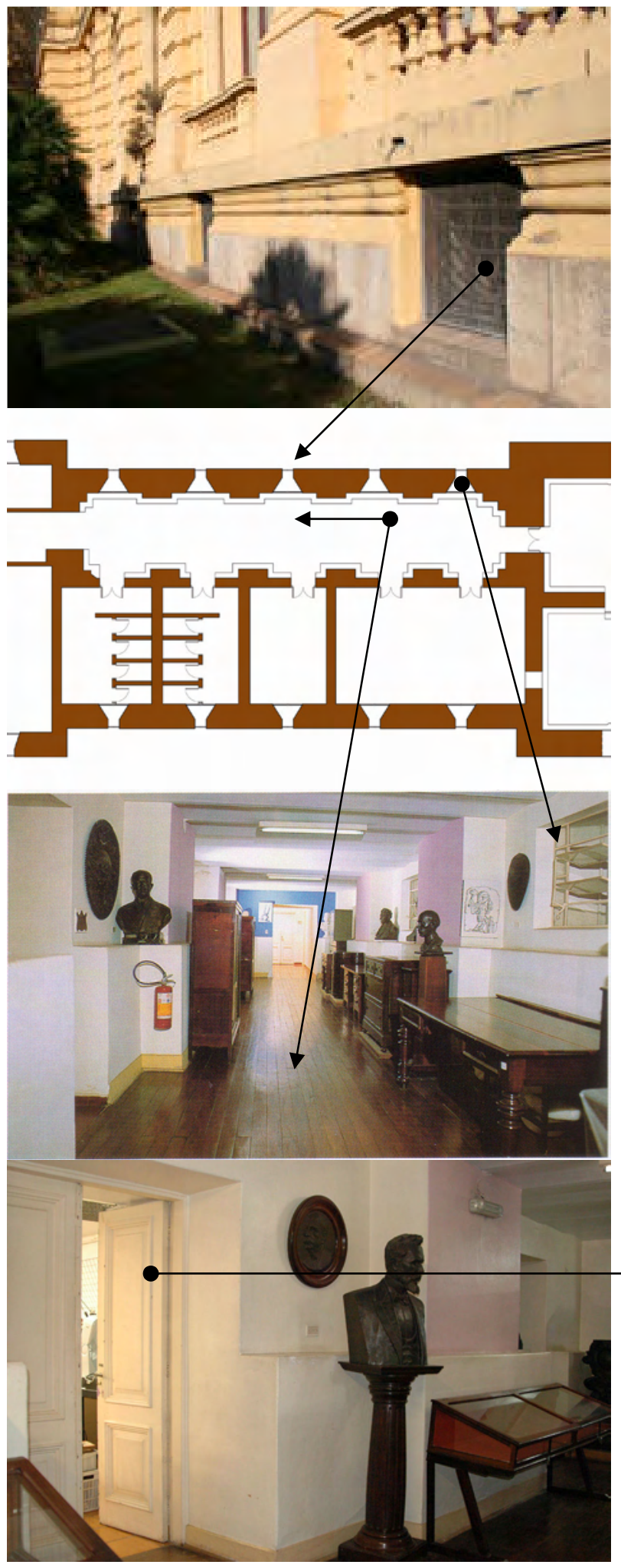

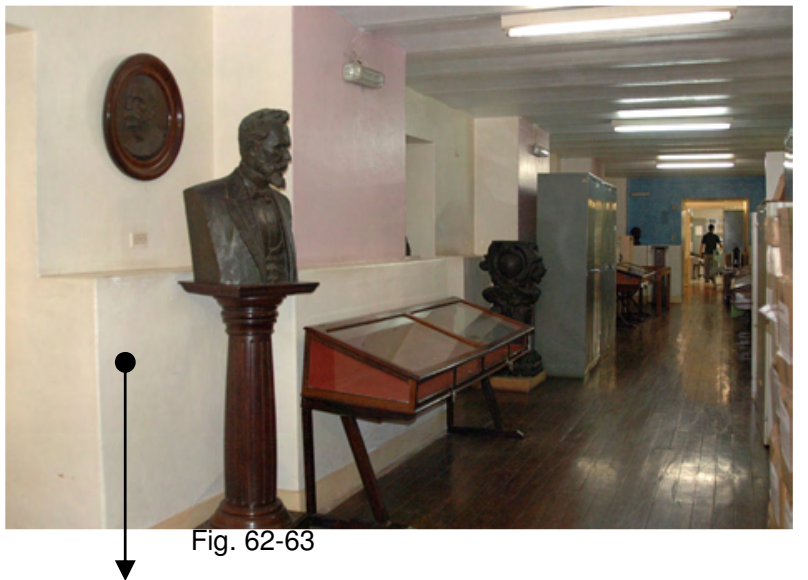

Fundação de pedra revestida com tijolo em espelho, distanciado da mesma por volta de $15 \mathrm{~cm}$. Esta solução foi adotada com o fim de isolar a umidade ascendente que era percebida no interior da galeria

$\mathrm{Na}$ área da Galeria não há nenhuma parede ou teto sem revestimento.

As paredes mestras e nos limites da área da galeria apresentam espessos maciços em formas retangulares.

Fig. 64

Não se tem informações a respeito de como eram estes locais, onde foram feitas as aberturas das portas de entrada das salas. Não é possível saber se era uma abertura retangular, como na Sala dos Ferros no Corpo Central, ou se era um arco sobre a alvenaria de pedra, como existem em diversos locais sob o Corpo Central.

Fig. 65 

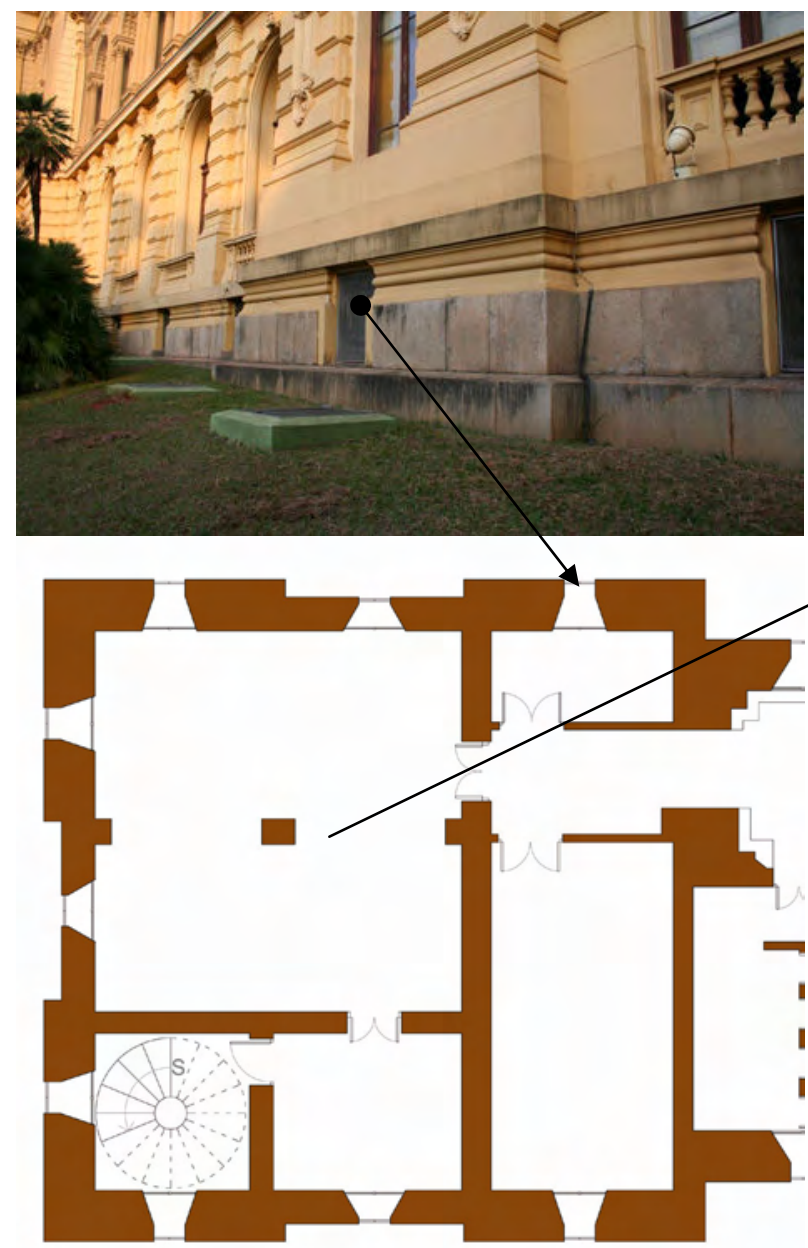

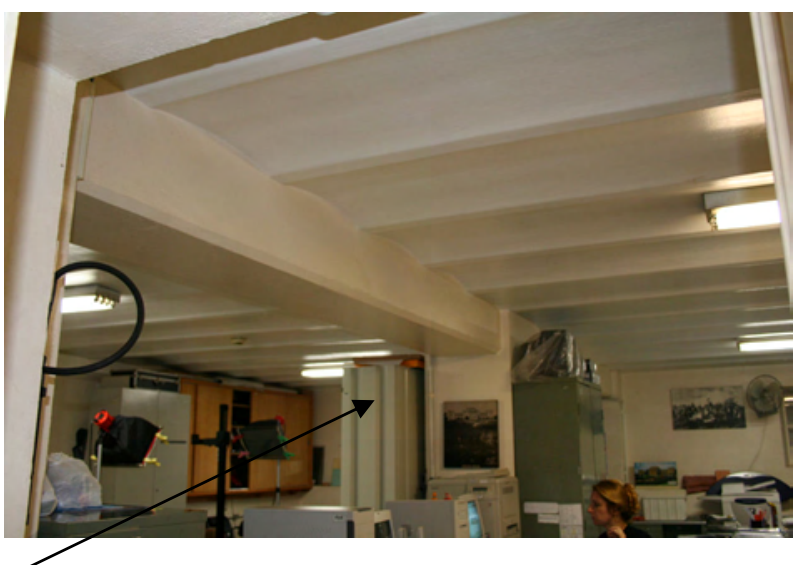

Fig. 66-67

As plantas das torres do subsolo se repetem no térreo e primeiro pavimento.

As paredes mestras se mantêm nas mesmas espessuras, variando apenas em relação às formas dos ornamentos em cada nível

As paredes das Torres em todas as fachadas, são exatamente iguais em todos os pavimentos. 


\section{PAVIMENTO TÉRREO - CORPO CENTRAL}

Neste pavimento podem ser observados os grandes maciços nas fachadas e nos espaços internos. As paredes mestras e as secundárias, se sobrepõem à planta do subsolo.

As paredes onde se apóiam as colunas isoladas da fachada principal, têm saliências com espessuras maiores do que as mesmas da face sul, onde as colunas são adossadas à parede.
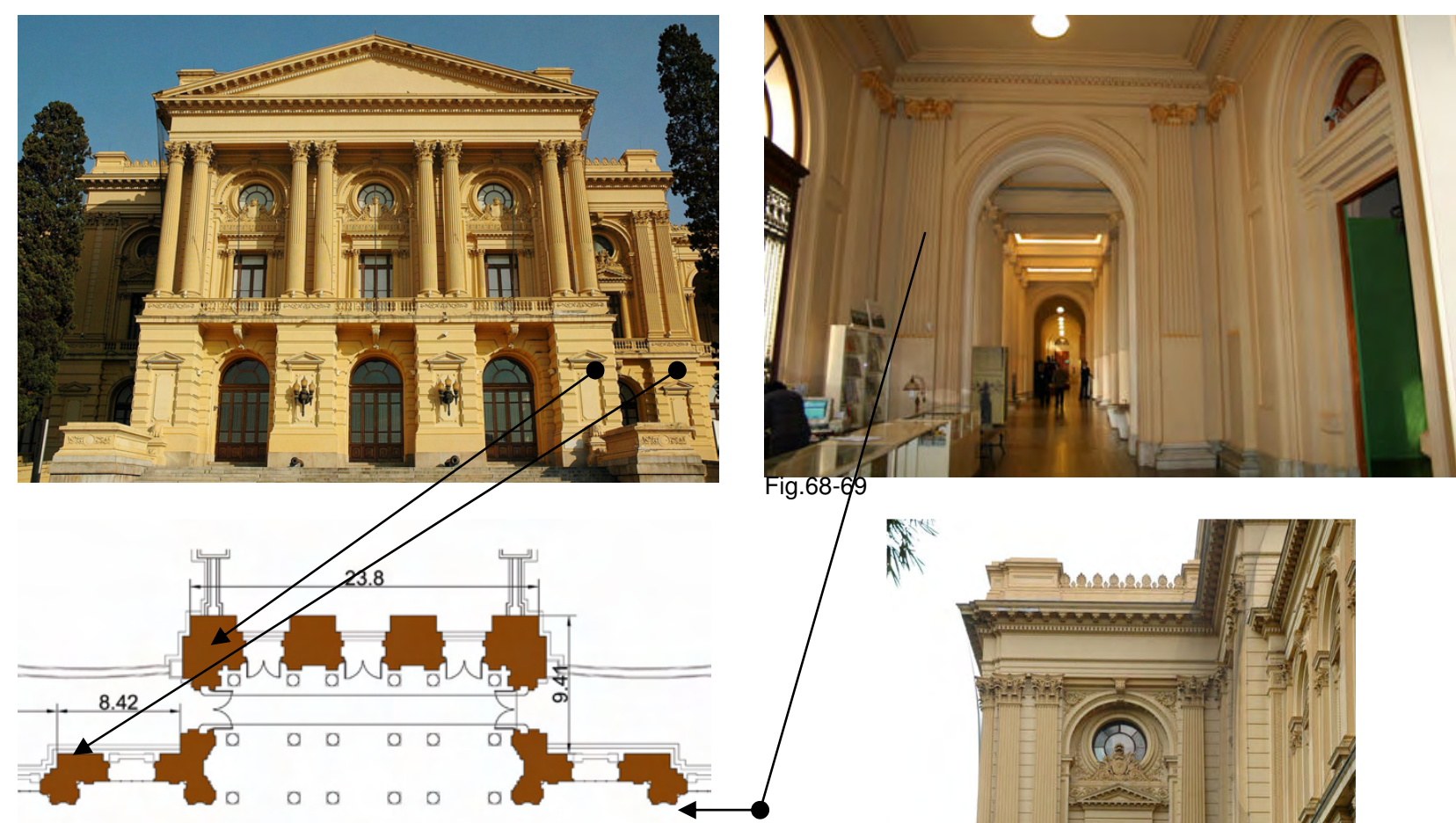

Fig.68-69
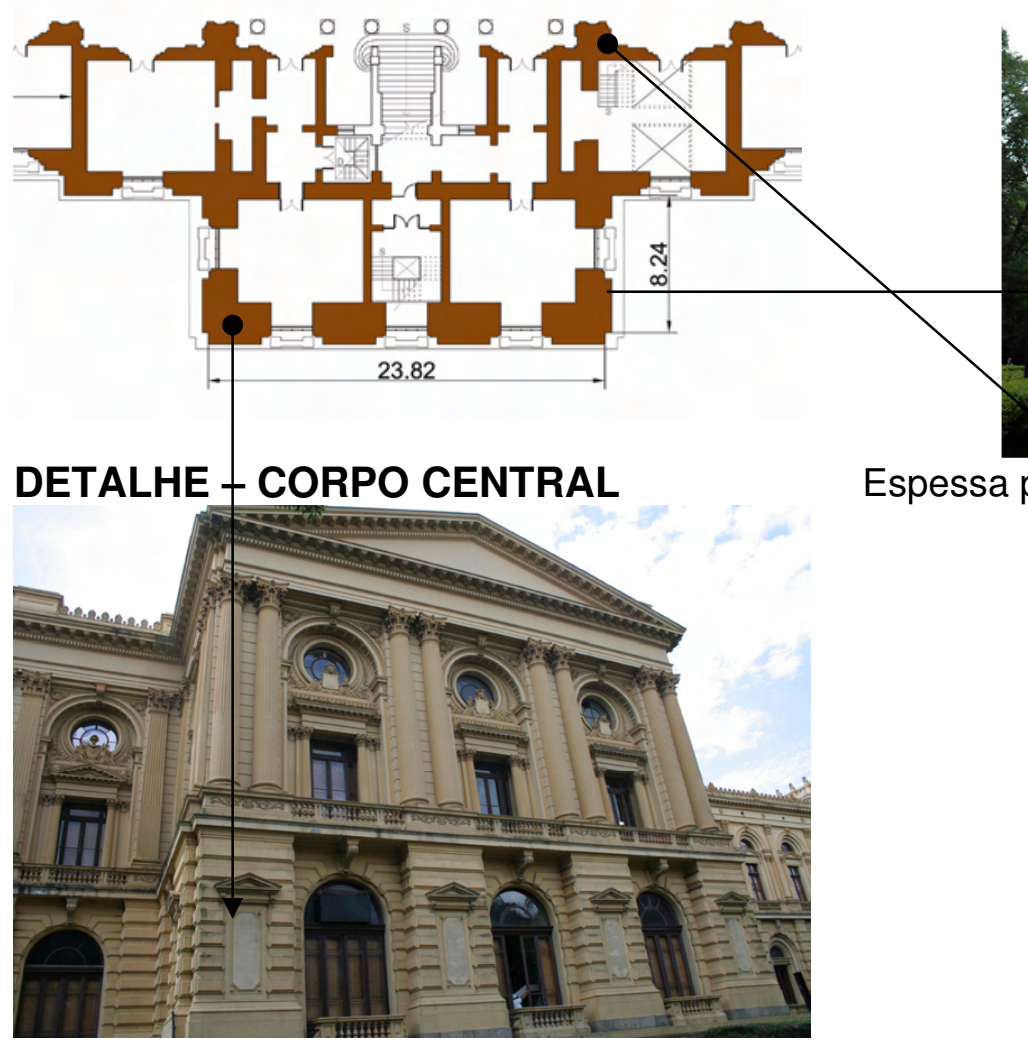

Espessa parede nas extremidades

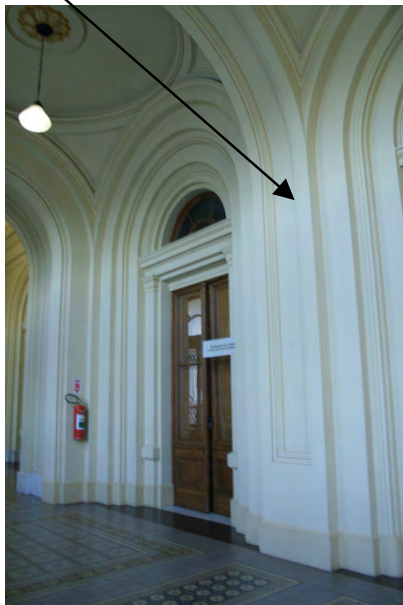

As fachadas norte e sul têm como acabamento a bossagem ou rusticado, o qual Bezzi chama de rústico toscano.

Na área interna do Corpo Central é utilizada a ordem jônica, considerada mais robusta, própria para um pavimento térreo. 


\section{PAVIMENTO TÉRREO - GALERIA}

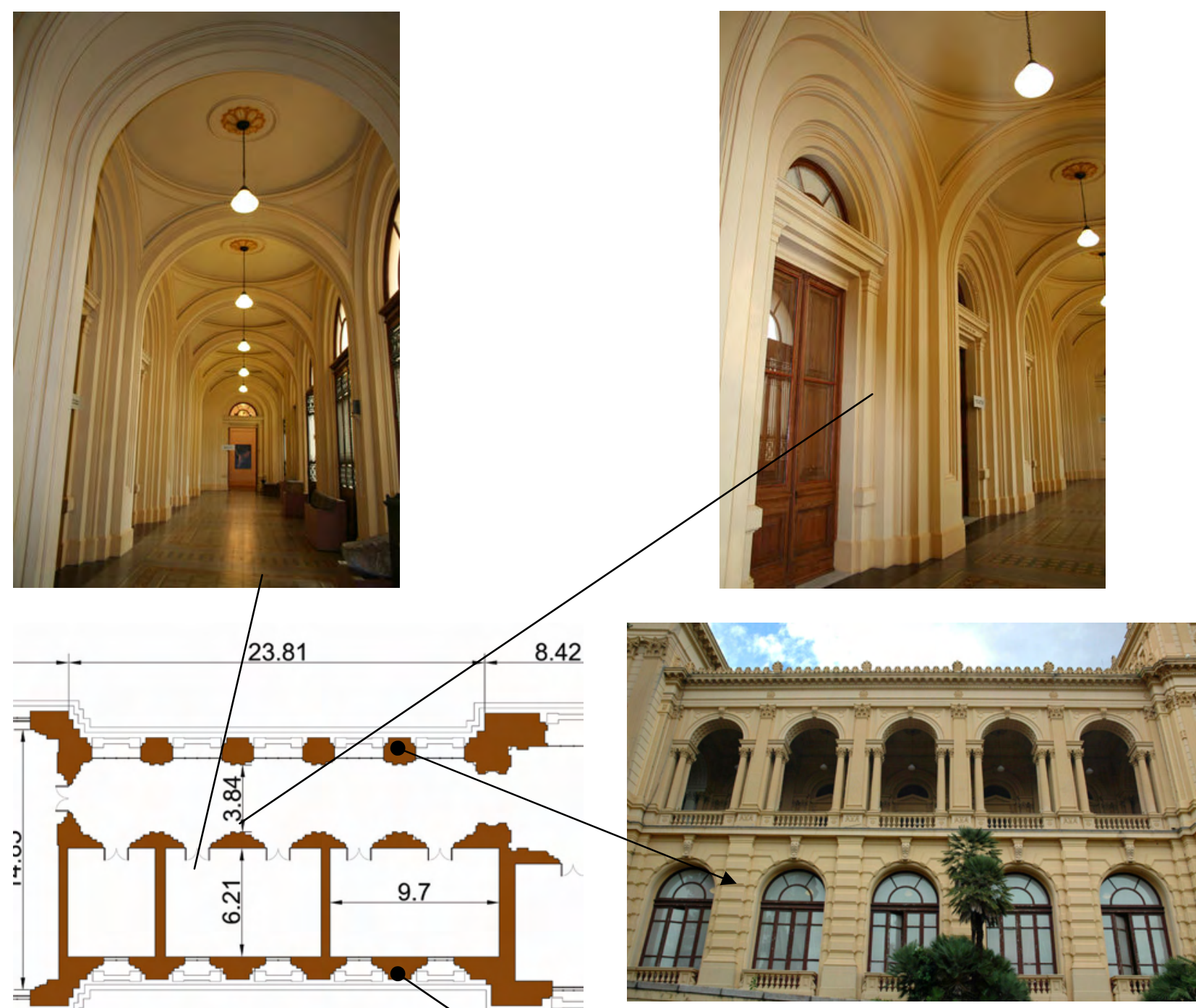

Fig.73-74-75-76

DETALHE - GALERIA

A face norte e a face sul das galerias têm soluções diferentes nas aberturas. Os arcos ressalvados têm menor largura de abertura e proporcionam maior dimensão aos pés-direitos

Galeria face norte - arcos semicirculares

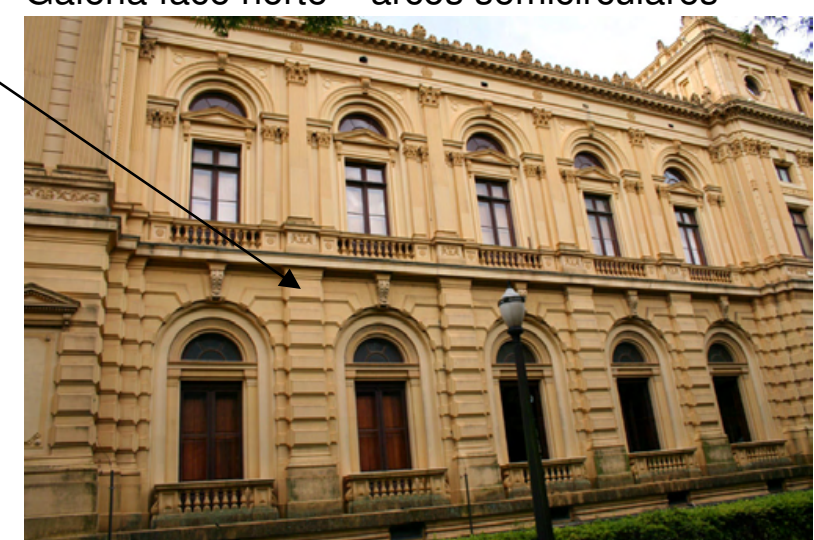

Galeria face sul - arcos de ressalva 
PAVIMENTO TÉRREO - TORRE
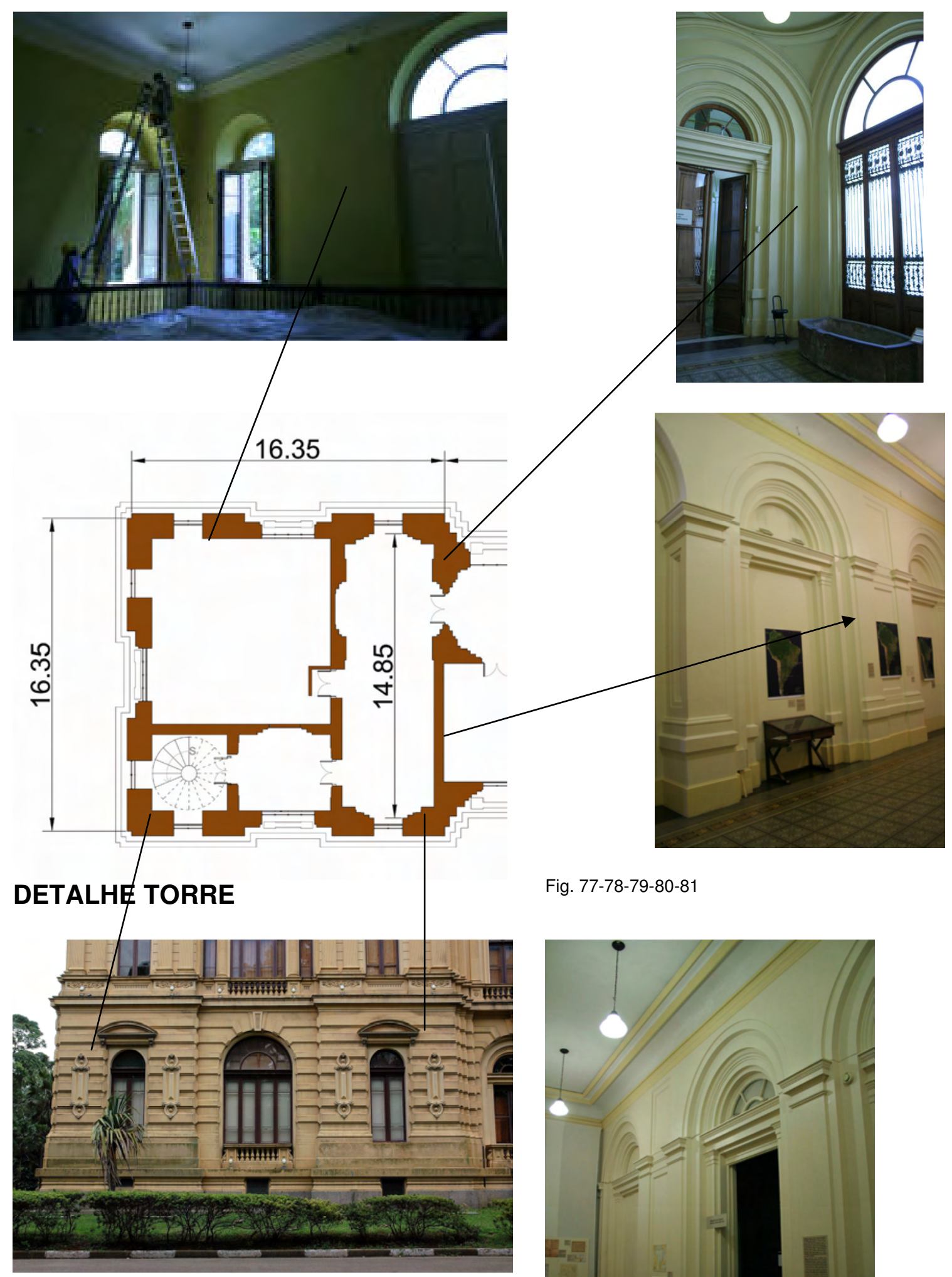

Fig. 77-78-79-80-81

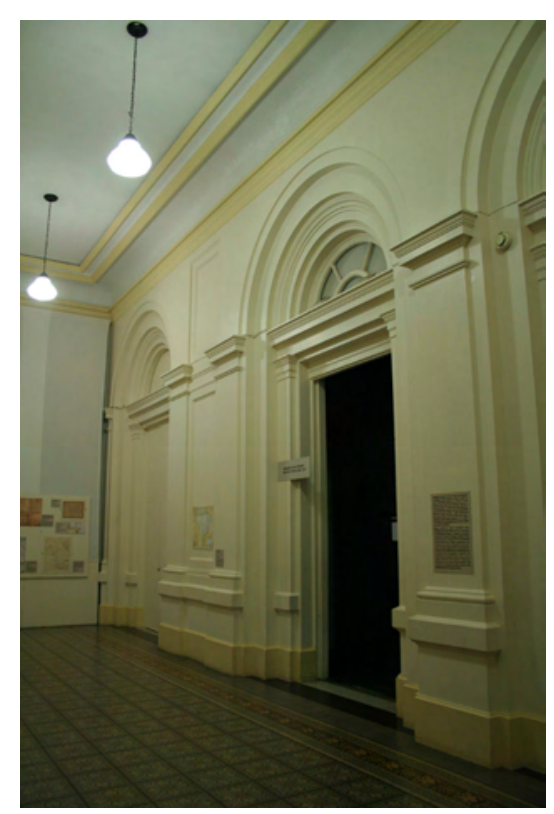


PRIMEIRO PAVIMENTO - CORPO CENTRAL

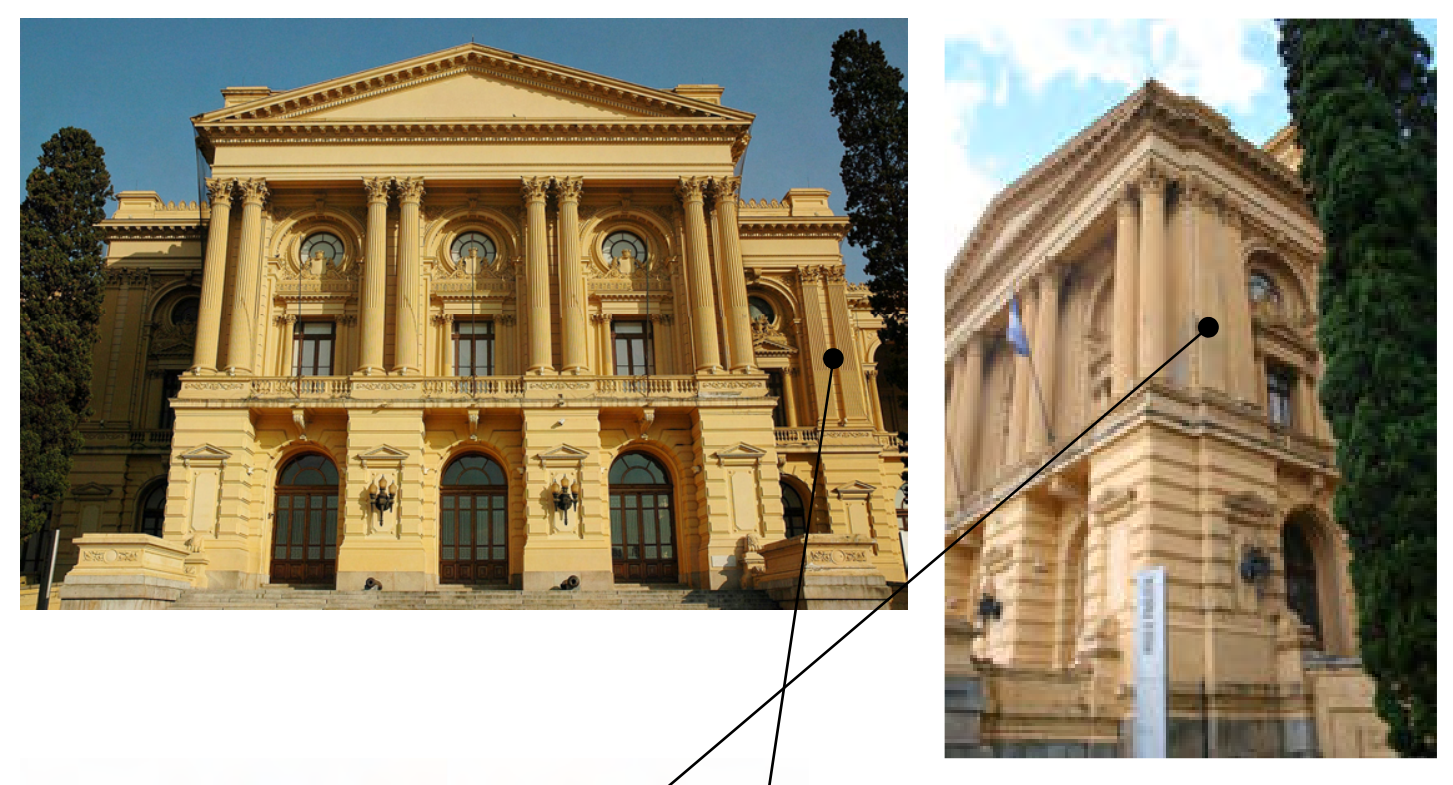

O Salão de Honra é o espaço que tem maior pé-direito (medida interna vertical)

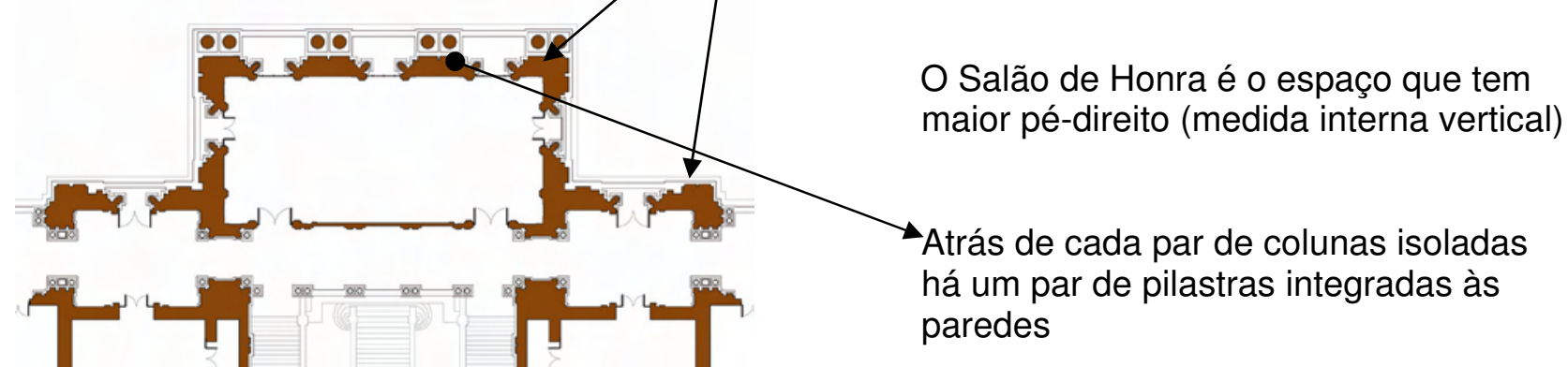

Grandes maciços são utilizados nas paredes mestras e nas intersecções com as paredes transversais e outras células

DETALHE CORPO CENTRAL

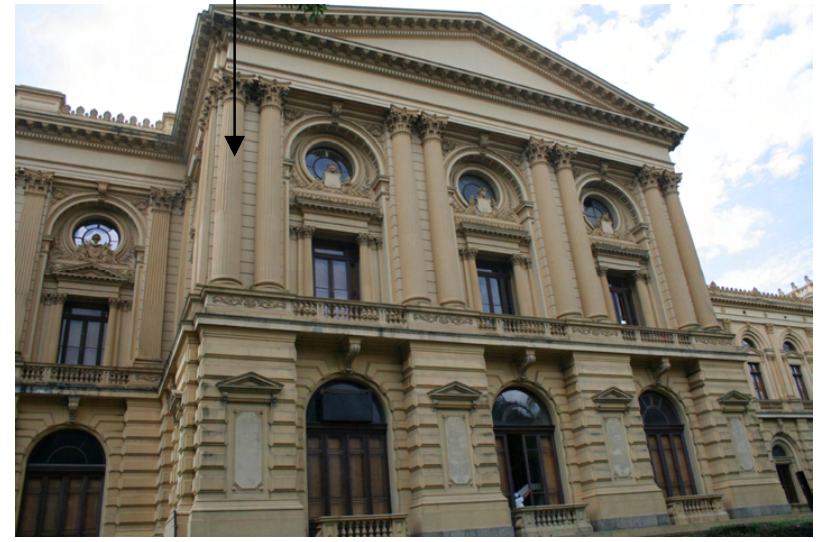

Fig. $81 \mathrm{~A}-82-83$

As colunas são adossadas às paredes e a saliência da arquitrave é muito reduzida. Entre as portas e os óculos há mais um pavimento, tanto no Corpo Central como em suas laterais 
Esta diferença de solução utilizada nas grandes colunas das fachadas norte e sul do Corpo Central, está relacionada à planta e à estrutura dos espaços voltados à face sul.

Ao grande pé-direito (medida da altura interna) do Salão de Honra, corresponde, na face sul, outro pavimento intermediário, de salas de trabalho. Considera-se que mais um pavimento aumentará a carga, assim, as paredes e pés-direitos deverão ser mais robustos.

Bezzi, no documento 237 da Pasta 4, afirma que as pilastras e colunas salientes 2/3 das paredes, serão consideradas como paredes, isto é, suportarão as cargas independentemente da forma estética que se apresentam.

Neste tipo de técnica, onde as cargas são distribuídas em toda sua área, o peso próprio de cada pavimento é somado e as fundações e o embasamento são previstos para suportar toda a carga. Normalmente, se tende a diminuir as espessuras dos maciços, conforme vão se elevando os pavimentos, e pode-se constatar este conceito nas Torres e, de certa forma, nas Galerias.

As plantas apresentadas de todos os pavimentos podem não representar com absoluta exatidão a realidade, devido à impossibilidade de medir todos os maciços por falta absoluta de acesso, mas permitem visualizar o conjunto.

No Corpo Central, é muito provável que estes maciços se mantenham praticamente até o ático com as mesmas dimensões, ou muito aproximadas, pois estes têm grande responsabilidade na estrutura, como veremos à frente. Referimos, por exemplo, à ancoragem nos maciços da imposta dos dois grandes arcos abatidos, da ancoragem do pórtico de aço que atiranta a estrutura metálica da clarabóia central, etc.
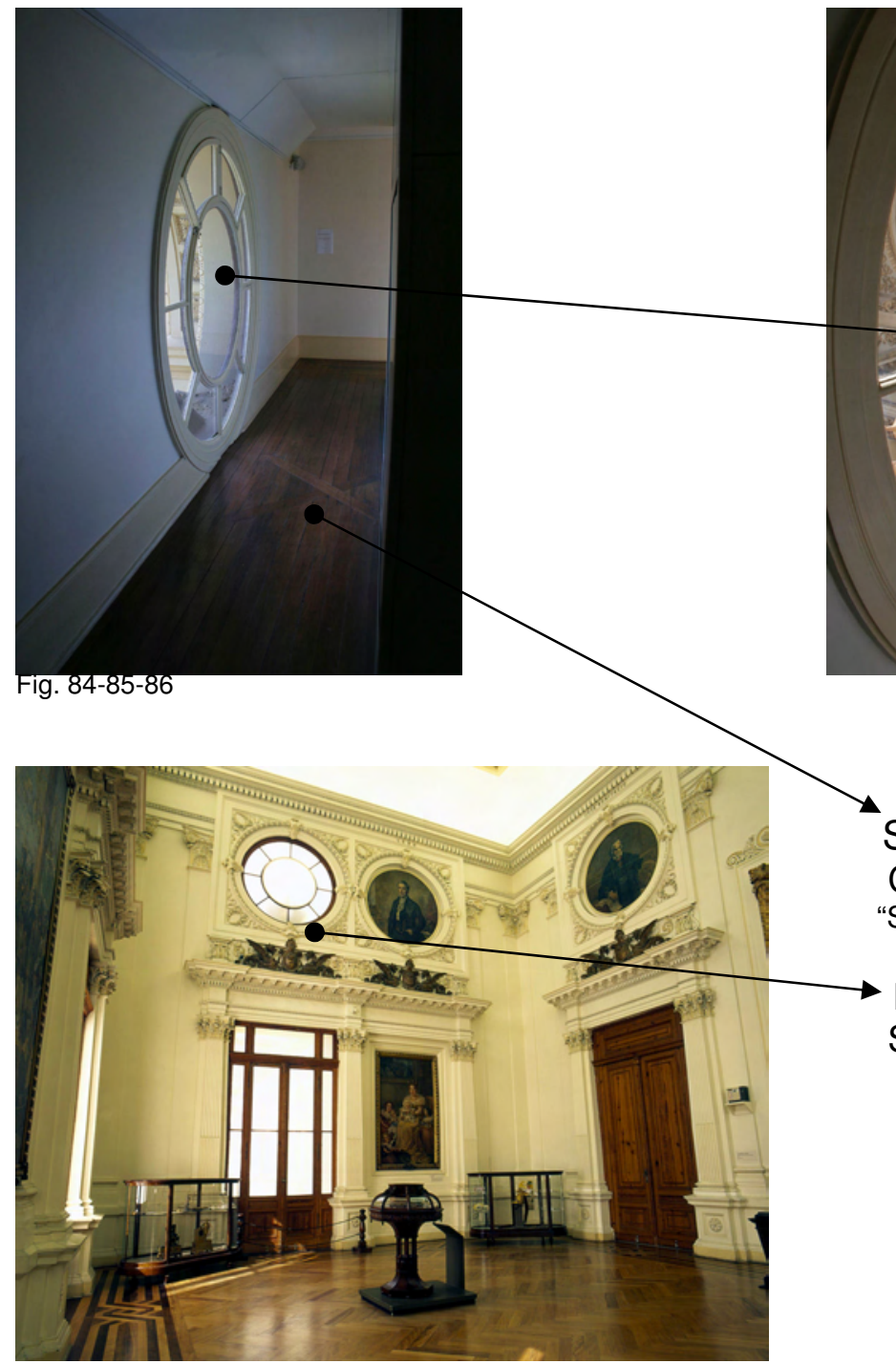

Segundo Pavimento na face sul do Corpo Central conforme planta:

"SEGUNDO PAVIMENTO - CORPO CENTRAL"

Nível do segundo pavimento em relação ao Salão de Honra 


\section{PRIMEIRO PAVIMENTO - GALERIA}
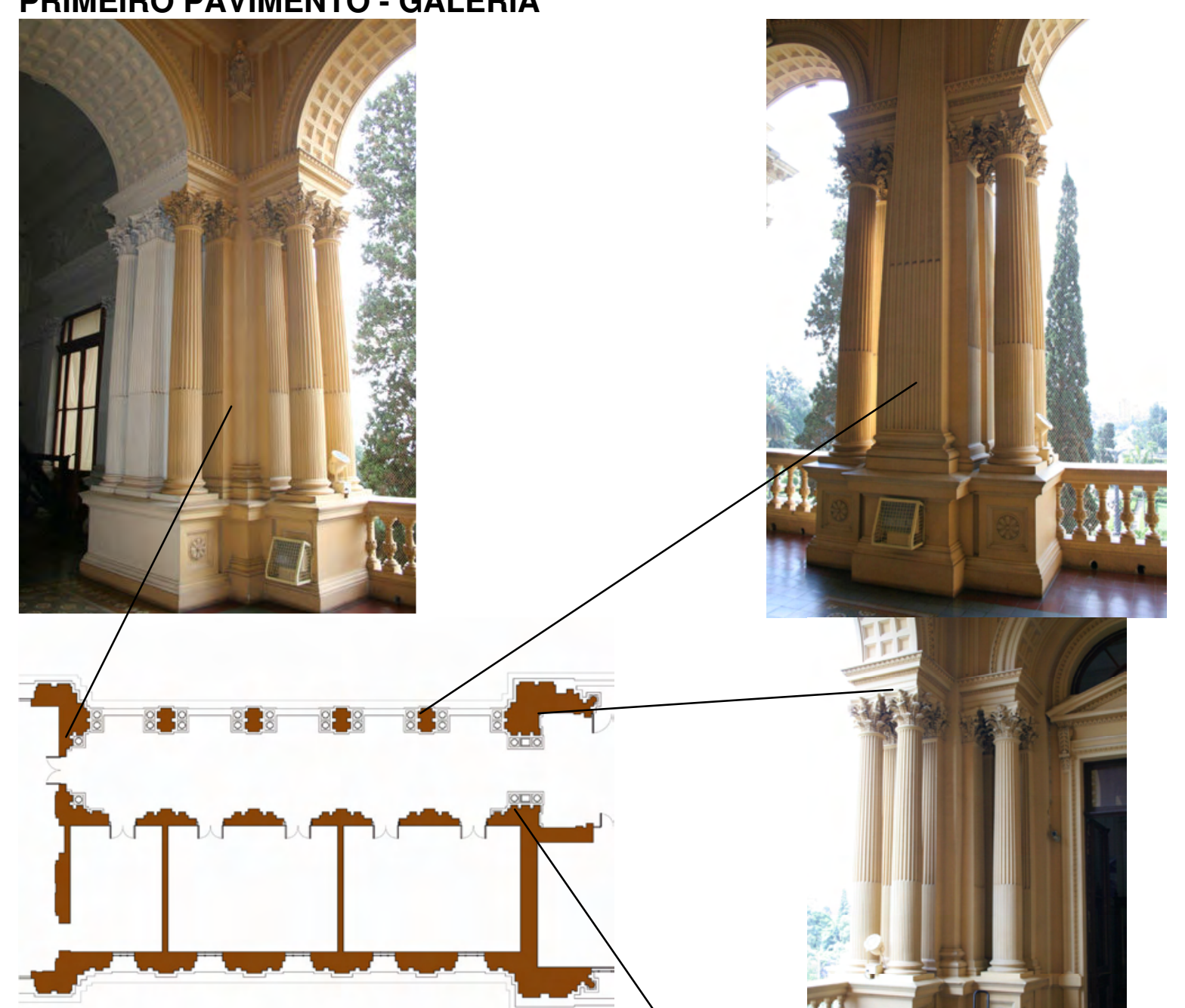

\section{DETALHE - GALERIA}

Os pés-direitos são constituídos por maciços com saliências e reentrâncias, em que são adossadas pilastras, tendo na sua frente ou laterais, colunas isoladas. Este conjunto, devido à variedade da volumetria e riqueza de ornamentos, apresenta leveza e movimento, apesar da espessura e peso dos pés-direitos, necessários a suportar os arcos. É uma solução estrutural que Bezzi emprega em vários locais, com as devidas variações, obtendo os mesmos resultados estéticos.

Neste pavimento é empregada a Ordem Coríntia, considerada a mais elegante e requintada, corresponde, no edifício, aos espaços mais nobres e de ligação do átrio, à escadaria monumental e Salão de Honra.

Fig. $87,88,89,90$ 
PRIMEIRO PAVIMENTO - TORRE

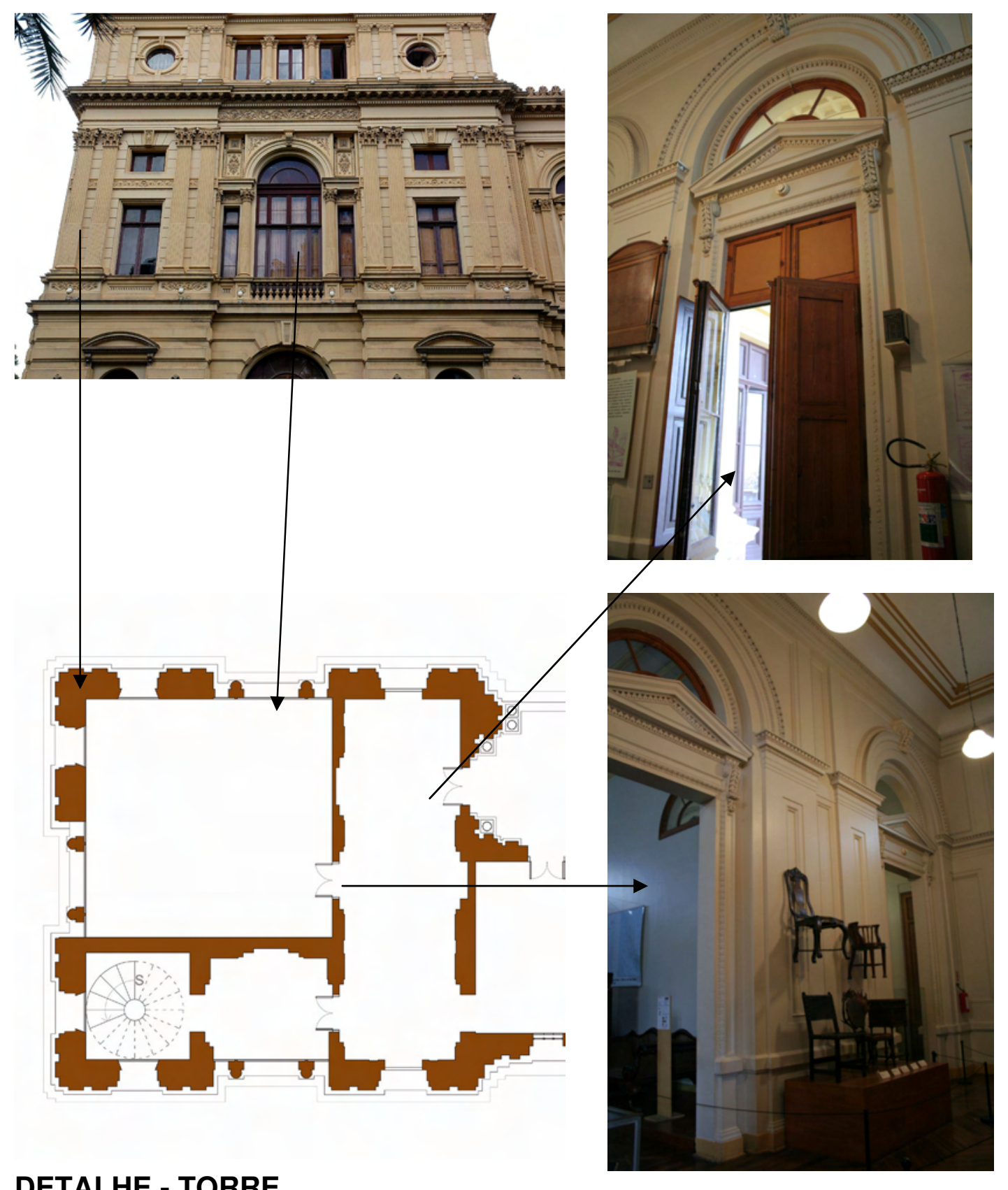

DETALHE - TORRE

Tanto a fachada como as paredes internas são ricamente ornamentadas pela Ordem Coríntia. As espessuras dos maciços se mantêm nas paredes mestras. Nas paredes internas são empregados arcos de ressalva, nas paredes de menor espessura, provavelmente como recurso para proporcionar maior resistência às cargas. Fig. 91,92,93 
SEGUNDO PAVIMENTO - CORPO CENTRAL

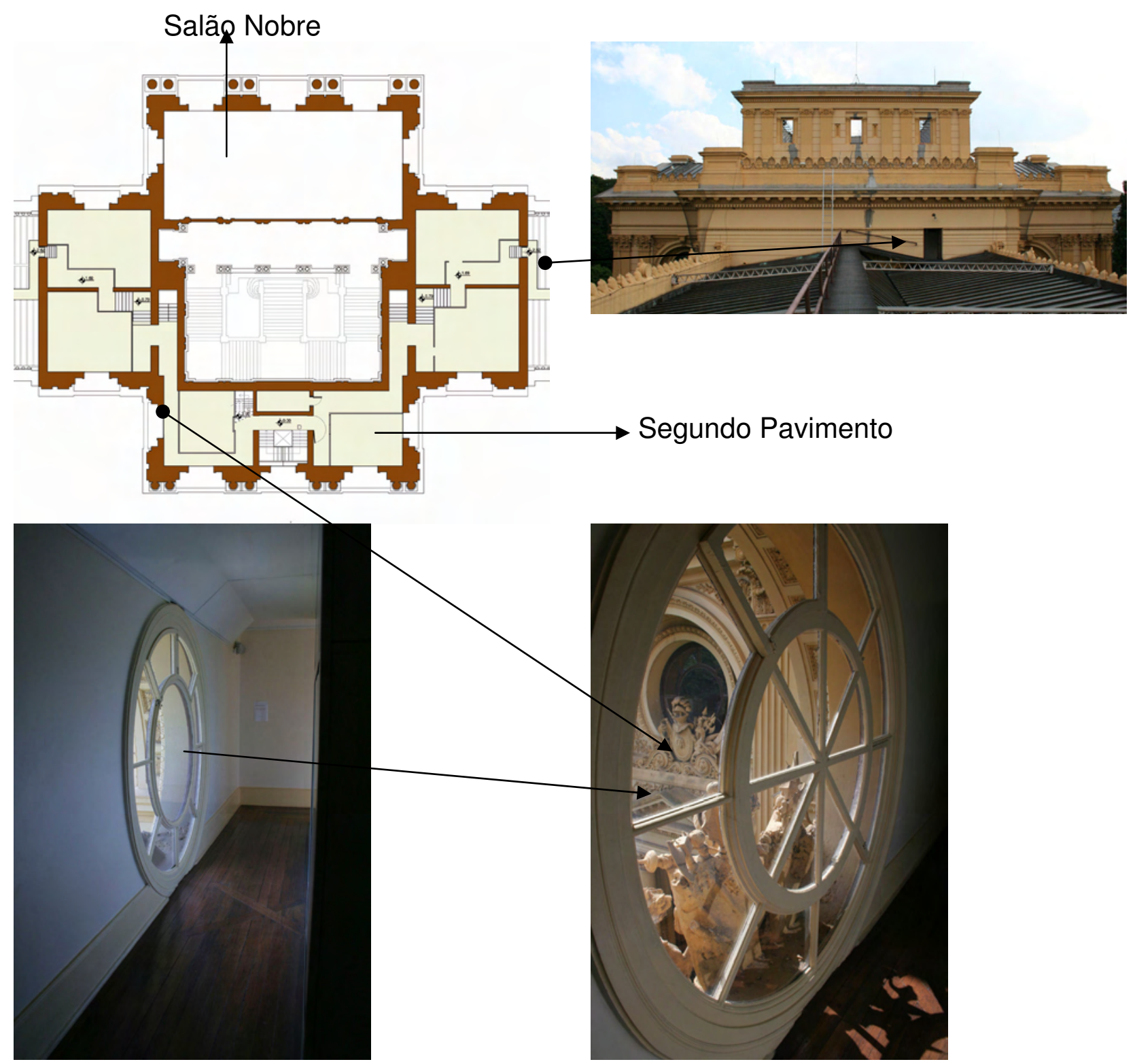

( $\left.{ }^{\star} 2\right)$ - Segundo pavimento do Corpo Central, face sul

Fig.94 95,96 


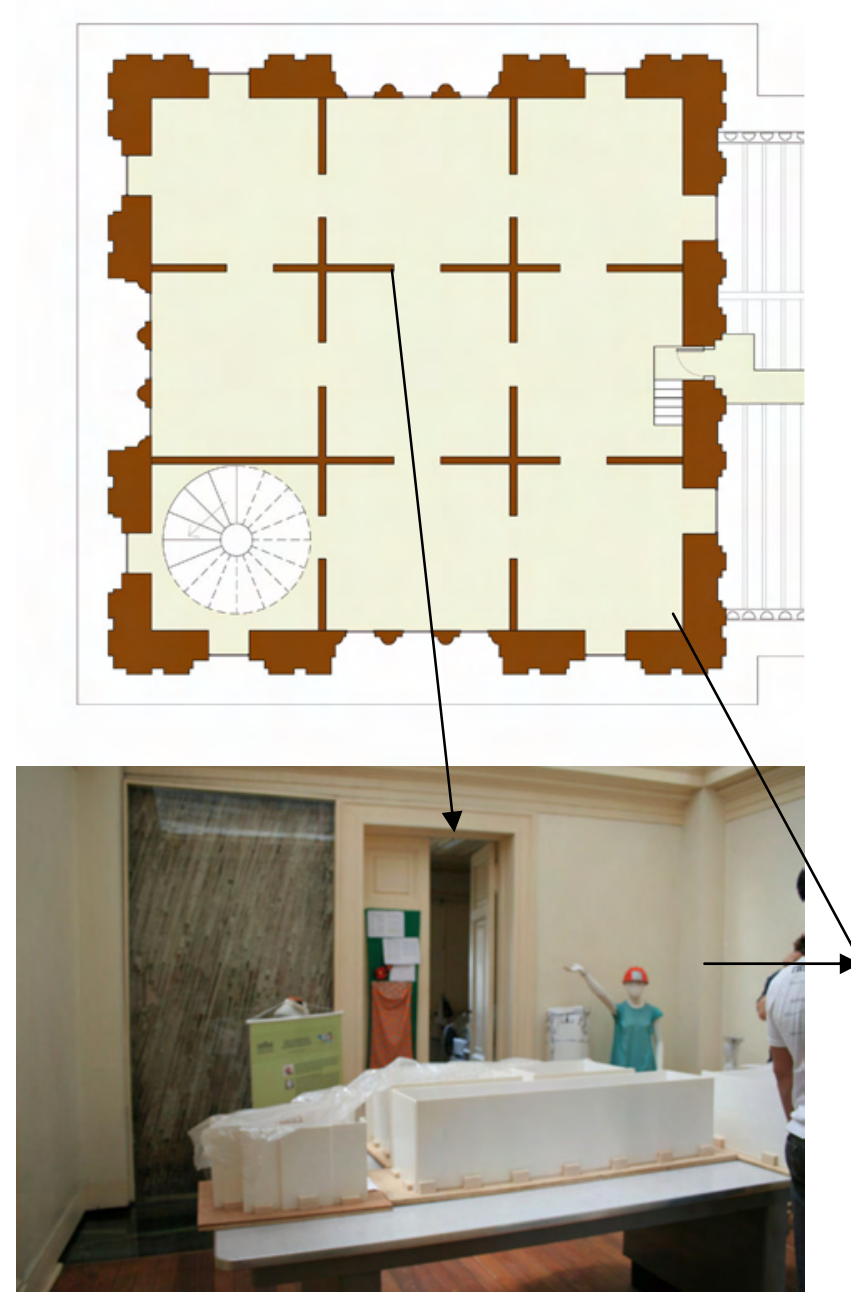

As paredes internas são divisórias em tabiques

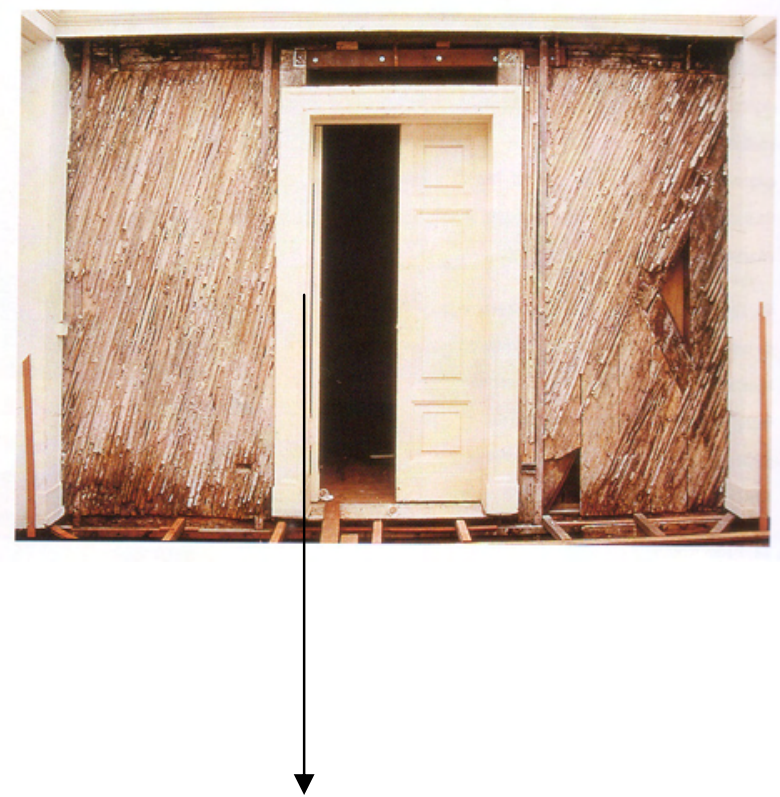

Estrutura conhecida como viga Vierendeel, atirantada na estrutura superior

Altura menor do que os demais pavimentos

Maciços nas paredes mestras se mantêm com as mesmas espessuras

Fig. 97, 98 


\section{APARELHO}

As paredes do edifício sem argamassa de revestimento podem ser vistas no subsolo, região onde foi escavado o solo original.

Não é possível verificar o aparelho utilizado numa secção horizontal, mas apenas em elevação do embasamento e intradorso dos arcos e abóbadas.

A escolha do tipo de aparelho de alvenaria de tijolo, depende da espessura da parede e de sua altura, e é indispensável para o travamento de uma fiada à outra, seja vertical, seja horizontalmente.

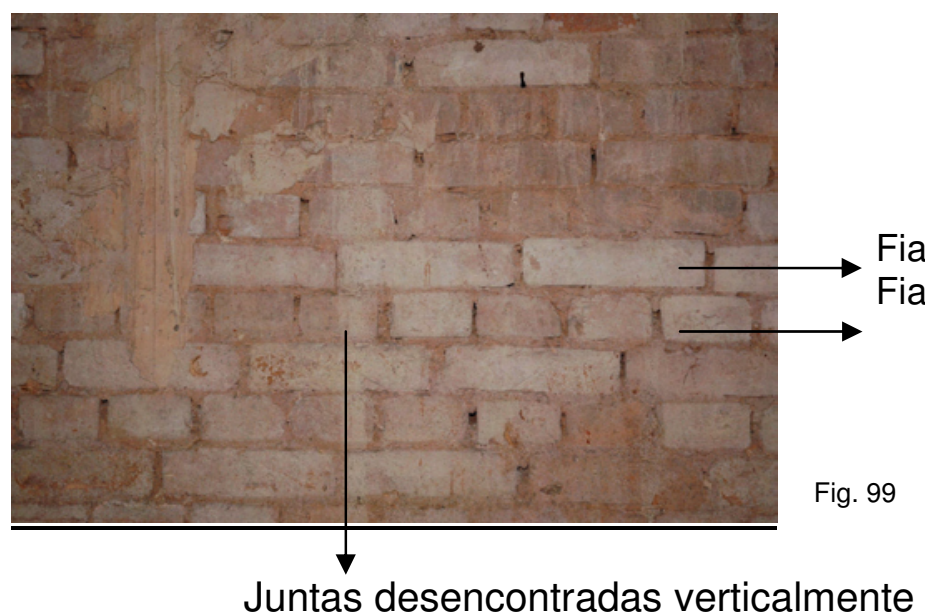

O chamado sistema inglês consiste em dispor alternadamente uma fiada de tijolos de um tijolo, ficando assim exposto o topo, e a outra, meio tijolo, ficando exposta à face do comprimento. Para paredes com espessuras maiores do que um tijolo, o que é freqüente neste edifício, não se pode observar o tipo do travamento utilizado.

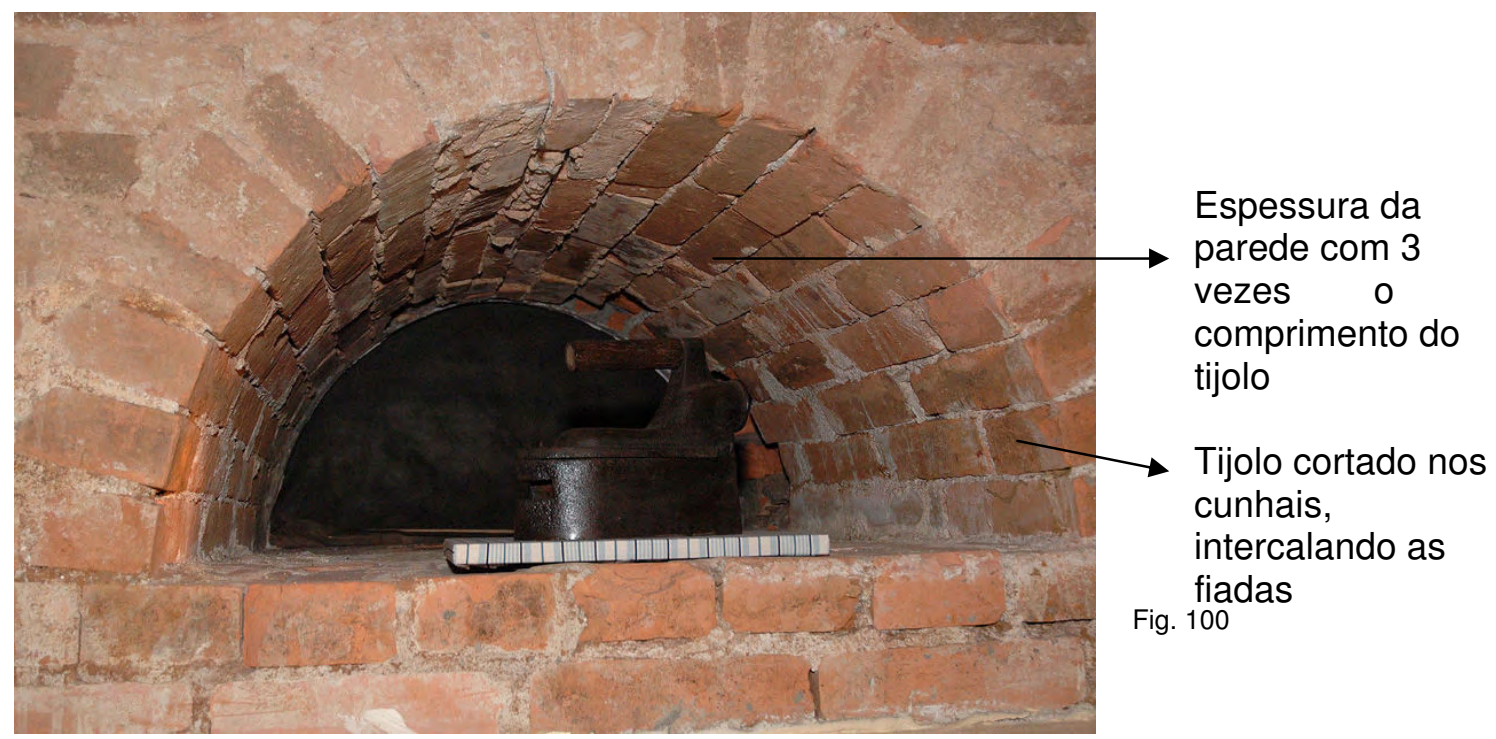




\section{ARCOS E ABÓBADAS}

\section{ARCOS SEMICIRCULARES}

Os arcos são um dos elementos principais nesta estrutura, juntamente com os pés-direitos, como já foi afirmado.

Há arcos desde a fundação, até o ático, e são utilizados três tipos: semicirculares, de ressalva, abatido, e as abóbadas.

$\mathrm{Na}$ fundação, os arcos semicirculares se localizam na alvenaria de tijolo do embasamento, sobre os alicerces de alvenaria de pedra, como pode ser observado na figura abaixo. Apresentam pequeno diâmetro, o intradorso acompanha a largura dos pés-direitos e dos grandes maciços de alvenaria. São utilizados em grande quantidade um próximo ao outro. É provável que foram planejados para proporcionar uma ventilação permanente longitudinal e transversalmente sob o edifício. É provável também que diversos arcos foram fechados, conforme a utilização das salas, como por exemplo, as destinadas aos banheiros.

Nesta região ainda foram encontradas duas abóbadas cilíndricas, uma do lado da outra, sob o piso entre os dois lances da grande escada de mármore.

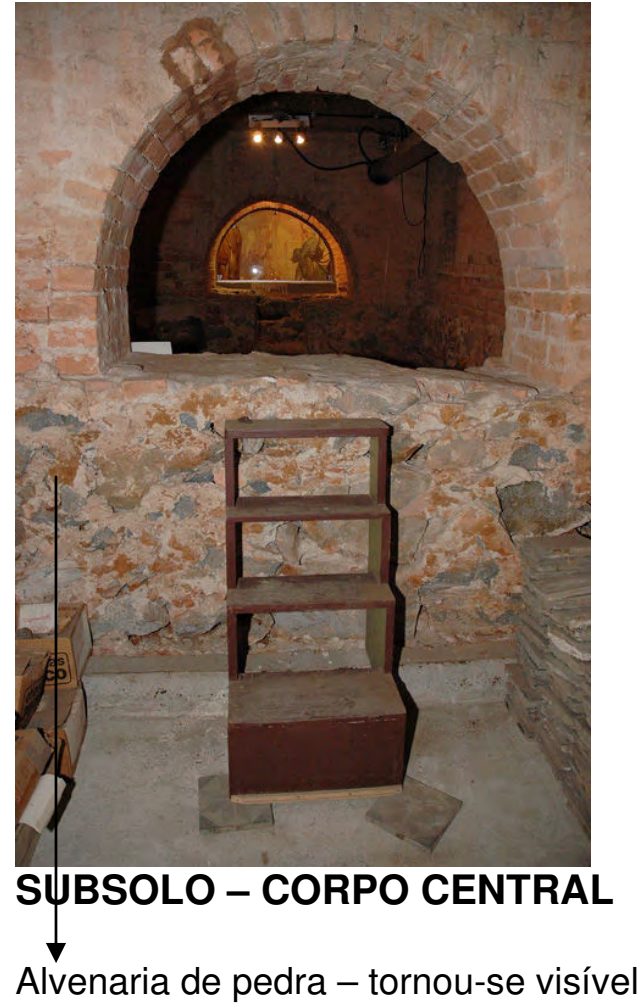

Após escavação do solo

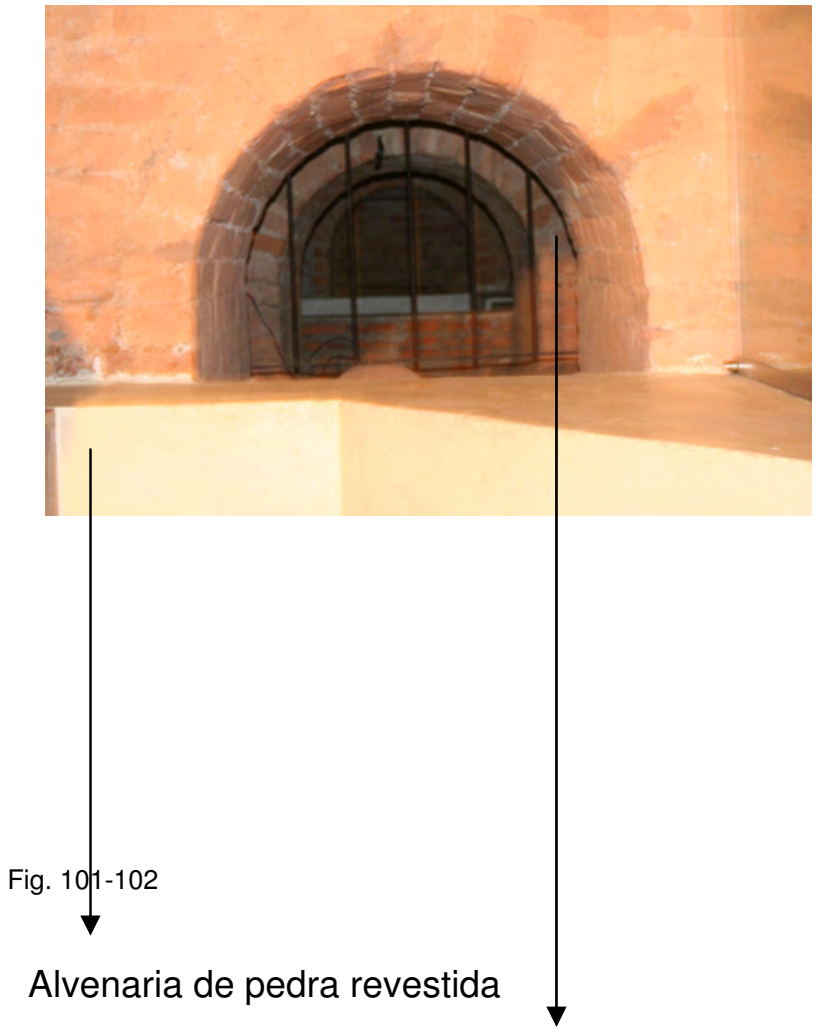

Arcos semicirculares 


\section{NOMENCLATURA E AS FUNCÕES ESTRUTURAIS DOS ARCOS E ABÓBADAS}

Os arcos são constituídos por um conjunto de elementos com uma determinada forma e cada qual com sua função.

\section{ELEMENTOS DOS ARCOS}

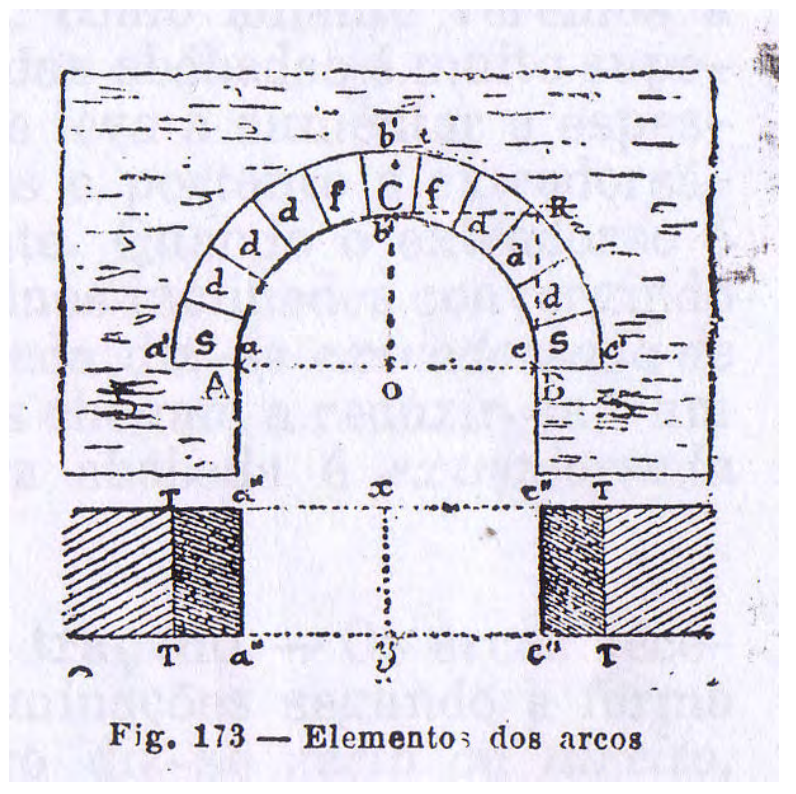

Segurado, Alvenaria e cantaria , p.143

Fig. 103

Definições: Para cobrir com alvenaria, ou cantaria, os vãos das portas e janelas, bem como os recintos murados, empregam-se os arcos e as abóbadas; os primeiros são, por assim dizer, abóbadas de pequeno comprimento. Servem para descarregar sobre os pés-direitos o próprio peso e o da construção que lhes fica superior. Os arcos são constituídos geralmente por blocos em forma de cunha, cujas juntas concorrem, em direção, no centro da curvatura do arco.

Temos que considerar em qualquer arco ou abóbada os seguintes elementos:

A e B - pés-direitos - onde se apóia o arco, que pode fazer parte integrante de uma parede ou serem constituídos por pilares isolados.

As partes do pé direito em que repousa diretamente o arco têm o nome de impostas, que costumam ser em geral molduras;

O plano superior que os separa do arco denomina-se plano das impostas, indicado na figura pela linha das impostas a' a - O - c c', resultante da intersecção do referido plano com a curva inferior e exterior do arco.

Os pontos a e c são os pontos de nascença, e as retas a" a" e c" c" as linhas de nascença.

A superfície interna $a \mathrm{~b} c$ do arco tem o nome de intradorso;

A externa a' b' c' de extradorso. Distinguem-se aqui as superfícies de intradorso e extradorso, das curvas de intradorso e extradorso. São as intersecções daquelas superfícies com os planos verticais, que limitam o arco ou abóbada.

Estas superfícies verticais recebem o nome de plano de testas.

Em abóbadas de cantaria os elementos cuneiformes $s, d, f, C, \ldots$ que as constituem chamamse aduelas, tendo algumas denominações especiais. 
Assim as que assentam diretamente nas impostas são saiméis $S, S$;

A que coroa a abóbada, é o fecho C;

As que ladeiam este último, são contrafechos $f$ e $f$.

Eixo da abóbada ou do arco é a reta $x$ y, traçada segundo o comprimento daquele, e passando pelo seu centro da figura.

Geratriz é a reta que pelo seu movimento gerou a abóbada, e diretriz a linha segundo a qual se fez esse movimento. No caso da figura, que representa um arco cilíndrico, a geratriz é a reta a" a" ou c" c" paralela ao eixo, que deslocando-se segundo a semi-circunferência a b c ou diretriz, no caso presente, produz a superfície do intradorso.

A flecha $\mathrm{O}$ b do arco é a altura medida da linha das impostas a c ao fecho, no intradorso;

O vão ou vivo do arco, é a largura a c medida naquela linha, isto é, a distância entre os pés direitos.

Os tímpanos da abóbada ou do arco são as superfícies b R c, compreendidas entre o semiarco do intradorso, a tangente horizontal deste arco, e a vertical da face interna dos pés direitos.

Os rins da abóbada são sólidos, compreendidos entre os tímpanos, as superfícies do intradorso, e o plano horizontal tangente a esta superfície no fecho.

Os arcos e as abóbadas chamam-se extradorsadas paralelamente, quando a curva do intradorso e a do extradorso são paralelas entre si, ou concêntricas. Por exemplo, é o caso, , da arquivolta das arcadas clássicas.

Geralmente, em abóbadas, não são paralelas as superfícies; a carga sobre os rins das abóbadas é muito superior à do fecho, o que leva a aumentar a espessura naqueles pontos, e portanto a extradorsá-las não paralelamente. Quando o extradorso é formado por dois planos inclinados, convergindo sobre o fecho, a abóbada diz-se extradorsada de chapa; os dois planos chegam a reduzir-se a um único horizontal, e a abóbada é extradorsada horizontalmente.[...]p.145

Arcos de círculo simples, semicircular ou de volta inteira, é o mais vulgar de todos os arcos, e o único empregado nas arcadas clássicas; a sua flecha, igual ao raio, é metade do vão, visto este corresponder ao diâmetro.[...]

O arco de volta abatido ou de gearção, é ainda um arco circular, mas de flecha inferior a metade de abertura. [...]

A curva do intradorso do arco de volta inteira é tangente na nascença à face interna dos pés-direitos; no arco de gearção essa tangente faz um ângulo com a linha da prumada dos pés-direitos.[...]

$\mathrm{Na}$ estrutura os arcos são concebidos a:

- vencer o vão entre os apoios

- resistir às cargas descarregadas sobre o seu extradorso (por exemplo parte do peso de uma abóbada ou de um pavimento de madeira)

- transmitir aos pés-direitos as sobrecargas e o seu peso próprio limitar o movimento dos pés-direitos que suportavam as abóbadas, quando a estrutura estivesse sujeita a ações horizontais

(MATEUS, 2002, p.80)

Em geral, os arcos semicirculares, de curva contínua e policêntricos, que constituem os tipos mais descritos na literatura, destinavam-se a suportar paredes, abóbadas e pavimentos de madeira. 
Estes arcos são os mais utilizados na estrutura do edifício em estudo.

\section{ABÓBADAS CILÍNDRICAS}

As abóbadas ocupavam geralmente a maior superfície em planta, e eram posicionadas superiormente a arcos, a paredes, a colunas e pilastras, sobre os quais descarregavam os seus peso próprio e sobrecargas de utilização.

Os arcos, se representados em planta, não eram geralmente mais largos que a espessura das paredes autoportantes.

Espessura das Abóbadas

A impulsão das abóbadas, isto é, o esforço que exercem sobre os pés-direitos, não tem o mesmo valor nos diversos tipos.

As abóbadas cilíndricas e as elevadas, como as ogivais, apresentam maior estabilidade e são suscetíveis de agüentar grandes cargas no fecho; a direção da impulsão ou reação dos pésdireitos é vertical ou quase.

A impulsão aumenta à medida que a flecha diminua. [...] Portanto os arcos abatidos emitem maior força oblíqua sobre os maciços.

(SEGURADO, sem data, p.184)

As abóbadas cilíndricas, de berço, de tumba ou de canudo, correspondem exatamente aos arcos de volta inteira, diferenciando-se apenas pelo seu maior comprimento. Podem igualmente ser diretas ou enviesadas, segundo as suas geratrizes, são perpendiculares ou não aos planos das testas.

Utiliza-se este tipo de abóbadas para cobrir espaços limitados por planta quadrada, retangular, romblidal ou paralelogrâmica em geral.[...] (SEGURADO, sem data, p.158)

As abóbadas eram concebidas de modo a:

- cobrir um determinado espaço e definir um determinado volume do edifício

- a resistir às cargas e sobrecargas de um pavimento instalado sobre o seu extradorso

- transmitir as sobrecargas e o seu peso próprio aos arcos ou diretamente aos pés-direitos

- apresentar um intradorso com um aspecto estético determinado

(MATEUS, 2002, p.80)

O documento 150 da Pasta 3 - Abobedas, é composto por 4 páginas. Na primeira página, procurou-se interpretar que:

- Abobedas entre as arcadas das galerias, seriam os próprios "arcos"

- Abobedas entre vigas de ferro do térreo e primeiro pavimento, tudo indica que são as abobadilhas

- Abobedas sob os patamares da escada de mármore - há um patamar central e num nível acima, dois patamares laterais, que devem ter uma estrutura bem robusta

- O nicho e a "callota" é o local onde está á escultura de D.Pedro

- Abobedas no vão entre os braços da escada de mármore, devem ser as que foram "descobertas" no subsolo, conforme as imagens indicam, no início do próximo item.

Somente estas portanto, são visíveis nesta área da escadaria de mármore.

Observando-se no subsolo o local sob o átrio (onde há o solo original), a parede longitudinal que é vista ao fundo neste local, está sob o piso da entrada de veículos. A respeito desta área, e a seguir a área sob a escadaria externa de cantaria, somente foi encontrada a citação neste documento, que há abóbadas sob a escadaria. Pasta 3, DOCUMENTO 150: 
Afrotredas de 16 "as

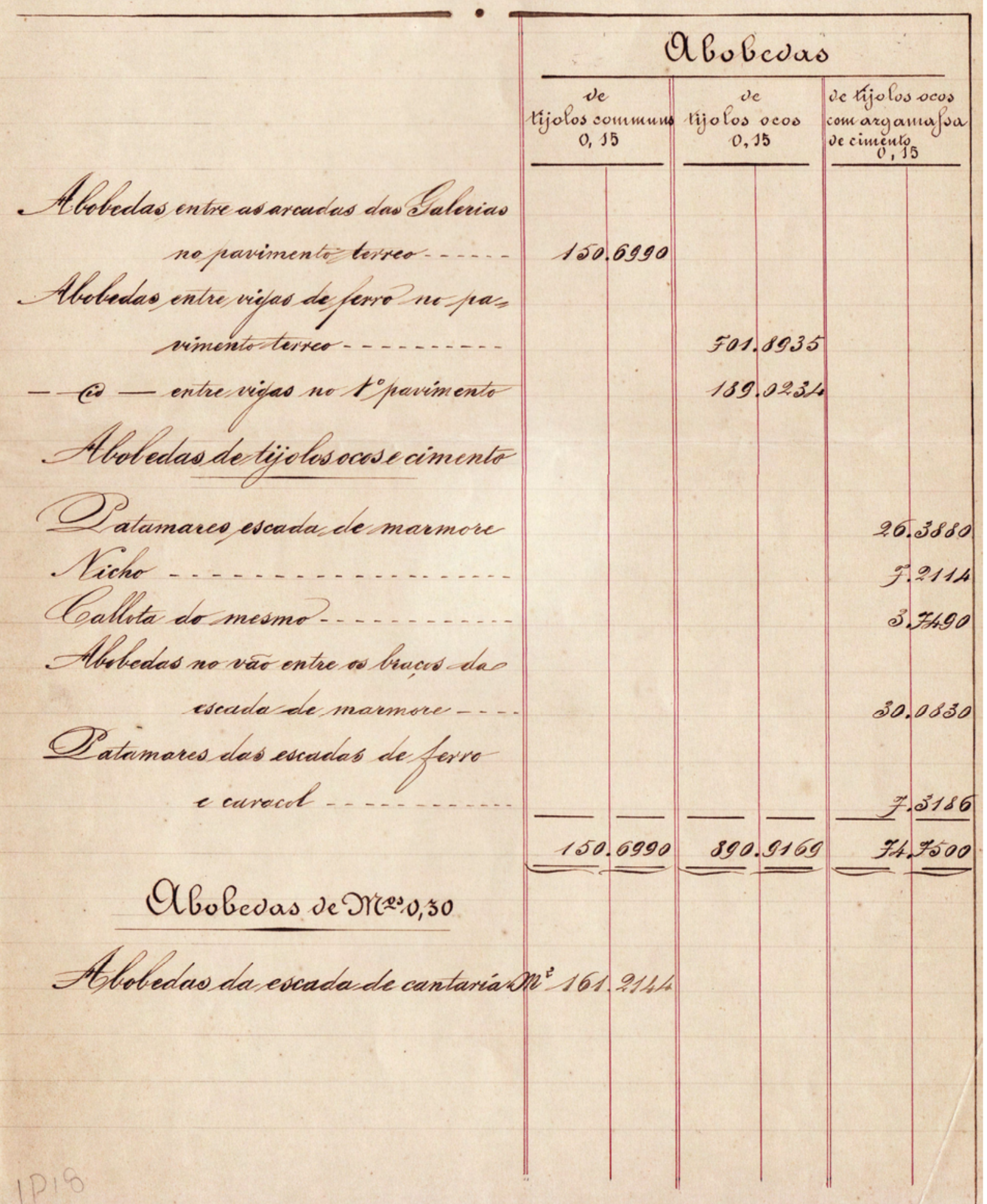




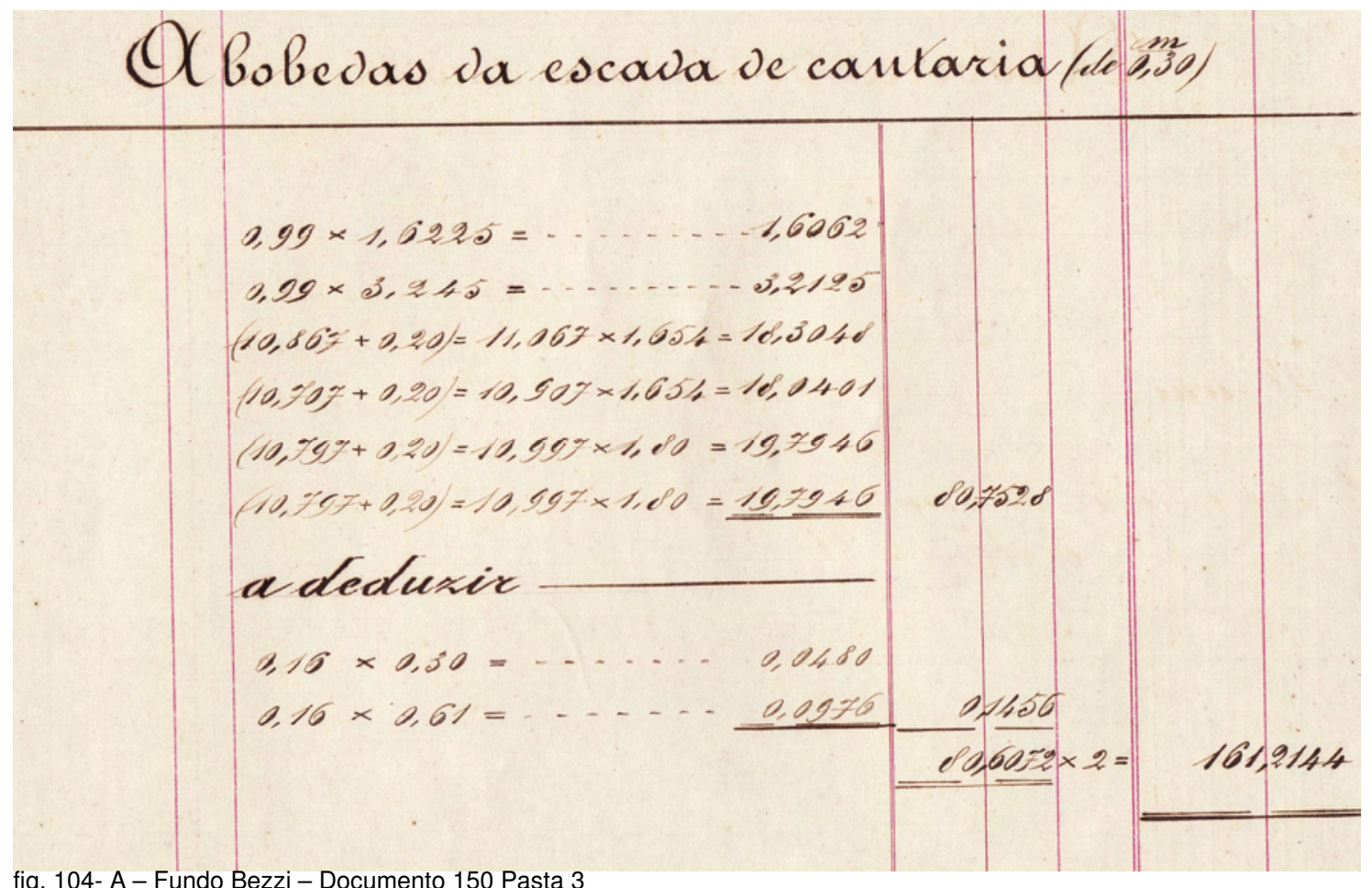

fig. 104- A - Fundo Bezzi - Documento 150 Pasta 3

Devido aos 6 itens, cada qual com dimensões diferentes, tem-se como hipótese, o emprego de 6 abóbadas nestas especificações.

Considera-se que uma abóbada é a solução estrutural que cobre um determinado espaço. Como indica o documento citado, Bezzi chamava de abobedas também os arcos com o intradorso um pouco mais largo, como os das arcadas das galerias, onde tem ornamentação em sua superfície.

O que tudo indica, é que nesta área da escada de mármore e mesmo na escada externa, tenham sido empregadas robustas abóbadas semelhantes às observadas no subsolo. Mas ainda resta o questionamento a respeito da solução empregada sob os lances da escada de mármore, se são "abóbadas cilíndricas rampantes" ou outra solução com vigas metálicas.

As abóbadas muito espessas que descarregam seus impulsos sobre pés-direitos e paredes igualmente espessos, são empregadas nos locais de maior responsabilidade estrutural, constituindo-se na característica fundamental desta técnica construtiva.

PLANTAS COM A LOCALIZAÇÃO DOS ARCOS E ABÓBADAS NO SUBSOLO, NO TÉRREO E NO PRIMEIRO PAVIMENTO

As plantas a seguir apresentam as localizações de arcos e abóbadas de forma geral na estrutura dos pavimentos, mas somente aqueles que podem ser observados.

Depois então, são individualizados os arcos e abóbadas, verificando-se a integração das soluções estruturais e ornamentais, que são inseparáveis. 


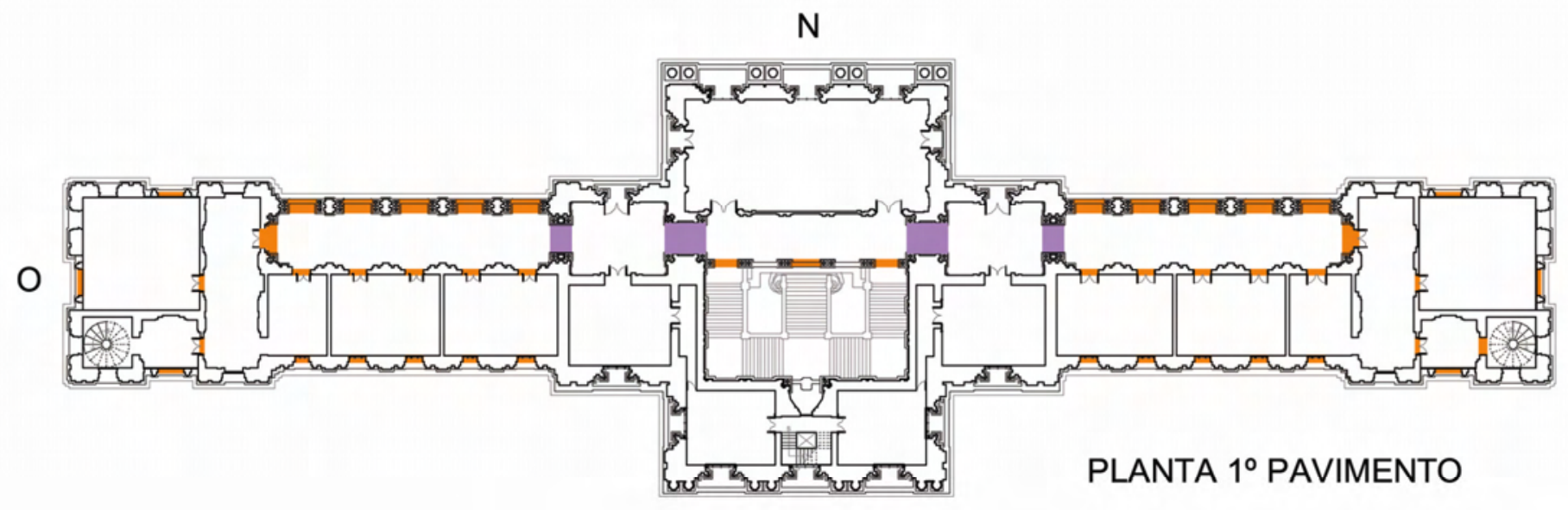

L
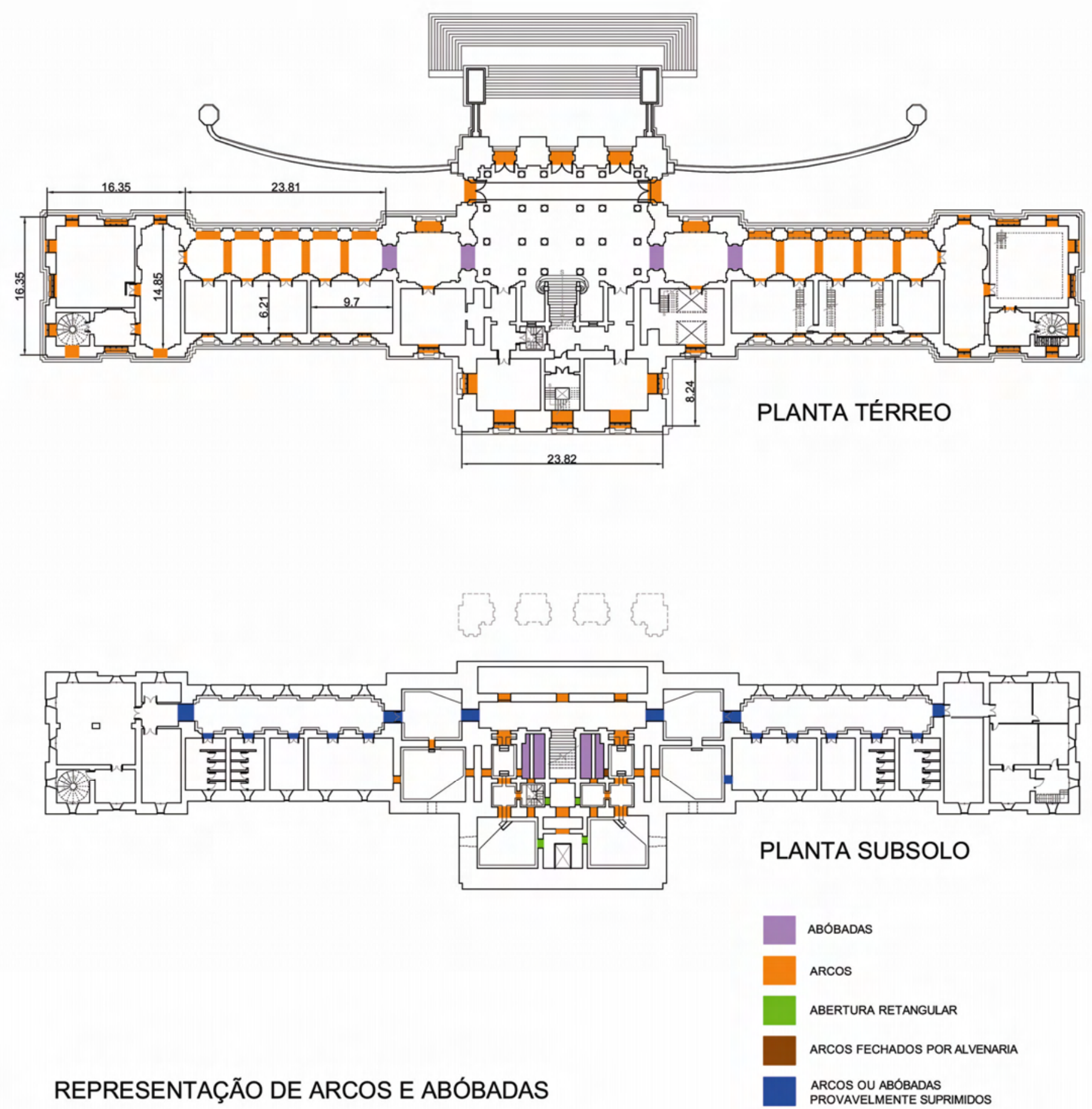


\section{ARCOS E ABÓBADAS \\ ARCOS SEMICIRCULARES E ABÓBADAS CILÍNDRICAS \\ SUBSOLO - CORPO CENTRAL (1)}

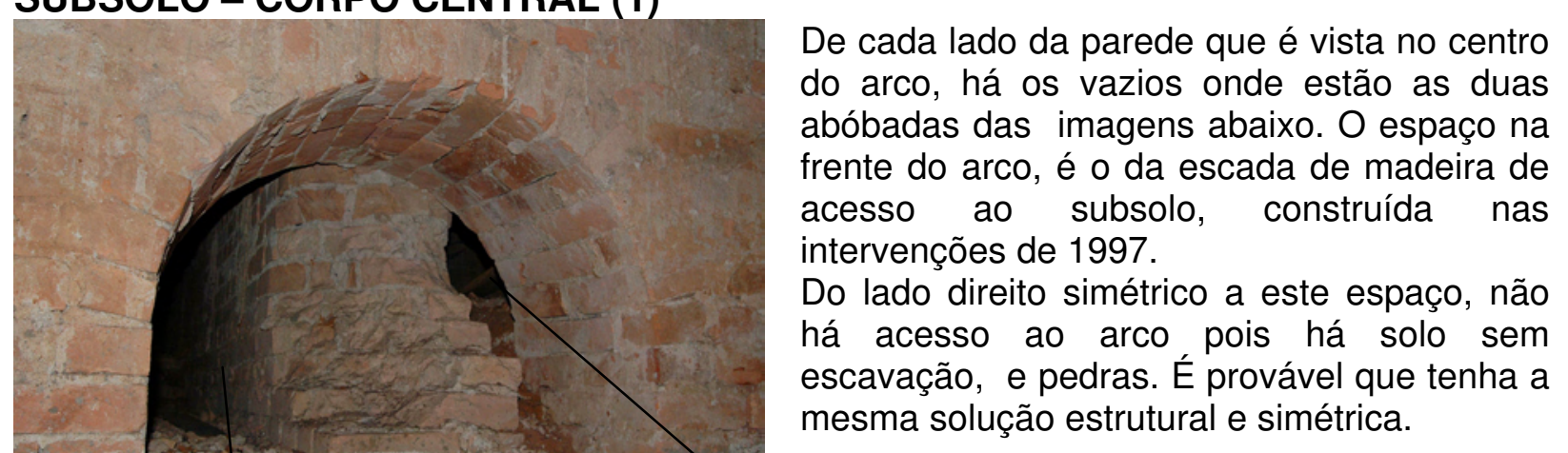

Fig. 105,106,107,108,109

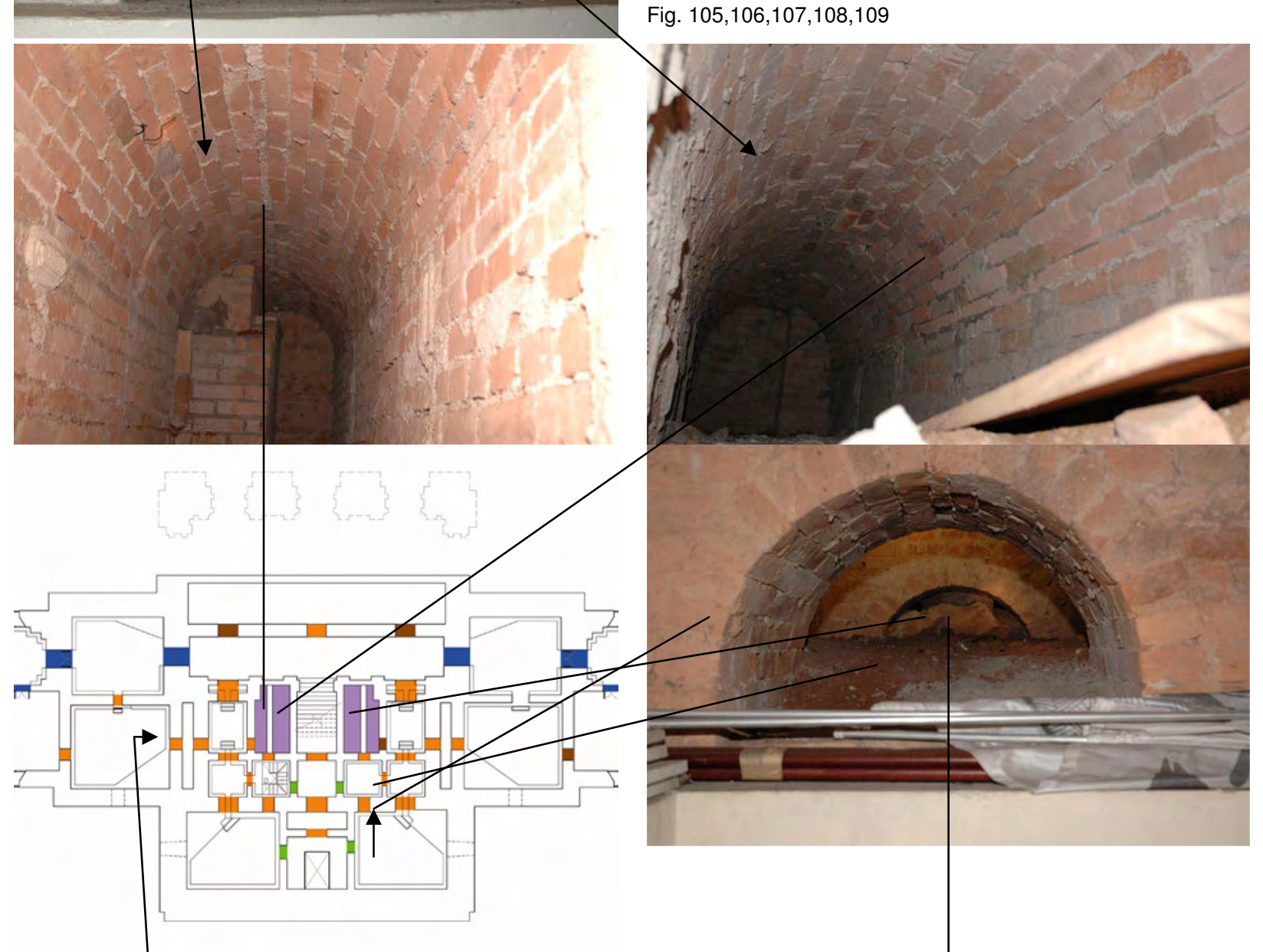

DETALHE - CORPO CENTRAL

Não há acesso para esttas abóbadas do lado direito da planta, há pedras e solo 
SUBSOLO - CORPO CENTRAL (2)

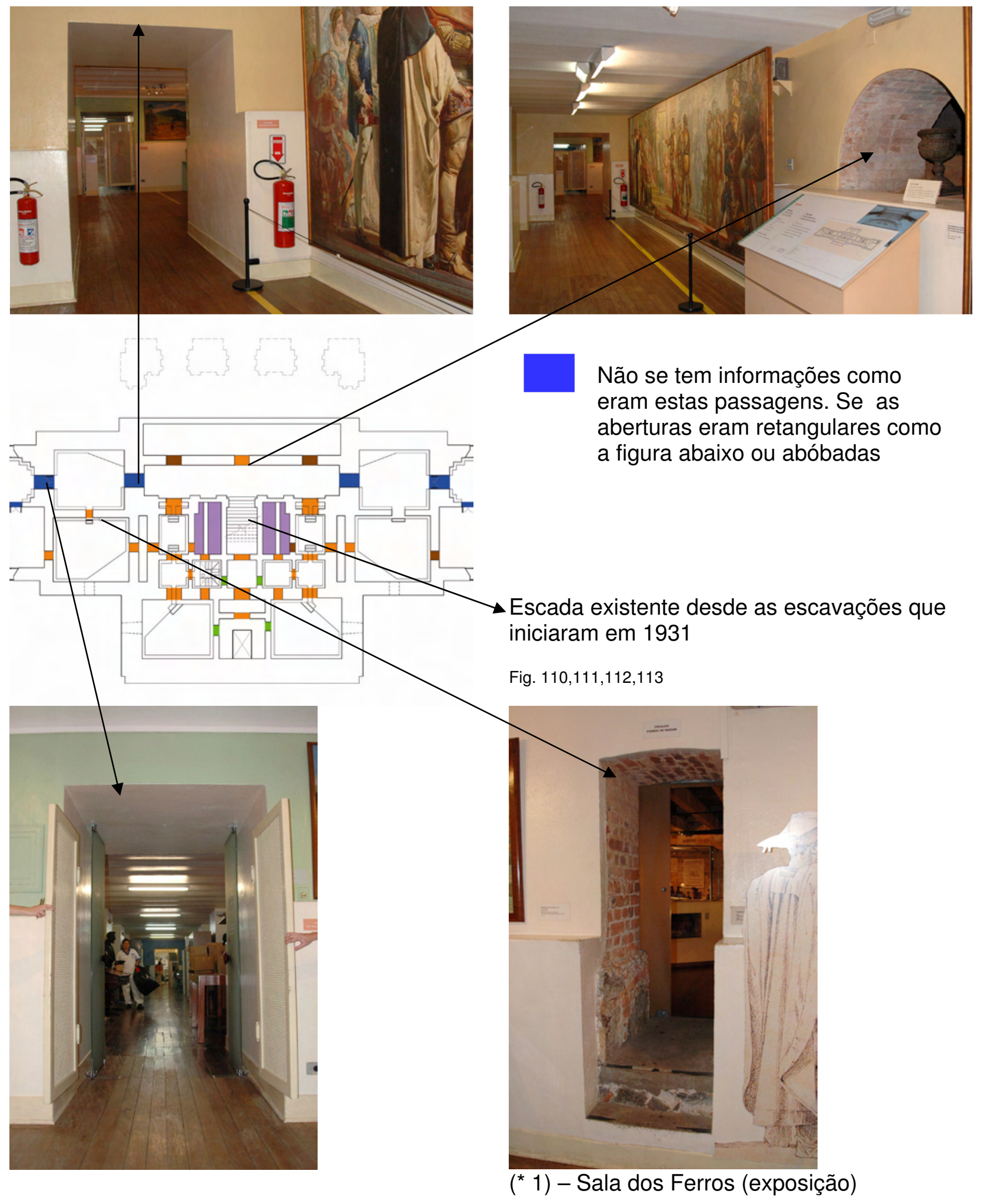


SUBSOLO - GALERIA

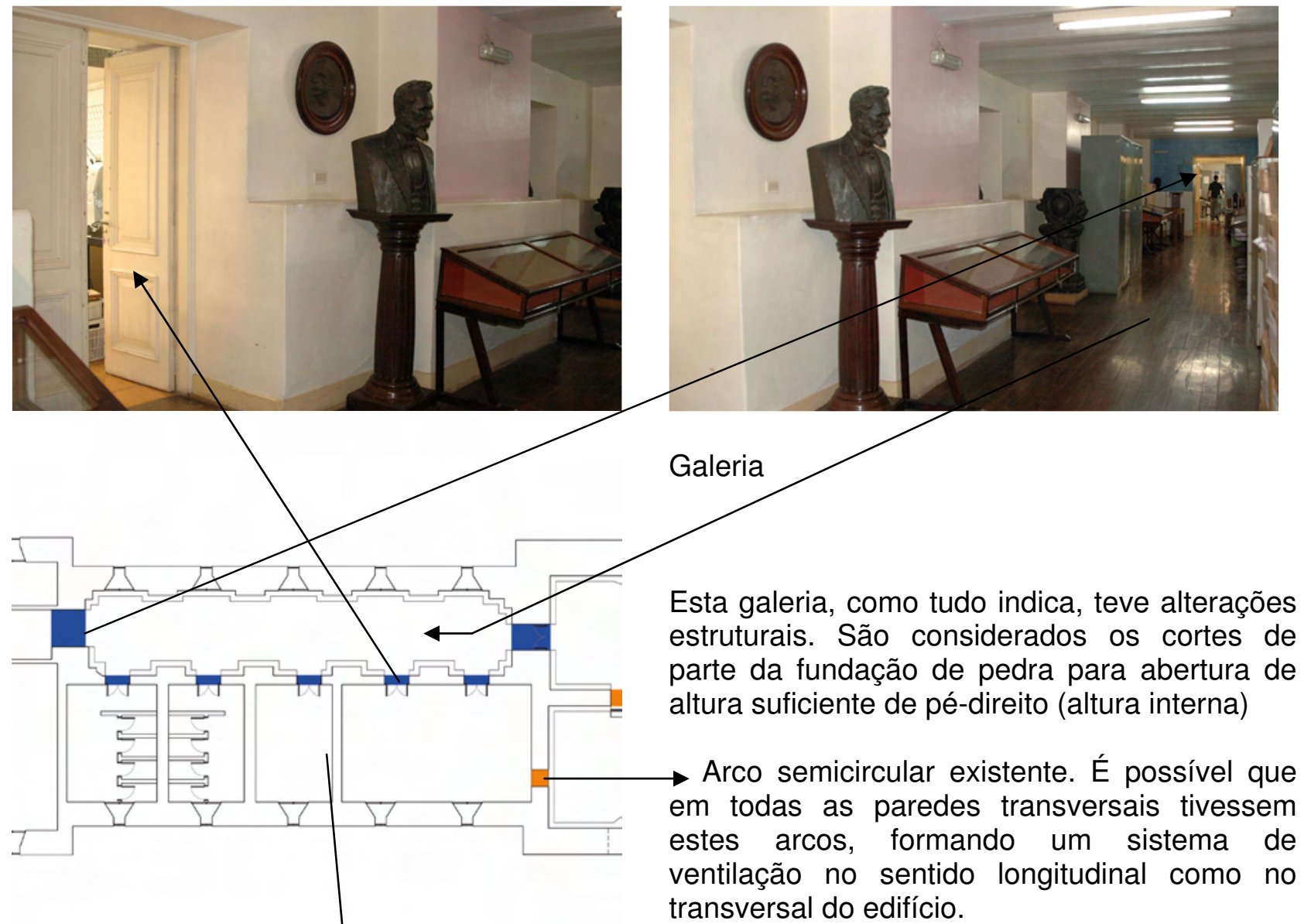

DETALHE - GALERIA

Fig. 114,115

Em diversas paredes transversais é possível que os arcos foram fechados, dependendo da função dada às salas ou banheiros 


\section{PAVIMENTO TÉRREO - CORPO CENTRAL}
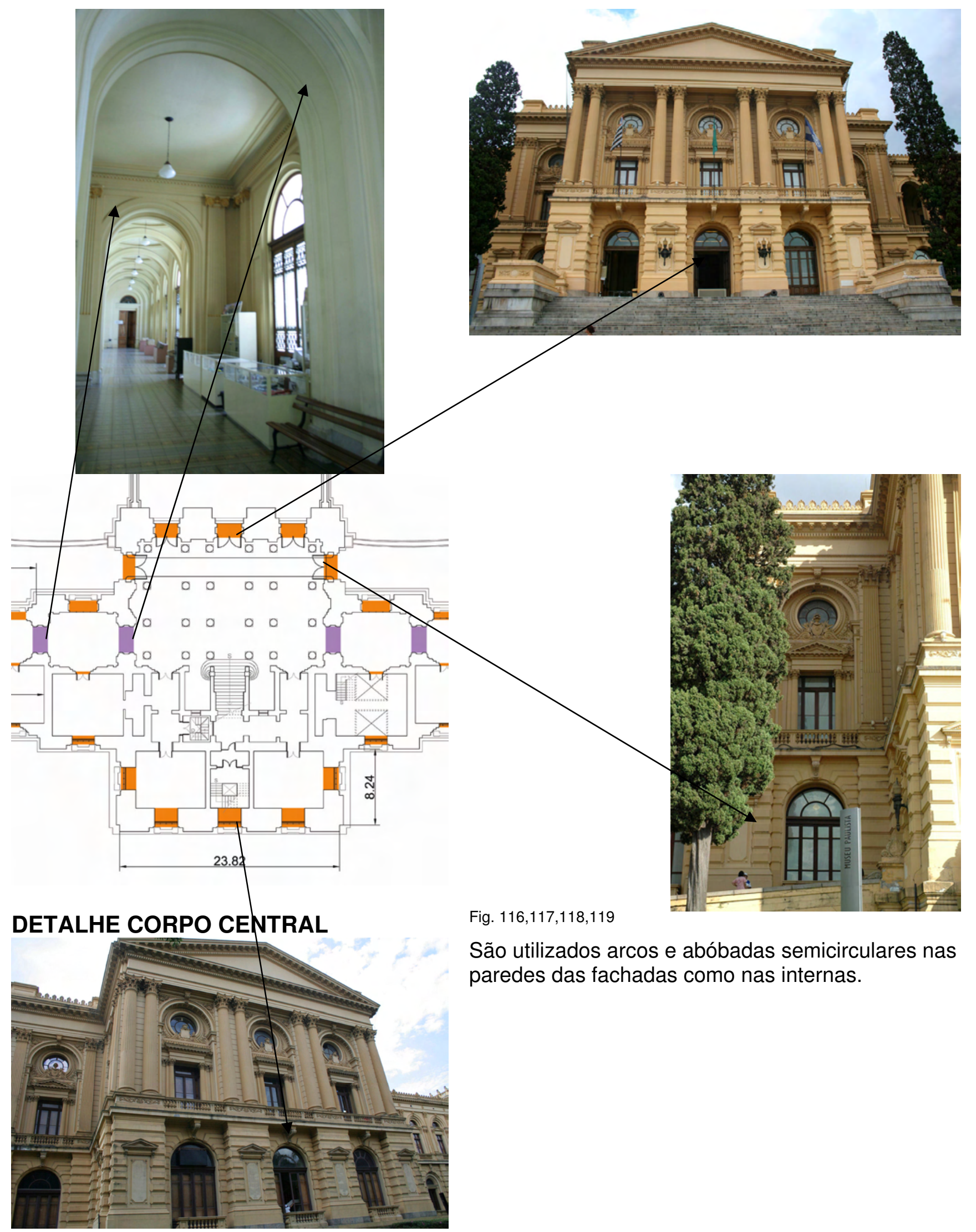

São utilizados arcos e abóbadas semicirculares nas paredes das fachadas como nas internas. 

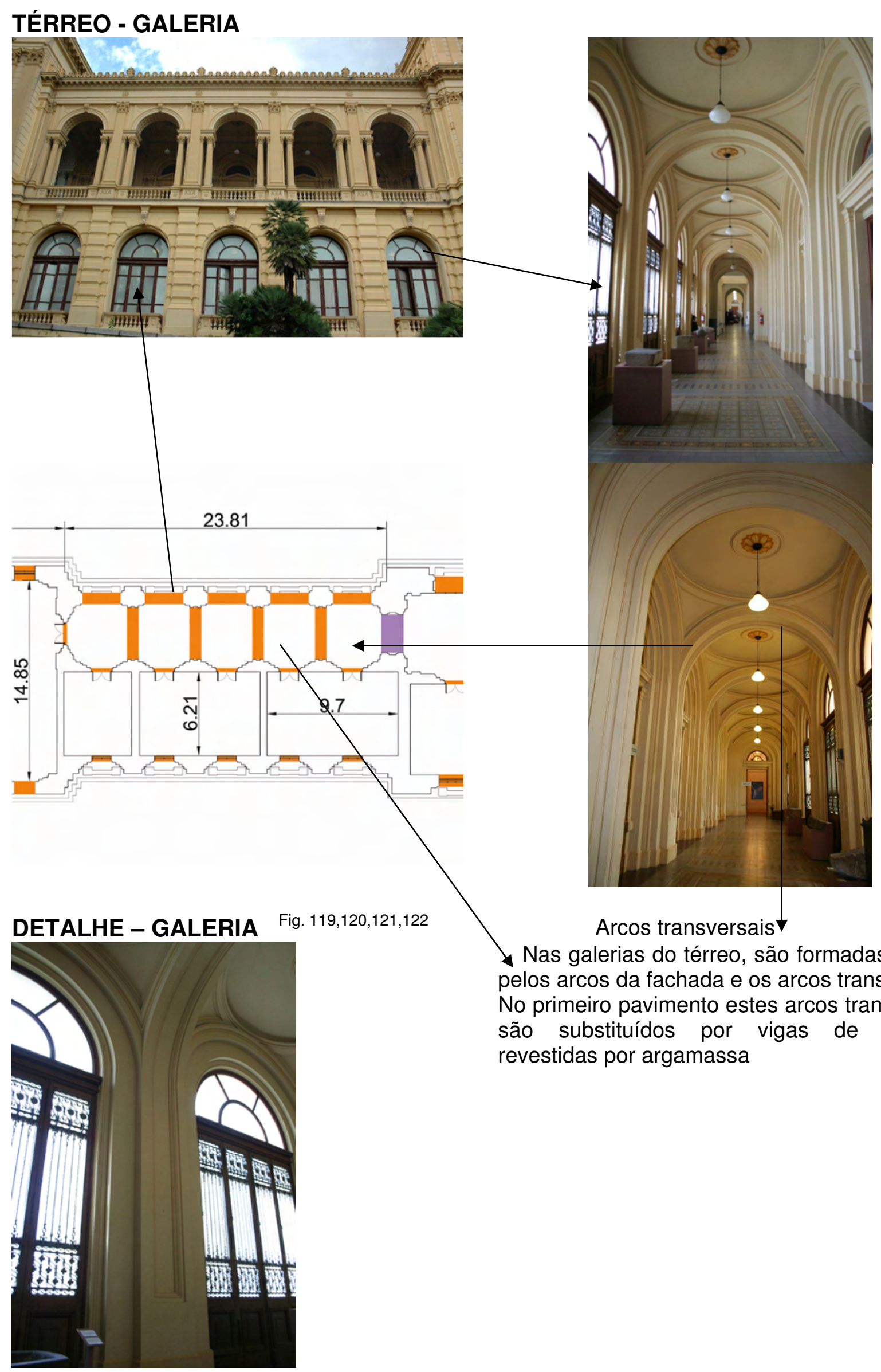

Nas galerias do térreo, são formadas células pelos arcos da fachada e os arcos transversais. No primeiro pavimento estes arcos transversais são substituídos por vigas de madeira revestidas por argamassa 


\section{TÉRREO - TORRE}
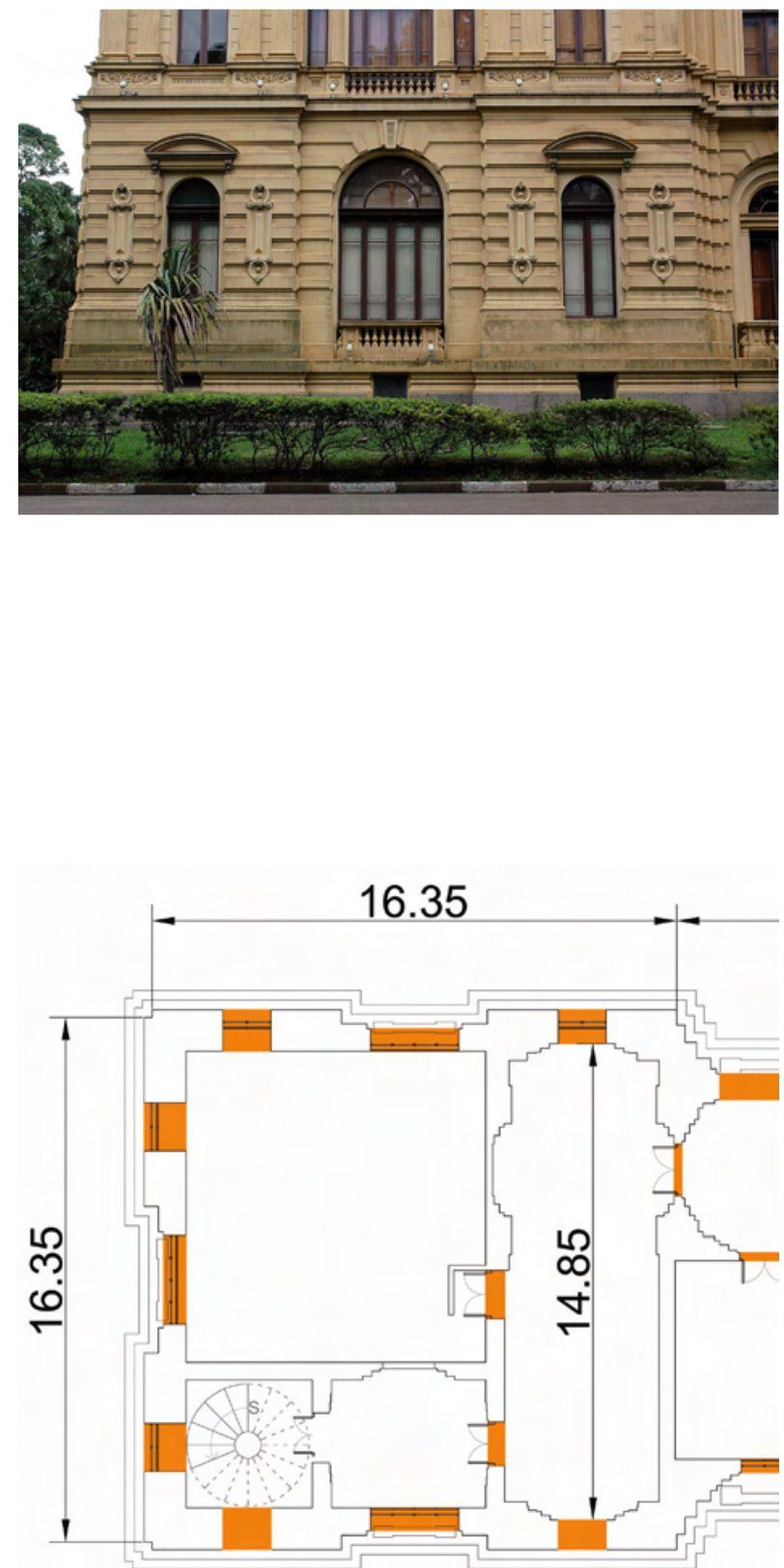

Nas paredes internas das torres são utilizados arcos de ressalva e nas paredes externas os semicirculares.

Fig. $123,124,125$

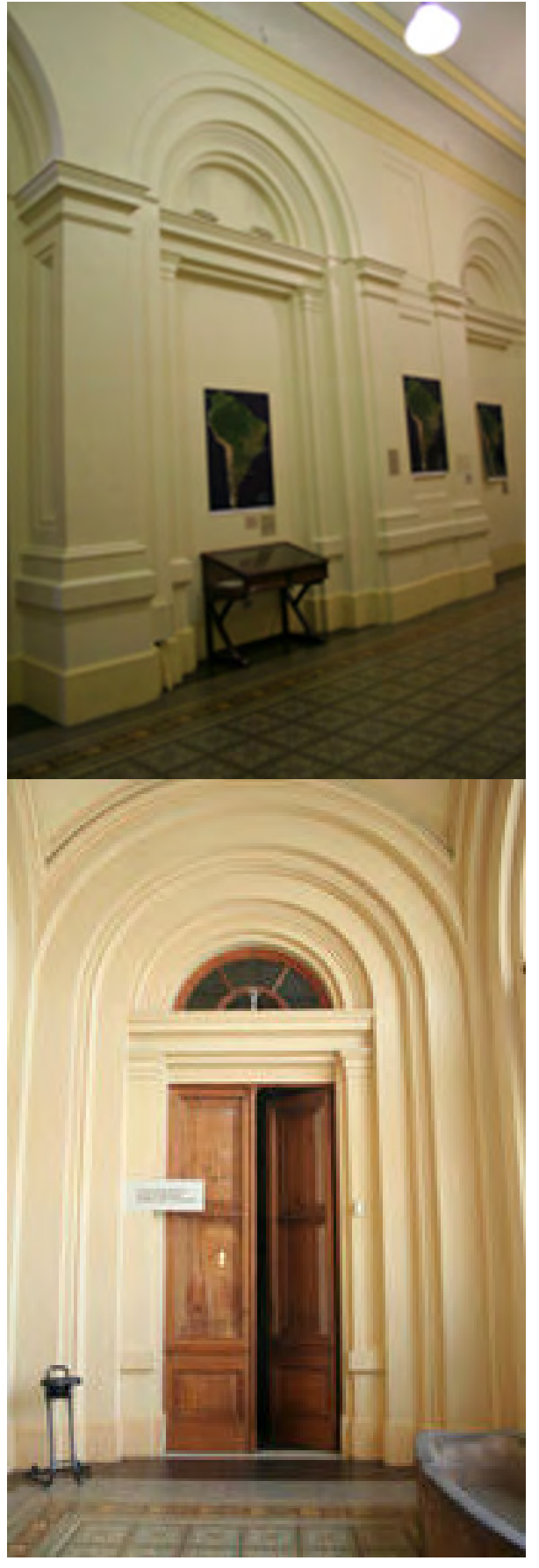


PRIMEIRO PAVIMENTO - CORPO CENTRAL

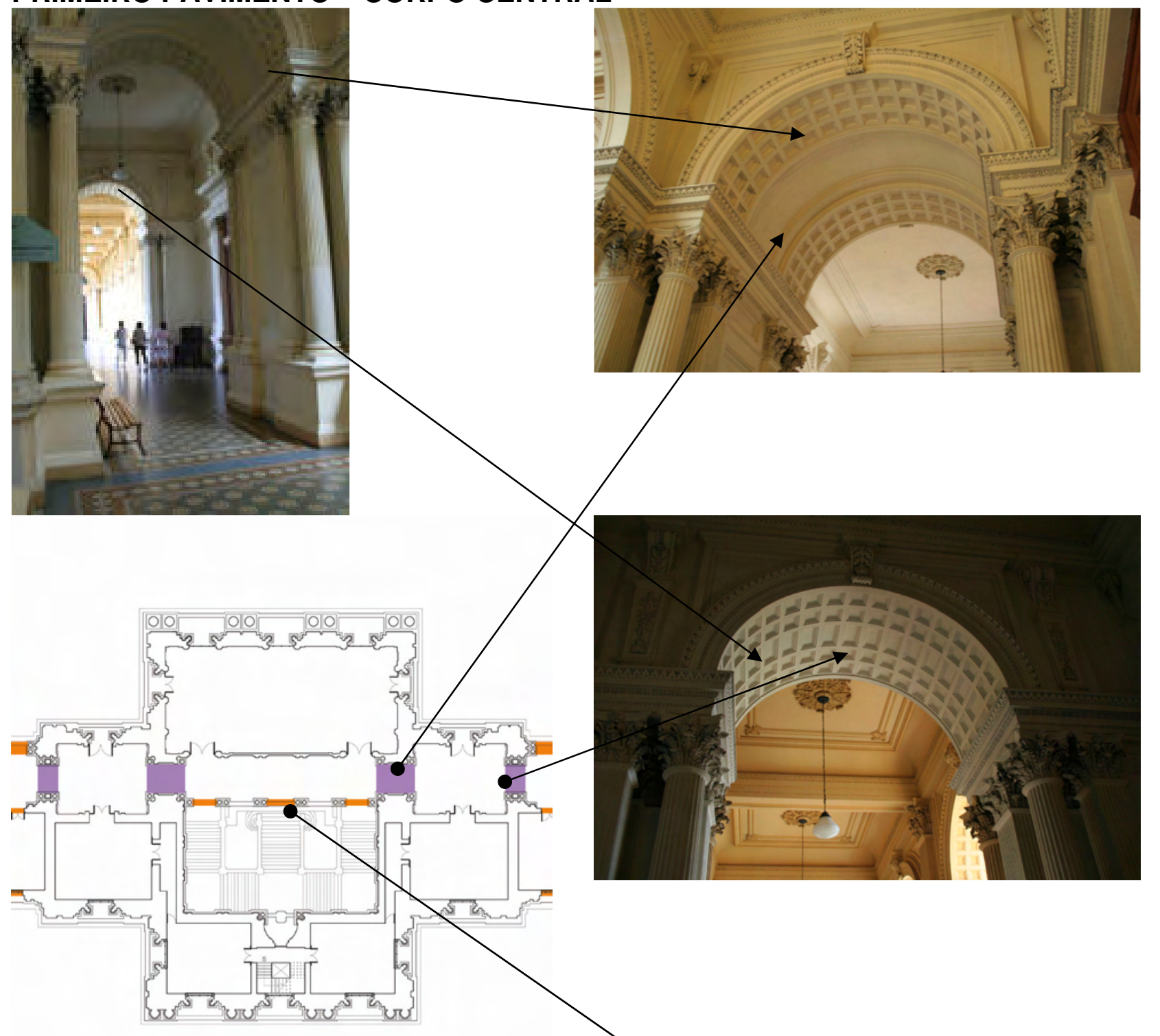

DETALHE - CORPO CENTRAL

Fig. $126,127,128,129$

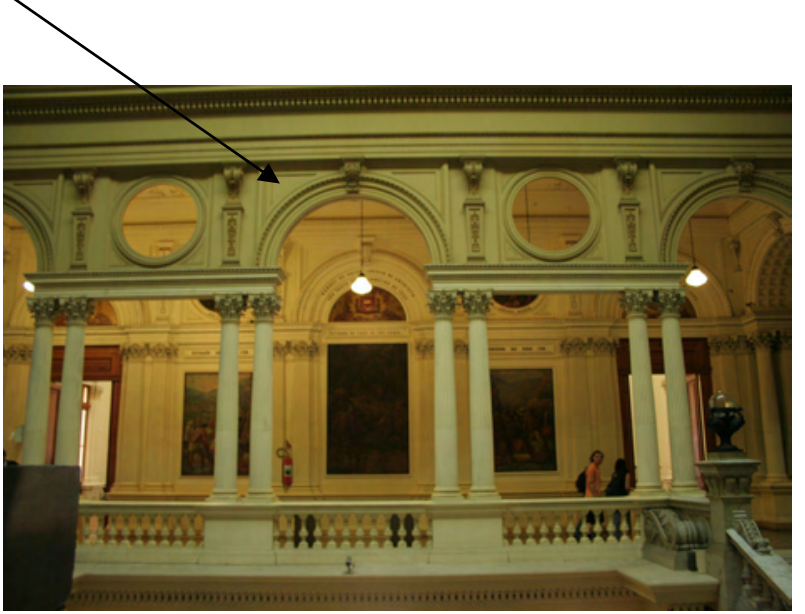

Conjunto de arcos semicirculares e óculos, formando um portal entre a escadaria e a galeria em frente do Salão de Honra 
PRIMEIRO PAVIMENTO - GALERIA

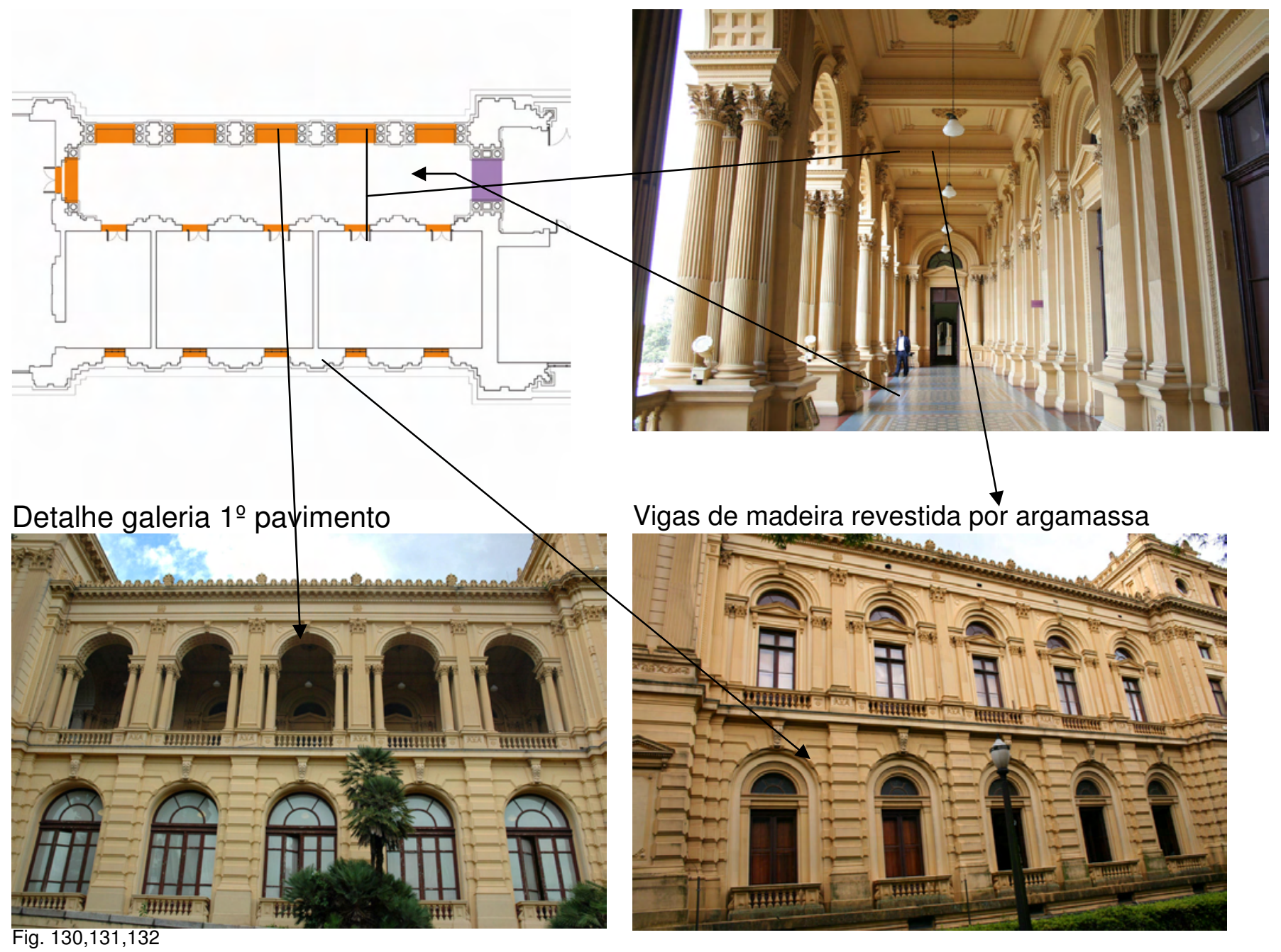




\section{PRIMEIRO PAVIMENTO - TORRE}
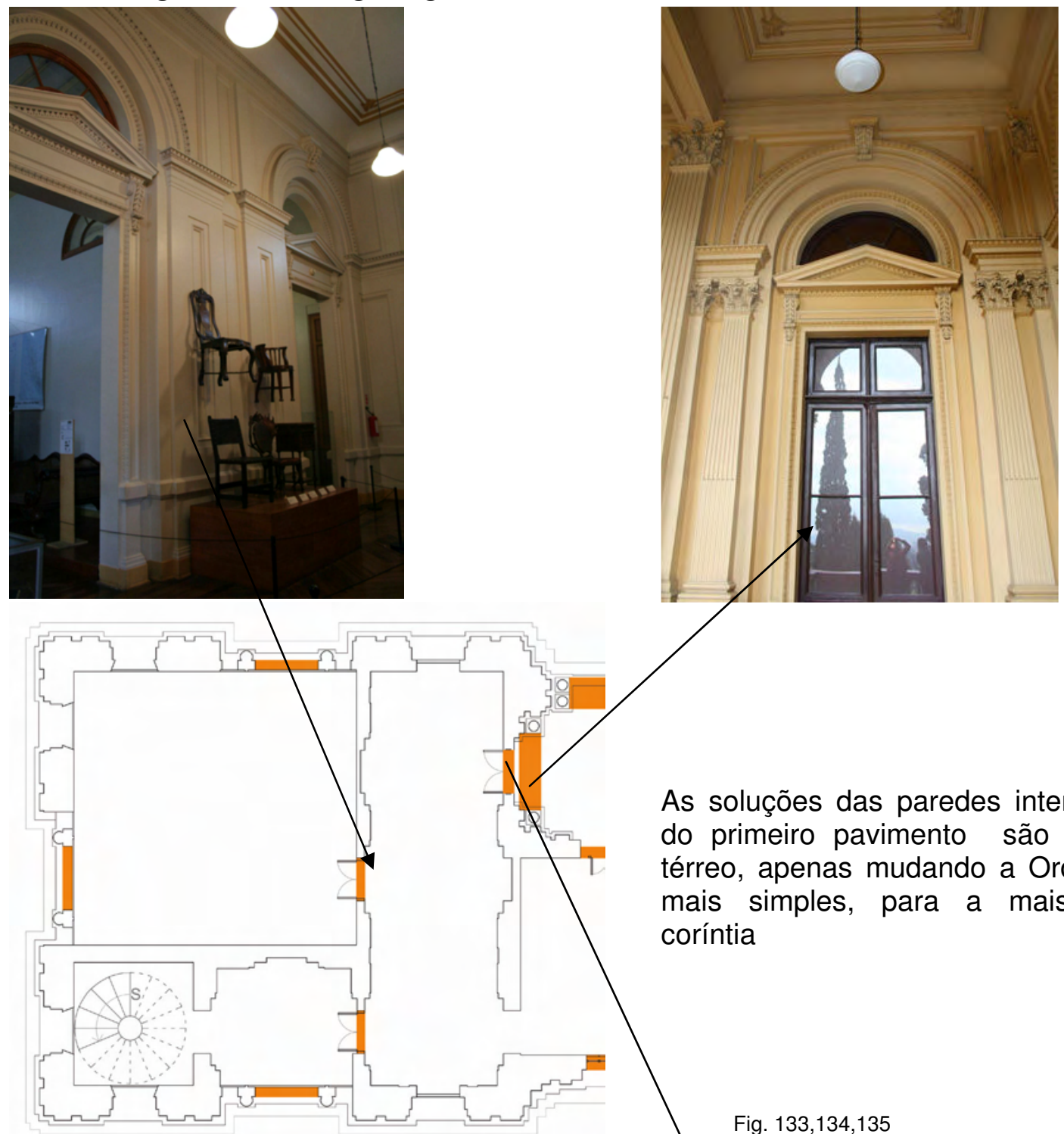

Detalhe torre $1^{\circ}$ pavimento

As soluções das paredes internas das Torres do primeiro pavimento são as mesmas do térreo, apenas mudando a Ordem, de Jônica, mais simples, para a mais ornamentada, coríntia

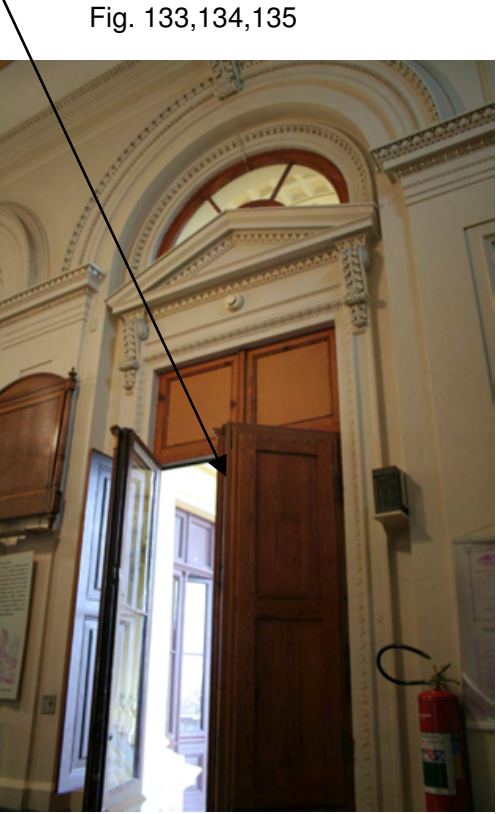




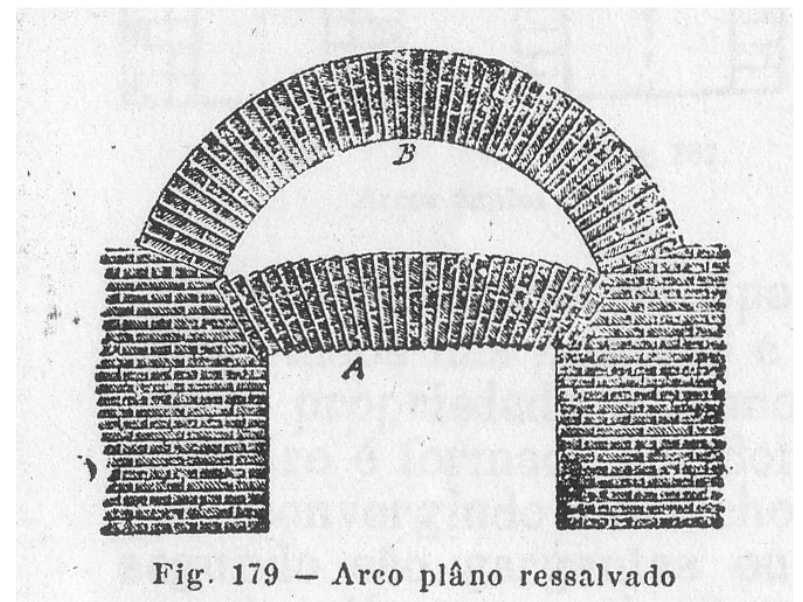

"Arco de ressalva: aquele constituído sobre a verga para aliviar a carga da alvenaria ali incidente; o mesmo que arco de escarção, arco de descarga, ou sobrearco." (SILVA, CALADO, 2005, p35)

Arco de ressalva: "suporta a maior parte das massas acima do arco plano, garantindo que este seja unicamente sujeito ao seu próprio peso e a um volume reduzido de alvenaria." (MATEUS, 2002,p.131)

Fig. ${ }_{136} \mathrm{O}$ arco está ressalvado, isto é, protegido por um arco circular B que the fica superior, a este arco se dá o nome de arco de ressalva - $B$.

A flecha em certos casos anula-se, desaparecendo o ângulo e ficando o arco plano

A - Arco plano; B - Arco de ressalva

(SEGURADO, sem data, p.148)

Os arcos planos apresentam menor estabilidade que os curvos, o que leva a fazê-los angulares, por vezes, enchendo-se seguidamente com o reboco para ficarem horizontais. Outro meio de os executar é preparar uma tábua, horizontalmente bem escorada, sobre a qual se faz com cacos e argamassa uma fôrma angular, sobre o qual se constrói o arco respectivo.

Os arcos chatos suportam pequena carga, sendo às vezes ressalvados, isto é, tendo um outro arco curvo $B$, apoiado nos pés direitos ou encontros, sobre o qual atua a maior parte do peso da construção que lhe fica superior.

A este arco de ressalva ou escarção, chamam nossos operários archete ou sobre-arco quando aplicado aos vãos de portas e janelas.

Arcos planos, platibanda e arcos abatidos de pequena flecha, eram utilizados na espessura das paredes, sobretudo sobre os vãos de janelas e portas, ou sempre que a altura das impostas era limitada por alguma razão.

Para além destas aplicações era particularmente importante o uso de arcos de ressalva [...] Integrados nas paredes resistentes ou nas paredes divisórias, esses arcos funcionavam como sistema estrutural de segurança [...] Permitiam assim preparar as paredes para eventuais aberturas de portas ou janelas, em função das necessidades funcionais da habitação [...]

(SEGURADO, sem data, p.172)

A seguir, as plantas apresentarão a localização dos arcos de ressalva, e as suas funções na estrutura do edifício. 

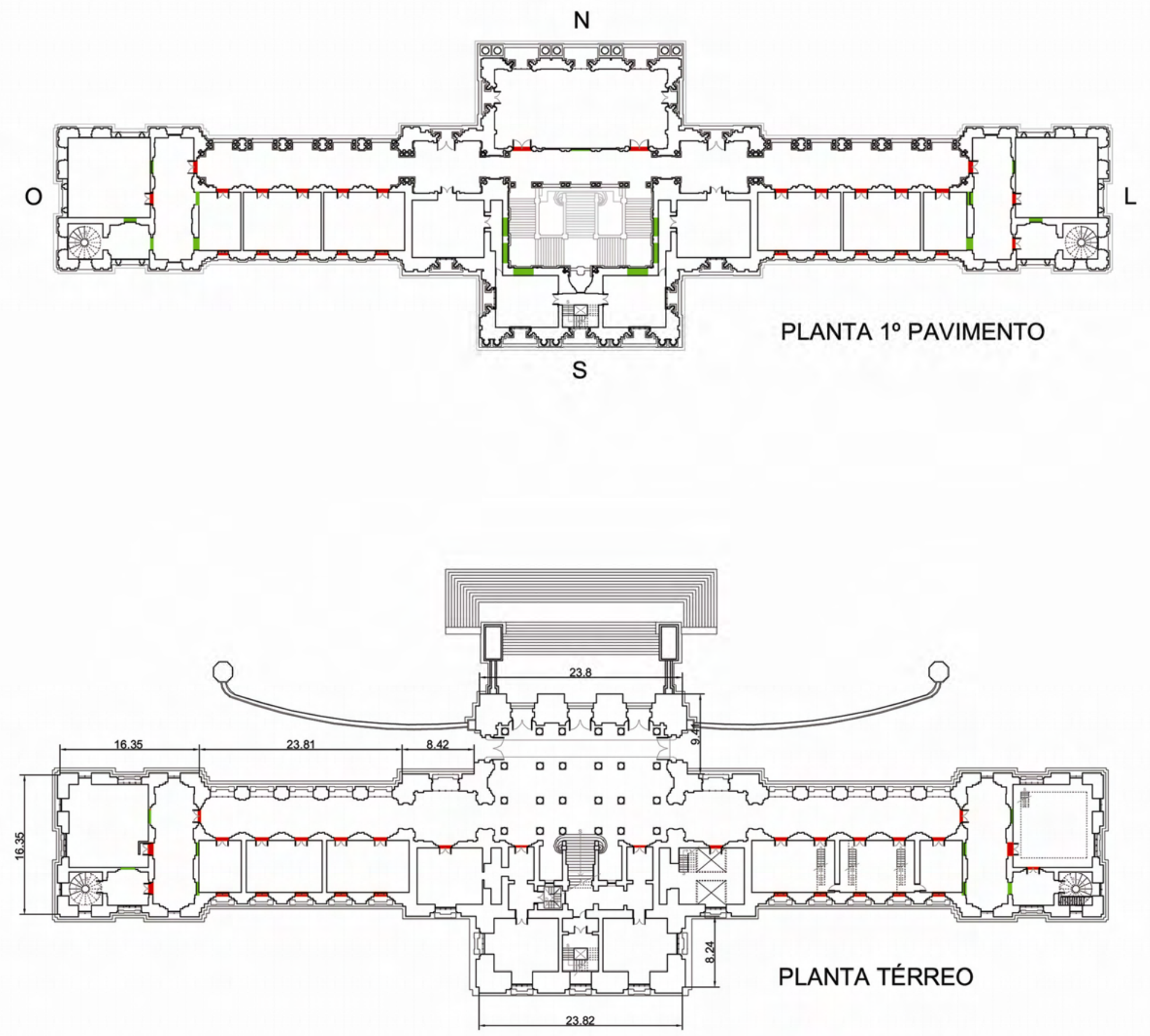

ARCOS DE RESSALVA

ARCO DE RESSALVA 


\section{ARCOS DE RESSALVA}

TÉRREO - CORPO CENTRAL

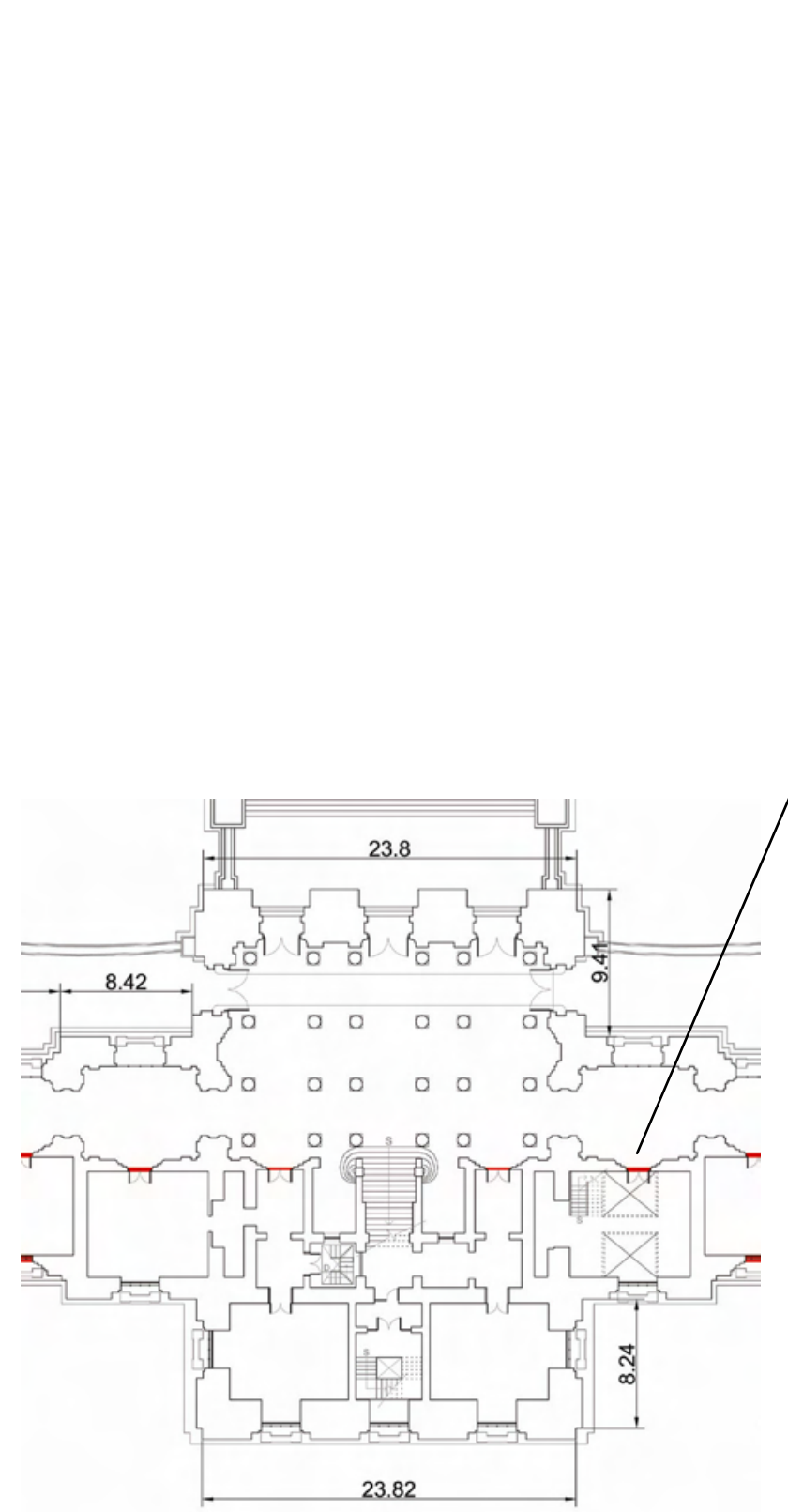

DETALHE CORPO CENTRAL

Os Arcos de Ressalva no térreo do Corpo Central, são utilizados com várias molduras salientes, e entre pés-direitos de grande espessura, compatíveis às funções estruturais deste pavimento, que suporta a carga dos outros pavimentos acima.

Tanto nas áreas internas como nas fachadas ao redor do Arco de Ressalva das portas, Bezzi utiliza as diversas saliências nos pés-direitos, tornando-os esteticamente mais leves.

Fig. 138 


\section{TÉRREO - GALERIA}
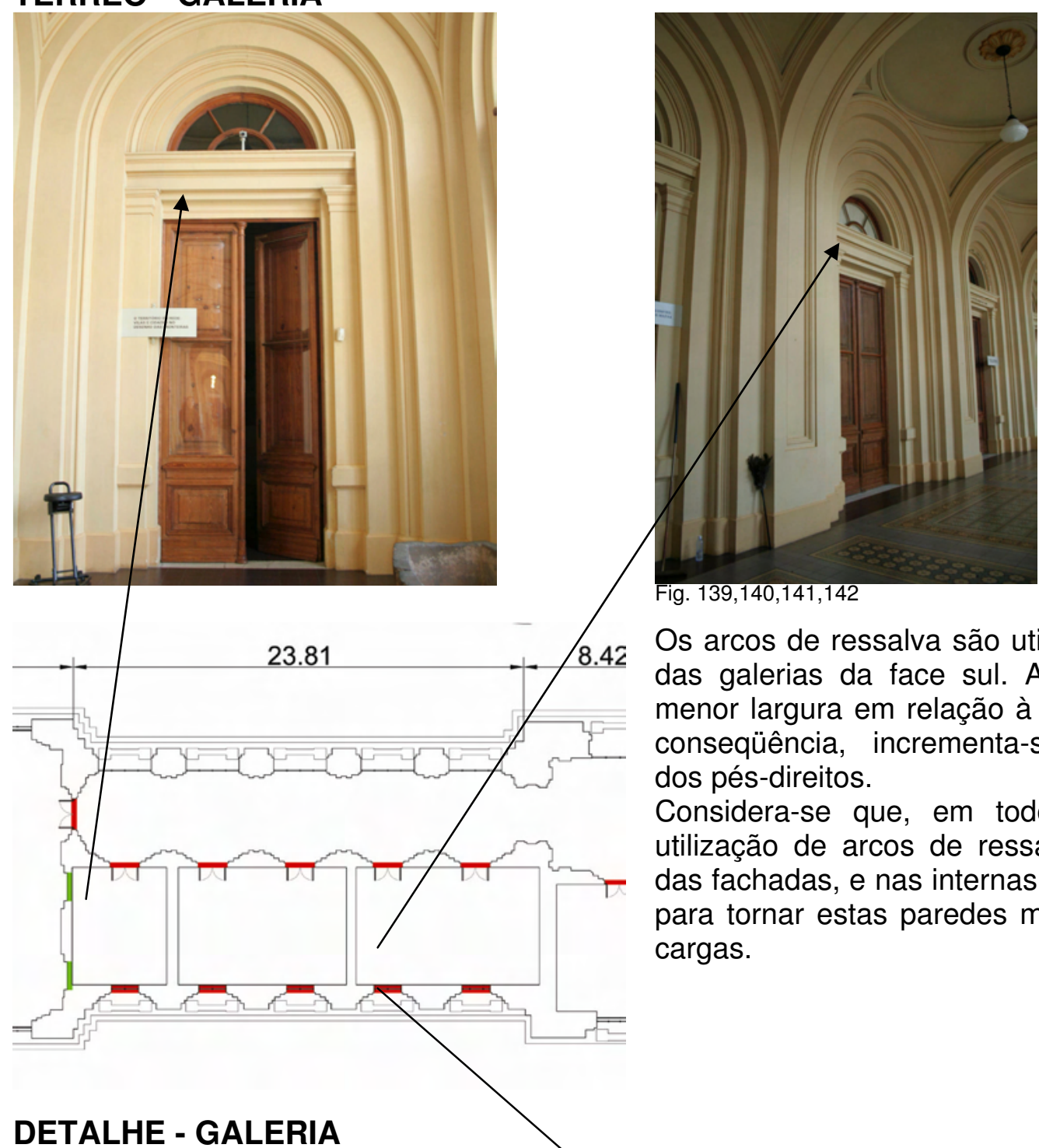

Fig. $139,140,141,142$

Os arcos de ressalva são utilizados no térreo das galerias da face sul. As aberturas têm menor largura em relação à face norte e, em conseqüência, incrementa-se a espessura dos pés-direitos.

Considera-se que, em todos os casos, a utilização de arcos de ressalva em paredes das fachadas, e nas internas, seja um recurso para tornar estas paredes mais resistente às cargas.

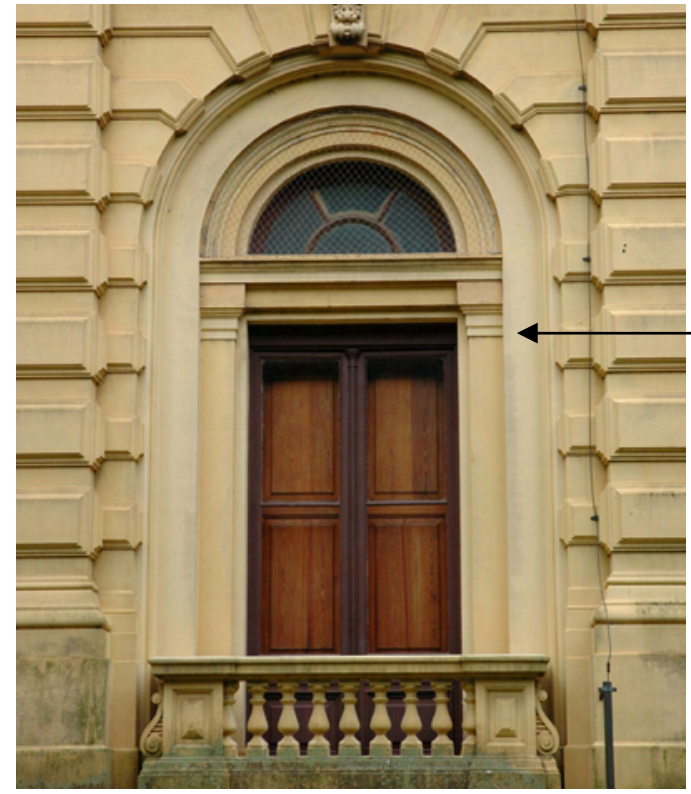

Detalhe do térreo da galeria face sul

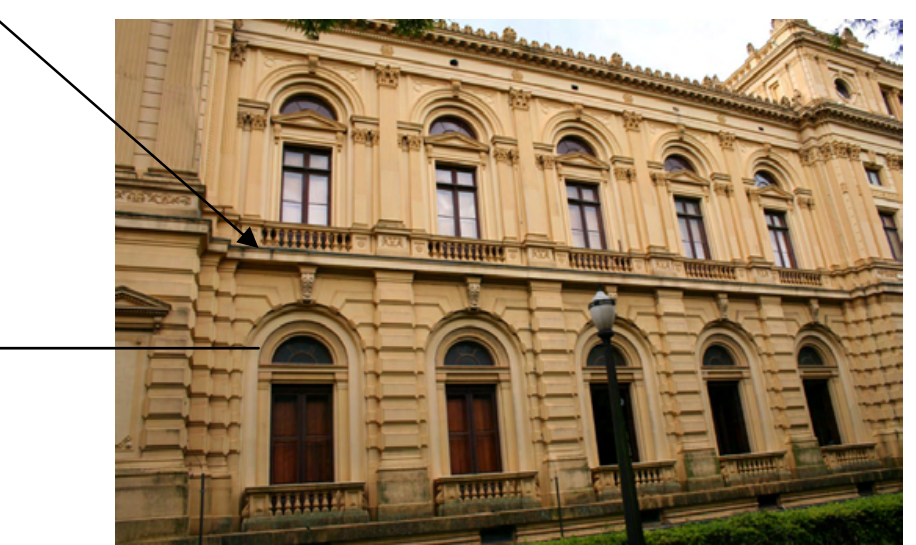

Galeria face sul 
TÉRREO - TORRE

Fig. 143,144

Arco de Ressalva com porta

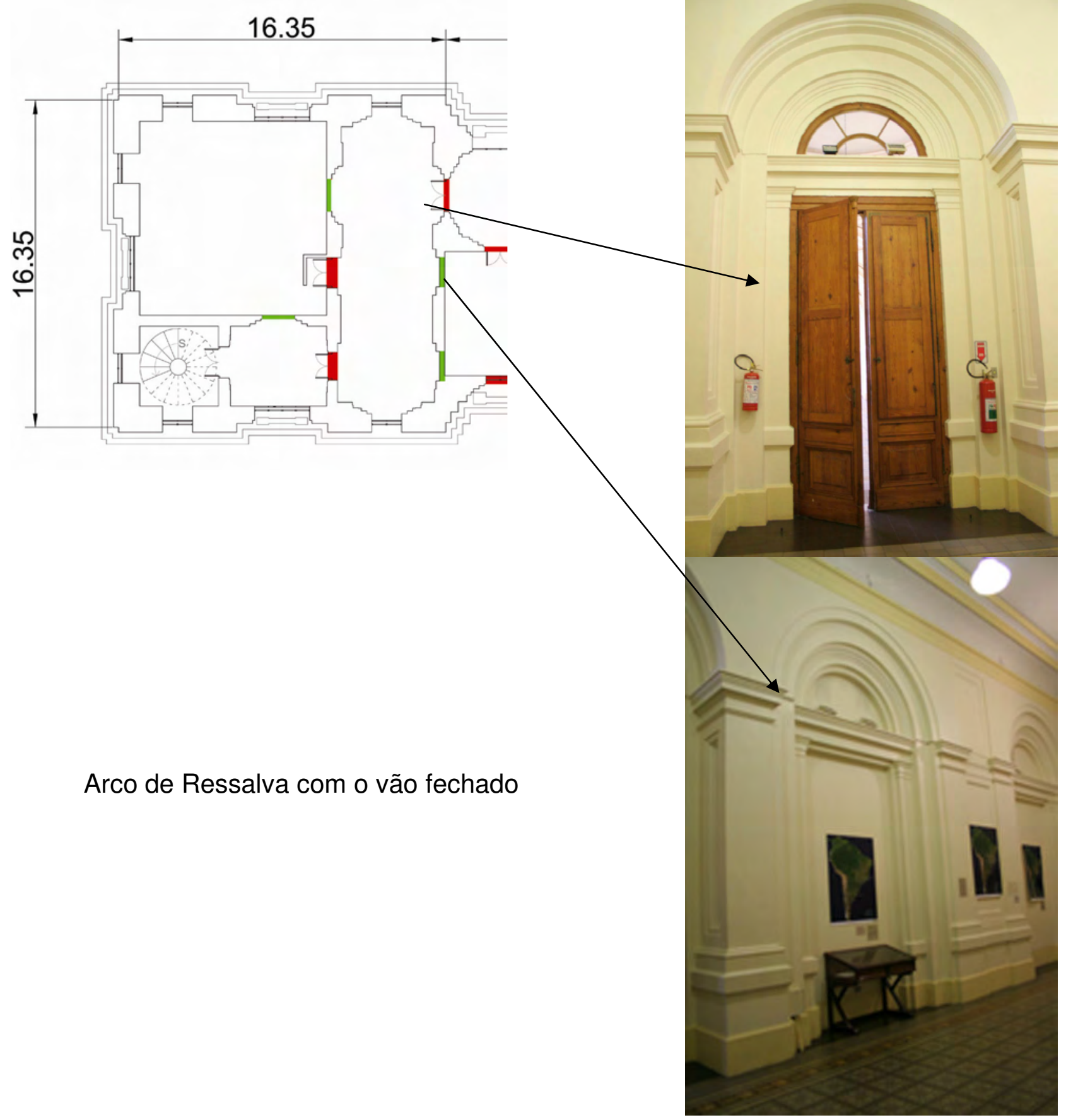




\section{PRIMEIRO PAVIMENTO - CORPO CENTRAL}

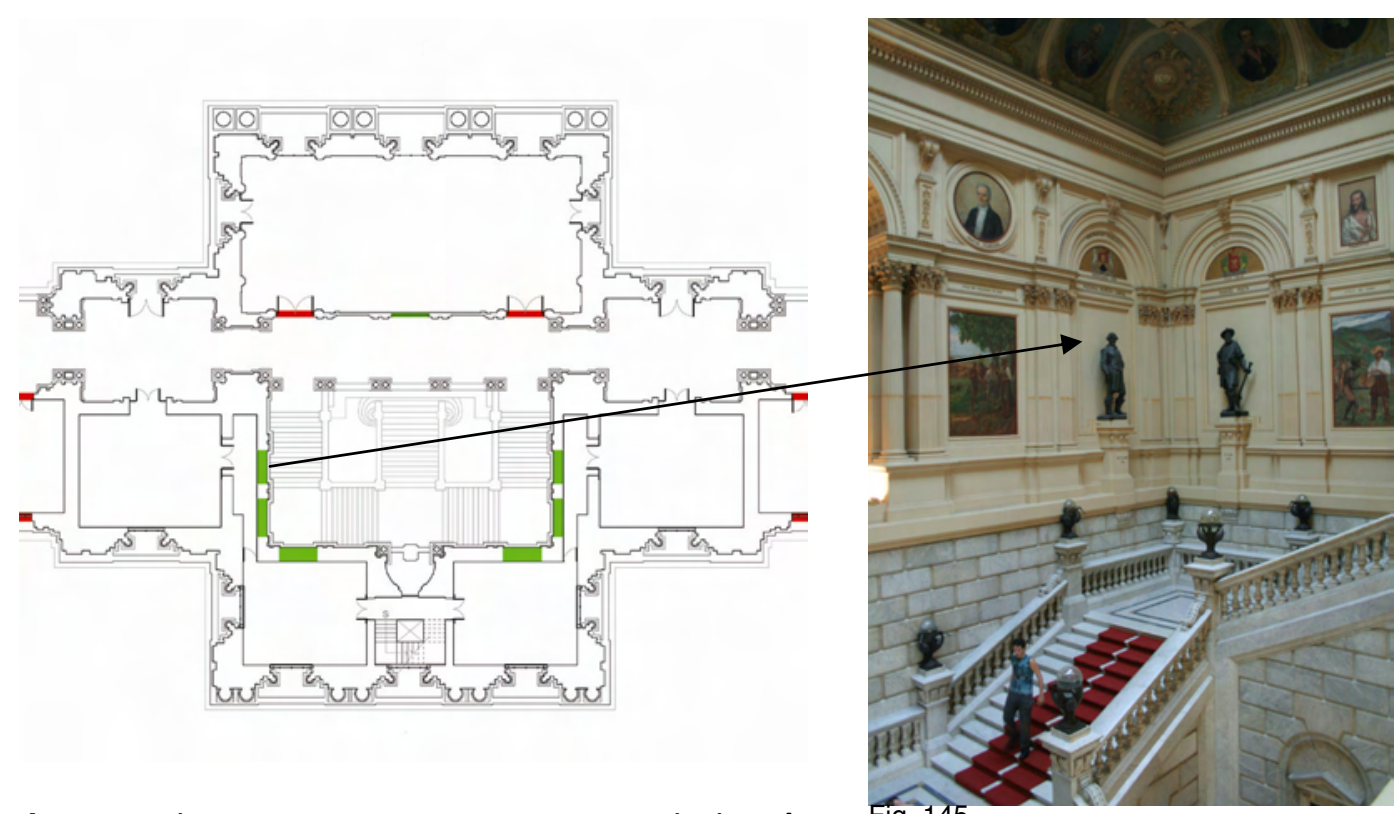

As paredes que contornam a escadaria têm Fig. 145 grandes dimensões. Considera-se que a utilização de Arcos de Ressalva fechados, óculos, seja um recurso para obter maior resistência, e suportar as cargas da cobertura e de seu peso próprio, que assim é diminuído.

Este é também utilizado como soluções ornamentais. 


\section{PRIMEIRO PAVIMENTO - GALERIA}
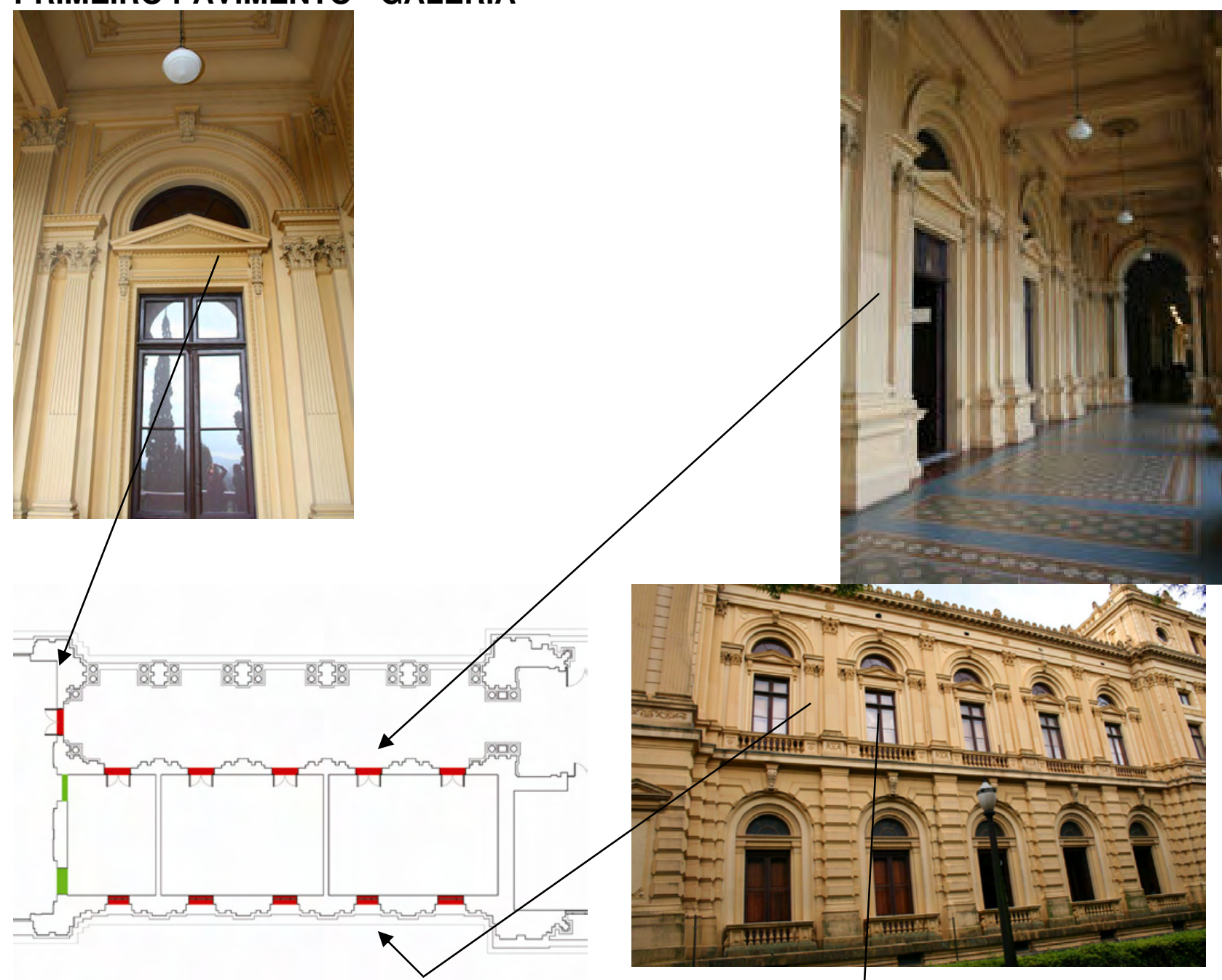

DETALHE - GALERIA

No primeiro pavimento da galeria da face sul, os Arcos de Ressalva criam aberturas com larguras bem menores, e pés-direitos mais robustos.

É uma grande diferença estrutural e estética, em relação às arcadas da face norte.

Neste pavimento, como é utilizada a Ordem Coríntia, estes Arcos aparecem com maior ornamentação.

Fig. $146,147,148,149$

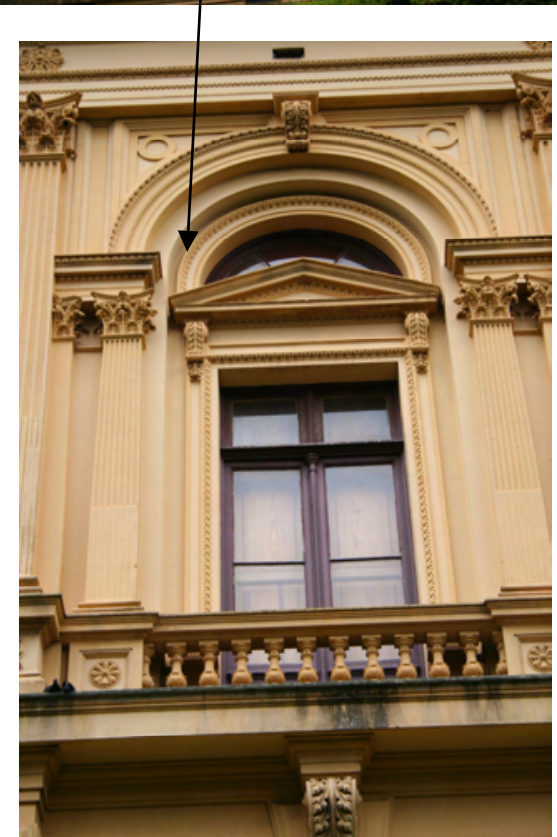


Nas Torres do primeiro pavimento, e do térreo, são utilizados os mesmos arcos de ressalva em paredes fechadas e nas portas.

Nota-se que as paredes internas têm menor espessura. Considera-se que os Arcos são utlizados para dar maior resistência estrutural a essas paredes.

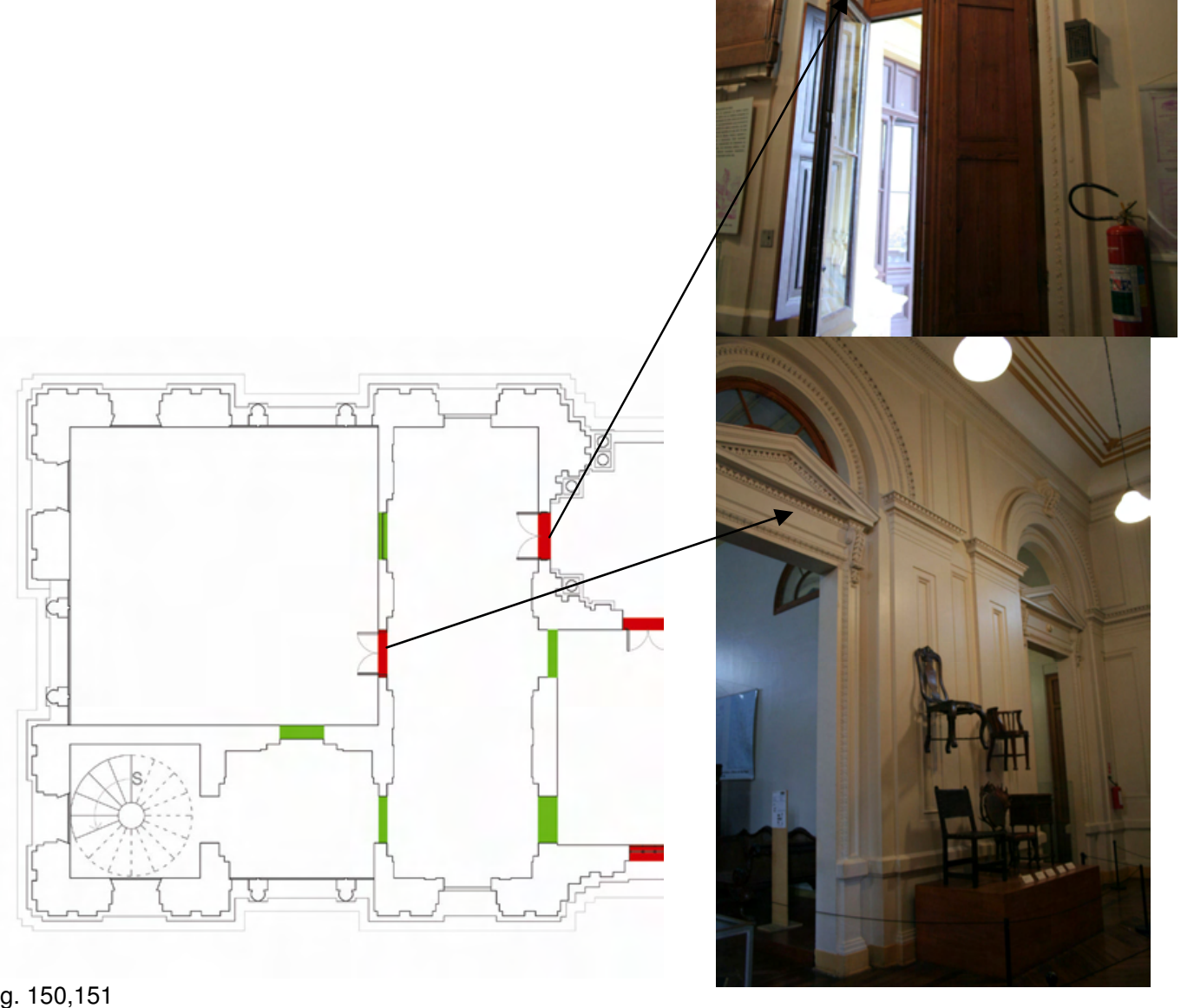

Fig. 150,151 


\section{ARCOS NO ÁTICO}

O ático é a região mais elevada da edificação, localizada sobre o Corpo Central.

A parte interna, sob o telhado, tem livre acesso devido à sua altura. Estão aí aparentes as estruturas metálicas, o madeiramento do telhado e dois tipos de arcos de alvenaria, elementos que constituem uma importante solução estrutural.

São utilizados dois tipos de arcos: os de tijolos furados, chamados assim por Bezzi, e os dois grandes arcos abatidos.

\section{ARCOS DE TIJOLOS FURADOS}

Arco de tijolos furados, semicirculares, fechados por alvenaria nas paredes do frontão e laterais do corpo central
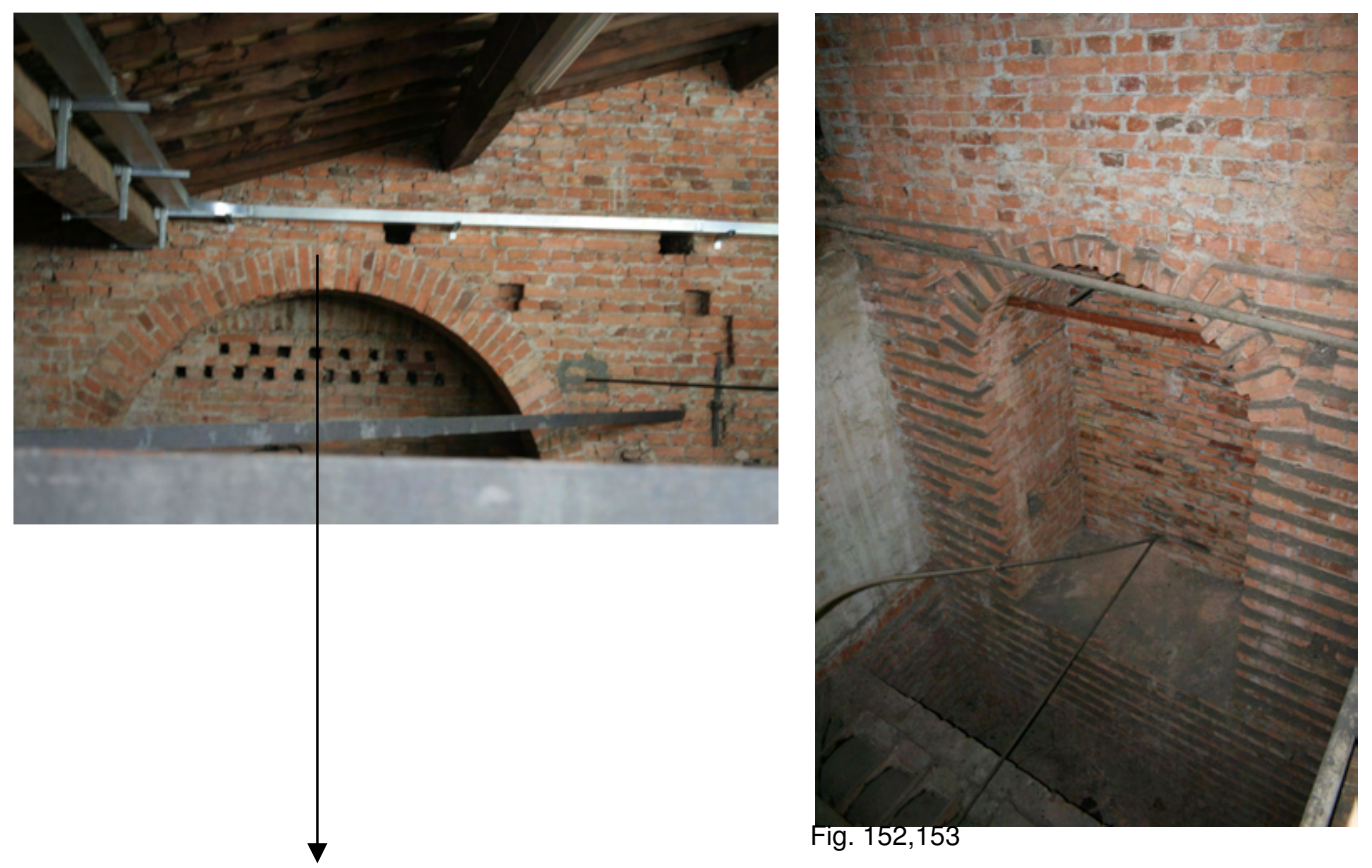

Parede do frontão

Documento 49, da pasta 1 de Bezzi, apresenta as especificações sobre as obras no ático, em que o engenheiro demonstra seus cuidados na execução:

São Paulo, 26 de dezembro de 1888

(Ofício ao Barão de Ramalho)

Cumprindo com as instruções verbais recebidas de V.Excia, vou fazer a análise dos preços de unidade especificando os materiais a empregar-se em cada metro cúbico das alvenarias, a executar-se no ático do corpo central do monumento do Ypiranga, e indicar a qualidade do trabalho a fazer-se nas diferentes unidades.

As obras aqui em seguida especificadas, deverão ser executadas de conformidade com o projeto geral das mesmas, já em poder do Empreiteiro, e segundo os planos detalhados da 
construção, que serão por mim fornecidos ao Empreiteiro, logo que V.Excia. mandar começo às obras.

O Empreiteiro deverá executar fielmente e rigorosamente as diferentes obras, com materiais de primeira qualidade tal e qual aqui ficam em seguida determinadas, e de conformidade com as instruções que receberá de mim durante o curso da construção das mesmas, ficando deste modo os presentes artigos adicionais, as especificações de perfeito acordo com as mesmas, que servirão de base para o contrato da empreitada.[...]

Alvenaria de tijolos furados de primeira qualidade assentados com argamassa idêntica ao indicado. Os vãos internos a estes muros, projetados para render mais leve a construção, serão na medição considerada como paredes cheias, e tanto os vãos internos como as paredes todas, serão emboçadas em rústico com uma leve camada da argamassa já citada. Para a medição destes muros se seguirá o mesmo sistema contemplado nas especificações $[\ldots]$

Este tipo de arco, como se registra no documento acima, tem a finalidade de tornar mais leve estas paredes que circundam o ático, evitando-se grandes paredes maciças.

\section{DOIS GRANDES ARCOS ABATIDOS DE ALVENARIA}

Há dois grandes arcos abatidos de alvenaria no ático, onde são visíveis debaixo do telhado e em uma parte menor, sobre o telhado. É um elemento estrutural de grande responsabilidade, que faz a conexão entre elementos da cobertura, das paredes do mirante, e dos maciços de alvenaria que compõe o corpo central.

No mesmo documento citado acima no Art. 1, Bezzi ainda se refere aos grandes arcos abatidos:

Artigo 1: Alvenaria dos arcos abatidos de $20,40 \mathrm{~m}$ de curva a 3,18 de flecha cuja imposta fica na altura de $18,823 \mathrm{~m}$ do nível do pavimento do átrio.

Alvenaria de tijolos prensados no meio do forno, escolhido de dimensões iguais e o mais que for possível homogêneos; murados com argamassa composta de 2 volumes de cimento Portland da melhor qualidade que se encontrar neste mercado e em perfeito estado de conservação, e 1 volume de areia de puro quartzo de grão fino e homogêneo, regulando cada grão em milímetro de diâmetro, passada em 3 peneiras e lavada até deixar a água completamente limpa. A argamassa feita em pequenas porções para não perder absolutamente nada de sua força de coesão.

Nota:- Quando de se medir o volume de cimento a empregar-se na argamassa, precisará se observar que tenha uma compressão idêntica àquela que tem quando está nas barricas.

Além dessas especificações, Bezzi deixa um documento 198 , manuscrito, na Pasta 3 , sobre o Volume do Arco:

Parte inferior alta $0,74 \mathrm{~m}-$ superfície $19,43 \times 0,88=$ Parte superior alta 0,64 $\mathrm{m}$ - superfície $17,56 \times 0,65=$ Cúbico total do arco $=$

Dimensão de um tijolo oco

$0,21 \mathrm{~m} \times 0,105 \mathrm{~m} \times 0,065 \mathrm{~m}$

Volume de um tijolo $=$ MC 0,00143325 $\mathrm{m}^{3}$
MC $17.098 \mathrm{~m}^{3}$

$\mathrm{MC} 11.414 \mathrm{~m}^{3}$

$28.512 \mathrm{~m}^{3}$ 
Considerando um metro cúbico de parede dos tijolos ditos acima composto na proporção de $4 / 5$ de tijolos e 1/5 de argamassa e cimento teremos

$\underline{0,800}=558$ número de tijolos necessários para formar um metro cúbico

0,00143325 de parede

Sendo

O peso de um tijolo igual a $1,710 \mathrm{Kg}$ teremos $1.710 \times 558=954,180$ de tijolos que em números

redondos o consideramos iguais a $\mathrm{Kg}$ 960,000

Sendo

O peso da argamassa igual a $1800 \mathrm{~K}$ por metro cúbico teremos

$1800 \times 0,200=a \mathrm{Kg}$ 360,000

Peso total de um metro cúbico de parede K 1320,000

Sendo

O volume total do arco igual a MC 28.512 teremos

$28.512 \mathrm{~m}^{3} \times 1320 \mathrm{~K}=\mathrm{Kg} 37.635,84$ peso do arco

O Rondelet , o Cantalupi e o Mazzocchi dão o peso de $5 \mathrm{~kg}$ para cada centímetro quadrado como carga mínima de segurança contra o esmagamento dos tijolos tubulares e depois multiplicando este coeficiente pela seção do arco em chave teremos a pressão total que os tijolos podem suportar.

Sendo a seção do arco $=0,65 \mathrm{~m} \times 0,64 \mathrm{~m}+0,88 \mathrm{~m} \times 0,74 \mathrm{~m}=10672$ que serão necessários para a segurança de 16 toneladas.

Considerando que o peso do arco em número redondo seja de 38 toneladas.

Considerando que o peso da construção sobreposta ao arco seja de 52 toneladas segundo os cálculos aproximativos teremos 90 toneladas = peso total que devem sustentar os tirantes de ferro a serem aplicados na imposta do arco.

Para determinar as dimensões dos tirantes acima citados começaremos considerando que a fórmula geral da resistência dos materiais é:

$A=P: R$ na qual

$A=$ Seção transversal em $\mathrm{mm}^{2}$ do material empregado

$\mathrm{P}=$ força que deve resistir o material

$\mathrm{R}=$ Coeficiente ou carga de segurança para cada $\mathrm{mm}^{2}$

Das tabelas dadas por Rondelet, Cantalupi e Mazzocchi temos o peso mínimo de $6 \mathrm{Kg}$ com o qual as barras de ferro laminado possam resistir com segurança à tração.

Considerando que é boa prática reduzir as acima ditas cargas de segurança quando os tirantes são subordinados a uma força de tração contínua.

Considerando que as ditas cargas podem diminuir até a $10 \mathrm{Kg}$ como diz Mazzocchi, e a 7 e mais como diz Rondelet.

Considerando que a fim de garantir com maior intensidade a segurança dos tirantes, contribui também a parte de paredes sobre as quais vem impostado o arco, pode-se considerar o coeficiente de segurança $=\mathrm{a} 3 \mathrm{Kg}$ por $\mathrm{mm}^{2}$.

Estes cálculos revelam que Bezzi aplicava, na construção do edifício, os conhecimentos da época, citando as tabelas e investigações de autores como Rondelet, Cantalupi e Mazzochi, que contribuíram para a evolução tecnológica e que permitia executar com segurança.

Estes arcos, por serem abatidos, imprimem uma grande força oblíqua na imposta dos pésdireitos. Desse modo, para equilibrar estas forças, foram aplicados 9 tirantes horizontais, devidamente calculados.

O Documento 197 da Pasta 3 também se refere a cálculos das secções dos tirantes, e é provável que Bezzi esteja comparando as diferentes fórmulas. 
$P=$ peso permanente que produz a ruptura

$A=$ seção da barra

$\mathrm{f}=$ esforço necessário para ruptura

$P=A . f \quad A=P / f$

Caso prático

$\mathrm{P}=30.000$

$A=x$

$f=12.205$

Devendo-se dividir a carga total em duas partes porque ali se aplicam 2 tirantes, teremos:

$\mathrm{P}=15.000$ mas considerando que a barra de ferro submetida a uma carga permanente, deve ter dimensão de

6 vezes maior aquela que se atribui como carga de ruptura, assim se terá:

$x=\frac{15.000 \times 6}{12.205}=\frac{90.000}{12.205}=7.375 \mathrm{~mm}^{2} \quad$ (secção da barra $)$

Atribuindo as 2 barras uma seção quadrada teremos o lado $=0,086 \mathrm{~m}$ (aproximadamente)

\section{Outra fórmula:}

$\mathrm{a}=$ alongamento

$\mathrm{F}=$ força ou carga de tração

C = coeficiente de elasticidade c. a $0,00046 \times 14.000$

$\mathrm{S}=$ seção

$\mathrm{S}=\mathrm{F} / \mathrm{c} . \mathrm{a}=30.000 / 0,00046 \mathrm{X} 14.000=2.820 \mathrm{~mm}$

Devendo-se atribuir dimensões 6 vezes maior tem-se:

$\mathrm{S}=2.820 \times 6=16.926$ e se as barras forem 2 teremos:

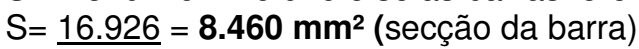

$$
2
$$

\section{Outra fórmula:}

$\mathrm{F}=$ (não é possível a leitura)

$\mathrm{A}=\mathrm{x}$ em $\mathrm{mm}^{2}$

$\mathrm{R}=$ coeficiente de resistência $=40 \quad$ e $\quad x=6.30 .000 / 40=4.500$

O Documento 198 é apresentado na sua forma original como Fig. 153 A e 153 B.

A seguir a Planta do segundo pavimento, como Fig. 154, focaliza o ático, as paredes do mirante, clarabóia, os dois grandes arcos abatidos, as tesouras do telhado, as transversais (vermelho e roxo) e as transversais (em verde), que sustentam o teto do Salão de Honra. É apresentado um detalhe que ainda localiza duas colunas metálicas, que partem do ático e descem pela parede da escadaria. 
Notrme sell areo

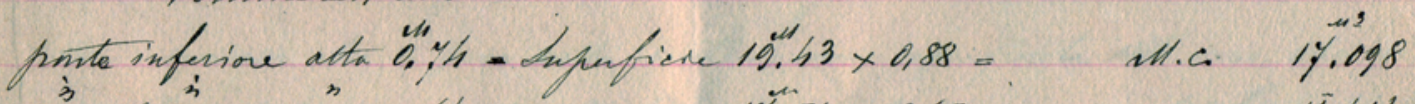

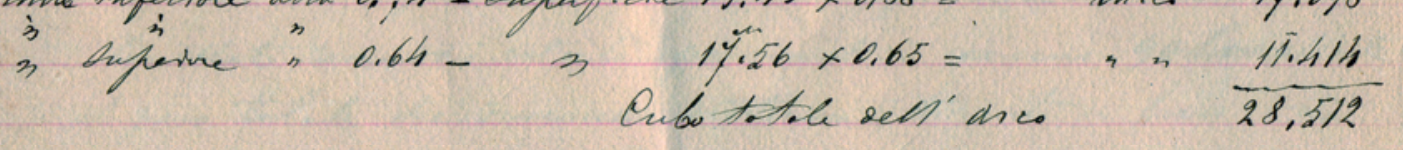

Dimensiven or m matlone nuot.

$\tilde{0.21} \times \tilde{0.105 \times 0,065}$

Folmes sim mattone $=$ Mlle 0,00143325

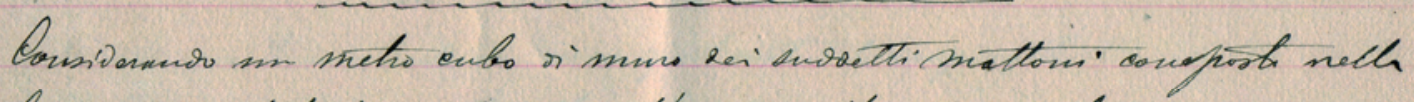

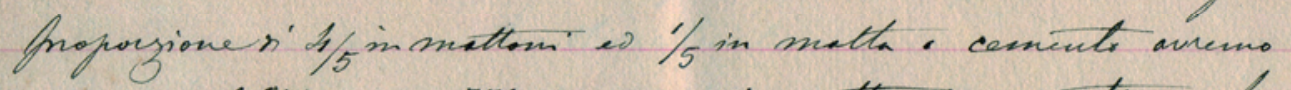

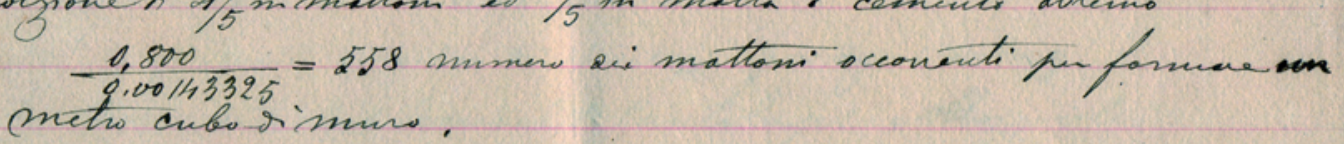

Pnerdo

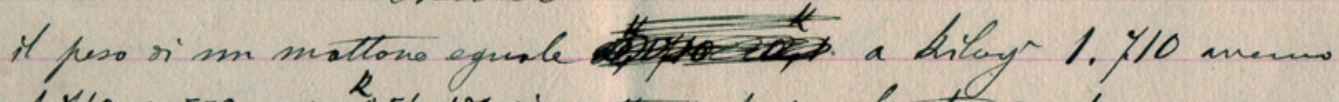

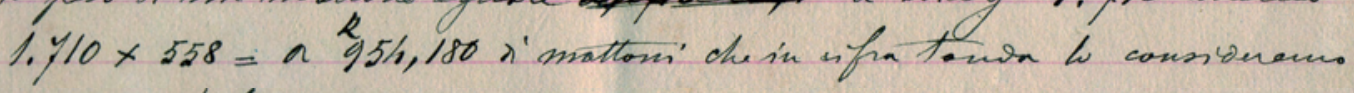

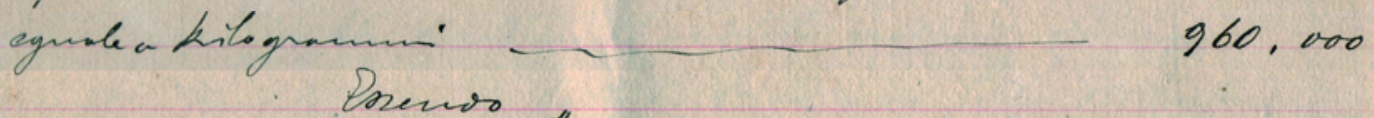

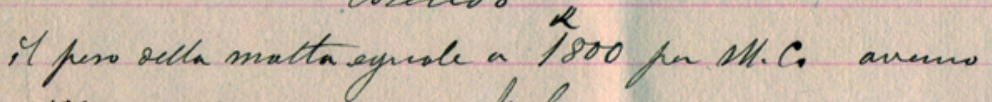

$1800 \times 0,200=$ Sesotolole rim metro enborimmo $\frac{360,000}{K 1320,000}$ Inenos

it volume totele eell ares eguale a Mth.C. 28.512 averno

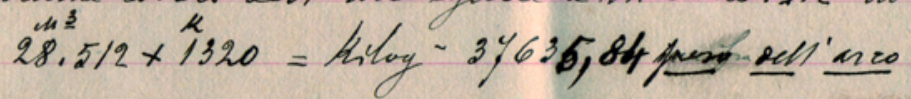

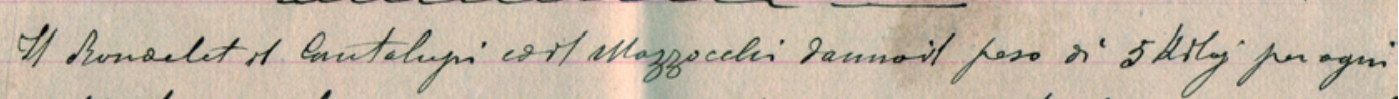

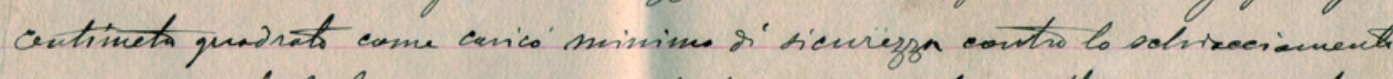

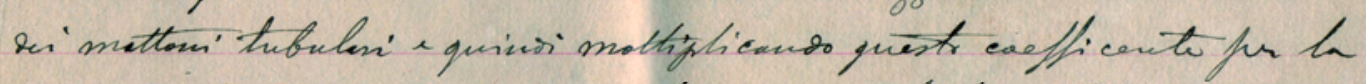

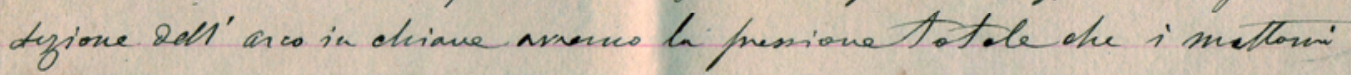
patramo soffortore.

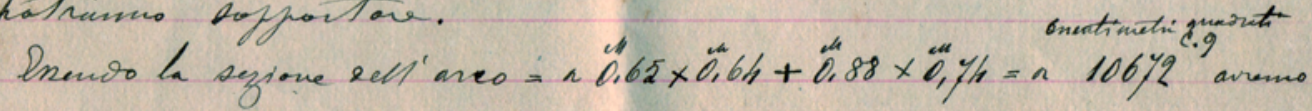

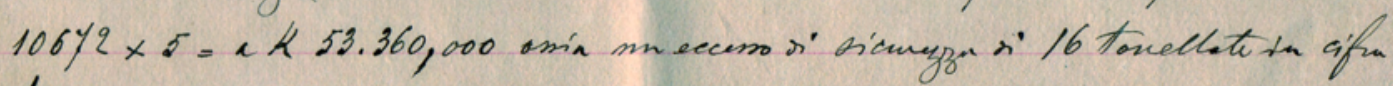
tanoa.

104 


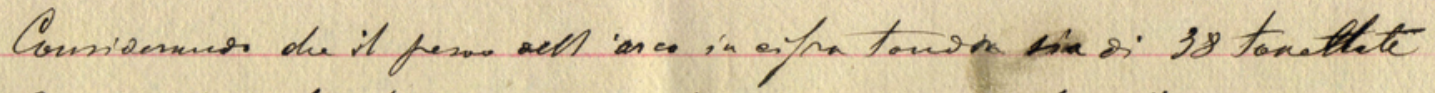

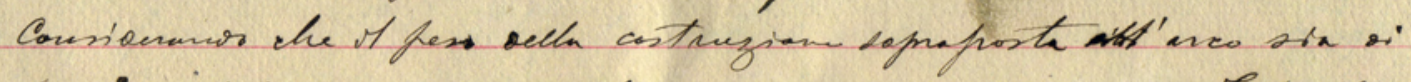

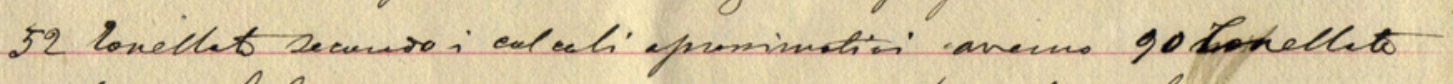
- Al pess tolale de rovame entenere itirantio furso ta

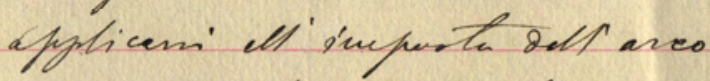

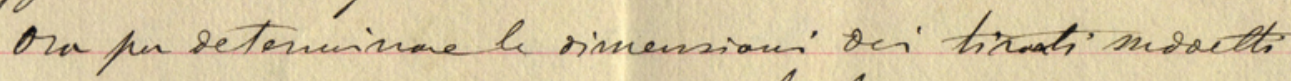

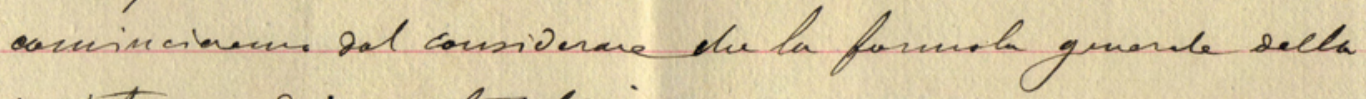

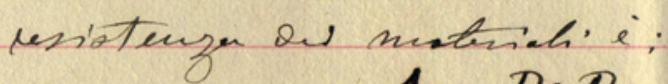

$$
A=P \cdot R \text { in an. }
$$

$A=$ Lefione trumsnasale in mom $g$ Sel materide impirg. \&

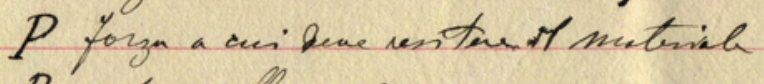
$R=$ d caefficente. caries rivicuezsn for agmi mm.g.

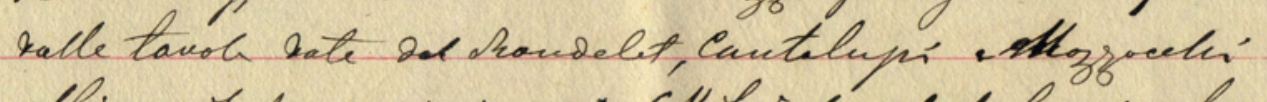
ablinus it peso saiminus or 6 kiloy d qude be bave tn feno

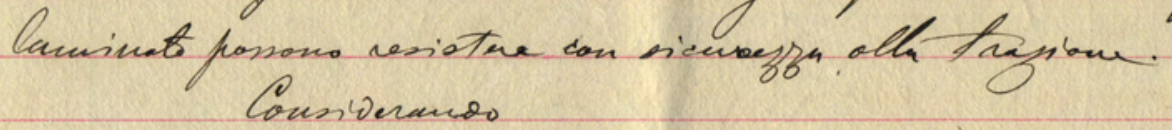

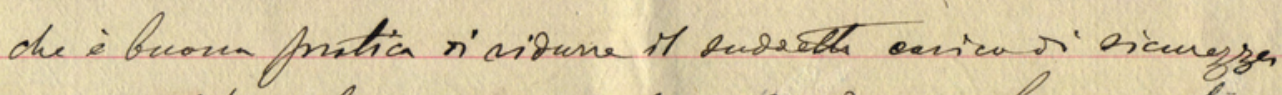

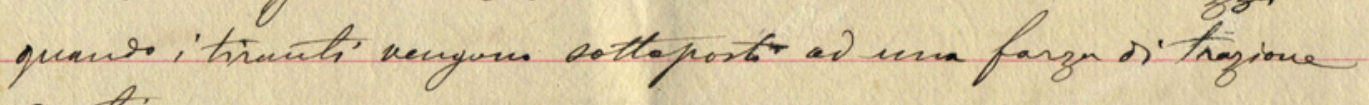
contiman Ponverano

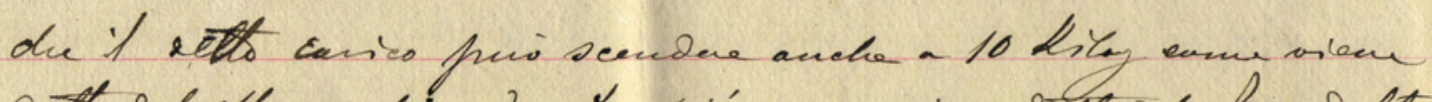

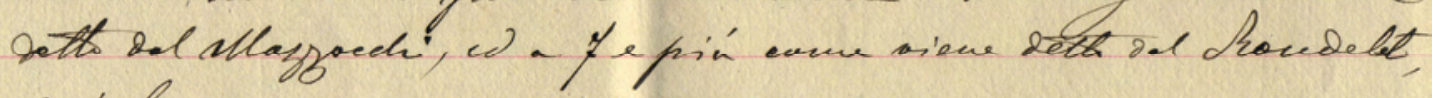
a) infine

Coustorands

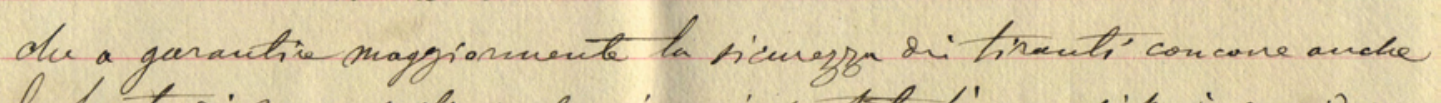
bu paste si mus sulla quale vine injostst I'ares, sipus considerme 11 caefficente ri sicurezzä $=3$ diloy 2 for mm g.

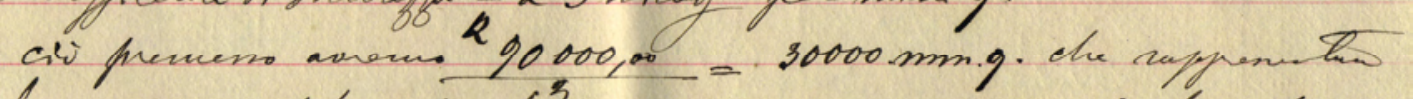

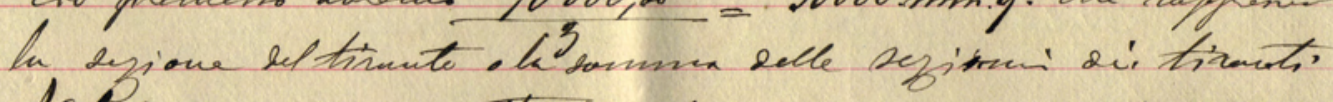

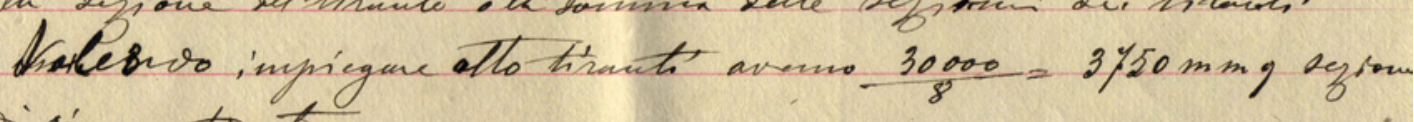
ri cieseun trinto

105 

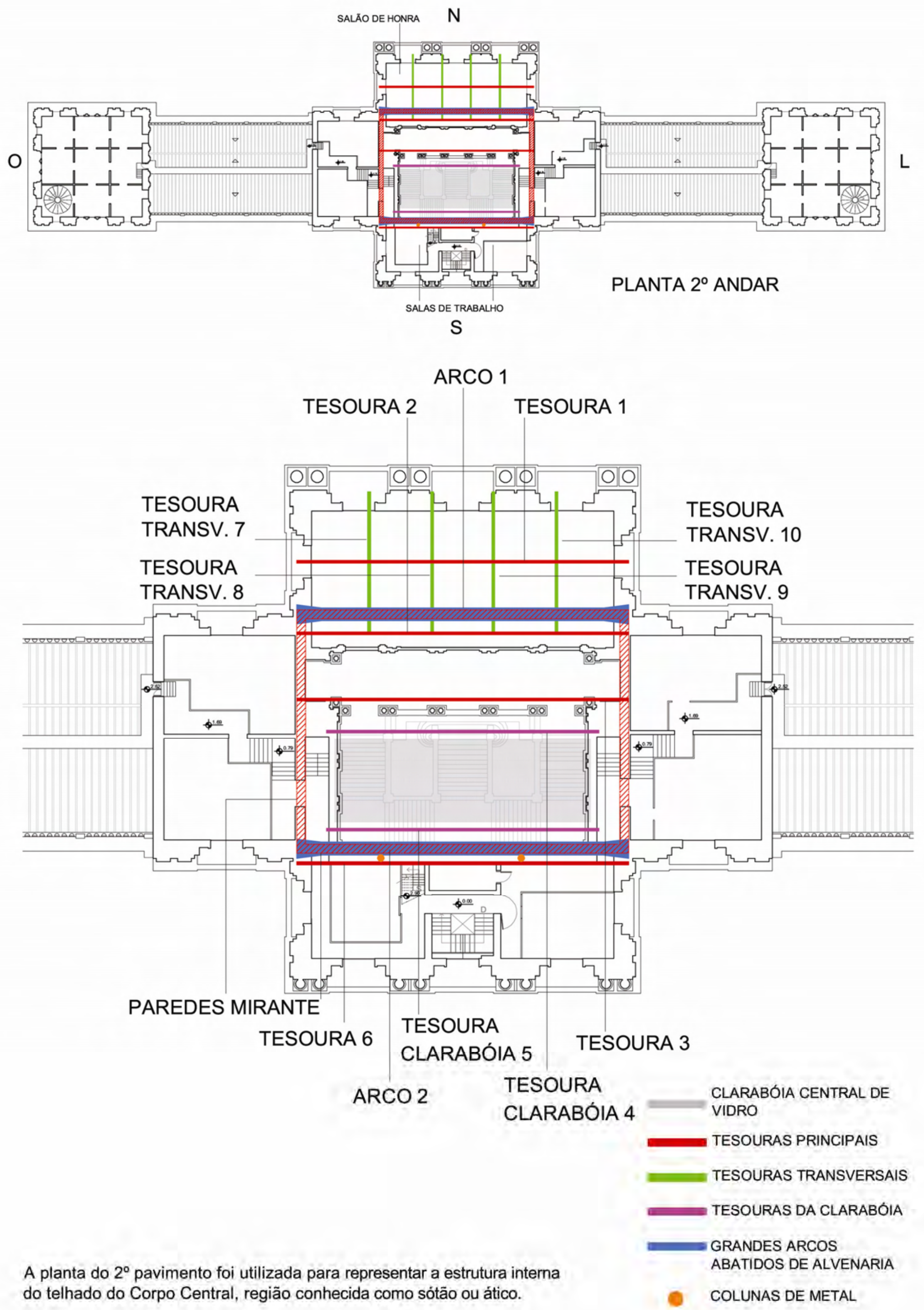


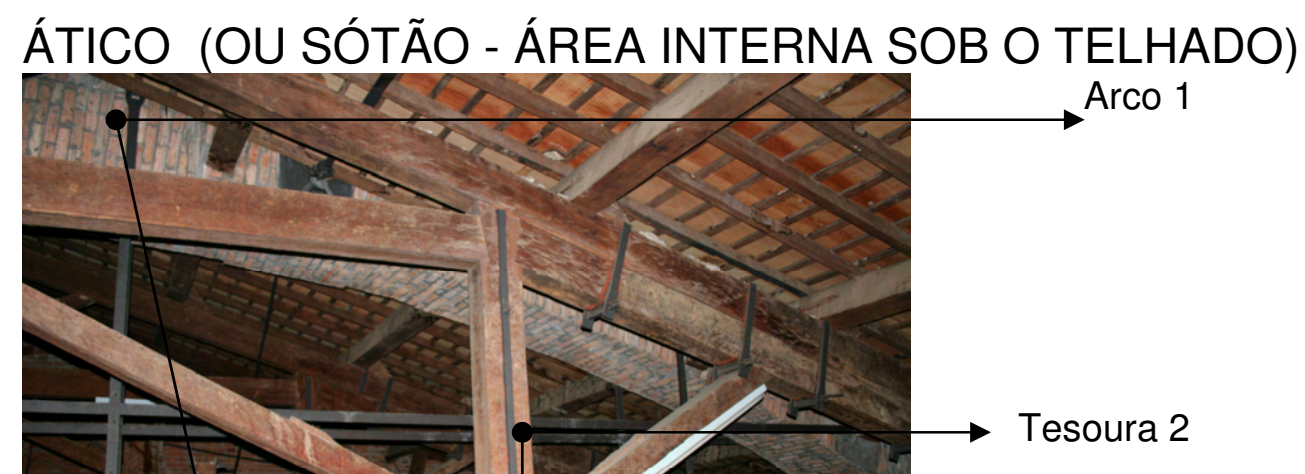

Fig. 155,156,157, 158
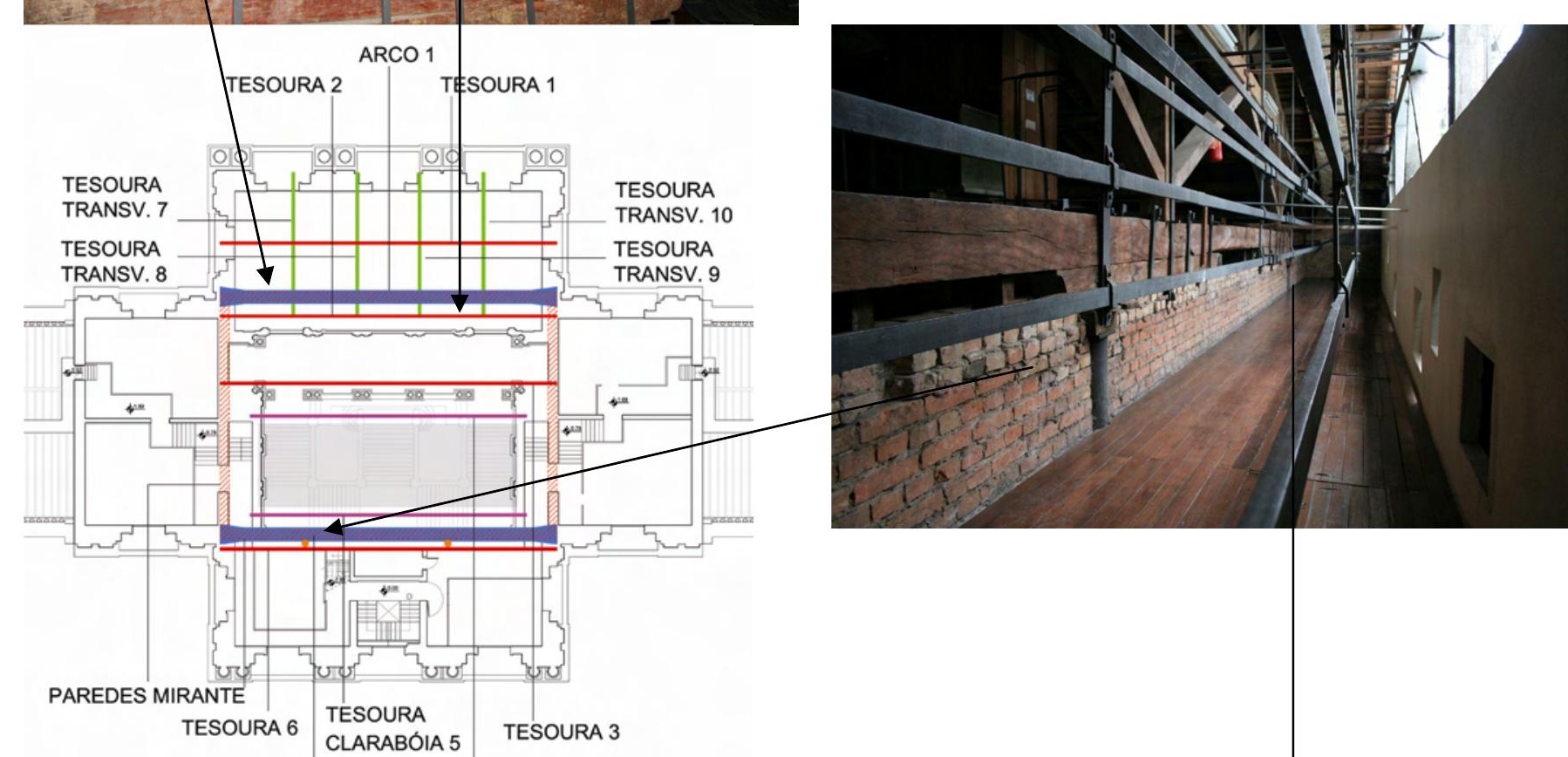

ARCO 2 TESOURA CLARABÓIA 4

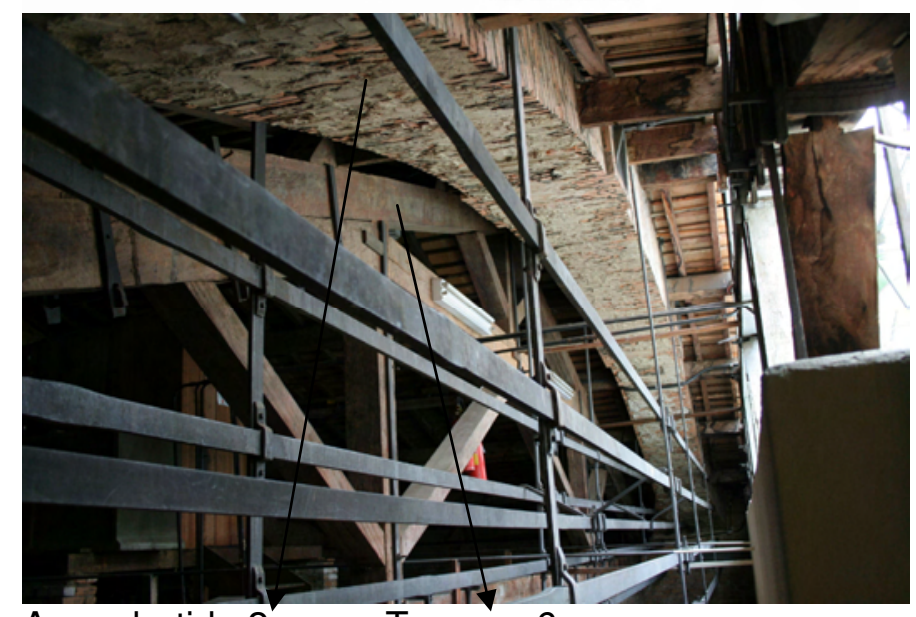

Arco abatido 2

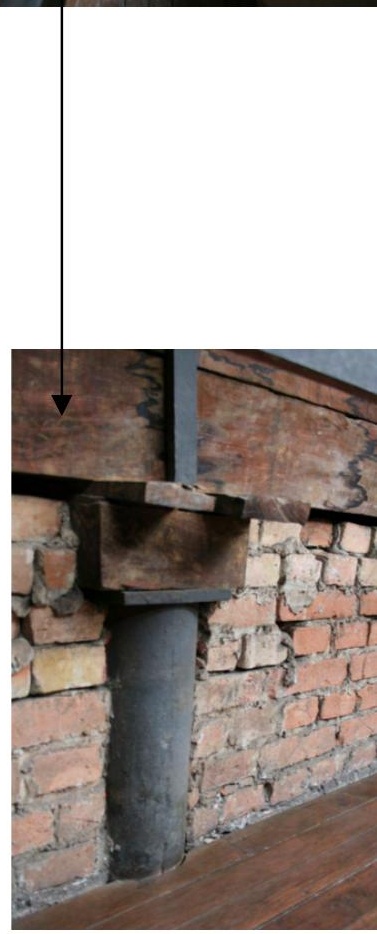

Detalhe coluna metálica 


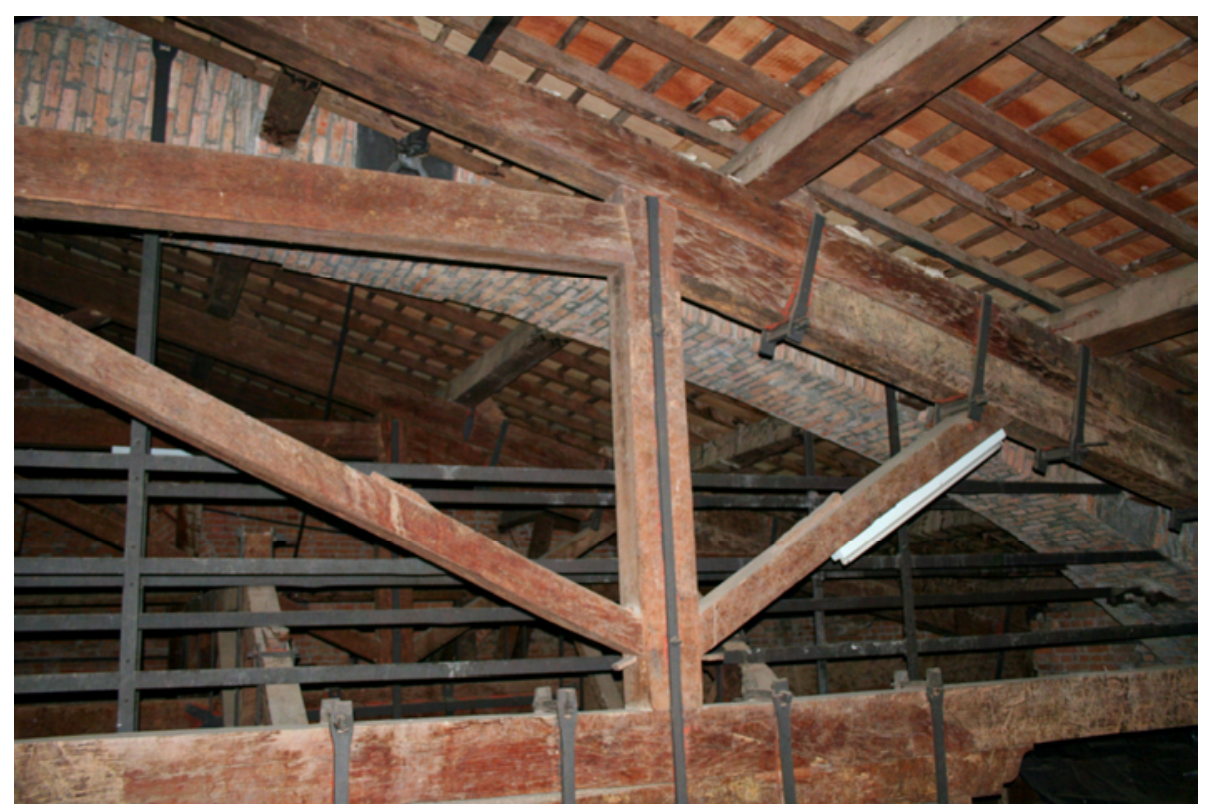

Ático - Grande Arco abatido 2 - entre a Clarabóia e a fachada norte

Curva de $20,40 \mathrm{~m}$ e de $3,18 \mathrm{~m}$ de seta

Fig. 159
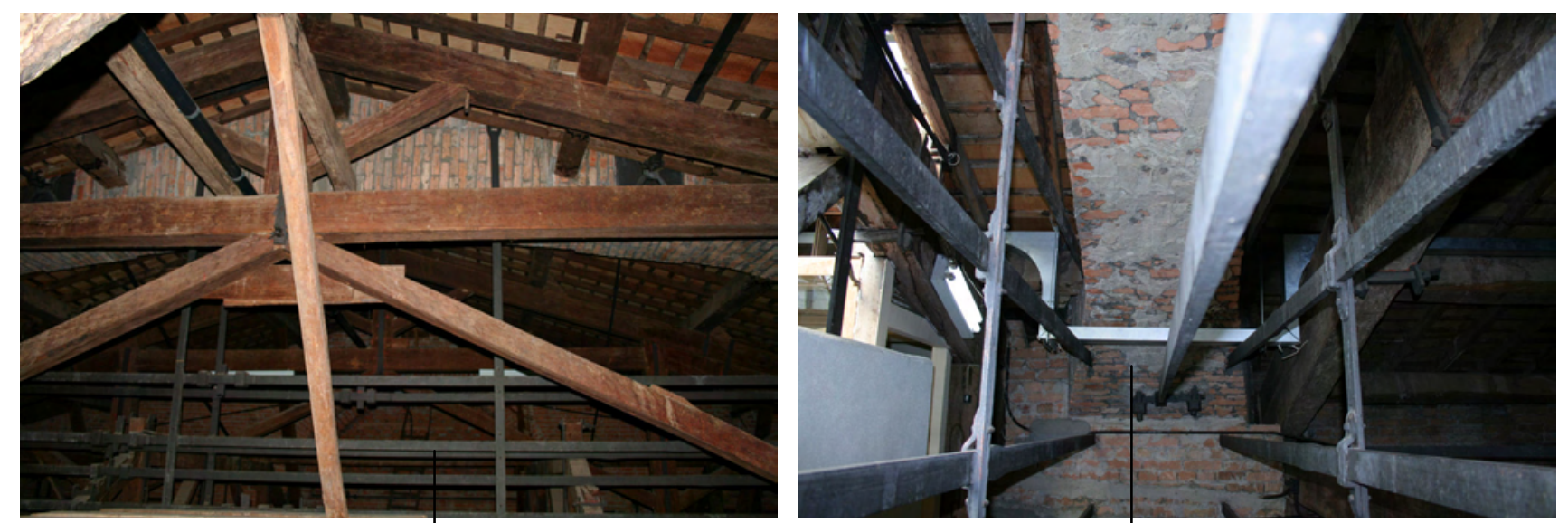

Grande Arco Abatido 2 - Detalhe na cumeeira do telhado e da imposta do arco
Fig. 160,161

Ferro chato de amarração do Grande Arco

O grande arco abatido, é um elemento estrutural que se interliga as vigas de madeira de sustentação do telhado, e sustenta as paredes do Mirante. Descarrega forças oblíquas nos maciços na altura da imposta, e tem uma grande amarração horizontal, através de 09 tirantes. 
COLEÇÃO CPOS
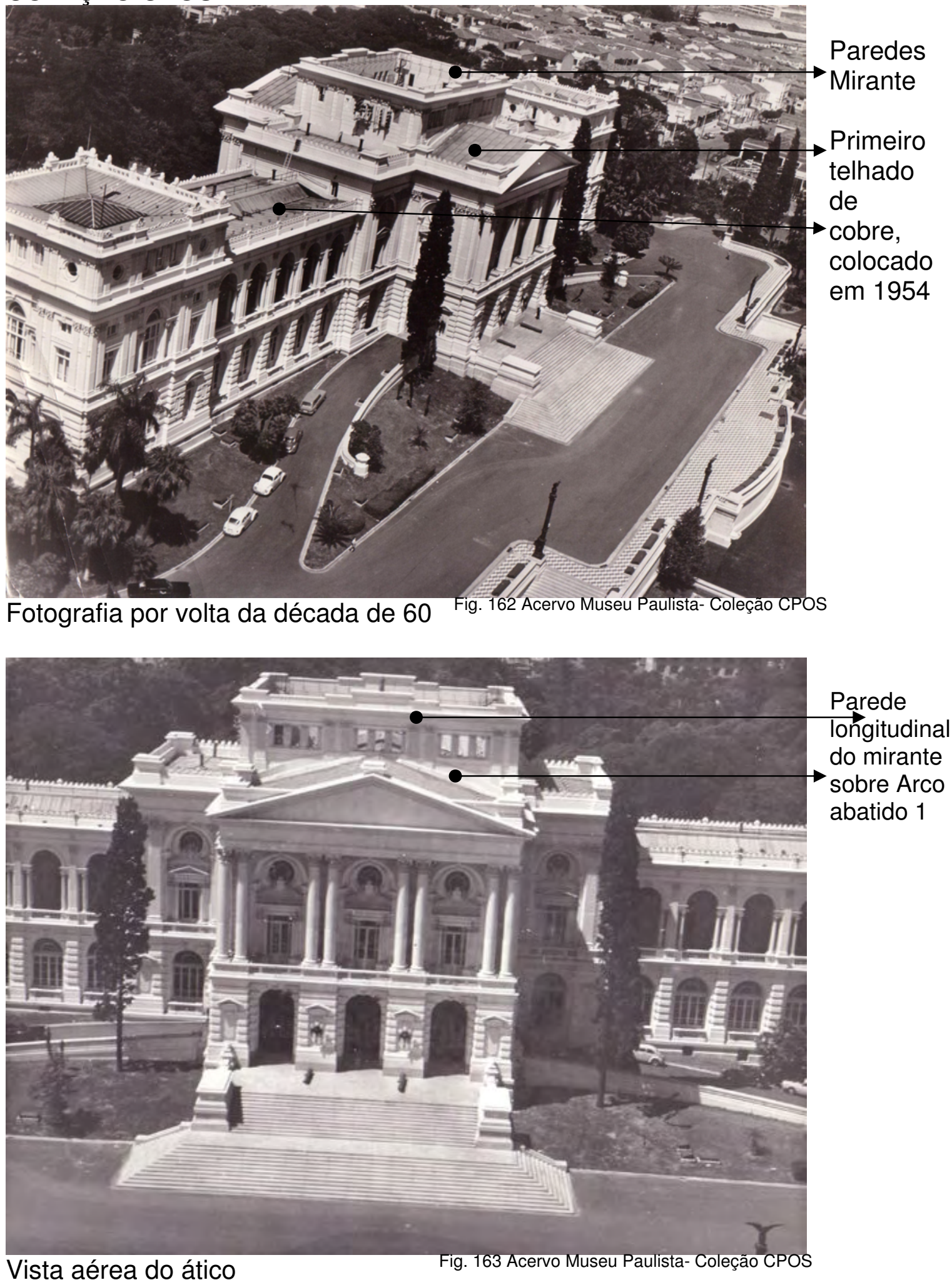


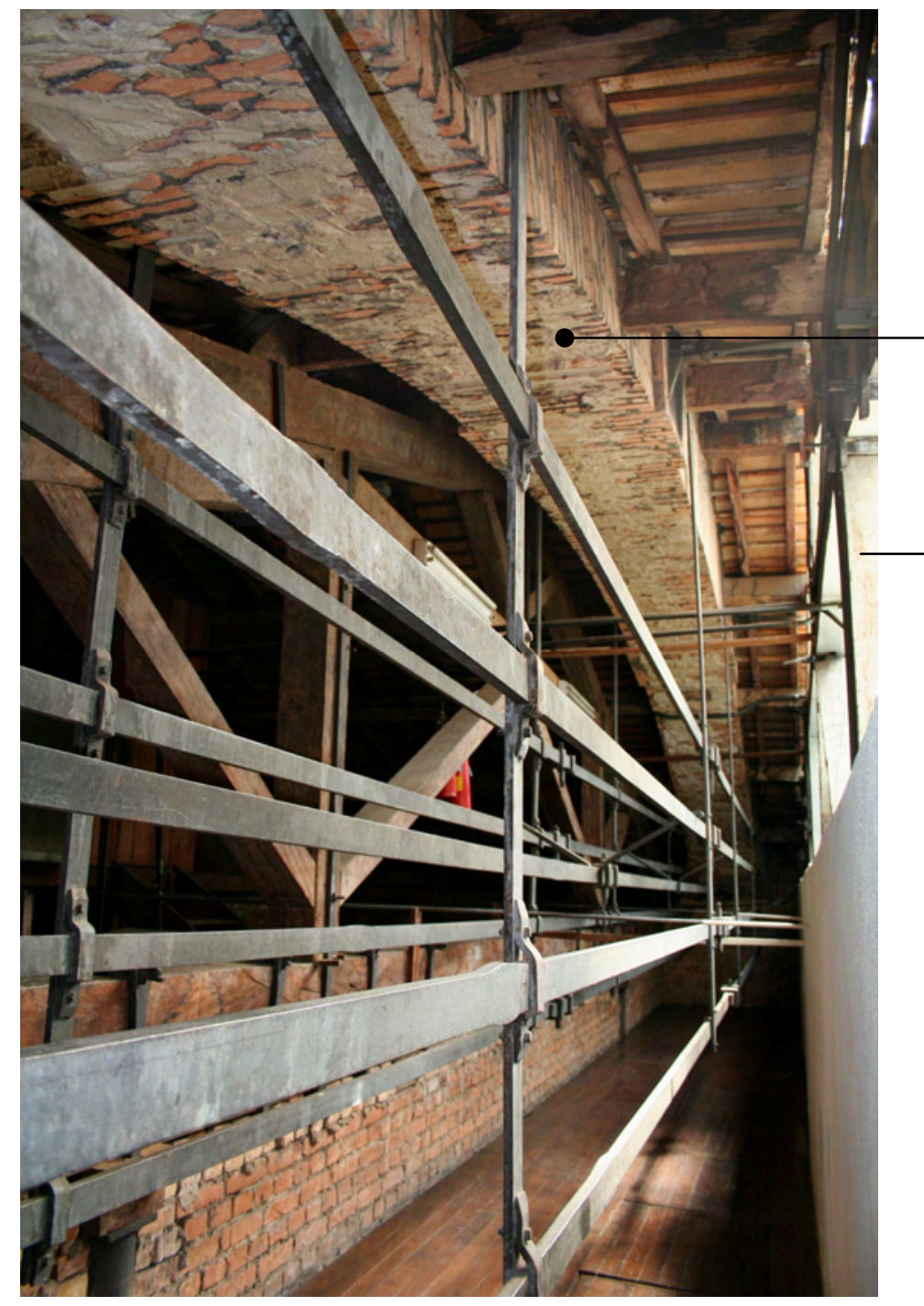

Grande Arco Abatido 1entre a clarabóia central e a fachada sul.

O arco ultrapassa 0 telhado e vai sustentar a parede longitudinal do mirante

Grande Arco Abatido Arco 2 (conforme planta)

Clarabóia

(à direita)

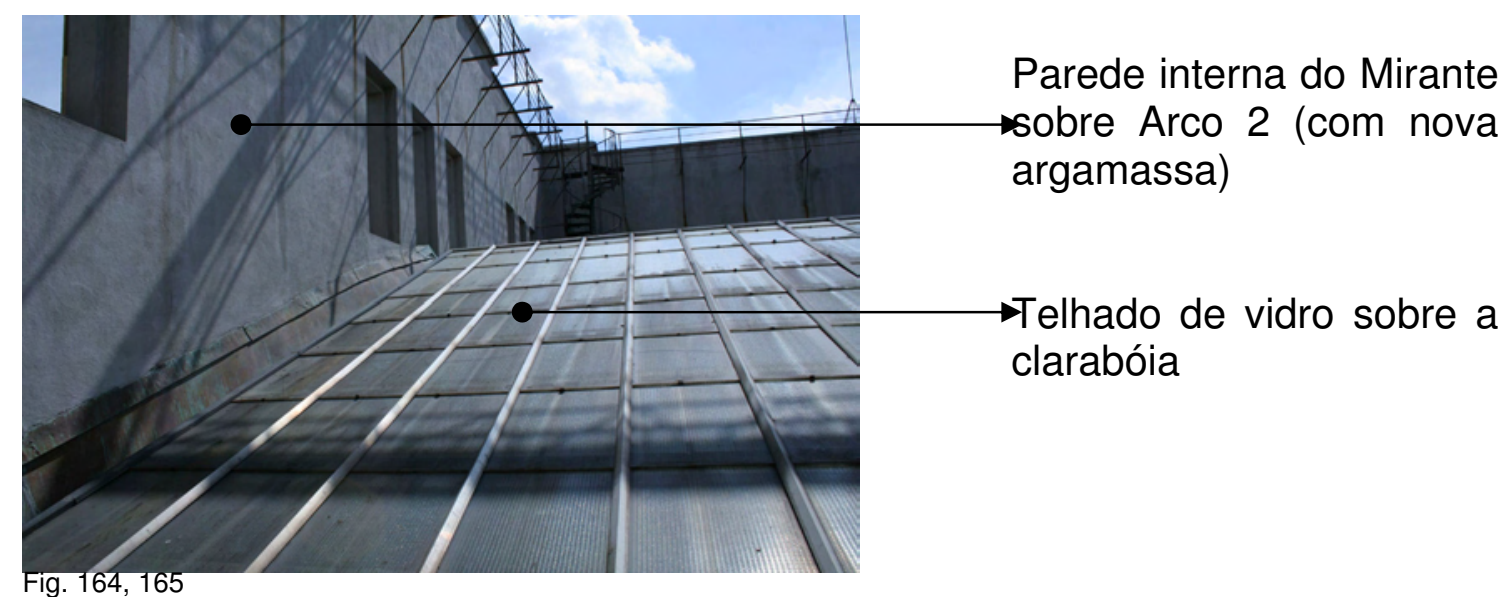




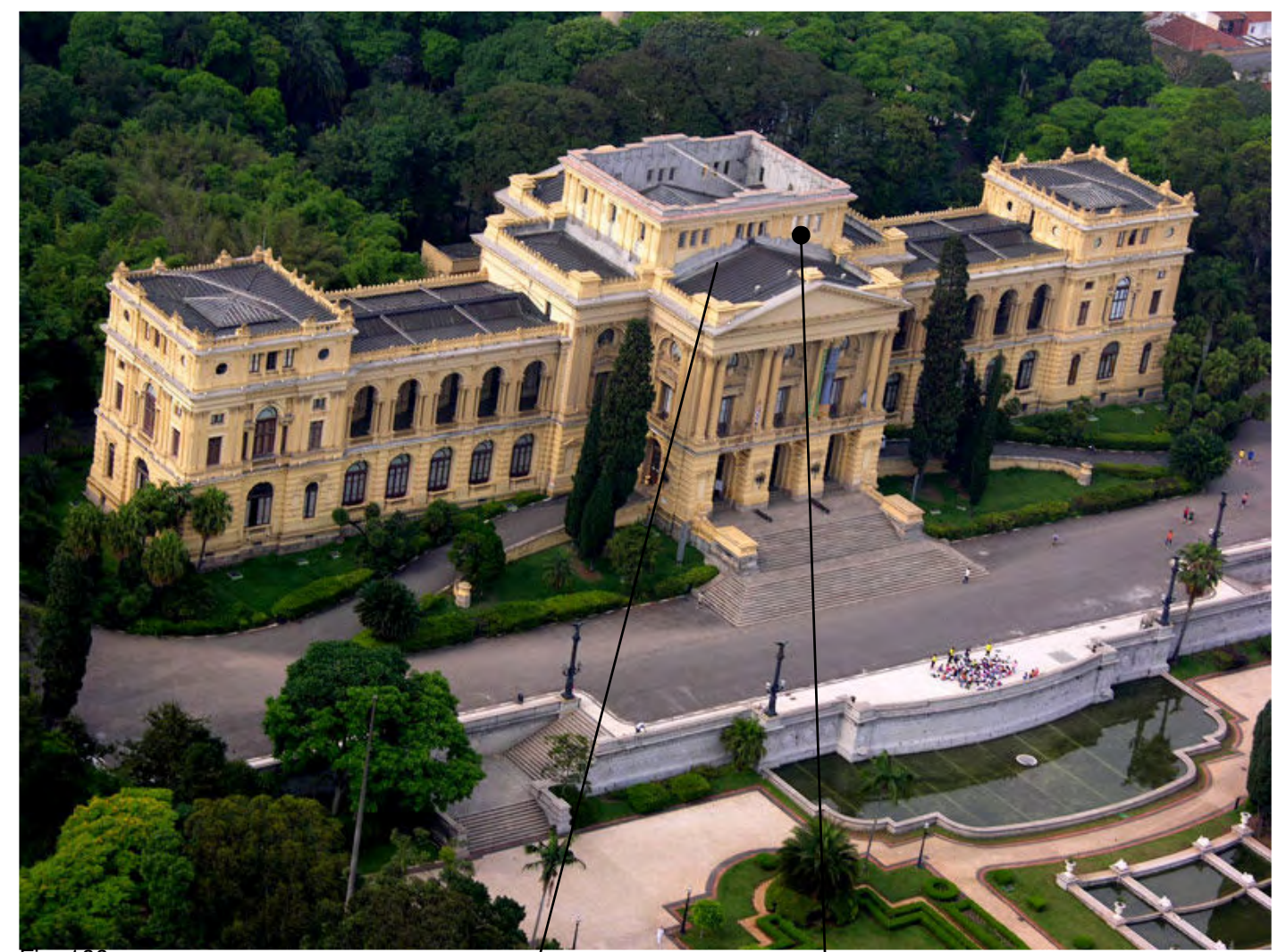

Fig. ${ }^{166}$ Imagem com a intervençăo de 2002 executada
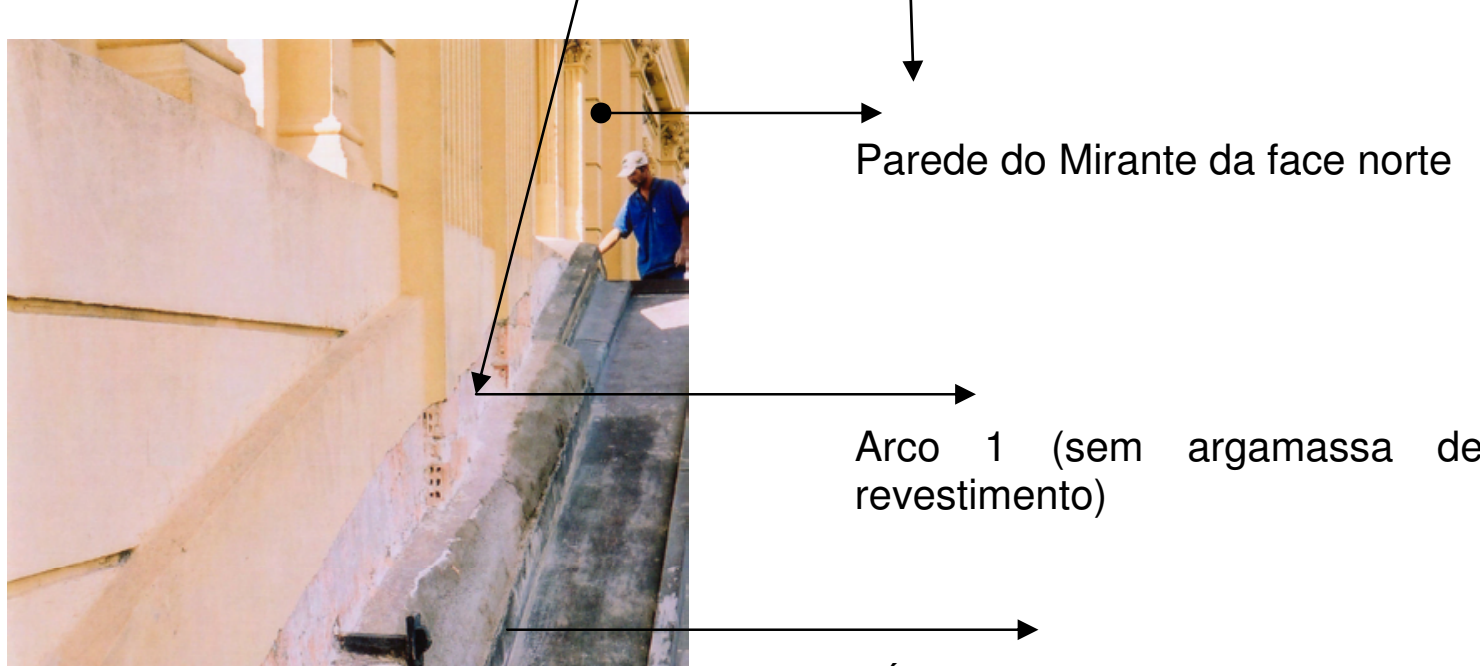

Área externa do Mirante sobre o Salão de Honra 
Área externa do Mirante - Imagens registradas durante intervenção do ano de 2002

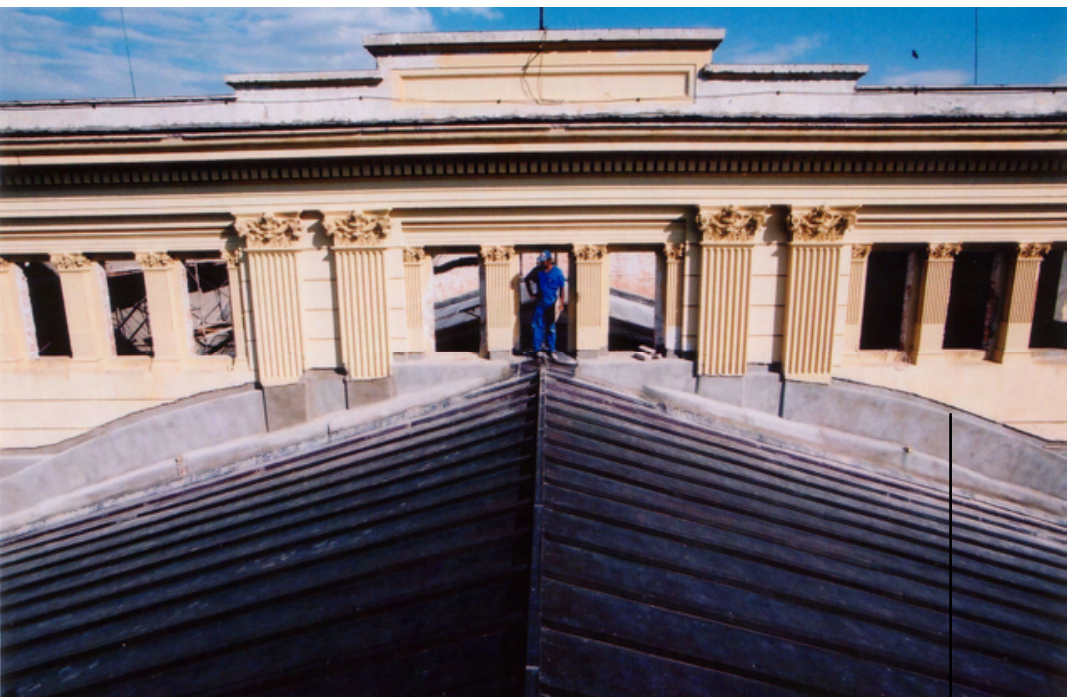

Fig. 168 Área externa do Mirante - Face Norte. Arco 1 com rềvestimento (como fotografia aérea anterior)

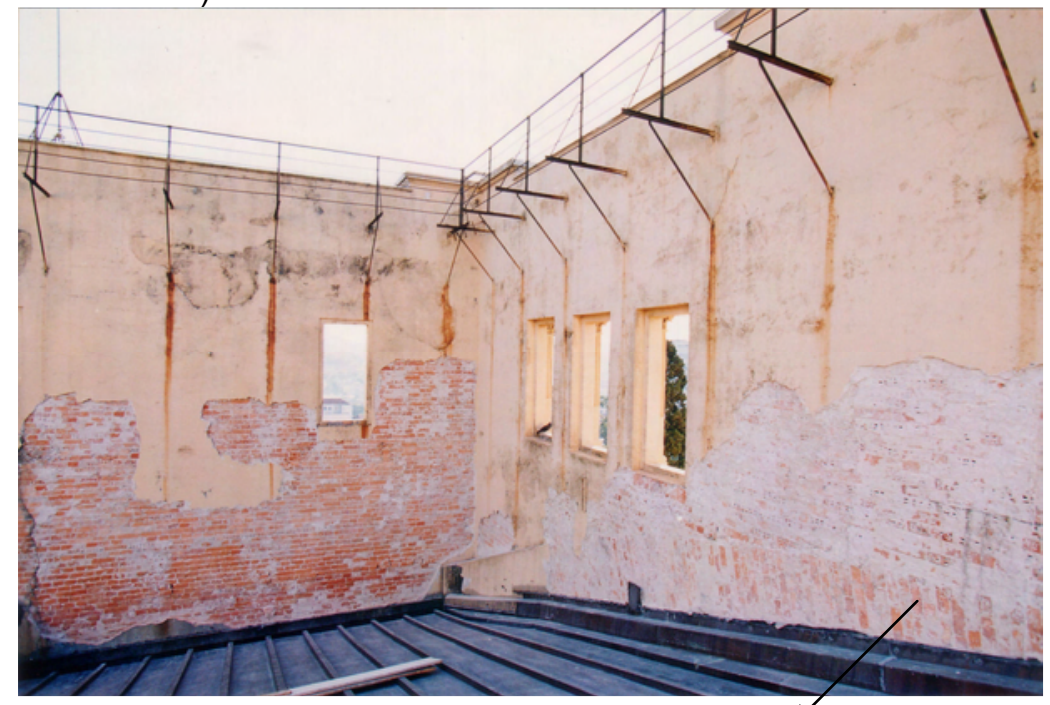

Fig. ${ }^{169}$ Arco 1, sem revestimento na área interna do Mirante

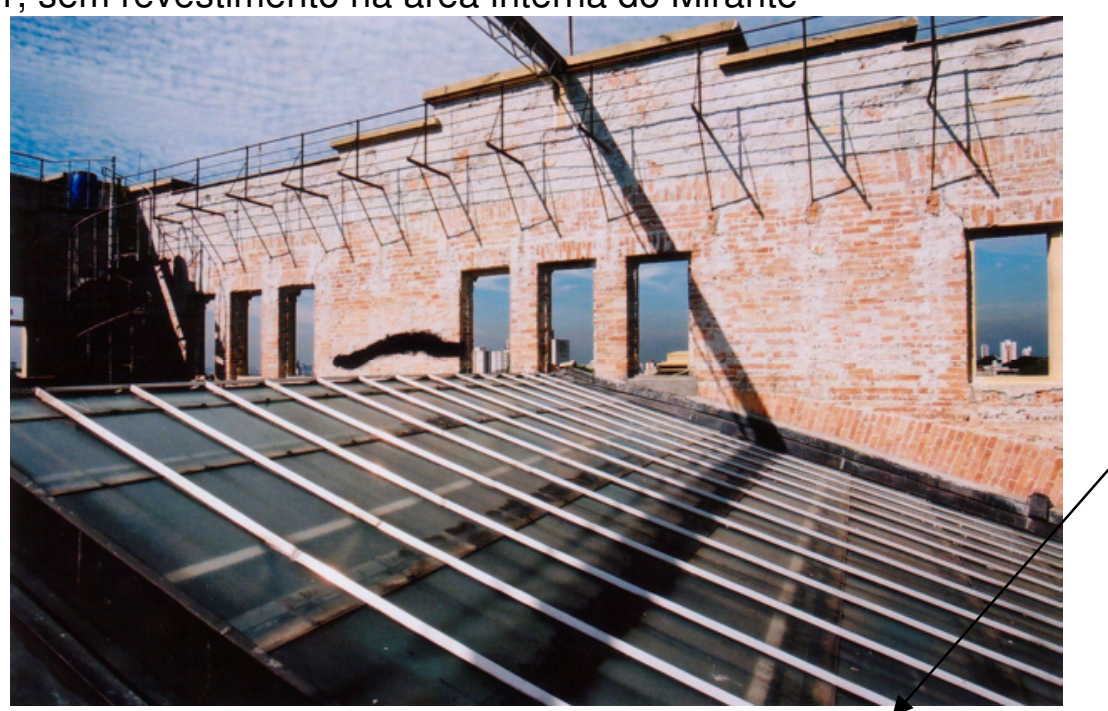

Fig. ${ }^{170}$ Arco 2, sem revestimento na área interna do Mirante que ultrapassa o telhado 


\section{ARCADAS E PÓRTICOS}

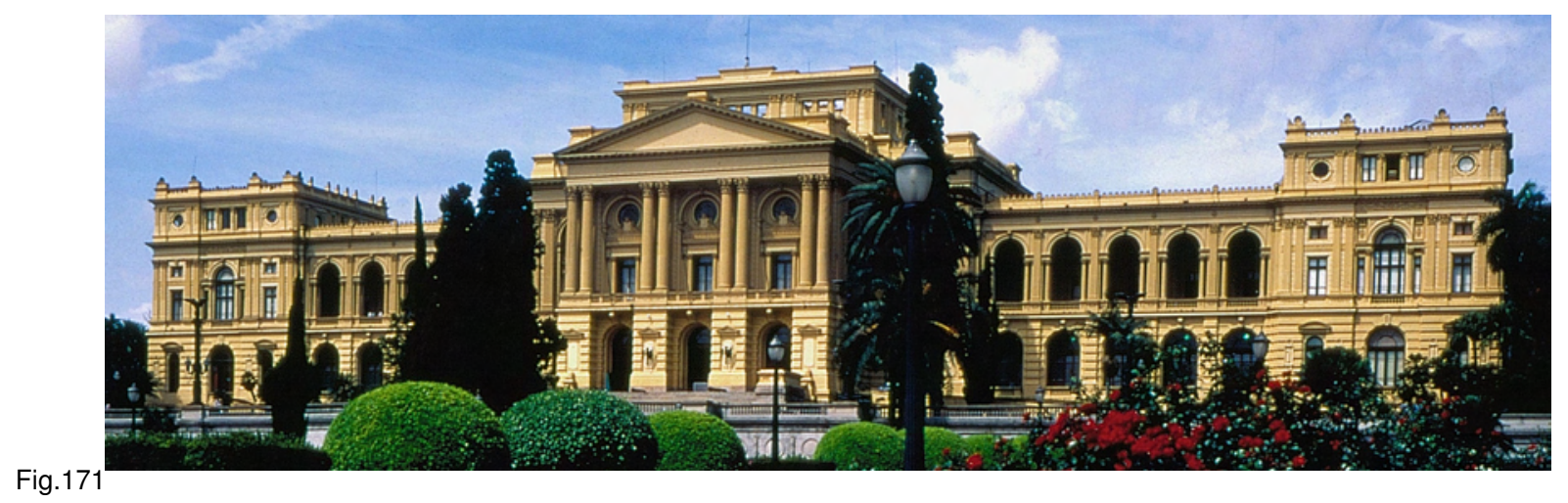

As fachadas do edifício são constituídas pelas colunas e arcos, que assumem formas e dimensões variadas de acentuada expressividade em cada corpo.

Os conjuntos de arcos nas galerias formam as arcadas, com cinco pórticos cada uma. Os pórticos representam, na evolução histórica arquitetônica, a solução estrutural que permitiu aumentar os vãos de apoio e de cobertura dos espaços, em substituição à tradição do sistema arquitravado grego.

SEGURADO (sem data, p.109-110) apresenta os significados da passagem do chamado sistema arquitravado para o sistema de arcos, bem como os conceitos dos elementos que constitui este, e que se aplicam ao edifício estudado:

[...] Nos seus monumentos os Gregos ligavam as colunas por meio de peças retas - as arquitraves - que faziam com que o entrecolúnio fosse bastante reduzido, pela dificuldade de vencer grandes vãos por este sistema.

Mais tarde os Romanos aplicaram às suas construções, os arcos e as abóbadas que a civilização etrusca Ihes legara, formando as arcadas e os pórticos, e permitindo-Ihes assim afastar os pontos de apoio ou colunas.

As arcadas e abóbadas, mesmo as cúpulas, são, porém, anteriores àquela época porque se encontram em ruínas das antiqüíssimas civilizações dos Caldeus e Assírios.

Uma arcada é o conjunto formado por uma série de colunas reunidas entre si por meio de abóbadas ou arcos semicirculares ou de volta inteira.

Em vez de colunas podem ser pilastras ou pés direitos que sirvam de apoio aos arcos.

Às molduras que encimam as pilastras ou pés-direitos, e servem de apoio aos arcos propriamente ditos, dá-se o nome de impostas.

Um pórtico é a combinação de arcos sobre pés direito, ladeados por duas colunas, fazendo saliência sobre aqueles. Forma geralmente uma galeria coberta paralelamente à frente de um edifício. 

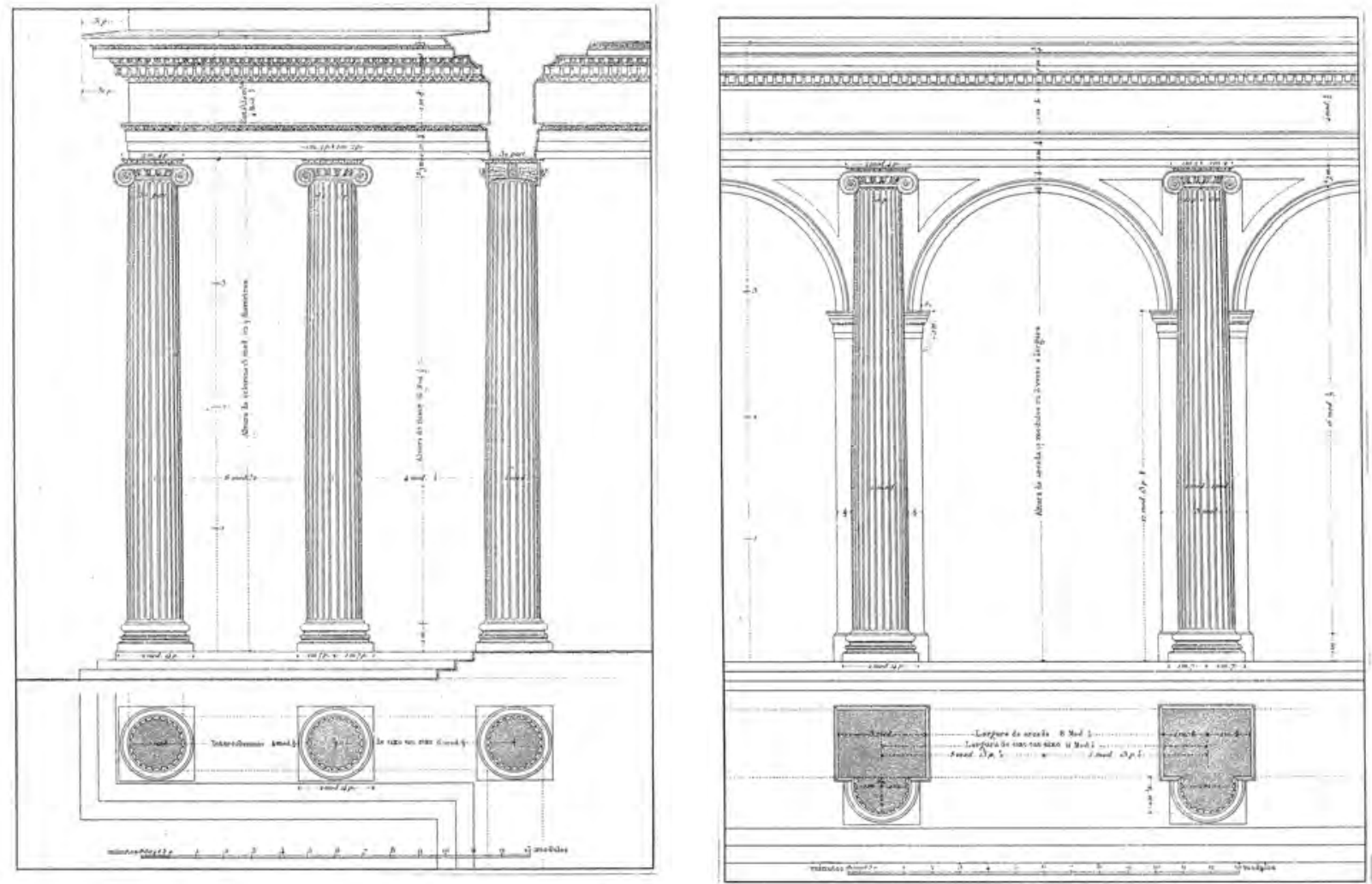

O entrecolúnio, distância entre as colunas, aumenta com o emprego dos arcos e arcadas Fig. 172,173

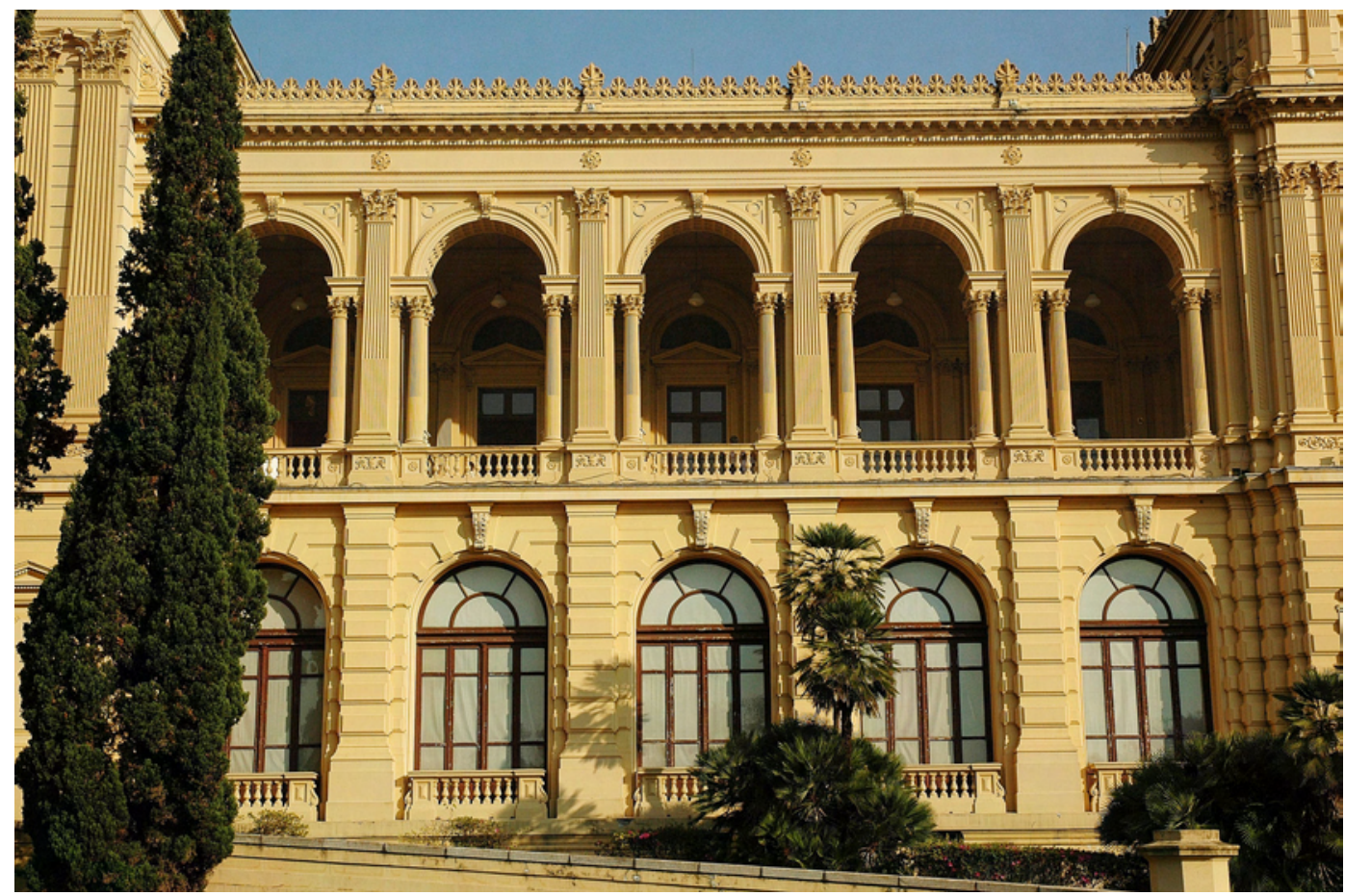

Fig. 174

E o autor continua, considerando-se as relações e proporções entre os elementos estruturais:

Arcadas - Os limites entre os quais se podem fazer variar os vãos das arcadas são mais amplos que os dos entrecolúnios, mas deve entender-se que aumentando o vão, deve crescer a robustez dos suportes e aumentar a espessura da abóbada, caracterizada pela arquivolta. 
Deve pois existir uma certa relação entre o vão, a largura dos pés direitos e a espessura do arco. Tem-se feito tentativas infrutíferas para conseguir estabelecer, para as arcadas, um sistema de proporções, simples e harmônico, analogamente ao que se fez com as colunas. Não quer isto dizer, porém, que não possam fixar certas regras acerca das arcadas: assim a altura, contada de sob o fecho ao solo, varia de $1 \frac{1 / 2}{2}$ a 2 vezes a largura do vão e a largura do pé direito oscila entre $1 / 3$ e 1/4 da mesma abertura.

As proporções da arquivolta, quando existem, são menos definidas, visto que a sua espessura não aumenta proporcionalmente à abertura da arcada, porque se a arquivolta deve efetivamente crescer em grossura quando o vão e a carga se tornam maiores, o que é certo é que aquele varia com o diâmetro, e esta atua sobre a semicircunferência do arco, quantidades que variam na razão de 1:1,57.

Conclui-se daqui que a relação entre a espessura de arquivolta e o vão diminui à medida que este aumenta.

(SEGURADO, sem data, p.110-111)
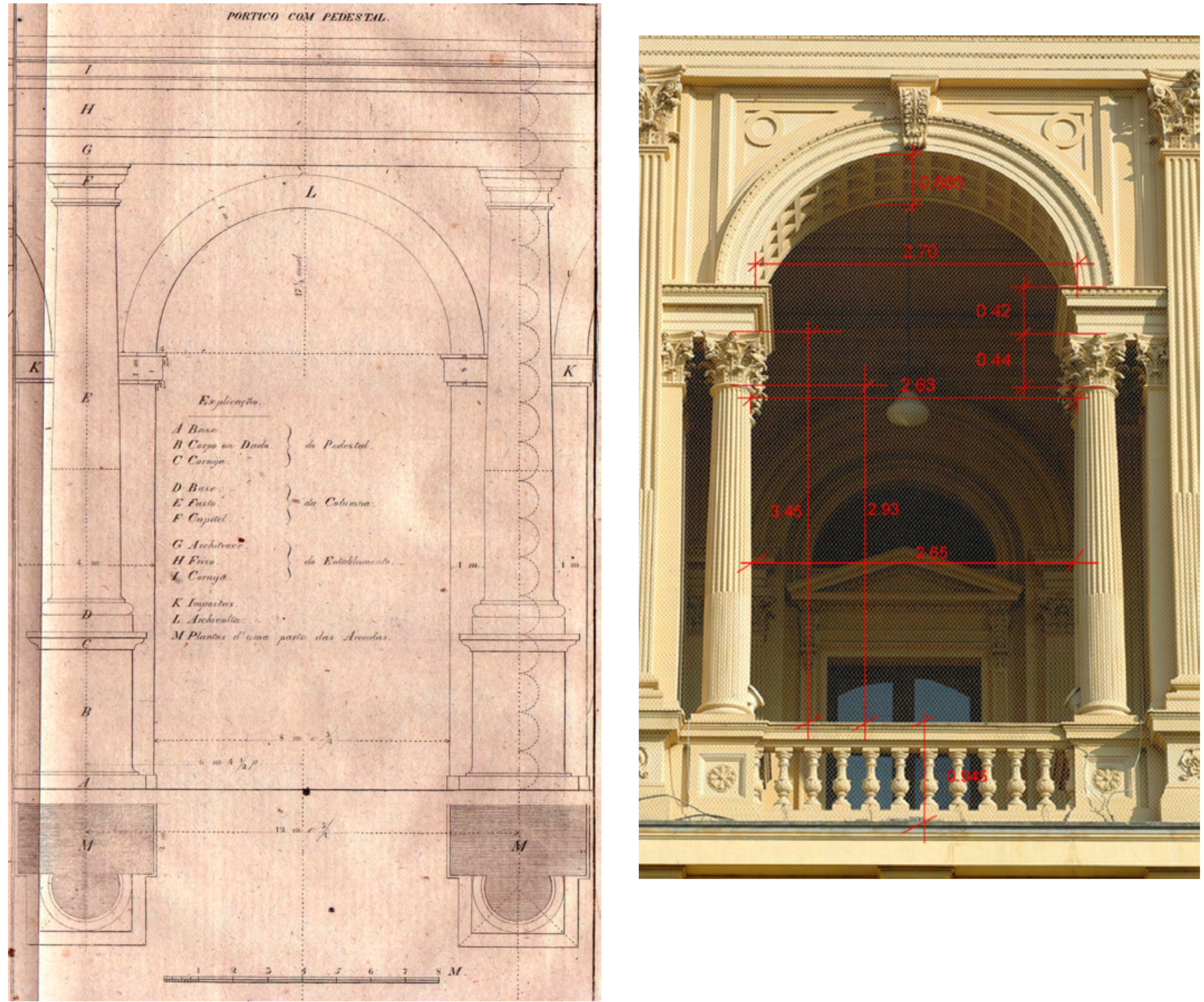

PÓRTICO COM PEDESTAL DE VIGNOLA. O pórtico de Bezzi com algumas variações Fig. 175,176 
As arcadas podem também ser empregadas sobre pilastras e pés-direitos, para compor os vão de portas e janelas.

SEGURADO, (sem data, p. 112) descreve este tipo, de arcadas, que podem deixar de apresentar impostas aparentes, sendo então a superfície do intradorso contínua com as dos pés-direitos, exemplificando com a figura abaixo e que se aproxima do edifício de Bezzi:
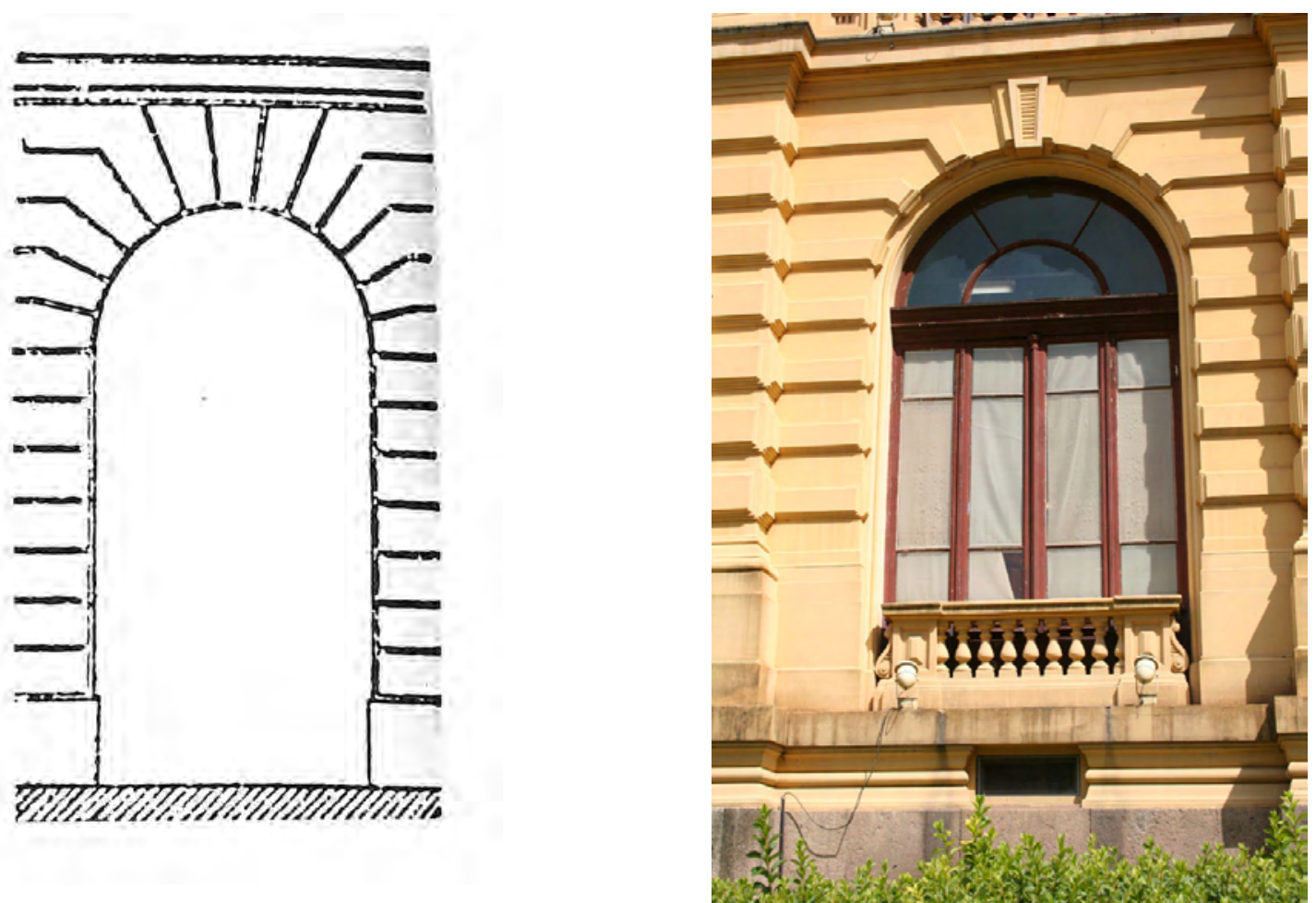

Fig. 177,178

As arcadas do térreo e do primeiro pavimento são, assim, elementos de grande expressão nesta linguagem arquitetônica e, ao mesmo tempo, representam uma solução estrutural que por séculos vem sendo utilizada. 


\section{PISOS - ASSOALHO E ABOBADILHA}

Basicamente, são dois os tipos de pisos empregados no edifício, o assoalho e a abobadilha. Eles são apoiados sobre as paredes e com travamentos horizontais através de estrutura metálica.

Além disso, verifica-se ainda a existência de estrutura de abóbadas duplas, sob piso de ladrilho, entre os lances da escadaria de mármore, que pode ser observado através do subsolo. Haveria outros locais, segundo documento em que Bezzi se refere às abóbadas, mas eles não possuiriam acesso visível.

Não são conhecidas as estruturas sob o lance das escadas.

No subsolo são visíveis os tetos, que constituem os pisos do pavimento térreo.

Podem-se identificar as abobadilhas sob as galerias, torres e 0 átrio (ou pelo menos parte do átrio)

Nas salas voltadas à face sul, e nos espaços sob o corpo central, foram utilizados os assoalhos de madeira, e somente em algumas salas de trabalho e banheiro, ele recebeu um forro plano como acabamento. Portanto, os pisos do térreo são definidos com clareza. Observando-se o piso do primeiro andar, somente as galerias são em ladrilho, e as salas da face sul, torres e Salão de Honra são de assoalho. Na documentação encontram-se mais algumas informações, que indicam que as soluções do pavimento térreo se repetem nos outros pavimentos, sendo empregado ou assoalho sobre vigamento de madeira ou ladrilho sobre abobadilha.

As abobadilhas permaneceram sem nenhum revestimento somente sob o átrio.

Nas áreas sob as galerias e torres, foram revestidas e pintadas, sem perder sua forma característica .

\section{ESTRUTURA DE MADEIRA}

Na Pasta 3 Documento 174 do Fundo Bezzi são apresentadas as seguintes dimensões do vigamento de madeira:

Dimensões que devem ter as vigas dos salões correspondentes às galerias com seus

respectivos tarugos

Primeiro pavimento

Comprimento $7,20 \mathrm{~m}$

Espessura $0,12 \mathrm{~m}$

Altura $\quad 0,30 \mathrm{~m}$

Colocadas em distâncias de $0,62 \mathrm{~m}$ de centro a centro; esse vigamento terá três ordens de tarugos de 0,08 de espessura com 0,15 de altura

Segundo pavimento

Comprimento 7,40m

Espessura $\quad 0,12 \mathrm{~m}$

Altura $\quad 0,30 \mathrm{~m}$

Colocadas em distância de 0,62 de centro a centro da viga, com respectivos tarugos como pelo primeiro pavimento

Assinado por Bezzi e Luiz Pucci . São Paulo, 1 de outubro de 1885 
Na Pasta 1 Documento 63, há esta citação, não muito clara, mas que provavelmente confirma o uso do ladrilho sobre abobadilha:

Que seja de ladrilho os pisos dos laboratórios no pavimento térreo, e abobadilha os pisos das galerias, átrios e laboratórios.

\section{ABOBADILHA}

São apresentadas nas figuras abaixo, exemplos da estrutura da abobadilha, utilizando ferro duplo $\mathrm{T}$ e tijolos montados sobre forma de madeira, provavelmente muito semelhante ao que foi executado.

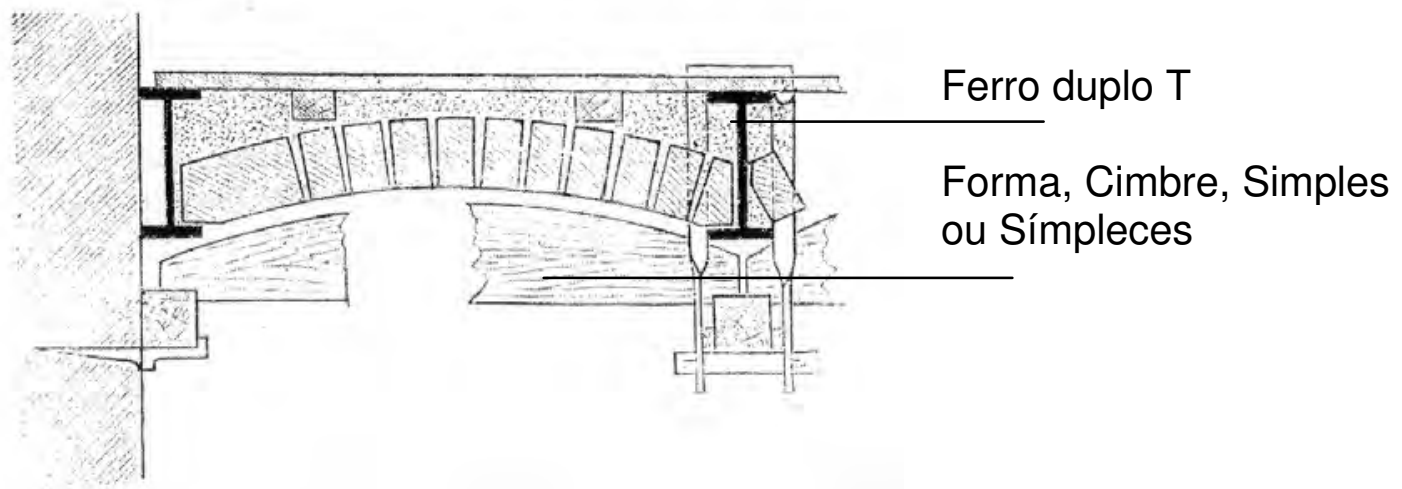

Fig. 179 (MATEUS, p.95)

Com o advento das vigas de ferro a abobadilha foi muito utilizada na arquitetura do século XIX e início do XX.

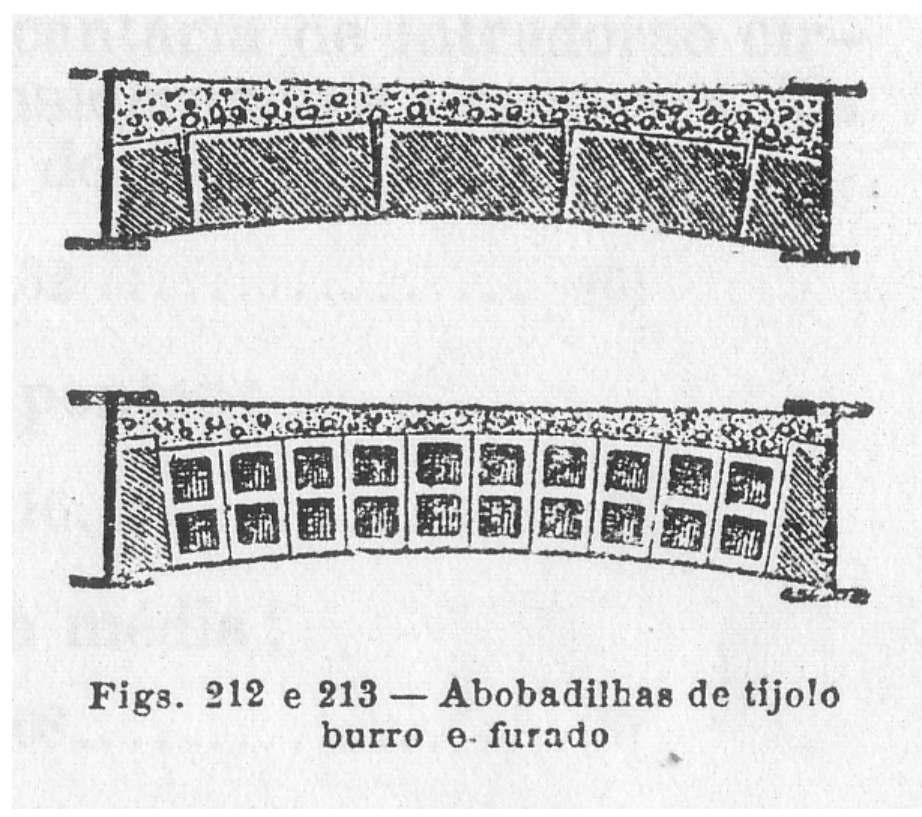

Fig. 180 (SEGURADO, p.163)

Abobadilha: são abóbadas semicirculares de pequena flecha ou mesmo chatas, construídas entre vigamentos de ferro pouco afastados entre si, a fim de formarem pavimentos incombustíveis; pode-se empregar para tal fim o tijolo burro ou o tijolo furado, ou simplesmente o beton. São muito usados pela grande resistência que oferecem e pela facilidade com que se constroem. 
No Fundo Bezzi há um croqui simplificado da abobadilha

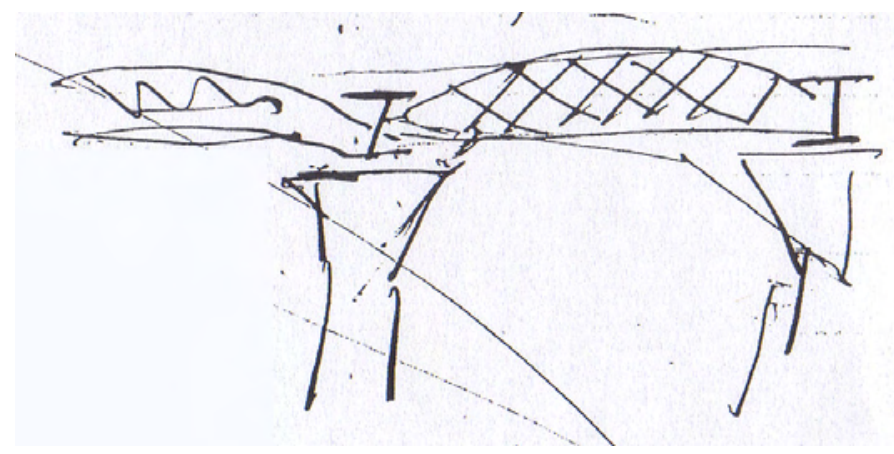

Pasta 3 Documento 209

Fig. 181

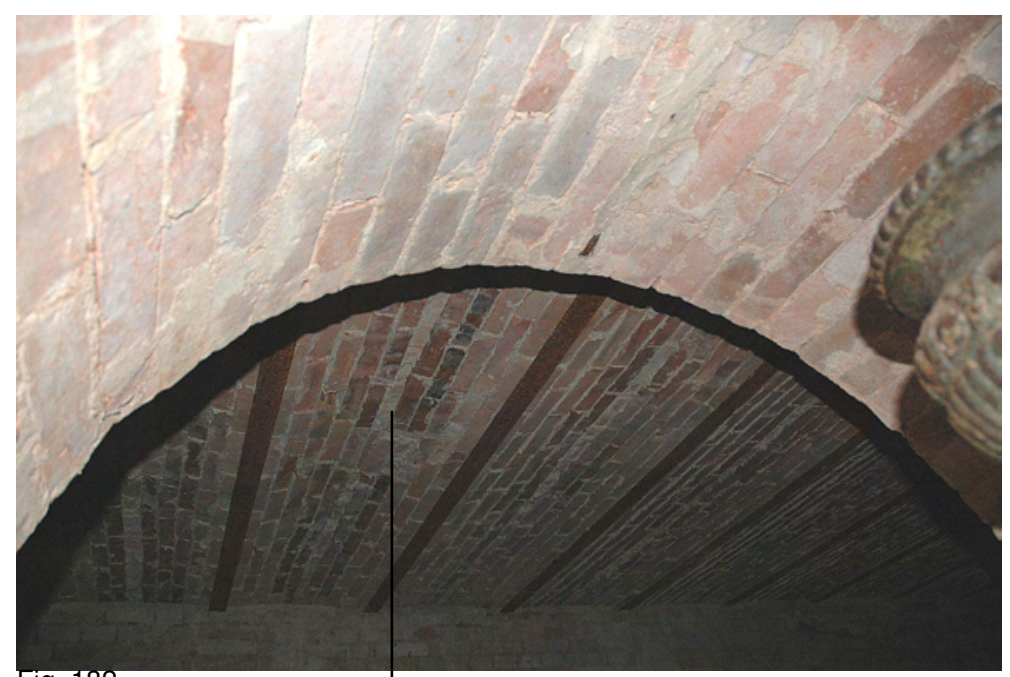

Fig. 182 Abobadilha sem revestimento, visível no subsolo. Área sob o átrio (saguão, térreo) 
Na Pasta 3 Documento 170, são apresentados os perfis de ferro duplo T dos tipos de A, $\mathrm{B}, \mathrm{C}$ e $\mathrm{D}$ e com dimensões variadas conforme o local onde são empregados.

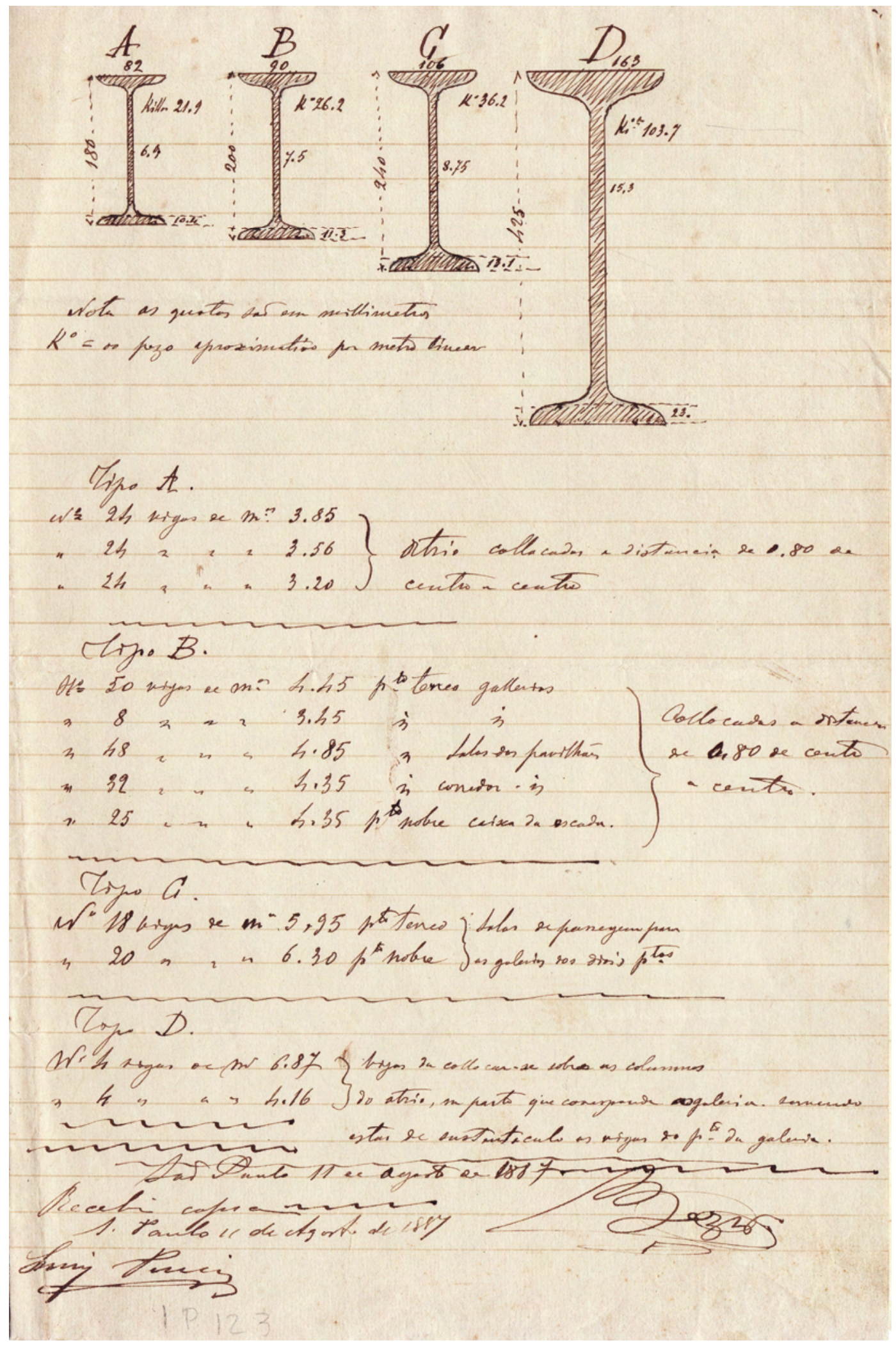

A seguir são apresentadas as plantas com a localização dos tipos de pisos em todos os pavimentos e os detalhes através das figuras. 

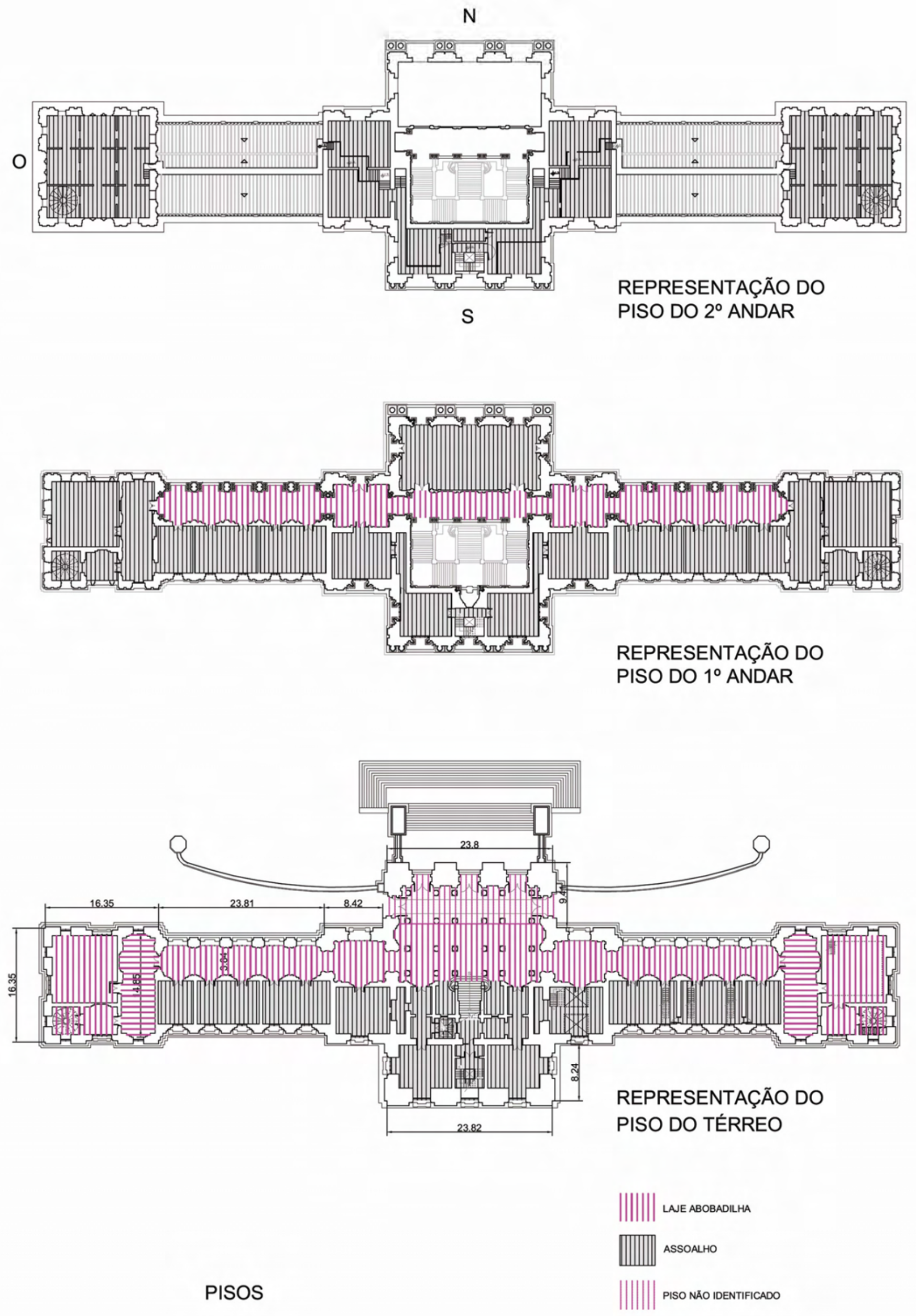


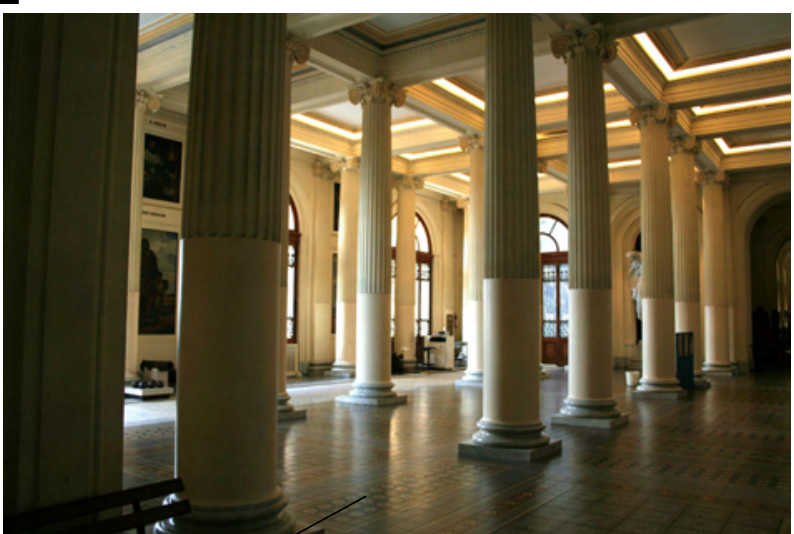

Piso de ladrilho sobre laje abobadilha no saguão (átrio)

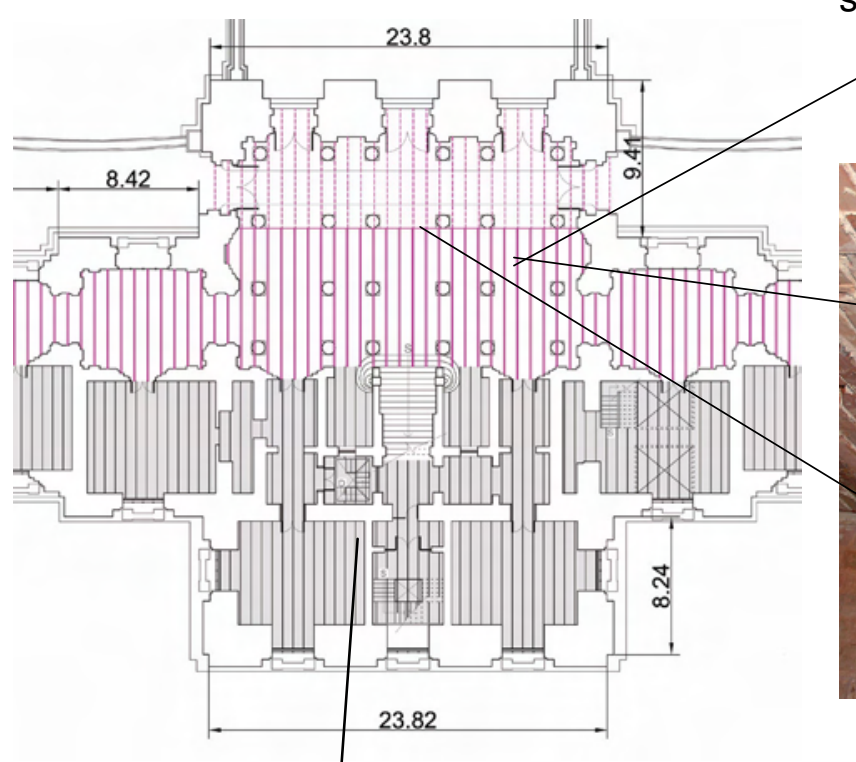

DETALHE - CORPO CENTRAL

Laje abobadilha aparente no subsolo correspondente ao piso do saguão

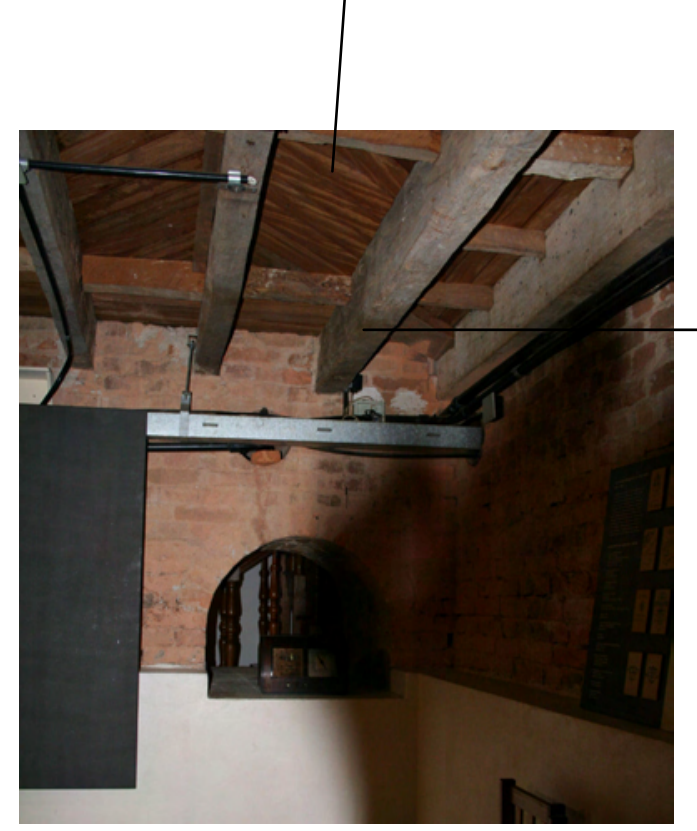

Assoalho de madeira visível e sem Acabamento, observado pelo subsolo

Assoalho de madeira correspondente à

Fig. $184,185,186$ sala de exposição do corpo central. 
Piso de ladrilho sobre laje abobadilha na galeria
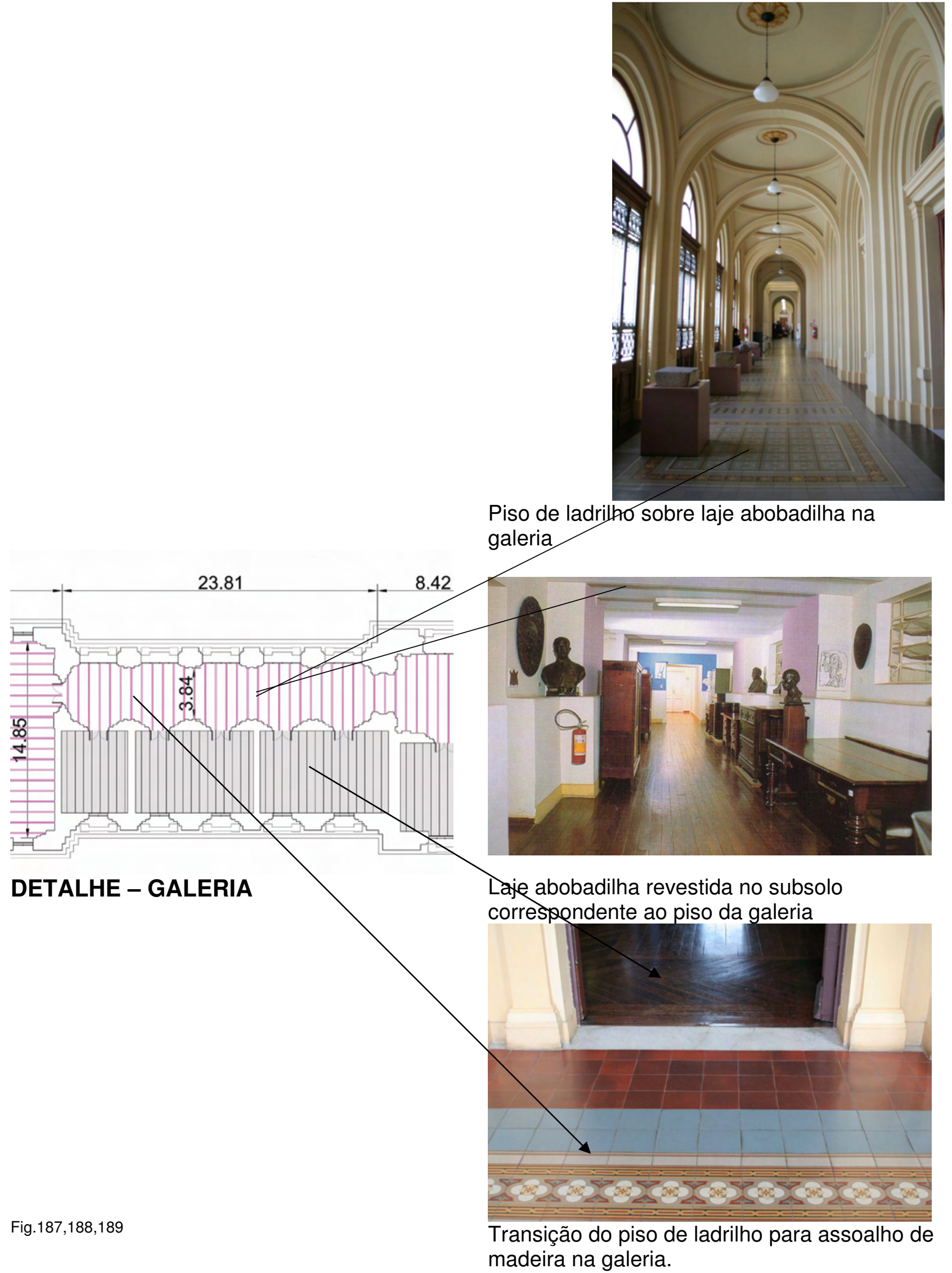
PAVIMENTO TÉRREO - TORRE

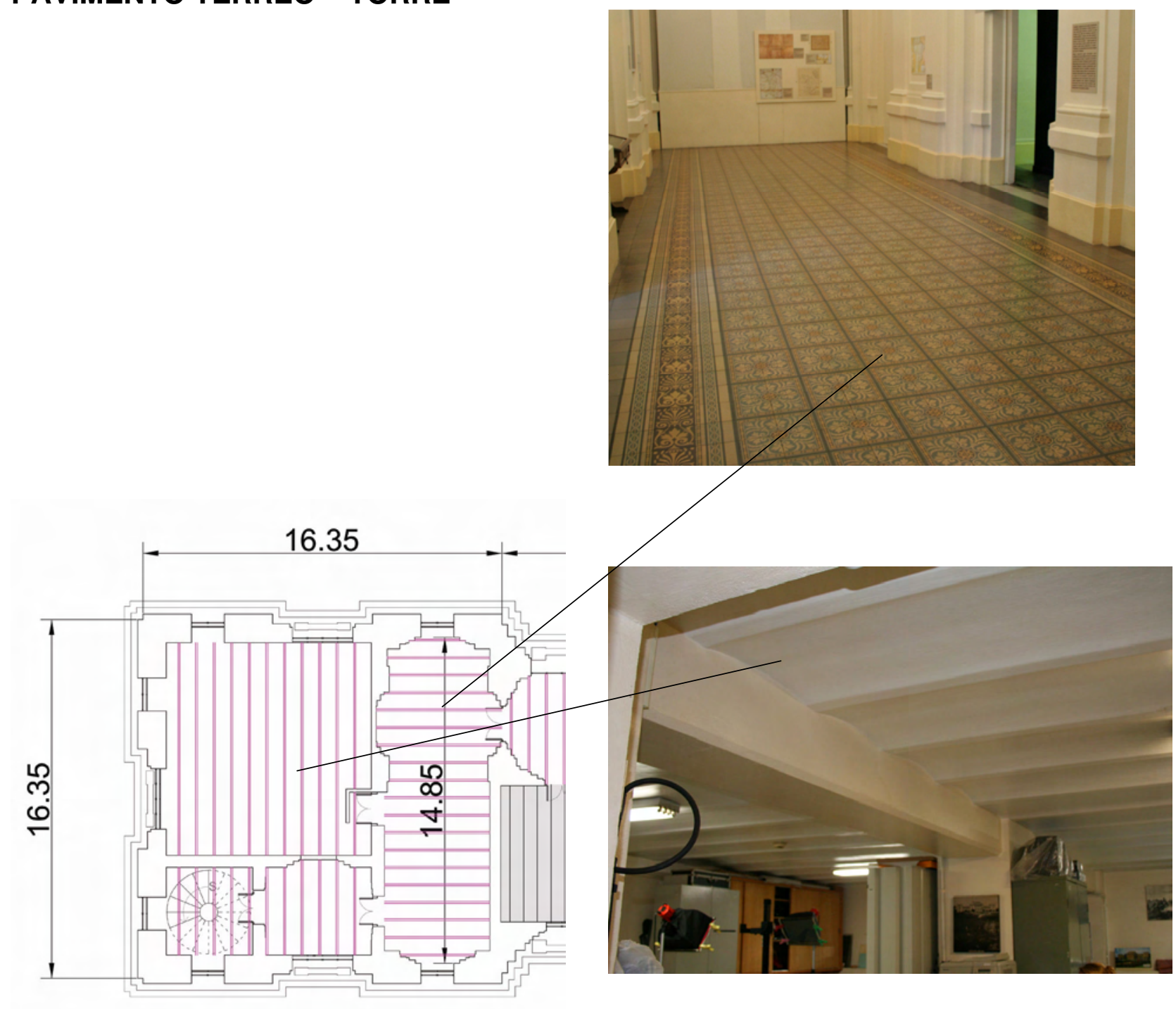

DETALHE - TORRE

Laje abobadilha revestida, sob o piso de ladrilho

Fig.190,191 
PRIMEIRO PAVIMENTO - CORPO CENTRAL

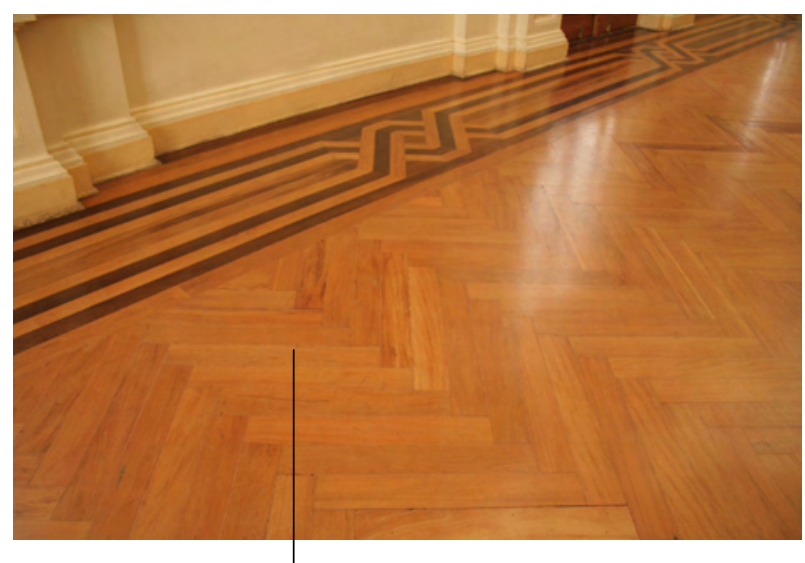

Piso de assoalhø de madeira no Salão de Honra

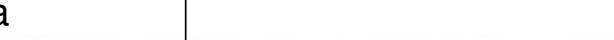

Transição do piso de ladrilho para assoalho de madeira do Salão de Honra - galeria interna

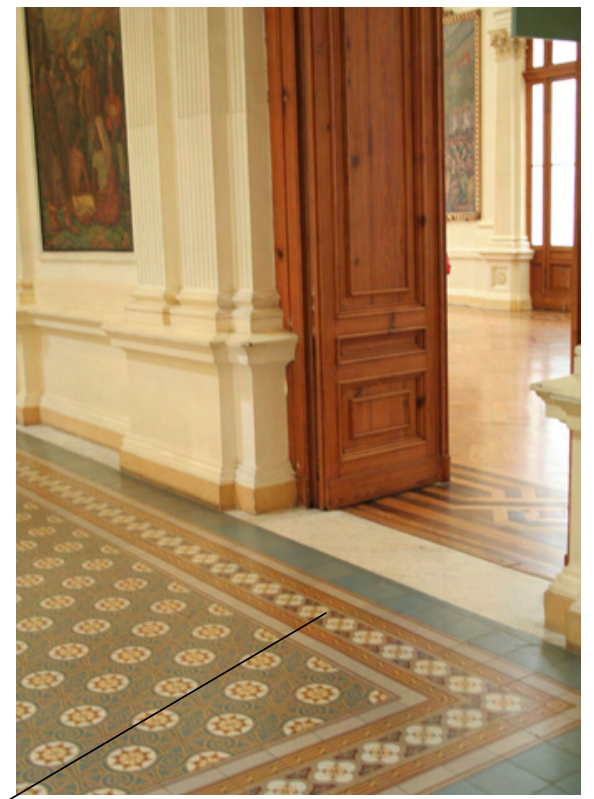




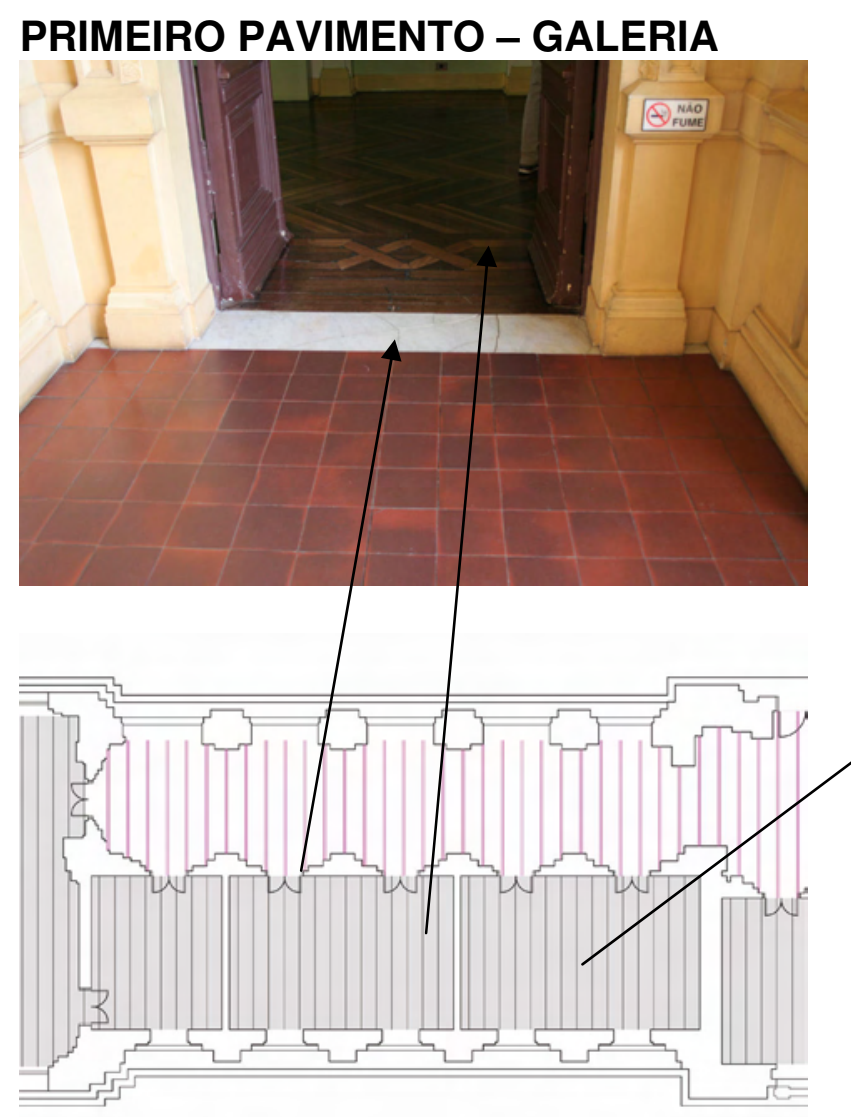

DETALHE - GALERIA

Acabamento em ladrilho hidráulico, muito provavelmente repetindo a solução do piso térreo, sobre laje abobadilha

Este piso não é visível pelo térreo, onde recebe um forro de estuque

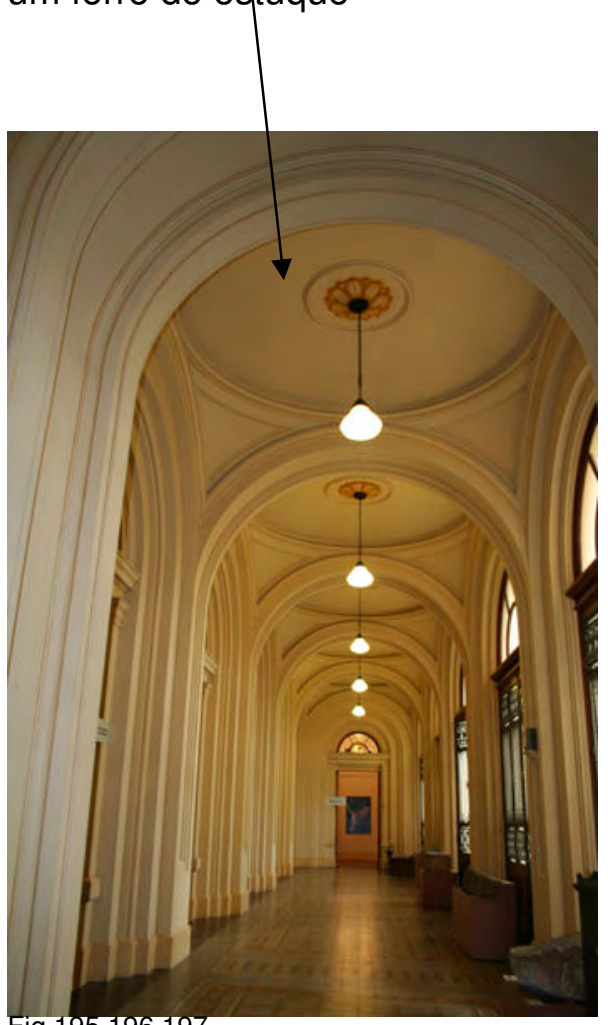

Fig.195,196,197 


\section{PRIMEIRO PAVIMENTO - TORRE}

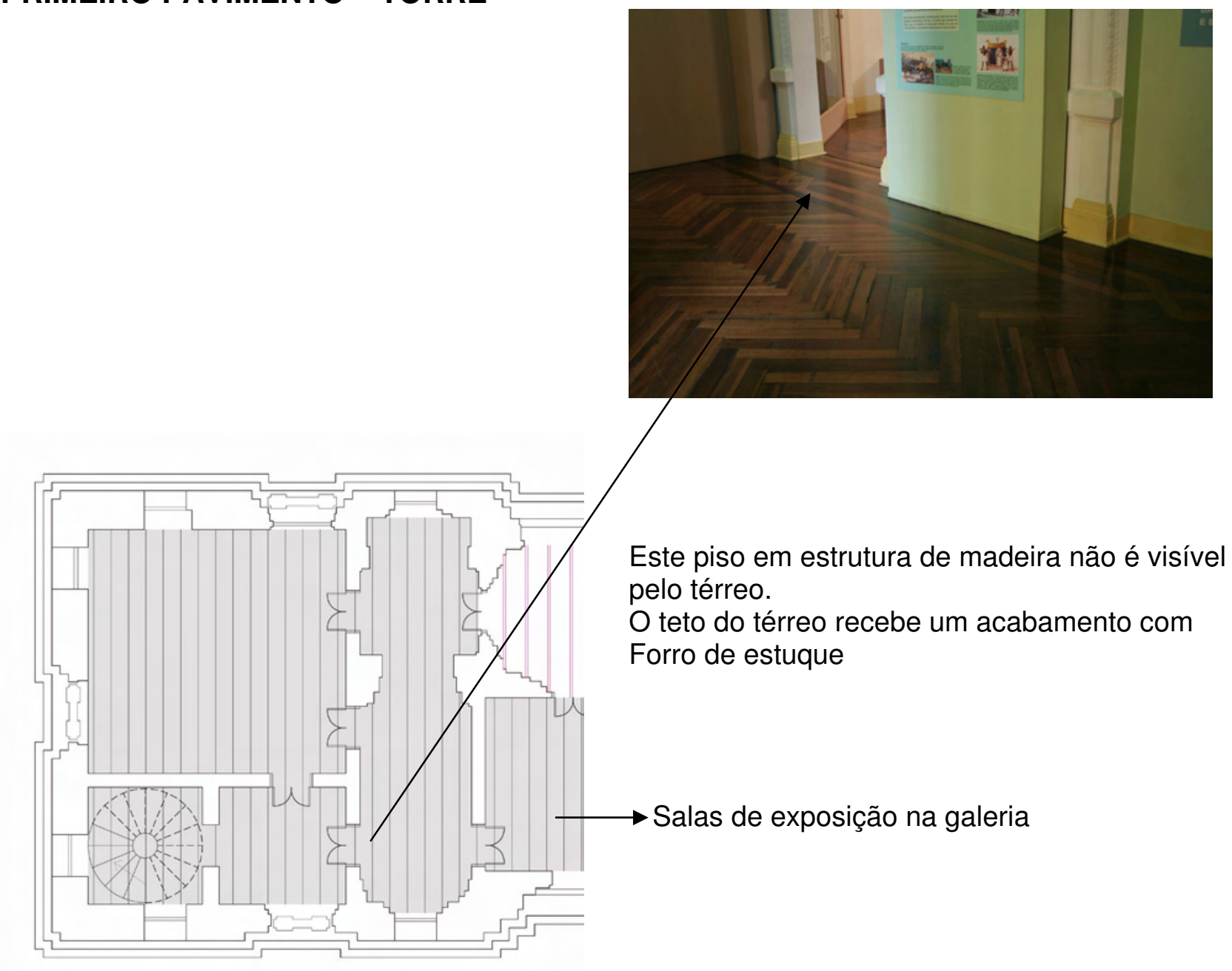

DETALHE - TORRE

Fig.198,199 


\section{COLUNAS E PILASTRAS}

Os textos abaixo exprimem os conceitos e os valores técnicos e expressivos das colunas e pilastras:

\section{Das Columnas}

36ํㅡ As Columnas são sem dúvida as mais bellas, e as mais nobres partes de qualquer edifício; por isso é que os antigos, e especialmente os Romanos, as multiplicavam com uma tão notável abundancia. Seus Templos, suas Thermas ou Banhos, seus Theatros, Amphiteatros, e as suas próprias habitações particulares, tudo era ornado de magníficas Columnas.

37ํㅡㄴ Segundo o systema de Vinhola, as Columnas no seu Diâmetro superior, devem ter menos uma sexta parte da grossura do inferior. Contudo algumas vezes é preciso alterarse esta regra, por causa das grandes alturas em que devem ser collocadas, bastando então a mesma elevação em que ficam, para parecerem muito mais delgadas do que são na realidade: effeito natural de todos os corpos que se elevam em demasia.

38ㅇ A diminuição das columnas pode começar logo desde as suas bases, até aos Colaretes: a maior parte costumam diminuir-se desde o terço inferior da altura do fusto; e alguns Architectos modernos as diminuem também desde o mesmo lugar, assim para a parte superior, como para a inferior do fusto, o que offende a solidez apparente; porque a columna parece então ceder ao peso que sustenta, prejudicando-se as regras da estabilidade, as quais ordenam, não só que seja verdadeiramente sólida qualquer construção, mas que indique ainda exteriormente a sua mesma consistência. Há um método particular de diminuir as columnas, bem como um instrumento próprio para esse fim, do que trataremos em seu competente lugar, á vista das estampas, as quais carecem absolutamente da necessária explicação, que ande a par de cada uma.

39ํㅡ Os capitéis das Ordens Toscana, e Dórica, devem ter meio Diâmetro, ou 1 Módulo de altura; o da Ordem Jônica, três quartos de Diâmetro, ou 1 Módulo e 1/2 ; os das Ordens Coríntia, e Compósita, 2 Módulos e 1/3. Nestas dimensões não se compreendem os Colaretes, porque fazem parte integrante das Columnas.

SEQUEIRA, José da Costa. Noções Theoricas de Architectura Civil, seguidas de um breve tractado das cinco ordens de J. B. de Vinhola.

\section{Pilastras}

As Pilastras são colunas cuja secção horizontal é quadrada ou retangular e empregam-se com dois fins opostos:

- Acentuar a robustez do suporte, e neste caso servem de apoio, e colocam-se na base do edifício, suportando arcadas sujeitas a grandes cargas

- Dar-lhe aspecto menos pesado. São simples contrafortes, pouco salientes sobre as paredes, sendo o seu papel simplesmente decorativo.

Permitem as Pilastras acentuar mais fortemente que as colunas, determinadas partes de um edifício, graças às suas arestas vivas e faces planas.

As suas proporções divergem um tanto das colunas: conservam quase a mesma largura em toda a altura, sendo a leve diminuição na parte superior necessária apenas para desfazer a ilusão óptica de parecerem mais largas em cima, em conseqüência da saliência do capitel. Com estas restrições as suas proporções são as mesmas das colunas.

O entablamento pode conservar o mesmo balanço que tinha na parede lisa, sendo todo corrido ou então contornar as pilastras, formando ressalto em frente destas. Isto que se faz às vezes com pequenas saliências é indispensável quando estas excedem metade da largura.

As Pilastras podem, como as colunas, apresentar caneluras, mas só na sua face anterior, sendo as suas proporções às mesmas das colunas, notando apenas que se considera 0 
diâmetro da coluna igual à largura da pilastra, e podem estas ser dupla como as colunas o são às vezes.

Modernamente tem-se empregado as Pilastras, com as mesmas proporções e decorações das colunas, mas é sempre bom dar ao capitel daquelas, menor balanço, simplificando ao mesmo tempo a ornamentação para distinguir estes dois tipos de suportes.

Nas fachadas servem as Pilastras para separar os diferentes corpos do edifício e para guarnecer os cunhais, isto é, os ângulos extremos salientes da construção.

As Pilastras e os pilares de menores dimensões são também muito empregados para decorar muros de vedação, para limitar os gradeamentos e portões de ferro e madeira.

SEGURADO, João Emilio dos Santos. Biblioteca de Instrução Profissional: Edificações.

No documento 237, localizado na Pasta 4 do Fundo Bezzi, "Especificações, preços e condições para a Construção das Obras do Monumento do Ypiranga", este especifica os materiais, argamassas, alturas tipos das colunas e pilastras no edifício do Museu Paulista:

$\S 5^{\circ}$ Alvenaria de Tijolos

Art 1 으

Paredes - serão de tijolos chamados de primeira qualidade, como os que são empregados nos edifícios luxuosos da capital da província, tendo em média as dimensões de 7,14 e 29 centímetros; serão de argila homogênea, bem amassada e bem cozidos. [...]

As pilastras e colunas salientes de $2 / 3$ das paredes, serão consideradas como paredes.

Art $4^{\circ}$

Colunas - as de Ordem Coríntia isoladas dos corpos centrais, com uma altura média de 8,60 m compreendida da base até o capitel, serão feitas com tijolos de forma apropriada, serão ocas e construídas com argamassa igual aquela das abobadas (2/5 de cal e $3 / 5$ de areia), os capitéis serão de cimento romano, e do grande modelo, e o fuste das mesmas será canelado, e com toros até o terço da altura.

Art 5ำ- As de Ordem Jônica caneladas do grande vestíbulo com uma altura média de 6,50 $\mathrm{m}$, compreendido o pedestal com as condições do artigo precedente.

Art 6 - As de Ordem Coríntia caneladas isoladas das grandes janelas do Corpo Central, com uma altura média de 3,50 m com as condições do artigo precedente.

Art $7^{\circ}$ - Colunas da galeria superior com altura média de $2,50 \mathrm{~m}$ com as condições do artigo precedente. 
CORPO CENTRAL FACHADA NORTE

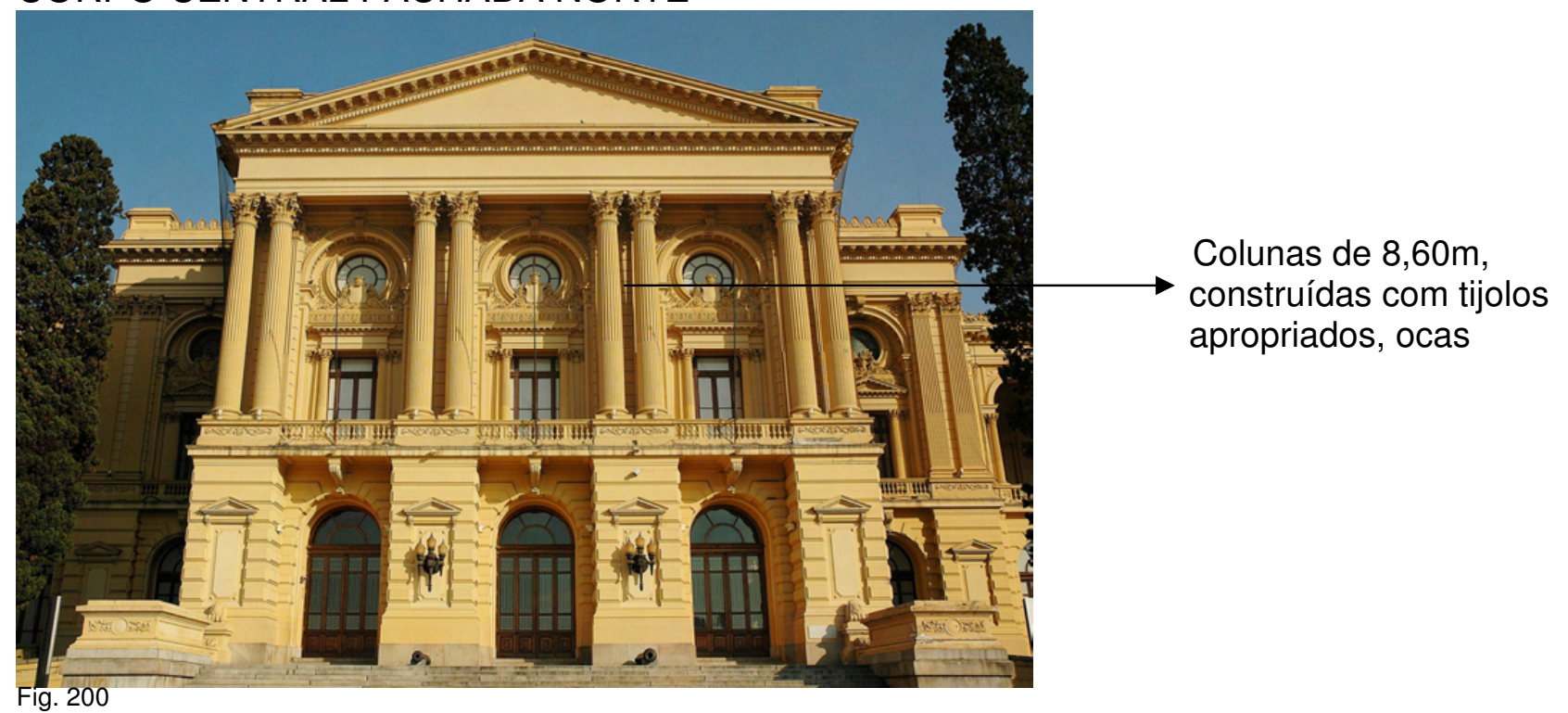

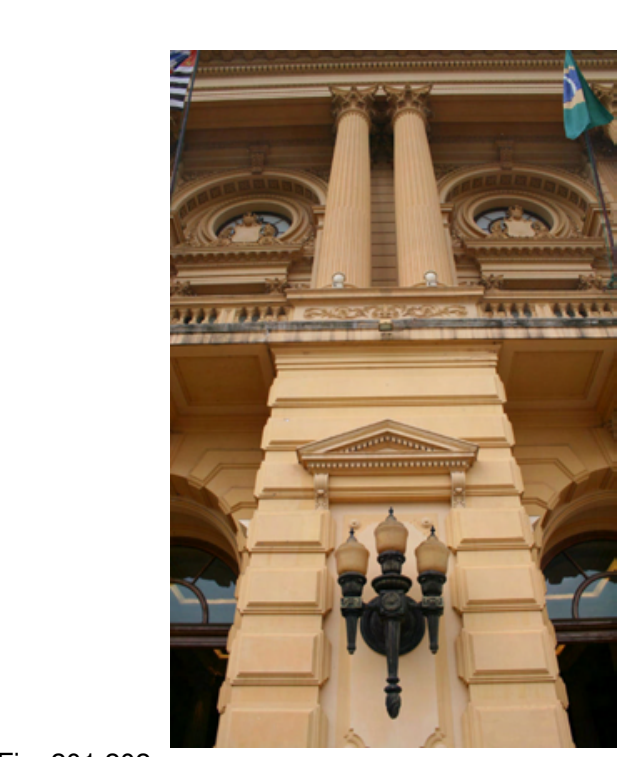

Fig. 201,202

Colunas sobre saliência do maciço

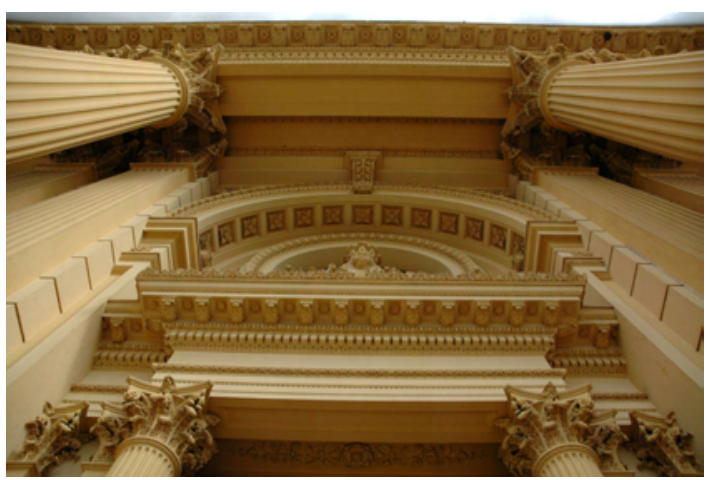

Colunas isoladas em frente de pilastras

$\mathrm{Na}$ fachada do Corpo Central Norte, entrada principal do edifício, o pavimento térreo é formado por grandes maciços salientes, e nas suas reentrâncias são localizadas as três portas principais. Sobre o maciço do térreo localiza-se um balcão em cada porta do Salão de Honra.

Do pavimento térreo partem quatro conjuntos de grandes colunas duplas de $8,60 \mathrm{~m}$ de altura. Este grande pé-direito interno propicia à fachada um valor monumental e corresponde internamente ao espaço mais importante e simbólico do Museu que é o Salão de Honra.

As grandes colunas são isoladas e localizadas na frente de pilastras duplas da mesma altura.

$\mathrm{Na}$ fachada sul a solução adotada é diferente. As saliências dos maciços são menores, as colunas estão adossadas à parede, e na altura do grande pé-direito interno há outro pavimento. Possivelmente esta solução mais robusta deve ter sido empregada em razão da maior carga presente nesta região, devido à existência de um pavimento adicional. 
CORPO CENTRAL FACHADA SUL

Fig. 203
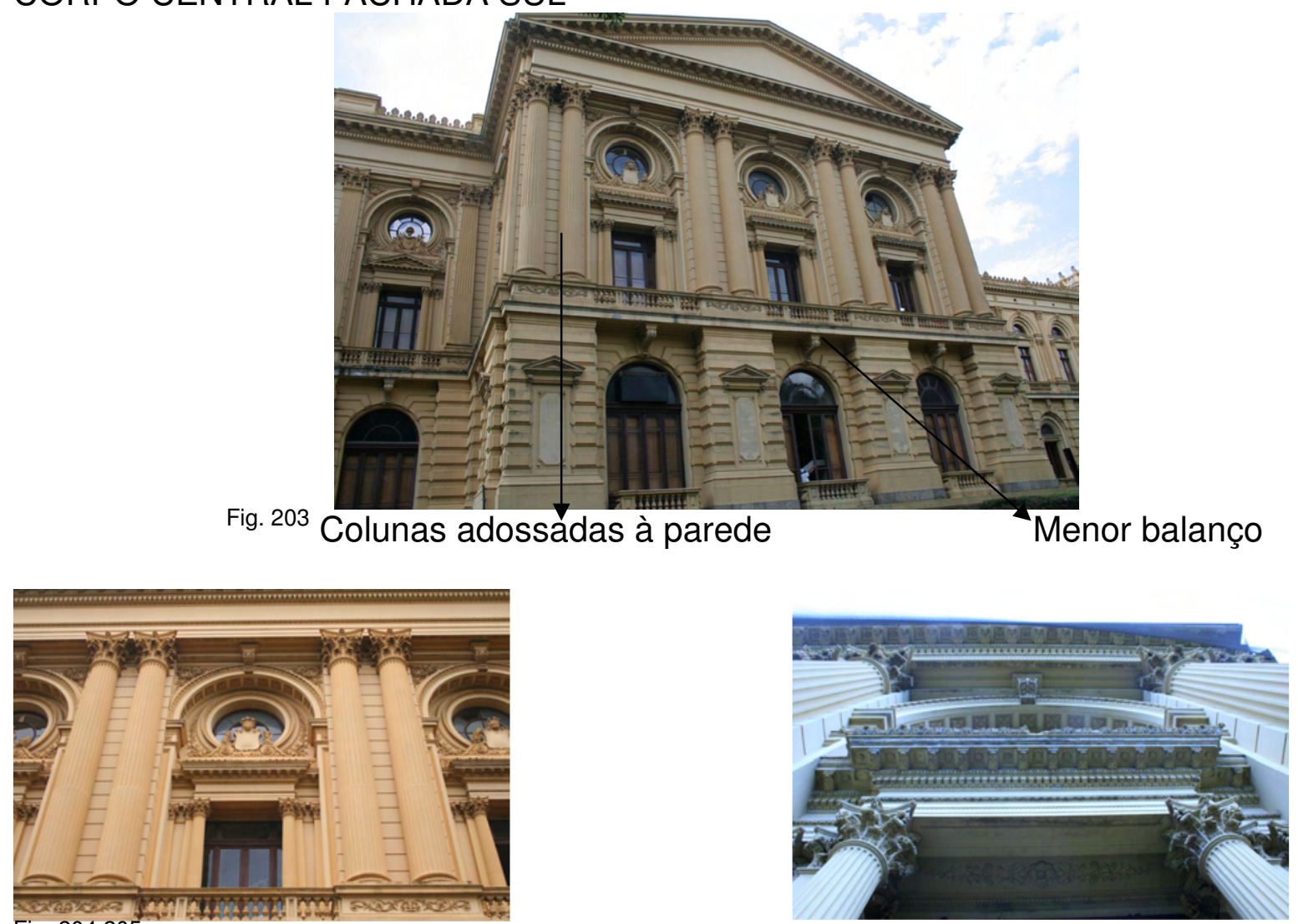

COLUNAS SALIENTES 2/3 NA PAREDE

No Corpo Central Sul a reentrância é menor que a do Corpo Central Norte, e com isso os 4 conjuntos de 2 colunas existentes no $1^{\circ}$ andar encostam-se à parede, sendo salientes $2 / 3$ da mesma.

LATERAL DO CORPO CENTRAL FACHADA

SUL

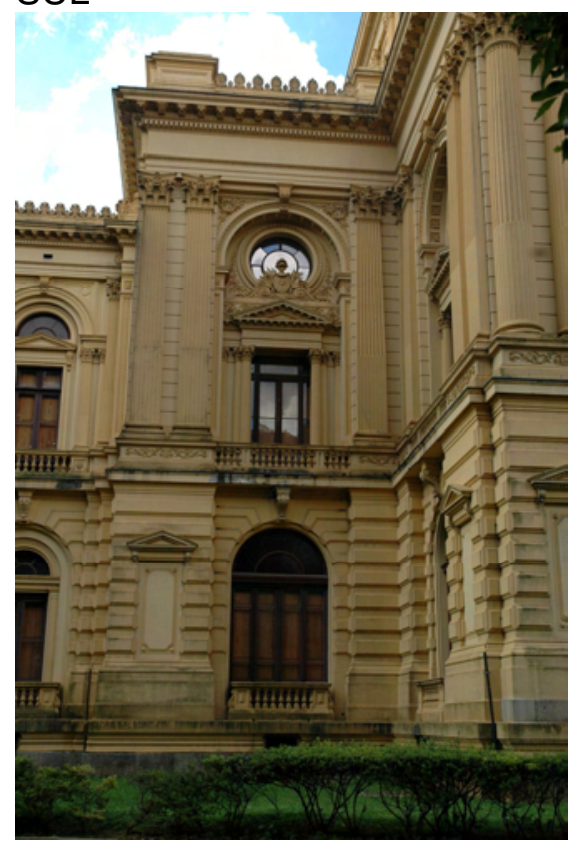

Os Corpos Centrais Laterais apresentam pilastras, localizadas no primeiro pavimento. Estas aparecem nas laterais das aberturas, sendo duas no canto externo e uma no canto interno, salientes $1 / 4$ da parede e de altura igual às das colunas dos Corpos Centrais Norte e Sul.

As pilastras acompanham a espessura dos pés-direitos, criam ritmo e leveza, especialmente no andar nobre do edifício.

Fig. 206 
GALERIAS

Fig 207

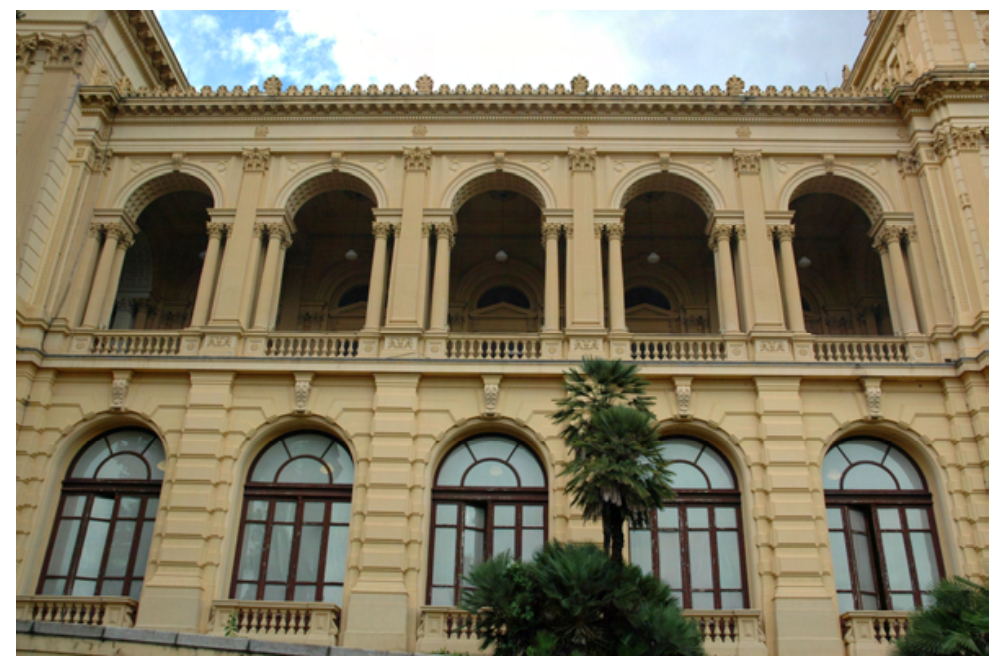

\section{GALERIA FACE NORTE}
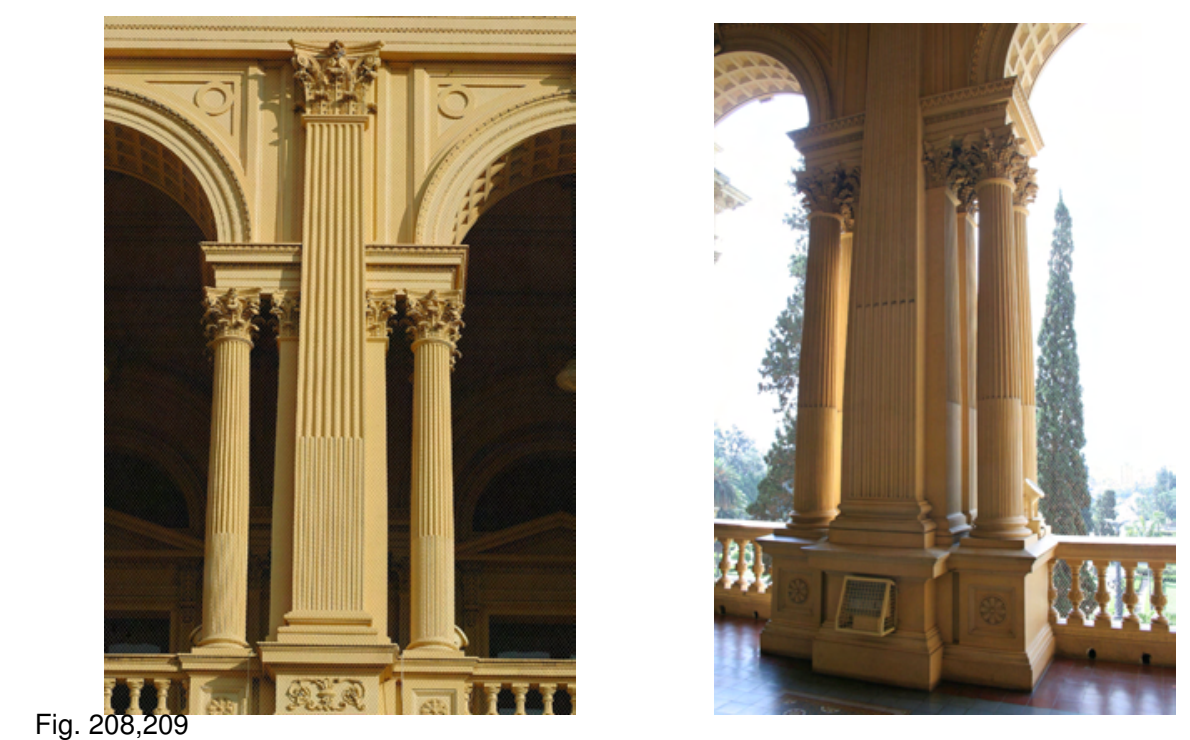

As galerias Norte apresentam colunas e pilastras somente no $1^{\circ}$ pavimento. Acima de cada bloco de alvenaria do térreo, há um bloco composto por pilastras e colunas no $1^{\circ}$ pavimento. Existem duas pilastras com a altura total deste andar, sendo uma externa e uma interna. Sob o entablamento há mais duas pilastras que agregam também ao maciço.

Na frente de cada uma das $1 / 2$ pilastras, há uma coluna de mesma altura.

Provavelmente as colunas tenham uma função estrutural reduzida, e tem um papel importante na linguagem expressiva nas arcadas do primeiro pavimento, que com as loggias imprimem movimento de luz e sombra, conferindo destaque à fachada. 
GALERIA FACE SUL
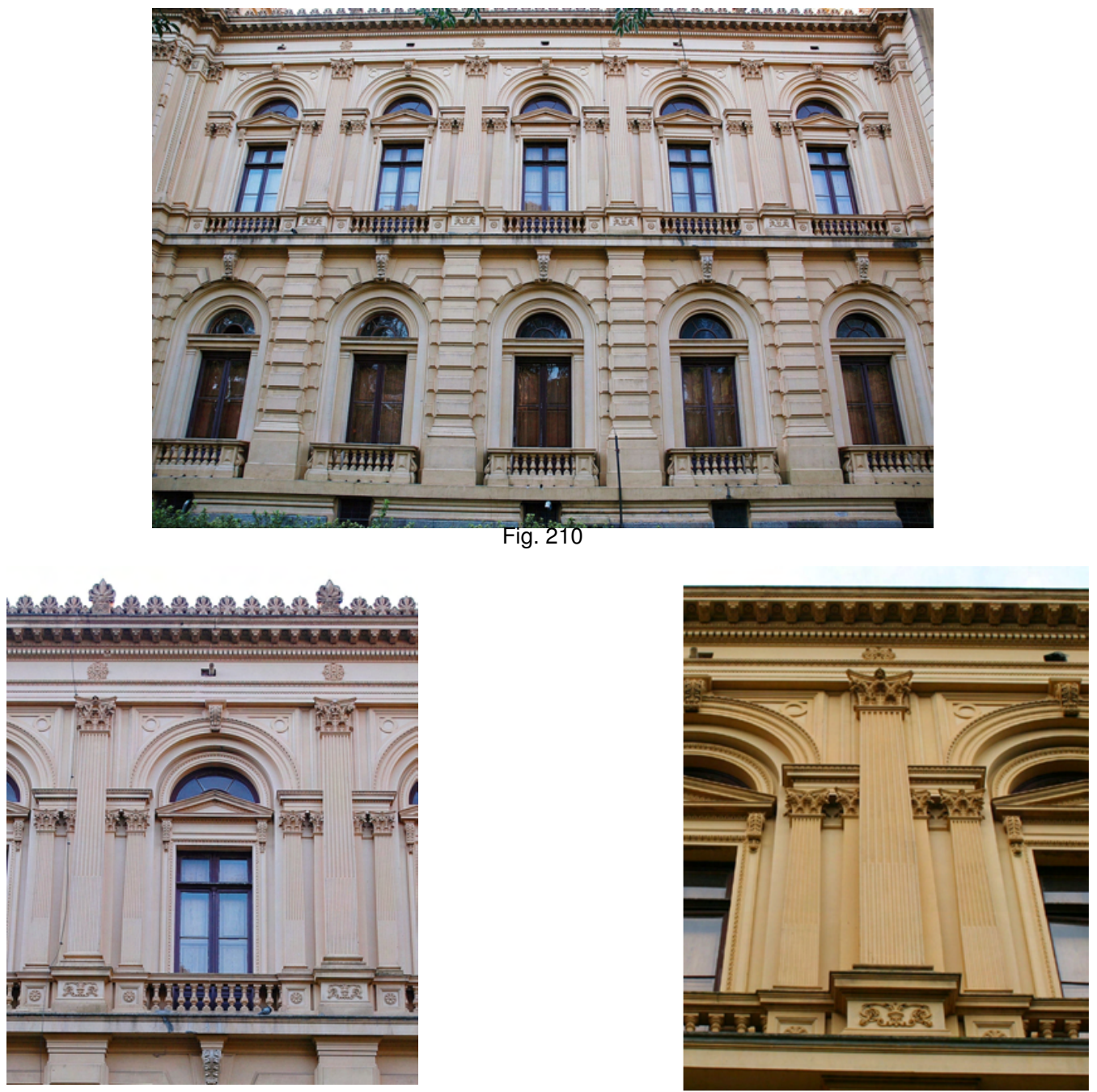

Fig. 211,212

As Galerias da fachada Sul apresentam soluções estruturais e expressivas bem diferentes da fachada norte, e acompanham a maior robustez adotada no corpo central sul. Não têm colunas isoladas e as pilastras são bastante utilizadas, com alturas diferentes, compondo os pés-direitos.

Entre as pilastras, os módulos das aberturas, tanto no térreo quanto no primeiro pavimento, são menores que no lado Norte. 


\section{TORRES}

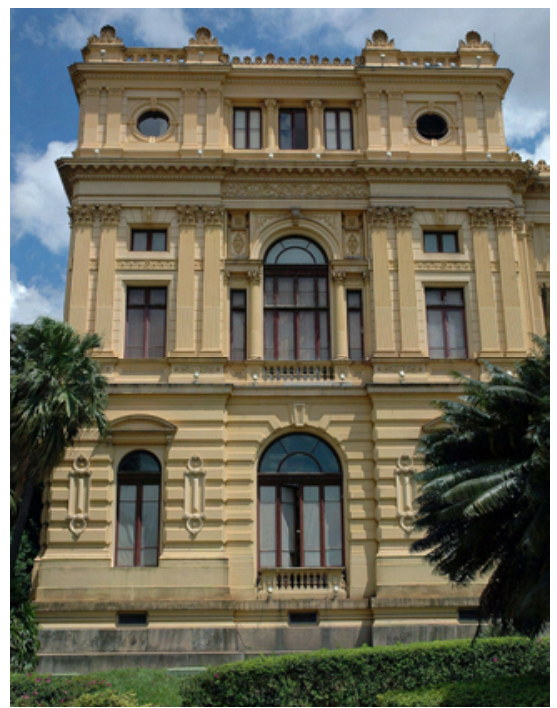

Fig. $213,214,215$
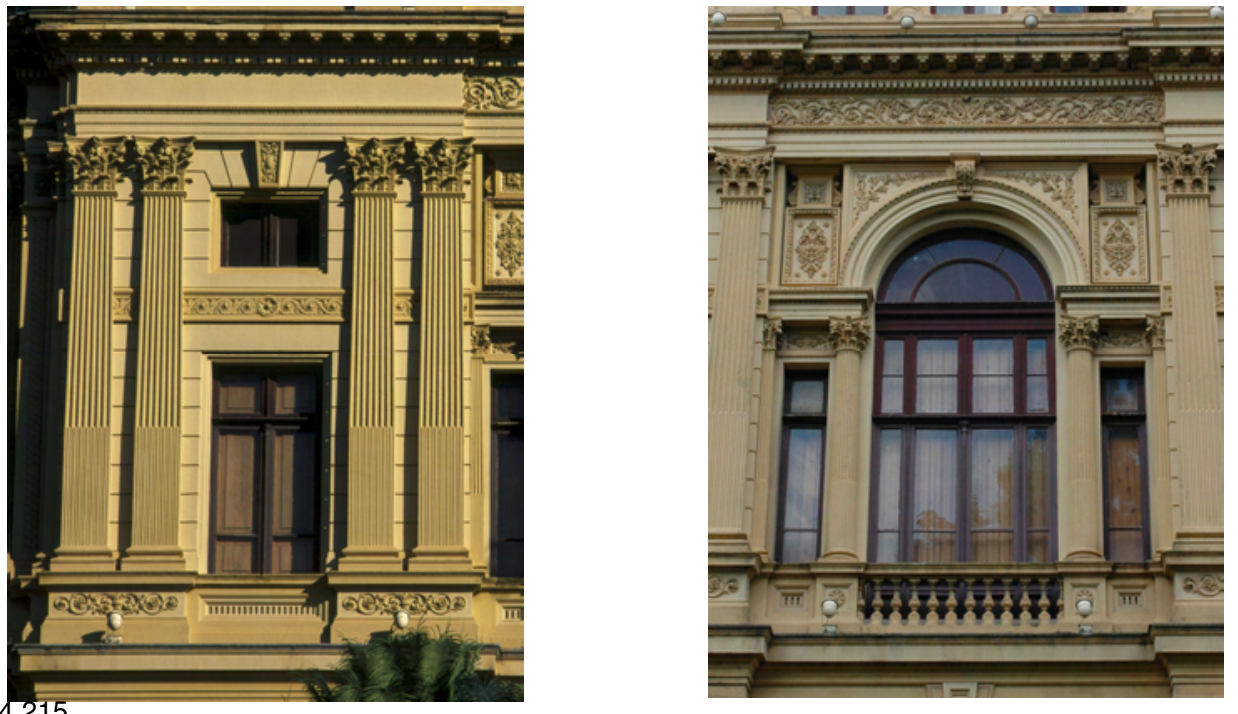

As torres apresentam colunas e pilastras somente no primeiro e segundo pavimentos. No primeiro pavimento, as partes laterais apresentam dois conjuntos com duas pilastras salientes $1 / 2$ da parede cada uma, localizadas nas laterais das janelas retangulares. Estas pilastras fazem parte da parede, e estabelecem limites dividindo a área em elementos verticais, que promovem ritmo e movimento.

Na parte central, as arquitraves de sustentação do arco são suportadas de cada lado, por uma coluna e 1/4 de pilastra, separadas entre si por uma janela retangular. São utilizadas meias colunas aderidas ao pé-direito de sustentação do arco. 

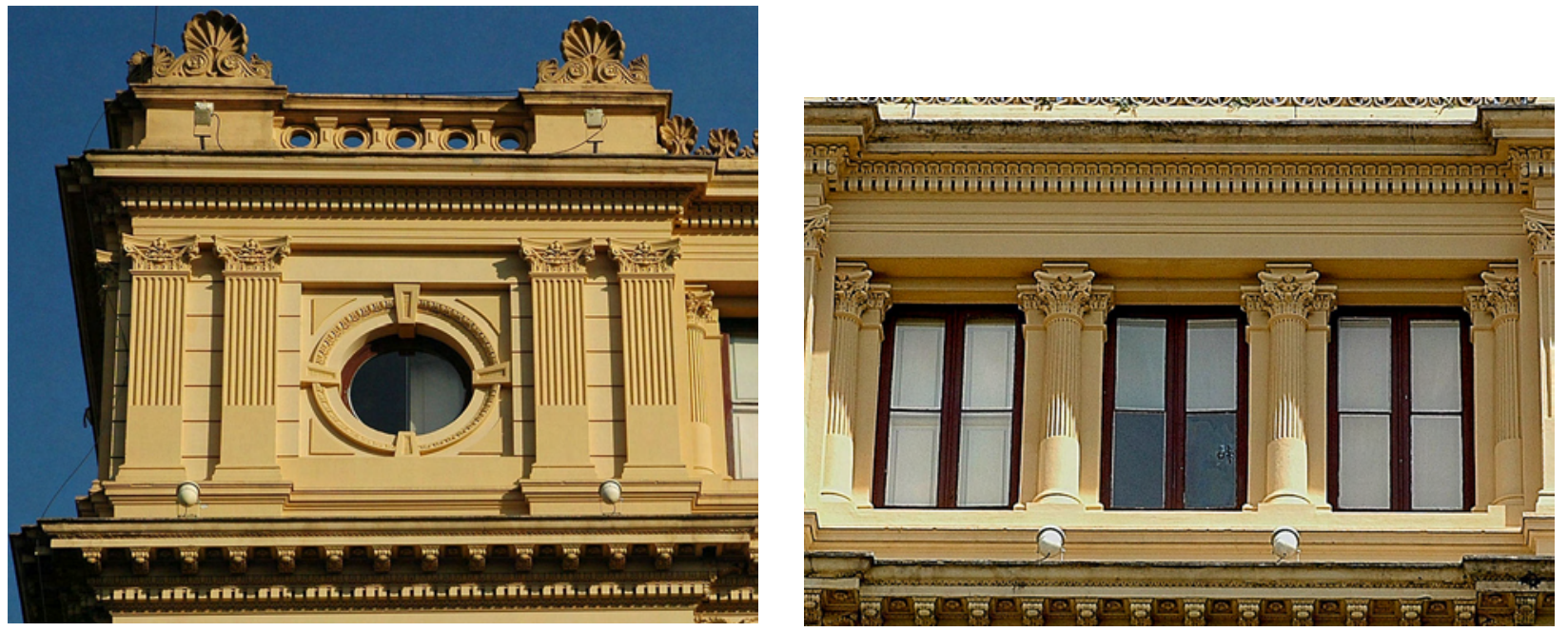

Fig. 216,217

No segundo pavimento, a altura é bem menor, e as aberturas são proporcionalmente menores. As duas laterais recebem dois conjuntos de duas pilastras salientes da parede, localizadas exatamente no eixo das pilastras do primeiro pavimento, sendo portanto consideradas parede e tendo sido utilizadas por Bezzi como um meio de promover uma maior leveza visual ao bloco estrutural.

No caso da parte central, entre as três aberturas retangulares, há uma pilastra saliente da parede, seguida de uma coluna saliente da pilastra. Estes conjuntos de colunas e pilastras têm função estrutural no edifício. 
ÁREAS INTERNAS

As áreas internas seguem as soluções estéticas das ordens adotadas nas fachadas.

TÉRREO - ORDEM JÔNICA

Fig. 218

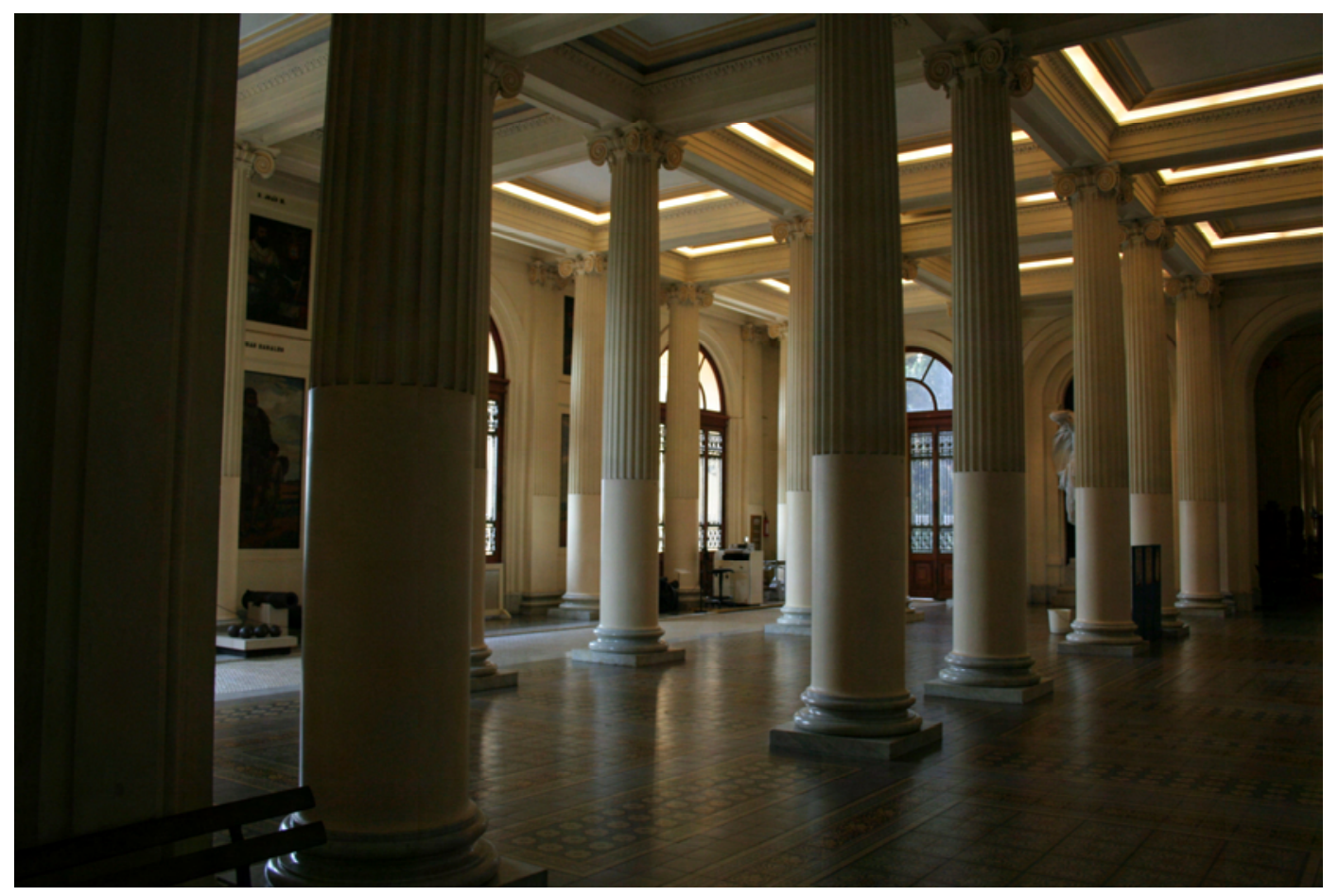

ÁTRIO - CORPO CENTRAL 12 colunas da Ordem Jônica, com alma de metal.

Colunas Jônicas isoladas. Na proximidade das paredes estão na frente de pilastras

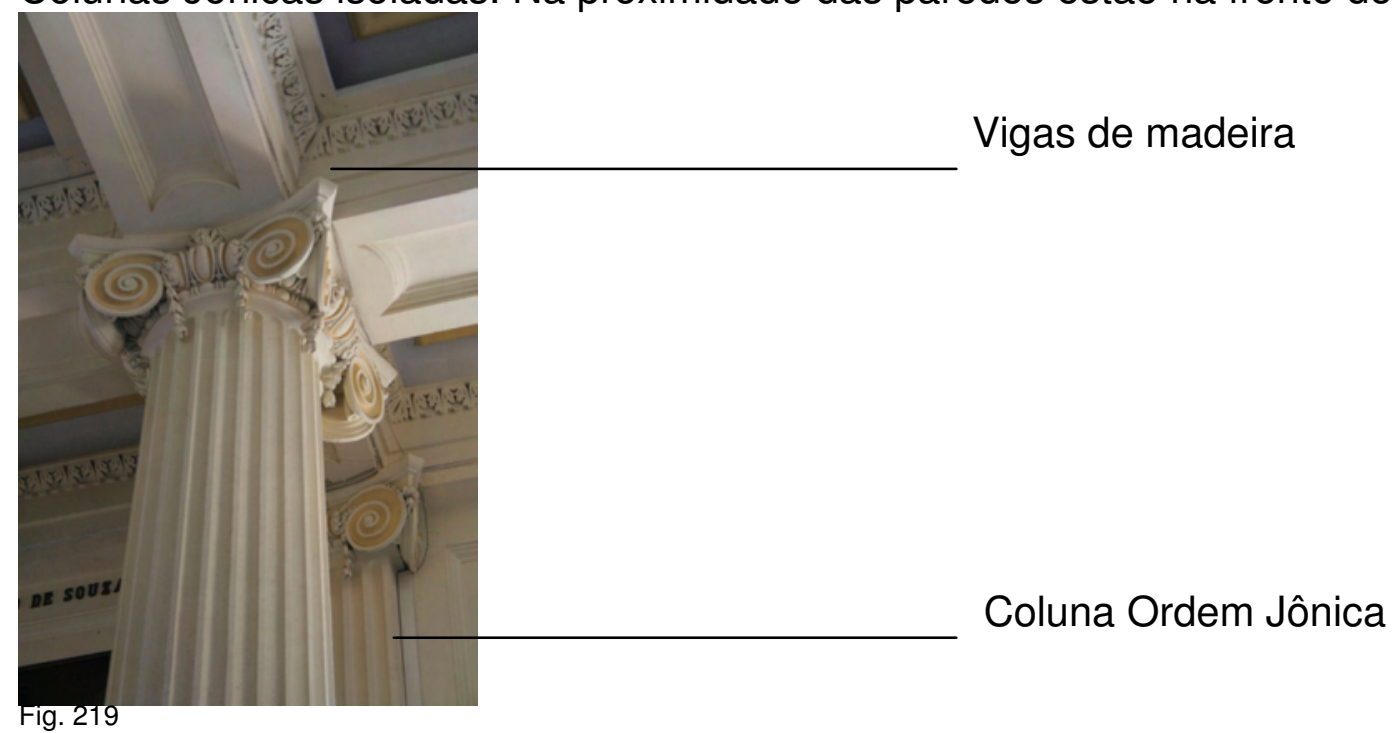




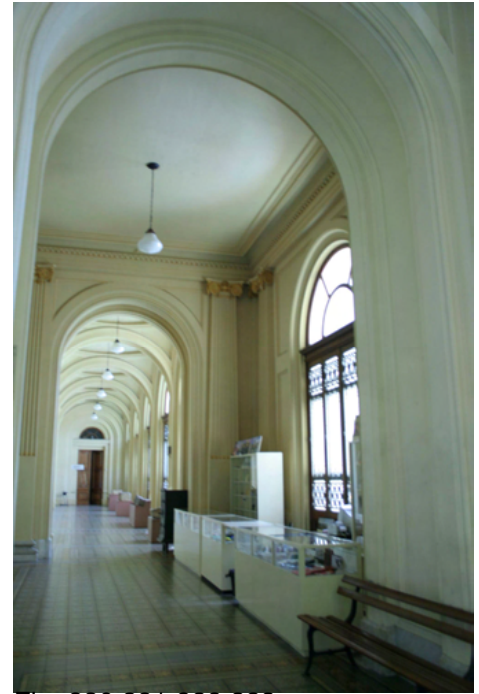

Fig. 220,221,222,223

LATERAL CORPO CENTRAL

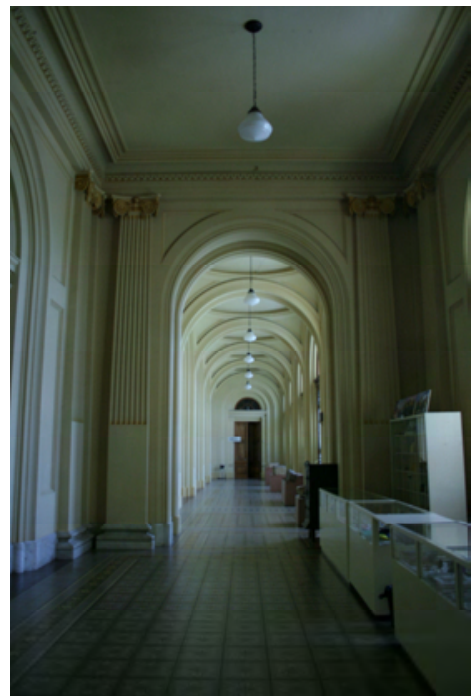

GALERIA

As abóbadas têm molduras lisas e as pilastras são da Ordem Jônica, caracterizando um pavimento mais robusto que suporta as cargas do pavimento acima
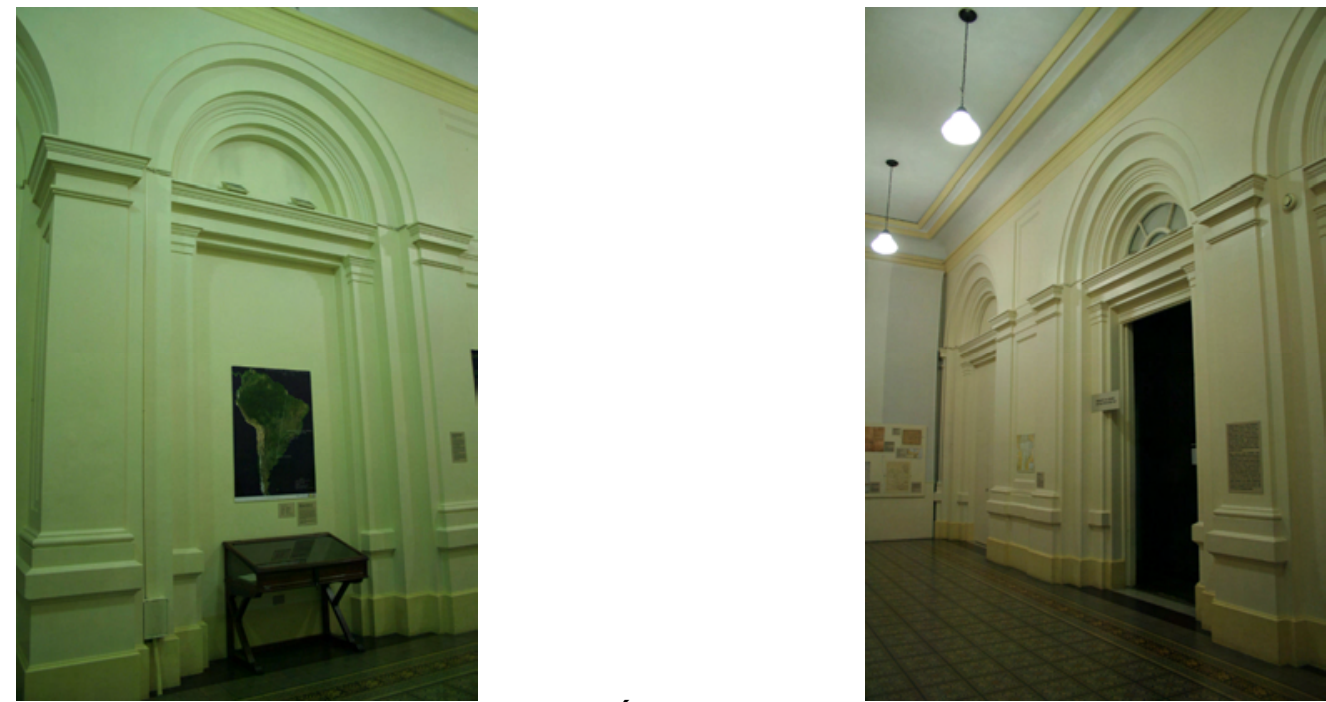

TORRE OESTE PAVIMENTO TÉRREO - apresentam ornamentação simplificada 

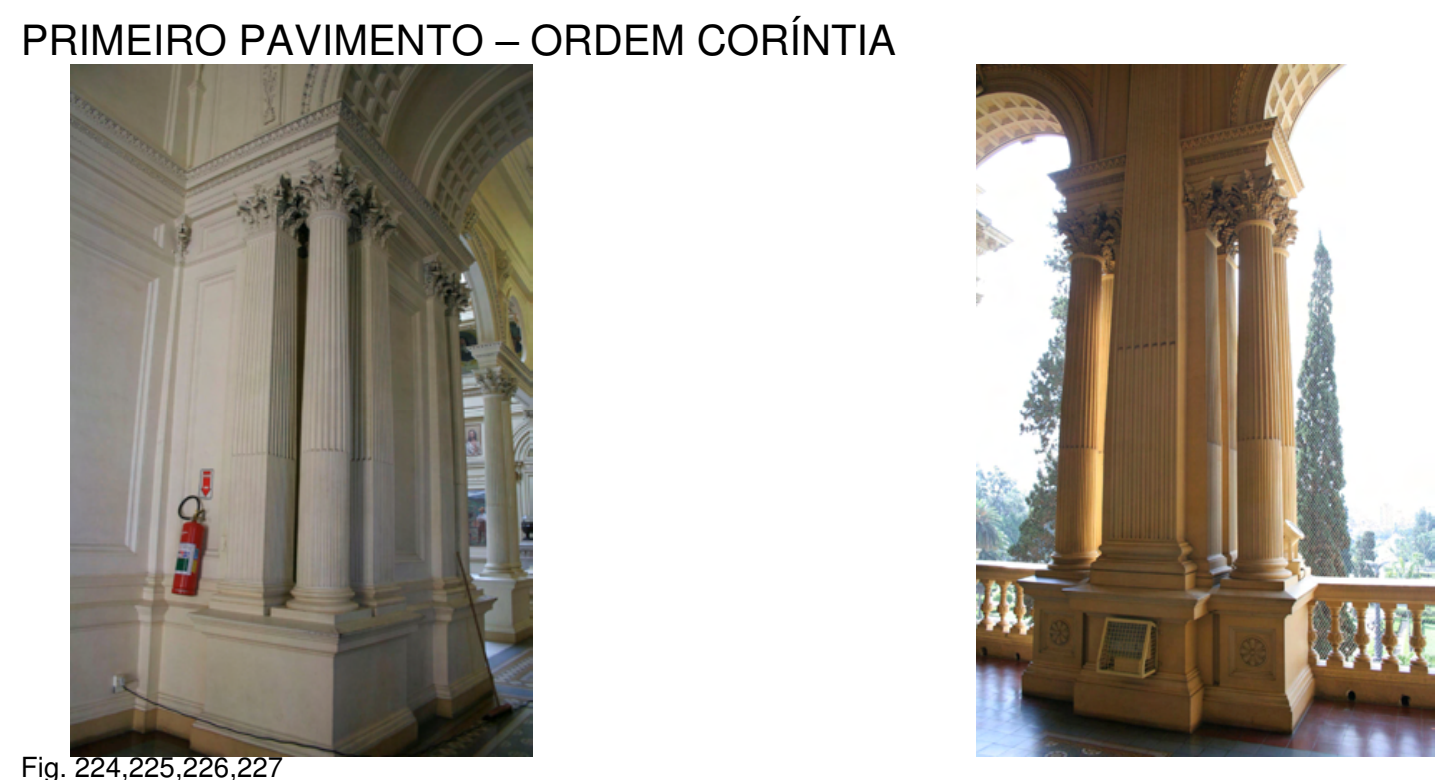

Como foi apresentado no item Paredes e Pés-direitos, neste pavimento de Ordem Coríntia são utilizadas diversas colunas isoladas, sempre próximas às pilastras

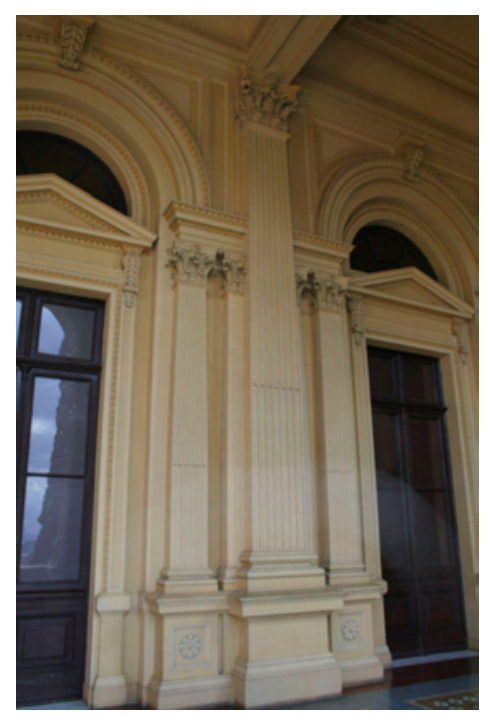

A parede longitudinal interna onde se abrem as salas da face sul, como ocorre no pavimento térreo, são em arco ressalvado com a ornamentação da Ordem Coríntia.

Nos pés-direitos são utilizadas três pilastras, sendo a do centro de maior altura. Aqui é adotado também o recurso de saliências e reentrâncias, criando ritmo, movimento e leveza ao conjunto

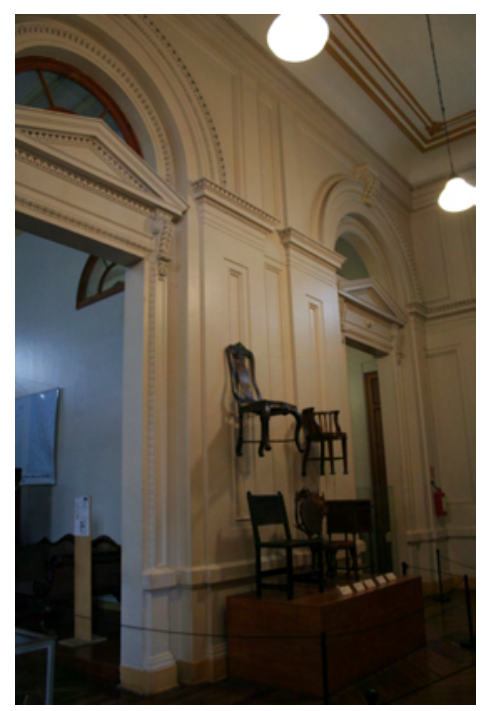

Nas áreas internas das torres, as aberturas seguem o mesmo padrão das aberturas das salas que se abrem nas galerias 
TORRE OESTE PRIMEIRO PAVIMENTO

Fig. 228,229,230,231

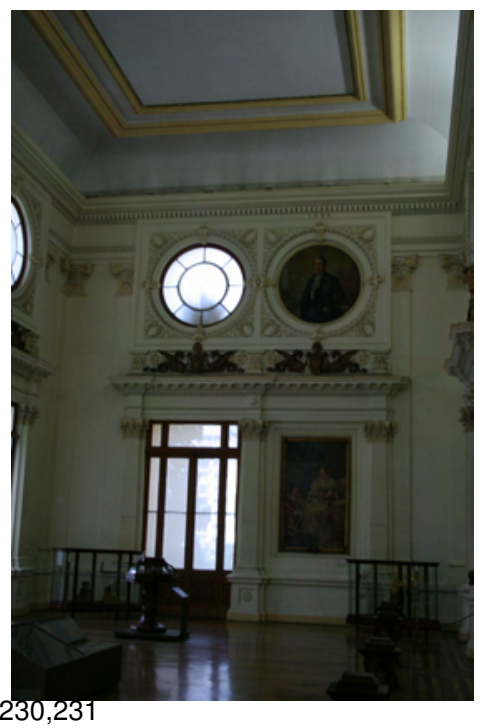

No primeiro pavimento, a utilização de colunas e pilastras, de ornamentação da Ordem Coríntia, refletem a importância do pavimento nobre do edifício.

Na parte mais elevada do Salão de Honra, observa-se o emprego da Ordem Compósita, como ocorre no segundo pavimento das fachadas das Torres.

\section{SALÃO DE HONRA OU SALÃO NOBRE - CORPO CENTRAL}

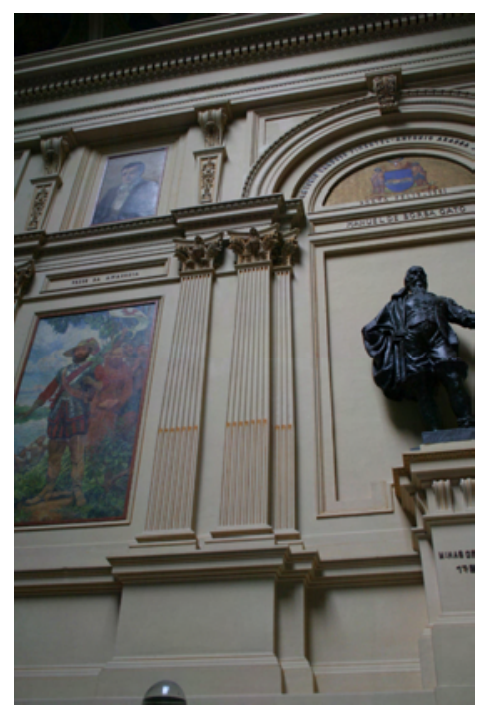

Caixa de escada - Corpo Central

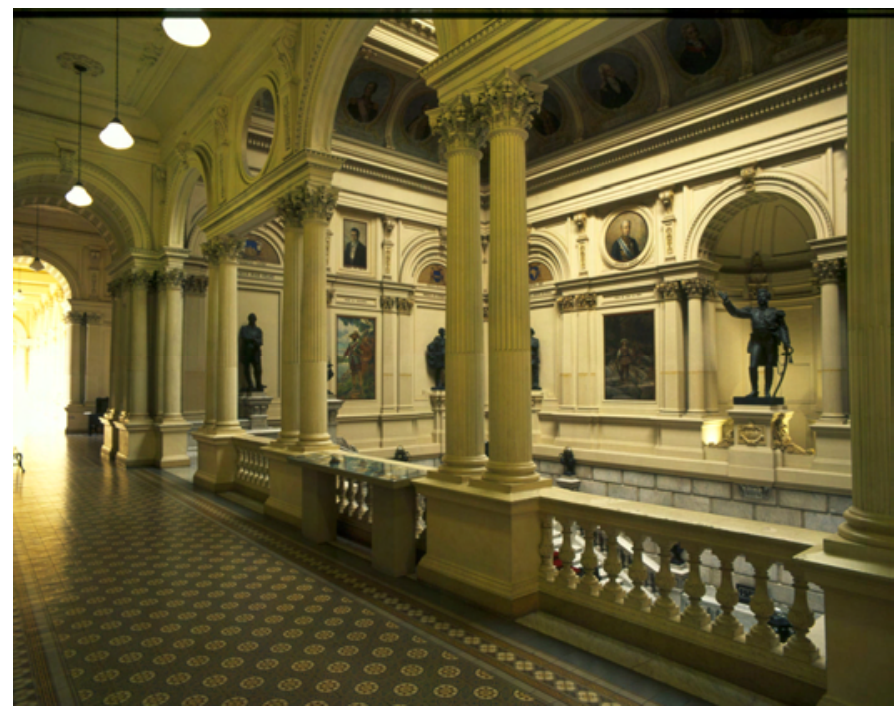

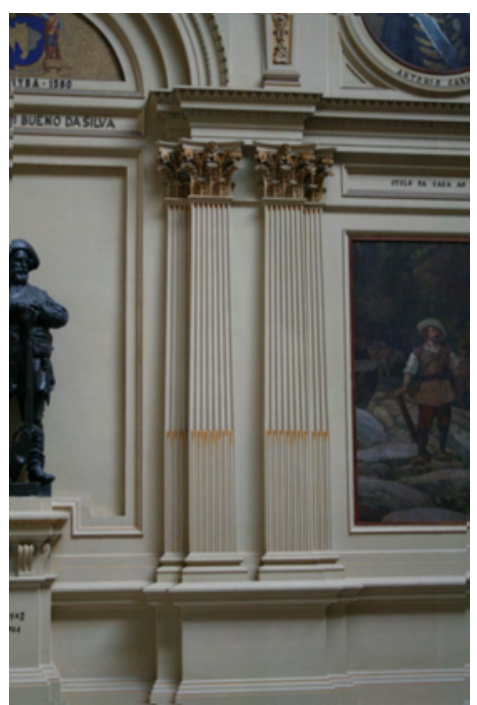

As paredes que delimitam a escadaria monumental são ricamente ornamentadas. Há nichos retangulares e circulares para as pinturas e arcos de ressalva fechados. A Ordem aqui utilizada é a Coríntia 
CORPO CENTRAL - ESCADARIA MONUMENTAL

Fig. 232,233,234,235,236
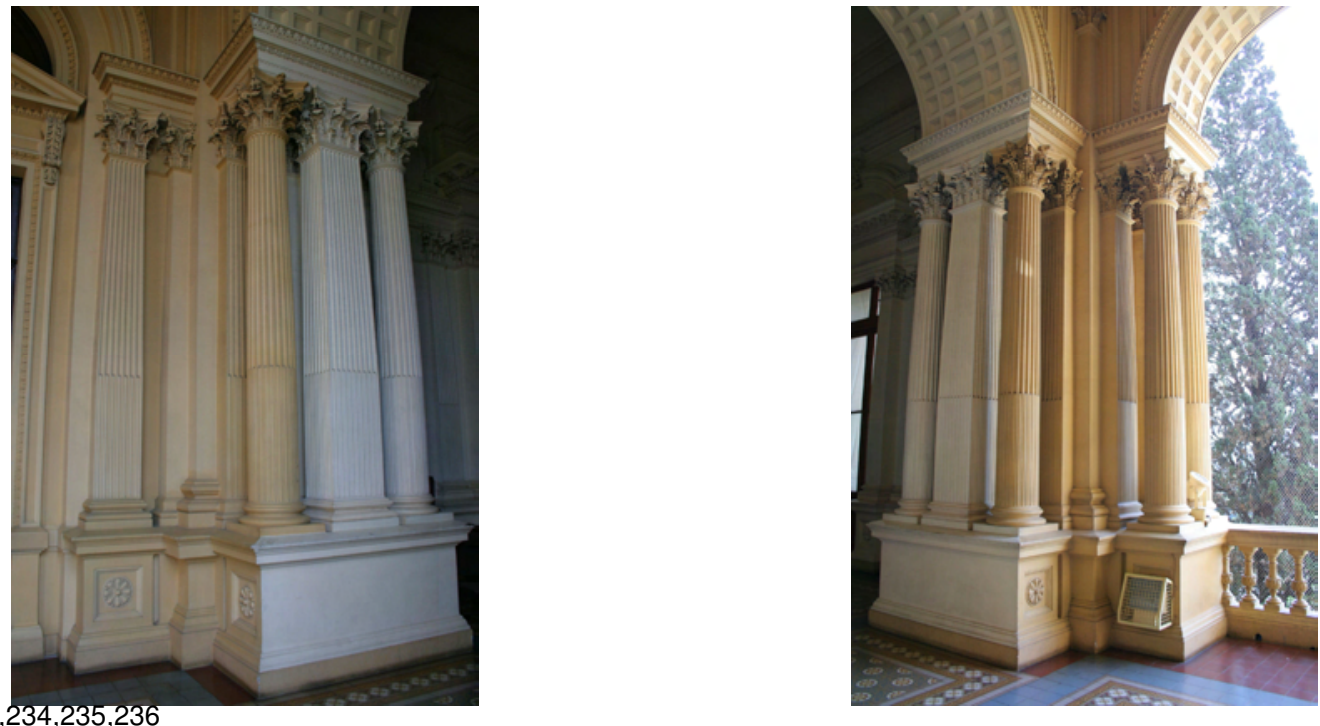

TRANSIÇÃO DO CORPO CENTRAL PARA AS GALERIAS NORTE-LESTE
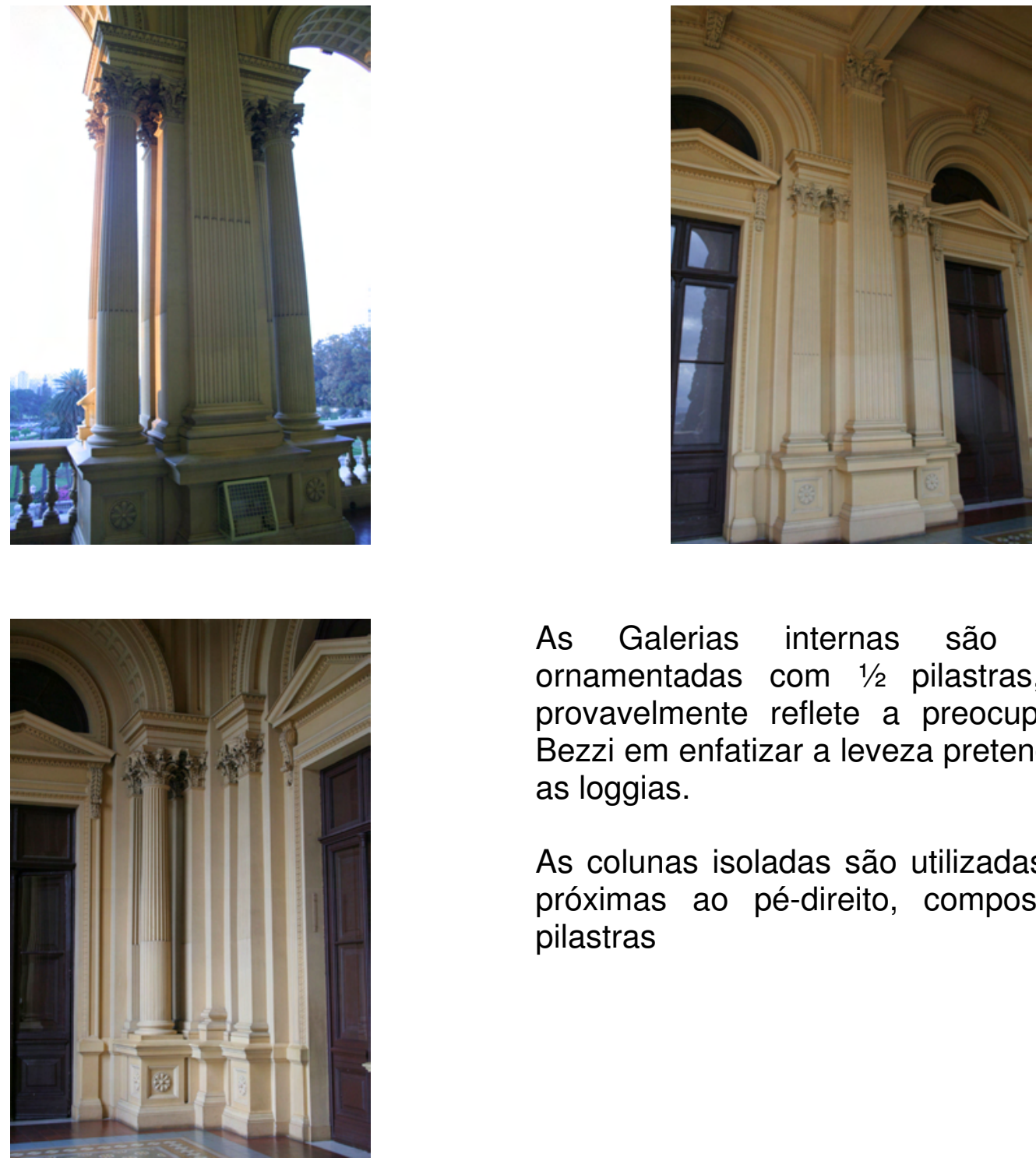

As Galerias internas são bastante ornamentadas com $1 / 2$ pilastras, 0 que provavelmente reflete a preocupação de Bezzi em enfatizar a leveza pretendida com as loggias.

As colunas isoladas são utilizadas sempre próximas ao pé-direito, composto pelas pilastras 


\section{GALERIA NORTE-LESTE}

Em todos os locais onde há pilastras no edifício elas funcionam como parede, pois todas são salientes $2 / 3$ ou menos da parede, delimitando uma parede ou pé-direito.

Bezzi utiliza as pilastras como uma forma de minimizar o peso visual do bloco de alvenaria maciço, criando com elas, inclusive, as saliências e reentrâncias.

No caso das colunas, quando isoladas podem receber só a carga local e reduzida de seu peso próprio.

As colunas do átrio são uma exceção entre as demais. São autoportantes e sua resistência foi aumentada através da utilização de "alma de ferro".

No Museu Paulista, a utilização de colunas e pilastras, foi essencial para conferir ao edifício um caráter Monumental. Bezzi faz uso do jogo de cheios e vazios, claros e escuros, promovendo assim maior leveza ao edifício, solução cuja expressão máxima se pode observar nas loggias das Galerias da face Norte. 


\section{FUNDAÇÃO}

O edifício foi concebido com pavimento térreo sobre um porão de ventilação, distanciado do solo de modo a garantir a salubridade do edifício. A citação a seguir se refere ao Regulamento de Salubridade em Lisboa e no Brasil, que permaneceu em vigência até data posterior à construção do edifício:

Subsolo

O Regulamento de Salubridade das Edificações Urbanas, de Lisboa, de 14 de fevereiro de 1903, estabelece, no seu artigo 9, a altura mínima de 0,60m para caixa de ar, sempre que se não revista o solo de uma camada impermeável.

No Rio de Janeiro exige-se que toda superfície ocupada por uma edificação receba um revestimento impermeável de asfalto ou beton com $0,15 \mathrm{~m}$ no mínimo de espessura. Quando se deixa caixa de ar, que no Brasil tem o nome de porão, a sua altura nunca será inferior a $0,60 \mathrm{~m}$ e nem superior a $3,00 \mathrm{~m}$, podendo ser dividida desde que o pé direito seja de $2,00 \mathrm{~m}$ ou mais; a medida é tomada desde o nível do revestimento impermeável até à face inferior do vigamento - Art. 16 do Regulamento para a construção, reconstrução, acréscimos e concertos de prédios, de 10 de fevereiro de 1903, em uso no Distrito Federal do Rio de Janeiro.

As caixas de ar serão convenientemente ventiladas por meio de aberturas em comunicação com o exterior, e protegidas por grades de ferro ou outras. Além destas aberturas prescrevese no regulamento brasileiro, em certos casos, a construção de chaminés para ventilação (SEGURADO, p.6)

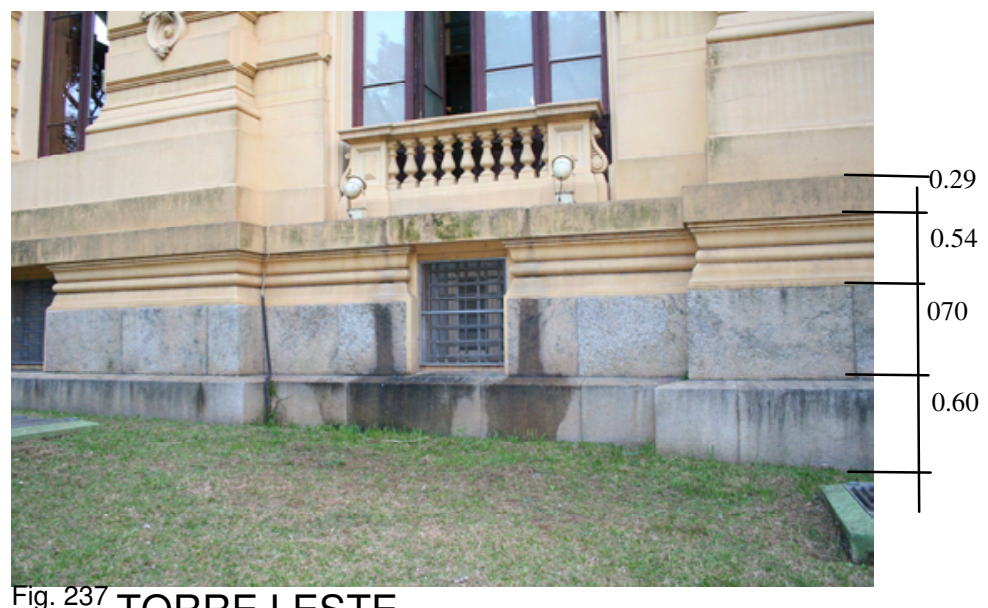

Fig. 237 TORRE LESTE
PORÃO:

FACHA SIMPLES

MOLDURA

SOCO OU ENVASAMENTO

A partir de 1931, o porão começou a ser escavado, tendo sido retiradas parte de solo firme e uma camada de entulho restante da obra, das áreas sob as torres e galerias. Em 1994, foi realizada a última escavação, sob o corpo central. $\mathrm{O}$ objetivo deste desaterro foi criar novos espaços para áreas de trabalho e de exposição. Nessa ocasião, para se obter o pé-direito interno suficiente, foram eliminados alguns arcos e partes das fundações. 


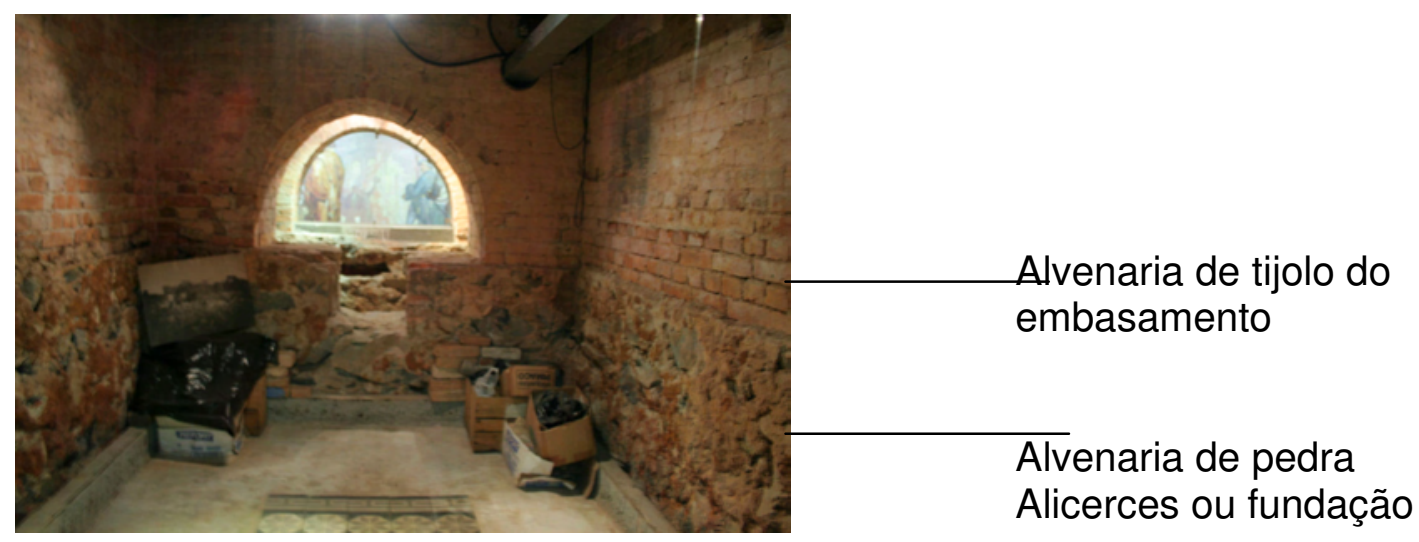

Fig. 238 FUNDAÇÃO SOB CORPO CENTRAL

Tipo: Ciclópico - pedras irregulares e argamassa de cal e areia

A alvenaria de pedra se tornou aparente devido à escavação, com a retirada de parte de entulho de obra e parte de solo firme; 1 metro de altura de alvenaria de pedra e mais 1 metro do piso para baixo. Aproximadamente 2 metros de altura.

$\mathrm{Na}$ Pasta 4, Documento 237 de Bezzi, em "Especificações, preços e condições para a Construção das Obras do Monumento do Ypiranga", o $§ 3^{\circ}$ define as condições da alvenaria de pedra dos alicerces e do beton

\section{$\S 3^{\circ}$ Alvenaria de Pedra}

Alvenaria de Pedra dos Alicerces

Os alicerces serão de pedras de grandes dimensões, colocadas de combinação com pedras das dimensões convenientes para estabelecerem uma perfeita amarração, e cimentadas com argamassa composta com a proporção de 1/3 de cal e 2/3 de areia bem lavada.

As grandes pedras serão das conhecidas com o nome de "uma em carro" e nos mesmos haverá as respectivas aberturas para colocação de canos, etc, executados conforme as regras da arte, e quantas forem necessárias, a juízo do engenheiro chefe. A pedra será de boa qualidade, rija e bem sadia, e das pedreiras da vizinhança da capital da província.

A cal a empregar-se será de pedra, e apagada no mesmo lugar das obras, devendo demorar no depósito, depois de apagada; pelo menos cinco dias antes de ser empregada.

A alvenaria dos mesmos terá dois preços distintos, nos quais será também compreendido o preço da excavação, e transporte da terra, no lugar indicado pelo engenheiro chefe das obras.

O primeiro preço será calculado por dois metros de profundidade, e o segundo a começar daí em diante 
$\S 4^{\circ}$ Beton

Art.1. O beton era composto de pedra quebrada e bem lavada de 0,005 a 0,009 de diâmetro, e com as seguintes proporções:

Pedra quebrada e bem lavada $40 \%$

Cal hydraulica $\quad 15 \%$

Areia bem lavada $\quad 30 \%$

Pedregulho bem lavado $\quad 15 \%$

O beton será empregado, se for necessário, nas fundações, e deverá ser calculado com uma profundidade média de 5,00m e compreendida a excavação

Art. 2. Dito para ser empregado sem escavação

O Documento 132, Bezzi ainda se refere às dimensões dos alicerces de "circunvallação".

Alicerces da frente Norte do Corpo Central com 2 metros de profundidade [...]

Laterais do Corpo Central com 2 metros de profundidade [...]

Frente Sul até 2 metros de profundidade [...]

Desde o alicerce do Corpo Central até o centro do alicerce do arco, com 2 metros de profundidade [...]

As alvenarias ordinárias de pedra ou tijolo foram utilizadas desde a mais remota Antiguidade. Não só constituíam as paredes resistentes que suportavam pavimentos e coberturas de madeira, como eram utilizadas na construção de arcos e abóbadas. Constituídas de blocos de pedra irregular ou de blocos modulares de tijolo, funcionavam associadas a argamassas de cal e areia ou cal e pozolana, utilizadas para repartir uniformemente as cargas, para permitir a coesão e a aderência dos diversos blocos e para transmitir continuidade na repartição de compressões. Nestes sistemas, os blocos eram de pequena ou média dimensão, sendo quase sempre necessários vários blocos para constituir a porção de alvenaria pretendida.[...] (MATEUS, 2002, p.77)

O documento 133, da pasta 3 do Fundo Bezzi, tem o título "Orçamento dos alicerces das paredes de circunvallação dos diferentes corpos do edifício Monumento do Ypiranga":

$\S^{\circ} 3^{\circ}$ Alvenaria de Pedra

1 - preço - 1850,5706 $\mathrm{m}^{3}$

$2^{\circ}$ preço $-94,8093 \mathrm{~m}^{3}$

Nota: Os alicerces das paredes divisórias internas, sustentáculos das colunas, escadas internas e externas e rampas, não estão calculados neste orçamento.

\section{ESTACAS DE MADEIRA}

Na Pasta 3, Documento 183, intitulado carga total, no início do texto há a referência a estacas, e somente neste documento se verifica a citação.

Carga total dos aumentos K14.400.000,00

Carga sobre uma estaca K16 000,00 correspondente K20 por centímetro quadrado que seria a metade da carga de esmagamento

Estacas calculadas a 0,90m de distância entre si:

Estacas de 0,32m de diâmetro e 8,00m de comprimento batidas até negar, $900 \mathrm{~m}$

Beton de pedra quebrada e cimento - $720 \mathrm{~m} 2$

Alicerces pela profundidade de 1,91m - 1072,440 m3

Não há referências sobre o material, mas tudo indica ser de madeira.

Estas especificações sobre as estacas coincidem com as citações de Mateus sobre o emprego de estacas. 
No que se refere ao pré-dimensionamento de estacaria, eram também estabelecidas regras práticas de dimensionamento.

Valores indicados por Rondelet e Breymann:

- As distâncias entre eixos de estacas variavam, consoante às secções e o comprimento das estacas - entre $0,80-1,20 \mathrm{~m}$.

- O comprimento máximo de uma estaca de carvalho era limitada a $8 \mathrm{~m}$.

- O diâmetro mínimo da estaca deveria ser igual a 1/20 do seu comprimento e superior a 18 $\mathrm{cm}$.

- O comprimento dependia da natureza dos solos e da espessura da camada compressível.

A secção relacionava-se com o comprimento e era diretamente proporcional às cargas a suportar. (MATEUS, 2002, p.129)

Em nenhum outro documento do Fundo Bezzi aparece novamente menção a estacas, e não se compreende porque no Documento 407, uma caderneta de obras escrita por Bezzi em cada mês sobre os trabalhos que haviam sido realizados, não faz referência à sua execução anteriormente à data do registro destas obras. Em novembro de 1885, iniciam-se as obras nas fundações com alvenaria de pedra, prolongando-se até agosto de 1886.

Não se tem certeza absoluta de que as estacas tenham sido realizadas, ou se foram produzidas por outros profissionais.

Documento 407

Novembro/ 1885

Alvenaria de pedra $593,75 \mathrm{~m}^{2}$ dos alicerces

Dezembro/ 1885

$690 \mathrm{~m} 3$ de alvenaria de tijolos do embasamento

$18,58 \mathrm{ml}$ de revestimento e cantaria executados

Janeiro/ 1886

$450 \mathrm{~m} 3$ de alvenaria de tijolos do embasamento

$106 \mathrm{ml}$ do revestimento em cantaria

$10.000 \mathrm{~m} 3$ de madeiramento grosso (vigamento do assoalho do pavimento térreo)

Fevereiro/ 1886

Executados $84 \mathrm{~m} 2$ de alvenaria de pedra dos alicerces internos

$200 \mathrm{~m} 3$ de alvenaria de tijolos do embasamento

$230 \mathrm{~m} 3$ de alvenaria de tijolos acima do embasamento

$80 \mathrm{ml}$ de revestimento de cantaria

$10 \mathrm{~m} 3$ de vigamento do assoalho do pavimento térreo

\section{Março/ 1886}

$250 \mathrm{~m} 3$ de alvenaria de pedra dos alicerces internos

$110 \mathrm{~m} 3$ de alvenaria de tijolos do embasamento

205m3 de alvenaria de tijolos das paredes acima do embasamento

Abril/ 1886

$140 \mathrm{~m} 3$ de alvenaria de pedra alicerces internos

$560 \mathrm{~m} 3$ alvenaria de tijolos acima do embasamento

Maio/ 1886

$570 \mathrm{~m} 3$ de alvenaria de tijolos acima do embasamento

Junho/ 1886

$610 \mathrm{~m} 3$ de alvenaria de tijolos acima do embasamento

Julho/ 1886

$860 \mathrm{~m} 3$ de alvenaria de tijolos acima do embasamento 


\section{Agosto/ 1886}

38.266 alvenaria de pedra alicerces internos

$438,894 \mathrm{~m} 3$ alvenaria tijolos embasamento

550,00 alvenaria de tijolos acima do embasamento

$13.990 \mathrm{~m}$ trabalho cantaria revestimento soco

51.800 trabalho cantaria sapata das pilastras

2.1346 madeiramento grosso pavimento térreo

25.7713 madeiramento grosso 1 pavimento
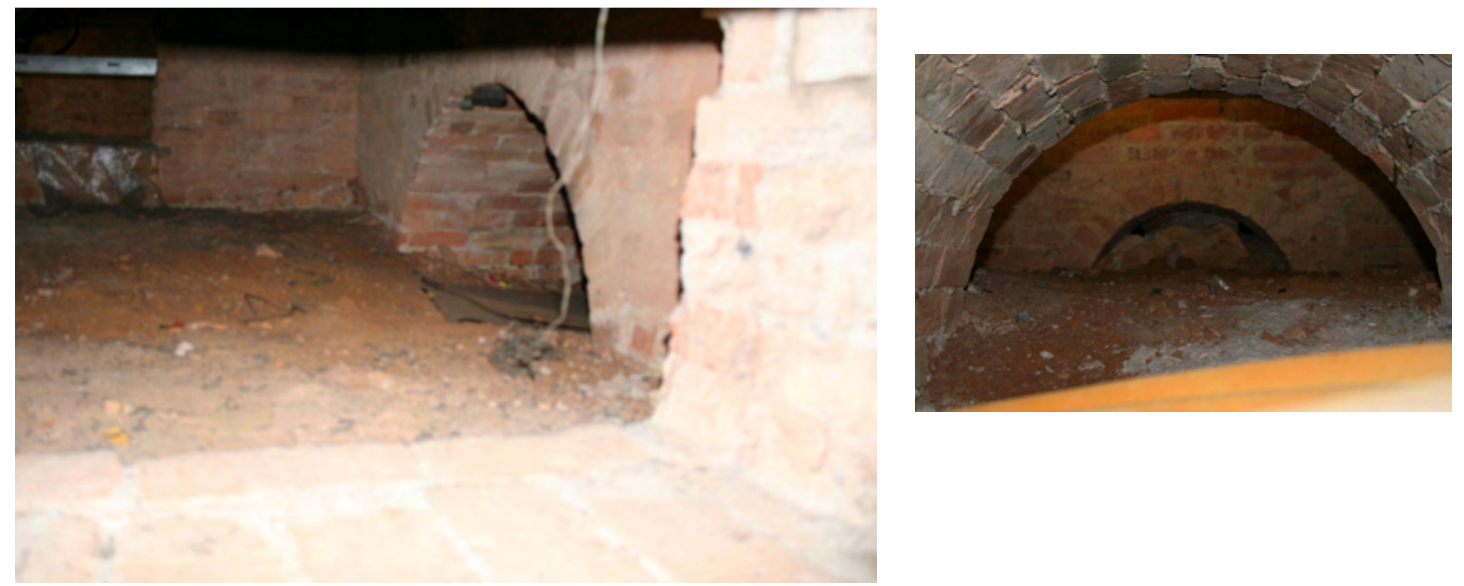

\section{Fig. 239,240 SUBSOLO SOB O CORPO CENTRAL}

Estas imagens mostram que o solo atingia a imposta dos arcos, semicirculares, na alvenaria do embasamento. Estes arcos foram utilizados em grande número nesta região e distribuem as cargas aos maciços das fundações, encravadas no solo.

O solo foi retirado, bem como os arcos nas galerias, para aumentar o pé-direito interno. É provável que tenham sido utilizados reforços nestes lugares onde os arcos foram eliminados. É possível que a transmissão de cargas dos pavimentos nos grandes maciços da fundação tenham sido alterada.
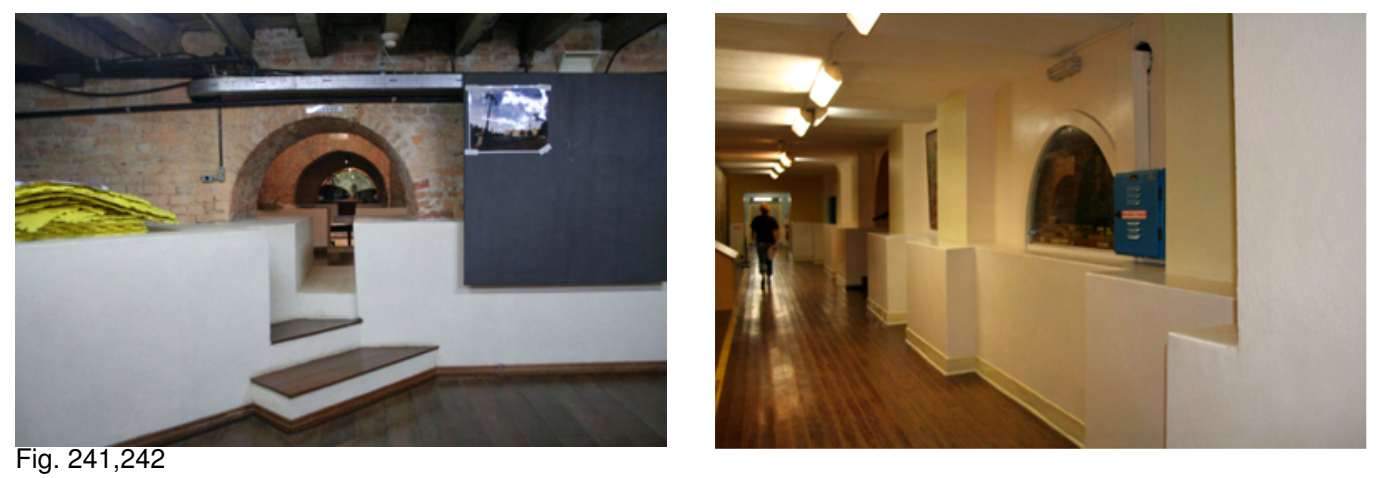

Sob o CORPO CENTRAL: escavação em 1994, fig.241

Sob a GALERIA: escavação a partir de 1931. As fundações de pedra foram revestidas com tijolos em espelho para isolar a umidade ascendente, fig.242 


\section{ESTRUTURA METÁLICA}

\section{ÁTICO E TELHADOS}

No ático ou sótão, região sob o telhado no Corpo Central, há um grande pé-direito interno a que se tem acesso por escadas. As estruturas estão visíveis e apresentam um conjunto de soluções interligadas ou sobrepostas, que se constituem num sistema característico da técnica tradicional de alvenaria.

Os dois grandes arcos abatidos de alvenaria (onde a flecha é menor do que o raio) estão ligados às vigas transversais do telhado e, por meio de perfis metálicos de amarração horizontais e tirantes verticais, transmitem as cargas para os também grandes maciços de alvenaria que vêm desde a fundação.
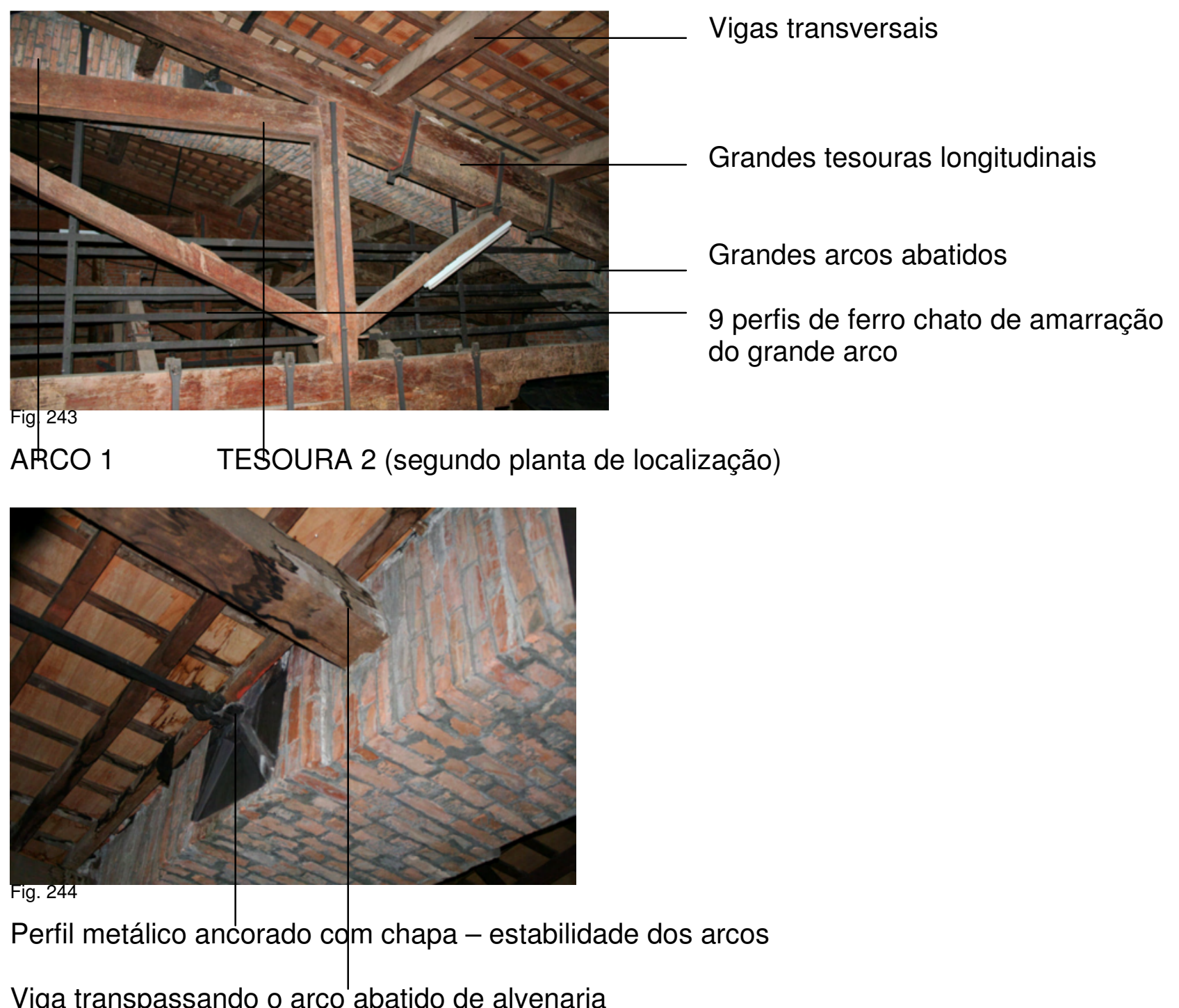

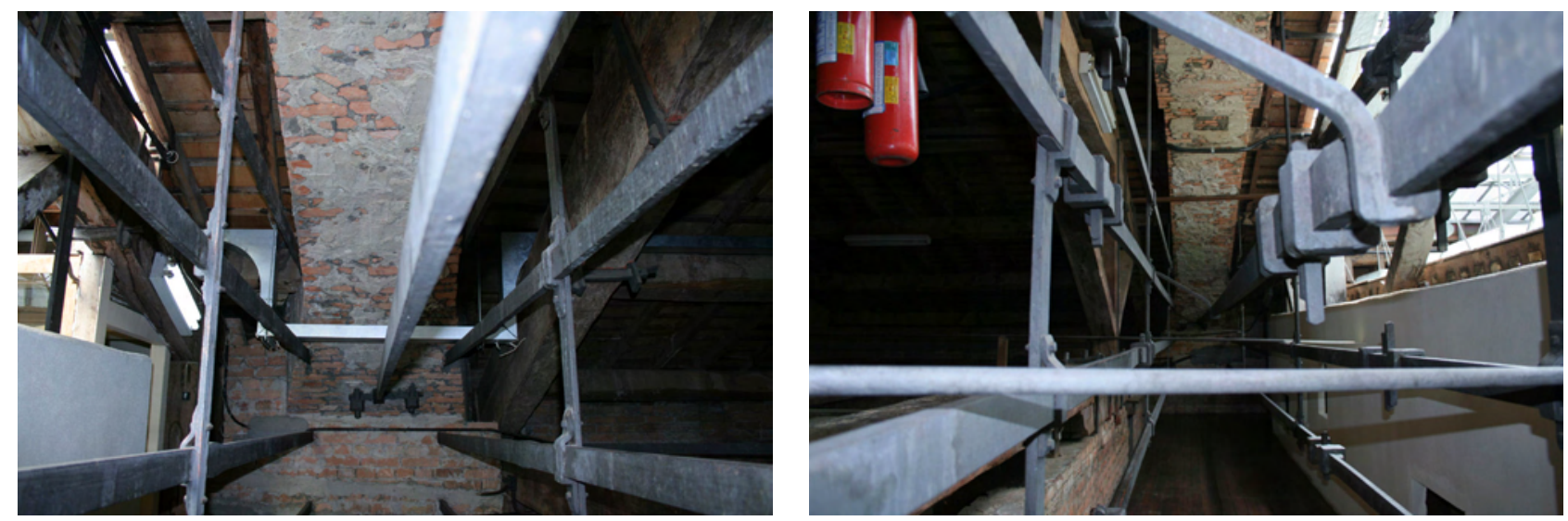

ARCO 2 (segundo planta de localização)

Tirantes de amarração ancorados na imposta do grande arco absorvendo o impulso oblíquo
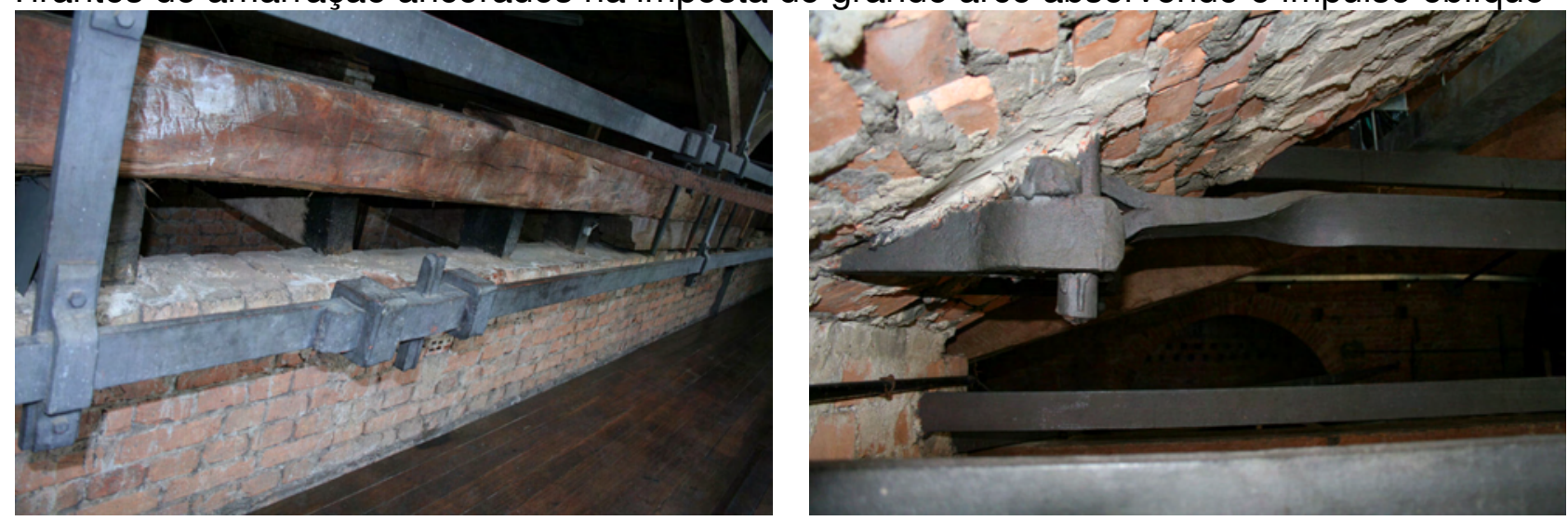

Sistema de amarração horizontal e atirantamento vertical. Detalhe de ancoragem na imposta do arco

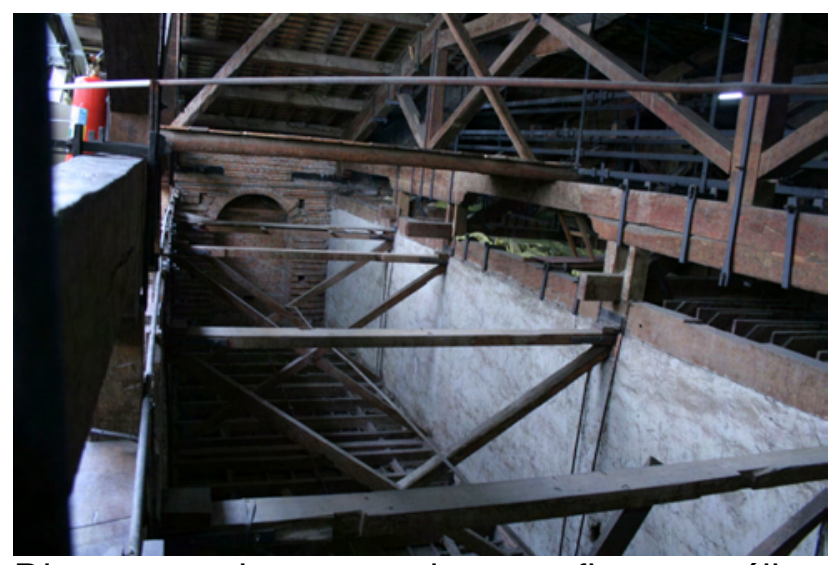

Diversos redondos

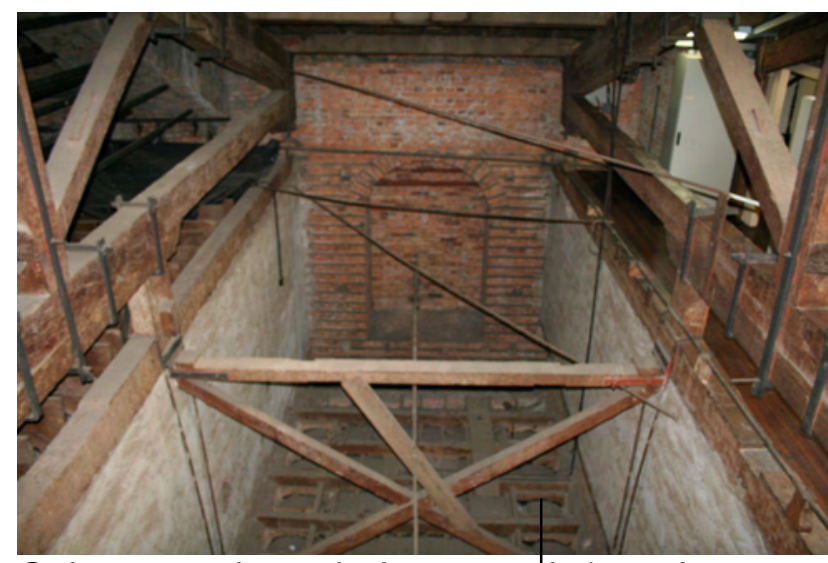

Cobertura da galeria central (em frente ao Salão de Honra) Fig. 245,246,247,248,249,250 


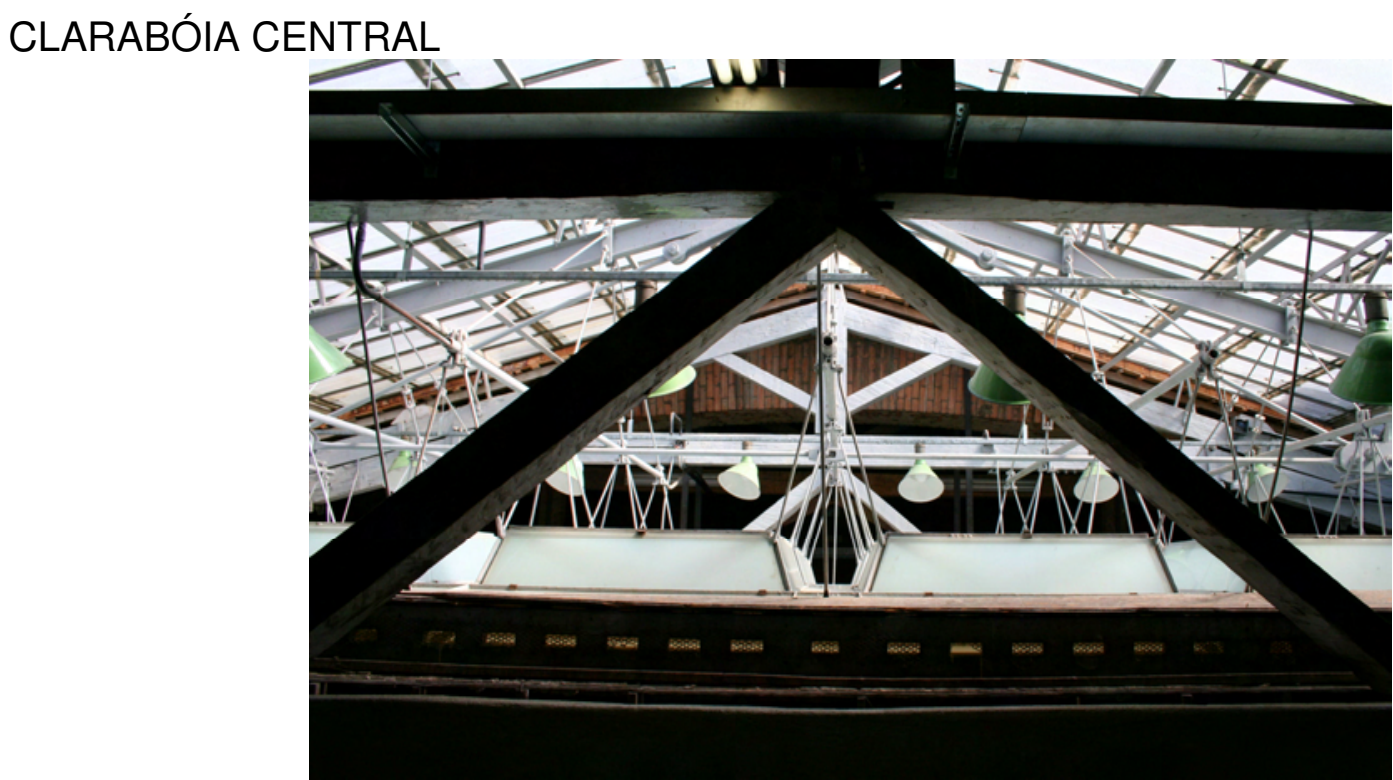

A clarabóia tem uma complexa estrutura metálica atirantada cujos pórticos ancoram em espessos maciços de alvenaria

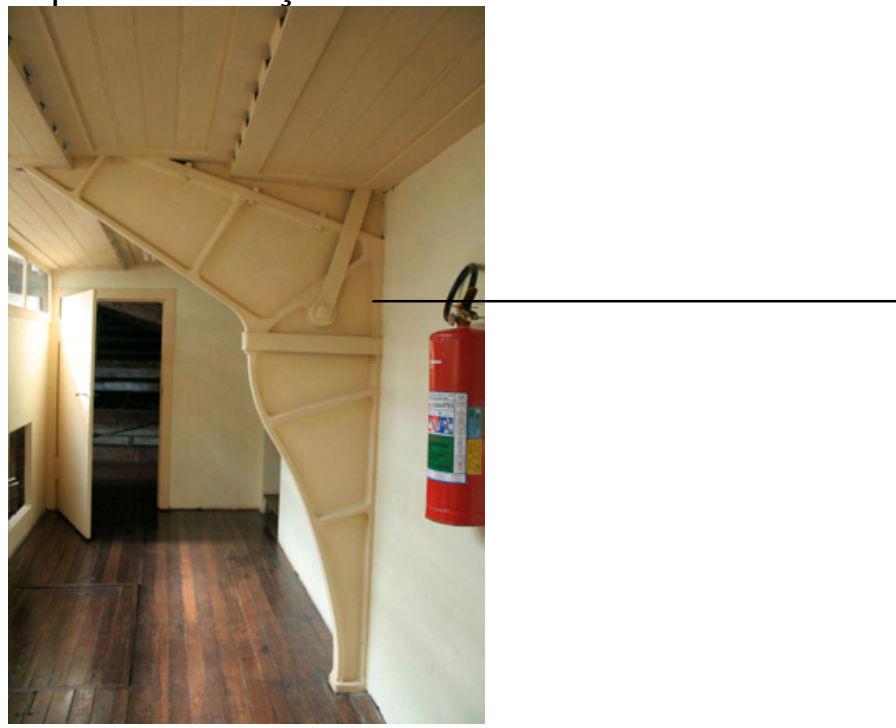

Balanço interno do pórtico de aço fundido em cuja extremidade fica apoiada a treliça metálica da cobertura de vidro

(Eng. Fusco)

Na Pasta 3, Documento 136 são apresentados em vários itens os tipos de perfis de ferro, dimensões e localizações e alguns croquis 


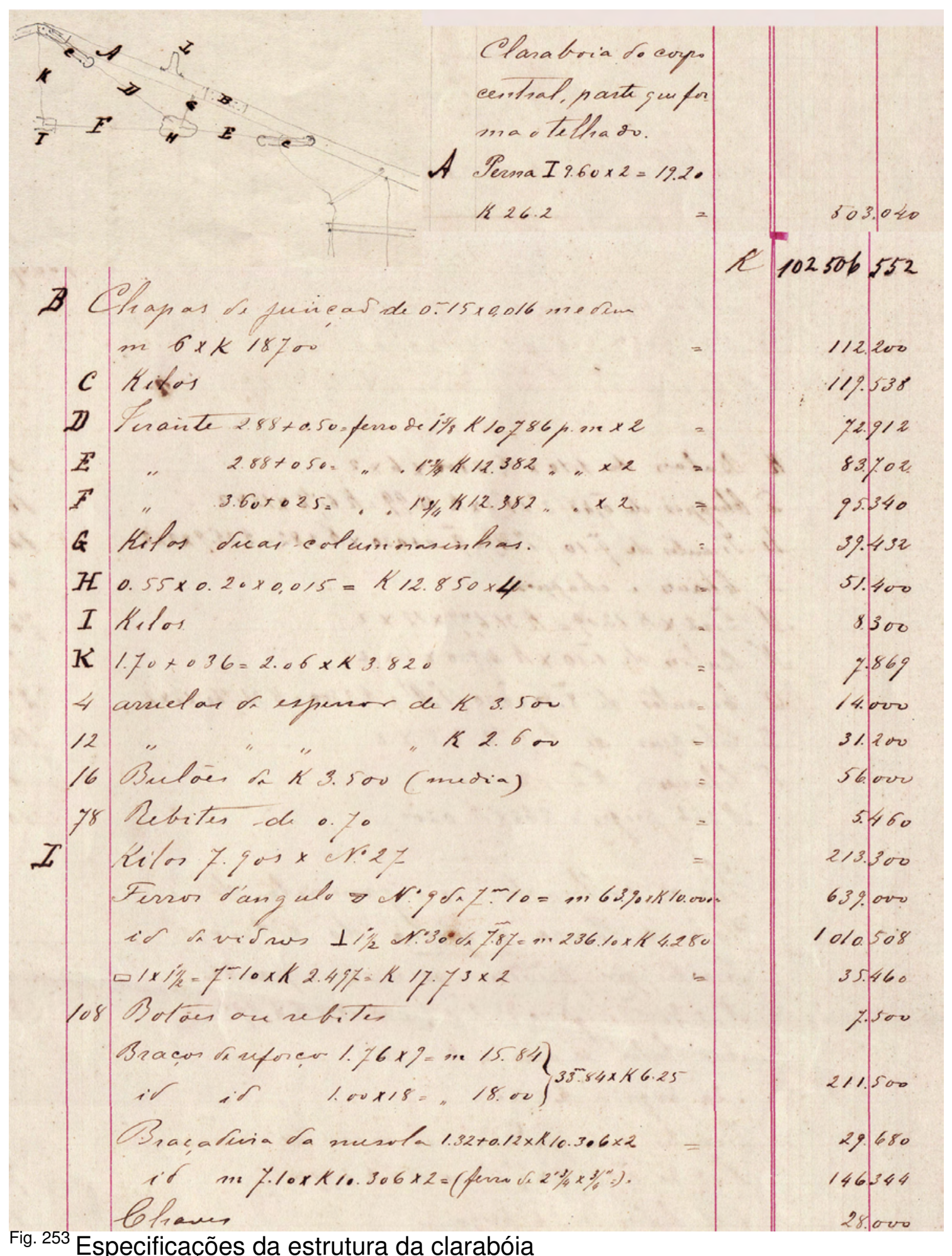




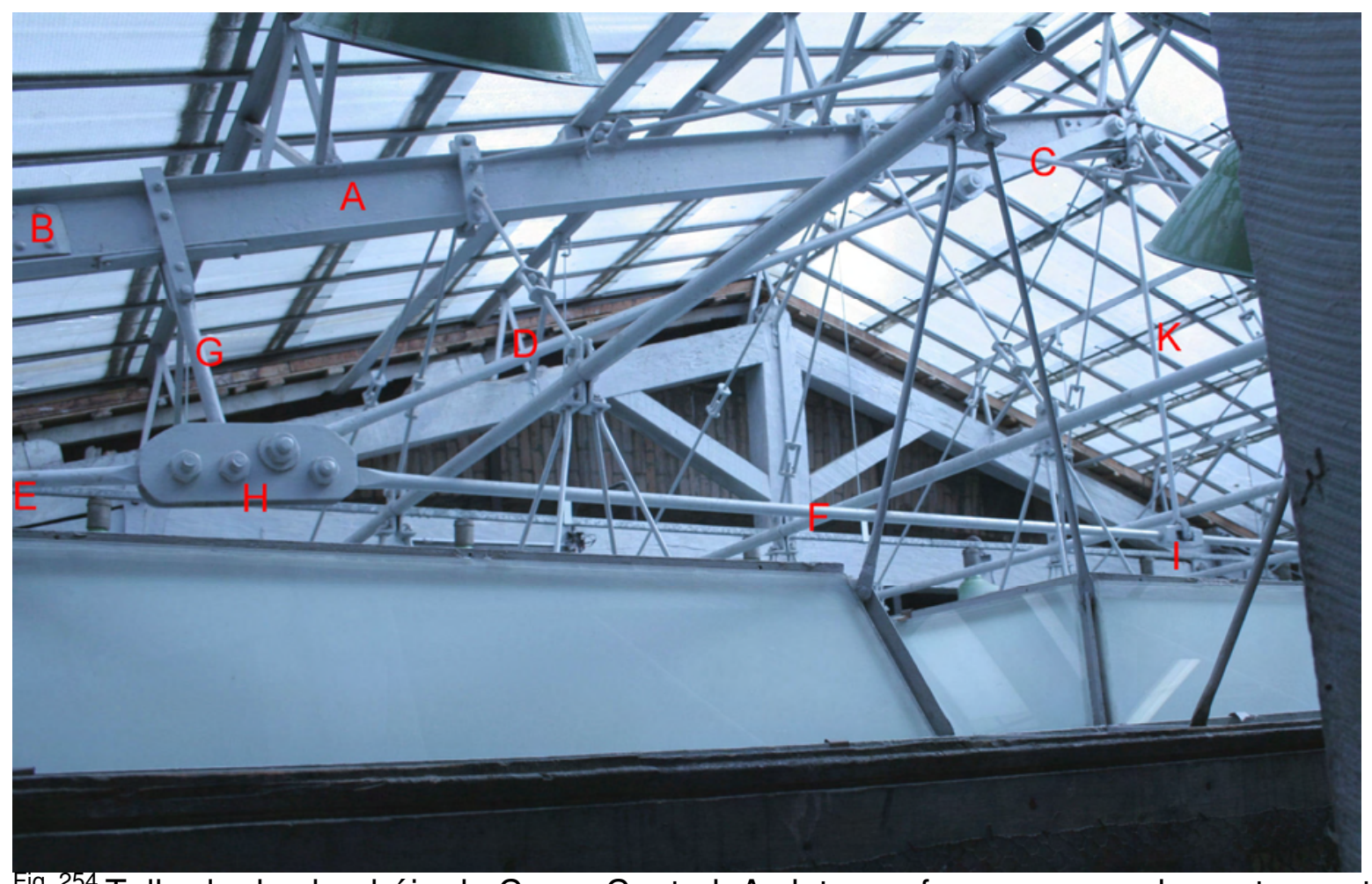

Fig. ${ }^{254}$ Telhado da clarabóia do Corpo Central. As letras referem-se aos elementos metálicos identificados por Bezzi no Documento 136.

\section{ESTRUTURA DE SUSTENTAÇÃO DO FORRO DO SALÃO DE HONRA}

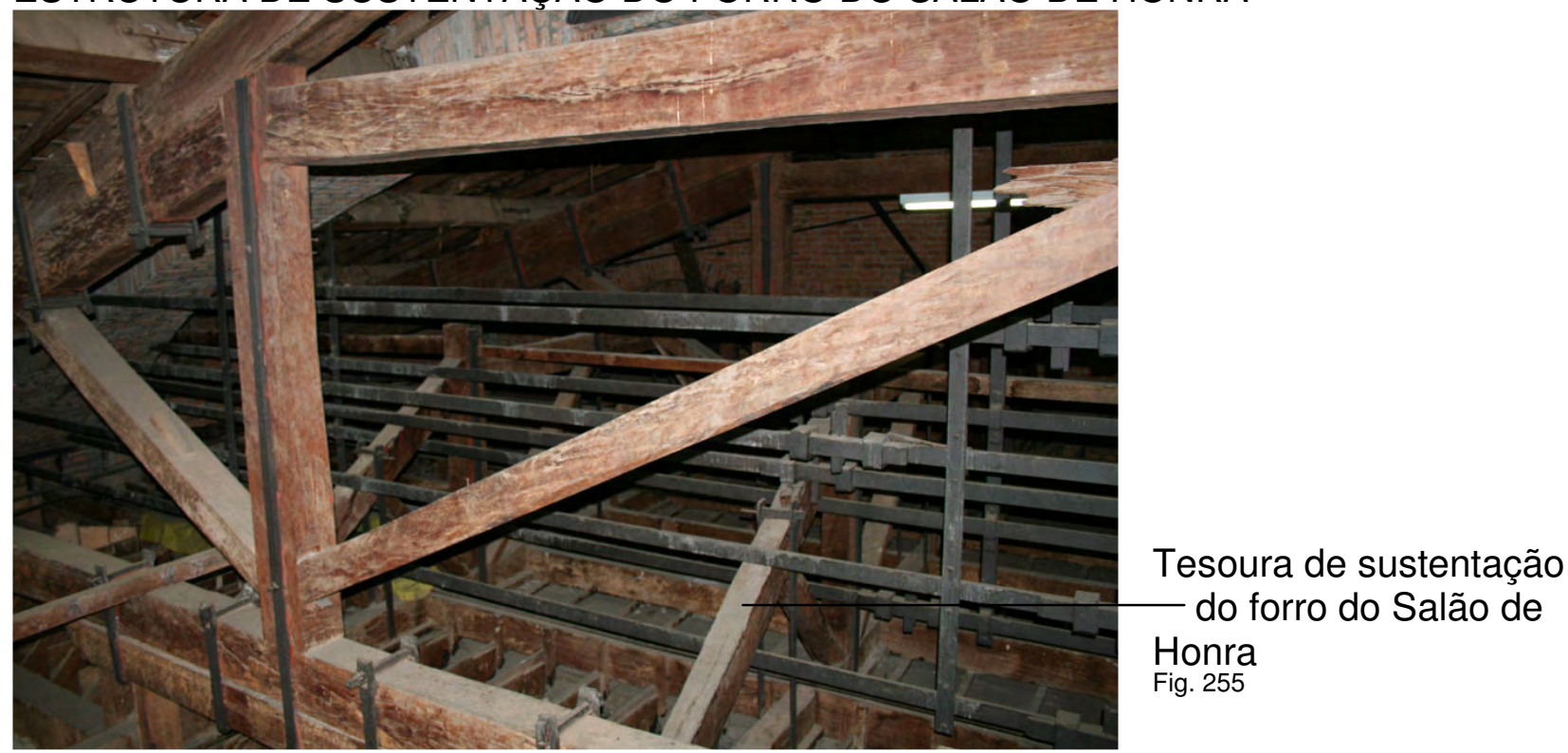



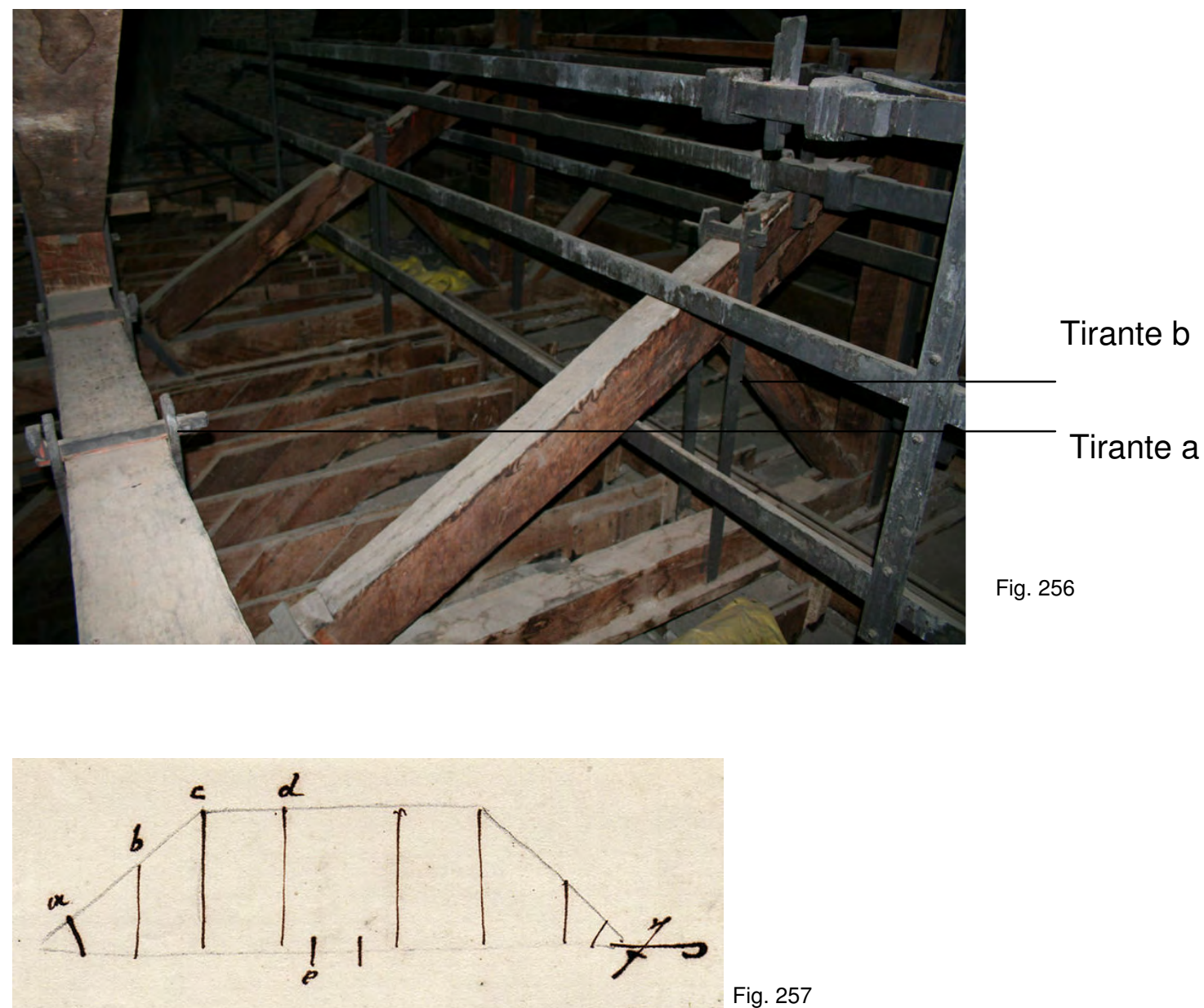

Fig. 257

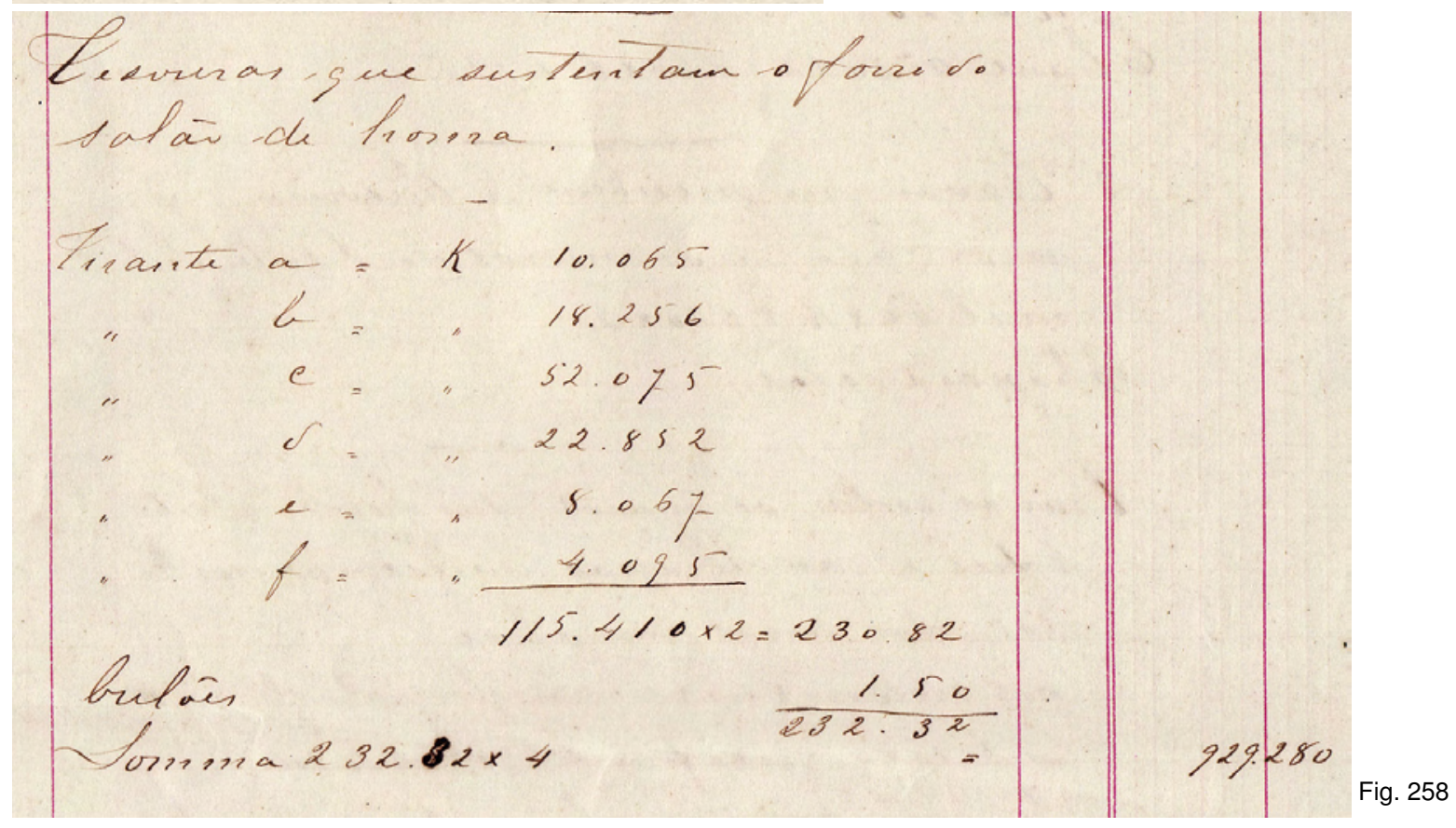

Croqui p. 11, referente às tesouras que sustentam o forro do Salão de Honra 


\section{TELHADO SOBRE A GALERIA}

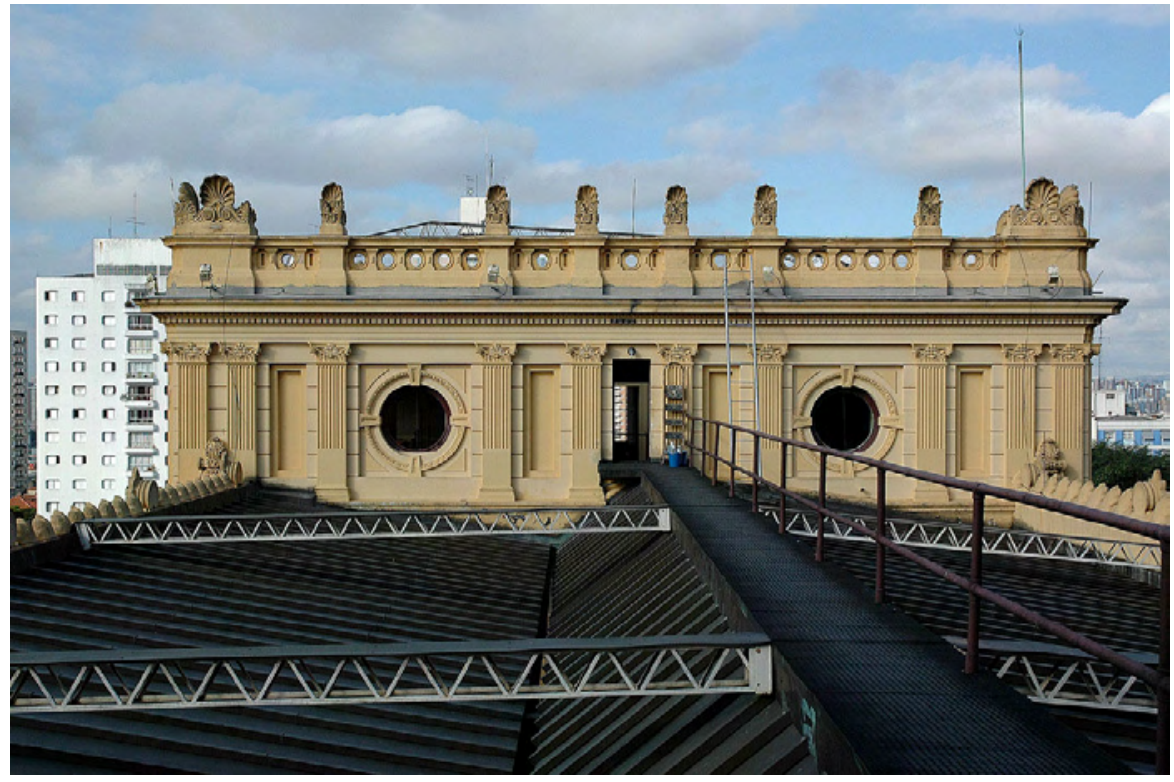

Vista da Torre Oeste
É de difícil acesso a área sob a galeria

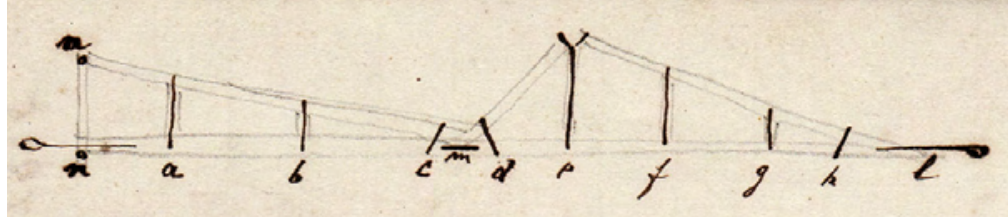

Fig. 260

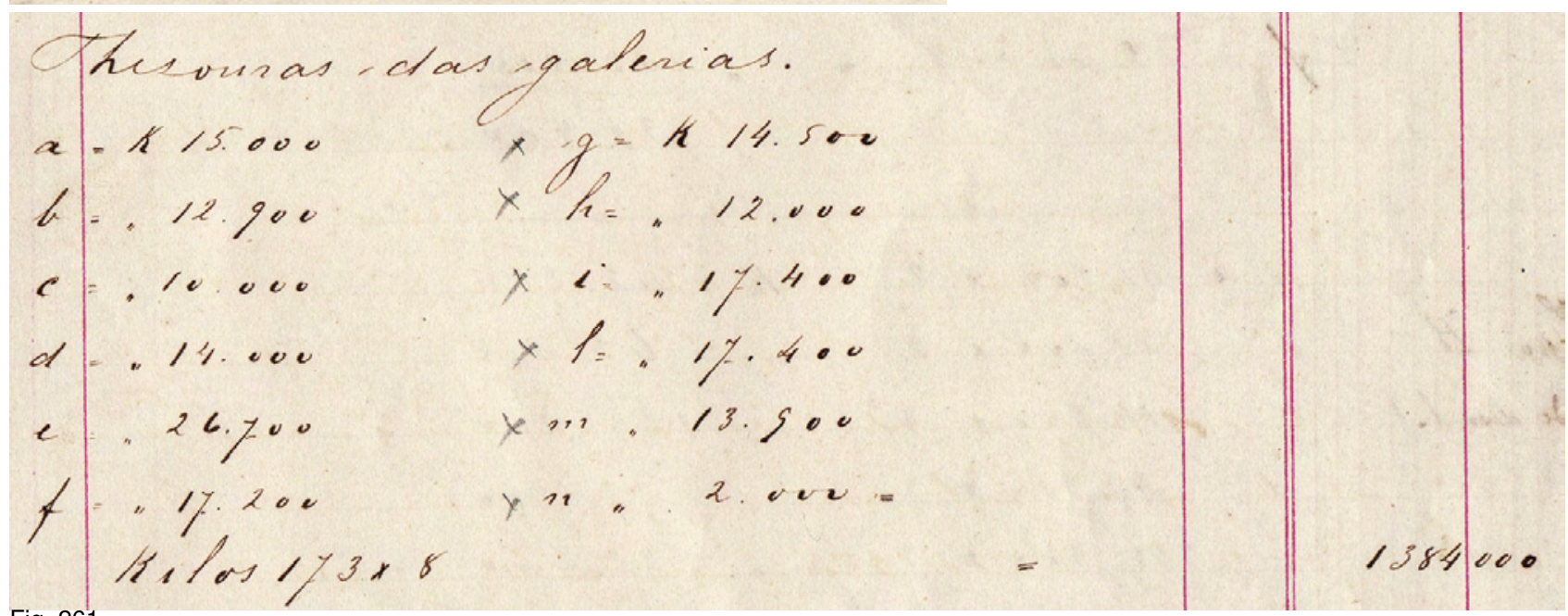

Fig. ${ }^{261}$ Croqui p. 3, referente às tesouras das Galerias

As tesouras do telhado sobre as galerias têm a mesma solução de reforço metálico com a utilização de tirantes. 
No mesmo Documento 136, constata-se que Bezzi utilizou no edifício uma grande quantidade de perfis metálicos para a amarração horizontal e, em alguns pontos, colunas metálicas para sustentação vertical.

Os custos destes perfis ultrapassam a primeira estimativa do custo da obra e Bezzi se justifica, a partir do início destas, afirmando que o solo não oferecia uma compactação segura para a estabilidade da construção, necessitando de uma maior quantidade de perfis. Neste tipo de estrutura, o travamento horizontal é uma característica fundamental.

Os grandes maciços de alvenaria que estruturam cada corpo, unem-se na vertical por sobreposições e na horizontal por elementos que delimitam cada espaço. Descarregam toda carga nas fundações com forças verticais e impulsos horizontais. As paredes externas de cada pavimento, os pisos e os elementos em balanço, são devidamente estruturados através de amarrações horizontais.

\section{Sistemas de travamento horizontal}

O edifício em alvenaria tradicional era concebido como uma estrutura tridimensional composta de elementos resistentes ligados entre si e com as fundações, capazes de resistir a ações verticais e horizontais.

Eram por isso previstos sistemas que assegurassem a boa ligação entre os diferentes elementos em elevação:

- entre abóbadas e pés direitos

- entre paredes contíguas e paralelas

Para estas diferentes ligações contribuíam não só os cuidados com a definição do aparelho, destinado a assegurar a ligação entre si dos diversos blocos singulares de pedra ou de tijolo, mas também a concepção de sistemas de travamento horizontal de cada um dos elementos estruturais que compunham o edifício.

O principal objetivo destes sistemas adicionais era aumentar a capacidade de resistência das estruturas em alvenaria em relação a:

- ações horizontais, vibrações, movimentos violentos e inesperados

- ações das cargas variáveis ligadas ao uso

- eventuais assentamentos do terreno de fundação

- eventuais deformações após o descimbramento.

É o caso da ligação dos elementos estruturais horizontais, arcos e abóbadas, aos elementos estruturais verticais pés-direitos, paredes, colunas e pilastras, sempre que houvesse dúvidas sobre a estabilidade dos pés-direitos sujeitos ao impulso dos arcos e abóbadas.

Previa-se, nestas situações, uma "reserva de resistência" assegurada por tirantes metálicos e justificada por experiências empíricas, como as referidas por Rondelet:

Quando os pés-direitos de abóbadas são fracos para sustentar um impulso, eles podem ser contidos por um peso duplicado da diferença entre o impulso e a resistência de um pé-direito, suspendido por um fio que passa pelas articulações colocadas ao centro dos rins, ou por um peso igual a esta diferença, colocada sob cada junta ao meio dos rins. É sobre esta propriedade que se fundamenta o sistema de armação das platibandas dos portais da Igreja de Santa Genoveva.

Os tirantes contribuíam também para garantir o movimento solidário de pés-direitos e respectivos arcos e abóbadas, de modo a limitar a amplitude dos deslocamentos, seja a aproximação, seja o afastamento das suas impostas, sempre que a estrutura estivesse sujeita a esforços horizontais. 
Para a ligação entre elementos estruturais verticais, contribuíam também os vigamentos em madeira dos diversos andares e a estrutura dos telhados. No caso das vigas de madeira dos pavimentos, era comum a semelhança dos tirantes de ferro, a sua ancoragem às paredes.

Para este fim eram pregados chapas de ferro munidas de um ferrolho ou espigão, ao longo das faces e na extremidade das vigas. Estes ferrolhos eram depois ancorados no exterior das paredes.

Não basta construir as paredes de um edifício nas dimensões desejadas e com toda atenção conveniente, pois como elas devem ser carregadas de pesos de assoalho e do telhado, que tendem naturalmente a crescer no vazio, se prende de andar a andar por precaução quando de sua construção, para prevenir toda separação, colocando no meio das paredes ou na sua espessura, cabos horizontais de ferro chato quadrado bem armados e solidamente preso às suas extremidades pela ancoragem. (RONDELET)

Para além da sua justificação, as obras analisadas preocupavam-se sobretudo a indicar:

- a posição na qual os tirantes seriam mais eficientes

- as diversas formas de emendas

- os melhores sistemas de ancoragem

No que se refere aos tirantes em arcos e abóbadas recomendavam-se os tirantes na altura dos rins (a 1/3 da flecha no caso das cilíndricas de volta inteira).

Para não fazer ver os tirantes, e não fazer as "alvenarias estruturais verticais" bastante sólidas, tem-se praticado de colocar os tirantes de ferro ocultos na espessura de arco ou abóbada [...] mas este tipo de tirantes pouco ou nada força. [...] No oposto ao tirante reto, colocada cerca $1 / 3$ da flecha do arco, para o impulso dos arcos ou abóbadas, sem rasgar-se, não pode nunca correr perigo, e é por isto que se deve compreender o serviço que faz um tirante em um edifício antes de o colocar, pois ele não é mais que um freio e uma reserva. (VALADIER)

Como no caso-limite de reforço, Rondelet refere-se às cinco cintas de ferro instaladas na

Cúpula de S.Pedro, no Vaticano.

Na presença de vigas de madeira, os tirantes eram normalmente previstos na direção

ortogonal à direção das vigas mestras (segundo a maior dimensão em planta).

$\mathrm{Na}$ maioria dos edifícios de habitação os tirantes, quando eram introduzidos, limitavam-se à ligação entre paredes divisórias e paredes autoportantes ortogonais, ficando embebidos nas paredes divisórias.

As emendas propostas eram de vários tipos, embora no final do século XIX, se afirmam as emendas roscadas, que permitiam adaptar-se exatamente aos vãos e deixar o tirante sob tensão.

As ancoragens dos tirantes nas alvenarias eram concebidas de modo:

- a mobilizar o máximo de superfície mural para que a sua ação fosse o mais eficaz possível em caso de movimentos horizontais da estrutura.

- distribuir a reação dos esforços a que os tirantes viessem a estar sujeitos, de forma uniforme e não concentrada.

Os travessões de ancoragem mais antigos, em ferro forjado com a forma de um $\mathbf{S}$ ou de um $\mathbf{Y}$, eram colocados oblíquos em relação às juntas horizontais e verticais, de modo a evitar rupturas ao longo das mesmas e mobilizar uma maior superfície de alvenaria.

Com os perfis industriais, passou a ser comum a realização de ancoragens com perfis I ou $\mathbf{L}$

Estes perfis são roscados às extremidades dos tirantes podendo ser ainda munidos de um prato metálico de redistribuição de esforços, colocado entre os ditos perfis e o paramento externo das alvenarias.

Os tirantes metálicos eram também introduzidos em edifícios já existentes, com o objetivo de consolidar e restaurar estruturas danificadas. 
Além dos sistemas de aparelho e dos tirantes, eram introduzidos durante a execução elementos de ligação pétreos, metálicos, de modo a aumentar o travamento entre os diversos blocos.

(MATEUS, 2002,p $105-107$ )

Ainda em relação ao Documento 136, são apresentados a seguir os perfis do sistema de travamento horizontal

\section{NÍVEL DO ASSOALHO DO PRIMEIRO PAVIMENTO}

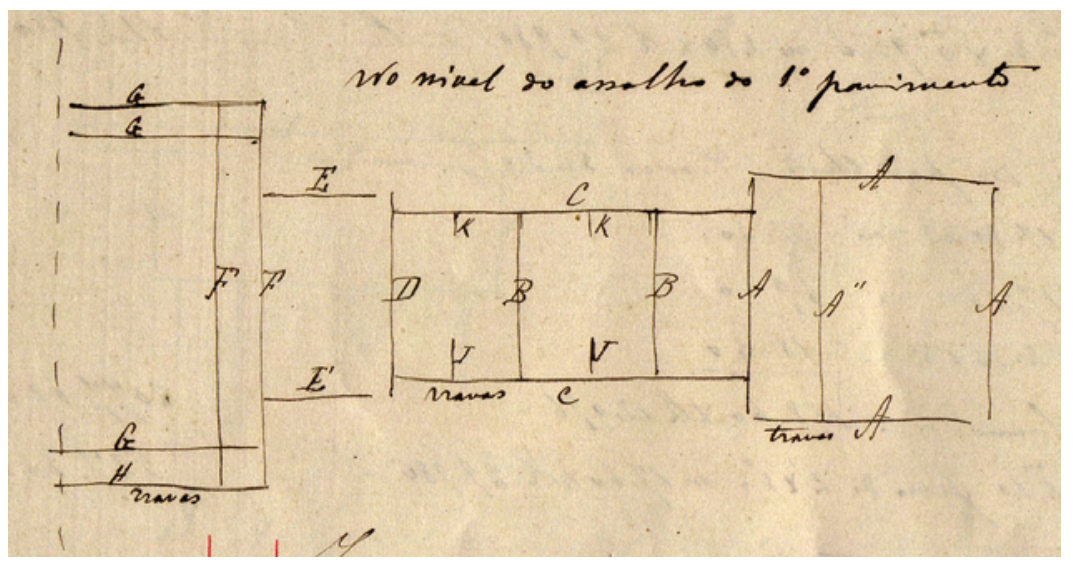

Croqui p. 1, referente a travas e chaves - Amarração horizontal

Fig. 262 


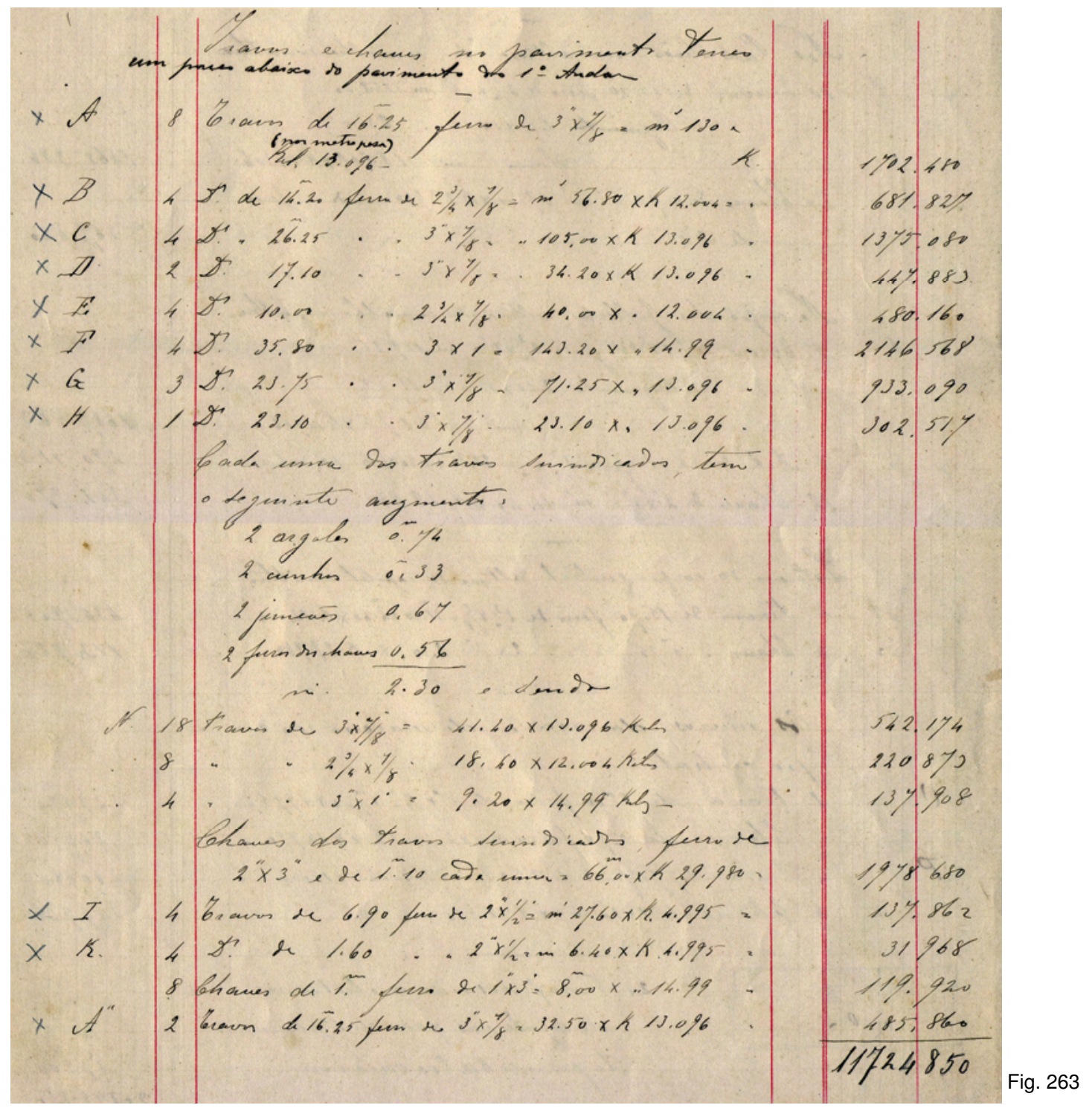

ALTURA DA ARQUITRAVE DAS LATERAIS DO CORPO CENTRAL 


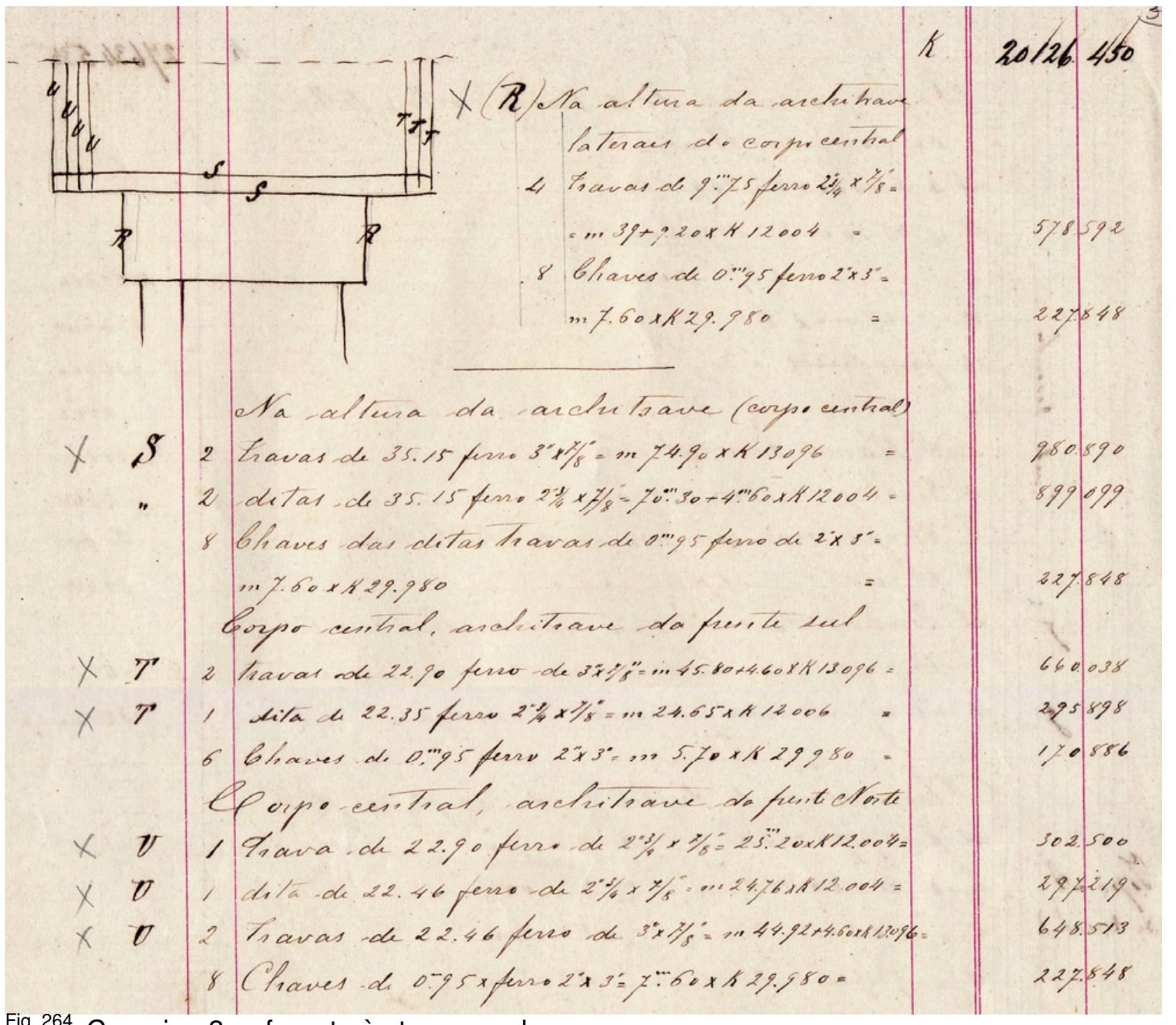

Fig. ${ }^{264}$ Croqui p. 3, referente às travas e chaves 
CORPO CENTRAL - ALTURA DA CIMALHA (Cornija) CORÍNTIA

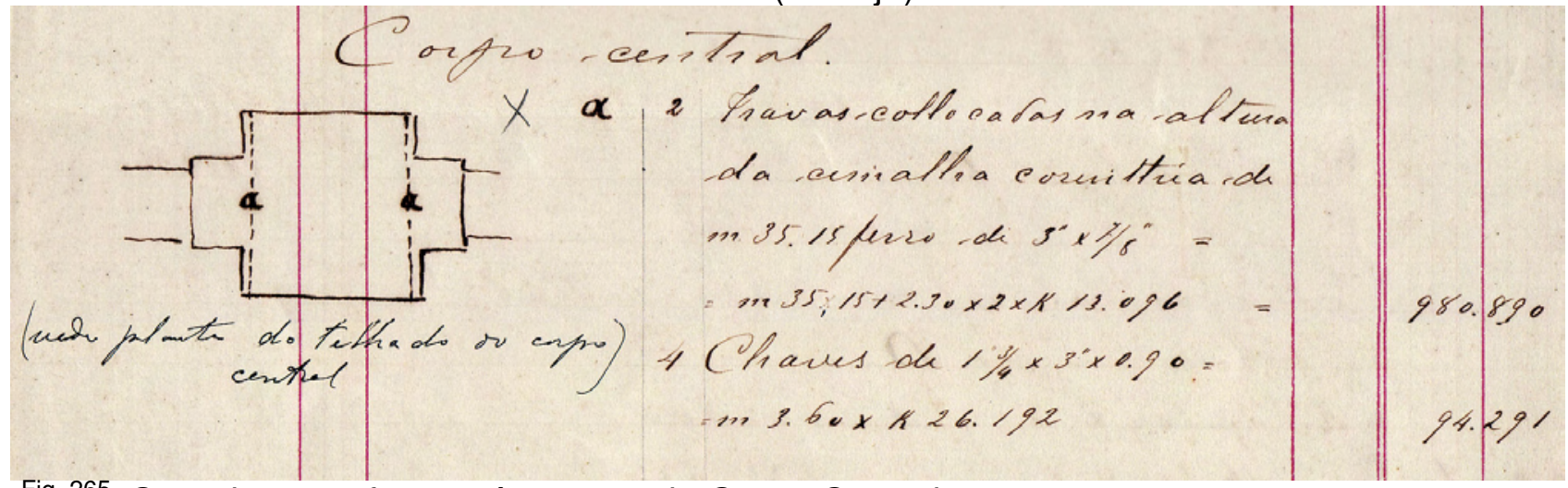

Fig. 265 Croqui p. 6, referente às travas do Corpo Central

MACIÇOS PRÓXIMO AO FRONTÃO ONDE HAVERIAM ESTÁTUAS

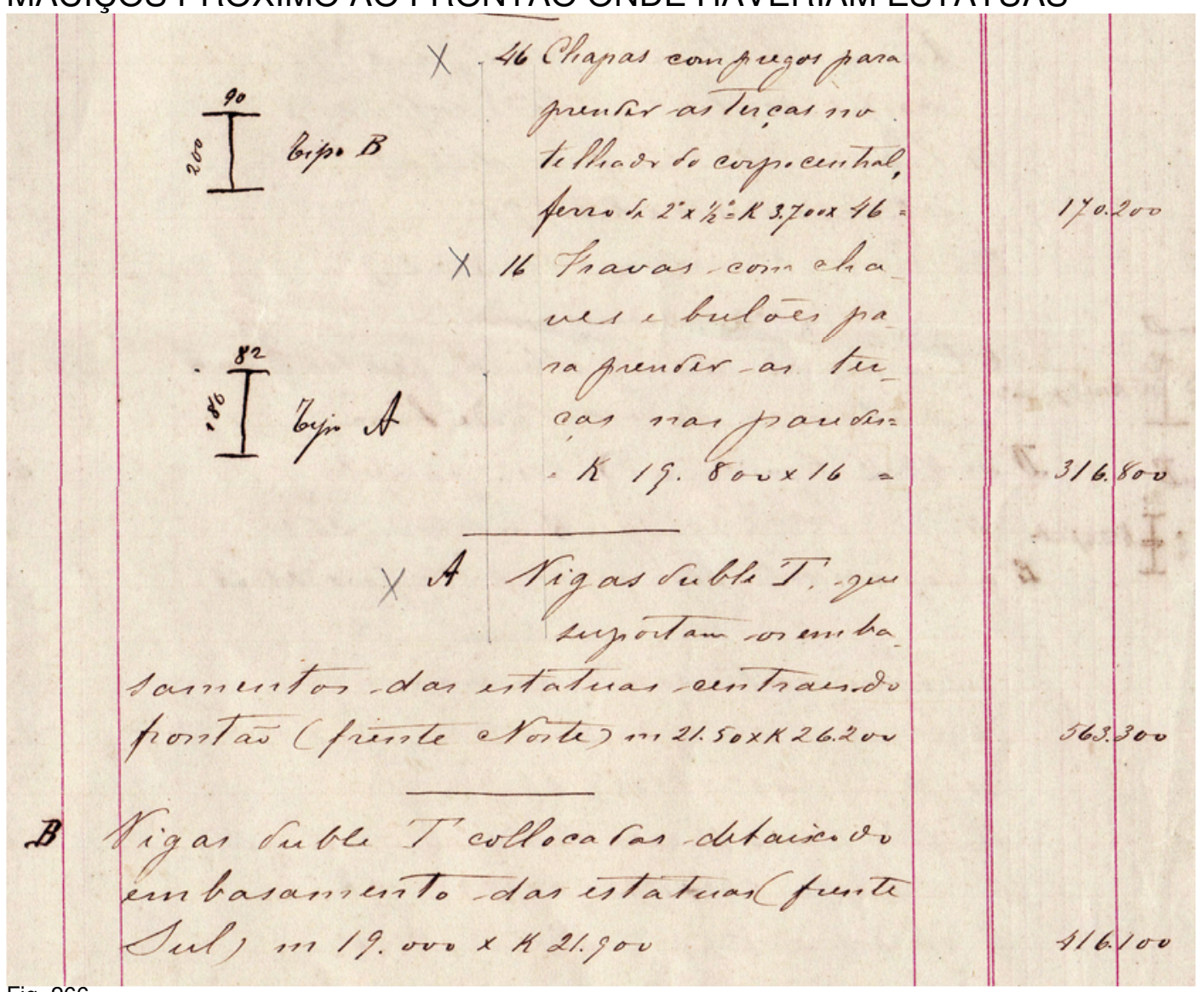

Fig. 266 Croqui p. 7, referente às vigas dos embasamentos 
TIRANTES NO VIGAMENTO DAS SALAS DAS TORRES
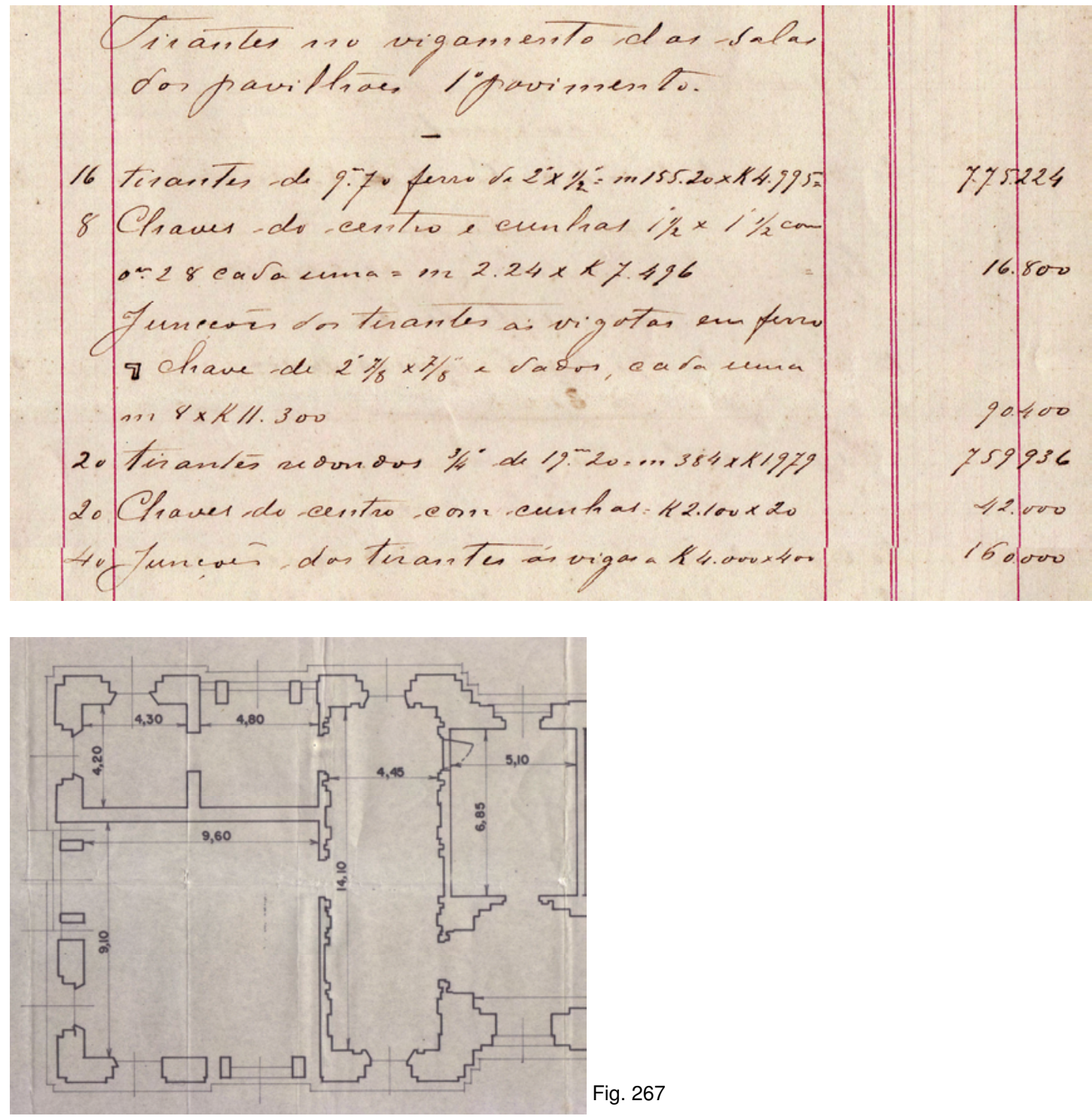

16 Tirantes de 9,70 (chato); 20 tirantes redondo de 19,20 
TIRANTES NO VIGAMENTO DAS SALAS CORRESPONDENTES ÀS GALERIAS (salas na face sul).

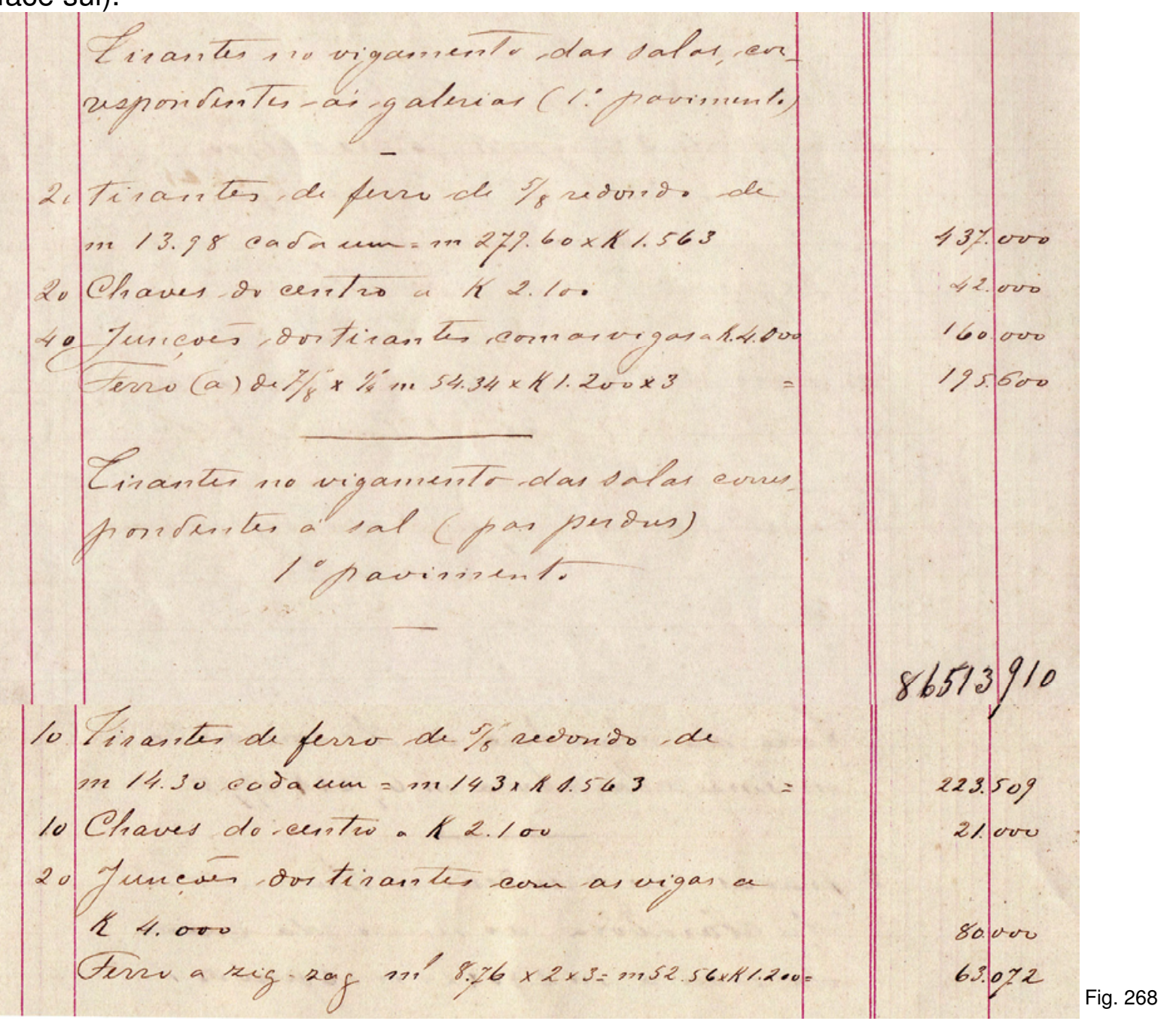

O Documento 170 da Pasta 3 do Fundo Bezzi, de 11 de agosto de 1887, tem o seguinte croqui das vigas metálicas utilizadas: 


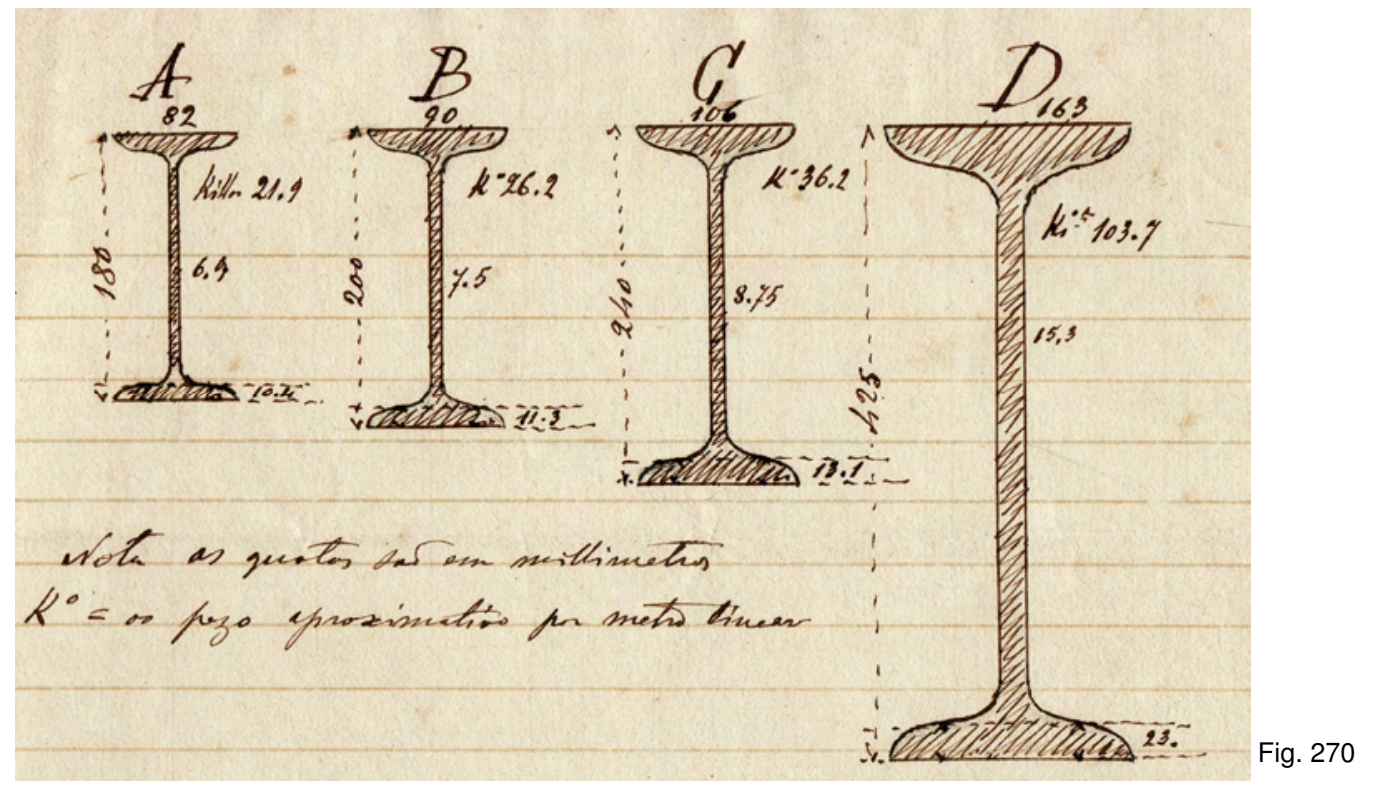

Tipo $\mathrm{A}$ - Átrio colocadas à distância de $0.80 \mathrm{~m}$ de centro a centro

Tipo B - Pavimento térreo galerias

Pavimento térreo salas dos pavilhões

Pavimento térreo salas dos pavilhões - Colocadas à distância de 0,80

Pavimento térreo corredor dos pavilhões de centro a centro

Pavimento nobre caixa de escada

Tipo $\mathrm{C}$ - Salas de passagem para as galerias dos dois pavimentos

Tipo D - Vigas sobre as colunas do átrio, na parte que corresponde à galeria.

\section{COLUNAS METÁLICAS}

O Documento 407 Pasta 6, que é uma caderneta de obras realizadas, registrada por Bezzi a cada mês, cita no $\mathbf{2} \mathbf{2 3}$ o emprego de estrutura metálica nas colunas do átrio. Possivelmente devido a utilização de tijolos ocos em formato circular, seja esta estrutura uma coluna (circular)

\section{Novembro / 1887}

$\S 05$ - Colunas corínthias das galerias: 40 unidades

$\S 11$ - Ladrilhos nacionais de cimento: $90 \mathrm{~m}^{2}$

$\S 13$ - Emboço e reboco externos: $150 \mathrm{~m}^{2}$

$\S 23$ - Ferro batido do comercio: $960 \mathrm{~kg}$

Adicional ao $\S 23$ - Ferro fundido, alma das colunas do átrio: $2359 \mathrm{~kg}$

No ático são visíveis duas colunas metálicas de $19 \mathrm{~cm}$ de diâmetro.

Pelo Documento 136, o item Ferro Fundido especifica 6 colunas existentes na parede de fundo da caixa de escada. Duas delas, acima citadas, se localizam próximas ao nicho onde se encontra a escultura de D.Pedro. As demais não são possíveis de serem localizadas. 


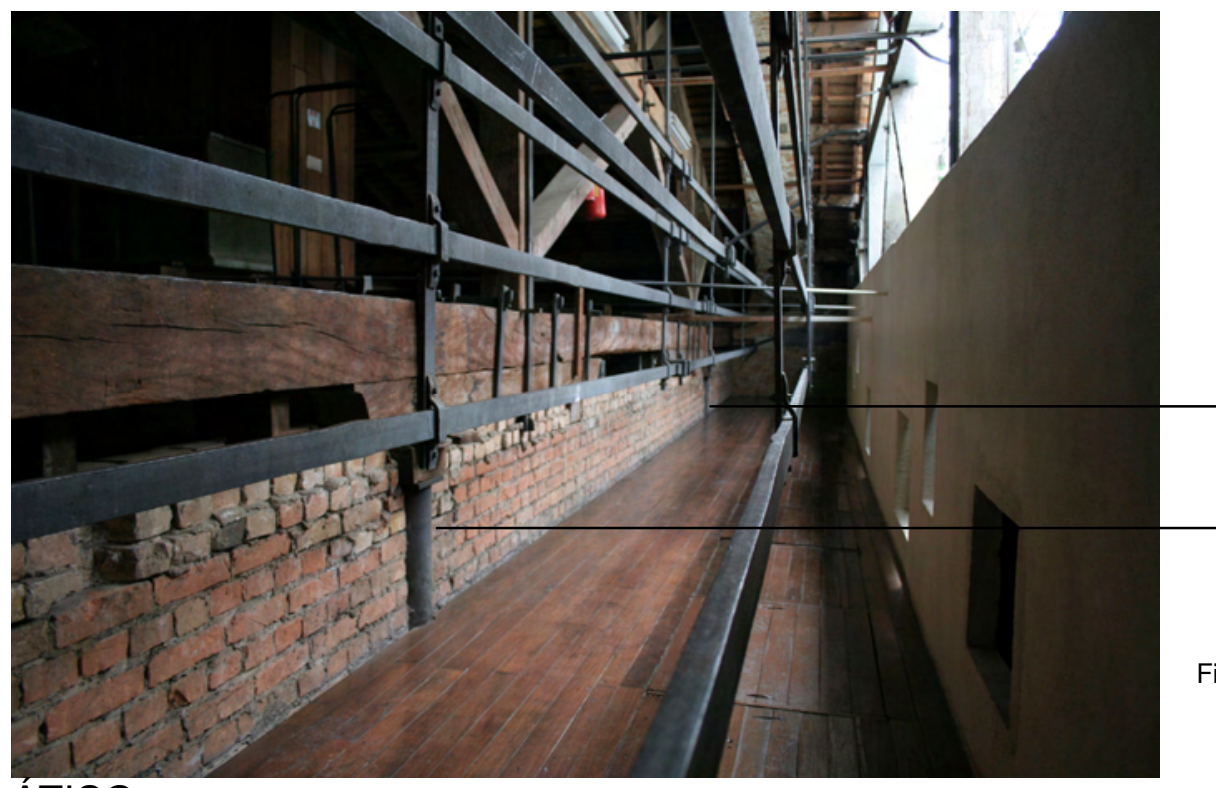

Duas Colunas

Cilíndricas

metálicas

Fig. 271

\section{ÁTICO}

Duas colunas cilíndricas metálicas situadas na parede da escadaria uma de cada lado ao nicho da escultura de D.Pedro

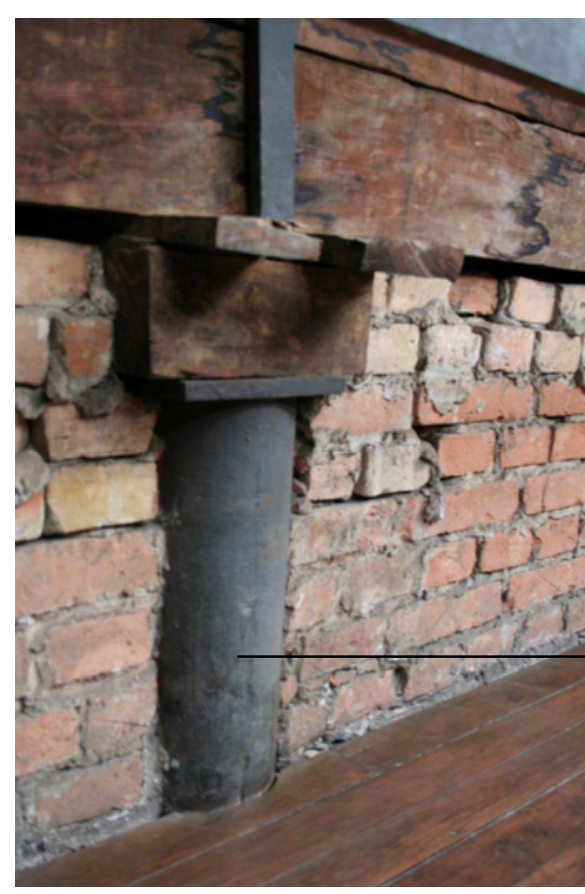

No Fundo Bezzi Pasta 3 Doc.136, no item Ferro Fundido é citado:

-2 colunas na parede de fundo da caixa da escada

-2 ditas

-2 ditas.

Tudo indica que são 6 colunas mas apenas 2 são visíveis

Detalhe coluna

Fig. 272 


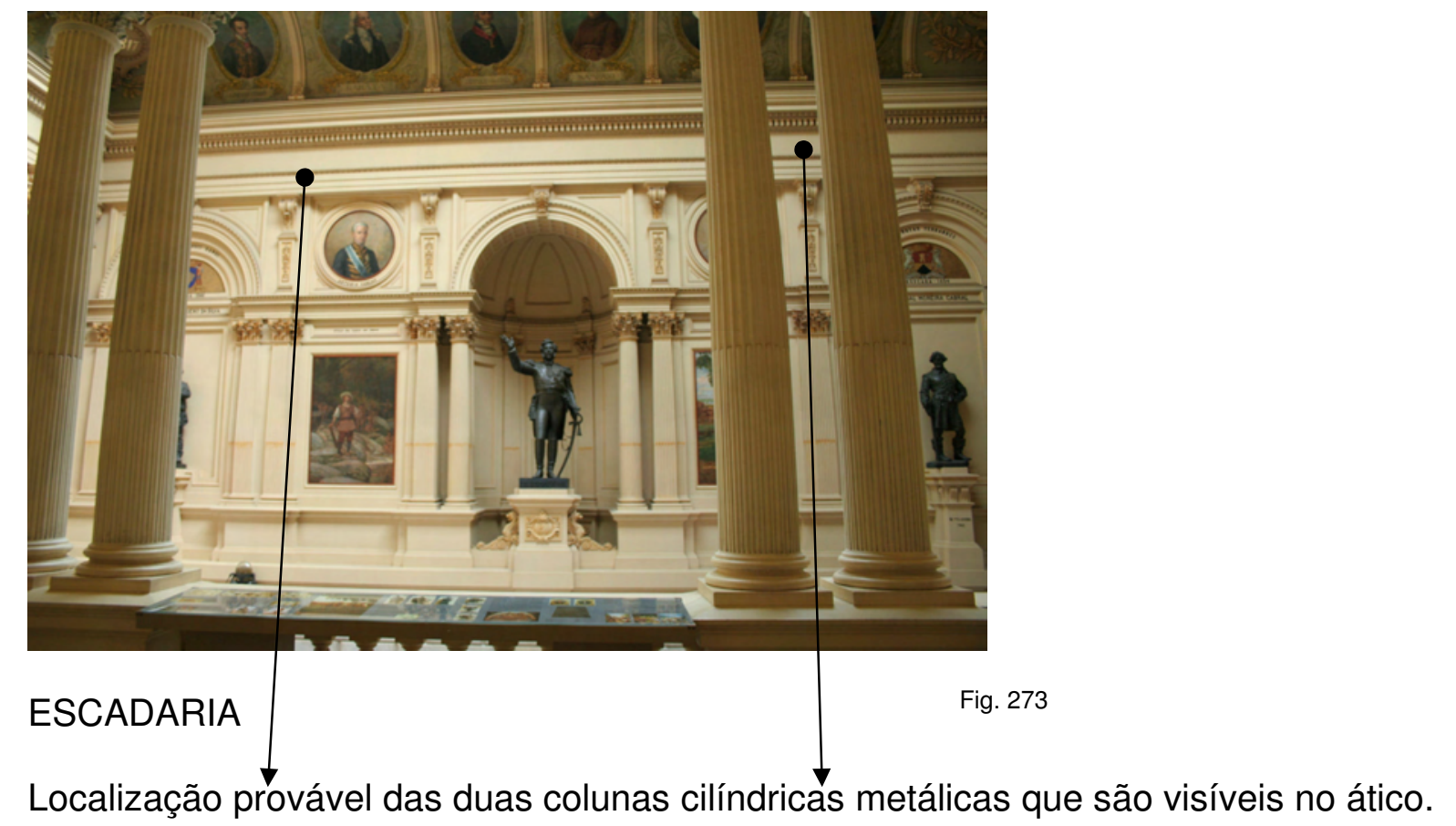

\section{ELEMENTOS EM BALANÇO - MÍSULAS E CORNIJAS}

Os elementos em balanço ou salientes da face das paredes como as cornijas, ou ornamentos isolados como as mísulas, são ancorados a elas utilizando peças de ferro.

No Documento 407, caderneta de obra, em Novembro de 1886, se refere às mísulas nas fachadas do Corpo Central norte e sul::

- Lages formando os esqueletos das mísulas das arcadas do pavimento térreo frente norte corpo central $(2,8 \times 0,9 \times 0,25): 3$ unidades

- Idem corpo central frente sul $(2 \times 0,9 \times 0,25): 3$ unidades

No Documento 25, Pasta 1, "Nota de algumas obras cujos preços não constam das especificações" que complementa esta informação.

- Mísulas ornamentadas, executadas com chapa de ferro retalhadas.

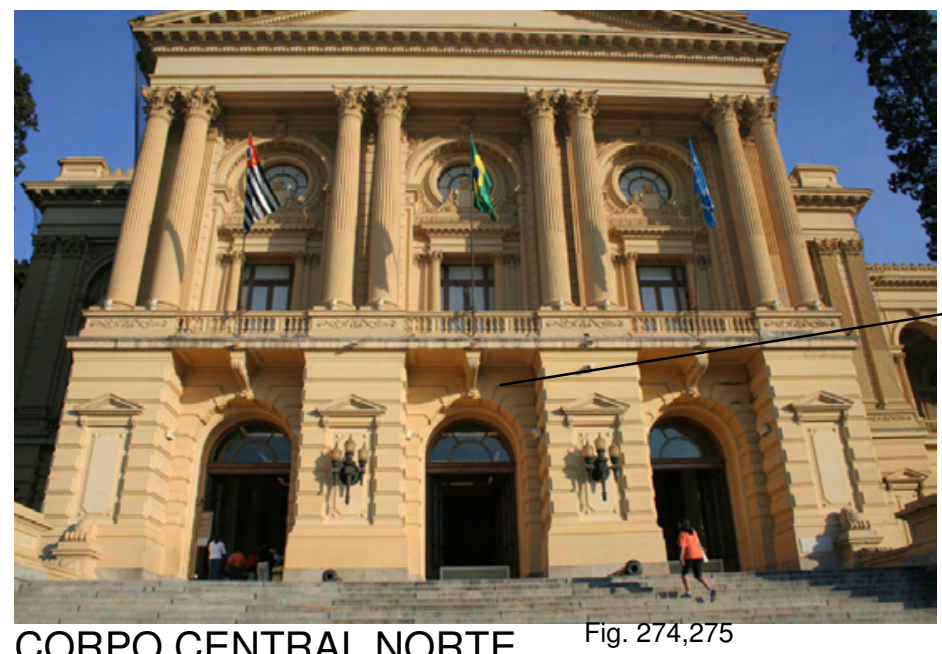

CORPO CENTRAL NORTE

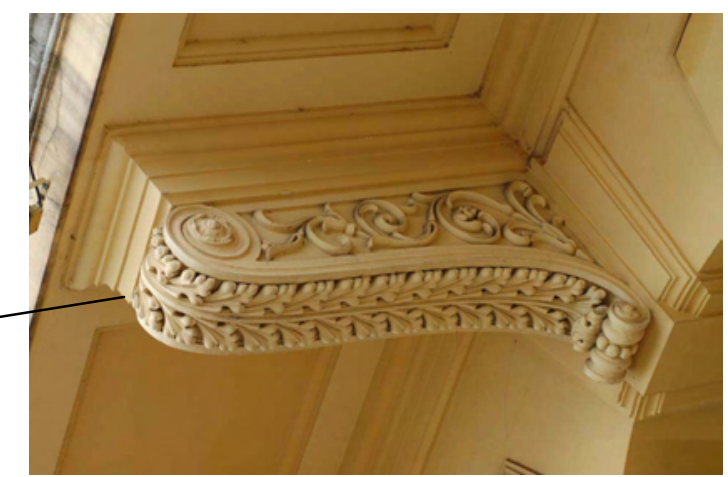

DETALHE MÍSULA 


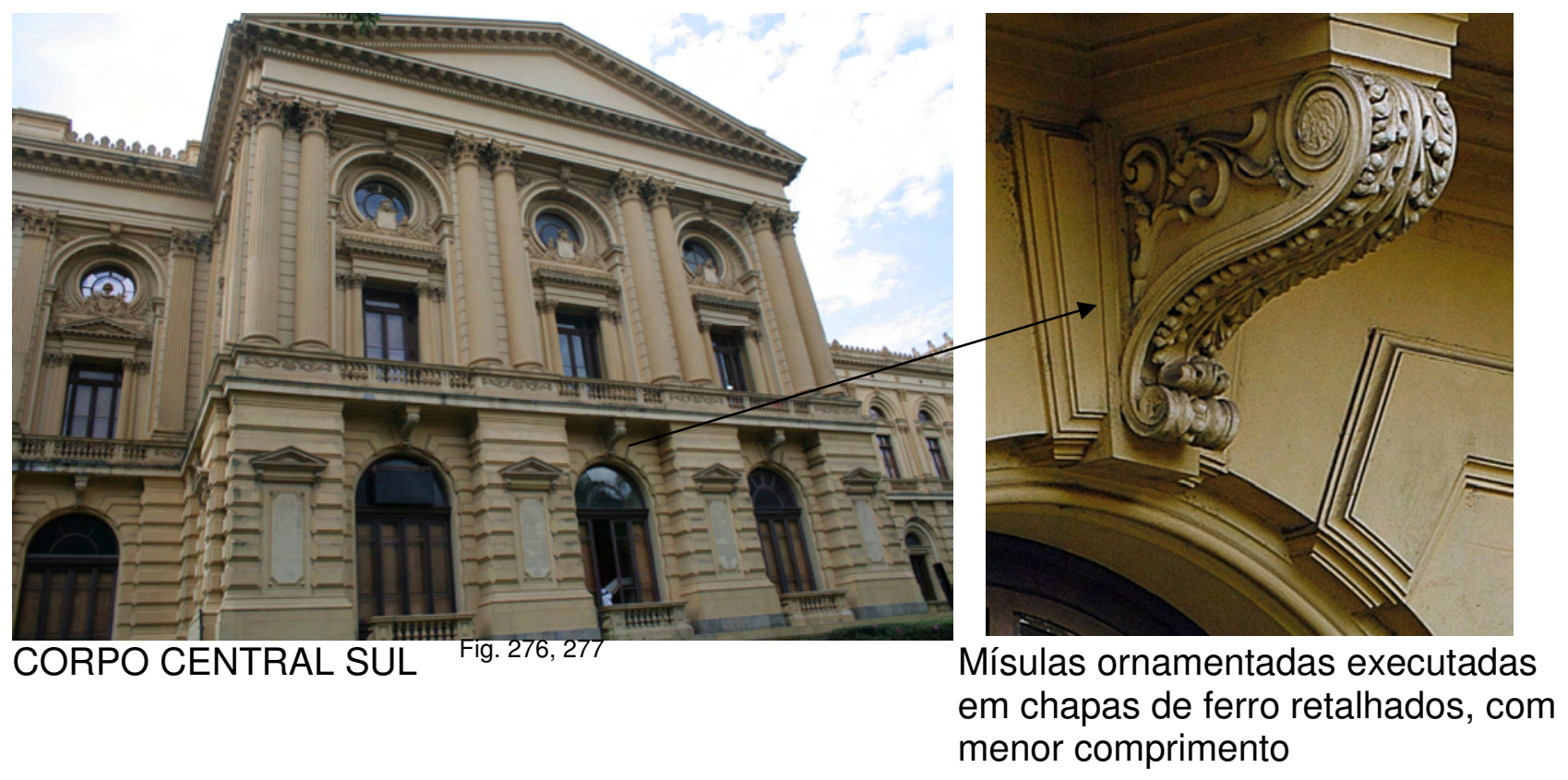

CORNIJA

No documento 7 da Pasta 1 ,Pucci especifica os preços de unidades das obras do ático do Corpo Central e há a seguinte citação:

- Cornija do ático feita inteiramente de cimento, moldado em formas de gesso, deixando no cubo os vãos que forem necessários.

O Documento 136, no item "Ferro Fundido e Ferro Batido", especifica a ferragem a ser utilizada na cornija na página 5 :

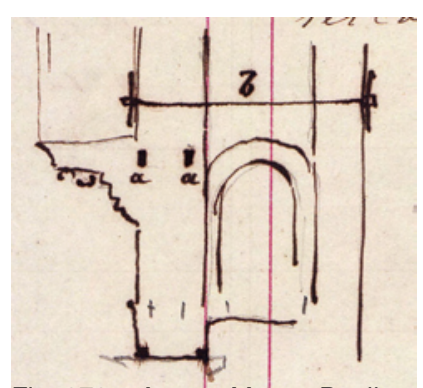

Corpo Central Frente Norte

- 2 travas na altura da gola da grande cornija de $22.65 \mathrm{~m}$ de ferro de 2" $\times 3 / 4$ " $=49.90 \mathrm{~m} \times 7.496 \mathrm{~K}$

4 chaves de $0.90 \times 1 " 1 / 2 \times 1 " 1 / 2=3.60 \mathrm{~m} \times \mathrm{K} 11.240$

- 7 travas para ligar o frontão com a parede interna de $2.80 \mathrm{~m}$ ferro de $2 " \times 3 / 4 "=21.70 \mathrm{~m} \times 7.496 \mathrm{~K}$

14 chaves de $1 " 1 / 2 \times 1 " 1 / 2=9.80 \mathrm{~m} \times 11.240 \mathrm{~K} "$

Fig. 278 - Acervo Museu Paulista 


\section{HISTÓRICO DO EDIFÍCIO E DAS INTERVENÇÕES PERÍODO DE 1823 A 1882 \\ Resumo em ordem cronológica dos documentos pesquisados}

\section{Antecedentes históricos da construção do Monumento do Ipiranga}

A idéia da construção de um monumento comemorativo da Independência no Ipiranga, é iniciada logo em seguida à proclamação da Independência da colônia em relação a Portugal. A medida irá fazer parte do conjunto de esforços de formação da identidade nacional, integrado ao processo mais amplo de construção do Estado Nacional, que caracteriza o século XIX no Brasil. Nesse sentido, o monumento destinado ao 7 de setembro, voltava-se para a fixação da data da Independência como um marco fundador do Estado brasileiro, constituindo-se numa referência para a construção de uma tradição e de uma história comum, que compartilhadas pelo imaginário coletivo, servissem de base para a identidade nacional. Nessa construção ideológica, São Paulo irá particularmente se consagrar, como lugar privilegiado de palco do nascimento do Estado nacional, qualidade essa reafirmada pela gestão posterior de Taunay. Não é de se estranhar, portanto, que foram justamente os políticos da região que tomaram, ainda em 1823, a iniciativa de construção do monumento.

Durante o longo período de 59 anos, de 1823 a 1882, são realizadas diversas tentativas com avanços e recuos. Apenas em 1875, com a instalação da Comissão presidida pelo Conselheiro Ramalho, encaminha-se finalmente a concretização do monumento. (QUADRO 1).

Em 1882, é escolhido o Engenheiro Bezzi para a realização do projeto e acompanhamento da construção. Em 1885 inicia-se a construção do Monumento à Independência. A construção, contudo, é paralisada já em 1890, sem estar concluída. Somente em 1894 são retomadas as obras, mas sem a presença do autor do projeto, cujo contrato foi rescindido em 1893. (QUADRO 2)

Neste item, a data de 1924 foi adotada como limite cronológico devido justamente ao fato de que a construção não havia sido terminada em 1890, quando as obras foram paralisadas. Em 1894, os trabalhos de construção são retomados e, ao mesmo tempo , já se tornava evidente a necessidade de conservação de certos setores do edifício que apresentavam danos.

No quadro abaixo de forma resumida são apresentados, de forma resumida, os principais fatos do histórico do edifício entre o intervalo de tempo referidos, com base em documentos pertinentes ao assunto encontrado ao longo da pesquisa.

QUADRO 1 - OS ANTECEDENTES DE 1823 A 1882

\begin{tabular}{|c|c|c|}
\hline DATA & EVENTO & REFERÊNCIA \\
\hline $\begin{array}{l}20 \text { de fevereiro de } \\
1823\end{array}$ & $\begin{array}{l}\text { Pedido de licença por Antonio da Silva Prado para abrir } \\
\text { subscrição para a construção de um monumento comemorativo } \\
\text { ao } 7 \text { de setembro, no Piranga. Enviado por José Bonifácio de } \\
\text { Andrade e Silva a D. Pedro I }\end{array}$ & $\begin{array}{l}\text { Guia da se } \\
\text { Museu Pau }\end{array}$ \\
\hline $\begin{array}{l}22 \text { de setembro } \\
\text { de } 1824\end{array}$ & $\begin{array}{l}\text { Presidente de São Paulo, Visconde de Congonhas do Campo, } \\
\text { pede contribuição das Câmaras Municipais de São Paulo para a } \\
\text { construção de monumento comemorativo da Independência. }\end{array}$ & $\begin{array}{l}\text { Guia da secção histórica do } \\
\text { Museu Paulista p.10 } \\
\text { Azevedo Marques, M. E., } \\
\text { Apontamentos históricos, } \\
\text { geográficos, biográficos, } \\
\text { estatísticos e noticiosos da } \\
\text { Província de São Paulo. } \\
\text { Tomo 1, p. } 345 \text {. }\end{array}$ \\
\hline $\begin{array}{l}27 \text { de setembro } \\
\text { de } 1824\end{array}$ & $\begin{array}{l}\text { O Presidente da Província Lucas Antonio Monteiro de Barros, } \\
\text { tentou dar começo a um Monumento, abrindo em toda a }\end{array}$ & $\begin{array}{l}\text { Revista do Museu Paulista } \\
\text { Vol. } 1 \text { - } 1895\end{array}$ \\
\hline
\end{tabular}




\begin{tabular}{|c|c|c|}
\hline & $\begin{array}{l}\text { província uma contribuição voluntária com aplicação especial a } \\
\text { essa grande obra. }\end{array}$ & $\begin{array}{l}\text { Hermann von lhering, - } \\
\text { História do Monumento do } \\
\text { Ypiranga e do Museu } \\
\text { Paulista p.10-16 }\end{array}$ \\
\hline 9 de abril de 1825 & $\begin{array}{l}\text { Estevam Ribeiro, Ministro do Império, determina ao presidente } \\
\text { da província que se erga, no "sitio do Piranga", o monumento em } \\
\text { memória da proclamação da independência. }\end{array}$ & $\begin{array}{l}\text { Guia da secção histórica do } \\
\text { Museu Paulista p.10 }\end{array}$ \\
\hline $\begin{array}{l}13 \text { de julho de } \\
1825\end{array}$ & $\begin{array}{l}\text { Capitão João Maria Chichorro comunica ao vice-presidente da } \\
\text { província a finalização dos ranchos para trabalho dos operários e } \\
\text { deposito de materiais. } \\
\text { "Não descobrimos a razão porque a obra, então começada, } \\
\text { deixou de progredir". Ingênuo este projeto de anonymo } \\
\text { architecto, com a sua fachadinha, com seus sessenta palmos } \\
(13,20) \text { de frente, a sua escadaria de quatorze degraus, } \\
\text { conduzindo os peregrinos da sagrada collina ao terraço } \\
\text { circundado de modestíssimo gradil, de onde se erguia um cubo } \\
\text { de alvenaria sobre o qual se elevava um cone, cujo vértice devia } \\
\text { ficar a uns } 14 \text { metros do solo, flanqueado de quatro grandes e } \\
\text { horrendos vasos e encimado pela coroa imperial [...] }\end{array}$ & $\begin{array}{l}\text { Guia da secção histórica do } \\
\text { Museu Paulista p.14 }\end{array}$ \\
\hline $\begin{array}{l}29 \text { de agosto de } \\
1825\end{array}$ & $\begin{array}{l}\text { O presidente da Província de São Paulo, Lucas Monteiros de } \\
\text { Barros, ordena à Câmara Municipal o pronto exame do local } \\
\text { conveniente para a construção do Monumento, no sítio do } \\
\text { Piranga. }\end{array}$ & $\begin{array}{l}\text { Guia da secção histórica do } \\
\text { Museu Paulista p.11 / } \\
\text { Azevedo Marques, M. E., } \\
\text { Op.citada, Tomo 1, p. } 345 .\end{array}$ \\
\hline $\begin{array}{l}03 \text { de setembro } \\
\text { de } 1825\end{array}$ & $\begin{array}{l}\text { Câmara responde à ordem presidencial confirmando escolha do } \\
\text { local e informando seu registro em ata: "[...] Sendo ahi accordou- } \\
\text { se unanimemente que o lugar mais próprio para este fim na } \\
\text { extremidade de huma linha de cento e oitenta e quatro braças, } \\
\text { tirada da dita ponte na direção de dez graus de Norte a Este [...]" }\end{array}$ & $\begin{array}{l}\text { Guia da secção histórica do } \\
\text { Museu Paulista p.11/ } \\
\text { Azevedo Marques, M. E., } \\
\text { Op.citada, Tomo 1, p. } 345 \text {. }\end{array}$ \\
\hline $\begin{array}{l}12 \text { de outubro de } \\
1825\end{array}$ & $\begin{array}{l}\text { Data designada pelo presidente da província para a colocação } \\
\text { da primeira pedra, o que foi feito em cerimônia solene. }\end{array}$ & $\begin{array}{l}\text { Guia da secção histórica do } \\
\text { Museu Paulista p.13 / } \\
\text { Azevedo Marques, M. E., } \\
\text { Op.citada, Tomo 1, p. } 345 \text {. }\end{array}$ \\
\hline $\begin{array}{l}29 \text { de março de } \\
1827\end{array}$ & $\begin{array}{l}\text { Consulta feita pelo Capitão João Maria de Souza Chichorro, } \\
\text { inspetor da obra, ao vice-presidente da Província, Antonio Neves } \\
\text { de Carvalho, a fim de saber se o material a ser usado na obra } \\
\text { seria pedra ou tijolo. O vice-presidente confirma o uso da pedra } \\
\text { de cantaria. }\end{array}$ & $\begin{array}{l}\text { Azevedo Marques, M. E., } \\
\text { Op.citada, Tomo 1, p. } 345 .\end{array}$ \\
\hline $\begin{array}{l}\text { Julho de } 1827 \text { a } \\
1836\end{array}$ & $\begin{array}{l}\text { Interrupção dos trabalhos iniciais de construção do Monumento } \\
\text { por razões desconhecidas. }\end{array}$ & $\begin{array}{l}\text { Azevedo Marques, M. E., } \\
\text { Op.citada, Tomo 1, p. } 345 .\end{array}$ \\
\hline 1831 & $\begin{array}{l}\text { Abdicação de D. Pedro I e rebeliões regenciais contribuem para } \\
\text { abandono da construção do Monumento. }\end{array}$ & $\begin{array}{l}\text { Guia da secção histórica do } \\
\text { Museu Paulista p.15 }\end{array}$ \\
\hline 1836 & $\begin{array}{l}\text { Câmara dos Deputados consigna } 4000 \$ \text { em leis orçamentárias } \\
\text { para construção do Monumento. }\end{array}$ & $\begin{array}{l}\text { Guia da secção histórica do } \\
\text { Museu Paulista p.15 / } \\
\text { Azevedo Marques, M. E., } \\
\text { Op.citada,Tomo 1, p. } 345 .\end{array}$ \\
\hline $1838 \epsilon$ & $\begin{array}{l}\text { Assembléia Provincial vota quotas orçamentárias destinadas à } \\
\text { construção do Monumento. }\end{array}$ & $\begin{array}{l}\text { Guia da secção histórica do } \\
\text { Museu Paulista p.15 / } \\
\text { Azevedo Marques, M. E., } \\
\text { Op.citada,Tomo 1, p. } 345 \text {. }\end{array}$ \\
\hline $\begin{array}{l}07 \text { de setembro } \\
\text { de } 1845\end{array}$ & $\begin{array}{l}\text { Mal. Manoel da Fonseca Lima e Silva, presidente da província, } \\
\text { pede à Assembléia que "votasse créditos" para a continuação } \\
\text { das obras adiadas. }\end{array}$ & $\begin{array}{l}\text { Guia da secção histórica do } \\
\text { Museu Paulista p.15 / } \\
\text { Azevedo Marques, M. E., } \\
\text { Op.Tomo 1, p. } 345 .\end{array}$ \\
\hline $\begin{array}{l}18 \text { de abril de } \\
1855\end{array}$ & $\begin{array}{l}\text { Lei provincial dispõe sobre a construção de um Monumento a } \\
\text { partir de subscrição a ser realizada por Comissão de nove } \\
\text { membros nomeada pelo presidente. Embora formada, Comissão } \\
\text { não chega a se reunir. }\end{array}$ & $\begin{array}{l}\text { Guia da secção histórica do } \\
\text { Museu Paulista p.19 / } \\
\text { Azevedo Marques, M. E., } \\
\text { Op.citada,Tomo 1, p. } 345 .\end{array}$ \\
\hline 1861 & $\begin{array}{l}\text { Instituição da Sociedade Zeladora da Glória do Ypiranga, pelo } \\
\text { presidente da província Dr. João Jacinto de Mendonça. }\end{array}$ & $\begin{array}{l}\text { Guia da secção histórica do } \\
\text { Museu Paulista p.19 / } \\
\text { Azevedo Marques, M. E., } \\
\text { Op.citada,Tomo 1, p. } 345 .\end{array}$ \\
\hline 1862 & $\begin{array}{l}\text { Senado aprova, em primeira discussão, projeto do Barão de } \\
\text { Antonina para a construção do Monumento. O projeto, contudo, } \\
\text { é rejeitado em segunda discussão. }\end{array}$ & $\begin{array}{l}\text { Guia da secção histórica do } \\
\text { Museu Paulista p.19 / } \\
\text { Azevedo Marques, M. E., } \\
\text { Op.citada, . Tomo 1, p. } 345 .\end{array}$ \\
\hline
\end{tabular}




\begin{tabular}{|c|c|c|}
\hline 1869 & $\begin{array}{l}\text { Comendador Jerônimo de Mesquita oferece à Câmara da Capital } \\
\text { donativo como incentivo à abertura de subscrição nacional. } \\
\text { Câmara elege Comissão de nove membros para administrar } \\
\text { recursos para a realização da obra. }\end{array}$ & $\begin{array}{l}\text { Guia da secção histórica do } \\
\text { Museu Paulista p.19 / } \\
\text { Azevedo Marques, M. E., } \\
\text { Op.citada,Tomo 1, p. } 345 .\end{array}$ \\
\hline 1872 & $\begin{array}{l}\text { Levantamento da planta do local por Carlos Rath. Exumação da } \\
\text { primeira pedra, presidida por Visconde do Bom Retiro. Esta foi } \\
\text { levada ao Palácio do Governo. }\end{array}$ & $\begin{array}{l}\text { Guia da secção histórica do } \\
\text { Museu Paulista p.20 / } \\
\text { Azevedo Marques, M. E., } \\
\text { Op.citada,Tomo 1, p. } 345 \text {. }\end{array}$ \\
\hline Maio de 1875 & $\begin{array}{l}\text { João Theodoro Xavier, então presidente da província, ordena } \\
\text { que a pedra seja reposta no Ipiranga. }\end{array}$ & $\begin{array}{l}\text { Guia da secção histórica do } \\
\text { Museu Paulista p.20 / } \\
\text { Azevedo Mareques, M.E. } \\
\text { Op.citada,. Tomo 1, p. } 345 .\end{array}$ \\
\hline $\begin{array}{l}15 \text { de agosto de } \\
1875\end{array}$ & $\begin{array}{l}\text { Instala-se a Comissão do Monumento presidida por Barão de } \\
\text { Ramalho }\end{array}$ & $\begin{array}{l}\text { Revista do Museu Paulista } \\
\text { Vol. } 1 \text { - } 1895 \\
\text { Hermann von Ihering- } \\
\text { História do Monumento do } \\
\text { Ypiranga e do Museu } \\
\text { Paulista p. } 10-16\end{array}$ \\
\hline Agosto de 1875 & $\begin{array}{l}\text { Muitas contribuições voluntárias permitem que se abram as } \\
\text { chamadas loterias do Ypiranga. Barão de Ramalho registra em } \\
\text { um de seus relatórios que a Comissão sempre pensou em } \\
\text { destinar o Monumento a um estabelecimento de educação e } \\
\text { instrução. }\end{array}$ & $\begin{array}{l}\text { Guia da secção histórica do } \\
\text { Museu Paulista p.20 }\end{array}$ \\
\hline $\begin{array}{l}15 \text { de dezembro } \\
\text { de } 1880\end{array}$ & $\begin{array}{l}\text { Comissão delibera que Monumento do Ipiranga se destinasse a } \\
\text { abrigar estabelecimento voltado à instrução primária. }\end{array}$ & $\begin{array}{l}\text { Revista do Museu Paulista } \\
\text { Vol. } 1 \text { - } 1895 \\
\text { Hermann von Ihering- } \\
\text { História do Monumento do } \\
\text { Ypiranga e do Museu } \\
\text { Paulista p.10-16 }\end{array}$ \\
\hline $\begin{array}{l}26 \text { de fevereiro de } \\
1881\end{array}$ & $\begin{array}{l}\text { Ocorre a primeira loteria concedida ao Monumento do Ipiranga } \\
\text { por Lei Provincial, dando como resultado a soma de mil contos } \\
\text { de réis. }\end{array}$ & $\begin{array}{l}\text { Revista do Museu Paulista, } \\
\text { Vol.1, } 1895 \text { pág. } 10 \text { / Guia da } \\
\text { seção histórica do Museu } \\
\text { Paulista, p. } 20 .\end{array}$ \\
\hline
\end{tabular}

\section{A ATUAÇÃO DO ENG. TOMMASO GAUDENZIO BEZZI DE 1882 A 1893}

A Comissão do Monumento do Ipiranga, presidida pelo Conselheiro Ramalho, abriu, no início de 1876, concurso destinado à apresentação de planos para o Monumento. Houve julgamentos de projetos tanto em São Paulo como no Rio de Janeiro, mas a seleção não foi levada a cabo.

Por outras vias, o projeto afinal escolhido foi o de Tommaso Gaudenzio Bezzi. Os documentos não esclarecem de forma completa o critério para a escolha de Bezzi para executar o projeto e a obra. Não é possível confirmar se houve indicação de autoridades como o Visconde do Rio Branco, antes de seu falecimento em 1880, ou mesmo de D.Pedro II. Isso porque Bezzi era amigo do filho do Visconde, o futuro Barão do Rio Branco.

As informações referentes à ocasião da escolha do projeto para o Monumento são apresentadas a seguir.

(FLYNN, 1990, p.14)

QUADRO 2 - A ATUAÇÃO DO ENG. BEZZI DE 1882 A 1893

\begin{tabular}{|l|l|l|}
\hline 3 de abril de 1882 & $\begin{array}{l}\text { Tommaso Gaudenzio Bezzi apresenta a planta de seu projeto, } \\
\text { que é aprovada pelo governo provincial. }\end{array}$ & $\begin{array}{l}\text { Revista do Museu Paulista, } \\
\text { Vol.1, 1895 pág.10 / Guia da } \\
\text { seção histórica do Museu } \\
\text { Paulista, p. 20. }\end{array}$ \\
\hline $\begin{array}{l}16 \text { de julho de } \\
1884\end{array}$ & $\begin{array}{l}\text { Lavra-se contrato entre o presidente da Província Luiz Carlos } \\
\text { Assumpção e Comissão do Monumento para a construção do } \\
\text { Monumento }\end{array}$ & $\begin{array}{l}\text { Galeria dos presidentes de } \\
\text { São Paulo, Vol I, p. 913 }\end{array}$ \\
\hline
\end{tabular}




\begin{tabular}{|c|c|c|}
\hline $\begin{array}{l}\text { Setembro } \\
1884\end{array}$ & $\begin{array}{l}\text { Nada se fez até setembro de } 1884 \\
\text { É rescindido o contrato com o arquiteto Bezzi e assinado outro, } \\
\text { pelo qual se pagaria ao arquiteto o tempo em que estivesse } \\
\text { empregado além dos quatro anos previstos para a construção da } \\
\text { obra. }\end{array}$ & $\begin{array}{l}\text { Revista do Museu Paulista, } \\
\text { Vol.1, } 1895 \text { pág. } 11 \text { / Guia da } \\
\text { seção histórica do Museu } \\
\text { Paulista, p. } 21 .\end{array}$ \\
\hline 1885 & $\begin{array}{l}\text { Relatório do Presidente da Província, José Luiz de Almeida } \\
\text { Couto, registra a escolha, mediante concurso organizado pela } \\
\text { Comissão, da proposta do empreiteiro Luiz Pucci, que também } \\
\text { recebe aprovação de Bezzi. Nesse ato é também designado o } \\
\text { dia } 25 \text { de março, aniversário da Constituição do Império, para a } \\
\text { inauguração as obras do edifício projetado. }\end{array}$ & $\begin{array}{l}\text { Relatórios da Província de } \\
\text { São Paulo. Relatório do } \\
\text { Exmo. Sr. Dr. José Luiz de } \\
\text { Almeida Couto Presidente } \\
\text { da Província de São Paulo } \\
\text { onde passou a } \\
\text { administração ao Vice- } \\
\text { presidente Exmo. Sr. Dr. } \\
\text { Francisco Antonio de Souza } \\
\text { Queiroz Filho, } 1885-\text { p.36 }\end{array}$ \\
\hline $\begin{array}{l}23 \text { de março de } \\
1885\end{array}$ & $\begin{array}{l}\text { Assembléia Provincial aprova lei que determina que o } \\
\text { Monumento se destine a um estabelecimento cientifico. }\end{array}$ & $\begin{array}{l}\text { Guia da secção histórica do } \\
\text { Museu Paulista p.2 / Revista } \\
\text { do Museu Paulista, Vol.1, } \\
1895 \text {, p. } 10 \text { a } 16\end{array}$ \\
\hline $\begin{array}{l}25 \text { de março de } \\
1885\end{array}$ & $\begin{array}{l}\text { Cerimônia de inauguração de obras do edifício. } \\
\text { Bezzi era excelente arquiteto, seu projeto completo comportava } \\
\text { um palácio da Renascença italiana em forma de E, com } \\
\text { belíssimo corpo central, nobre escadaria e pórtico, e duas alas. } \\
\text { Duas fachadas ambas ricamente decoradas, voltavam-se, a } \\
\text { principal para acidade de São Paulo, perpendicularmente ao eixo } \\
\text { do caminho do Cambucy, e a de traz, para a Serra, } \\
\text { aproximadamente na direção leste oeste.[..] } \\
\text { Bezzi se opondo à Comissão considerava inadequado alojar } \\
\text { crianças em lugar tão úmedo. Nas salas voltadas ao sul,eram } \\
\text { açoutadas pelo vento frígido encanados da Serra, com insolação } \\
\text { nula. Bezzi sacrificou a habitabilidade do edifício para conseguir } \\
\text { os efeitos arquitetônicos desejados: soberbo perystilo, } \\
\text { enobrecido por vigorosa colunata, monumental escadaria e } \\
\text { galeria, constituem um dos mais ricos e belos vestíbulos } \\
\text { existentes na América do Sul. }\end{array}$ & $\begin{array}{l}\text { Revista do Museu Paulista, } \\
\text { Vol.1, } 1895 \text { / Guia da } \\
\text { secção histórica do Museu } \\
\text { Paulista p.21 }\end{array}$ \\
\hline $\begin{array}{l}16 \text { de abril de } \\
1885\end{array}$ & $\begin{array}{l}\text { Presidente da província, José Luiz de Almeida Couto, expede } \\
\text { regulamento que determina execução de lei que dispunha sobre } \\
\text { matérias a serem ensinadas no Monumento. }\end{array}$ & $\begin{array}{l}\text { Relatórios da Província de } \\
\text { São Paulo. Relatório do } \\
\text { Exmo. Sr. Dr. José Luiz de } \\
\text { Almeida Couto Presidente } \\
\text { da Província de São Paulo } \\
\text { onde passou a } \\
\text { administração ao Vice- } \\
\text { presidente Exmo. Sr. Dr. } \\
\text { Francisco Antonio de Souza } \\
\text { Queiroz Filho, } 1885-\text { p.36 }\end{array}$ \\
\hline $\begin{array}{l}21 \text { de abril de } \\
1885\end{array}$ & $\begin{array}{l}\text { Luiz Pucci declara oficialmente início das obras, cujo término } \\
\text { estava previsto no prazo de trinta meses, conforme contrato. }\end{array}$ & $\begin{array}{l}\text { Relatórios da Província de } \\
\text { São Paulo. Relatório do } \\
\text { Exmo. Sr. Dr. José Luiz de } \\
\text { Almeida Couto Presidente } \\
\text { da Província de São Paulo } \\
\text { onde passou a } \\
\text { administração ao Vice- } \\
\text { presidente Exmo. Sr. Dr. } \\
\text { Francisco Antonio de Souza } \\
\text { Queiroz Filho, } 1885-\text { p.36 }\end{array}$ \\
\hline $\begin{array}{l}21 \text { de abril de } \\
1885\end{array}$ & $\begin{array}{l}\text { Aprovado, por ato presidencial, o traçado da via que ligaria a } \\
\text { Capital à localidade em que se construiria o Monumento. }\end{array}$ & $\begin{array}{l}\text { Relatório do Exmo. Sr. Dr. } \\
\text { Francisco Antonio de Souza } \\
\text { Queiroz Filho, Vice- } \\
\text { Presidente da Província de } \\
\text { São Paulo, onde passou a } \\
\text { administração ao Vice- } \\
\text { presidente Exmo. Sr. Dr. } \\
\text { Elias Antonio Pacheco e } \\
\text { Chaves } 1885-\text { p.32 }\end{array}$ \\
\hline 1885 & $\begin{array}{l}\text { A Comissão modificou o projeto original do arquiteto Bezzi com } \\
\text { planta em E, oficiando que fizesse reduções na planta já } \\
\text { aprovada e apresentar um orçamento que não exceda } 1000\end{array}$ & $\begin{array}{l}\text { Revista do Museu Paulista, } \\
\text { Vol.1, } 1895\end{array}$ \\
\hline
\end{tabular}




\begin{tabular}{|c|c|c|}
\hline & contos de réis & \\
\hline 1888 & $\begin{array}{l}\text { Planta da via que ligaria Monumento à Capital, elaborada por } \\
\text { Luiz Pucci, é aprovada por ato presidencial - partindo do } \\
\text { Monumento do Ypiranga segue em linha reta em direção a } \\
\text { Egreja Matriz da Freguesia do Braz, com uma quebra pouco } \\
\text { sensível ao atravessar a Rua da Mooca. Ficam assim satisfeitos } \\
\text { os desejos de Sua Majestade o Imperador, externados em sua } \\
\text { última viagem à Província no fim de } 1886 \text {. }\end{array}$ & $\begin{array}{l}\text { Relatório do Exmo Sr. Dr. } \\
\text { Francisco de Paula } \\
\text { Rodrigues Alves onde } \\
\text { passou a Administração da } \\
\text { Província de São Paulo ao } \\
\text { Exmo. Sr. Dr. Francisco } \\
\text { Antonio Dutra Rodrigues, } \\
\text { Vice-Presidente, no dia } 27 \\
\text { de abril de } 1888 \text {, p.48 }\end{array}$ \\
\hline 1889 & $\begin{array}{l}\text { Presidente da Província relata: } \\
\text { "Os estuques do interior e do exterior do edifício, a } \\
\text { ornamentação da caixa de escada; uma pequena parte do } \\
\text { interior das galerias e parte do exterior do pavimento térreo, e } \\
\text { bem assim os dois frontões do corpo central. A esquadria já está } \\
\text { concluída e em estado de ser convenientemente empregada; as } \\
\text { escadas de madeira já estão sendo assentadas nos pavilhões; a } \\
\text { de pedra de cantaria, que tem de ser posta na frente do edifício, } \\
\text { está em começo de construção; mas a grande escada de } \\
\text { mármore para o corpo central não será assentada senão depois } \\
\text { de concluído o edifício." }\end{array}$ & $\begin{array}{l}\text { Relatório apresentado à } \\
\text { Assembléia Legislativa } \\
\text { Provincial de São Paulo pelo } \\
\text { Presidente da Província Dr. } \\
\text { Pedro Vicente de Azevedo, } \\
\text { no dia } 11 \text { de janeiro de1889. }\end{array}$ \\
\hline $\begin{array}{l}7 \text { de setembro de } \\
1889\end{array}$ & $\begin{array}{l}\text { Relatório lido pelo presidente da Comissão do Monumento do } \\
\text { Ipiranga, Barão de Ramalho, informa que obras de construção } \\
\text { estavam adiantadas faltando pouco para a conclusão }\end{array}$ & $\begin{array}{l}\text { Revista do Museu Paulista, } \\
\text { Vol.1, } 1895\end{array}$ \\
\hline $\begin{array}{l}7 \text { de setembro de } \\
1889\end{array}$ & $\begin{array}{l}\text { Relatório lido por Barão de Ramalho informa que alas previstas } \\
\text { no projeto original de Bezzi não seriam construídas }\end{array}$ & $\begin{array}{l}\text { Guia da secção histórica do } \\
\text { Museu Paulista p.22 }\end{array}$ \\
\hline 1890 & $\begin{array}{l}\text { Paralisação das obras, que permanecem inacabadas. } \\
\text { "O Monumento foi considerado findo, mas o serviço foi } \\
\text { interrompido antes da conclusão das obras. Parece que foi por } \\
\text { falta de meios" }\end{array}$ & $\begin{array}{l}\text { Guia da secção histórica do } \\
\text { Museu Paulista p.22 / } \\
\text { Revista do Museu Paulista, } \\
\text { Vol.1, } 1895\end{array}$ \\
\hline \multirow[t]{2}{*}{ De 1890 até 1894} & $\begin{array}{l}\text { O Monumento fica desocupado e sem destino. } \\
\text { O Museu "esteve desocupado. Não se sabia que destino lhe dar. } \\
\text { Felizmente occorreu a idéia de para alli se transferir o Museu do } \\
\text { Estado. Pensara-se, neste ínterim, até em convertê-lo em } \\
\text { Pantheon! Mas muito havia a fazer então naquelle palácio [...]. E } \\
\text { quanto se cortara no projeto de Bezzi! Assim, a escadaria } \\
\text { monumental faltavam os complementos imaginados pelo } \\
\text { architecto, o emplacamento de mármore do fundo do vestíbulo, a } \\
\text { decoração pictorea e escultural, etc" }\end{array}$ & $\begin{array}{l}\text { Revista do Museu Paulista, } \\
\text { Vol.1, } 1895\end{array}$ \\
\hline & $\begin{array}{l}\text { Idéia de transformação do Monumento em sede do Museu do } \\
\text { Estado. Aprova-se dotação adicional para adequá-lo à finalidade. }\end{array}$ & $\begin{array}{l}\text { Guia da secção histórica do } \\
\text { Museu Paulista p.22 }\end{array}$ \\
\hline $\begin{array}{l}25 \text { de agosto de } \\
1892\end{array}$ & Lei considera Monumento próprio do Estado de São Paulo. & $\begin{array}{l}\text { Guia da secção histórica do } \\
\text { Museu Paulista p.22 }\end{array}$ \\
\hline 1892 & $\begin{array}{l}\text { O Congresso do Estado declara por lei N.76 de } 25 \text { de Agosto de } \\
1892 \text { o Monumento de Ipiranga e suas dependências } \\
\text { patrimônios do Estado. }\end{array}$ & $\begin{array}{l}\text { Revista do Museu Paulista, } \\
\text { Vol.1, } 1895\end{array}$ \\
\hline 1893 & $\begin{array}{l}\text { O Congresso vota leis destinando o Monumento para o Museu } \\
\text { do Estado (lei n.192 de } 26 \text { de agosto) e reorganizando o Museu } \\
\text { (lei n.200 de } 29 \text { de agosto). Foram executadas no início de } 1894\end{array}$ & $\begin{array}{l}\text { Revista do Museu Paulista, } \\
\text { Vol.1, } 1895\end{array}$ \\
\hline 1894 & $\begin{array}{l}\text { E declarado findo o contrato celebrado com o arquiteto Bezzi, } \\
\text { passando a administração do Monumento ao diretor geral do } \\
\text { tesouro, Coronel Pedro Gonçalves Dente. }\end{array}$ & $\begin{array}{l}\text { Revista do Museu Paulista, } \\
\text { Vol.1, } 1895\end{array}$ \\
\hline
\end{tabular}

No Fundo Bezzi encontra-se o Documento 354, da Pasta 6 de 1905, em que são anexados documentos que compõem a petição de indenização de Bezzi. A petição do engenheiro visava a obter os direitos devidos ao fato de seu contrato com a Comissão e o Governo ter sido rescindido ilegalmente e fora do prazo. Tem como título - Memorandum Explicativo dos Direitos do Engenheiro T.G. Bezzi, Oriundos da rescisão dos contratos do Monumento do ypiranga. Da página 5 a 11, o texto refere-se à época de contratação e 
definição do projeto e apontam algumas inexatidões em relação às datas citadas nos Anais do Museu, volume 1, apresentadas no QUADRO 2.

No ano de 1882 a Comissão anulou os concursos porque não satisfaziam as suas exigências, e na dúvida de fazer outros e encontrar as mesmas condições, encarregou Dr. Ignácio da Gama Cochrane, Superintendente das Obras Públicas de São Paulo, de indicar um engenheiro com capacidade para executar o projeto e fiscalizar a obra.

Em 25 de outubro de 1882 Cochrane encarregou Bezzi da execução do projeto, através de contratação verbal, e que não excedesse o orçamento de 800 contos de réis, e que pudesse ser aumentado futuramente quando houvesse verba disponível. É por isso que existe o modelo em gesso, em forma de um "E", e o que foi executado é em forma de "l".

Sobre a justificativa relativa ao modelo em gesso, temos que observar que, de acordo com os documentos de 1883, como será apresentado, trata-se da reprodução em miniatura do projeto com as alas na fachada detrás. O modelo em gesso foi executado no período de 1888 a 1890, mas a concepção deste projeto não tem uma data indicada em nenhum documento.

Quando foi publicado o edital a verba foi aumentada para mil contos de réis.

Em 25 de novembro de 1882 Bezzi apresentou os planos, que indicavam no meio da grande praça do Ypiranga o lugar para o Monumento Central, e em 3 de abril de 18830 Presidente da Província aprovou os planos com pequenas modificações.

Bezzi então foi contratado em 25 de maio de 1883 para dirigir e fiscalizar as obras executando fielmente seu projeto.

Após a contratação, a Comissão abriu concorrência para a empreitada da obra. Foram feitos dois concursos e o primeiro foi anulado. O segundo apresentou um orçamento que excedia 340 contos de réis do orçamento previsto de 1000 contos de réis, e então a Comissão pediu que Bezzi apresentasse reduções no projeto para dar início à construção. Bezzi resistiu à mudança pois considerava que causava danos ao Monumento e assim foi rescindido o contrato, e este, protestou através de ofício à Comissão em 22 de julho de 1884 e foi publicado em detalhes o fato nos jornais Correio Paulistano e Do Commercio do Rio de Janeiro.

Ao tomar posse do governo da Província Dr. José Luiz de Almeida Couto, solicitou à Comissão que desse início às obras e assim foi pedido a Bezzi as suas plantas, pois intencionavam que outro engenheiro as executasse.

Bezzi respondeu que as plantas não pertenciam à Comissão e que tinha sido contratado para fazer o projeto e executar a obra, não consentindo que fosse executada por outro.

Assinado um contrato a Comissão enviou um ofício com a data de 20 de outubro de 1884 no qual se comprometia se não fosse possível terminar o Monumento em quatro anos a partir de 25 de maio de 1883, os pagamentos continuariam até a conclusão das obras.

Em 23 de março de 1885 é firmado um contrato entre Comissão e o empreiteiro.

O documento 354 ainda se refere a um novo contrato assinado em 23 de dezembro de 1886 entre Bezzi e a Comissão, mas não esclarece o conteúdo. Na página 11 finaliza o texto, que no dia 9 de dezembro de 1892 o Presidente da Comissão notificou ao Engenheiro Bezzi, que em virtude do ofício do Ministro da Fazenda do Estado, datado de 6 de dezembro, rescindia-lhe os contratos estipulados para as obras do Monumento.

Até 15 de fevereiro de 1897, data da petição apresentada a Campos Salles, presidente do Estado, por Bezzi, o engenheiro teria realizado numerosas tentativas de acordo sem obter solução alguma.

Como registram os documentos apresentados, em 1890 a construção foi considerada finalizada. De acordo com o projeto, contudo, muito ainda faltava para concluir as obras. 
No período posterior à paralisação dos trabalhos, entre 1890 e 1894, é que o acordo firmado entre Bezzi e a Comissão do Monumento, representante do Governo, é rescindido. Nesse mesmo momento, o edifício, já levantado, ficou desocupado e sem função. No entanto, no ano de 1892 o Congresso declara o Monumento como propriedade do Estado e vota leis destinando o Monumento à sede do Museu estadual.

Dois anos mais tarde, em janeiro, é nomeado o primeiro diretor, Hermann von Ihering. Em 3 de fevereiro começa a funcionar no Monumento o Museu Paulista. É somente em 1894 que recomeçaram os trabalhos de conclusão da obra e de conservação, sendo que em 7 de setembro de 1895 o Monumento é inaugurado em cerimônia solene. Com a saída do Bezzi da direção das obras, após a rescisão de seu contrato, assume a administração do Monumento o Coronel Pedro Gonçalves Dente, Diretor Geral do Tesouro.

O período de 1882 a 1893 se refere à atuação de Bezzi na construção do edifício. Pelos ofícios e orçamentos que integram o Fundo Bezzi, podem ser verificadas as dificuldades que o engenheiro enfrentou com relação à Comissão, em particular no que se refere às alterações do custo, dos materiais e do prazo de término das obras.Desse modo, não conseguiu executar seu projeto em sua totalidade e passou por situações muito difíceis devido à rescisão ilegal do contrato. Além disso, não recebeu os pagamentos que considerava que lhe eram devidos quanto ao trabalho na construção, bem como na execução do modelo em gesso.

As alterações ocorridas nas obras, em relação ao projeto de Bezzi, surgiram no decorrer de sua execução, por razões técnicas ignoradas pelo autor do projeto antes da determinação do orçamento. Os ofícios abaixo transcritos demonstram sua exigências junto à Comissão, nem sempre atendidas incondicionalmente, com objetivos de manter a qualidade técnica dos materiais e da execução da obra. Também se manifestam nesses pedidos a dificuldade do transporte de materiais e a demora da chegada dos materiais importados, bem como a escassez da mão-de-obra especializada em certas circunstâncias, comprometendo o prazo estabelecido.

No documento transcrito a seguir, no item Chaves e Travas, Bezzi propõe um travamento nos muros (paredes) devido a pouca resistência do terreno que atinge em média 12 metros de profundidade, a qual Bezzi toma ciência somente quando é feita a sondagem do terreno e considera necessário o acréscimo de ferro para atender a tal fim..

Pasta 6 - Documento 363 - Fundo Bezzi, Acervo Museu Paulista

São Paulo, 26 de janeiro de 1887

Exmo. Sr. Presidente e Mais Membros da Comissão das Obras do Monumento do Ypiranga,

Tendo chegado a ocasião de se fazer a encomenda dos mármores e outros materiais, que, querendo a Exma. Comissão pode entrar na construção do Monumento do Ypiranga, e tendo em, de conformidade com o ofício de V.Exas., de 20 de Março de 1885 a obrigação de dirigir as obras de modo que as mesmas não passem o preço fixado de mil contos de Réis, submeto a V.Exas. a escolha dos materiais que aqui em seguida vem especificado:

$1^{\circ}$ Escada principal - Mármores $\left(\S 10^{\circ}\right)$

$7^{\circ}$ Ferro Batido do Commercio

Vigamento dos assoalhos das galerias, átrio e laboratórios que no atual orçamento são de madeira, para serem de ferro e duplo T com abóbadas de tijolos e ladrilhados (abobadilha)

8ํㅡㄹ Chaves e Travas

No calculo aproximativo de mil contos feito anteriormente à edificação não tinha incluído o ferro batido para ser empregado em peças de resistência como seriam as chaves e as travas chatas que 
fui obrigado depois a usar para o travamento dos muros em vista da pouca resistência que ofereceu o terreno, e isso para a economia na construção dos alicerces, os quais, a não ser as travas de ferro como estão colocadas no edifício, haveriam importado em avultada quantia, devendo pela má qualidade do terreno atingir a profundidade média de 12 metros. Como antes de se abrirem os alicerces e o poço de sondagem eu não conhecia a qualidade do mesmo, não podia prever esse aumento de despesa; portanto peço a V. Exas. de não incluir no orçamento de mil contos de Réis o preço das chaves e travas chatas de ferro batido acima indicados e que foram empregados na construção por especial autorização verbal do Exmo. Sr. Cons. Ramalho, assim como proponho mais o emprego dos mesmos materiais que forem necessários na continuação das obras para a maior segurança das mesmas e que, a importância dessas verbas não sejam incluídas no orçamento dos mil contos de Réis.

9o Ferro fundido sem ornamentação, como seriam as colunas e vigas e outras peças de resistência. Não tendo nas especificações o preço para o ferro fundido proponho a Exma. Comissão o de 420 Réis o quilo, posto em obra e assentado. Devendo-se empregar nas obras várias peças de resistência, e com o mesmo fim que as travas e chaves, peço a V.Exas. que a importância dessa verba seja calculada também fora do orçamento dos Mil contos de Réis.

A respeito do ferro batido e fundido empregado na construção como peças de resistência, há tempo tinha falado com o Exmo. Sr. Conselheiro Ramalho, declarando-lhe que era minha intenção não travar os muros; vendo-me depois da inspeção o terreno obrigado a travá-los no sentido da solidez das obras e economia dos alicerces. A Exma. Comissão tornando em consideração essas razões poderá com justiça excluir do orçamento dos Mil contos a importância desses materiais.

Bezzi

Bezzi propõe à Comissão outras alterações nos materiais de acabamento, tais como: assoalhos em espinha de peixe, as esquadrias do Corpo Central e suas laterais de jacarandá pardo envernizado, e não como as demais em pinho de riga pintada, os forros em estuque, revestimento da parte superior das cornijas e frontão, com ladrilho nacional para proteção da infiltração de umidade para dar maior resistência, duração e beleza à construção, que dentro do previsto anteriormente, ficaria em alguns locais de pouca duração e sem harmonia.

Ainda da mesma data, o segundo documento, um relatório do andamento das obras, não está assinado, mas provavelmente é de autoria do próprio Bezzi.

Pasta 4 - Documento 236 - Fundo Bezzi

São Paulo 14 de agosto de 1887 (primeiro ofício)

Ao Exmo. Presidente e demais membros da Comissão de Obras do Monumento do Ypiranga

De conformidade com as instruções verbais do Exmo. Barão de Ramalho proponho a Exma. Comissão a substituição de alguns materiais a empregar na construção do Monumento a fim de fazer a obra de modo que apresente a maior resistência duração e beleza sendo que a fazer a obra no limite dos mil contos de reis esta ficaria em algumas partes de pouca duração, e em outro sem a harmonia indispensável para um edifício d'esta ordem.

A substituição a fazer-se são as seguintes:

1. assoalhos que deveriam ser construídos de tábuas corridas, devem ser feitos pelo sistema de espinha ou zig-zag. A diferença de preço seria de $2 \$ 500$ por mais ao metro superficial e .. daria um total de 2:660\$000

2. esquadrias do salão de honra e salas laterais do mesmo corpo central que deverão ser de pinho de riga pintado, ser de jacarandá pardo com lustre de boneca e ferragens de metal amarelo ou branco, importando esta substituição à quantia de 13:843\$000 aproximadamente.

O preço desta esquadria seria assim de $85 \$ 000$ ao metro ... pela de 0,07 de espessura e de $75 \$ 000$ de 0,04 e 0,05 de espessura .

a.Os forros das salas e quartos do ... e do 1 andar que deveriam ser de pinho, seria de estuque de cal, importando estes a diferença de $25 \%$ para mais sobre o preço dos forros de pinho e sendo a diferença total de preços entre estes dois sistemas aproximadamente de 3:500\$000 
b.Autorização para revestir com ladrilhos nacionais de cimento a parte superior das cornijas e frontões para impedir ou ... as infiltrações das águas de chuva, sendo que pelo orçamento dos mil contos esta coberta deveria ser feita com argamassa de cal. O preço destes ladrilhos está indicado no $\$ 11$ Art. 4 das Especificações e os preços acima propostos foram feitos a meu pedido pelo empreiteiro de obras

Espero que V.Exa. dignarão resolver a respeito das substituições acima indicada para dar as obras maior andamento

Bezzi

São Paulo 14 de agosto de 1887 (segundo oficio)

Ao Barão de Ramalho

Em resposta ao prezado Ofício de V.Exa. com data 28 de julho cumpre-me informar V.Exa. que o trabalho da construção do Monumento do Ypiranga tem continuado até esta data regularmente e de conformidade com o contrato e ulteriores indicações que me forma dadas por V.Exa.

As obras estão muito adiantadas tendo já colocado todo o madeiramento dos telhados e as telhas as quais em parte estão sem emboçar.

A construção de tijolos está acabada nos pavilhões e galerias, faltando para ficar completo somente a platibanda do ático, frontão do Corpo Central e muros sustentáculos das escadas.

Está já em andamento o reboque exterior dos pavilhões e galerias e nestas já estão colocadas partes das colunas que formam a ornamentação das mesmas.

As esquadrias estão em construção fazendo a empregar todos os esforços para dar obras por concluídas no prazo ultimamente marcado

As quantidades de obras executadas e pagas constam das informações mensais que tenho remetido a V.Exa. para o controle dos respectivos pagamentos.

Espero desta ter sido satisfeito as Ordens de V. Exa. em outro ofício desta mesma data dirigido ao Exma. Comissão submetido os melhoramentos e indicações que a bem do serviço das obras do Monumento me aconselharam (ou aconselharão) (não está assinado)

Barão de Ramalho, presidente da Comissão do Monumento, envia um ofício em reposta a Bezzi, autorizando a redução da planta original em favor da resistência, duração e beleza do Monumento. A medida também visava à limitação do custo das obras, de modo a não exceder os 1000 contos de réis. No Documento 55, portanto, Barão de Ramalho autoriza a redução da planta. Observa-se que no Documento 63, a Comissão opta por materiais de mais qualidade e no Documento 361, comprova-se que mesmo assim, há um acréscimo no valor do orçamento inicial

Em 1885 registra-se a referência que a Comissão já havia modificado o projeto de Bezzi. Observa-se também que a redução da planta se deu em 1887. Nos documentos pesquisados, na realidade, as datas nem sempre coincidem. De qualquer modo, importanos hoje muito mais o fato em si e as conseqüências havidas na arquitetura do edifício, do que propriamente a absoluta precisão cronológica, embora os eventos são citados em conformidade rigorosa com as datas encontradas nos documentos originais.

Pasta 1- Documento 55

Ofício de Barão de Ramalho a Bezzi

São Paulo, 9 de setembro de 1887

Exmo.Sr.

Levei à presença da Comissão das Obras o ofício de 14 do mês próximo passado (agosto), em que V.Sa. propõem a substituição de alguns materiais por outros de melhor qualidade e maior valor, para serem empregados no edifício que se encontra na Colina do Ypiranga, de modo que este apresente maior resistência, duração e beleza ; porque nos limites dos mil contos de réis, ficará a obra, em algumas partes, de pouca duração e em outras sem a harmonia indispensável em um edifício desta ordem. 
Enviando a Comissão tão grave assunto, em sessão de 6 de setembro, deliberou que V.Sa., sem prejuízo da solidez e beleza do edifício, faça uso da autorização que tem para reduzir a planta aprovada, a não exceder o custo da obra a mil contos de réis: o que comunico a V.Sa. para seu conhecimento.

Pasta 1 - Documento 63

12 de setembro de 1887

Ofício do Barão de Ramalho a Bezzi

A Comissão declara:

1 - Que deve ser de mármore:

- A escada principal

- Os rodapés do átrio, da caixa de escada e das galerias

- As soleiras das portas e janelas

- Os pavimentos das galerias e átrios, que também podem ser de ladrilhos

- As bases das colunas e pilastras do grande átrio

2 - Que seja de ladrilho o assoalho dos laboratórios do pavimento térreo e de ferro duplo T, com abóbadas de tijolos e ladrilhos, os vigamentos dos assoalhos das galerias, átrios e laboratórios

3. Que ficam aprovadas as lajes de pedra dos balcões e galerias, as chaves e travas de ferro batido que foram colocados na construção do edifício para maior segurança do mesmo, podendo serem empregadas outras peças semelhantes que ainda sejam necessárias ... proposta do arquiteto e aprovação da Comissão, assim como as de ferro fundido, indicadas no Art 3 do referido ofício

4.Que quanto ao preço dos materiais que tem de ser empregados mas que não estão previstos nas especificações, ficam aprovadas as propostas pelo empreiteiro a saber por:

- 24 bases de colunas ...

- 16 bases de pilastras ...

- 4/4 de bases de pilastras ...

- 2 bases de pilastras ...

- Cada kilo de ferro fundido ...

5. Que não fará aumento para Orçamento de mil contos de réis em que está calculado o edifício

- A diferença entre o preço do material mais barato e o mais caro, previsto nas especificações e empregado na construção do edifício, com autorização da comissão

- O preço das peças de resistência, como travas, chaves e outras, feitas de ferro batido e peças de ferro fundido autorizadas verbalmente pela Comissão

- O preço das peças de resistência que foram feitas de ferro batido e empregadas na construção

para maior segurança do edifício por... proposta do arquiteto e aprovação da Comissão

Pasta 6 - Documento 361

São Paulo, 11 de julho de 1888

Ilmo. Sr. Conselheiro Barão de Ramalho

Presidente da Comissão de Obras do Monumento do Ypiranga ,

Em resposta ao oficio de V. Exa. com data 5 de julho do corrente ano cumpre-me informar a V. Exa. que as obras do Monumento acham-se bastante adiantadas relativamente aos meios que aqui no País podemos dispor tendo a Exma. Comissão. Já despendido com elas até o fim do mês passado à quantia de 759:737\$657 como consta oficialmente pelas folhas mensais de pagamento das obras executadas.

Pelo orçamento de mil contos de Réis fixados para se dar princípios aos trabalhos ter-se-ia podido realizar a construção do Monumento com o emprego de materiais baratos, mas tendo depois a Exma. Comissão decidido de não se fazer economias que pudessem com o tempo prejudicar a solidez e beleza do Monumento, foi autorizado a substituir materiais baratos por outros mais caros e mais próprios para a construção d'um Monumento e empregar vigas de ferro nas galerias, átrio e pavilhões, travas para maior segurança e estabilidade do edifício, substituir a grande escada de madeira por uma de mármore, as bases das colunas do átrio que eram orçadas de tijolos por outras de mármore, tetos de madeira por tetos de estuque, escadaria exterior da frente orçada para ser de cimento por outra de cantaria de aparelho, e vários outros aumentos de conformidade com os planos gerais 
aprovados pelo governo: importando estas obras as necessidades para se poder efetuar a inauguração a quantia aproximada de 460 contos de Réis.

As despesas feitas e para se fazerem ficam d'este modo distribuídas como aqui em seguido:

1ํ Quantia despendida na construção das obras até o fim do mês próximo:

$759: 737 \$ 657$

$2^{\circ}$ Quantia a despender para se acabar o edifício nas condições do orçamento de mil contos de Réis e aumentos necessários autorizados pela Comissão, compreendendo nesta despesa a fazer-se do Monumento de conformidade com a planta aprovada

$460: 000 \$ 000$

Total

$1: 219: 737 \$ 657$

D. G. por muitos anos a V. Exa.

Bezzi, Tommaso Engenheiro Chefe das Obras

O Documento 362 revela a preocupação de Bezzi com a execução apressada do emboço e reboco sobre paredes, pois não estavam suficientemente secas, aparecendo manchas causadas pela umidade no interior dessas paredes. Para atender ao prazo de conclusão da obra, a execução de atividades como essa pode ter sido comprometida, considerandose ainda a quantidade de operários, a complexidade e as dimensões da obra.

Pasta 6 - Documento 362

São Paulo, 15 de agosto de 1888

Ilmo. Exmo. Sr. Conselheiro Barão de Ramalho

Presidente da Comissão de Obras do Monumento do Ypiranga

Em resposta ao oficio de $V$. Exa. cumpre-me responder do modo seguinte.

As obras do Monumento estão muito adiantadas relativamente ao tempo que foram principiadas. A dificuldade de pessoal idôneo para a execução de certos trabalhos e o tempo que foi necessário gastar-se para fazer-se os diferentes serviços com aquela perfeição requerida pela natureza das obras tem aparentemente feito supor que não se trabalhava no Monumento com bastante atividade. É verdade que em tempos passados presumia com toda convicção que para o dia 7 de setembro do corrente ano haveria podido dar pronto o edifício em construção, mas apareceram alguns contratempos, próprios de uma obra desta natureza, e que está se construindo em lugar afastado da cidade e com bastantes dificuldades para os transportes dos materiais, dependendo pode-se dizer completamente do serviço da estrada Inglesa, a qual em certas épocas do ano não pode fazer com tanta prontidão o transporte de materiais.

É costume, quero dizer é de regra logo que os alicerces de uma grande construção estão feitos, de os deixar se consolidar algum tempo antes que levem por cima todo o peso dos muros. No Ypiranga não se fez isto, mas trabalhou-se com mais vagar para sem prejuízo da solidez dos alicerces, poder-se adiantar quanto do possível o serviço. Acabados os muros foi necessário começar-se o emboço e o reboco, e isto foi feito com tanta precipitação para não atrasar a conclusão das obras, que uma parte do coroamento do ático tanto do Corpo Central como dos pavilhões que foram revestidos pouco tempo depois de feitos, mancharam, inconveniente este devido a não estarem completamente secas as paredes que foram rebocadas.

As obras que faltam para a conclusão do Monumento são o emboço e reboco liso do interior do edifício, o ornamentado da caixa de escada, a pequena parte do interior das galerias e parte do exterior do pavimento térreo.

O ático que se deve construir não está assente no seu lugar, mas já está quase toda pronta sendo as madeiras do mesmo, desde muito tempo preparadas e em estado de serem fixadas na obra.

As escadas de madeira já estão se montando nos pavilhões, a de pedra da frente norte do Corpo Central está em andamento, tendo já chegado nas obras bastante peças de cantaria que lá mesmo se 
estão aparelhando. A escada de mármore do Corpo Central como não se pode colocar se não depois de todo o edifício completamente pronto, deixei-a para último, devendo nestes dias entregar os empreiteiro os desenhos de tamanho natural para serem mandados para a Itália onde tem que ser executados, sendo coisa muito fácil de fazer-se sem demora naquelas grandes fábricas, que dispõem de milhares de habilíssimos operários e poderosas máquinas.

O contra embasamento de cantaria que formará uma espécie de rodapés todo em volta do edifício, também nestes dias deve-se dar começo, tendo já dado ao empreiteiro as medidas das pedras necessárias para esse serviço.

Pelo estado atual das obras espero que para o mês de Março de 1889 estejam em condições de serem inauguradas.

Espero deste modo ter satisfeito ao pedido de V. Exa.

D. G. por muitos anos a V. Exa.

Bezzi, Tommaso Engenheiro Chefe das Obras

Nos documentos de 19 de agosto de 1889 e no de 5 de maio de 1890 , Bezzi se refere às alas perpendiculares à construção existente, que farão o edifício ter a forma de $\mathrm{E} e$ harmonia entre as partes, tal como foi projetado.

Ao que tudo indica, Bezzi não aceitava o fato de o edifício ficar incompleto. Ele deixou registrada sua insatisfação ao escrever sobre algumas fotografias.

Pasta 4 - Documento 227

19 de agosto de 1889

Ofício de Bezzi ao Barão de Ramalho - (como tudo indica)

Acusando recebimento do ofício de V.Exa. datado de 9 do corrente mês, tenho a honra de responder a alguns dos quesitos d'elle constando pela seguinte forma, deixando de tomar em consideração alguns outros, como por V.Exa. me foi passado, em vista da innoportunidade deste momento formular as respectivas respostas, conforme já tive a honra de verbalmente ponderar a V.Exa.

Em razão de não terem chegado alguns materiais da grande escada de mármore encomendada na Europa, nem podemos esperar que chegue a tempo de terem instalado até dia 7 de setembro vindouro, o edifício não pode ficar concluído nessa data, faltando ainda assentar a grande escada de mármore, os pavimentos ladrilhados do átrio e das galerias inferiores e superiores, devendo serem estes os últimos serviços a realizar-se; construir as rampas laterais ao Corpo Central que serão ingresso aos veículos para dentro do Monumento, serviço este que até o presente não pode ser efetuado por depender da conclusão de outras obras no lugar onde devem ser construídas as supra mencionadas rampas; construir e colocar a clarabóia da caixa da grande escada do Corpo Central a que ainda até agora não pode ser efetuado, dependendo também este serviço da prévia construção do grande ático do Corpo Central, a clarabóia superior e conclusão do telhado, o que por sua vez só podia ser feito depois de terminado o ático, que há pouco tempo ficou concluído, além destes faltam alguns pequenos serviços que pela mesma dependência de outras mais importantes acima indicados, só poderão ser realizadas ulteriormente.

Em vista do exposto, as obras que até o presente tem sido autorizadas pela Comissão e acham-se em via de execução, só poderão ser definitivamente ultimado em 31 de dezembro do corrente ano, de cuja data em diante poderá ser fixado com segurança o dia da inauguração do Monumento.

Cumpre-me ainda ponderar a V.Exa. que quanto às obras já autorizadas que acima indiquei, terminadas, como ficaram (ficarão) em 31 de dezembro, todavia faltando-lhes os complementos decorativos já projetado como estátuas, grupos alegóricos decorativos da parte superior do Corpo Central, altos relevos dos grandes tímpanos respectivos e pinturas decorativas adequadas no átrio, caixa de escada, Salão de Honra e interno das galerias.

Quanto porém ao projeto geral na forma por assim dizer confeccionada compreende-lhe além das construções atualmente autorizadas, mais dois corpos iguais nas laterais, projetados perpendicularmente aos mesmos já existentes, de modo que a construção total do Monumento venha a ter a forma de um $E$ na sua frente principal e bem assim galerias térreas que partindo das frentes laterais dos pavilhões, venham a circunscrever a praça principal, em cujo centro devem ser erigido um monumento comemorativo. Restará finalmente realizar o projeto por mim delineado para abertura da alameda perpendicular ao Monumento até o córrego do Ypiranga, bem como o projeto das ruas, praças e jardins da nova povoação d'aquela localidade. 
Julgo desta forma ter satisfeito as requisições que atualmente é possível satisfazer, como já verbalmente tive a honra de informar a V.Exa.

Pasta 1 - Documento 39

São Paulo, 5 de maio de 1890

Carta de Bezzi ao Presidente e membros da Comissão de Obras do Monumento do Ipiranga

Cumprindo as ordens recebidas de V.Exa. remeto-lhe conjuntamente com este ofício um mapa demonstrativo do estado atual das obras executadas, e a executar-se, como também a respeito dos pagamentos feitos e a fazerem-se ao empreiteiro, pelas obras já executadas de conformidade com os contratos de empreitada celebradas pelo mesmo com V. Exa.

As obras até agora executadas e que o Sr. Eng. Pucci, empreiteiro das mesmas reclama os pagamentos, foram construídas de conformidade com os meus desenhos e indicações, e com os materiais indicados nas minhas Especificações, que servirão de base ao contrato de empreitada de 23 de maio de 1885 e subseqüentes termos posteriormente assinados, entendo portanto ao dito empreiteiro o direito de receber da Exma. Comissão de Obras do Monumento a qual V.Exa. é seu D. Presidente a quantia integral, compreendido o movimento de terra, de 349:673\$941 correspondente ao importe das obras até hoje executadas, sendo desta soma já deduzidas as quantias por ele empreiteiro recebidas mensalmente por contas das mesmas obras.

As obras que fazem parte dos contratos de empreitada do Sr.Eng.Luiz Pucci e que ainda restam a executar-se não incluindo o movimento de terra importam em 43:314\$174.

O movimento de terra que resta a executar-se para o nivelamento total da praça principal e terreno adjacente de conformidade com o projeto aprovado e em parte executado importa em 59:177\$448.

$[\ldots]$

Pelos dois corpos iguais aos laterais projetados perpendicularmente aos mesmos já existentes, de modo que a construção total do Monumento venha a ter a forma de um E na sua frente principal, como mostra a planta junto, dando estas obras projetadas necessárias para que o edifício Monumento esteja completo e com todas as partes em harmonia entre si, é necessário aproximadamente a despesa de 760:000\$000.

Para se levar os encanamentos de água da Cantareira até o Monumento é necessária, segundo consta que me foi apresentada pela respectiva companhia, a despesa de 23:677\$000. Para levar os encanamentos do gaz até o Monumento, é necessária a despesa de 236:344\$000.

Os trabalhos do projeto de delineação e de demarcação de ruas, praças e linhas de bonde para a nova povoação do Ipiranga, os quais me foram pedido pelo Exmo. Sr. Governador deste Estado e por V. Exa. estão em andamento e logo que ficarem prontos os remeterei a V.Exa.

Julgo deste modo ter fielmente cumprido as instruções de V.Exa. e dos Membros da Comissão, e embora persuadido que V.Exa. aceitem este meu trabalho como corretíssimo, peço entretanto a V.Exa. o favor de fazer submeter pelo Exmo.Sr. Governador ao IImo. Superintendente das Obras Públicas com o fim de salvar no futuro a minha responsabilidade.

Bezzi, Tommaso Gaudenzio Arquiteto e engenheiro em chefe das obras do Monumento do Ipiranga

Após os diversos ofícios enviados à Comissão reclamando os valores pagos na execução do modelo em gesso e dos pagamentos referentes ao tempo trabalhado e à manutenção deste até a conclusão das obras, nota-se à indignação de Bezzi diante das frustrações no Documento 365.

Pasta 6 - Documento 365

Dados biográficos de Bezzi escritos por ele próprio

$[\ldots]$

O Jornal do Comercio de Julho de 1912, grande jornal do Brasil, [...] a mim somente censurou, iniciando deste modo a campanha jacobina que provocou a ilegal e violenta rescisão dos contratos em corrente execução - que havia firmado para projetar e dirigir os trabalhos do palácio do "Ypiranga", comemorativo da Independência do Brasil.

A minha simples conduta italiana me fez assim sofrer a mais tenaz e dura guerra possível. Não me pagaram nem menos um dinheiro aos quais eu tinha direito, pela rescisão dos contratos. Todas as minhas combinações para a execução de vários outros trabalhos do estado, já bem encaminhados, faliram e depois de haver despendido, na esperança de tempos melhores, toda a minha economia, 
para sustentar dignamente a minha numerosa família, visto que a hostilidade continuava, cumpri depois de meses, abandonar São Paulo para fixar-me no Rio de Janeiro, onde fiquei por muitos anos consecutivos, sempre perseguindo continuar a lutar contra todas as dificuldades imagináveis.

Este conjunto complexo de acontecimentos não são esclarecidos completamente nos documentos. Mas como conseqüência, pode-se considerar que o edifício teve duas grandes perdas:

- A primeira quando foi reduzida a planta em E que apresentava harmonia e equilíbrio entre os volumes, tal como concebida.

Pena foi, e muita, que se não houvesse procedido a conclusão do palácio de Bezzi. Em vez do pequeno pavilhão que magramente coroa o alto da colina, em virtude tão vasto quanto majestoso, fronteiro a mais dilata e grandiosa perspectiva, possuiria São Paulo o mais imponente e harmonioso conjunto arquitetônico não só do Brasil como da América do Sul.

Temos aliás a convicção profunda de que, mais annos menos annos, fará o Governo de São Paulo executar o projeto integral de Bezzi, construindo os corpos avanádos que estão faltando ao palácio do Ypiranga e ao nobre conspecto de seu soberbo parque.[...]

(TAUNAY, GUIA DA SECÇÃO HISTÓRICA DO MUSEU PAULISTA, 1937,p.23)

- A segunda quando o Engenheiro Bezzi foi dispensado da execução da obra, que havia projetado e para a qual havia realizado os cálculos das soluções estruturais, bem como tomado os cuidados pertinentes à sua execução. As propostas de Bezzi são coerentes com as características da técnica construtiva, demonstrando sólido conhecimento acerca da técnica construtiva, inclusive da evolução que este conhecimento teve no decorrer do século XIX

OS PROJETOS PARA O MONUMENTO

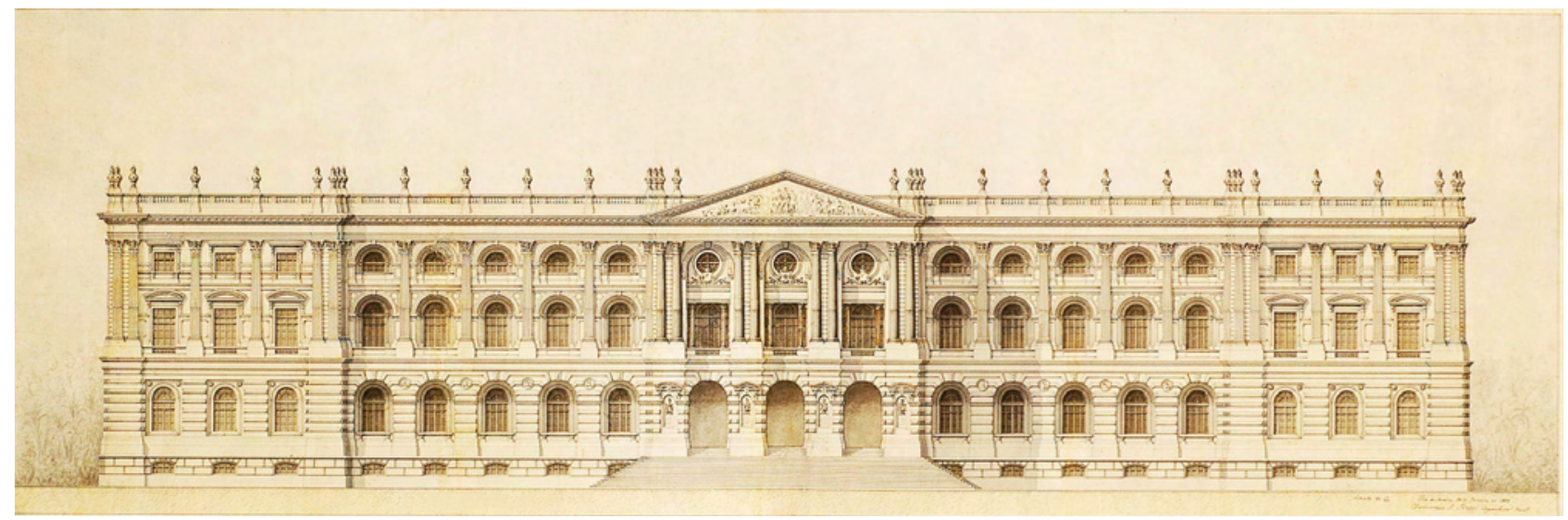

Fig. 279 -Fundo Bezzi - Acervo Museu Paulista

IC 15158 - FACHADA PRINCIPAL

PROJETO DE 1883 - como tudo indica, o primeiro a ser apresentado.

As plantas:

- IC 15158: Fachada principal

- IC 13083: Planta de implantação

- IC 15154: Planta do pavimento colocado encima do embasamento

- IC 15156: Planta do pavimento nobre,

Tem a mesma legenda, com os mesmos tipos de letra manuscrita, mesma data, e assim se referem ao mesmo projeto. Supõe-se que este projeto foi a primeira proposta 
apresentada por Bezzi, antes mesmo de transferir sua residência do Rio de Janeiro para São Paulo.

\section{Legenda:}

Rio de Janeiro 22 de janeiro de 1883.

Tommaso G. Bezzi - engenheiro civil

Obras monumentais commemorativas da Independência do Império

Planta geral das obras monumentais do Ipiranga sendo em tinta preta o que vai ser executado na atualidade e em tinta rosa o que poderá ser aumentado no futuro.

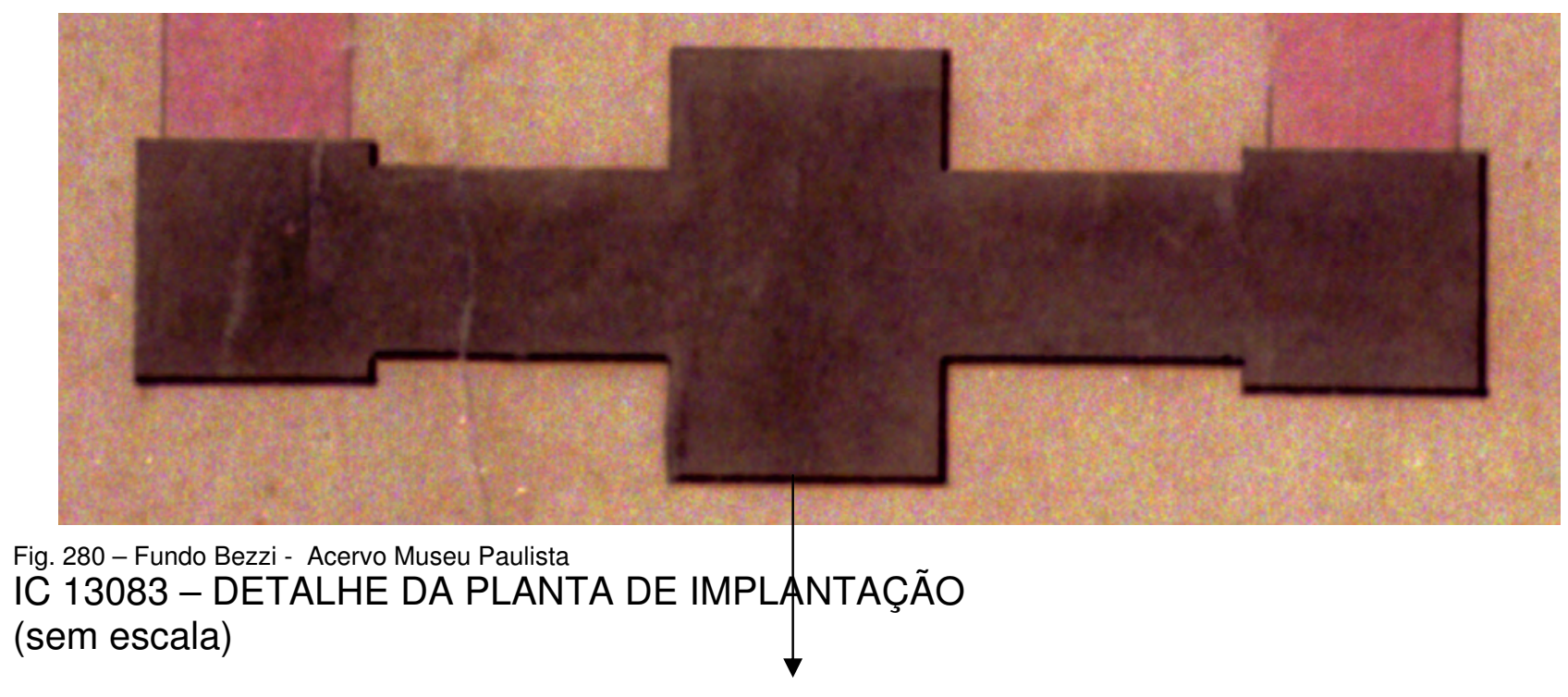

Fachada Principal: voltada para a cidade

IC 13308 - A IMPLANTAÇÃO DO EDIFÍCIO:

Observa-se que o Corpo Central tem a forma de um retângulo, não possui, nesse momento as Laterais do Corpo Central.

Nesse projeto as alas perpendiculares ao corpo inicial, são localizadas na face sul, posterior. Na fachada principal, como se verifica na imagem de IC 15158, as alas não são representadas. 


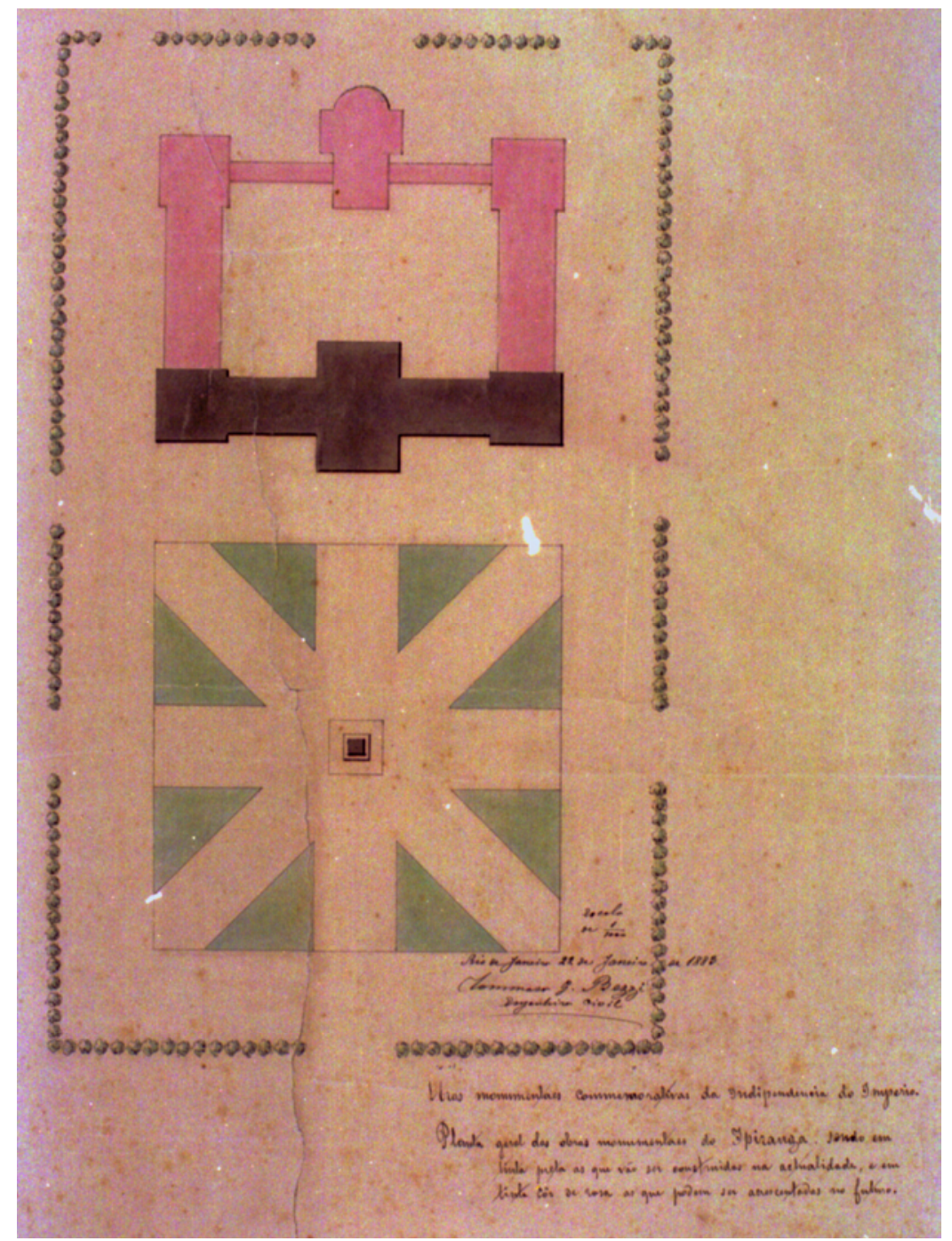

Fig. 281 - Fundo Bezzi - Acervo Museu Paulista IC 13308 - PLANTA GERAL

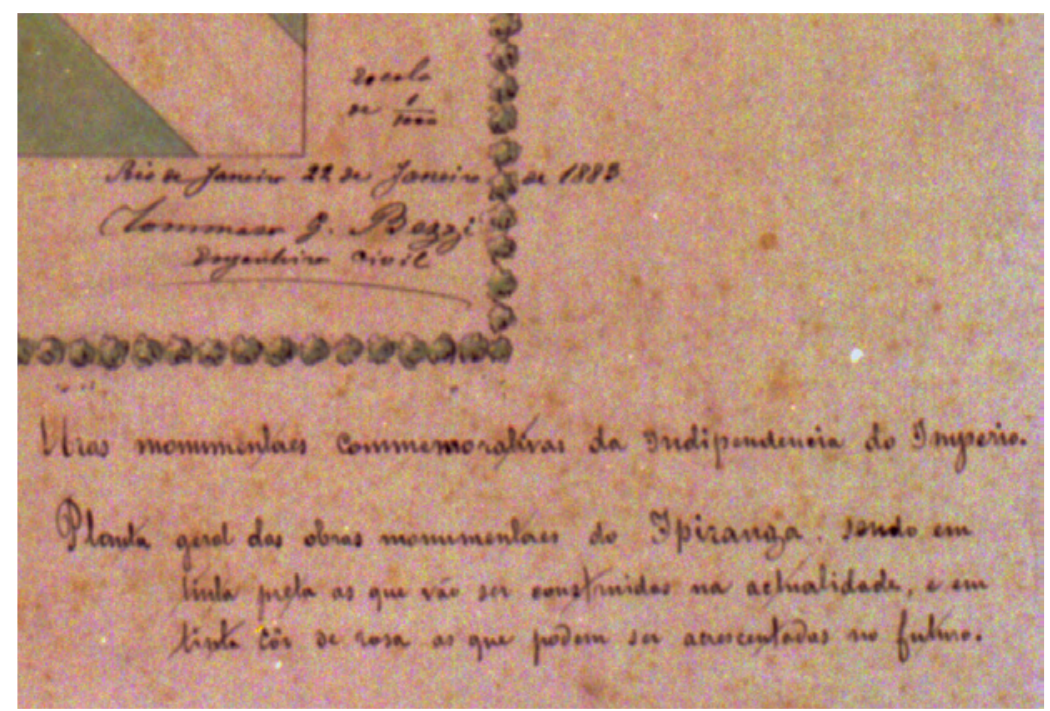

Fig. 282 - Fundo Bezzi - Acervo Museu Paulista

IC 13308 - PLANTA GERAL - DETALHE DA LEGENDA 
Linhas tracejadas cor de rosa, representando as alas na fachada sul a serem executadas no futuro

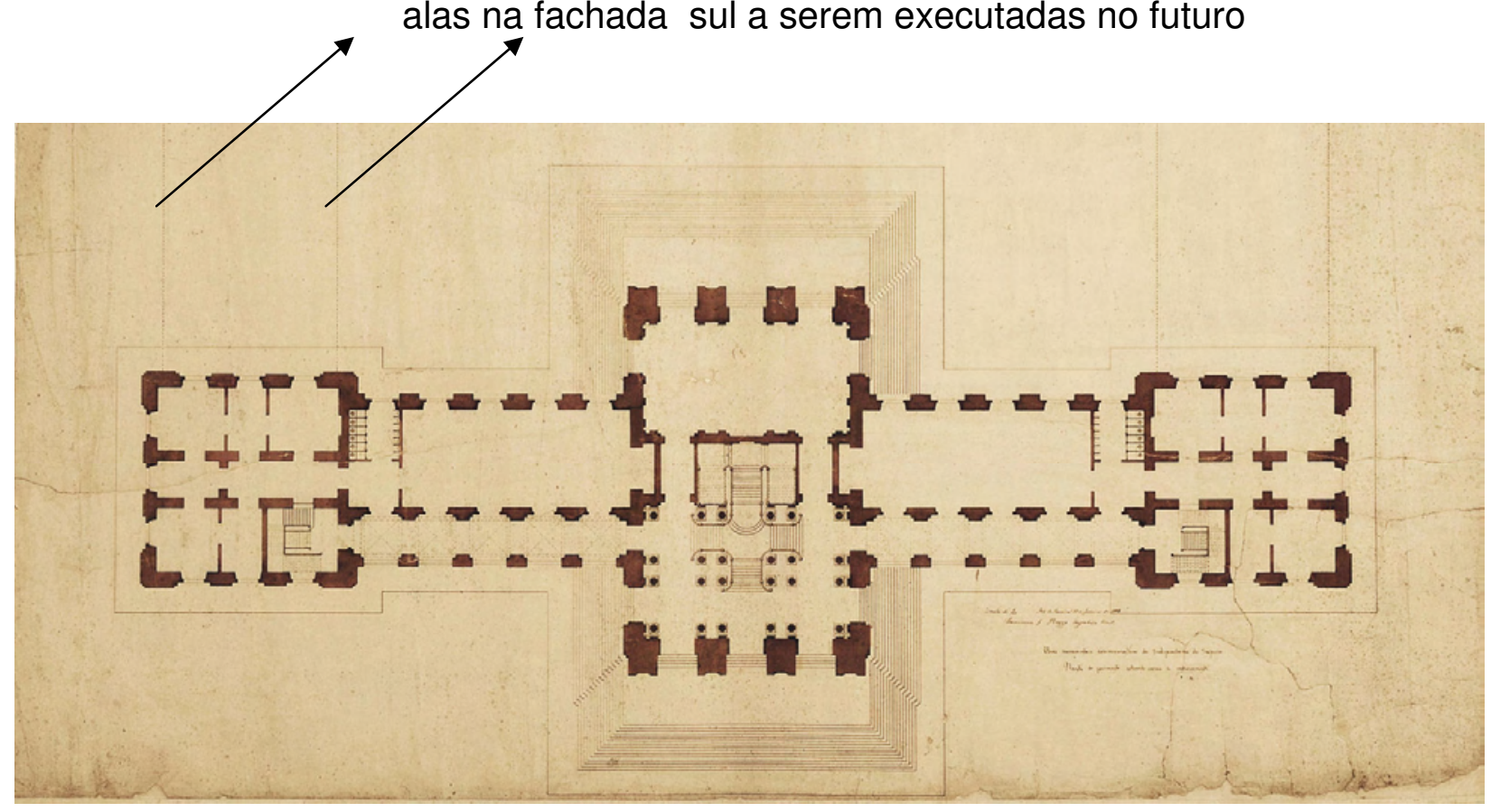

Fig. 283 - Fundo Bezzi - Acervo Museu Paulista

IC 15154 - PLANTA DO PAVIMENTO COLOCADO ENCIMA DO EMBASAMENTO

Rio de Janeiro 22 de janeiro de 1883.

Tommaso G. Bezzi - engenheiro civil

Obras monumentais commemorativas da Independência do Império

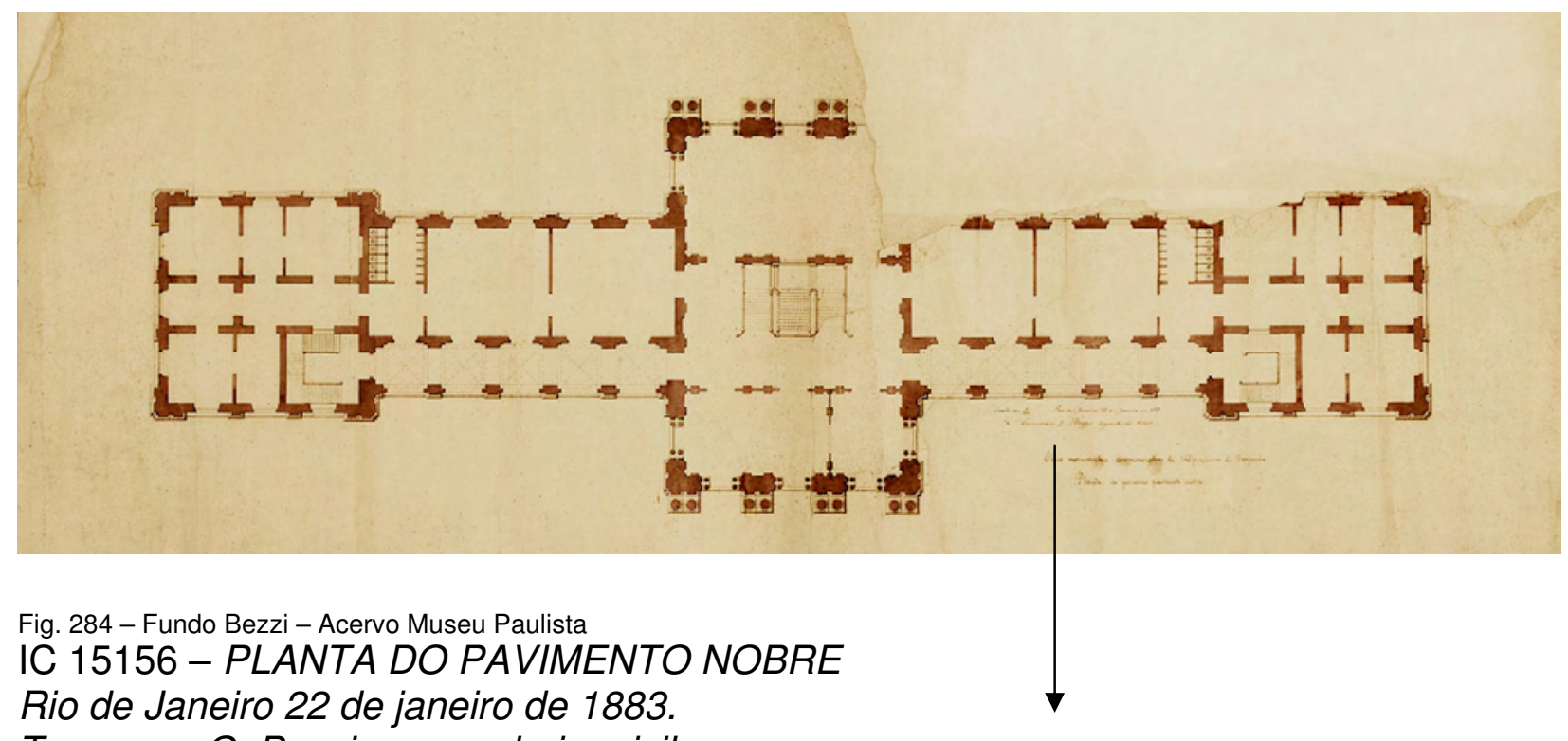

Tommaso G. Bezzi - engenheiro civil

Obras monumentais commemorativas da Independência do Império 


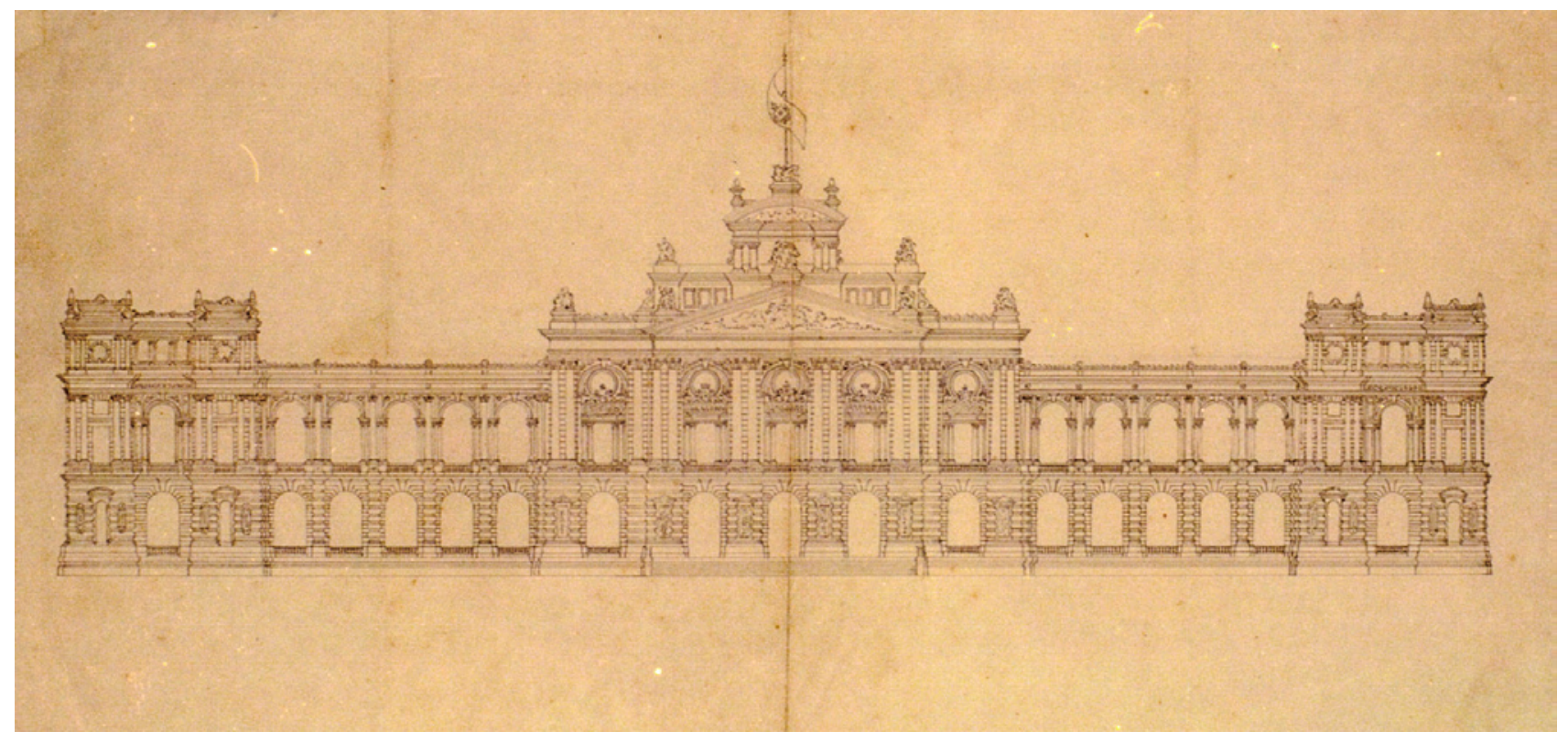

Fig. 285 -Fundo Bezzi - Acervo Museu Paulista

IC 13108

Outro projeto com as laterais do Corpo Central com uma solução semelhante ao que foi executado, diferenciado no acabamento do ático. Não há legenda, data ou outra referência.

\section{PROJETO EXECUTADO}

O projeto com as laterais do Corpo Central, tal como foi executado.

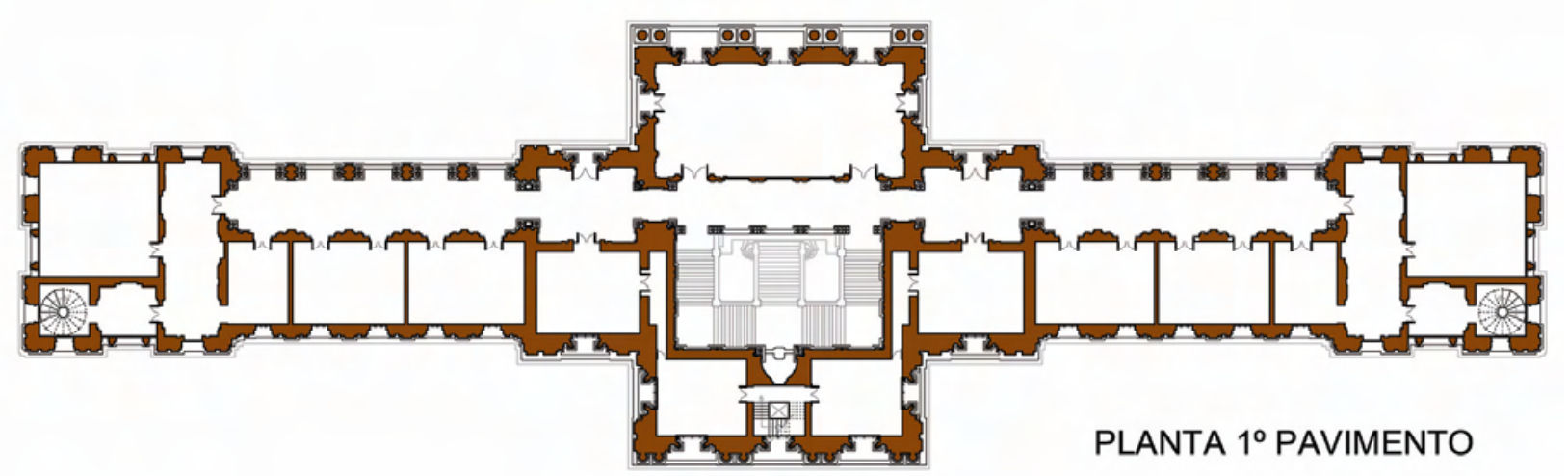

Fig. 286 - Planta executada por Flávia Lourenção

(fachada norte lateral superior) 


\section{MAQUETE DO PROJETO COM AS ALAS LATERAIS PERPENDICULARES À FACHADA PRINCIPAL, EM FORMA DE E}

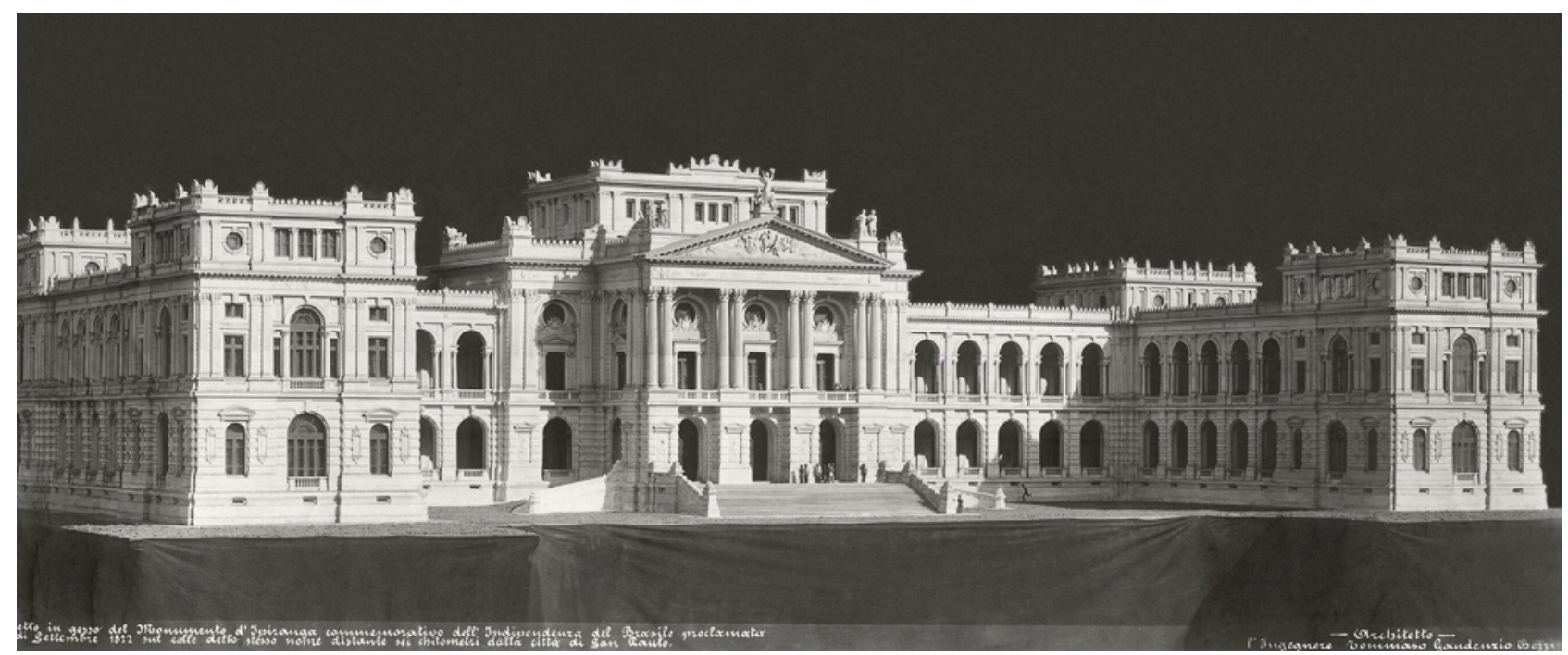

Fig. 287 - Fundo Bezzi - Acervo Museu Paulista

IC 13297 - MAQUETE - MODELO EM GESSO

Outra evidência de projeto é a maquete em gesso existente no Museu Paulista, com as alas perpendiculares à fachada principal norte. A maquete foi projetada aproximadamente entre 1888 a 1890, conforme documentos anexos, e ocorreu durante o período de construção do edifício. Foi executada sob direção do Bezzi em sua própria residência.

Não há informações a respeito da passagem do projeto de 1883 para este, com as alas perpendiculares localizadas na fachada principal, da data em que foi apresentado e aprovado, ou de sua redução por motivos financeiros. O tratamento ornamental e arquitetônico das fachadas na maquete é o mesmo executado no edifício em forma de I.

É possível que Bezzi considerasse a maquete como um eloqüente argumento a favor de se construir o edifício completo em forma de $\mathrm{E}$.

Sobre a fotografia da maquete há uma inscrição manuscrita de Bezzi, em que afirma como deveria ser o edifício completo, tal como seu projeto. Cita também a rescisão "ilegal" do contrato que garantia a sua administração da obra até seu término. Ele escreve em outras fotografias sobre o mesmo tema como forma de manifestar sua insatisfação.

Bozzeto in gesso del Monumento d' Ipiranga commemorativo dell' independenza del Brasile proclamata il 7 di settembre 1822 sul colle dello stesso nome distante sei chilometri dalla città di San Paolo. Architetto - l'Ingegnere Tommaso Gaudenzio Bezzi.

Questa fotografia del bozzetto in gesso mostra il monumento colla forma di um E como dovrà essere quando sara completamente finito, se por questo si serviranno dei miei disegni. Dico se si serviranno dei miei disegni perche il mio contratto per la direzione dei lavori fu rescisso, illegalmente, nel 1892

Maquete em gesso do Monumento do Ipiranga comemorativo da independência do Brasil proclamada em 7 de setembro de 1822 acima da colina de mesmo nome distante seis quilômetros da cidade de São Paulo. Architeto - O engenheiro Tommaso Gaudenzio Bezzi.

Esta fotografia do modelo em gesso apresenta o Monumento com a forma de um E como deverá ser quando estiver completamente pronto, se para isto usarem os meus desenhos. Digo se usarem 
os meus desenhos porque o meu contrato para a direção dos trabalhos foi rescindido, ilegalmente, em 1892.

São Paulo, Abril de 1898 Tommaso Gaudenzio Bezzi

(Pasta 04 - Documento 230)

S. Paulo 20 de Dezembro de 1888

Exmo. Sr. Presidente e mais membros da Com. de obras do Monumento do Ypiranga.

Pelo presente tenho a honra de requisitar de V. Exas. o abono das quantias por mim desembolsadas para o pagamento dos operários e alguns materiais empregados para a construcção do modelo em gesso do Monumento do Ypiranga, baseando este meu pedido nas razões seguintes:

V. Exma. Comissão ciente da absoluta necessidade da confecção do modelo do Monumento. Do Ypiranga, e seguindo a praxe adoptada nos casos congeneros, auxiliava-me na nova tarefa do desempenho da minha commissão, autorizava-me a construir o modelo em questão, ao qual actualmente estou dando os últimos toques para acaba-la.

Pelo contracto por mim assignado para satisfazer a vontade manifestada por V. Exas. obrigava-me a acabar e entregar prompto o modelo em gesso pela quantia de 3:800\$000, que já recebi, e sendo essa quantia insuficiente para a conclusão do mesmo, tive de continuar a sua construcção à minha custa, não somente para o fiel cumprimento da quantia eu tinha com a Exma. Comissão Contractado, mas também forçado pela necessidade sempre constante de novos estudos a fazerem-se no decurso da construcção do Monumento, e porque isso era essencial para o perfeito acabamento dos trabalhos a meu cargo como reconheceu a própria Exma. Comissão quando encarregou-me de execução do modelo.

A Exma. Comissão. sabe perfeitamente que todo o trabalho do modelo foi feito na minha casa de morada e com grande incommodo durante mais de três annos para minha numerosa família, e que além da minha direção constante e immediata sobre os operários empregados na sua construcção, tenho, não somente com o fim de poupar despezas a Exma. Comissão, mas também para adiantar o serviço, trabalhado pessoalmente na confecção dos modelos e também na fundição sem por isso nunca ter tido nem pedido remuneração alguma especial por este serviço.

A Exma. Comissão sabe que o modelo não é objeto que se preste a especulação alguma, ficando d'este modo para sempre excluída a idéia de lucros por minha parte; portanto a empreitada que tomei há tempo quanto a Exma. Comissão não quis mais continuar com o trabalho do mesmo administrativamente, foi por mim acceita somente para não contrariar V. Exa. que assim tinham decidido.

À Exma. Comissão faço observar que desde o dia em que começaram as obras do Monumento do Ypiranga não acceitei mais nenhum trabalho da minha profissão para não ... das minhas obrigações e conseqüentemente desde este tempo vivo exclusivamente do ordenado que a Exma. Comissão abona como remuneração do meu cargo de Eng. Chefe das Obras.

Não estando ainda completamente acabado o modelo, aqui em seguida vou enumerar detalhadamente as peças que faltam e cuja execução é imprescindível, devendo servir de base para o que tenho ainda que planejar a fim de completar as obras do Monumento. em andamento, 1 ..... 2 ..... 3 .... etc etc etc etc.

Depois que a Exma. Comissão me pagou a quantia de 3:800\#000 despendi com o salário pago aos empregados como consta dos recibos mensaes por elles assignados e que estão em meu poder, até o dia 30 de novembro p. p., a quantia de 9:638\#665 e deduzindo d'esta quantia 3:800\#000 já recebidos, fico com um desembolso de 5:838\#665 sendo o pagamento d'esta quantia o objeto da minha reclamação.

Na Pasta 1, Documento 39 do Fundo Bezzi, no ofício de Bezzi ao Conselheiro Barão de Ramalho, Presidente da Comissão de Obras do Monumento do Ypiranga, o engenheiro se refere à maquete:

Pelo modelo em gesso do Monumento do Ypiranga tenho despendido de minha conta particular até o dia de hoje a quantia de 12:548\$555 e a esse respeito peço a V.Excia. e aos Exmos Membros da Comissão o especial obséquio de rever meus ofícios de 20 de fevereiro de 1889 e 9 de outubro do mesmo ano a fim de me mandar satisfazer d'esta importância que como consta dos citados ofícios, foi com grande sacrifício meu, esta quantia adiantada para eu poder prosseguir com o andamento regular das obras do Monumento.

Pelos dois corpos iguais aos laterais projetados perpendicularmente aos mesmos já existentes, de modo que a construção total do Monumento venha a ter a forma de um E na sua frente principal, como 
mostra a planta junto, sendo estas obras projetadas necessárias para que edifício Monumento esteja completo e com todas as suas partes de harmonia entre si, é necessário aproximadamente a despeza de 760:000\$000.

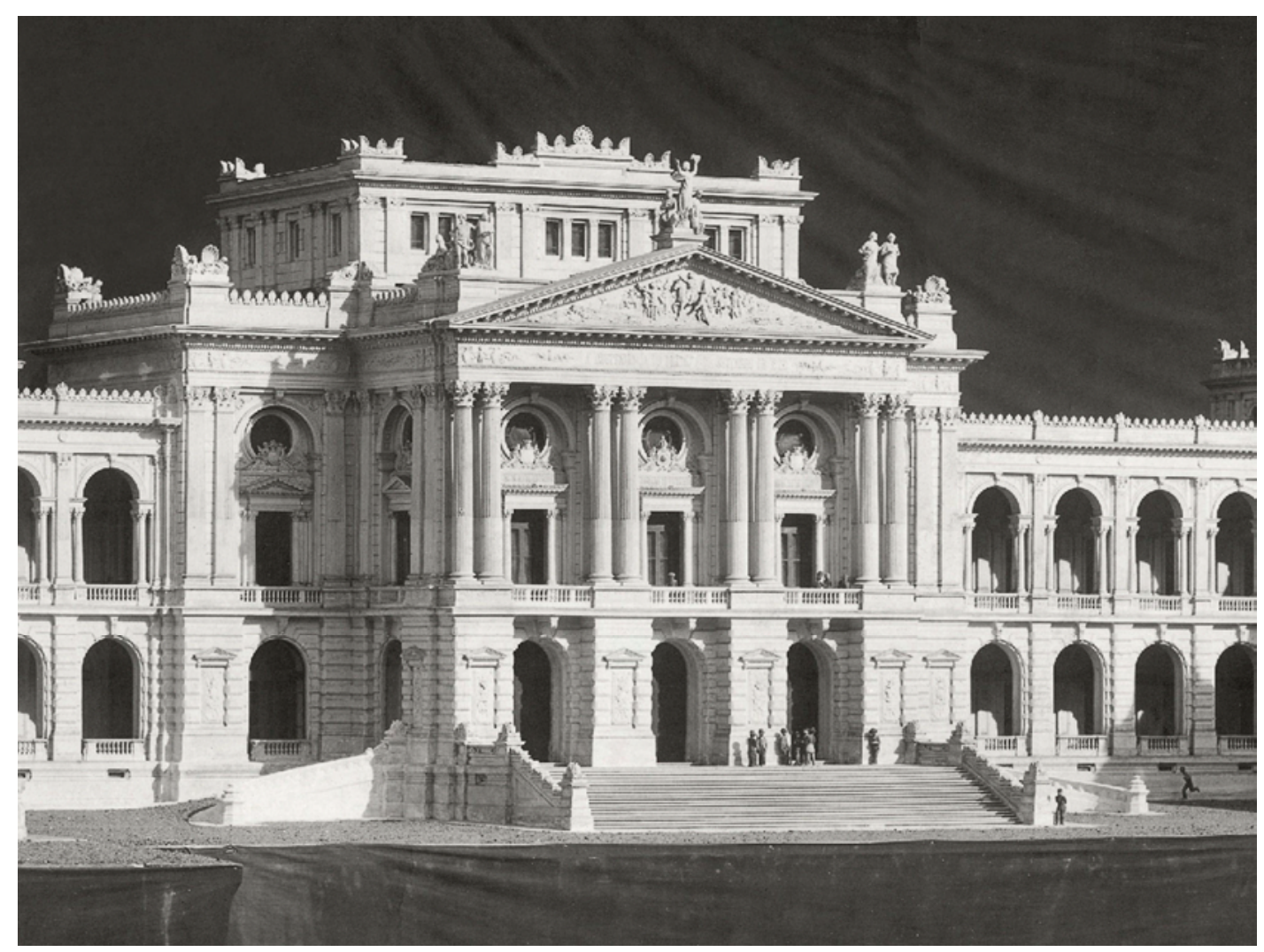

Fig. 288 - Acervo Museu Paulista

IC 13297 - DETALHE - CORPO CENTRAL

\section{ORNAMENTAÇÃO PROJETADA E NÃO REALIZADA}

- Frontão com ornamentação em alto relevo com a temática da Proclamação da Independência.

- Três conjuntos de esculturas sobre o frontão e platibanda do Corpo Central, projeto de Bernadelli.

- Friso ornamentado entre colunas monumentais e frontão

- Ornamentação sobre as cartelas nas laterais dos portais do andar térreo 


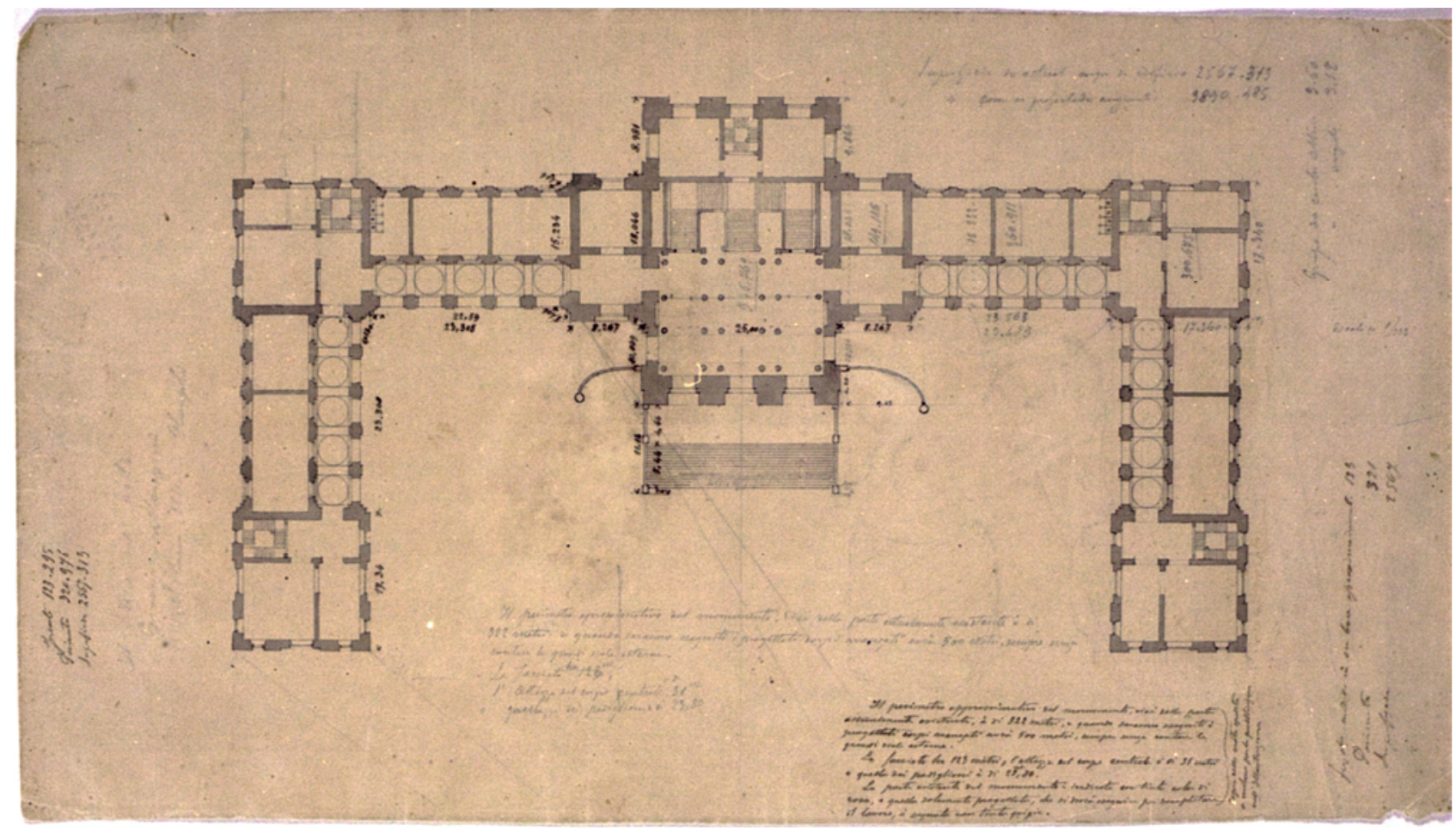

Fig. 289

IC 13.116 - PLANTA EM FORMA DE E

II perimetro aprossimativo del monumento, cioè della parte attualmente esistente, é di 322 metri, e quando saranno eseguiti i progettati corpi avanzati avrá 500 metri, sempre senza contare le grandi scale esterne. La fasciata ha 123 metri, l'attezza del corpo centrale è di 31 metri e quella dei padiglioni è di 23,80 $\mathrm{m}$. La parte esistente del monumento è indicata con tinta color di rosa, e quella solamente progettata, che si dovrà esequire per completare il lavoro, è segnata com tinta grigia. (Copia dell note espedita a Milano per la pubblicazione nell Illustrazione).

O perímetro aproximativo do Monumento, ou seja, da parte atualmente existente, é de 322 metros, e quando estiverem executados os projetados corpos avançados terá 500 metros, sempre sem contar as grandes escadas externas. A fachada tem 123 metros, a altura do Corpo Central é de 31 metros e a dos pavilhões é de $23,80 \mathrm{~m}$. A parte existente do Monumento é indicada com tinta rosa, e aquela somente projetada, que se deverá executar para completar o trabalho, é desenhada com cinza. (Cópia de nota expedida a Milão para a publicação na lllustrazione).

Observa-se que as soluções arquitetônicas adotadas no projeto de 1883 apresentam a linguagem mais próxima ao Neoclassicismo. Há maior regularidade de ritmo e de proporção entre parede e aberturas. Apesar de encontrarem-se definidos os volumes do Corpo Central, Galerias e Torres, as fachadas são mais semelhantes umas às outras, mais compactas e expressam maior solidez.

As fachadas da maquete e do edifício que foi executado são caracterizadas por maior liberdade criativa. Possuem ritmos diferenciados e movimento mais acentuado. Nas galerias, com loggias, as aberturas são maiores e os pés-direitos estreitos e recobertos por pilastras e colunas, o que proporciona leveza e contrastes de luz e sombra. O edifício é considerado um bom exemplo do Ecletismo em São Paulo, tendo se constituído em modelo imitado por outros profissionais. 
QUADRO 3 - O INÍCIO DO MUEU PAULISTA DE 1894 A 1912

\begin{tabular}{|c|c|c|}
\hline $\begin{array}{l}03 \text { de fevereiro de } \\
1894\end{array}$ & $\begin{array}{l}\text { O Museu Paulista começa a funcionar no Monumento do } \\
\text { lpiranga }\end{array}$ & $\begin{array}{l}\text { Guia da secção histórica do } \\
\text { Museu Paulista p.22 }\end{array}$ \\
\hline $\begin{array}{l}15 \text { de janeiro de } \\
1894\end{array}$ & Dr. Hermann von Ihering é nomeado diretor do Museu. & $\begin{array}{l}\text { Revista do Museu Paulista, } \\
\text { Vol.1, } 1895\end{array}$ \\
\hline $\begin{array}{l}3 \text { de fevereiro de } \\
1894\end{array}$ & $\begin{array}{l}\text { Administração do Museu é entregue a Hermann von lhering. } \\
\text { Inicia-se transferência de Museu para o Monumento, terminada a } \\
1 \text { de maio do mesmo ano. }\end{array}$ & $\begin{array}{l}\text { Revista do Museu Paulista, } \\
\text { Vol.1, } 1895\end{array}$ \\
\hline 1894 & $\begin{array}{l}\text { Recomeçam os trabalhos no Monumento: } \\
\text {-Colocação da Clarabóia } \\
\text {-Assoalhamento de dois quartos no andar térreo } \\
\text {-Assentamento dos pára-raios } \\
\text {-Cercamento do terreno situado atrás do Monumento }\end{array}$ & $\begin{array}{l}\text { Revista do Museu Paulista, } \\
\text { Vol.1, } 1895\end{array}$ \\
\hline $\begin{array}{l}07 \text { de setembro } \\
\text { de } 1895\end{array}$ & $\begin{array}{l}\text { Inauguração solene do Museu Paulista. Festividade presidida } \\
\text { pelo presidente Bernardino de Campos. } \\
\text { Ainda por anos continuou o palácio com sua fachada afeiada } \\
\text { pela falta de portas e sua frente, um campo cheio de } \\
\text { irregularidades }\end{array}$ & $\begin{array}{l}\text { Guia da secção histórica do } \\
\text { Museu Paulista p.23 / } \\
\text { Revista do Museu Paulista, } \\
\text { Vol.1, } 1895 \text { p. } 10-16\end{array}$ \\
\hline $\begin{array}{l}07 \text { de setembro } \\
\text { de } 1895\end{array}$ & $\begin{array}{l}\text { Bernardino de Campos enfatiza importância das coleções do } \\
\text { Museu: "O museu collocado no Ypiranga e inaugurado em } 7 \text { de } \\
\text { setembro do ano passado, oferece campo de estudo pela } \\
\text { incontestável utilidade de suas coleções, entre as quaes, foi } \\
\text { recentemente collocada a de numismática." }\end{array}$ & $\begin{array}{l}\text { Galeria dos Presidentes. Vol } \\
\text { II, p. } 71\end{array}$ \\
\hline 1895 & $\begin{array}{l}\text { Realização de obras: } \\
\text {-Conserto do telhado } \\
\text {-Abastecimento de água encanada vinda de Cassununga } \\
\text {-Colocação de duas caixas de água de depósito embaixo do } \\
\text { telhado } \\
\text {-Finalização da grande escada } \\
\text {-Finalização das rampas de entrada } \\
\text {-Conserto do aterro, muito estragado pelas águas pluviais } \\
\text {-Plantação de grama nas rampas do aterro } \\
\text {-Construção de sarjetas para o esgoto das águas pluviais } \\
\text {-Colocação, no vestíbulo, de vasos ornamentais e tapetes } \\
\text { "Os telhados construídos de telhas nacionais muito ordinárias } \\
\text { sem o caimento necessário, os corredores estreitos demais que } \\
\text { unem B 7e } 8 \text { e B } 9 \text { e10, de modo que nos domingos, quando há } \\
\text { muita gente ali não se pode fazer a circulação do público, a } \\
\text { distribuição das escadas interiores, as galerias abertas e as } \\
\text { salas acanhadas entram no número destas disposições } \\
\text { arquitetônicas que dificultam o serviço do Museu. O que mais } \\
\text { ainda é a lamentar é que o edifício não tem muito espaço, } \\
\text { contando com a fachada de } 123 \text { m. apenas } 13 \text { de fundo, } \\
\text { levando ainda as galerias abertas e o vestíbulo a metade do } \\
\text { lugar disponível" (p.30) }\end{array}$ & $\begin{array}{l}\text { Revista do Museu Paulista, } \\
\text { Vol.1, } 1895\end{array}$ \\
\hline $\begin{array}{l}31 \text { de dezembro } \\
\text { de } 1900\end{array}$ & $\begin{array}{l}\text { Hermann von Ihering, relata a necessidade de realização de } \\
\text { obras de conservação no edifício, a despeito da decisão } \\
\text { governamental de eliminar gastos com consertos de edifícios } \\
\text { públicos. Afirma necessidade de compra de terrenos vizinhos } \\
\text { para manutenção da praça, já que grande porção de terra havia } \\
\text { sido levada pela chuva. Enfim, pede revisão de vencimentos de } \\
\text { pessoal empregado no Museu. }\end{array}$ & $\begin{array}{l}\text { Revista do Museu Paulista, } \\
\text { Vol.5, 1902, p. } 11\end{array}$ \\
\hline $\begin{array}{l}31 \text { de dezembro } \\
\text { de } 1902\end{array}$ & $\begin{array}{l}\text { Hermann von Ihering, justifica ocorrência de obras de } \\
\text { conservação dirigidas por Eduardo Loschi, cujo custo foi de dez } \\
\text { contos, em decorrência da interrupção de reparos regulares } \\
\text { determinada por decisão governamental. Informa emprego do } \\
\text { pessoal na conservação interna do Monumento e em consertos } \\
\text { menores (clarabóias, telhado e pára-raios). Destaca ainda o } \\
\text { cumprimento, pelo governo estadual, de sua proposta de } \\
\text { demarcação da Avenida da Independência, contígua ao Museu, } \\
\text { como terreno do Estado. Por fim, reclama jardinamento da Praça }\end{array}$ & $\begin{array}{l}\text { Revista do Museu Paulista, } \\
\text { Vol. } 6,1904 \text { p. } 3\end{array}$ \\
\hline
\end{tabular}




\begin{tabular}{|c|c|c|}
\hline & do Museu. & \\
\hline $\begin{array}{l}03 \text { de julho de } \\
1902 \text { a } 01 \text { de } \\
\text { maio de } 1904\end{array}$ & $\begin{array}{l}\text { Coronel Fernando Prestes de Albuquerque: Obras Públicas - } \\
\text { Reparação e melhoramentos do Museu Paulista (não é dado ano } \\
\text { específico) }\end{array}$ & $\begin{array}{l}\text { Galeria dos Presidentes de } \\
\text { São Paulo. Vol. Il p. } 153\end{array}$ \\
\hline 1903 A 1905 & $\begin{array}{l}\text { Rodolpho von Ihering aponta realização no período de obras de } \\
\text { conservação, das quais a mais importante foi da construção de } \\
12 \text { portas nas galerias e } 5 \text { portões da fachada do Monumento. } \\
\text { Tais obras visavam à defesa contra roubos e intempéries. } \\
\text { Realizam-se também o conserto do telhado, dos condutores de } \\
\text { água e da clarabóia. O diretor registra ainda o tratamento do } \\
\text { terreno anexo ao Museu: terreno dos fundos recebe tratamento e } \\
\text { mudas para formação de Horto Botânico, incubida a H. } \\
\text { Luderwaldt; o terreno frontal recebe jardinagem dirigida por } \\
\text { Arsene Puttmans. }\end{array}$ & $\begin{array}{l}\text { Revista do Museu Paulista } \\
\text { Vol. 7, } 1907 \text { p..10, }\end{array}$ \\
\hline 1906 a 1908 & $\begin{array}{l}\text { Término do ajardinamento. Ihering registra necessidade de } \\
\text { ajustes técnicos e acabamentos relativos aos canteiros e } \\
\text { caminhos e às sarjetas e à canalização. }\end{array}$ & $\begin{array}{l}\text { Revista do Museu Paulista } \\
\text { Vol. } 8,1911\end{array}$ \\
\hline $1910,1911,1912$ & $\begin{array}{l}\text { Serviços anexos: O Monumento, aliás, edifício de construção } \\
\text { aprimorada, tem o seu ponto fraco, o telhado } \\
\text {-telhado : Ano por ano, tornou-se necessário proceder a } \\
\text { reparos mais ou menos extensos para tomar as goteiras. } \\
\text { Nos últimos tempos, era justamente a parte que cobre as } \\
\text { galerias do andar superior que deixava a desejar. Agora, } \\
\text { depois de ter sido coberta toda esta parte com chapas de } \\
\text { metal, parece que o mal está sanado de vez. } \\
\text { O edifício todo reclamava há tempos uma pintura geral } \\
\text {-pintura geral: não podendo ser feito agora todo o serviço, } \\
\text { foi tentado a título de experiência, a pintura a óleo nas } \\
\text { partes mais sujeitas ao tempo. } \\
\text {-Danos nos condutores de água pluvial }\end{array}$ & $\begin{array}{l}\text { Revista do Museu Paulista } \\
\text { Vol.9, } 1914 \text { p. } 14\end{array}$ \\
\hline
\end{tabular}

O Museu Paulista começa a funcionar precariamente, faltando ainda diversos acabamentos como o fechamento das portas do térreo de toda a fachada principal, alguns pisos, clarabóia, etc. Em 1894, quando recomeçam os trabalhos, foi colocada a clarabóia (mas o documento não especifica qual delas); o assoalho de duas salas no térreo, a grande escada externa é finalizada e terminam-se as rampas. Somente no período de 1903 a 1905 são colocadas as 12 portas no térreo da fachada principal. Até então, o Museu ficara aberto.

A partir de 1895, começa a ser citado na documentação o vazamento nos telhados, resultado do fato de ter sido construído com telhas de má qualidade e, principalmente, com inclinação insuficiente. As clarabóias, os condutores de água pluvial também apresentavam danos e foram conservados diversas vezes. No período de 1910 a 1912, o telhado sobre as galerias ainda continuava a apresentar goteiras. Nessa ocasião, as telhas de barro foram substituídas por placas de metal.

Neste período, o edifício necessitava de pintura e foi tentada a título de experiência a pintura a óleo nas partes mais sujeitas ao tempo. Não são determinados os locais, a extensão e nem a cor. Também neste momento, é possível que já se considerasse a pintura à cal menos protetora das superfícies das fachadas do que, por exemplo, uma tinta a óleo. Pode ser considerado também que se inicia a alteração do processo de evaporação da umidade existente nas paredes deste edifício.

QUADRO 4 - PERÍODO DE 1916 A 1924

\begin{tabular}{|l|l|l|}
\hline 1916 & $\begin{array}{l}\text { Taunay, diretor do Museu, registra estado de boa conservação } \\
\text { do edifício. Informa, porém, que numerosas portas e janelas } \\
\text { foram consertadas, pois estavam empenadas; portas exteriores, } \\
\text { gradis e portões foram envernizados e aluminados; telhado e } \\
\text { calhas sofreram pequenos reparos; as fendas nos portais da }\end{array}$ & Vaulista \\
\hline
\end{tabular}




\begin{tabular}{|c|c|c|}
\hline & $\begin{array}{l}\text { galeria do andar térreo foram observadas, não se notando seu } \\
\text { aumento. }\end{array}$ & \\
\hline 1917 & $\begin{array}{l}\text { Taunay registra abertura ao público de duas novas salas no } \\
\text { andar térreo no começo do ano, e prevê abertura de mais duas } \\
\text { salas, a A11 e A12. } \\
\text { Estando bem conservado, o edifício recebe poucas reparações: } \\
\text { Conserto de goteiras; } \\
\text { Desentupimento de calha que umedecia parede do Salão Nobre } \\
\text { Substituição de vidros da clarabóia quebrados por granizos. } \\
\text {-No interior destaca-se o levantamento de uma parede na sala } \\
\text { A10, destinada não só a mascarar a grande porta aberta para } \\
\text { um pequeno cômodo contíguo, do despejo, como a obter maior } \\
\text { área para expor quadros. } \\
\text { - A sala A7 é pintada e as grades do corredor térreo foram } \\
\text { removidas a fim de deixar livre a entrada das salas A6 e A7, } \\
\text { A10 e A11. } \\
\text { - Na torre leste um dos cômodos se converte em "Câmara } \\
\text { escura fotográfica", sendo aí instalada uma pia; instala-se } \\
\text { um elevador e um quarto. }\end{array}$ & $\begin{array}{l}\text { Revista do Museu Paulista, } \\
\text { Vol } 10,1918, \text { p. } 994\end{array}$ \\
\hline 1918 & $\begin{array}{l}\text { Taunay registra ocorrência de reparos insignificantes, } \\
\text { destacando-se o conserto dos grandes mastros alçados nos } \\
\text { dias festivos. }\end{array}$ & $\begin{array}{l}\text { Revista do Museu Paulista, } \\
\text { Vol } 11,1919\end{array}$ \\
\hline 1919 & $\begin{array}{l}\text { Além de reiterar estado geral de boa conservação do edifício, } \\
\text { Taunay registra interrupção do tratamento do jardim frontal em } \\
\text { razão da destruição ocasionada pelos trabalhos de construção } \\
\text { da avenida que ligaria Museu à Capital. Afirma ainda a posse } \\
\text { estatal do terreno da construção, contestada pelo Cel. } \\
\text { Constantino Xavier, que mandou embargar obras. }\end{array}$ & $\begin{array}{l}\text { Revista do Museu Paulista } \\
\text { Vol. } 12 \text { - 1920, p. } 463\end{array}$ \\
\hline 1920 & $\begin{array}{l}\text { Taunay comenta inexistência de obras de expansão do Museu, } \\
\text { enfatizando a necessidade de construção da área anexa para } \\
\text { solucionar problema da falta de espaço. O projeto de tal área } \\
\text { havia sido enviado ao Secretário do Interior anterior. }\end{array}$ & $\begin{array}{l}\text { Revista do Museu Paulista } \\
\text { Vol. } 13-1922, \text { p. } 1309\end{array}$ \\
\hline 1921 & $\begin{array}{l}\text { Taunay relata ocorrência de remodelação de pintura externa e } \\
\text { interna do edifício, preparando as paredes com a raspagem da } \\
\text { pintura à cal ; bem como de importantes reparos e modificações, } \\
\text { dos quais se destacam a criação de esgotos e instalações } \\
\text { sanitárias. Os serviços ficaram a cargo do arquiteto Dr. Bruno } \\
\text { Simões Magro, nomeado pela Secretaria da Agricultura. }\end{array}$ & $\begin{array}{l}\text { Revista do Museu Paulista } \\
\text { Vol. } 14 \text { - 1926, p. } 700\end{array}$ \\
\hline 1922 & $\begin{array}{l}\text { Taunay informa que a caixa da escada de mármore do Museu foi } \\
\text { revestida com o mesmo material. } \\
\text { Conclusão das intervenções registradas no ano anterior: } \\
\text { "Até agora não tivera o Museu esgotos! Temos agora modelar } \\
\text { instalação sanitária" } \\
\text { O prédio e as coleções foram asseguradas no valor de mil } \\
\text { contos de réis, para cobrir eventuais danos causados por } \\
\text { operários empregados nas obras e incêndios. }\end{array}$ & $\begin{array}{l}\text { Revista do Museu Paulista } \\
\text { Vol. } 14-1926 \text {, pp. } 730 \text { e } \\
751\end{array}$ \\
\hline 1923 & $\begin{array}{l}\text { Taunay constata falta de espaço do Museu. Lamenta o fato de } \\
\text { projeto de área anexa, que se destinaria à administração, } \\
\text { laboratórios, depósitos, oficinas e bibliotecas não ter se } \\
\text { concretizado. }\end{array}$ & $\begin{array}{l}\text { Revista do Museu Paulista } \\
\text { Vol. } 14-1926, \text { p. } 778\end{array}$ \\
\hline $\begin{array}{l}01 \text { de maio de } \\
1920 \text { a } 01 \text { de } \\
\text { maio de } 1924\end{array}$ & $\begin{array}{l}\text { Washington Luiz Pereira de Souza (1/05/1920 à 1/05/1924): } \\
\text { Obras para o centenário da Independência. Contrato assinado a } \\
23 \text { de junho de 1920: } \\
\text {-Os dois terraços do novo jardim francês, situado em frente do } \\
\text { museu, construídos em alvenaria e cantaria de pedra granítica; } \\
\text {-as duas muretas das rampas de acesso à esplanada do museu, } \\
\text { construídas também da mesma natureza da obra precedente; } \\
\text {-os pequenos muros de sustentação das ruas de acesso ao } \\
\text { edifício do museu, construídos em alvenaria de tijolo e } \\
\text { capeamento de cantaria de granito; } \\
\text {-a nova escadaria do edifício do Museu em cantaria de granito; } \\
\text {-o novo plintho do edifício do museu em cantaria de granito. }\end{array}$ & $\begin{array}{l}\text { Galeria dos Presidentes de } \\
\text { São Paulo. Vol. III, p. 138- } \\
139\end{array}$ \\
\hline $\begin{array}{l}1920-2^{0} \\
\text { semestre }\end{array}$ & Execução das obras para o Centenário da Independência & $\begin{array}{l}\text { Galeria dos Presidentes de } \\
\text { São Paulo. Vol. III, p. } 218\end{array}$ \\
\hline $\begin{array}{l}01 \text { de maio de } \\
1920 \text { a } 01 \text { de }\end{array}$ & $\begin{array}{l}\text { Realização de obras de "conservação": } \\
\text {-Reforma geral de toda a esquadria interna e externa, }\end{array}$ & $\begin{array}{l}\text { Galeria dos Presidentes de } \\
\text { São Paulo. Vol. III, p.220 }\end{array}$ \\
\hline
\end{tabular}




\begin{tabular}{|c|c|c|}
\hline maio de 1924 & $\begin{array}{l}\text {-Detalhamento e a Revisão de todo o serviço de esgotamento } \\
\text { pluvial, } \\
\text {-conserto de paredes, abóbadas e arcos fundidos. } \\
\text {-Renovação do revestimento das paredes e do estuque do forro, } \\
\text { onde se tornava necessário. } \\
\text {-Reparação de grande numero de molduras, ornamentos e } \\
\text { elementos arquitetônicos } \\
\text { Realização de obras de "acabamento": } \\
\text {-Modificação e complemento de molduras; a execução de } \\
\text { ornatos, consolos e capitéis, que a ordenança arquitetônica } \\
\text { reclamava. } \\
\text { "Em tais serviços, procurou-se manter a harmonia do conjunto, } \\
\text { mediante cuidadoso estudo da composição do edifício." }\end{array}$ & \\
\hline $\begin{array}{l}01 \text { de maio de } \\
1920 \text { a } 01 \text { de } \\
\text { maio de } 1924\end{array}$ & $\begin{array}{l}\text { Obras de reparação da pintura geral para as festas do } \\
\text { Centenário da Independência. }\end{array}$ & $\begin{array}{l}\text { Galeria dos Presidentes de } \\
\text { São Paulo. Vol. III, p.248 }\end{array}$ \\
\hline
\end{tabular}

Em 1916 há, na documentação, uma observação sobre as fendas nos portais da galeria do andar térreo, afirmando que estas não aumentaram. É possível que se trate dos arcos nos portais da fachada, cujos danos atualmente, contudo, não são evidentes. Mas são os arcos transversais, correspondentes a cada portal, que apresentam, desde algum tempo, rompimento e deslocamento para baixo, bem no centro do arco. Esta metade que se desloca para baixo é a que se liga à fachada.

Neste período ocorre a instalação de esgotos e instalações sanitárias, o que traz higiene e conforto, substituindo o costume que existiu no período imperial de instalações externas à construção.

No período de 1920 a 1924 há vários trabalhos de conservação que se referem à alvenaria, renovação no revestimento de paredes, de estuque, de arcos e abóbadas, molduras, ornamentos arquitetônicos, capitéis - mas estas informações não especificam os tipos de danos, localização nem a quantidade destas ocorrências. 


\author{
SECRETARIA DA VIAÇÃO E OBRAS PÚBLICAS DO ESTADO DE SÃO PAULO \\ CPOS - COMPANHIA PAULISTA DE OBRAS E SERVIÇOS (atualmente)
}

\begin{tabular}{|c|c|c|}
\hline DATA & EVENTO & REFERÊNCIA \\
\hline $\begin{array}{l}10 \text { de fevereiro } \\
\text { de } 1931\end{array}$ & Adaptação dos porões das alas esquerda e direita (escavação) & $\begin{array}{l}\text { Secretaria da Viação e } \\
\text { Obras Públicas do Estado } \\
\text { de São Paulo: } \\
\text { 02/02/1931, v. } 1 \text { (Doc.01) }\end{array}$ \\
\hline $\begin{array}{l}\text { 18 de fevereiro } \\
\text { de } 1931\end{array}$ & $\begin{array}{l}\text { Obras executadas na escavação: } \\
\text { - Escavação do solo dos porões } \\
\text { - Forro de estuque de argamassa mista sobre abobadilha } \\
\text { - Abertura de vãos } \\
\text { - Colocação de vergas de cimento armado } \\
\text { - Revestimento com argamassa de cal e areia }\end{array}$ & Idem (Doc.03) \\
\hline $\begin{array}{l}15 \text { de abril de } \\
1931\end{array}$ & $\begin{array}{l}\text { Obras executadas na escavação: } \\
\text { - Aumento nas escavações } \\
\text { - Assentamento de vigas de ferro }\end{array}$ & Idem (Doc.09) \\
\hline $\begin{array}{l}27 \text { de abril de } \\
1931\end{array}$ & $\begin{array}{l}\text { Obras de adaptação dos porões das partes salientes das } \\
\text { alas esquerda e direita. }\end{array}$ & Idem (Doc.15) \\
\hline $\begin{array}{l}7 \text { de maio de } \\
1931\end{array}$ & $\begin{array}{l}\text { Obras executadas na escavação: } \\
\text { - Continuidade de escavação de alas } \\
\text { - Soalho na ala esquerda } \\
\text { - Colocação de vergas de cimento armado nas alas }\end{array}$ & Idem (Doc.16) \\
\hline $\begin{array}{l}14 \text { de maio de } \\
1931\end{array}$ & $\begin{array}{l}\text { Obras executadas na escavação: } \\
\text { - Revestimento em argamassa de cal e areia das alas dos } \\
\text { Porões } \\
\text { - Colocação de portas de cedro nas alas dos porões } \\
\text { - Caixilhos de Cedro: }\end{array}$ & Idem (Doc.23) \\
\hline $\begin{array}{l}29 \text { de maio de } \\
1931\end{array}$ & $\begin{array}{l}\text { Obras executadas na escavação: } \\
\text {-Aumento nas escavações } \\
\text {-Demolição e remoção de detritos } \\
\text {-Construção de pilares: a) Fundação em alvenaria; } \\
\text { b) Elevação em alvenaria; c) Soccos de concreto } \\
\text {-Assentamento de vigas de ferro } \\
\text {-Assentamento de conductores: } \\
\text {-Preparo do embasamento de pedra } \\
\text {-Enchimento de vigas } \\
\text {-Aumento de revestimento } \\
\text {-Chanframento de peitoris } \\
\text {-Assentamento de portas e caixilhos: } \\
\text {-Colocação de rodapés } \\
\text {-Pintura a óleo }\end{array}$ & Idem (Doc.30) \\
\hline $\begin{array}{l}6 \text { de junho de } \\
1931\end{array}$ & Reforço do soalho & Idem (Doc. 41) \\
\hline $\begin{array}{l}8 \text { de junho de } \\
1931\end{array}$ & $\begin{array}{l}\text { Obras executadas na escavação: } \\
\text { Colocação de grades de ferro }\end{array}$ & Idem (Doc. 35) \\
\hline $\begin{array}{l}23 \text { de junho de } \\
1931\end{array}$ & $\begin{array}{l}\text {-Adaptação dos porões das partes salientes das alas } \\
\text { esquerda e direita. }\end{array}$ & Idem (Doc.46) \\
\hline $\begin{array}{l}8 \text { de julho de } \\
1931 \text { a } 6 \text { de } \\
\text { agosto de } \\
1931\end{array}$ & Instalações elétricas e assentamento de conduítes e fios & $\begin{array}{l}\text { Idem (Docs. 53, 55, } 62 \text { e } \\
67)\end{array}$ \\
\hline
\end{tabular}




\begin{tabular}{|c|c|c|}
\hline $\begin{array}{l}6 \text { de agosto de } \\
1931 \text { a } 30 \text { de } \\
\text { março de } 1943\end{array}$ & $\begin{array}{l}\text {-Obras de reparo do passadiço, reforma de clarabóia, pintura de } \\
\text { caixilhos externos, pinturas pontuais, reparos urgentes no telhado, } \\
\text { limpeza interna e reforma de pára-raios. }\end{array}$ & $\begin{array}{l}\text { Idem (Docs. 83, 100, 105, } \\
117,125,137,150,155 \\
163,171,182,193,202 \\
213,222)\end{array}$ \\
\hline $\begin{array}{l}9 \text { de maio de } \\
1936\end{array}$ & Instalação de elevador elétrico & Idem (Doc.133) \\
\hline $\begin{array}{l}10 \text { de } \\
\text { dezembro de } \\
1945 \text { a } 31 \text { de } \\
\text { julho de } 1946\end{array}$ & $\begin{array}{l}\text { Serviços no telhado: } \\
\text { Telhados das torres das alas direita e esquerda: } \\
\text { desmonte da cobertura existente; limpeza dos forros; colocação de } \\
\text { ripas novas de peroba; substituição de telhas côncavas, tipo paulista, } \\
\text { procedente da Cerâmica de Vila Prudente; reparos nos rufos de } \\
\text { cimento; } \\
\text {-revestimento interno e capeamento das platibandas com argamassa de } \\
\text { traço (cal, cimento e areia). } \\
\text { Telhados das laterais do corpo central da ala direita e esquerda: } \\
\text { desmonte da cobertura existente; limpeza dos forros; colocação de } \\
\text { ripas novas de peroba; substituição de telhas côncavas, tipo paulista; } \\
\text { reparos nos rufos de argamassa de cimento e areia (1:4); soldas em } \\
\text { calhas de cobre } \\
\text { Telhado do corpo central: substituição de telhas quebradas, emboço } \\
\text { de cumeeiras, reparos nos rufos de cimento e limpeza de forros. Soldas } \\
\text { em calhas de cobre. } \\
\text { Clarabóias } \\
\text { a) Clarabóia do corpo central: retirada da massa existente, raspagem } \\
\text { dos ferros da armadura, incluindo uma demão da pintura a zarcão; } \\
\text { b) Clarabóia dos torreões das alas direita e esquerda: colocação de } \\
\text { telhas de vidro de } 5 m m \text { de espessura para a cobertura das clarabóias } \\
\text { dos torreões das alas direita e esquerda, incluindo a clarabóia do corpo } \\
\text { central. } \\
\text { - Substituição da caixa d'água de zinco por caixa de concreto; }\end{array}$ & $\begin{array}{l}\text { Idem (Doc.19) } \\
\text { Idem (Docs.26-30) }\end{array}$ \\
\hline $\begin{array}{l}1 \text { de abril de } \\
1948\end{array}$ & $\begin{array}{l}\text { Adaptação do porão para a secção de Numismática } \\
\text {-Reparos no telhado. }\end{array}$ & Idem (Doc.41) \\
\hline $\begin{array}{l}18 \text { de janeiro } \\
\text { de } 1951 \text { a } 10 \\
\text { de janeiro de } \\
1952\end{array}$ & $\begin{array}{l}\text { Adaptação de ala direita do porão: } \\
\text {-Assentamento de grade de ferro quadrada; colocação de caixilhos de } \\
\text { ferro basculante; Colocação de vidros duplos transparentes; pintura a } \\
2 \text { demãos de grafite sorell de Zarcão sobre as grades e caixilhos; - } \\
\text { recomposição do revestimento das alvenarias onde foram colocados as } \\
\text { grades e caixilhos; } \\
\text {-Colocação de uma escada em caracol, em madeira de peroba para } \\
\text { ingresso ao porão (balaustrada de guarda corpo e corrimão) } \\
\text { levantamento do piso e confecção do patamar e recomposição das } \\
\text { alvenarias (torreão oeste) } \\
\text {-revisão do telhado do prédio com substituição de telhas quebradas, } \\
\text { recomposição de rufos e solda de calhas; } \\
\text {-abertura de vãos para alargamento de portas internas; colocação de } \\
\text { vergas de concreto armado; caiação a } 3 \text { demãos de forros }\end{array}$ & Idem (Docs.52, 63 e 65) \\
\hline $\begin{array}{l}22 \text { de janeiro } \\
\text { de } 1954\end{array}$ & $\begin{array}{l}\text {-Mudança das instalações sanitárias (banheiro) do pavimento térreo } \\
\text { para o porão; } \\
\text {-Substituição da cobertura do telhado por chapas de cobre; } \\
\text {-Pinturas gerais }\end{array}$ & Idem (Doc.70) \\
\hline $\begin{array}{l}16 \text { de fevereiro } \\
\text { de } 1954\end{array}$ & $\begin{array}{l}\text { Obras de reforma: pintura das paredes das galerias e salas Pintura } \\
\text { interna sobre esquadrias de madeira. }\end{array}$ & Idem (Doc.74) \\
\hline $\begin{array}{l}13 \text { de maio de } \\
1954\end{array}$ & $\begin{array}{l}\text { Obras de reforma: } \\
\text {-Pintura sobre paredes de salas e galerias etc; Pintura interna sobre } \\
\text { esquadrias de madeira; pintura a verniz; pintura a grafite; pintura a óleo } \\
\text { sobre forros de madeira }\end{array}$ & Idem (Doc.81) \\
\hline $\begin{array}{l}05 \text { de } \\
\text { novembro de } \\
1954\end{array}$ & $\begin{array}{l}\text { Obras de reforma: } \\
\text { - retirada de telhas de barro e chapas galvanizadas; } \\
\text { - substituição do madeiramento inutilizado do telhado por } \\
\text { peças de peroba rosa; } \\
\text { - retirada de massa, limpeza de caixilhos de ferro } \\
\text { - pintura, zarcão na clarabóia; } \\
\text { - colocação de vidros planos lisos; } \\
\text { - limpeza e solda de calhas; } \\
\text { - cobertura com chapa lisa de cobre }\end{array}$ & Idem (Doc.100) \\
\hline
\end{tabular}




\begin{tabular}{|c|c|c|}
\hline $\begin{array}{l}\text { 03 de fevereiro } \\
\text { de } 1955\end{array}$ & $\begin{array}{l}\text { Obras de adaptação do porão } \\
\text {-movimento de terra; } \\
\text {-chapisco com argamassa de cal e areia; } \\
\text {-Alvenaria de elevação com argamassa de cal ,areia 1:4, 1/2 tijolo } \\
\text {-revestimento interno com emboço de argamassa de cal e } \\
\text { areia e reboco com argamassa de cal e areia; } \\
\text {-hidráulica: canalização de esgoto; } \\
\text {-instalação elétrica; } \\
\text {-substituição de vidros; } \\
\text {-pintura sobre esquadrias de madeira. }\end{array}$ & Idem (Doc.111) \\
\hline $\begin{array}{l}02 \text { de maio de } \\
1956 \text { a } 5 \text { de } \\
\text { agosto de } \\
1957\end{array}$ & 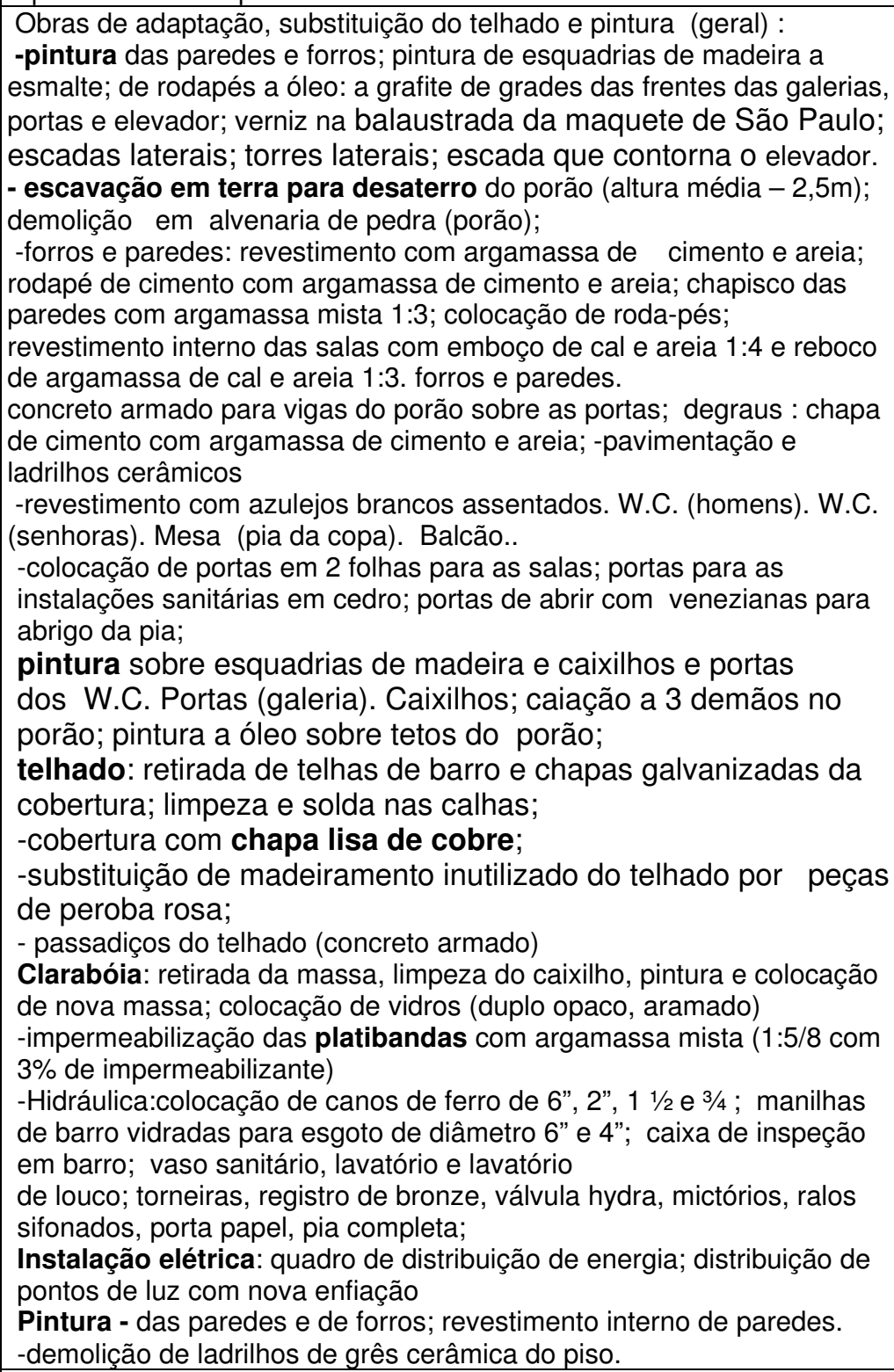 & $\begin{array}{l}\text { Idem (Docs.134-151; } \\
\text { 198; 211) }\end{array}$ \\
\hline $\begin{array}{l}15 \text { de abril de } \\
1958\end{array}$ & $\begin{array}{l}\text { Colocação de porta pantográfica necessária à segurança da } \\
\text { Seção de Numismática do Museu Paulista. }\end{array}$ & Idem (Doc.219) \\
\hline $\begin{array}{l}29 \text { de junho de } \\
1958\end{array}$ & Pintura em esquadrias de madeira. & Idem (Doc.234) \\
\hline $\begin{array}{l}11 \text { de } \\
\text { dezembro de } \\
1961 \text { a } 7 \text { de } \\
\text { junho de } 1962\end{array}$ & $\begin{array}{l}\text { Reforma do telhado: } \\
\text { Retirada das telhas de barro tipo colonial assentada com } \\
\text { argamassa de cimento e areia; Soldas em calha e cobertura de } \\
\text { cobre; emassamento com duas demãos sobre caixilhos do } \\
\text { telhado; Colocação de vidros planos aramados; pintura de } \\
\text { caixilhos com duas demãos de grafite sobre uma de zarcão; } \\
\text { raspagem da pintura existente; cobertura com chapa lisa de } \\
\text { cobre e caiação a } 3 \text { demãos em cores claras lisas do depósito }\end{array}$ & $\begin{array}{l}\text { Secretaria da Viação e } \\
\text { Obras Públicas do Estado } \\
\text { de São Paulo - Diretoria } \\
\text { de Obras Públicas - } \\
\text { 18/08/1961, v. } 3 \text { (Docs.05, } \\
11,21 \text { e 22) }\end{array}$ \\
\hline
\end{tabular}




\begin{tabular}{|c|c|c|}
\hline & $\begin{array}{l}\text { de livros; raspagem da pintura velha a óleo sobre paredes } \\
\text { emassadas e lixadas; rufo de chapa de cobre;arremate do } \\
\text { telhado com alvenaria; pintura de esquadrias }\end{array}$ & \\
\hline $\begin{array}{l}04 \text { de fevereiro } \\
\text { a } 5 \text { de agosto } \\
\text { de } 1963\end{array}$ & $\begin{array}{l}\text { Telhado do torreão central e laterais: } \\
\text { Retirada dos vidros e pintura nas ferragens com zarcão e recolocação } \\
\text { dos mesmos; colocação de chumbo em lençol. }\end{array}$ & Idem (Docs.43 e 55) \\
\hline $\begin{array}{l}19 \text { de julho de } \\
1957\end{array}$ & $\begin{array}{l}\text { As obras de reforma do telhado, substituição das telhas de barro por } \\
\text { cobre foram paralisadas em outubro de } 1956 \text { pela empreiteira. A } \\
\text { interrupção da substituição das telhas de barro do torreão central gerou } \\
\text { uma serie de problemas com a infiltração de água dentro do prédio e } \\
\text { sucessivas tentativas de reparo. A questão teve de ser resolvida na } \\
\text { justiça durante os anos seguintes e, em } 1961 \text { abriu-se nova } \\
\text { concorrência para que as obras fossem concluídas, o que ocorreu em } \\
1963 .\end{array}$ & $\begin{array}{l}\text { Secretaria da Viação e } \\
\text { Obras Públicas do Estado } \\
\text { de São Paulo - Diretoria } \\
\text { de Obras Públicas, } \\
\text { 17/01/1957, v.5 (Doc.17) }\end{array}$ \\
\hline $\begin{array}{l}30 \text { de } \\
\text { dezembro de } \\
1957\end{array}$ & $\begin{array}{l}\text {-Serviços gerais: de demolição para abertura de vãos; de pedreiro: de } \\
\text { concreto; de estucador (revestimentos); de pavimentador } \\
\text { (pavimentação com ladrilhos); de marceneiro (execução de portões } \\
\text { internos, rodapés, batentes, armários etc); de marmorista; de } \\
\text { vidraceiro; de eletricista; de encanador (colocação de tanque do tipo de } \\
\text { lavar roupas); de pintor (pintura a óleo de } 3 \text { demãos sobre bases bem } \\
\text { aparelhadas e emassadas e portas) }\end{array}$ & Idem (Doc.74-76) \\
\hline $\begin{array}{l}10 \text { de } \\
\text { dezembro de } \\
1958\end{array}$ & $\begin{array}{l}\text { Serviços não previstos: divisões de eucatex; prateleiras; cavaletes; } \\
\text { forro de pinho; soalho de peroba; torneira; tubo e sifão de chumbo; } \\
\text { vidros, reparos em rodapés; pintura de portas e de rodapés. }\end{array}$ & Idem (Doc.95) \\
\hline $\begin{array}{l}11 \text { de Março } \\
\text { de } 1961\end{array}$ & Vazamentos na clarabóia & $\begin{array}{l}\text { Arquivo Intermediário } \\
\text { Fundo Museu Paulista P- } \\
78\end{array}$ \\
\hline $\begin{array}{l}03 \text { de julho de } \\
1962\end{array}$ & $\begin{array}{l}\text {-Retomada e conclusão total das obras de reforma das coberturas de } \\
\text { cobre } \\
\text {-Reforma de partes de vidro }\end{array}$ & $\begin{array}{l}\text { Secretaria de Viação e } \\
\text { Obras Públicas do Estado } \\
\text { de São Paulo - } \\
\text { Diretoria de Obras } \\
\text { Públicas, 05/09/1966, v.8 } \\
\text { (Doc.05) } \\
\text { Cf. informações sobre } \\
\text { procedimentos técnicos } \\
\text { da reforma da cobertura } \\
\text { no documento }\end{array}$ \\
\hline $\begin{array}{l}27 \text { de } \\
\text { novembro de } \\
1962\end{array}$ & $\begin{array}{l}\text { Reformas no telhado: } \\
\text { - Reforma e pintura de clarabóia, troca dos vidros do telhado do torreão } \\
\text { - Retirada dos vidros com pintura de zarcão e recolocação dos } \\
\text { mesmos. } \\
\text { - Retirada dos vidros da segunda clarabóia. } \\
\text { - Fornecimento e colocação de vidro aramado. } \\
\text { - Fornecimento e colocação de vidros opacos. } \\
\text { - Fornecimento e colocação de chumbo em lençol de } 0,06 \text {. } \\
\text { - Pintura a óleo a } 3 \text { demãos de tinta sobre estrutura de ferro. } \\
\text { - Reforma das duas hastes do pára-raio. }\end{array}$ & Idem (Doc.44) \\
\hline $\begin{array}{l}10 \text { de } \\
\text { setembro de } \\
1959\end{array}$ & $\begin{array}{l}\text { Conclusão das obras de adaptação do porão e do pavimento superior } \\
\text { do prédio: demolição do banheiro da Sala B12 e transferência para o } \\
\text { subsolo }\end{array}$ & Idem (Doc.109) \\
\hline $\begin{array}{l}15 \text { de maio de } \\
1968\end{array}$ & Substituição de vidros quebrados na clarabóia. & Idem (Doc.113) \\
\hline $\begin{array}{l}10 \text { de agosto } \\
\text { de } 1971\end{array}$ & $\begin{array}{l}\text { Solicitação e justificativa para a realização de limpeza e pintura externa } \\
\text { do edifício em razão do } 150^{\circ} \text { aniversário da Independência. }\end{array}$ & $\begin{array}{l}\text { Secretaria dos Serviços e } \\
\text { Obras Públicas do Estado } \\
\text { de São Paulo - } \\
\text { Departamento de Edifícios } \\
\text { Públicos- Limpeza e } \\
\text { pintura externa (Doc.01) }\end{array}$ \\
\hline $\begin{array}{l}03 \text { de } \\
\text { novembro de } \\
1971\end{array}$ & $\begin{array}{l}\text { Diretrizes e especificações levantadas das obras de limpeza e pintura } \\
\text { externa; definição de posturas a serem adotadas pela empreiteira e } \\
\text { indicações de materiais. }\end{array}$ & Idem (Docs.05 - 11) \\
\hline $\begin{array}{l}04 \text { de } \\
\text { novembro de } \\
1971\end{array}$ & $\begin{array}{l}\text { Relatório assinado pelo engenheiro fiscal Fernando } \\
\text { José d'Oliveira contendo: } \\
\text {-Levantamento de quantidades. } \\
\text {-Especificações técnicas. }\end{array}$ & Idem (Doc.41-43) \\
\hline
\end{tabular}




\begin{tabular}{|l|l|l|}
\hline & $\begin{array}{l}\text {-Equipamentos e cronologia dos serviços. } \\
\text {-Serviços não incluídos no orçamento. } \\
\text {-Quantidades. } \\
\text {-Resumo final. }\end{array}$ & \\
\hline $\begin{array}{l}20 \text { de março } \\
\text { de } 1972\end{array}$ & $\begin{array}{l}\text { Definição de orçamento dos serviços de pintura externa e restauração } \\
\text { das fachadas }\end{array}$ & Idem (Doc. 52) \\
\hline $\begin{array}{l}07 \text { de abril de } \\
1972\end{array}$ & Doação de tintas pelas Tintas Coral às obras de pintura externa. & Idem (Doc.54) \\
\hline $\begin{array}{l}17 \text { de maio de } \\
1972\end{array}$ & $\begin{array}{l}\text { Engenheiro Fiscal Fernando José d'Oliveira faz alterações feitas nos } \\
\text { documentos 41-43 de acordo com os novos rumos tomados na } \\
\text { Reunião do dia 15 do mesmo mês. }\end{array}$ & $\begin{array}{l}\text { Idem (Doc.55 - 58) } \\
\text { Ver cópia do documento } \\
\text { p.X }\end{array}$ \\
\hline $\begin{array}{l}22 \text { de maio de } \\
1972\end{array}$ & $\begin{array}{l}\text { Abertura de processo de licitação para a realização da obra de pintura } \\
\text { externa baseada nas diretrizes determinadas pela reunião do dia 20 do } \\
\text { mesmo mês. }\end{array}$ & $\begin{array}{l}\text { Idem (Docs. 67 e sem } \\
\text { numeração) }\end{array}$ \\
\hline
\end{tabular}

A CPOS se incumbiu das obras no Museu Paulista de 1931 a 1972.

- No período entre 1931 e 1959 são realizadas as obras de adaptação do porão,de modo a criar mais um pavimento com novos espaços para salas de trabalho, de exposição e banheiros. Para se obter esses espaços, foram necessárias diversas alterações na estrutura do edifício e nas funções do porão, como a caixa de ar, a ventilação e afastamento da umidade do solo - como era concebido originalmente.

O pé-direito de $2,50 \mathrm{~m}$ foi obtido através do rebaixamento do piso por meio de escavação do solo e da eliminação de alguns arcos para aumentar a altura. Para as aberturas das portas, partes da alvenaria de pedra foram cortadas e foram utilizadas vergas de concreto. Foram Introduzidas também vigas metálicas, mas a documentação não especifica em que local, sua quantidade, nem sua função.

O porão, ou a região do embasamento do edifício, era constituído de alvenaria de pedra e de tijolos, sem revestimento, por onde a umidade ascendente pudesse caminhar para a superfície e evaporar livremente, com a ventilação permanente. Havia uma grande circulação de ar livre, longitudinal e transversalmente, de ponta a ponta do edifício, através de diversos pequenos arcos internos, que se interligavam entre si e às aberturas externas. No entanto, para a instalação de banheiros e salas de trabalho, muitos desses arcos foram fechados e a ventilação então teve uma significativa alteração. Desse modo, quando começou o pavimento criado passou a ser utilizado, no subsolo, constatou-se que havia muita umidade ascendente na alvenaria de pedra das fundações sob as paredes internas e externas, e a alvenaria de pedra foi revestida com tijolos em espelho afastados dessa alvenaria por volta de $10 \mathrm{~cm}$, para impedir a transmissão da umidade para os ambientes internos. O teto sob as abobadilhas recebeu revestimento de argamassa e pintura. As paredes foram pintadas com tinta óleo, camada sobre camada, repetidamente no correr dos anos e até hoje. Como conseqüência, as paredes internas e os tetos do embasamento e os tetos, perderam a permeabilidade à água ou ao vapor e a evaporação por meio da ventilação permanente e livre, como era concebido originalmente.

- Estruturalmente houve mudanças na distribuição de cargas sobre a fundação, por causa dos cortes feitos para criar as aberturas, em que foram extraídas partes da alvenaria de pedra, diminuindo sua altura nesses pontos, e que anteriormente eram corpos sólidos e contínuos. A fundação de alvenaria de pedra foi construída escavada no solo. Com a retirada deste solo, perdeu-se a sustentação lateral.

Foi realizada, assim, uma grande alteração na função do porão de ventilação e, com a umidade ascendente tendo dificuldade para evaporar nas superfícies verticais da 
fundação, ocorre o aumento de sua altura, que chega a atingir paredes externas e internas do pavimento acima (este assunto será tratado posteriormente).

- A planta a seguir, de 18 de fevereiro de 1956, aponta a transferência do banheiro do pavimento térreo para o subsolo, em dois conjuntos, sendo um em cada ala; a escada de acesso do térreo para o sub-solo, no centro do edifício de $2.97 \mathrm{~m}$ de largura, com 18 degraus; a execução da escada caracol do térreo para o sub-solo, na Torre Oeste. No detalhe, define-se o desnível entre o solo externo e o interno.

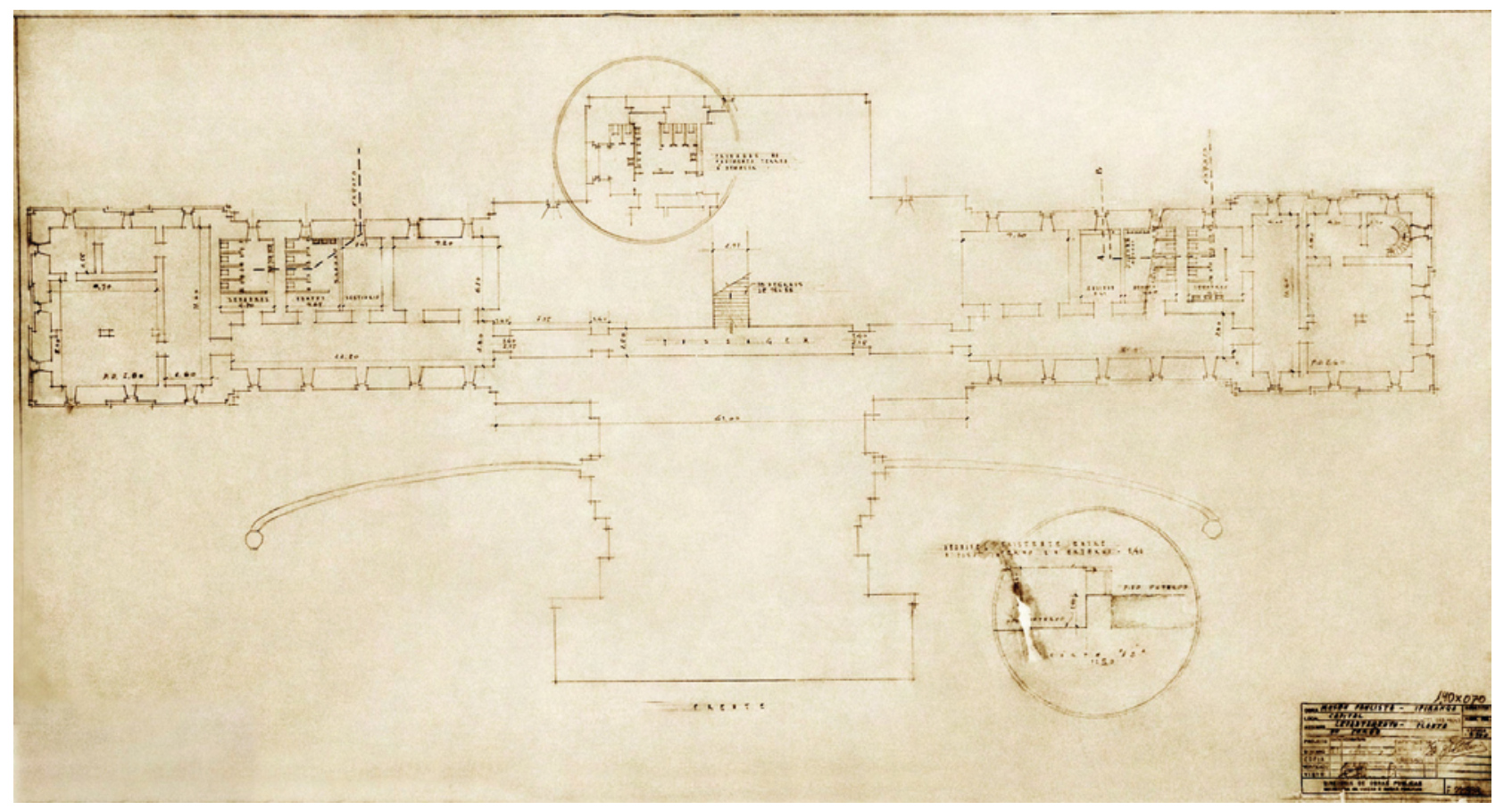

Fig. 290 - Acervo Museu Paulista
Coleção CPOS - PLANTA DO SUBSOLO

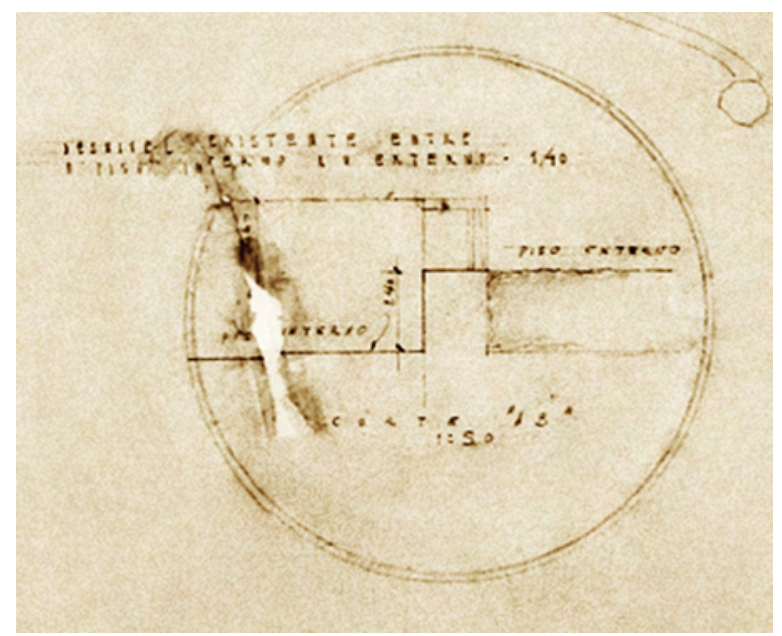

Fig. 291 - Acervo Museu Paulista

DETALHE: Desnível entre o piso interno e o externo de 1,40m

Aparecem também todas as passagens e portas abertas para acesso às salas. Sob o Corpo Central ainda permanece o solo original. 
Em agosto de 1959 terminam as obras na sala do pavimento térreo da onde saiu o banheiro e da adaptação do porão.

- O telhado, como foi referido anteriormente, desde 1895 exigiu consertos. No período entre 1910 e 1912, as telhas de barro sobre as Galerias foram substituídas por chapas de cobre.

Os trabalhos com os telhados e clarabóias continuaram e em 1954 o restante da cobertura de telhas foi substituída pelas chapas de cobre. É ainda citado na documentação a execução, em 1957 e 1962, de trabalhos com os telhados de chapas de cobre.

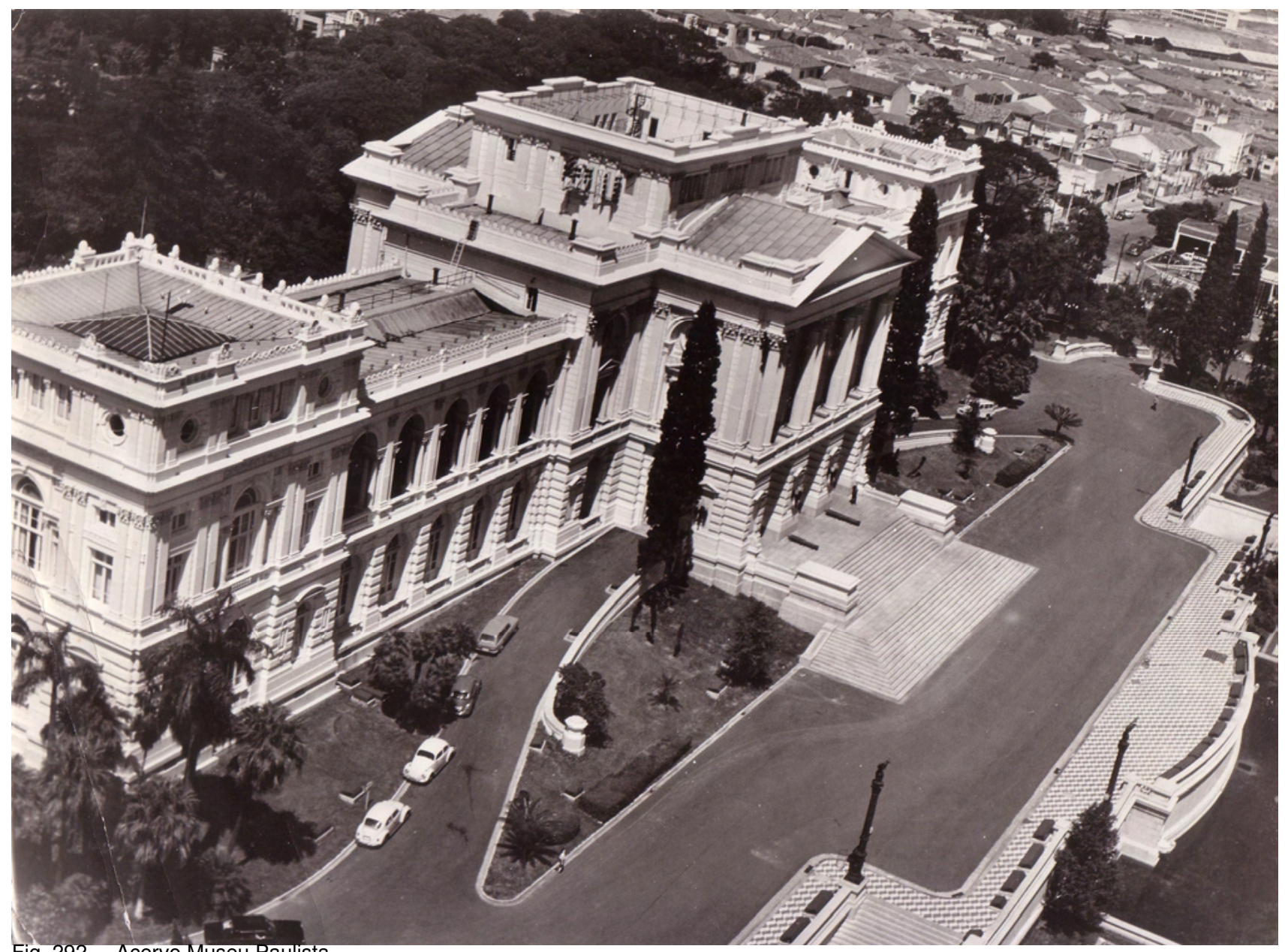

Fig. 292 - Acervo Museu Paulista

COLEÇÃO CPOS (não catalogada) - VISTA AÉREA

Esta imagem não apresenta data, mas supõe-se que date dentre a década de 60 e início da 70 . Verifica-se que todos os telhados foram executados em chapas de cobre.

Conclusão das obras de instalação elétrica

Instalação de elevador elétrico 1936

Revestimento e capeamento das platibandas e impermeabilização

- Em agosto de 1971 são solicitadas a limpeza e pintura das fachadas para a comemoração do $150^{\circ}$ aniversário da Independência, sendo em 29 de outubro de 1971 apresentada a primeira proposta (Documentos 41, 42 43, frente e verso). No Doc. 41, 0 item 1. Levantamento de Quantidades, se refere à impossibilidade de calcular as áreas de 
todos ornamentos, de modo que se propõe um preço global da empreitada. Nos itens 1.5.5. e 1.5.7. é citado o fato de que a maior dificuldade das tarefas não está no serviço de pintura em si, mas na restauração das partes danificadas, que exigiria o trabalho de um pedreiro especializado em moldagens artísticas nas folhas estilizadas, modilhões e principalmente nos escudos sobre as portas do Corpo Central, como de fato se pode observar nas imagens abaixo.
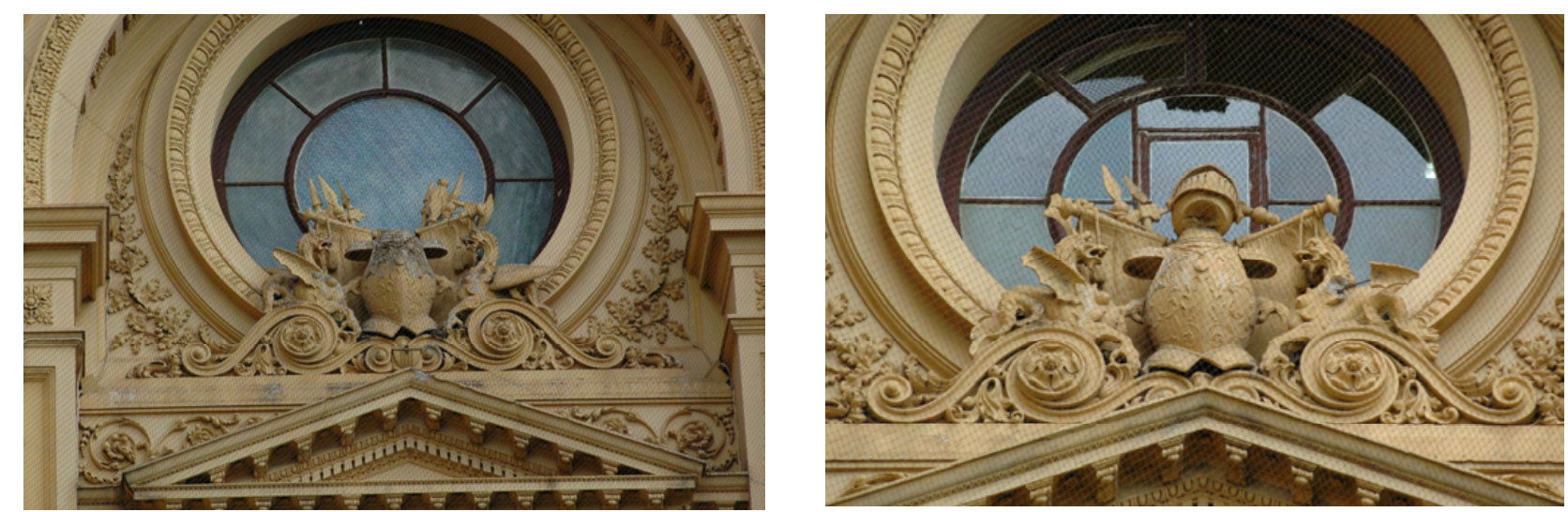

Fig. 293 e 294 - Escudos sobre aberturas do Corpo Central: perdas de partes do ornamento

Ainda nessa ocasião, foi solicitada uma cópia em papel transparente da fachada principal para compor a proposta. Na Coleção CPOS, há uma fachada de 2,00mX0,40m, na qual no canto inferior direito encontra-se apenas uma assinatura de difícil leitura: Waldenier Ganggel, 1921, sem mais nenhuma outra informação sobre sua origem.

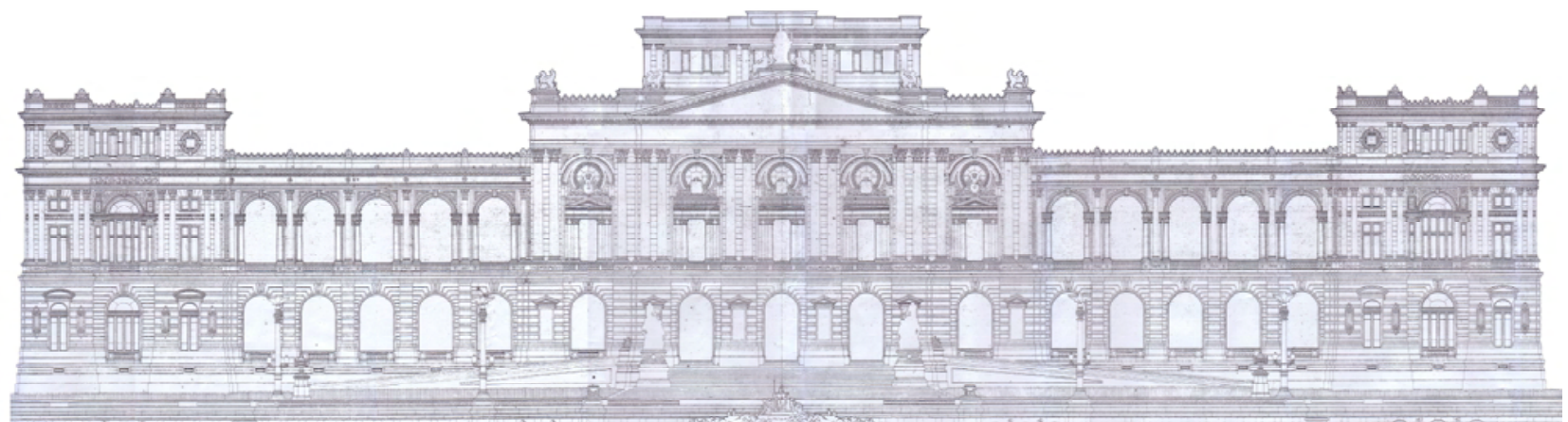

Fig. 295 - Coleção CPOS - Acervo Museu Paulista

FACHADA PRINCIPAL 


\section{2 - ESPECIFICACOES TÁCNICAS}

A-fim de que fôsse possível especificar as etapas de serviço e o tipo de pintura a ser usado na parte de revestimento, consultamos: Tintas Coral S/A, Pinturas Ipiranga Ltda, João Rezende \& Cia Ltda e S. Sparapani \& Filhos Ltda (em fase de término de suas atividades) que foi indicada pelos demais como a que possuia mais experiência em tempo e em serviços similares aos que se pretendem fazer no MUSUU PAU LISTA. As sugestões que nos foram fornecidas e de acôrdo com o estado atual do prédio que não recebe pintura externa, condizente com a obra, desde que foi construido (1890-informação que não foi possível confirmar ou desmentir); podemos resumir:-

2.1 - Limpeza:- pelos métodos tradicionais e manual para que não haja dano aos ornatos;

2.2 - Preparo da superfície:-

2.2.1 - deveria ser retirado todo o revestimento atacado pelos agentes atmosféricos e revestido de nôvo, impraticável em virtude do prazo e da falta atualmente de "frentistas" especializados.

2.2.2 - reparos ligeiros com argamassa de cimento, areia e cal, cimento e areia e só nata de cimento-praticável;

2.2.3 - aplicação de massa; isto é betumar a superfície para rê ceber a pintura;

\section{3 - Tipo de massa:}

A maioria das opiniões foi de que o tipo de pintura deveria ser a óleo sôbre massa corrida lixada com lixa d'água;isto é o tipo tradicional e ainda, não ultrapassado pois, para o tipo de tintas mais modernas há necessidade de uma superfície em melhores condiçoses das existentes. Os ornatos foram executa dos com material "fraco" (leve) e a aplicação de uma tinta "for te" pode danificá-los.

2.4 - 0 problema de realçar a beleza dos ornatos (baixos e altos relệ vo) foi também levado em conta e o serviço de pátiná teve sempre maior uso na pintura a óleo.

2.5 - Os materiais usados para confeccionar as tintas e massas de betumar deverão ser de qualidade SUPERIOR.

2.6 - A aplicação deverá merecer os maiores cuidados técnícos que vão desde o tipo da superfície, direção de aplicação, tempo e condi ções de secagem até a hora do dia de aplicação (mais calor menos calor).

2.7 - Aplicação final de tînta a base de "silicone" para proteger as fachadas contra a ação das águas da chuva e procurar evitar a

rco : formação de fungos e aumentar o tempo de vida da pintura.

2.8 - . Og téonicos verificaram a existência de vestigios de massa a óleo na oimalha do 20 Pavimento o que parece indicar que inicial mente o Museu Paulista foi pintado segundo o- método aqui propos to e que sobe para aprovacão (em anexo $7 \mathrm{fls}$ de ESPECIFICACOES TECNICAS que se fôrem aprovadas farão parte do Caderno de Concorrência).

-segue-verso- 
No Documento 42, acima, que contém a primeira proposta, no item 2, Especificações técnicas, é prevista a limpeza mediante métodos tradicionais e manuais para não danificar os ornatos , mas não os esclarece suficientemente.

Destaca-se o comentário de que "de acordo com o estado atual do prédio, não recebe pintura externa condizente com a obra, desde que foi construído em 1890". $\mathrm{Na}$ preparação da superfície, admite-se que o revestimento atacado pelos agentes atmosféricos deveria ser retirado e revestido de novo. No entanto, essa atividade seria impraticável, devido ao prazo exíguo e à falta de "frentistas" especializados. Propõe-se então "reparos ligeiros" com argamassa e aplicação de massa para receber a pintura. Indica-se a pintura a óleo sobre massa corrida lixada - isto é, o tipo de tinta tradicional e não ultrapassada pelas tintas modernas, e também mais própria para executar pátinas.

$\mathrm{E}$, no último item, o texto afirma que os técnicos verificaram a existência de vestígios de massa a óleo na cimalha do segundo pavimento, o que parece indicar que inicialmente 0 Museu Paulista fora pintado segundo o método previsto. A proposta foi encaminhada à aprovação, em 4 de novembro de 1971.

Nos Documentos 55 a 58, de 12 de maio de 1972, encontram-se propostas de modificações e reformulações nas Especificações Técnicas, contidas no Documento 41 e 42. As modificações propostas substituem a tinta óleo, composta pelos materiais do item 7 (Doc 63, 64): alvaiade, óleo de linhaça, água raz, gesso crê , devendo ser escolhido o tipo de pintura entre a tinta látex sem massa e a cal. A decisão ficou a cargo de "instância superior", isto é, foi submetida a uma escala decisória superior, tornando-se questão de hierarquia.

No item 4 (Documento de 55 a 58,apresentado a seguir), o engenheiro fiscal declara que em todas as reuniões com os representantes das firmas especializadas em que esteve presente, apresentou suas restrições à pintura de tinta látex, e que os reparos "ligeiros" nos revestimentos devido à impossibilidade de tempo e de verba para restauração trariam problemas futuros. Os ornatos com rugosidades, se não fossem restaurados não poderiam ser disfarçados com massa e pintura e principalmente, se pintados com "tinta mais forte" ajudaria a destacar partes do revestimento e dos próprios ornatos - e que a restauração futura se tornaria mais difícil.

Depois de uma criteriosa avaliação de todas as superfícies das fachadas do edifício, pode-se constatar que as rugosidades nos ornamentos são encontradas nas palmetas da platibanda. Ou pelo menos podem ser adotados como ótimos exemplos de uma inadequada intervenção anterior.

Hoje podemos constatar, que pelo menos nesta afirmação o engenheiro fiscal tinha toda razão: os danos foram acentuados, há perdas nas formas das superfícies desses ornamentos e a restauração hoje será extremamente trabalhosa. 


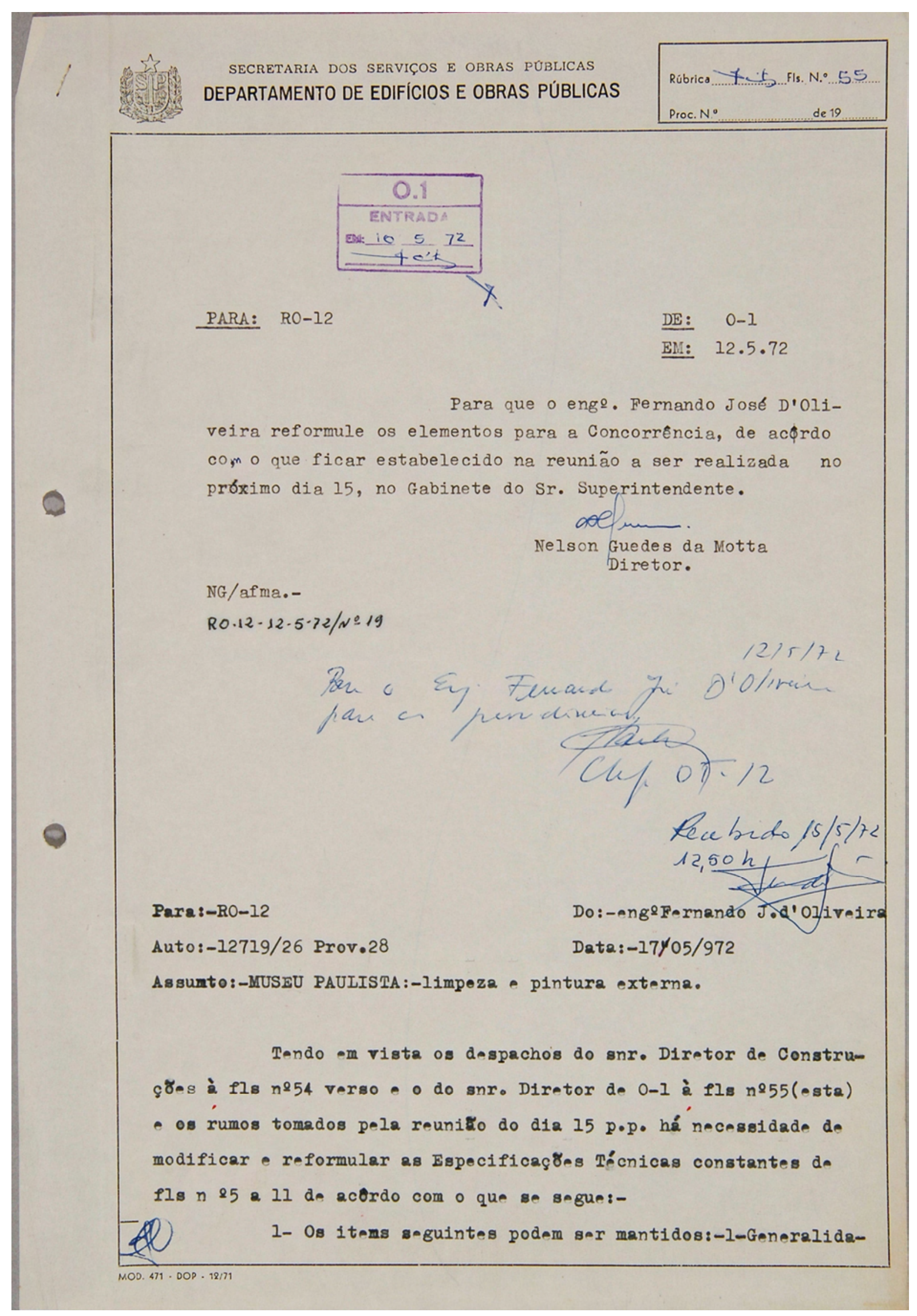


SECRETARIA DOS SERVICOS E OBRAS PÚBLICAS DEPARTAMENTO DE EDIFÍCIOS E OBRAS PÚBLICAS

des;2-Instalaçăo do Canteiro;3-Materiais.4-Mťo de Obra

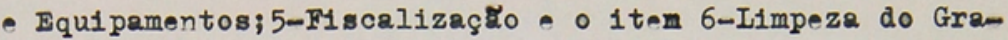
nito;

2- 0 1tem 7-Pintura:

2.1- De 7.1-Generalidades,mantido dòmente o numero 7.I.1;

2.2- De 7.2-Materiais, totalmente anulado;

2.3- De 7.3-Esquadris de ferro,mantido totalmente;

2.4- De 7.4-Esquadrias de Madeira,mantidos os numeros $7 \cdot 4 \cdot 1,7 \cdot 4 \cdot 3,7 \cdot 4 \cdot 4,7 \cdot 4 \cdot 5,7 \cdot 4 \cdot 7$ (excluidos os numerod 7.4 .2 e 7.4.6). Devendo ser escolnido o tipo de pinture entre:-

1- à oleo com meio brilho;

2-

3- esmalte;

2.5- De 7.5-Pintura das Fachadas o final do numero 7.5.1 "e teræ̃o acabamentp brilhante" deverá ser suprimido. Os numeros $7.5 .2,7.5 .3,7.5 .5,7.5 .8$ serăo mantidos e os demais deverăo ser excluidos.Devendo ser escolnido o tipo de pintura:-

1-pintura com tinta a base de latex sem massa;

2-pintura com cal com cuidados especials afim de que haja melhor aderencia.

3-Reiteramos nossa solicitaço à fls ne43 de29-10-971, afim de que: -

3.I- aprovaçăo pelo setor competente do critério para elaboraço do orçamento no que se refere as quantidades, po1s em se tratando de obra de natureza especial nơ seguímos as normas do Manual Técnico do DOP;

3.2- aprovaço pelo Setor competante das Especificaçช̆es Tócnicas com as restrições mencionadas e delxando pa- 
SECRETARIA DOS SERVIÇOS E OBRAS PÜBLICAS DEPARTAMENTO DE EDIFÍCIOS E OBRAS PÚBLICAS

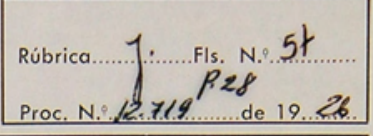

ra especificar a pintura com tinta a base de latex ou pintura à cal, conform. o que för por instencia superior decidido.

4-Tendo em vista as reunioõs q que estivemos presente, as manifestaçסิes das firmas especializadas que se fizeram representar, reiteramos resumidamente as nossas restriçбes a pintura com tinta a base de latex, conforme declaramos em todas as reuniores;que ge prendem a exiguidade de prazo que obrigará a reparos "Iigeiros"nos revestimentos e impossibilidam de de tempo e da verba para atender a restauraçăo, acarretando o que se segue:-

4-1- os ornatos apresentam rugosidades que năo poderão ser disfarçadas com pintura;isto ’́ com massa de pintor ou tinta;

4.2- a restauraçăo "futura" se tornará mais dificil se hoje for pintado com tinta mais resistente por cime dos ornatos sem restauraçăo;

4.3- há a possibilidade de uma "tinta mais forte" ajudar a destacar partas do revestimento e ornatos que em virtude do prazo exíghio de execuça n⿳̆ poderăo ser restaurados e reparados como seria necessério de acordo com a $/ b 0 a$ tecnica";

4.4- uma "pintura" de melhor qualidade mas năo incluindo tơdas as etapas necessárias a sua execução(em virtuda da exiguidade do prazo)irá regaltar ainda ma1s os defeitos o obrtgarpa que os reparos no revestimento sem jam feltos até o ponto limite que será a passagem de um plano para outro, afim de que estes reparos em vez de meIhorar o asspecto, năo piorarem;pois a descont1nuidade de reparos seró mais passivel de ser observada

Fig. 297 - Coleção CPOS - Acervo Museu Paulista

DOCUMENTO 57 - SEGUNDA PROPOSTA 
SECRETARIA DOS SERVIÇOS E OBRAS PÚBLICAS DEPARTAMENTO DE EDIFICIOS E OBRAS PÚBLICAS

por quelquer leigo;

4.5- a pintura a latex impedirá que seja dada a pátina necesséria para que sejam resaltados os elementos arquitetônicos - impedirá ou dificultará a formaç̆o de pátina (pelo tempo);pois ou se destacará em laminas(se a superficie n⿺辶⿻ for convinietemento reparada)ou ficará aderente impedindo ou dificultando como atraz foi dito a formaço de "fungos" que dará a pátina pelo tempo.

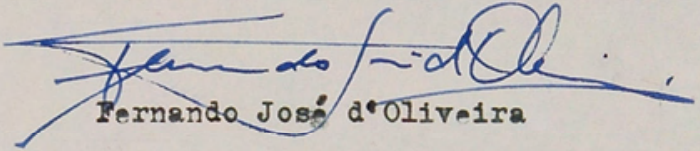
engo fiscel

Part D.
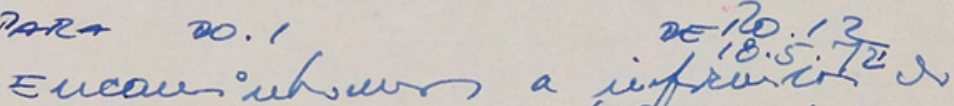

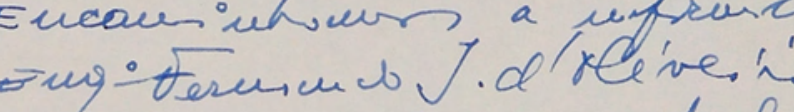
turc, eur nith o dertrol de o5 55.

Fig. 298 - Coleção CPOS - Acervo Museu Paulista

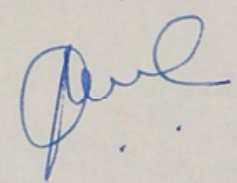




\section{ARQUIVO INTERMEDIÁRIO - FUNDO MUSEU PAULISTA}

\section{Decorridos 16 anos, retorna a questão da necessidade de nova pintura e são avaliados os critérios a serem adotados.}

QUADRO 6 -1988 A 1993

\begin{tabular}{|c|c|c|}
\hline $\begin{array}{l}02 \text { de Maio de } \\
1988\end{array}$ & $\begin{array}{l}\text { Emissão de informe das Tintas Coral SA. Referente à visita feita } \\
\text { no dia } 29 / 04 \text {, em companhia de Secretario e empreiteiro para a } \\
\text { avaliação do estado geral do edifício e orientação do sistema } \\
\text { adequado de pintura. }\end{array}$ & $\begin{array}{l}\text { Arquivo Intermediário Fundo } \\
\text { Museu Paulista Pasta } 74\end{array}$ \\
\hline $\begin{array}{l}14 \text { de Julho de } \\
1988\end{array}$ & $\begin{array}{l}\text { Definição do orçamento de mão de obra para execução da } \\
\text { pintura das fachadas. Serviços: impermeabilização das cimalhas, } \\
\text { substituição de trechos deteriorados de argamassa, raspagem, } \\
\text { preparação do fundo e pintura geral das fachadas. O material } \\
\text { seria fornecido pelas Tintas Coral S.A. }\end{array}$ & $\begin{array}{l}\text { Arquivo Intermediário Fundo } \\
\text { Museu Paulista Pasta74 }\end{array}$ \\
\hline $\begin{array}{l}29 \text { de Julho de } \\
1988\end{array}$ & $\begin{array}{l}\text { Informe apresentado pela CPC em reunião do dia 07.10.1988 } \\
\text { contendo especificações para a pintura no Museu Paulista: } \\
\text { 1. Serviços de limpeza: Não utilizar processos mecânicos para } \\
\text { remoção de pintura existente (como lixamento, jateamento, etc.) } \\
\text { que possam agredir a estratificação, sobretudo camadas } \\
\text { originais. Limite: regularização da superfície sobre o ultimo } \\
\text { extrato. } \\
\text { 2. Características Técnicas do Material a ser utilizado: } \\
\text { recomendada a utilização de tintas à base de água. Resultado } \\
\text { desejado no final da pintura: características físicas dos } \\
\text { processos tradicionais de caiação: textura aveludada, opacidade } \\
\text { e porosidade. } \\
\text { 3. Cor: As prospecções preliminares indicam que a coloração } \\
\text { original aproximava-se do amarelo (oxido de ferro), empregado } \\
\text { em tons e sobretons. Necessário promover estudos e } \\
\text { prospecções complementares, para se chegar a um resultado } \\
\text { aproximativo do tom e sobretons originais (variação media). }\end{array}$ & $\begin{array}{l}\text { Arquivo Intermediário Fundo } \\
\text { Museu Paulista Pasta73 }\end{array}$ \\
\hline $\begin{array}{l}02 \text { de Setembro } \\
\text { de } 1988\end{array}$ & $\begin{array}{l}\text { Determinação de realização de prospecções para escolha de } \\
\text { cores }\end{array}$ & $\begin{array}{l}\text { Arquivo Intermediário Fundo } \\
\text { Museu Paulista Pasta73 e } \\
74\end{array}$ \\
\hline Outubro de1988 & Inicio das obras de pintura externa. & $\begin{array}{l}\text { Arquivo Intermediário Fundo } \\
\text { Museu Paulista Pasta73 }\end{array}$ \\
\hline $\begin{array}{l}\text { Novembro } \\
1988\end{array}$ & $\begin{array}{l}\text { As especificações e procedimentos da empresa Tintas Coral } \\
\text { contrariam as orientações estabelecidas pela CPC, referendado } \\
\text { pelo CONDEPHAAT especialmente considerando-se: } \\
\text {-os processos de limpeza e preparo das superfícies, podendo } \\
\text { eliminar os vestígios das estratificações existentes cuja } \\
\text { conservação é imprescindível para assegurar o desenvolvimento } \\
\text { de estudos posteriores sobre revestimentos e tintas da } \\
\text { arquitetura tradicional brasileira. Pressupões para limpeza o } \\
\text { emprego de jateamento de água, lixamento e raspagem. } \\
\text { - a utilização de massa acrílica, para eliminar imperfeições e } \\
\text { uniformizar as superfícies, } \\
\text { - bem como a intenção de se refazer as áreas de revestimento } \\
\text { que se encontram desagregadas acarretará mudanças } \\
\text { significativas nas características originais do revestimento do } \\
\text { edifício, desconhecendo a conveniência de se recompor as } \\
\text { texturas primitivas, típicas dos processos de pintura que } \\
\text { empregam produtos a base de cal. } \\
\text { Os trabalhos de pintura, uma vez necessário corrigir superfícies } \\
\text { desagregadas, exigem o desenvolvimento de ensaios da } \\
\text { argamassa original, de modo a evitar diferenças de } \\
\text { comportamento no tocante à absorção de umidade, contração, } \\
\text { expansão, etc. devem ser impedidos serviços de pintura das } \\
\text { portas e janelas, pois é fundamental promover preliminarmente } \\
\text { as prospecções dos extratos existentes para identificar com o }\end{array}$ & $\begin{array}{l}\text { Arquivo Intermediário Fundo } \\
\text { Museu Paulista Pasta73 e } \\
74\end{array}$ \\
\hline
\end{tabular}




\begin{tabular}{|c|c|c|}
\hline & $\begin{array}{l}\text { necessário rigor os materiais e policromias utilizadas, sobretudo } \\
\text { em consideração à perspectiva da eliminação de quaisquer } \\
\text { vestígios. É frisado que toda iniciativa que dispense exames } \\
\text { prévios dos materiais e tonalidades contraria todo e qualquer } \\
\text { trabalho de restauração conseqüente, menosprezando } \\
\text { metodologias universalmente consagradas, causando danos } \\
\text { irreversíveis ao patrimônio cultural. } \\
\text { Todavia, tratando-se de serviços de natureza complexa e nem } \\
\text { sempre possíveis de serem avaliados corretamente na ausência } \\
\text { de informações completas, admito que a execução de um teste } \\
\text { no local poderá contribuir para o esclarecimento de pontos de } \\
\text { vista, favorecendo a solução técnica a ser adotada. Nesse } \\
\text { sentido, entendo que numa área do edifício já prejudicada, a ser } \\
\text { indicada pela comissão, deverão ser executadas três superfícies } \\
\text { de testes: a primeira com amostra do tratamento de limpeza, a } \\
\text { segunda contendo o preparo para a pintura e a terceira com o } \\
\text { acabamento final, compreendendo módulos não superiores a } \\
\text { dois metros quadrados cada um. }\end{array}$ & \\
\hline $\begin{array}{l}10 \text { de Novembro } \\
\text { de } 1988\end{array}$ & $\begin{array}{l}\text { Ata de Reunião: } \\
\text {-Sugestão de serem resguardados, nos trabalhos de limpeza e } \\
\text { preparação para pintura, setores do edifício, de modo a } \\
\text { assegurar a permanência de extratos pictóricos, necessários } \\
\text { para o desenvolvimento futuro de quaisquer estudos e } \\
\text { pesquisas. } \\
\text {-A utilização da cor ocre e evidenciando os elementos de } \\
\text { modenatura na cor marfim, pareceu inadequado e insatisfatório. } \\
\text { Os fragmentos na cor ocre encontrados pelos técnicos nas } \\
\text { paredes superiores do corpo central do edifício, que serviram } \\
\text { como referência para o teste realizado, são restos de pintura } \\
\text { relativamente recente, provavelmente utilizando produto com } \\
\text { características de impermeabilizante, empregado na proteção de } \\
\text { áreas sujeitas a infiltrações. A partir de prospecções preliminares } \\
\text { executadas nas paredes externas do edifício, constatamos que a } \\
\text { cor original era amarela, em duas tonalidades, utilizadas nas } \\
\text { superfícies lisas e nos elementos de modenatura. Tintas Coral se } \\
\text { dispuseram a produzir exatamente a cor indicada, a ser } \\
\text { determinada pela Universidade. Dessa forma, resguardados o } \\
\text { torreão direito e as paredes internas da galeria contígua, os } \\
\text { serviços de preparação para a pintura, poderão continuar. } \\
\text {-Na preparação das superfícies deverá ser utilizado processo de } \\
\text { jateamento d'água com fungicida diluído. Enquanto se processa } \\
\text { a limpeza, serão desenvolvidas as análises e ensaios para a } \\
\text { definição das tonalidades, supervisionadas pela Universidade, } \\
\text { com o apoio técnico da Tintas Coral. No que se refere à pintura a } \\
\text { óleo das portas, janelas e caixilhos, concordamos com os } \\
\text { procedimentos seguidos pela Tintas Coral. } \\
\text {-É preciso realizar preliminarmente as necessárias prospecções, } \\
\text { para a identificação dos extratos e colorações, elementos } \\
\text { indispensáveis para a definição das especificações técnicas a } \\
\text { serem fornecidas pela universidade. Afirmamos por fim que tais } \\
\text { entendimentos estariam sujeitos à confirmação da CPC. }\end{array}$ & $\begin{array}{l}\text { Arquivo Intermediário Fundo } \\
\text { Museu Paulista Pasta73 e } \\
74\end{array}$ \\
\hline $\begin{array}{l}10 \text { de Março de } \\
1989\end{array}$ & $\begin{array}{l}\text { Projeto cromático: conclusão dos trabalhos de prospecção onde } \\
\text { permitiram identificar os tons originais e é imprescindível } \\
\text { acompanhar a confecção de amostras de tinta. Os estudos } \\
\text { devem ser continuados, recolhendo amostras de argamassa } \\
\text { para análises laboratoriais, estudos dos processos técnico- } \\
\text { construtivos e resgatar os padrões cromáticos recorrentes no } \\
\text { período. }\end{array}$ & $\begin{array}{l}\text { Arquivo Intermediário Fundo } \\
\text { Museu Paulista Pasta73 }\end{array}$ \\
\hline $\begin{array}{l}20 \text { de Abril de } \\
1989\end{array}$ & $\begin{array}{l}\text { Ofício do CONDEPHAAT a Tintas Coral informando a verificação } \\
\text { de erros na execução dos trabalhos de restauração da fachada, } \\
\text { que leva à sua interrupção. Os trabalhos de restauração deve } \\
\text { ser executado por pessoal habilitado. }\end{array}$ & $\begin{array}{l}\text { Arquivo Intermediário Fundo } \\
\text { Museu Paulista Pasta74 }\end{array}$ \\
\hline
\end{tabular}




\begin{tabular}{|c|c|c|}
\hline $\begin{array}{l}31 \text { de Agosto de } \\
1989\end{array}$ & $\begin{array}{l}\text { Foi elaborado um relatório técnico sobre reconstituição de traço } \\
\text { de argamassa e análise granulométrica do agregado. }\end{array}$ & $\begin{array}{l}\text { Arquivo Intermediário Fundo } \\
\text { Museu Paulista Pasta73 }\end{array}$ \\
\hline $\begin{array}{l}20 \text { de setembro } \\
\text { de } 1989\end{array}$ & 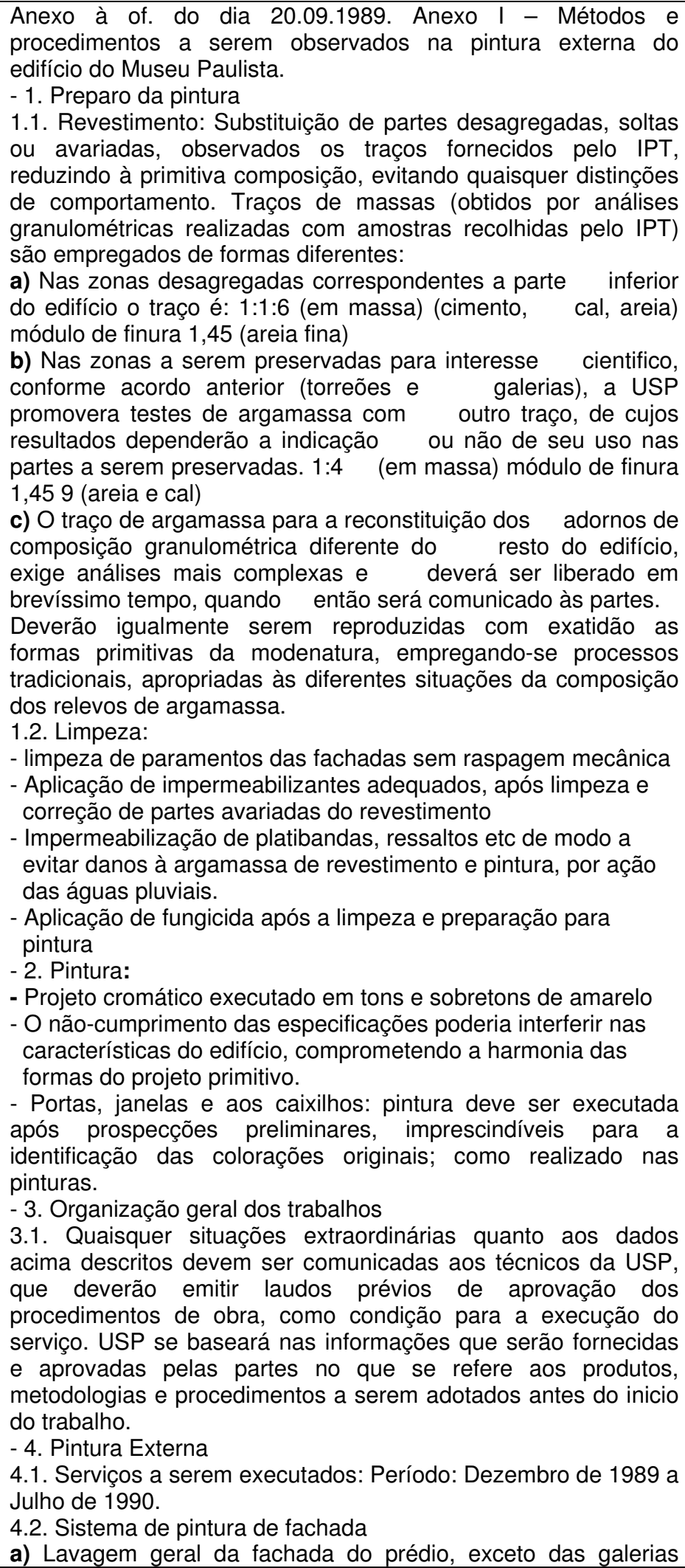 & $\begin{array}{l}\text { Arquivo Intermediário Fundo } \\
\text { Museu Paulista Pasta73 e } \\
78\end{array}$ \\
\hline
\end{tabular}




\begin{tabular}{|c|c|c|}
\hline & $\begin{array}{l}\text { abertas, a ser executada em duas etapas (jateamento de água } \\
\text { com solução de hipoclorito de sódio, jateamento de água pura). } \\
\text { b) Substituição ou reconstituição de partes soltas ou avariadas } \\
\text { do revestimento por meio de argamassas, em traço adequado } \\
\text { a cada zona de trabalho, com acompanhamento de técnicos } \\
\text { da USP, observando-se os traços de argamassa fornecidos } \\
\text { pelo IPT. } \\
\text { c) Aplicação de CoralPlus Fundo preparador de Paredes } \\
\text { diluído com Coralraz, em proporção } 1: 1 \text { de forma a } \\
\text { uniformizar e selar toda a superfície. } \\
\text { d) Impermeabilização de anteparos horizontais, peitorais, } \\
\text { platibandas, ábacos, etc., através da plastificação de } \\
\text { Coralplus Impermeabilizante acrílico em duas demãos, sendo } \\
\text { a primeira diluída com } 30 \% \text { de água e a segunda com } 10 \% \text {. } \\
\text { e) Eliminação de pequenas imperfeições com Coralplus } \\
\text { Massa Acrílica e posterior lixamento fino. } \\
\text { f) Acabamento final com duas a três demãos de Coralplus } \\
100 \% \text { acrílico com diluição em água (até } 20 \% \text { aplicadas em } \\
\text { tons e sobretons de amarelo, conforme item } 2 \text { deste anexo. } \\
4.4 \text { Exclusão, nesta proposta, da recuperação de portas e } \\
\text { janelas, por implicarem em trabalho a ser executado na área } \\
\text { interna do museu cujo dimensionamento dos serviços é } \\
\text { impossível prever. }\end{array}$ & \\
\hline $\begin{array}{l}22 \text { de Fevereiro } \\
\text { de } 1990\end{array}$ & $\begin{array}{l}\text { Contrato de doação de tintas e patrocínio para pintura do Museu } \\
\text { Paulista pelas Tintas Coral, apresentando quantidades e tipos de } \\
\text { materiais e tinta:Ocre Palácio, Ocre Nobreza. Massa acrílica, } \\
\text { látex acrílico, Coralraz, Verniz com filtro solar, fundo sintético } \\
\text { nivelador, tinta a óleo. }\end{array}$ & $\begin{array}{l}\text { Arquivo Intermediário Fundo } \\
\text { Museu Paulista Pasta74 }\end{array}$ \\
\hline $\begin{array}{l}17 \text { de Janeiro de } \\
1991\end{array}$ & $\begin{array}{l}\text { Aprovação de verba para pintura dos caixilhos internos e } \\
\text { externos. Os caixilhos envidraçados externos serão na cor } \\
\text { marrom barroco brilhante e internamente em marfim acetinado. } \\
\text { Os procedimentos para execução da pintura devem levar em } \\
\text { conta o destacamento da argamassa ao longo dos anos e será } \\
\text { refeita a argamassa conforme traço estabelecido no contrato- } \\
1: 1: 6 \text { (cimento, cal, areia). } \\
\text { Foi constatado que embaixo dos balcões na fachada sul a } \\
\text { pintura está deteriorada. }\end{array}$ & $\begin{array}{l}\text { Arquivo Intermediário Fundo } \\
\text { Museu Paulista Pasta73 }\end{array}$ \\
\hline $\begin{array}{l}27 \text { de Fevereiro } \\
\text { de } 1991\end{array}$ & $\begin{array}{l}\text { Reunião da CPC registra: } \\
\text {-Testes para acertar a diluição do impermeabilizante. } \\
\text {-Decisão de manutenção das janelas que não possuíam acesso } \\
\text { pelo lado interno do Museu } \\
\text {-Recomendação de melhor acabamento de rebocos e de pintura } \\
\text { de caixilhos com tintas Coral } \\
\text {-Pedido de limpeza de pedras sujadas durante pintura } \\
\text {-Indicação de que tubos externos atrapalham a harmonia } \\
\text { estética do Museu }\end{array}$ & $\begin{array}{l}\text { Arquivo Intermediário Fundo } \\
\text { Museu Paulista Pasta73 }\end{array}$ \\
\hline $\begin{array}{l}18 \text { de Março de } \\
1991\end{array}$ & $\begin{array}{l}\text { Relato dos procedimentos adotados para a individualização da } \\
\text { cor original do edifício: } \\
\text { - Método: estratigrafia cromática (remoção gradativa de todas } \\
\text { as camadas de tinta aplicadas sobre a superfície murária, } \\
\text { partindo daquela visível ate atingir aquela } \\
\text { diretamente sobre a preparação da base). } \\
\text { - Local: diferentes pontos da fachada, balcões e partes internas } \\
\text { do torreão, para analisar a tinta em suas diversas condições de } \\
\text { exposição, de modo que o resultado das aberturas se } \\
\text { constituísse em uma amostragem significativa da cor original. } \\
\text { - Caixilharia: O mesmo procedimento foi adotado. } \\
\text { - Conclusão: baseada em exames visuais: toda a parte externa } \\
\text { do edifício era recoberta com uma tinta de cor ocre, cujos } \\
\text { matizes, dependendo da superfície analisada, variavam do } \\
\text { amarelo médio ao avermelhado. } \\
\text { - Observações: Pigmentos ocres, usuais na caiação do período }\end{array}$ & $\begin{array}{l}\text { Arquivo Intermediário Fundo } \\
\text { Museu Paulista Pasta73 }\end{array}$ \\
\hline
\end{tabular}




\begin{tabular}{|c|c|c|}
\hline & $\begin{array}{l}\text { de pintura original do edifício, sofrem mutações cromáticas por } \\
\text { sua composição terrosa. Mudanças físico-químicas e } \\
\text { recobrimentos de pinturas tornavam difícil aferição de matiz } \\
\text { original exato através exames técnicos. Daí pesquisa } \\
\text { documental (gravuras), que indicou uso predominante de } \\
\text { amarelos em edifícios da época. Amarelos verificados foram } \\
\text { codificados em escala cromática Munsell, tendo sua média } \\
\text { deduzida - cor essa próxima do original. Tintas Coral produziram } \\
\text { o tom; testes de aplicação determinaram grau de saturação de } \\
\text { cor mais clara a ser combinado com tom básico na pintura. } \\
\text { - O Projeto Cromático: Pesquisa documental e prospecções } \\
\text { constatam uso de amarelos diferentes quanto aos graus de } \\
\text { saturação na pintura original para demarcação de volumes e } \\
\text { detalhes. Para garantir mínima intervenção em linguagem } \\
\text { cromática original, opta-se pela desaturação de tom básico e } \\
\text { distribuição de dois tons de acordo com tipologia arquitetônica do } \\
\text { edifício. Destacam-se horizontalização de elementos } \\
\text { predominantes, desenho de linhas principais e envergaduras. }\end{array}$ & \\
\hline 5 de abril de 1991 & $\begin{array}{l}\text {-Bolhas na pintura a parte superior do edifício, ocorria devido à } \\
\text { manta asfáltica não estar em boas condições } \\
\text {-problemas com as calhas com muito vazamento de águas } \\
\text { pluviais } \\
\text { - péssimas condições dos telhados }\end{array}$ & $\begin{array}{l}\text { Arquivo Intermediário Fundo } \\
\text { Museu Paulista Pasta } 73\end{array}$ \\
\hline 5 de abril de 1991 & $\begin{array}{l}\text { Gazeta do Ipiranga: "Para disfarçar a hepatite do Museu Paulista } \\
\text { algum "Iumitar" mandou decorar algumas saliências com a cor } \\
\text { branca. Um tremendo contraste de mau gosto. Qual seria a cor } \\
\text { original do nosso Museu? Esse horrível amarelão? Não } \\
\text { acredito... }\end{array}$ & 5 de abril de 1991 \\
\hline $\begin{array}{l}18 \text { de Abril de } \\
1991\end{array}$ & $\begin{array}{l}\text { Reunião da CPC registra: } \\
\text {-Craquelamento de pinturas recentes das paredes de parte } \\
\text { superior do edifício; } \\
\text {-Decisão de não se restaurar palmetos, trabalho que exigiria } \\
\text { estudos especiais, dada sua perda de constituição, serão } \\
\text { apenas pintados; } \\
\text {-Constatação de inadequação da lavagem de parede prévia à } \\
\text { pintura. }\end{array}$ & $\begin{array}{l}\text { Arquivo Intermediário Fundo } \\
\text { Museu Paulista Pasta73 }\end{array}$ \\
\hline $\begin{array}{l}25 \text { de Abril de } \\
1991\end{array}$ & $\begin{array}{l}\text { Solicitação de verba a CPC para resolução de problemas em } \\
\text { telhados que comprometiam pintura interna. }\end{array}$ & $\begin{array}{l}\text { Arquivo Intermediário Fundo } \\
\text { Museu Paulista P-73 }\end{array}$ \\
\hline $\begin{array}{l}25 \text { de Abril de } \\
1991\end{array}$ & $\begin{array}{l}\text { Ata de Reunião da CPC registra: } \\
\text {-Cumprimento de providências sobre problemas constatados na } \\
\text { pintura } \\
\text {-Associação de problema de bolhas na pintura a estado } \\
\text { precário de manta asfáltica que recobre a parte superior do } \\
\text { edifício } \\
\text {-Constatação de problemas nas calhas e necessidade de } \\
\text { exigência de verbas para reparos. }\end{array}$ & $\begin{array}{l}\text { Arquivo Intermediário Fundo } \\
\text { Museu Paulista Pasta73 }\end{array}$ \\
\hline $\begin{array}{l}08 \text { de Maio de } \\
1991\end{array}$ & $\begin{array}{l}\text {-Relatório sobre obras emergenciais na cobertura verifica muitos } \\
\text { danos por infiltração, goteiras, e propõe soluções diversas para } \\
\text { cada tipo de problema. Danos nas chapas de metal da cobertura } \\
\text {-rompimento de tubos de águas pluviais. Alguns condutores } \\
\text { devem ser imediatamente reparados para que se possa } \\
\text { prosseguir com a pintura externa (...) } \\
\text { A tinta Coralplus, de base acrílica, (...) quando aplicada sobre o } \\
\text { emborrachado do neoprene, por incompatibilidade do material, } \\
\text { fazem com que a película de tinta não sofra perfeita adesão. (...) } \\
\text { se desprendem, sob a forma de bolhas que depois estouram. (...) } \\
\text { gostaríamos de frisar que uma impermeabilização adequada só } \\
\text { será possível com a remoção completa da manta emborrachada. } \\
\text { - Problemas gerais na cobertura:Os beirais internos dos torreões } \\
\text { e mureta (...) foram, como aqueles externos, impermeabilizados } \\
\text { com neoprene. A degradação ocorreu principalmente, por } \\
\text { aplicação indevida. (...) em vários trechos inspecionados, onde }\end{array}$ & $\begin{array}{l}\text { Arquivo Intermediário Fundo } \\
\text { Museu Paulista Pasta73 }\end{array}$ \\
\hline
\end{tabular}




\begin{tabular}{|c|c|c|}
\hline & $\begin{array}{l}\text { pudemos arrancar a camada do emborrachado em } \\
\text { descolamento, percebemos que esta foi executada sobre uma } \\
\text { argamassa já degradada (...) }\end{array}$ & \\
\hline $\begin{array}{l}13 \text { de Maio de } \\
1991\end{array}$ & $\begin{array}{l}\text { Relatório de vistoria dos beirais superiores contata a existência } \\
\text { de dois tipos de impermeabilização: na parte interna dos torreões } \\
\text { e nos beirais superiores e estão deteriorados. Para a pintura } \\
\text { deve ser removida toda a impermeabilização anterior e } \\
\text { executada uma outra.Ainda há problema em não conseguir } \\
\text { extrair completamente a impermeabilização anterior, o que } \\
\text { prejudica a aderência do novo material. Após esta aplicação } \\
\text { surgiram bolhas nos beirais devido às chuvas. As bolhas devem } \\
\text { ser raspadas eliminando as partes soltas, aplicar uma demão de } \\
\text { Coralplus Fundo Preparador de Impermeabilizante acrílico. } \\
\text { Corrigir imperfeições com Coralplus Massa Acrílica. }\end{array}$ & $\begin{array}{l}\text { Arquivo Intermediário Fundo } \\
\text { Museu Paulista Pasta73 }\end{array}$ \\
\hline $\begin{array}{l}16 \text { de Maio de } \\
1991\end{array}$ & $\begin{array}{l}\text { Reunião da CPC registra: } \\
\text {-Problemas relativos à execução das obras de conservação e } \\
\text { pintura. } \\
\text {-Discussão do laudo efetuado pela ServCoral com referência às } \\
\text { platibandas superiores, onde ocorria infiltração de água e } \\
\text { formação de bolhas na pintura. }\end{array}$ & $\begin{array}{l}\text { Arquivo Intermediário Fundo } \\
\text { Museu Paulista Pasta73 }\end{array}$ \\
\hline $\begin{array}{l}17 \text { de Maio de } \\
1991\end{array}$ & $\begin{array}{l}\text { Solicitação de latas de tinta látex (18 litros cada) e outros } \\
\text { materiais para pintura das dependências internas. }\end{array}$ & $\begin{array}{l}\text { Arquivo Intermediário Fundo } \\
\text { Museu Paulista Pasta73 }\end{array}$ \\
\hline $\begin{array}{l}11 \text { de Julho de } \\
1991\end{array}$ & $\begin{array}{l}\text { Reunião registra: } \\
\text {-Aprovação de execução da pintura das galerias norte e sul e a } \\
\text { recomposição e impermeabilização da manta butílica. } \\
\text {-Cronogramas da pintura. } \\
\text { - Solicitação de interdição das áreas a serem pintadas. } \\
\text {-Vistoria da pintura, sendo encontrado em perfeita harmonia com } \\
\text { as especificações e cronograma. }\end{array}$ & $\begin{array}{l}\text { Arquivo Intermediário Fundo } \\
\text { Museu Paulista Pasta73 }\end{array}$ \\
\hline $\begin{array}{l}\text { Setembro de } \\
1991\end{array}$ & $\begin{array}{l}\text { Texto sobre a pintura e a revalorização do Monumento do } \\
\text { lpiranga cita a colaboração da Tintas Coral SA, que pela } \\
\text { segunda vez doa os materiais necessários à pintura das } \\
\text { fachadas do Museu. Demonstra ainda as preocupações em } \\
\text { relação à pintura, devido ao tombamento do edifício, e relata as } \\
\text { prospecções feitas na pintura e na argamassa. } \\
\text { Assim ao invés de simplesmente reproduzir o tom rosa utilizado } \\
\text { há quase meio século (e que já sabia que não era a cor original), } \\
\text { foram desenvolvidas pesquisas para determinar a cor e } \\
\text { tonalidade adequada. Prospecções realizadas nos balcões e } \\
\text { partes internas do Torreão, assim como na caixilharia, para } \\
\text { analisar as diversas condições de exposição e alterações dos } \\
\text { pigmentos e estabelecer uma estratigrafia cromática permitindo a } \\
\text { maior aproximação possível à cor e média tonal primitivas. } \\
\text { Testes aplicados às paredes fundamentaram a escolha do grau } \\
\text { de saturação da cor mais clara a ser empregada juntamente com } \\
\text { a cor básica. Não se tratava, apenas, de mecanicamente } \\
\text { reconstituir o passado, mas sobretudo, de preservar, na } \\
\text { linguagem cromática do edifício valores fundamentais.Por isso, a } \\
\text { tonalidade ocre (amarelo) proposta é seguramente próxima } \\
\text { daquelas superfícies pintadas com tinta à cal pelos capomastri } \\
\text { que atuaram em São Paulo na virada do século. A } \\
\text { horizontalidade dos elementos predominantes, o desenho das } \\
\text { linhas principais das envasaduras foram trabalhadas de modo a } \\
\text { se destacarem, acentuando o jogo de volumes pretendido no } \\
\text { projeto arquitetônico, que seria prejudicado com pintura } \\
\text { chapada. }\end{array}$ & $\begin{array}{l}\text { Arquivo Intermediário Fundo } \\
\text { Museu Paulista Pasta73 }\end{array}$ \\
\hline $\begin{array}{l}\text { Setembro } \\
1991\end{array}$ & $\begin{array}{l}\text { Relatório das Tintas Coral SA citando alguns métodos utilizados } \\
\text { no trabalho de pintura: } \\
\text {-A linha "Coralplus" é produzida à base de resinas acrílicas } \\
\text { estirenadas, de acordo com os mais altos padrões de } \\
\text { tecnologia, tornando estes produtos altamente resistentes às } \\
\text { intempéries. }\end{array}$ & $\begin{array}{l}\text { Arquivo Intermediário Fundo } \\
\text { Museu Paulista Pasta73 }\end{array}$ \\
\hline
\end{tabular}




\begin{tabular}{|c|c|c|}
\hline & $\begin{array}{l}\text {-Tonalidades não constavam da cartela de cores da linha } \\
\text { Coralplus'. Foram desenvolvidas e produzidas recebendo os } \\
\text { nomes "Ocre Nobreza" (escuro) e Ocre Palácio (claro). - } \\
\text { Especificação da pintura: feita pelos técnicos do "ServCoral". } \\
\text {-Primeira fase: lavagem de toda a fachada (jateamento) de uma } \\
\text { mistura de água sanitária e água, novo jateamento apenas } \\
\text { com água. } \\
\text {-Segunda fase: recuperação da argamassa. Lixamento da } \\
\text { superfície, aplicação de uma demão de "Coralplus" Fundo } \\
\text { preparador de Paredes, diluído com "Coralraz". } \\
\text { Três demãos de "Coralplus" Látex Acrílico. } \\
\text { - Portas e janelas: tratadas com Fundo Sintético Nivelador e } \\
\text { Massa óleo recebendo em seguida duas demãos de "Coralit" } \\
\text { Esmalte Sintético nas cores Marrom, marrom Barroco e Areia. } \\
\text { - Porta central: pintada com verniz "Coramar", com filtro solar } \\
\text { (vida útil de pelo menos o dobro do tempo dos vernizes } \\
\text { convencionais). } \\
\text { - A pintura foi feita em oito meses, de janeiro a agosto deste ano, } \\
\text { e utilizou } 40 \text { mil litros de tintas }\end{array}$ & \\
\hline $\begin{array}{l}21 \text { de Novembro } \\
\text { de } 1991\end{array}$ & $\begin{array}{l}\text { Problemas com os condutores de águas pluviais - rompimento } \\
\text { em dois pontos distintos, entupimento na altura do subsolo, e as } \\
\text { tentativas de soluções tomadas foram soldagem, desobstrução. } \\
\text { Foi solicitada a substituição do trecho inferior do condutor. }\end{array}$ & $\begin{array}{l}\text { Arquivo Intermediário Fundo } \\
\text { Museu Paulista Pasta78 }\end{array}$ \\
\hline $\begin{array}{l}25 \text { de Novembro } \\
\text { de } 1991\end{array}$ & $\begin{array}{l}\text { Solicitação de autorização para intervenções de urgência na } \\
\text { fachada, que sofria danos devido a um entupimento nos } \\
\text { condutores de águas pluviais. }\end{array}$ & $\begin{array}{l}\text { Arquivo Intermediário Fundo } \\
\text { Museu Paulista Pasta74 }\end{array}$ \\
\hline $\begin{array}{l}13 \text { de Outubro de } \\
1993\end{array}$ & $\begin{array}{l}\text { Relatório de vistoria ao edifício por ocasião do desprendimento } \\
\text { da argamassa na área interna da escadaria nobre. }\end{array}$ & $\begin{array}{l}\text { Arquivo Intermediário Fundo } \\
\text { Museu Paulista Pasta78 }\end{array}$ \\
\hline
\end{tabular}

Nesse período, apesar do empenho em conduzir os trabalhos de pintura das fachadas segundo critérios e procedimentos técnicos baseados na devida valorização do edifício como mostra a documentação consultada - restou a questão fundamental: a consideração das características da técnica construtiva própria do edifício e dos materiais empregados, que determinam o comportamento das paredes em relação ao meio ambiente. Desse modo, a existência da umidade e sua interferência nas paredes, através processo que ocorre com a umidade ascendente e a umidade descendente, não foram levadas em conta, ou ainda, a umidade que se origina dentro das paredes devido aos danos nos condutores de águas pluviais e no sistema de águas servidas nas tubulações, igualmente não foram previstas.

O tipo de tinta empregada na pintura do edifício, sem dúvida, é resultado do desenvolvimento tecnológico baseado em pesquisa científica. A tecnologia empregada em sua fabricação permitiu torná-la altamente resistente às intempéries. Contudo, essa tinta, ao criar uma película polimérica não permeável, constituiu-se numa enorme barreira à evaporação da umidade, que deveria ocorrer sem dificuldades. Por essa razão, a despeito das propriedades superiores da tinta em questão, seu uso na pintura apresentou incompatibilidade com as características da técnica construtiva do edifício, da natureza física e química de seus materiais.

Não obstante tais equívocos, é importante salientar que as intervenções realizadas e suas conseqüências, manifestadas através de deteriorações, observadas hoje, permitem o aprofundamento do aprendizado quanto às características desta técnica construtiva, de modo a fundamentar eventuais intervenções posteriores. 


\section{LIVRO: MUSEU PAULISTA UM MONUMENTO NO IPIRANGA: HISTÓRIA DE UM EDIFÍCIO CENTENÁRIO E DE SUA RECUPERAÇÃO}

As intervenções realizadas neste período foram publicadas no livro Museu Paulista, um Monumento no Ipiranga, História de um Edifício Centenário e de sua Recuperação, editado em 1997.

Este livro é constituído por textos de diversos autores, que abordam a história do edifício e a realização de diversas intervenções.

\section{COBERTURA}

A cobertura é composta por duas clarabóias, uma em cada Torre, e uma central, sobre a escadaria monumental que liga o átrio (saguão de entrada) ao primeiro pavimento.

As demais áreas da cobertura são telhados em chapas de cobre, sobre estrutura de madeira.

O telhado original executado com telhas côncavas de barro, desde o período da construção, começou a apresentar vazamentos, e continuou sendo citado nos documentos por vários anos, devido ao mesmo problema. Fatos semelhantes ocorreram com as clarabóias, que em diversos momentos exigiram reparos.

Entre 1910 e 1912, nas áreas de cobertura sobre as Galerias, as telhas de barro foram substituídas por chapas de cobre para sanar as goteiras existentes.

Em 1954 nos telhados que ainda permaneciam telhas de barro, foram também substituídas pelas chapas de metal.

Com o passar do tempo, voltaram as infiltrações de água em diversos locais, tanto nos telhados de chapas de cobre como nas clarabóias, causando sérios danos aos materiais atingidos, como madeiras empregadas na estrutura, as alvenarias e os tabiques.

Este telhado, feito em 1954, era composto por chapas de cobre unidas por remanches (dobras) e não permitia movimentação adequada devido à dilatação deste metal e causou rasgos nas chapas, por onde a água infiltrava. As bases das chapas eram de compensado de madeira recoberto por resina asfáltica (betume), que em muitas partes já quase não existia, apodrecida pela água. Sobre esse compensado havia um papelão ondulado para acomodar o cobre.

No período de 1995 a 1997 todo telhado e as clarabóias passaram por um trabalho completo. As chapas de cobre foram totalmente substituídas, foi refeita a estrutura de suporte, com recursos técnicos e materiais de melhor desempenho.

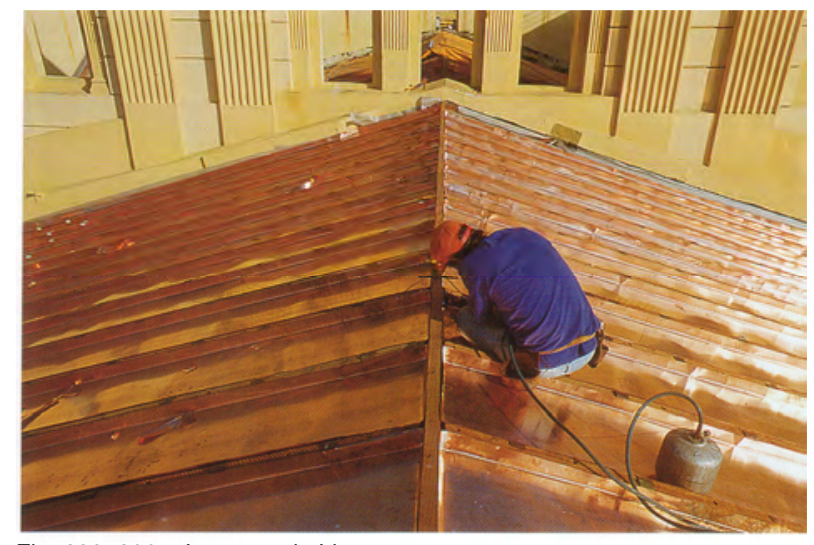

Fig. 299, 300 - Imagens do Livro

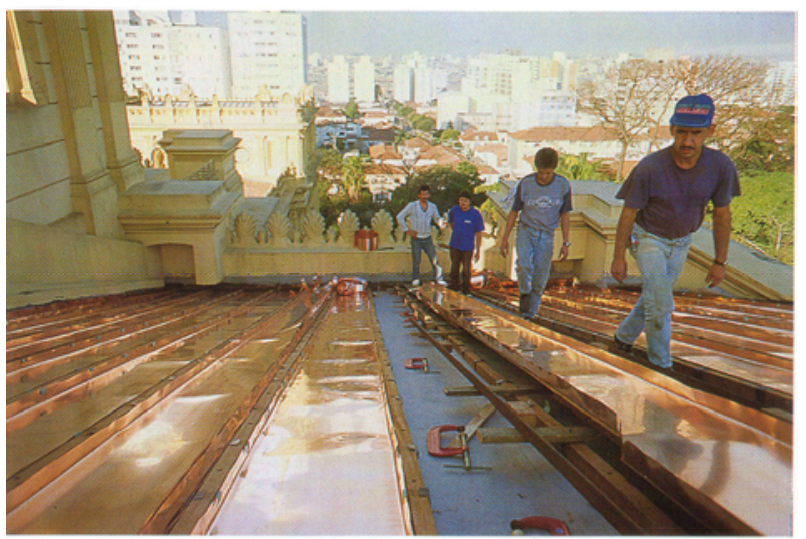

Execução do telhado com chapas de cobre

As chapas de compensado, utilizadas anteriormente, foram substituídas por compensado naval, recoberto com manta de elastômero pré-vulcanizada. O papelão utilizado anteriormente sob a placa foi trocado por manta de lã de rocha, que protege a borracha do atrito causado pela dilatação do cobre. Sobre a manta foram posicionados caibros, para formar o desenho do telhado. 
As chapas foram deixadas livres, permitindo a movimentação, e facilitando a retirada e manutenção.

\section{TELHADO DE VIDRO SOBRE A CLARABÓIA}

Dentro do espaço definido pelo mirante, situa-se o telhado de vidro, em duas águas sobre a clarabóia central, cuja estrutura interna é plana, formada por um conjunto de módulos.

Havia vidros quebrados por onde se infiltrava água, que atingia a clarabóia e as paredes próximas. Nas intervenções, foi conservada a estrutura e os vidros quebrados foram substituídos

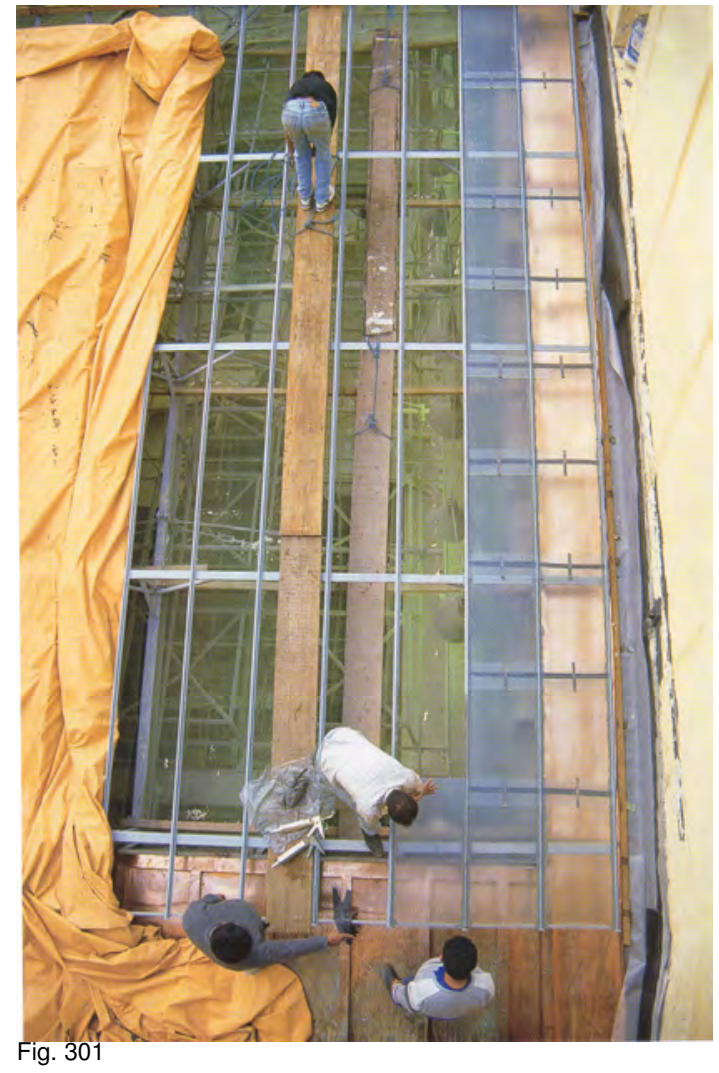

Telhado em duas águas, com vidro aramado, sobre a clarabóia central da escadaria de mármore

\section{CLARABÓIA CENTRAL}

$\mathrm{Na}$ clarabóia central, havia vidros rachados e o material de calafetação e fixações dos vidros à estrutura metálica, estavam bem deterioradas e não cumpriam mais sua função.

Estes danos causavam goteiras sobre a escadaria principal e infiltrações nas paredes ao seu redor, provenientes de água de chuva.

Os vidros das clarabóias foram substituídos e a instalação cuidadosamente realizada.

Este trabalho apresentou bom resultado e permanece numa condição estável até hoje. Assim este problema foi finalmente resolvido. 


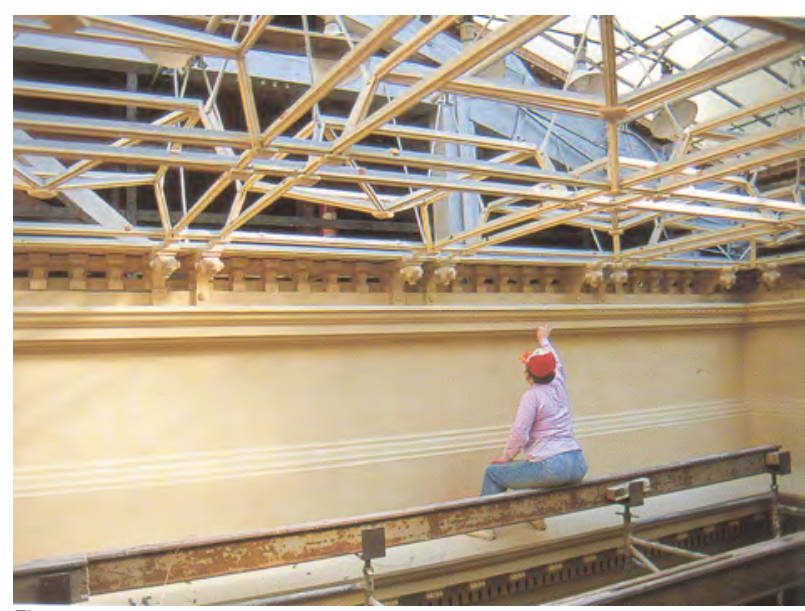

Fig. 302, 303 Estrutura da clarabóia.

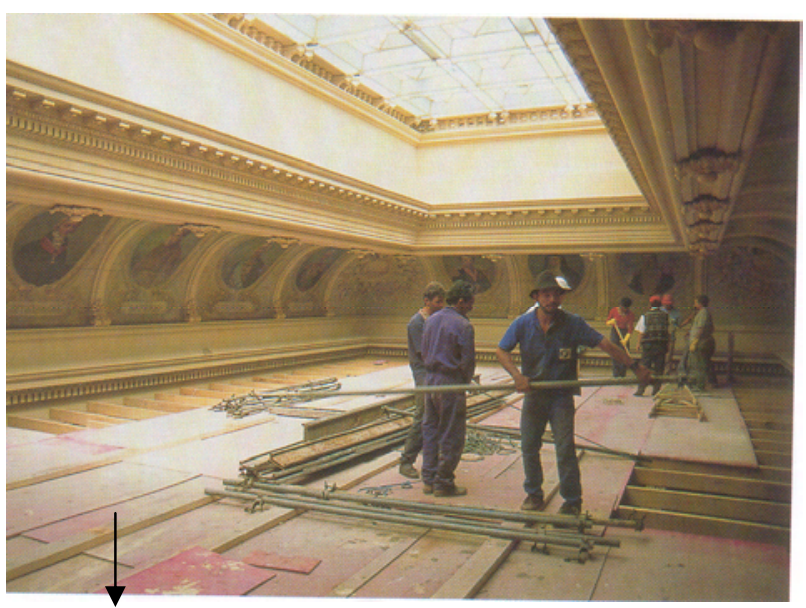

Andaime montado na altura da Sanca,

\section{FRISO ORNAMENTADO NA PARTE SUPERIOR DA SANCA}

A água que infiltrava através da clarabóia central atingiu a estrutura de sustentação, de jiçara, do friso ornamentado, na parte superior da Sanca, provocando o desprendimento dos ornamentos em argamassa.

Para a restauração deste friso, das pinturas da Sanca e da estrutura interna da clarabóia central, foi montado um grande andaime, na altura conveniente.

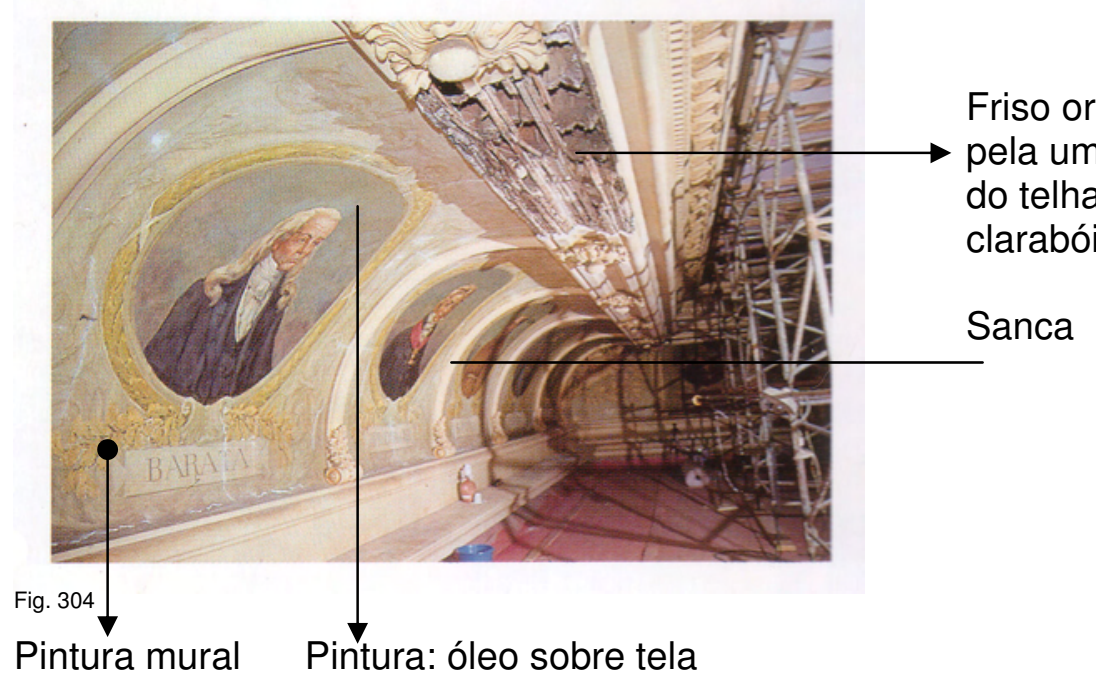

\section{A CONSERVAÇÃO E RESTAURAÇÃO DAS PINTURAS DA SANCA}

Chama-se Sanca a faixa de parede curva, situada na região superior das paredes da Escadaria Principal, próxima à clarabóia. Ela está aproximadamente a 14 metros de altura em relação ao piso térreo.

A Sanca é o suporte de 18 retratos, óleo sobre tela, colados sobre a parede, técnica conhecida por marouflage. Compondo os quadros, ao redor desses retratos, de forma elíptica ou circular, encontra-se uma pintura mural decorativa.

As pinturas estavam com o verniz esbranquiçado, sujidade acumulada, alterando a leitura e nitidez das cores. Havia algumas perdas na camada pictórica e duas pinturas tinha descolamento pontuais do suporte. 
Na pintura mural havia também desprendimento e perdas da policromia, as quais foram fixadas e retocadas.

$O$ andaime no nível da Sanca,
criando o espaço de trabalho.

Um canto de parede da

Sanca, onde se localiza um Brasão.

Fotos de Yara Petrella
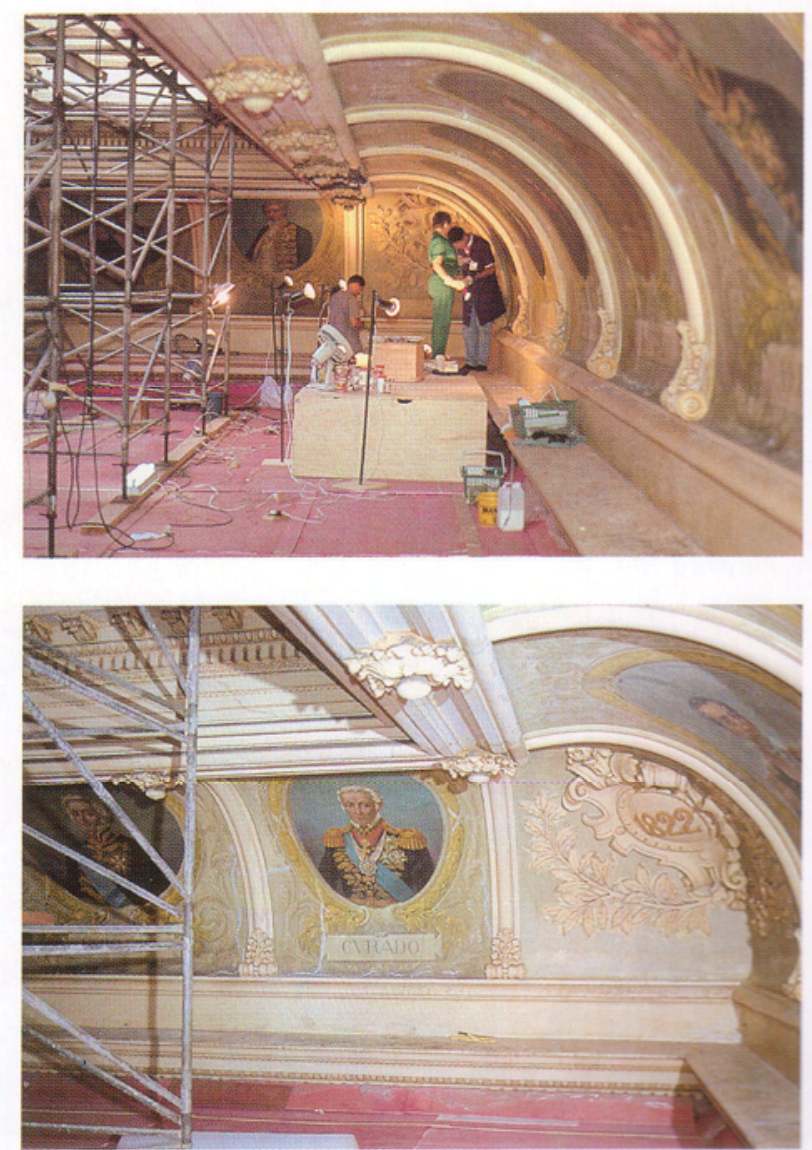

Fig. 305, 306

\section{INSTALAÇÃO ELÉTRICA}

A antiga instalação elétrica, com fios sem isolação antichama, corria sobre o solo no porão antes da escavação, sem conduites ou canaletas. Não se tinha segurança quanto a demanda de cada circuito. Era um risco permanente os fios agrupados desordenadamente.

A enfiação antiga foi substituída e foram refeitos os quadros de luz com nova distribuição de circuitos, atendendo ao grande aumento de novos equipamentos como os computadores e os seus acessórios. 


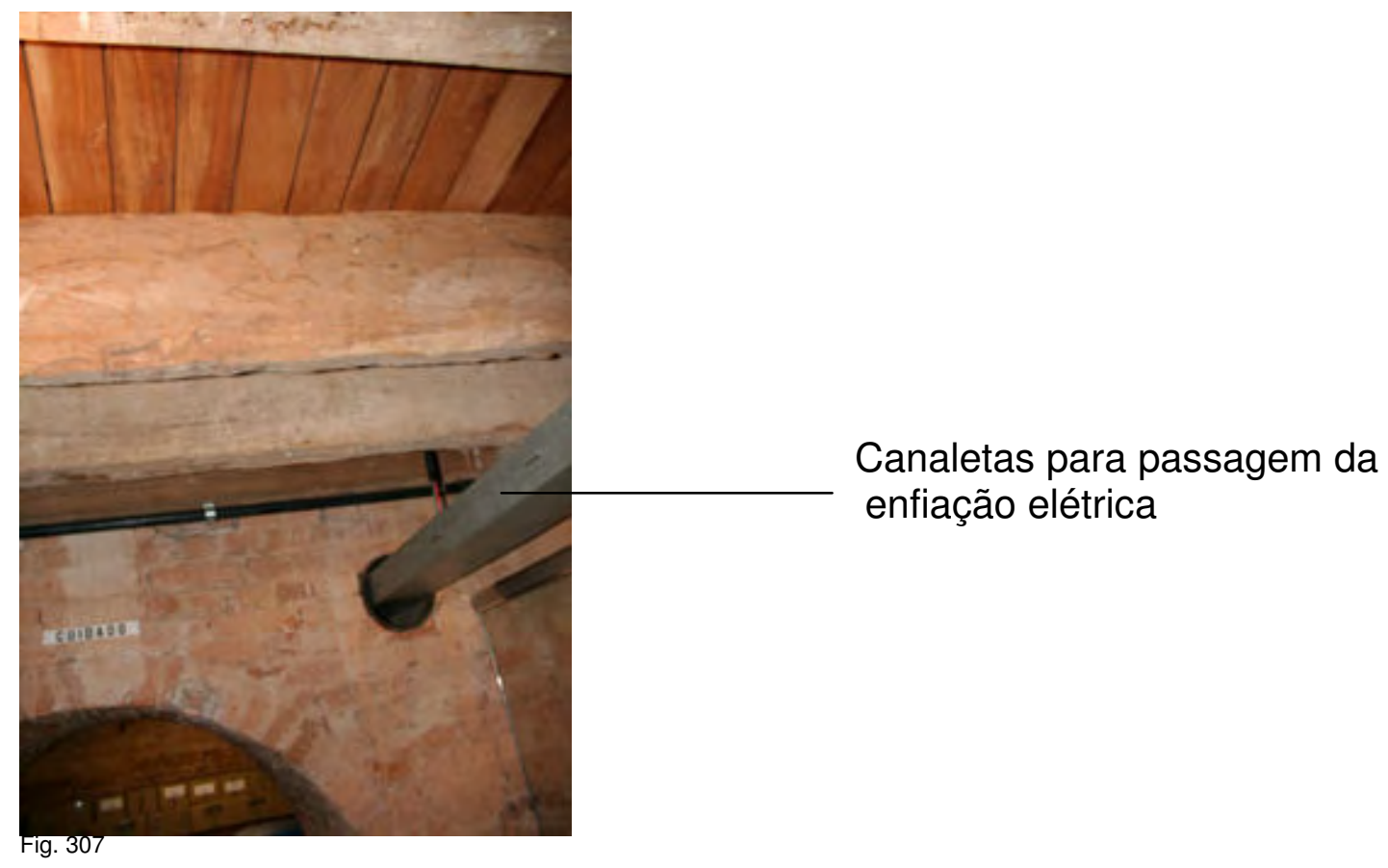

\section{DESENTULHAMENTO DO SUBSOLO}

Em 1993, foi executada mais uma etapa de desentulhamento no subsolo, sob a área do Corpo Central.

Nestes espaços foram criadas novas salas, sendo que as da lateral oeste receberam acabamento para serem utilizadas para exposição e atividades educativas. As fundações não foram alteradas e os arcos das aberturas foram mantidos.

$\mathrm{Na}$ outra lateral, as fundações em pedra e as paredes em alvenaria permaneceram sem revestimento como testemunho da construção.
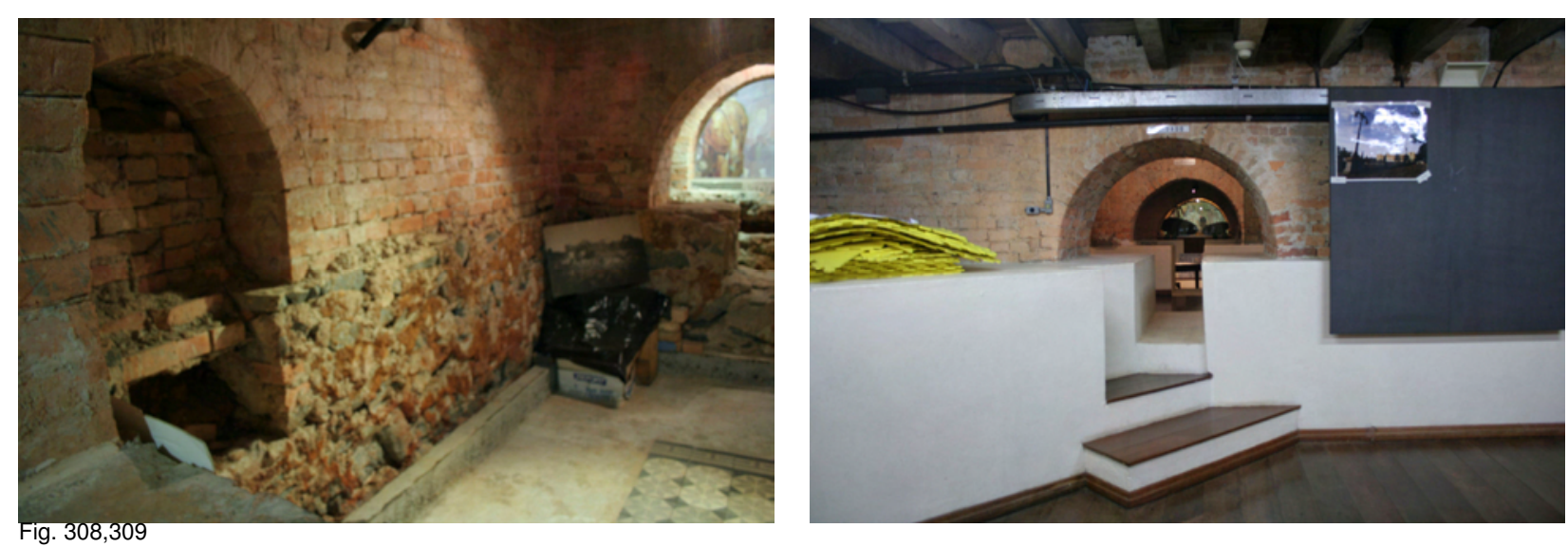

\section{RETIRADA DE ENTULHO DE OBRA}

Durante a limpeza, foi retirada uma grande quantidade de entulho no ático, atrás da Sanca. Para isso, foram abertos alçapões no assoalho sobre a Sanca, e janelas nas paredes de tabique que cerca a clarabóia central.

No Documento 407 da Pasta 5, a Caderneta de Obras, em julho de 1889, há uma referência à demolição da alvenaria das impostas dos grandes arcos abatidos. Não se pode afirmar que esta é a origem deste entulho sobre a Sanca, ou se este tinha uma função estrutural, pois estava localizado numa região a qual é chamada rim, em Portugal. 
O Eng. João Mascarenhas Mateus, ao visitar o Museu, afirmou que esta região do Ático, sob o telhado, propiciaria por si só , uma significativa pesquisa devido à sua complexidade.

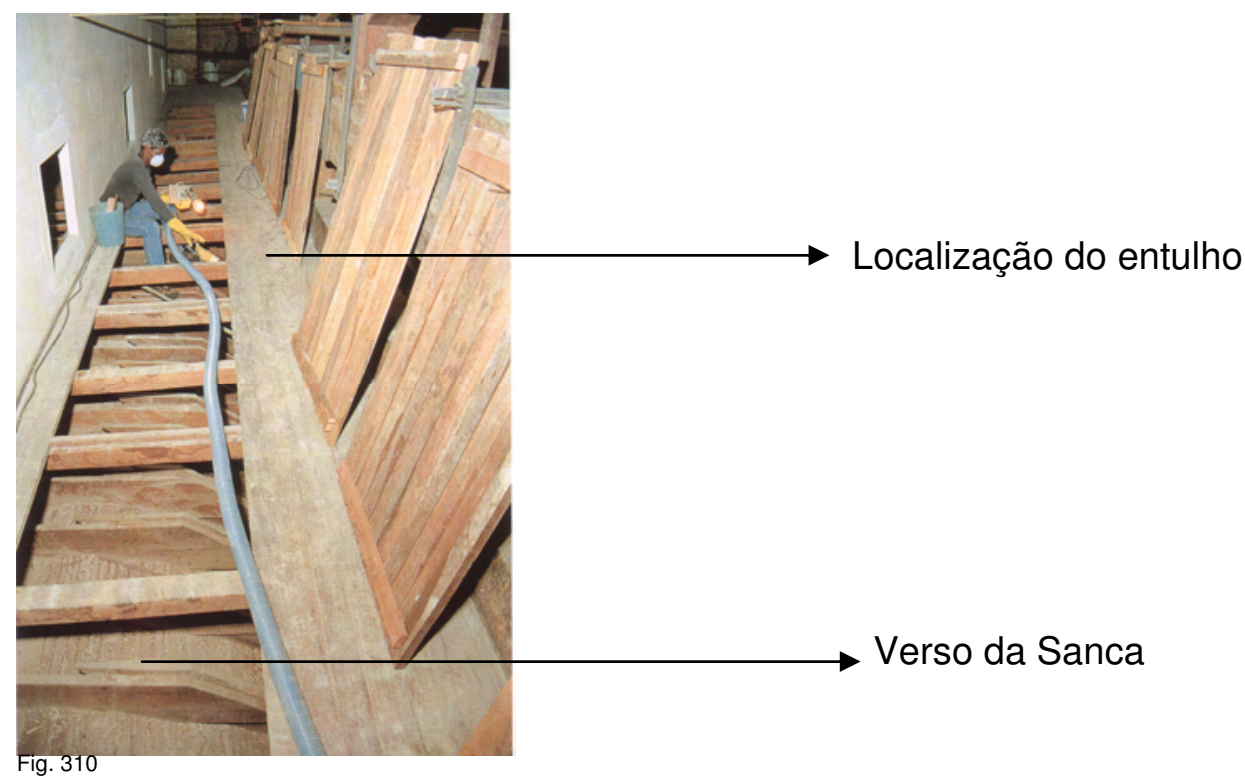

INTRODUÇÃO DE VIGAS METÁLICAS NO PISO DA TORRE OESTE
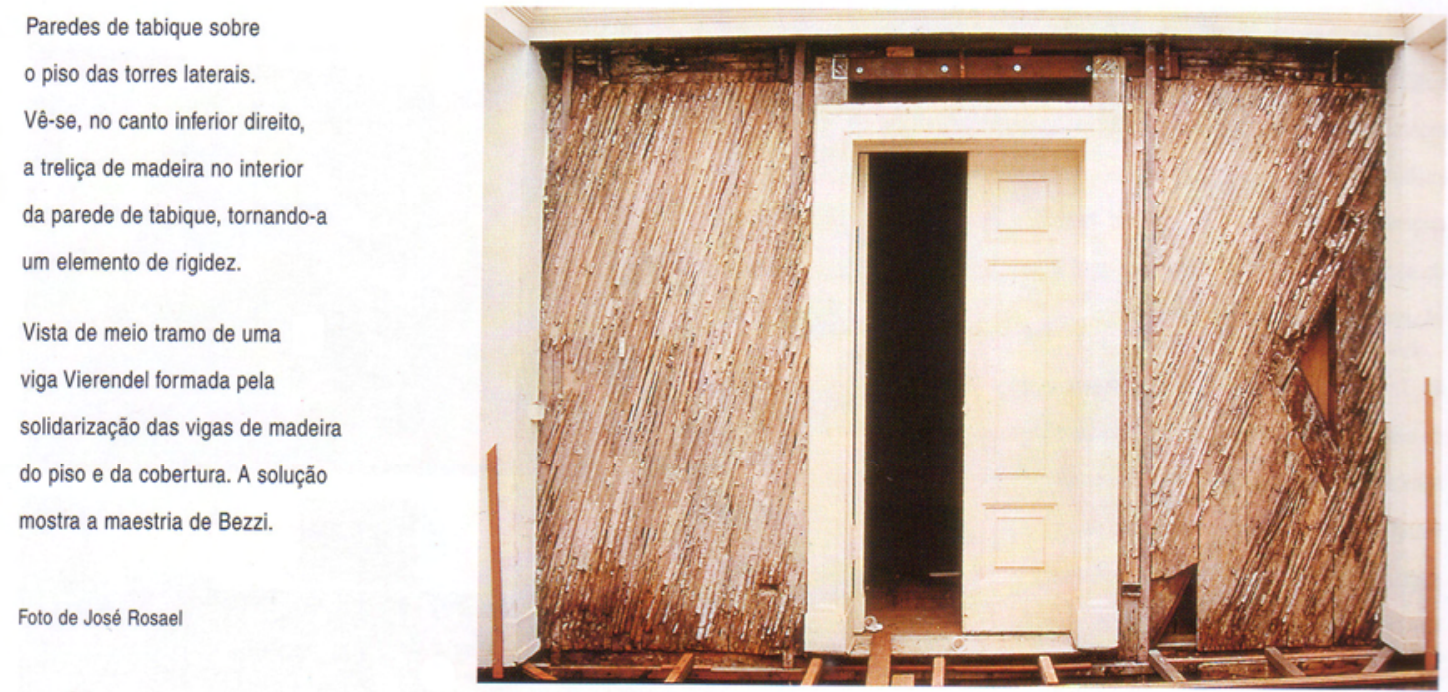

\section{Fig. 311 Tabique com tirantes}

As intervenções estruturais ficaram sob responsabilidade do Eng. Péricles Fusco.

Os procedimentos adotados nestas intervenções se basearam em estudos prévios, com o objetivo de conhecer as especificidades da estrutura do edifício como um todo e das soluções adotadas pelo Bezzi neste pavimento da torre.

$\mathrm{Na}$ Torre oeste, no pavimento superior, vigas e pilares de madeira estavam fragilizados, devido à infiltração de água durante um longo tempo, colocando em risco a estrutura deste local.

Foram planejadas as intervenções e assim verificou-se as soluções estruturais surpreendentes realizadas pelo Bezzi. 


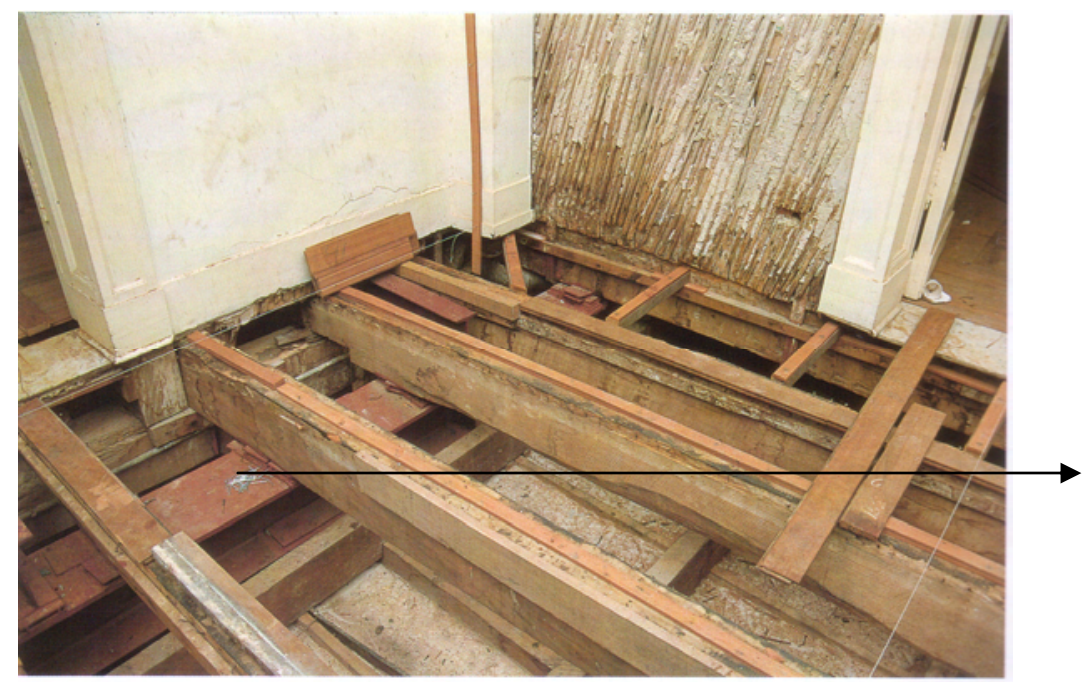

Vigas metálicas

Fig. 312 Introdução de vigas metálicas no piso

Este terceiro pavimento das Torres somente as paredes externas foram construídas em alvenaria de tijolos. Internamente foram utilizados tabiques como paredes divisórias

Foram então introduzidas vigas metálicas no piso deste pavimento, para substituir as funções estruturais das peças danificadas.

FUSCO (1997, p.74) descreve esta intervenção a qual se baseou no conhecimento das soluções originais adotadas pelo Bezzi:

A região delimitada pelas paredes de alvenaria que vinham desde a fundação foi dividida em um pátio interno coberto e em três salas delimitadas por paredes de tabique apoiadas sobre o vigamento do piso.

Estava criado um terrível desafio para a técnica da época.

As cargas representadas pelos pesos próprios das paredes eram incompatíveis com a resistência e com a rigidez de vigas de madeira lavrada com 10m de vão, as únicas que podiam ser empregadas em uma solução simplista.

Em uma demonstração de exímio conhecimento de mecânica das estruturas e das propriedades dos materiais estruturais, Bezzi concebeu o que hoje poderia ser chamada de uma grelha Vierendeel, associando, em duas direções ortogonais, as vigas de madeira da cobertura sobre estas mesmas paredes, ligando-as por trechos rígidos onde tais paredes divisórias seriam cegas e confiando na flexão local dessas vigas de madeira tãosomente na travessia das aberturas das portas.

Como mostra a Figura 311, a treliça de madeira no interior da parede de tabique, a torna um elemento de enorme rigidez perante as vigas horizontais de madeira.

A intervenção, assim teve como objetivo a eliminação do risco de colapso do conjunto, em virtude de vazamentos do telhado que levaram ao apodrecimento de trechos das vigas de madeira superiores das vigas Vierendeel, mostra as partes enrijecidas pelos tabiques de madeira e os tirantes metálicos verticais, colocados de ambos os lados da abertura da porta, fazendo com que os trechos das vigas horizontais de madeira, nessa travessia da porta, funcionassem como biengastados nos tabiques adjacentes. [...]

Para compensar o apodrecimento parcial das vigas de madeira que formam os banzos superiores das vigas Vierendeel, imaginou-se uma estrutura metálica paralela que não interferisse com a estrutura construída por Bezzi.

Esta estrutura de reforço partiu do princípio de que não se deveria mexer na estrutura original, pois qualquer reforço direto dessa estrutura exigiria acesso ao banzo superior das vigas Vierendeel, para o que seria necessária a retirada da cobertura da torre, com grave 
risco de danos ao acervo do Museu por eventual chuva durante a realização desses trabalhos.

A solução adotada foi a colocação de duas vigas de aço no espaço existente entre o topo das vigas de madeira de apoio do assoalho do piso, uma de cada lado da viga de madeira do banzo inferior da viga Vierendeel principal.

Os perfis metálicos foram inicialmente esquartejados e a seguir levados, aos pedaços, para suas posições finais entre o vigamento de madeira da estrutura original.

Em suas posições finais os pedaços foram soldados, reconstituindo-se assim a viga de aço de reforço.

Uma vez colocadas estas vigas de aço, por cima delas foram colocadas quatro vigas metálicas secundárias que, por meio de tirantes, passaram a sustentar diretamente a viga de madeira do banzo inferior da viga Vierendel principal, e com este reforço o piso está preparado para receber novamente o assoalho de madeira.

Com este reforço, as vigas que recebem o assoalho de madeira ficaram apoiadas diretamente sobre a mesa superior dos perfis de aço, ajustadas por meio de cunhas metálicas.

A viga de madeira do banzo inferior da viga Vierendeel principal foi assim aliviada do peso próprio do piso e das cargas acidentais de sua utilização. Por sua vez, essa viga de madeira, apoiada nas paredes de alvenaria das extremidades e em quatro tirantes metálicos intermediários, poderá funcionar, com segurança, como uma viga contínua de cinco tramos, com vãos da ordem de $2 \mathrm{~m}$, suportando apenas seu peso próprio e, eventualmente, as cargas transmitidas pelos tabiques. [...],

\section{AS ALTERAÇÕES NA ESTRUTURA DO SUBSOLO}

Como é conhecido, o pavimento do subsolo foi criado no vazio que existia no porão, e para se obter o pé-direito e a circulação necessária, foi realizada a escavação para rebaixar o nível de solo original de $1,20 \mathrm{~m}$ de profundidade. Em todos locais onde havia a fundação e a alvenaria do embasamento, foram feitas aberturas, extraindo blocos da fundação de alvenaria de pedra, igualmente de 1,20m de profundidade pela largura de cada passagem. Nestes locais a altura das fundações foi reduzida a $1 \mathrm{~m}$ comprometendo a rigidez da estrutura.

Segundo FUSCO (1997, p.61,68) :

Com uma clara visão de rigidez global que deveria ser mantida pelo conjunto, e sabendo das características de fragilidade das estruturas de alvenaria, Bezzi idealizou as fundações do edifício com um arranjo geral monolítico [...].

As fundações foram aprofundadas e construídas na forma de sapatas corridas de concreto ciclópico, com seção transversal de largura média de 2,20m [...]

O maior dano causado à estrutura do edifício foi devido ao corte de todas as sapatas sob diferentes paredes transversais, para abertura da galeria de circulação atualmente existente neste local. Com isso a parede longitudinal frontal precisou se reequilibrar por conta própria, em virtude da menor colaboração que passou a ser dada pelas sapatas transversais. Com estas agressões ficou em parte comprometido o monolitismo da fundação.

A perda da rigidez das sapatas transversais, que exerciam o papel de vigas-alavancas, responsáveis pela centragem da carga da fundação dos monólitos da parede externa longitudinal, provocou uma alteração no campo das pressões aplicadas por essas sapatas ao terreno .

As excentridades assim geradas nas cargas acarretam uma nova acomodação das sapatas no terreno com ligeiras rotações dessas sapatas e consequentemente ocorrendo rotações dos próprios monólitos.

Essa movimentação da estrutura provocou a fissuração dos arcos de alvenaria que ligam os monólitos da parede longitudinal externa aos monólitos da parede longitudinal interna. 
De maneira análoga, os cortes da sapata corrida sob a parede longitudinal interna também fizeram que elas perdessem em parte sua função de vigas-alavancas, permitindo que ocorresse uma rotação dos monólitos das paredes interna longitudinal, paralelamente à fachada, causando fissuração dos arcos de alvenaria que ligam estes monólitos.[...]

Estas alterações então, devem ser levadas em consideração pois trazem conseqüências à preservação do edifício, prevendo-se a continuidade de estudos e monitoramento da estrutura. Este tema é citado pela sua relevância, mas o seu detalhamento não faz parte desta pesquisa.

\section{INTERVENÇÕES REALIZADAS EM 2002}
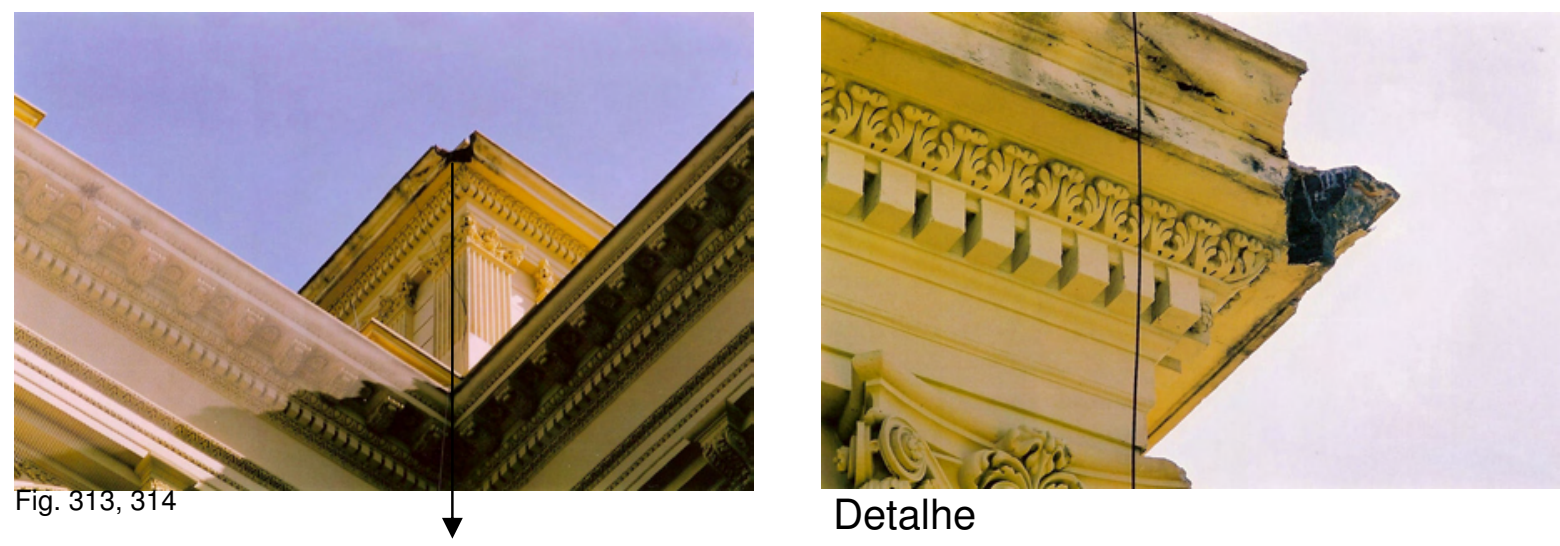

\section{Detalhe}

\section{CORNIJA E O TOPO DAS PAREDES DO MIRANTE}

Em 2002 foram realizadas intervenções na região do mirante e de todas cornijas, que dividem um pavimento de outro.

$\mathrm{Na}$ superfície do topo das paredes, da cornija do mirante, uma estrutura oca, havia diversas rachaduras por onde infiltrava água e atingia o interior das paredes. Como mostram as figuras 313 e 314 , houve desprendimento de um fragmento Foram retirados os revestimentos da superfície do topo das paredes, foi feita a regularização das superfícies e aplicada mantas asfálticas coladas com maçarico. E ainda foram revestidas com ladrilho hidráulico.
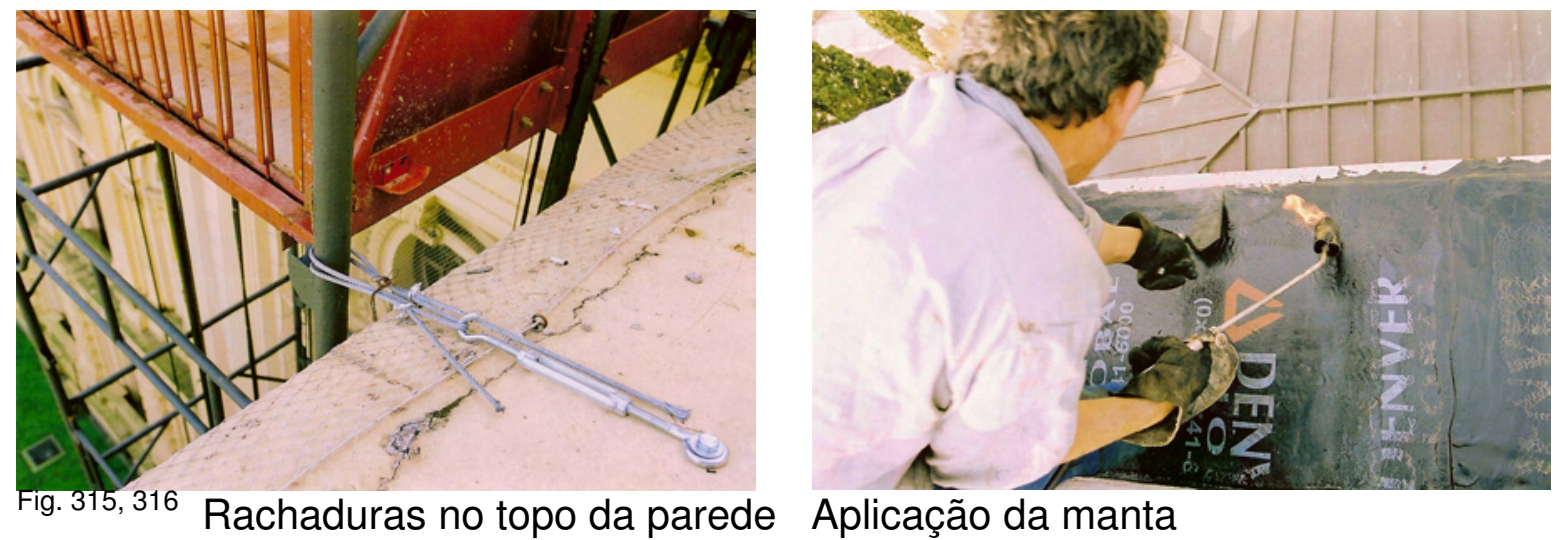
AS RACHADURAS NAS PAREDES

Havia rachaduras nas paredes transversais e foram aplicadas faixas de manta EPDM coladas no substrato devidamente regularizados e cobertas com manta asfáltica para tornar o sistema duplamente protegido

\section{O REVESTIMENTO INTERNO DAS PAREDES}

A infiltração de água através do topo das paredes e da cornija, atingindo o interior das paredes, provocou o desprendimento do revestimento da alvenaria e neste momento foi totalmente extraída e aplicada argamassa rígida com adição de hidrófugo.
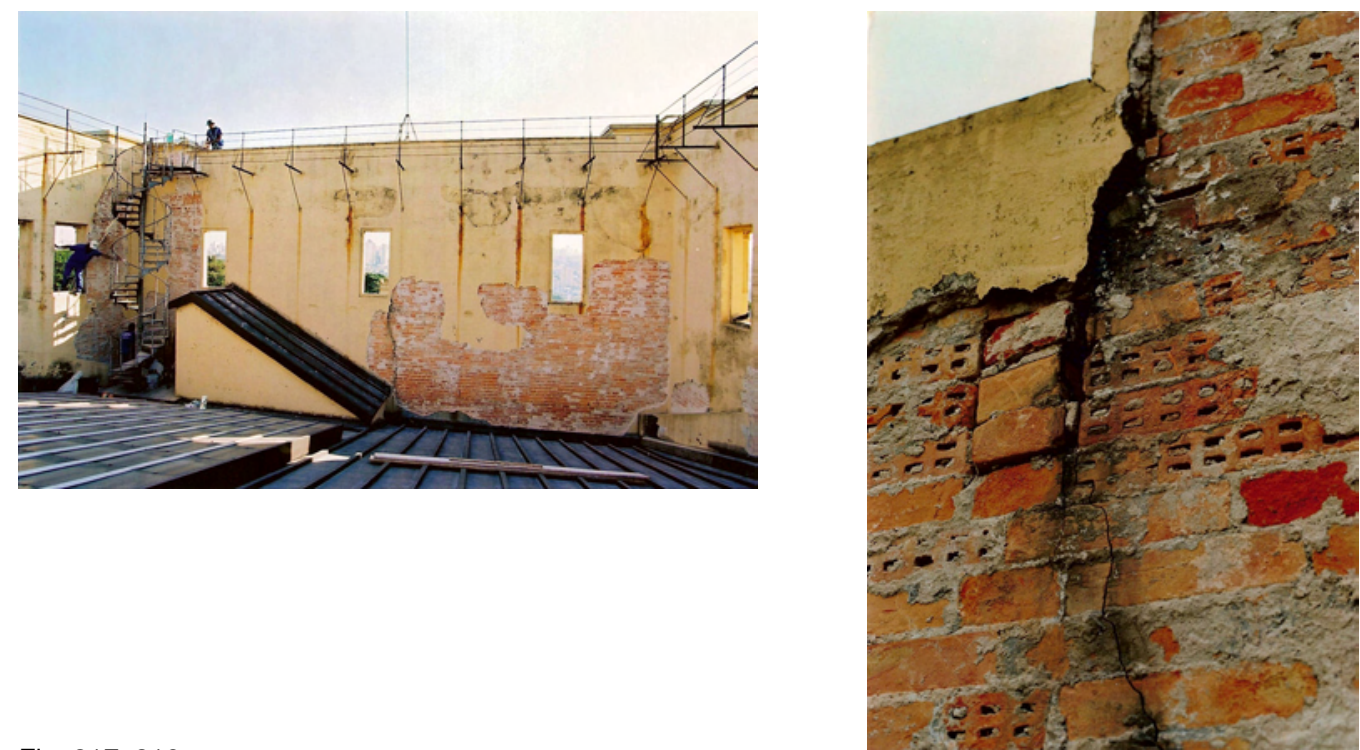

Fig. 317,318 Rachaduras e descolamento da argamassa
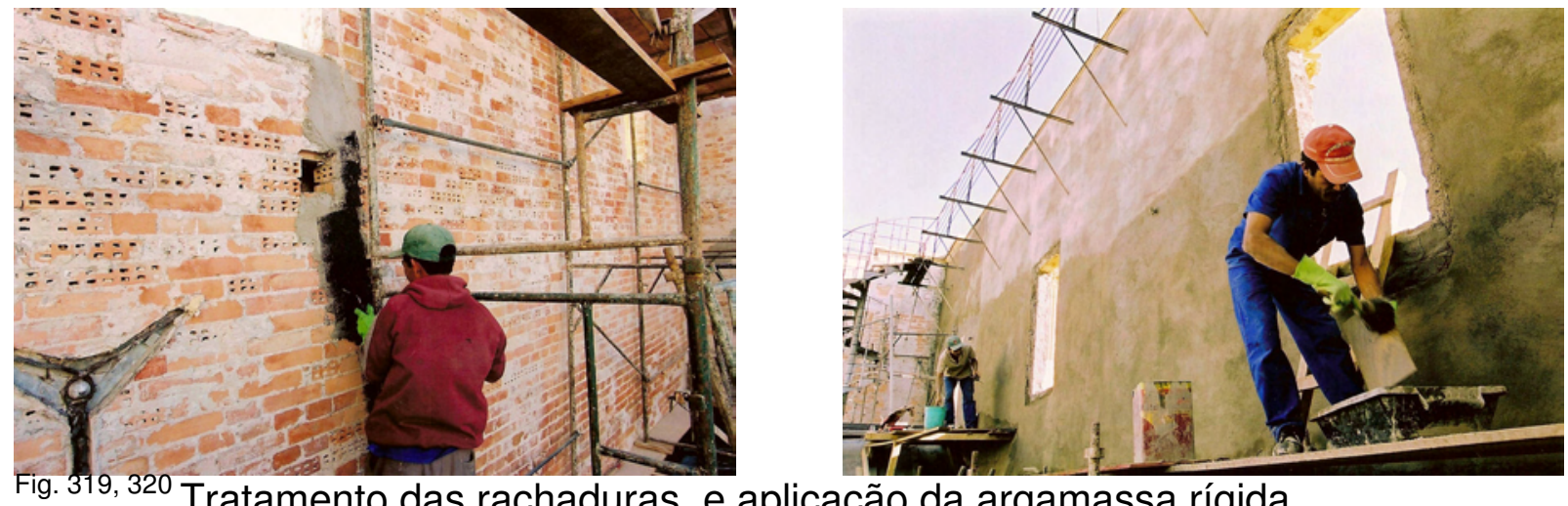

Tratamento das rachaduras e aplicação da argamassa rígida

REGIÃO INFERIOR DAS PAREDES 

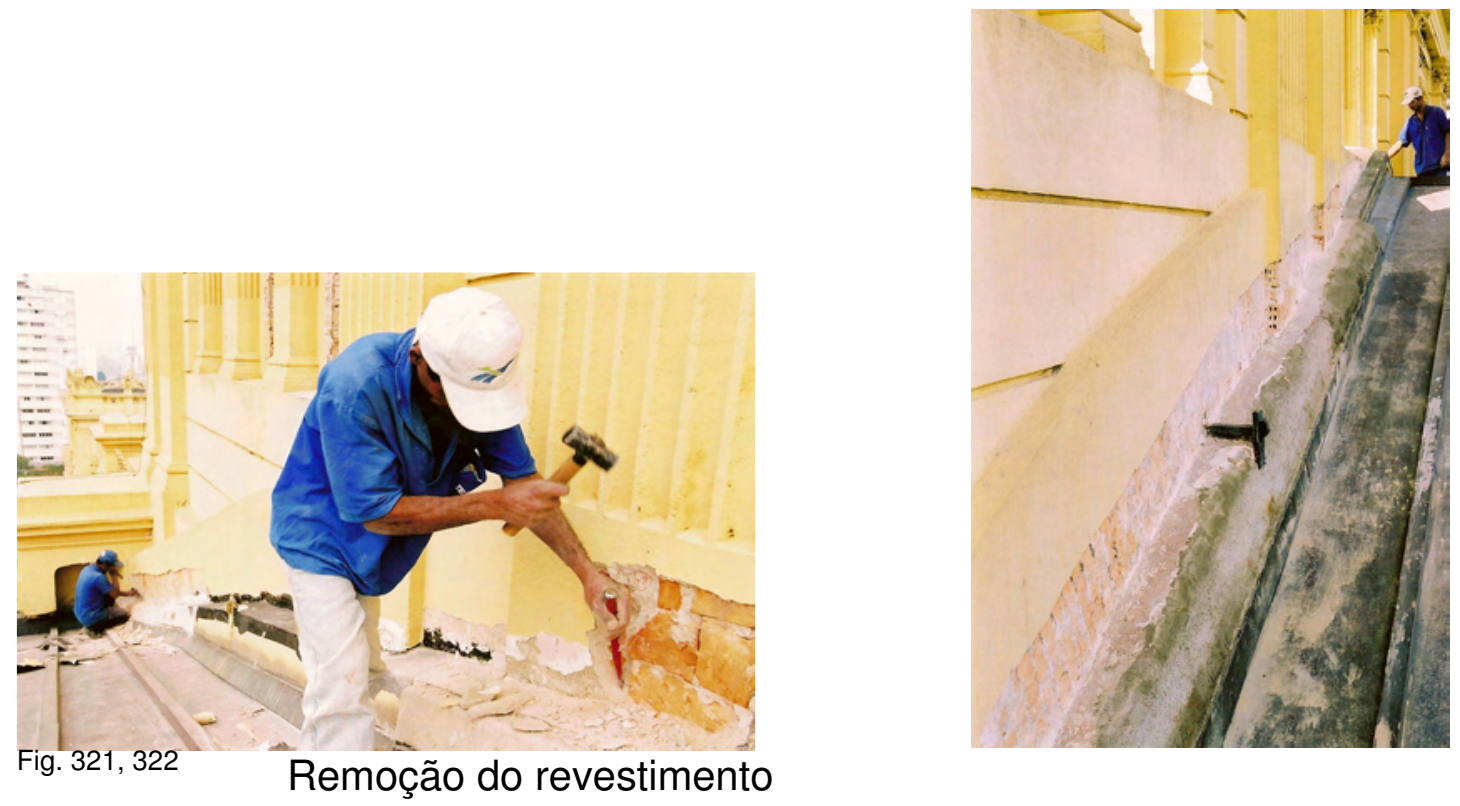

Em todo perímetro interno e externo das paredes do mirante, foi removido até níveis de ancoragem de impermeabilização, todo o reboco, feito o tratamento antifungicidas e aplicada uma regularização dessas superfícies com argamassa rígida impermeabilizante, a fim de proporcionar uma base firme para aplicação de camada impermeável, de manta asfáltica de $4 \mathrm{~mm}$ com elastômeros e estruturante de poliéster, a fim de tornar estanque esta região limítrofe entre as paredes, o telhado e as calhas, por onde havia infiltrações
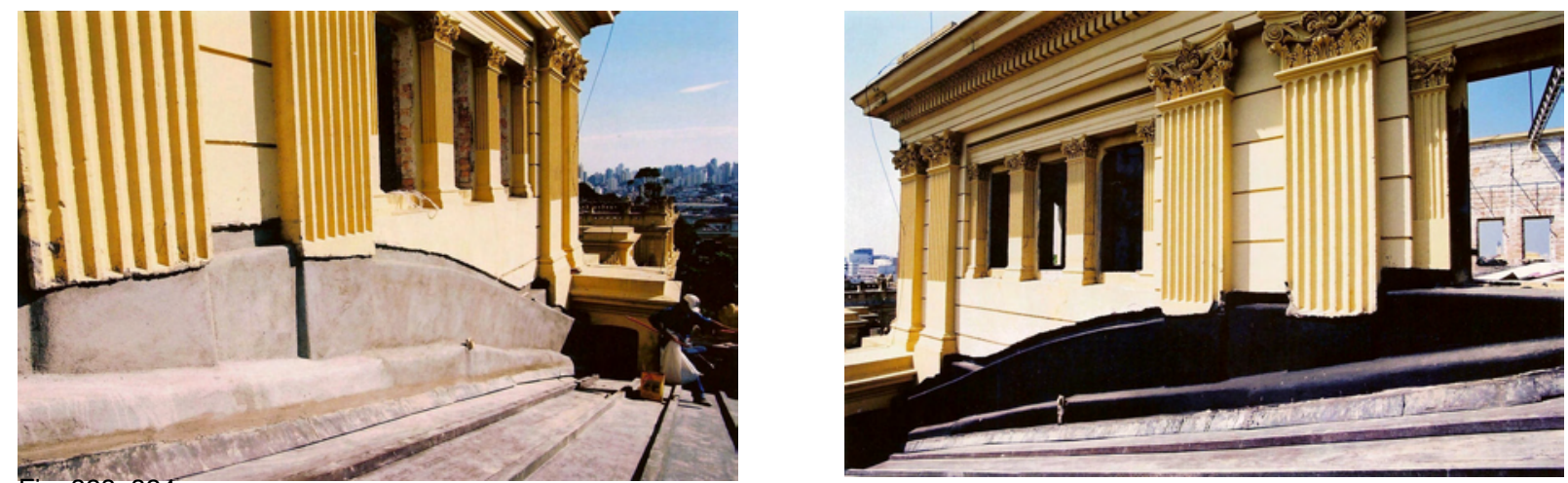

Fig. 323,324

Aplicada à argamassa rígida e a impermeabilização 


\section{PLATIBANDA}

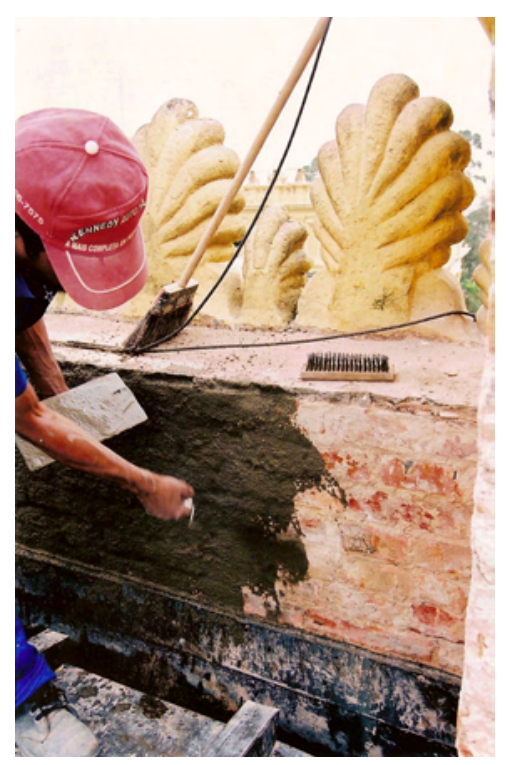

O revestimento das platibandas foi extraído e aplicado argamassa polimérica estruturada com tela de poliéster.

Fig. 325

Segundo a empresa responsável por estas intervenções, foi considerado que:

Estas regiões deveriam receber impermeabilização totalmente elástica, mas como isso demandaria a remoção de parte das lajotas de ladrilhos hidráulicos que a compuseram, e haveria a desagregação do beiral inferiormente, e isto necessitaria de reconstituição dos ornamentos que seriam removidos conjuntamente.

Assim sendo, numa próxima etapa, deverão ser removidos novamente todos esses revestimentos, e impermeabilizados com material totalmente elástico e protegidos com os referidos ladrilhos hidráulicos como acabamento restaurado.

O friso sob as palmetas que corresponde à platibanda, mais uma vez foi impermeabilizada. Na face externa, continua o empolamento na película da pintura, que já havia sido tratado em 1990, voltaram a surgir e permanecem até hoje.

Segundo as observações acima citadas, foi considerado que esta intervenção realizada em 2002 não foi solucionada totalmente. 
Em 2006, foram feitas estas imagens, onde foi constatado que as fissuras estão aparentes novamente, após quatro anos.
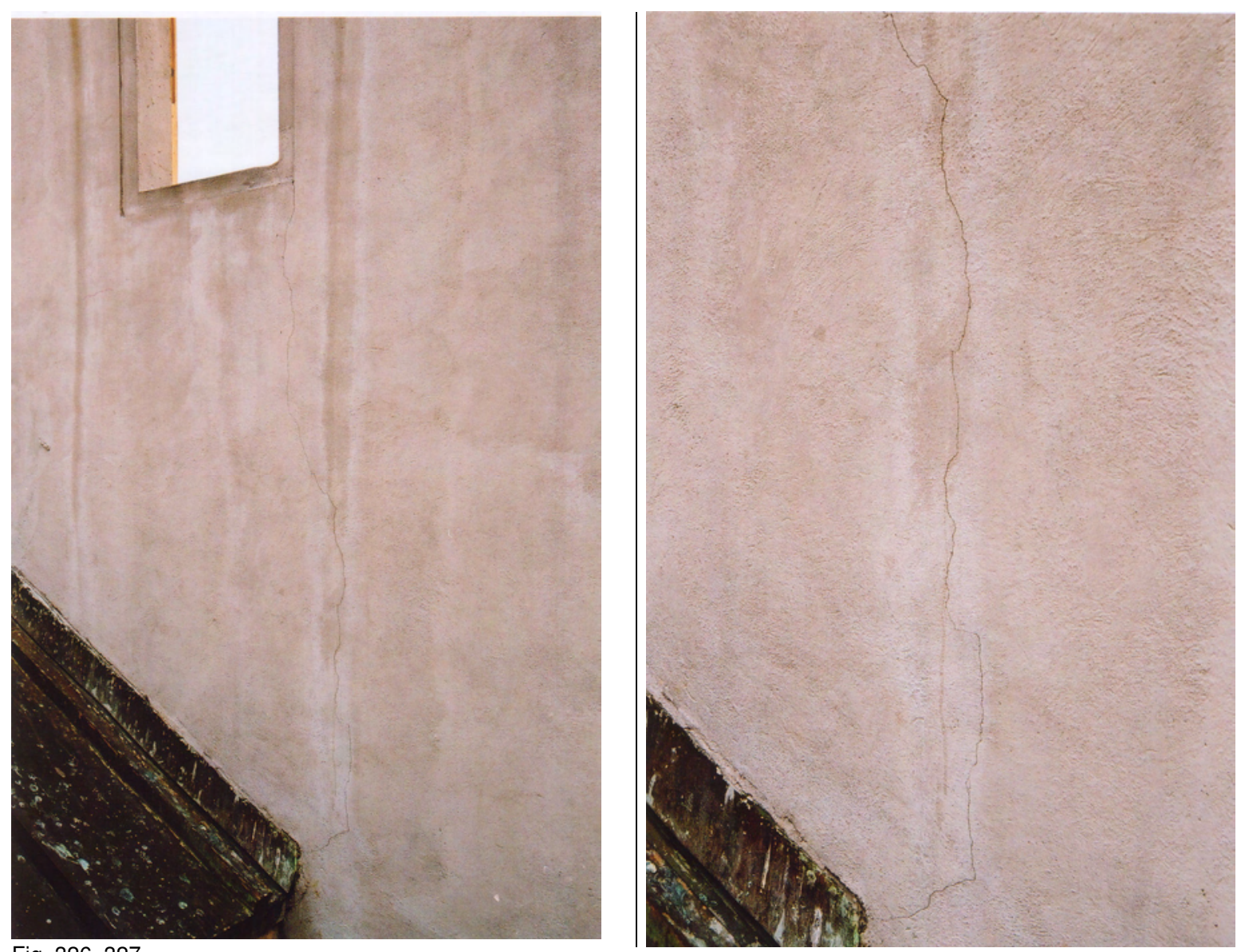

Fig. 326, 327 Detalhe rachaduras
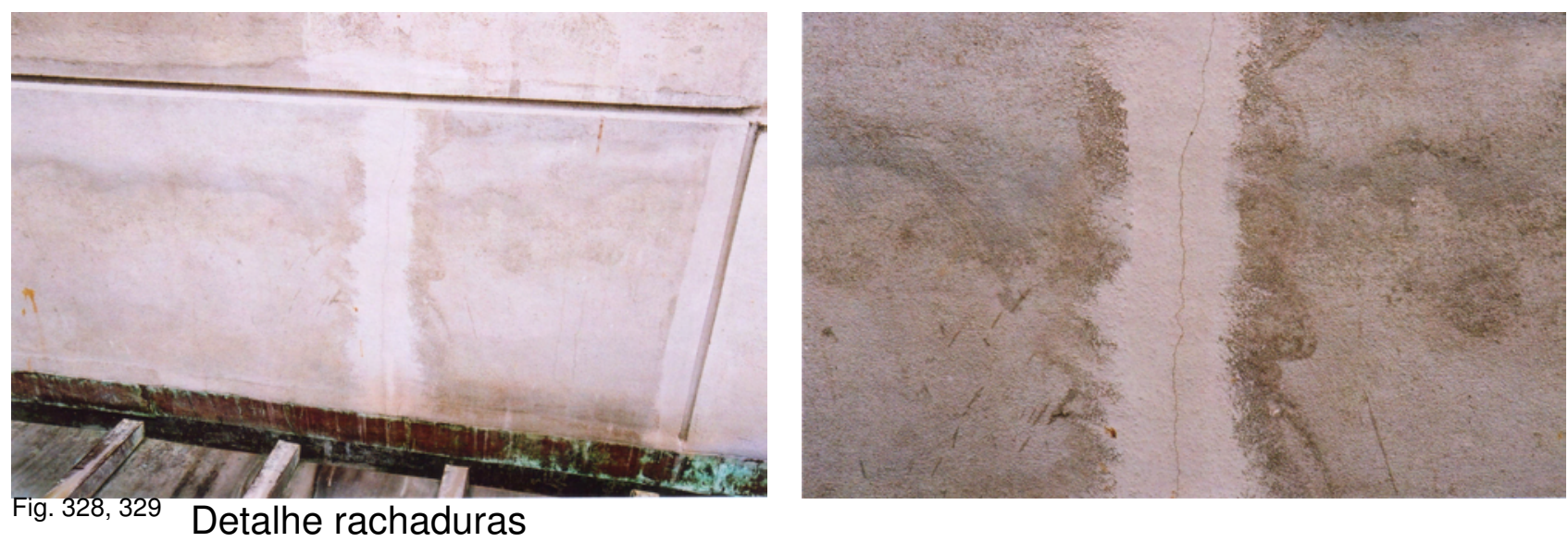

As fissuras também reapareceram nas faixas sobre as calhas e rufos onde foram aplicadas mantas de EPDM e mantas asfálticas 
As paredes internas do mirante que anteriormente eram pintadas com tinta látex, nesta intervenção recebendo a argamassa rígida com hidrofugante, continuou sendo não permeável à umidade. Deve-se ressaltar que com a intervenção no topo das paredes foi eliminada a infiltração de água que havia nesta superfície.

Assim a face interna e a face externa dessas paredes não são permeáveis à umidade, dificultando a sua evaporação.

Nesta situação a umidade poderá penetrar somente pelas fissuras da nova argamassa e da pintura externa - e terá dificuldade para evaporar.

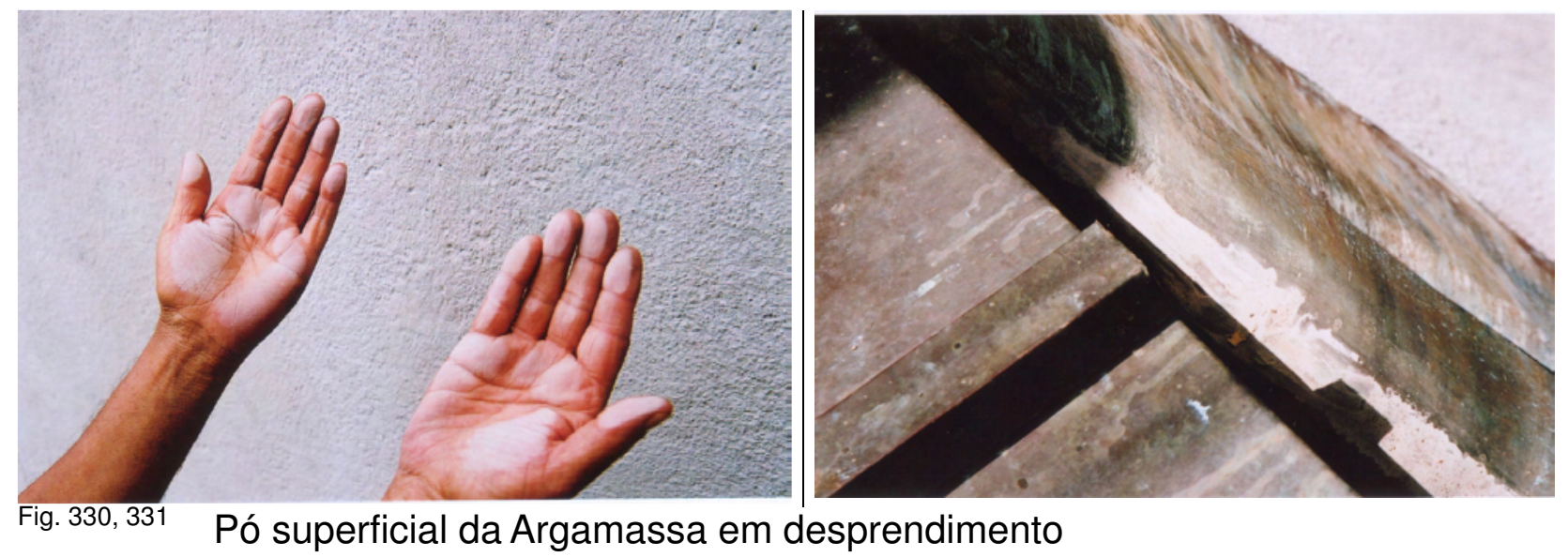




\section{EDIFÍCIO HISTÓRICO E AS QUESTÕES DA UMIDADE, SALINIDADE, POROSIDADE E A PINTURA}

Um Edifício Histórico, ou um Edifício de Técnicas Tradicionais Construtivas de Alvenarias, como foi apresentado, se caracteriza pelo emprego de espessas estruturas em tijolos maciços, com grande peso por $\mathrm{m}^{2}$ de parede.

Sua fundação, não sendo impermeabilizada, permite a ascensão da umidade do solo por capilaridade devido à porosidade dos materiais, produzindo nas paredes um alto teor de umidade. Esta umidade nas paredes é uma das causas mais freqüentes de problemas, pois cria condições de insalubridade e desconforto para as pessoas, compromete a estética do edifício e, sobretudo, acelera a deterioração de seus materiais. Desse modo, é fundamental conhecer as formas pelas quais a umidade se manifesta, suas possíveis causas, e os parâmetros em que se fundamentam os fenômenos e se processam os danos.

Outro fenômeno manifestado nos materiais dos edifícios antigos consiste na interação entre os sais solúveis e a umidade. Essa interação contribui de forma decisiva para a formação das anomalias das paredes. No entanto, se a presença de água for evitada nesse caso, seja em seu estado líquido ou gasoso, os sais não oferecerão problemas patológicos para os revestimentos e as alvenarias dos edifícios.

A água, ao se caminhar por entre poros e fissuras da argamassa e alvenaria, transporta os agentes dissolvidos - carbonatos, cloretos, sulfatos, nitratos, etc , depositando-os nas regiões onde se produz evaporação. Com a evaporação da água, os sais voltam a cristalizar na superfície da argamassa e alvenaria e, devido às forças expansivas criadas pela cristalização, causam a desagregação das argamassas, tornando-se uma das causas mais sérias de degradação. Assim, os sais, quando depositados nas superfícies, dão origem à formação de eflorescências ou, quando a cristalização ocorre sob os revestimentos de parede, a criptoflorescência (NAPPI , S.) Deve-se observar que essa conceituação é corrente entre os estudiosos portugueses. No Brasil, o termo eflorescências é empregado para se referir a ambos os casos, embora o termo criptoflorescência seja bastante esclarecedor por denotar o processo de cristalização "oculto", por assim dizer, sob os revestimentos de parede.

HENRIQUES salienta que, em termos gerais, a evaporação de uma parede úmida não provoca danos nas superfícies, desde que ocorra permanentemente. Nas zonas em que essa evaporação é intermitente, porém, verificam-se dilatação e vesículas nos seus revestimentos, resultantes da cristalização dos sais solúveis sempre que essa zona secar. A cristalização desses sais solúveis sempre é acompanhada por um aumento de volume, que, na seqüência de diversos ciclos de umedecimento/ secagem, provoca o destaque e desagregação dos materiais superficiais.

Esta evaporação livre e constante de toda umidade ascendente pelas fundações e paredes, é exatamente uma das importantes características da técnica construtiva do edifício em estudo, do seu comportamento natural, da sua relação com o meio ambiente e a umidade, tal como foi concebido.

Assim, a umidade deve evaporar sem dificuldades, sem barreiras que não provoquem danos na argamassa de revestimento, na argamassa de assentamento e nos tijolos. Essas barreiras podem ser constituídas por materiais não permeáveis ao vapor ou à água, como os utilizados nas impermeabilizações e, como ocorre no caso em estudo, pelo tipo de tinta à base de resina empregada na pintura das paredes externas e internas. 
A escolha do tipo de tinta empregada nas paredes de edifícios que contenham umidade, é, portanto, um fator de grande relevância na preservação, tanto no que se refere ao processo de evaporação quanto ao que diz respeito à presença dos sais solúveis.

Segundo NAPPI, a pintura, cujas funções principais são proteger e embelezar o edifício, torna-se um elemento muito importante nas edificações históricas, porque, além desses pressupostos, não deve degradar o interior de suas paredes. Isso porque, dadas suas características, as paredes desses edifícios necessitam principalmente de uma permeabilidade muito elevada ao vapor de água. Assim, a escolha do tipo de tinta, deve considerar nesse caso:

- A consolidação do suporte - isto é, a pintura não pode ser uma causa de dano à parede

- A proteção do agente atmosférico e da poluição - Qual é o comportamento da tinta como proteção às intempéries e às agressões da poluição

- Não alterar a permeabilidade ao vapor de água do suporte

- Como fato cultural importante levando em conta a estética, a textura e cores utilizadas em determinadas épocas (não é um sub item só)

As considerações acima indicam, portanto, que quanto mais vasto o conhecimento acerca do processamento dos fenômenos da umidade, salinidade e sua relação com a pintura que cobre as superfícies das paredes, bem como acerca da formação das anomalias e de sua manifestação, mais consistente será a elaboração de um diagnóstico.

\section{FORMAS DE MANIFESTAÇÃO DA UMIDADE}

São várias as formas pelas quais a umidade se manifesta. E para cada tipo de causa corresponderão conjuntos de sintomas, que poderão ser detectados por observação visual, através de ensaios, ou cálculos específicos.

Nem sempre apenas por uma observação visual podem-se identificar as causas das anomalias. Para cada tipo de dano não correspondem necessariamente um único tipo de causa isolada. É freqüente que um ou mais tipos de fenômenos apareçam associados, por haver condições propícias para que ocorram, ou por ser conseqüência um do outro.

Pode-se afirmar que a umidade em uma edificação se manifesta de formas diferentes, dentre as quais destacam-se:

- A umidade de Construção

- A umidade do Terreno

- A umidade de Precipitação

- A umidade de Condensação

- A umidade devida a fenômenos de Higroscopicidade

- A umidade devida a outras causas

- A UMIDADE DA CONSTRUÇÃO

Quase todos os materiais utilizados nas construções ou nas intervenções posteriores necessitam de água para sua confecção e seu emprego. Também na fase de construção os materiais estão mais sujeitos à ação direta da água da chuva, o que amplia o teor de umidade nos materiais. Parte desta água evapora rapidamente, mas outra parte demora muito tempo.

Segundo HENRIQUES (1995), o processo de secagem de materiais porosos acontece em três fases: 
1. A primeira consiste na evaporação da água superficial, ocorrendo rapidamente

2. A segunda, a evaporação da água nos poros de maiores dimensões. Esse processo é bastante mais demorado, na medida em que a maior parte da água está contida no interior dos materiais, tornando-se necessário que atravesse sob forma líquida ou de vapor todos os poros até atingir a superfície.

3. A terceira fase é a libertação da água existente nos poros de menores dimensões. Esse processo é extremamente lento, decorrendo muitas vezes ao longo de vários anos.

A umidade de construção pode causar danos generalizados ou localizados.

A água, ao evaporar-se, pode provocar expansões ou destaques de alguns materiais ou, devido mesmo à sua existência, diminuir a temperatura superficial dos materiais, dando origem à ocorrência de condensações. De forma geral, contudo, essas anomalias cessam num período mais ou menos curto de tempo, dependendo das características da edificação, do tipo de utilização do edifício e de sua região climática.

No Documento 362, da Pasta 6, Bezzi se refere à manchas surgidas em algumas paredes devido à pressa da execução da obra:

[...] Acabados os muros foi necessário começar-se o emboço e o reboco, e isto foi feito com tanta precipitação para não atrasar a conclusão das obras que uma parte do coroamento do ático tanto do Corpo Central como dos pavilhões que foram revestidos pouco tempo depois de feitos, mancharam, inconveniente este devido a não estarem completamente secas as paredes que foram rebocadas.

Um fato desse tipo, além de ocorrer devido às circunstâncias da execução da obra, pode também ser provocado pelas chuvas que atingem as paredes em construção. Esse tipo de umidade se manifesta em toda superfície das paredes, na face exterior e interior. No processo de secagem, o teor de umidade se mantém na mesma altura e vai decrescendo do interior da parede para as áreas externas, variando ao longo de um tempo que não é possível determinar. Mas, como indica o texto acima, a manifestação foi logo após a execução.

Este tipo de ocorrência de umidade, após 117 anos de vida deste edifício, não é possível ser considerada e mesmo se examinasse as espessas paredes com sondas longas, havendo umidade, poderia ser confundida com a umidade ascendente do terreno ou outras ocorrências, como vazamentos no sistema hidráulico.

\section{- A UMIDADE DO TERRENO}

A umidade do terreno pode se originar das águas freáticas e das águas superficiais. A umidade provocada pelas águas freáticas produz fenômenos que não se alteram durante 0 ano devido à atividade permanente da fonte, sendo a altura das manchas constantes em todas as paredes, embora maiores nas internas, devido às condições menos favoráveis de evaporação.

As águas superficiais geram fenômenos que variam durante $o$ ano. As alturas que atinge a umidade podem variar de parede para parede, sendo maiores nas paredes externas. 


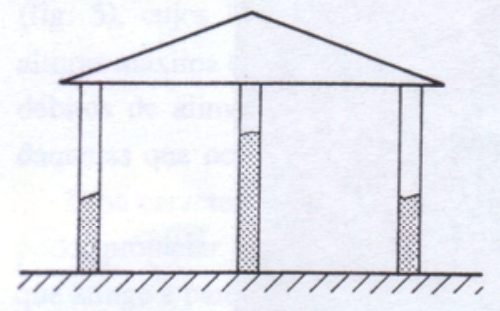

a) Águas freáticas

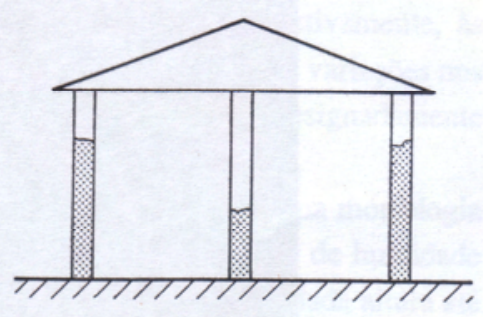

b) Águas superficiais
Variação das

alturas atingidas

pela umidade do

terreno em

paredes

interiores e

exteriores, em

função do tipo de

alimentação

A água existente no terreno pode freqüentemente provocar umidade nas paredes das edificações, tanto no subsolo como no pavimento térreo. Os materiais de construção, antigos ou modernos, na sua grande maioria, possuem uma capilaridade elevada, fazendo com que a água ascender por entre esta capilaridade. Se não houver nenhuma espécie de barreira estanque, essa migração pode ser horizontal e vertical e aparece quando:

- Existir zonas das paredes em contato com a água do solo

- Quando as paredes tiver materiais com elevada capilaridade

- Não existir ou quando for deficiente o posicionamento de barreiras estanques nas paredes (HENRIQUES, 2001)

Segundo NAPPI, a ascensão da água nas paredes pode ocorrer até elevadas alturas, sendo inversamente proporcional ao diâmetro dos poros. Ou seja, quanto menor o seu diâmetro, maior é a altura que a água poderá atingir. Esses condutos capilares são canais de diâmetro finíssimo que serpenteiam através dos materiais com uma rede de conexões com ar entre si, saturando os materiais com água que avançam vencendo a força da gravidade.

Motivo determinante dos fenômenos de capilaridade é o diâmetro dos canais. A água sobe nestes condutos, segundo o seu diâmetro. De acordo com EICHLER (1973), a água pode atingir as seguintes alturas:

\begin{tabular}{|c|c|}
\hline Diâmetro dos capilares $(\mathrm{mm})$ & Altura máxima $(\mathrm{mm})$ \\
\hline 1,00 & 15 \\
\hline 0,001 & 1500 \\
\hline 0,0001 & 150000 \\
\hline
\end{tabular}

Pode-se considerar que a ascensão de água numa parede atingirá o nível em que a quantidade de água evaporada pela parede compense aquela que é absorvida do solo por capilaridade. Assim, sempre que são diminuídas as condições de evaporação duma parede - por exemplo, utilizando um revestimento impermeável - a altura atingida pela água tem tendência a aumentar até um nível em que se restabeleça um novo equilíbrio. 


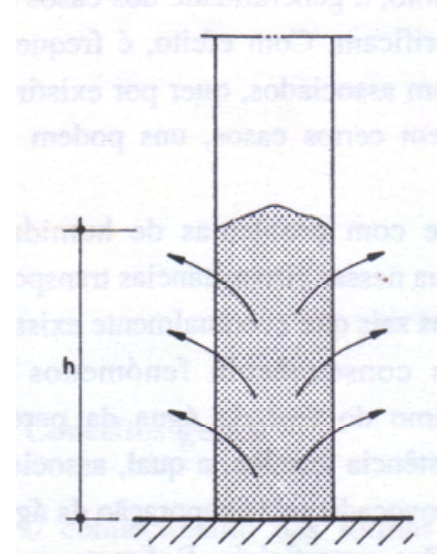

Fig. 333

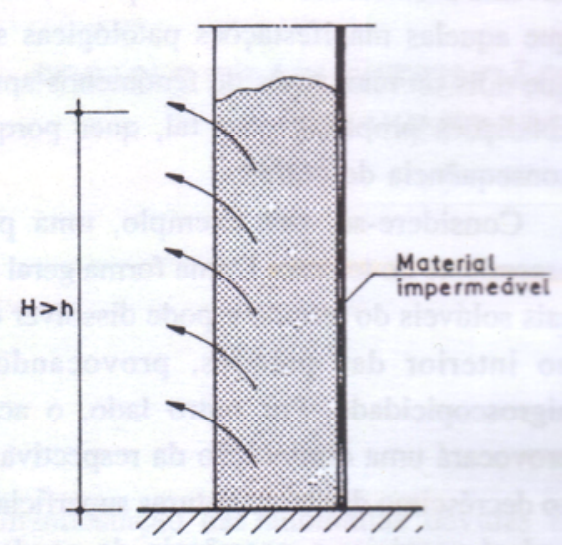

Altura atingida pela água nas paredes, em função das condições evaporação

Considerando constantes as condições ambientes, e para uma dada constituição das paredes, quanto maior for a espessura, maior será a altura atingida pela umidade. $O$ autor cita o caso da Igreja de S.Bernardo em Roma, cujas paredes de $4 \mathrm{~m}$ de espessura permitiram a ascensão da água até uma altura de $5,3 \mathrm{~m}$

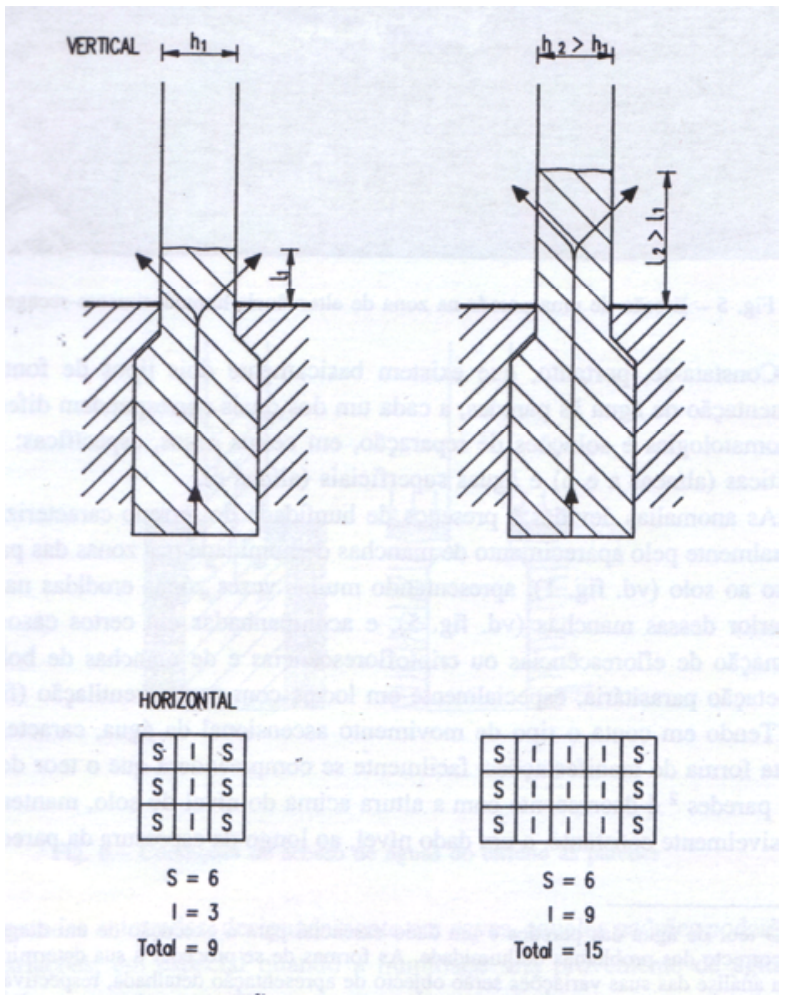

Altura atingida pela água nas paredes, em função da espessura

Comparação de duas paredes: uma mais fina e outra mais grossa, representadas através de uma malha de cubos, sendo $S$ os superficiais e I os internos. A altura que atinge a umidade depende da espessura, das condições de evaporação, da orientação magnética, da época da construção e da técnica construtiva e, por fim, da quantidade de água que está em contato com as paredes. 
Também os sais existentes no terreno e nos próprios materiais de construção são dissolvidos pela água e transportados através das paredes até níveis superiores. Assim que a água evaporar, os sais cristalizarão e colmatarão os poros existentes, reduzindo a sua permeabilidade e, assim, elevando também a altura da umidade.

Nas umidades provenientes do terreno, visualmente pode ser detectado o aparecimento de manchas nas regiões junto ao solo, apresentando muitas vezes zonas com vesículas no nível superior destas, acompanhadas de manchas de bolor, criptoflorescências, eflorescências ou vegetação parasitária, principalmente nos locais de pouca ventilação.

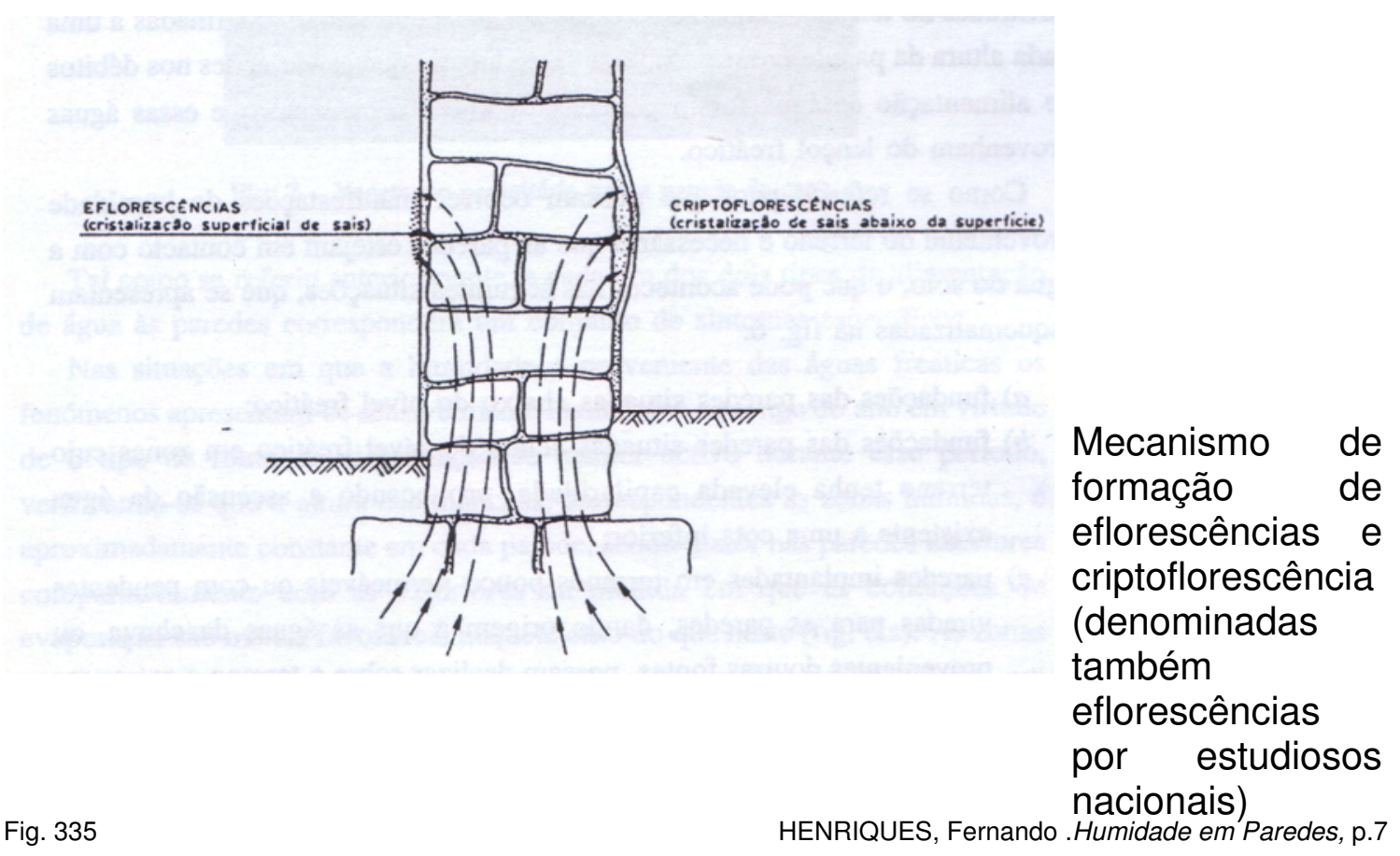

Na figura acima, observa-se que o fenômeno da criptoflorescência é freqüente no edifício em estudo, devido ao fato de as paredes receberem revestimento de argamassa e pintura, ocasionando assim o desprendimento do revestimento da alvenaria e, em determinados casos, apresentando vesículas e argamassa em desagregação.

As anomalias devidas à presença de umidade do terreno, caracterizam-se visualmente pelo aparecimento de manchas de umidade nas zonas das paredes junto ao solo, apresentando muitas vezes zonas com vesículas na parte superior destas manchas, e acompanhadas em certos casos pela formação de eflorescências ou criptoflorescências, e de manchas de bolor ou vegetação parasitária, especialmente em locais com pouca ventilação.

Tendo em conta o tipo de movimento ascensional da água, característico destas formas de manifestações, facilmente se compreenderá que o teor de água das paredes é decrescente com a altura acima do nível do solo, mantendo-se sensivelmente constante, a um dado nível, ao longo da espessura da parede.

No caso de paredes enterradas, quando há subsolo, aqueles padrões poderão sofrer variações, em especial quando a umidade for proveniente de águas superficiais. 


\section{- A UMIDADE DE PRECIPITAÇÃO}

A chuva em si não se constitui em problema para a construção. No entanto, se for acompanhada de vento, gera uma componente horizontal proporcional à sua intensidade. A ação da chuva sobre uma parede pode assumir diversos componentes:

A energia cinética das gotas de água pode provocar penetração direta destas gotas sobre fissuras ou em juntas mal vedadas.

Também essa ação continuada da chuva pode formar uma cortina de água que, ao escorrer pela parede, pode penetrar nela por gravidade, como resultado da sobrepressão causada pelo vento ou por ação da capilaridade dos materiais.

As anomalias manifestam-se através do aparecimento de manchas, e umidade de dimensões variáveis nos paramentos interiores das paredes exteriores, em correspondência com a ocorrência de precipitações, que tendem a desaparecer quando cessam os períodos de chuva. No entanto, em períodos prolongados de chuva, pode haver a ocorrência de bolores, eflorescência e criptoflorescência.

\section{- A UMIDADE DE CONDENSAÇÃO}

$\mathrm{Na}$ composição do ar existe, além de gases, uma determinada quantidade de vapor d'água. A quantidade máxima de vapor de água, chamado limite de Saturação, varia conforme a Temperatura - aumenta se a Temperatura aumenta - diminui quando a Temperatura diminui.

Quando uma massa de ar diminui a Temperatura, certa quantidade de vapor se condensa dando origem à formação de gotículas.

A condensação do vapor existente no ar acontece normalmente no interior das edificações, na face interna das paredes externas, pois, de modo geral, estas faces têm uma temperatura inferior à do ar ambiente. Esta Temperatura mais baixa provoca um aumento da Umidade Relativa do ar em contato com a parede e ocorre assim a condensação.

$\mathrm{UR}=\mathrm{UA} / \mathrm{S}$

Umidade Relativa é o quociente entre a quantidade de vapor de água que o ar contém, ou Umidade Absoluta e a quantidade máxima de vapor que este ar poderia conter na mesma Temperatura, chamada Saturação.

O nível de Saturação varia diretamente com a Temperatura: aumenta quando aumenta a Temperatura.

Mas aumentando a Temperatura a Umidade Relativa diminui.

Quando o ar se encontra no limite de sua Saturação, isto é $100 \%$, tem-se os valores de Umidade Absoluta igual ao de Umidade de Saturação.

\section{- A UMIDADE DEVIDO AOS FENÔMENOS DE HIGROSCOPICIDADE}

Segundo HERIQUES, a higroscopicidade é a capacidade que os sais solúveis têm de absorver umidade do ar em forma de vapor, ou no estado líquido, dissolvendo-se quando esta umidade se encontra entre o intervalo de 65 e $75 \%$, voltando a cristalizar-se quando abaixo deste intervalo, apresentando significativo aumento de volume.

Os sais solúveis são muito comuns em edifícios antigos, e causam patologias de correção muito difícil pela impossibilidade física de remoção desses sais do interior dos materiais porosos, como tijolo, argamassa, pedra. Os sais podem permanecer no interior desses materiais porosos até o final de sua vida útil. Se forem retirados das superfícies, os sais não removidos serão conduzidos novamente para estas áreas limpas. 
Por essa razão, portanto, importa avaliar os seus potenciais mecanismos de degradação. O valor da umidade relativa, quando ocorre a transição da dissolução e cristalização, varia em função do tipo de sal, do seu grau de pureza e de eventual combinação com outros sais - o que determina o abaixamento da Umidade Relativa necessária para ocorrer a dissolução (isto é, quando aumenta o nível de Saturação do ar).

HENRIQUES, citando CHAROLA, afirma que foi verificado experimentalmente que as trocas de vapor de água entre os sais e a atmosfera ocorrem preferencialmente em poros de média ou grande dimensão e que os fenômenos de cristalização se verificam em geral em poros com diâmetro da ordem de 1 um a 10 um (microns).

Sempre que ocorre dissolução, numa primeira fase, na superfície dos materiais, a sua porosidade encarrega-se de fazer chegar à frente úmida as zonas mais interiores onde pode dissolver os sais ali existentes. Inversamente, quando o ambiente externo seca, as primeiras cristalizações verificam-se à superfície, ocorrendo posteriormente uma secagem progressiva para o interior com a evaporação que a porosidade possibilita, a qual é acompanhada por um deslocamento da franja úmida para as zonas mais externas.

A ação degradativa dos sais, como é correntemente admitido, deve-se ao aumento do volume quando ocorre a cristalização, o qual, induzindo tensões por vezes elevadas no nível da estrutura porosa, dará origem a um progressivo enfraquecimento da sua capacidade resistente e, em conseqüência, à sua total perda de coesão, ou a desagregação já referida.

Segundo SOUSA, a ação destrutiva dos sais sobre os rebocos depende fundamentalmente de dois fatores:

- O primeiro é a estrutura porosa do reboco que é diretamente relacionada com o tipo de ligante utilizado ou do traço empregado. Quanto mais poroso for o reboco, menor será sua resistência mecânica

- O segundo é o ponto onde ocorre a cristalização dos sais

O ponto onde ocorre a cristalização é determinado pelo balanço dinâmico entre a taxa de evaporação à superfície, e a quantidade de água que atinge este local. Se a quantidade de água for ligeiramente superior à evaporação, dá-se a cristalização à superfície, com a formação de eflorescências.

Em geral, as eflorescências comprometem a estética, mas sua presença indica que em outro local a cristalização pode ocorrer no interior da estrutura porosa, provocando a desagregação da camada superficial, devida ao aumento de volume que geralmente acompanha os aumentos dos cristais. A formação de cristais no interior dos materiais dáse quando a taxa de migração da solução no sistema poroso do material é inferior à taxa de evaporação. Irá desenvolver-se uma zona relativamente seca abaixo da superfície, e os cristais desenvolvem-se na interface entre essa zona seca e a zona úmida do reboco. A este fenômeno é atribuída a designação criptoflorescência (Richardson, 1980) (Veiga e Aguiar, 2002) (Kumar e Kumar, 1999)

A cristalização se dá numa escala muito reduzida e, se fosse esporádica, poderia passar despercebida. Mas as variações de umidade relativa em torno do valor para que ocorra o fenômeno, típico de cada sal, são uma constante, acontecendo várias vezes no decorrer de um dia em condições normais. São ações, portanto, de pequena intensidade, mas de freqüência continuada ao longo de cada ano. 
Os sais mais freqüentes em edifícios são os cloretos, os nitratos e os sulfatos.

Os sulfatos têm uma ação pouco higroscópica. Por exemplo, o sulfato de cálcio bihidratado (gesso) apenas sofre dissolução com Umidade Relativa da ordem de $99 \%$ a $20^{\circ}$ $\mathrm{C}-\mathrm{o}$ que configura situações pouco freqüentes.

A presença de Cloretos está associada à proximidade com ambientes marítimos ou à utilização de materiais em que esses sais se encontravam presentes, como é o caso freqüente do uso de areia da praia mal lavada.

A ocorrência de nitratos decorre em geral da atividade dos seres vivos. Por esta razão, permitem indiciar eventuais fenômenos de umidade ascendente do solo - sempre rico em nitratos ou possíveis ruptura de canalizações de esgoto.

Observou-se, no local de ocorrência de eflorescência do nosso objeto de estudo, a lacuna na Entrada Leste, que o aparecimento dos sais cristalizados na superfície foi intenso em dias frios e com chuva. Conforme a temperatura foi aumentando, os sais praticamente desapareceram, a sua ocorrência é intermitente. Quando faz muito calor a evaporação é bem mais rápida e os cristais desaparecem mais rapidamente. Mas o que devemos salientar é que, quando há cristalização nos poros dos tijolos, provoca-se esfoliação ou sua desagregação, comprometendo seriamente a resistência das paredes. Originam-se assim vazios nos tijolos, devido ao desprendimento de parte de seu material. 


\section{PATOLOGIA NA ARGAMASSA DE REVESTIMENTO OU REBOCO}

Segundo MAGALHÃES (2002, p.69), o reboco é a "pele" que recobrindo a alvenaria a protege das ações agressivas de natureza física, mecânica, química ou biológica. $E$ assim, é susceptível às deteriorações e pode comprometer a durabilidade da alvenaria.

Os danos mais comuns em rebocos são causados pela umidade, pela sujidade, pela biodeterioração, e que se manifestam através de perda de aderência da argamassa da alvenaria, da eflorescência, das fissuras, perda de coesão e erosão.

Pela existência de uma diversidade de causas que atuam conjuntamente para originar uma única anomalia nos rebocos das paredes, torna-se necessária uma compreensão mais aprofundada dos mecanismos e das causas das anomalias, para possibilitar a elaboração de um correto diagnóstico,

Considerando-se esta diversidade de causas, que podem ocorrer num processo de dano, buscou-se identificar os materiais empregados no edifício para compreender as suas reações, perante as intervenções anteriores e ao meio ambiente.

Foram assim observadas as manifestações quanto à porosidade dos materiais, a presença inevitável da umidade, salinidade, e o tipo de tinta empregada na pintura..

Não se observa no texto da autora citada acima, em Patologia de Rebocos Antigos, referência alguma ao tipo de tinta aplicada sobre a argamassa de revestimento, e ao modo como interage com as causas de danos mais freqüentes aos rebocos.

De um lado os conceitos teóricos adotados por pesquisadores nesta área de estudo são fundamentais, e de outro lado, tem que se considerar o edifício como um estudo de caso, em suas particularidades, que foram sendo criadas no decorrer de sua existência.

No edifício em estudo, há um mascaramento total da argamassa de revestimento, devido à espessa camada de tinta impermeável. Esta tinta acrílica tem alta resistência às agressões do meio ambiente, e somente quando se rompe abrindo lacunas, é que permite que a argamassa manifeste o seu estado de conservação.

Os processos dos danos não ocorrem sempre visíveis, para que possam ser percebidos numa primeira análise.

Uma forma é quando a argamassa de revestimento perde a aderência da alvenaria e há um descolamento inicial.

O descolamento pode ser identificado pelo "som cavo", que se ouve quando a parede é submetida à percussão. Não é visível, pois tanto a tinta como a própria argamassa podem aparentar normalidade como é o exemplo a seguir: 


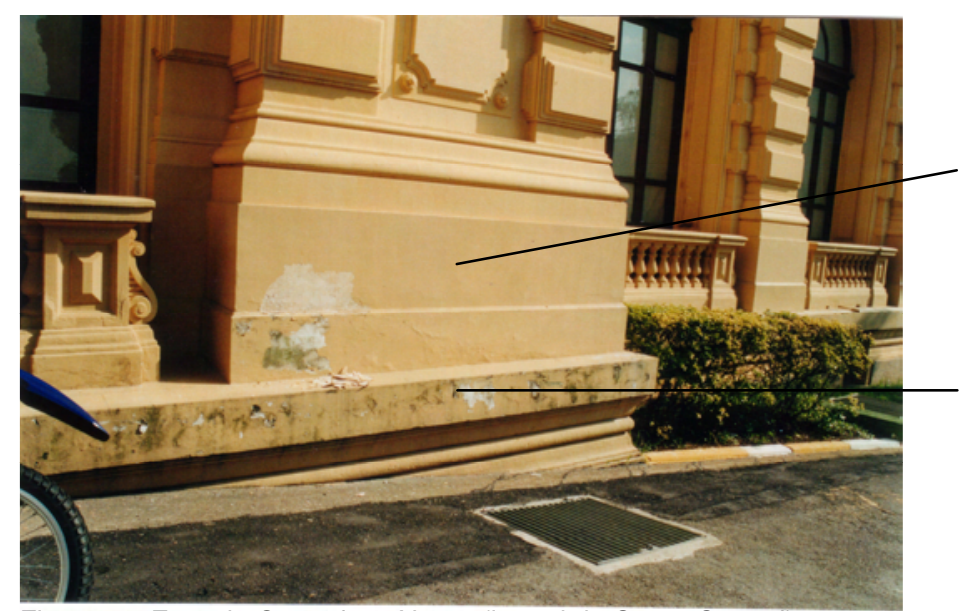

Fig. 336 - Entrada Oeste face Norte (lateral do Corpo Central)
Esta faixa da parede até à altura do friso apresenta descolamento da alvenaria . A película de tinta e a argamassa de revestimento, não aparentam este descolamento, estão planas, sem nenhum outro dano

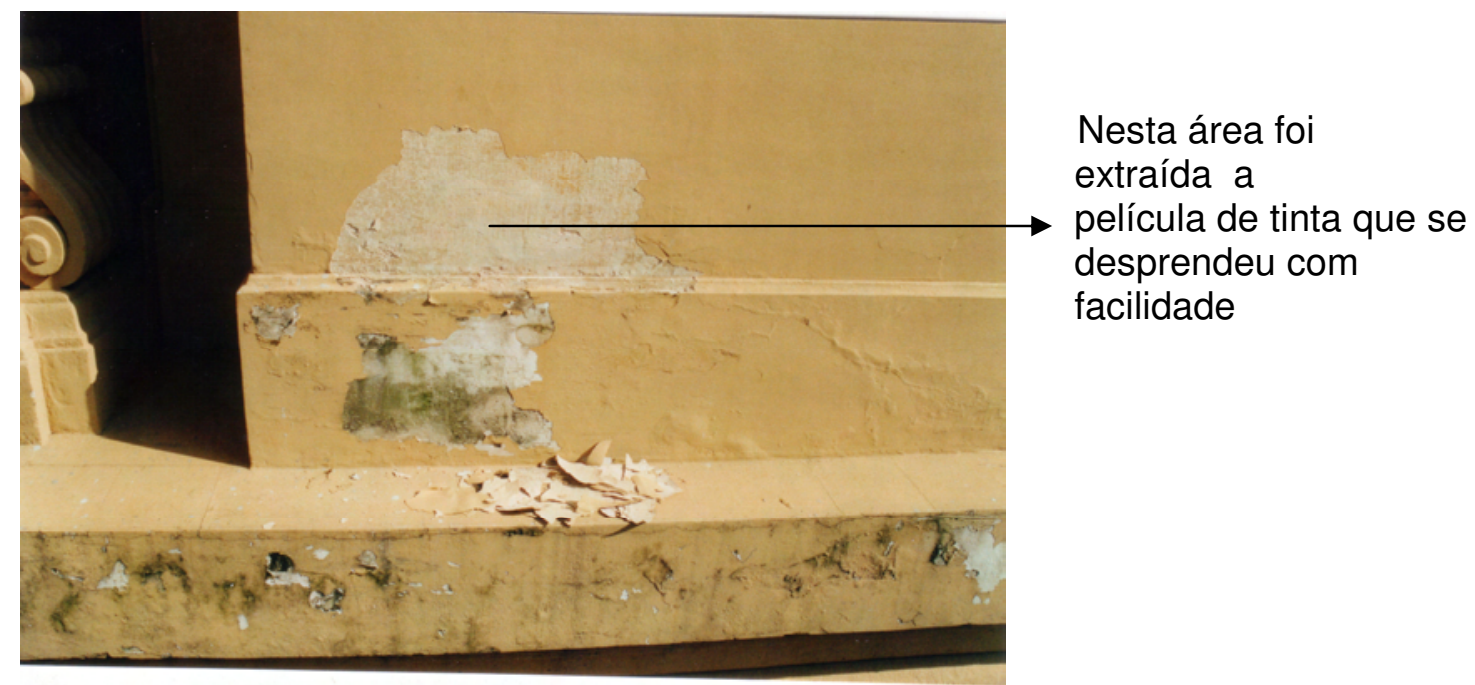

Fig. 337 - Detalhe Imagem em 2003

Esta imagem foi registrada em 2003. Verificou-se que neste local, a película de tinta e o reboco se apresentavam planos e aparentemente em bom estado. Entretanto, a película de tinta ao ser extraída, se desprendeu com facilidade, pois já se encontrava descolada do reboco.

Através de uma simples percussão, constatou-se que ocorre até uma altura aproximada de 1 metro do nível do piso externo, o descolamento da argamassa da alvenaria. Este dano ocorre em todas as fachadas do edifício, progredindo em silêncio.

Num período de quatro anos a manchas esverdeadas aumentaram e indicam a presença de umidade, que pode se originar tanto das águas superficiais como do solo. 


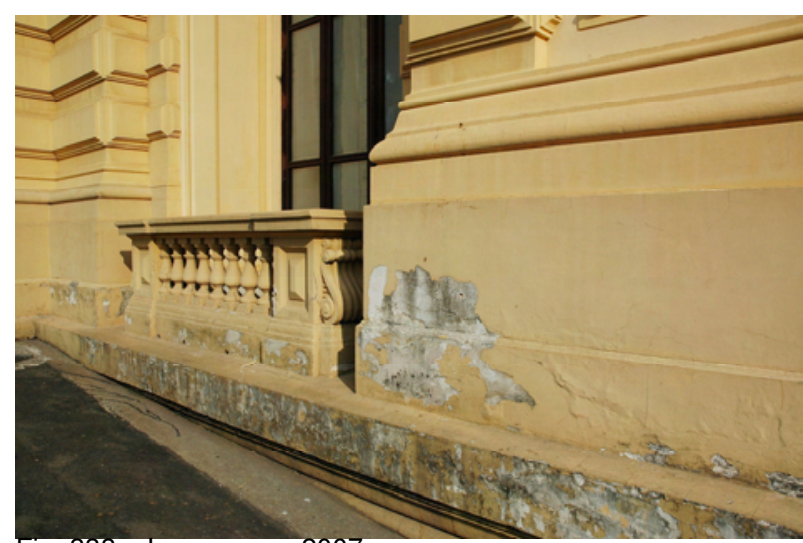

Fig. $338-$ Imagem em 2007
Imagem atual - aponta que a umidade está presente nas paredes e balaustrada, e se manifesta através de manchas verdes, vesículas, dilatação da película de tinta, fissuras e rachaduras.

Quando ocorrem fissuras ou perda da película de tinta, a umidade da parede se encaminha para estas aberturas, devido a maior facilidade de se evaporar e carreando os sais, então os danos são bastante agravados. Ocorre um abaulamento na placa da argamassa devido à presença prolongada de água e a conseqüente cristalização dos sais.

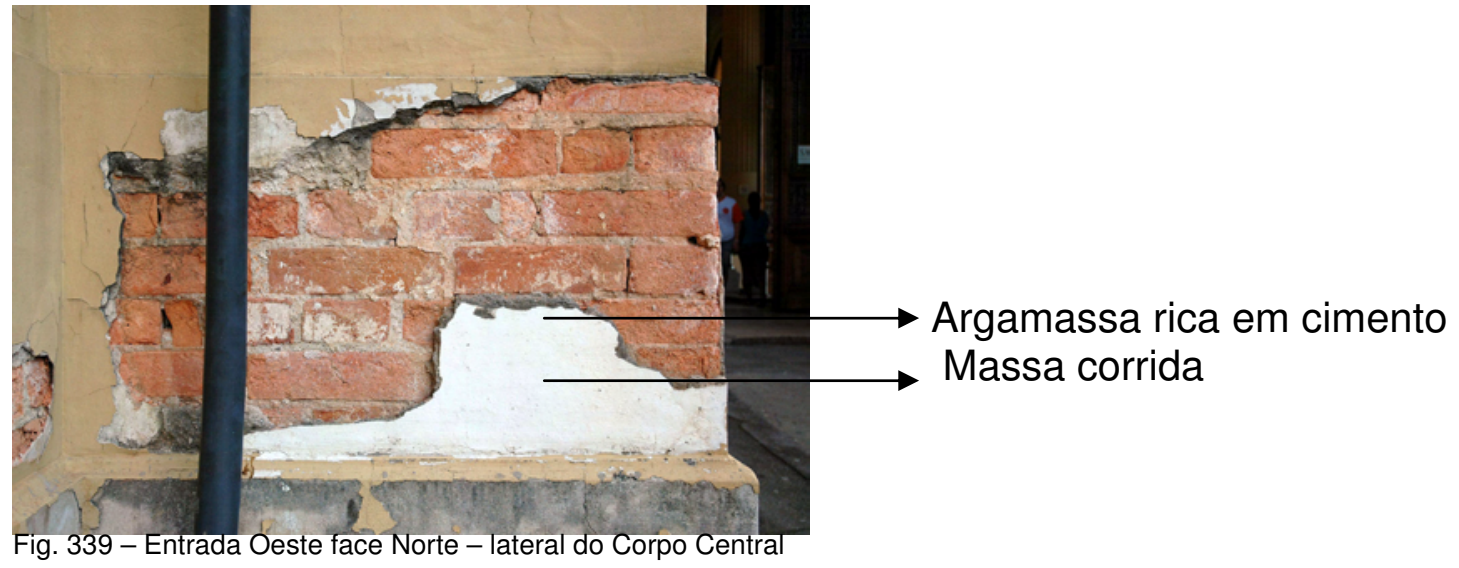

Este local recebeu uma intervenção tempos atrás, que ainda se observa na presença de massa corrida (branca) e argamassa rica em cimento. Esta lacuna fica próxima ao solo, onde há um pequeno jardim, e consequentemente, umidade ascendente.

Após a primeira intervenção, o desprendimento do reboco continuou, e a argamassa desta intervenção foi extraída como se apresenta na Fig. 339, para realizar outra intervenção. Seria da mesma forma que a primeira, com os mesmos materiais e novamente a parede reagiria, "expulsando" a argamassa rica em cimento. Nesse momento foi solicitado que não fosse realizada esta segunda intervenção, para fins de estudo e a busca de uma solução adequada às características da parede.

Assim, foi criada uma situação diferenciada em relação a todo revestimento do edifício. Estando a alvenaria sem o revestimento, surgiu uma grande eflorescência sobre os tijolos, e sob o reboco, e produziu os abaulamentos ao redor desta área sem revestimento. 


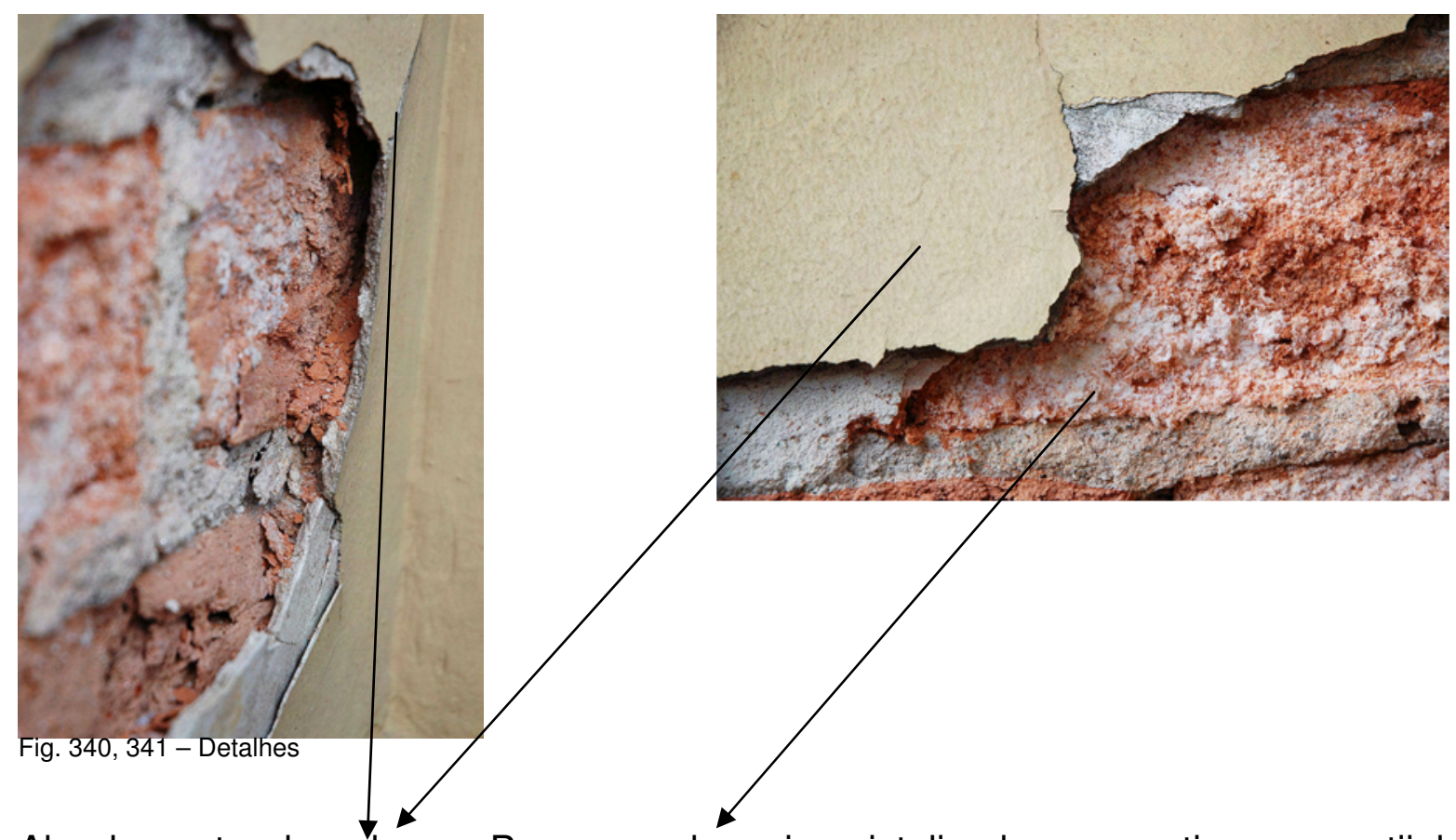

Abaulamento do réboco. Presença de sais cristalizados que atingem os tijolos e a argamassa de assentamento.

É bem provável, que pelo fato de toda parede ter uma pintura impermeável que dificulta a evaporação da umidade, havendo este local sem reboco e pintura, a umidade ao redor se dirigiu para o caminho mais fácil, ocorrendo assim uma alta concentração de umidade, consequentemente de sais solúveis que se cristalizam novamente. A eflorescência produziu a esfoliação dos tijolos, enfraquecendo sua estrutura.

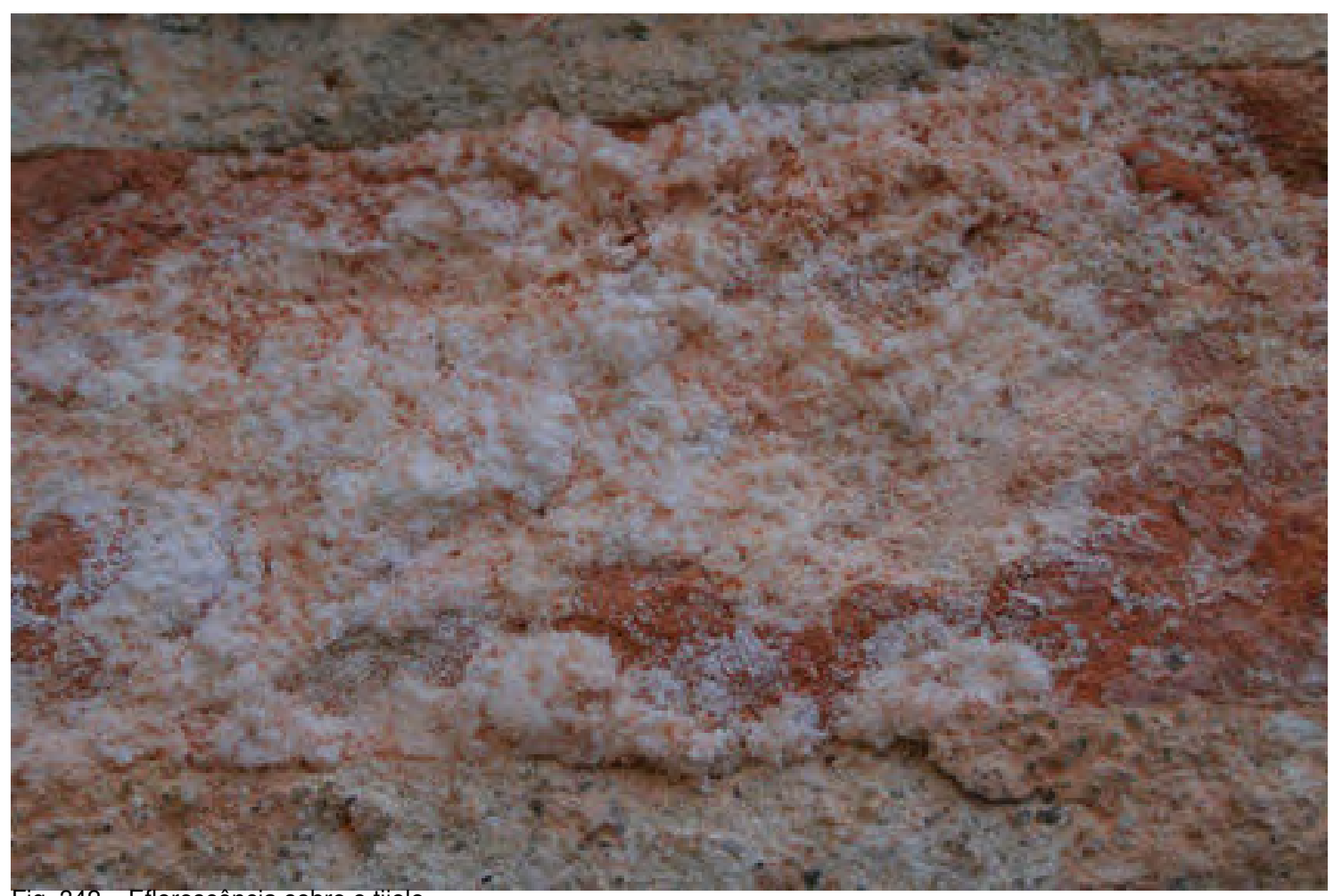

Fig. 342 - Eflorescência sobre o tijolo 


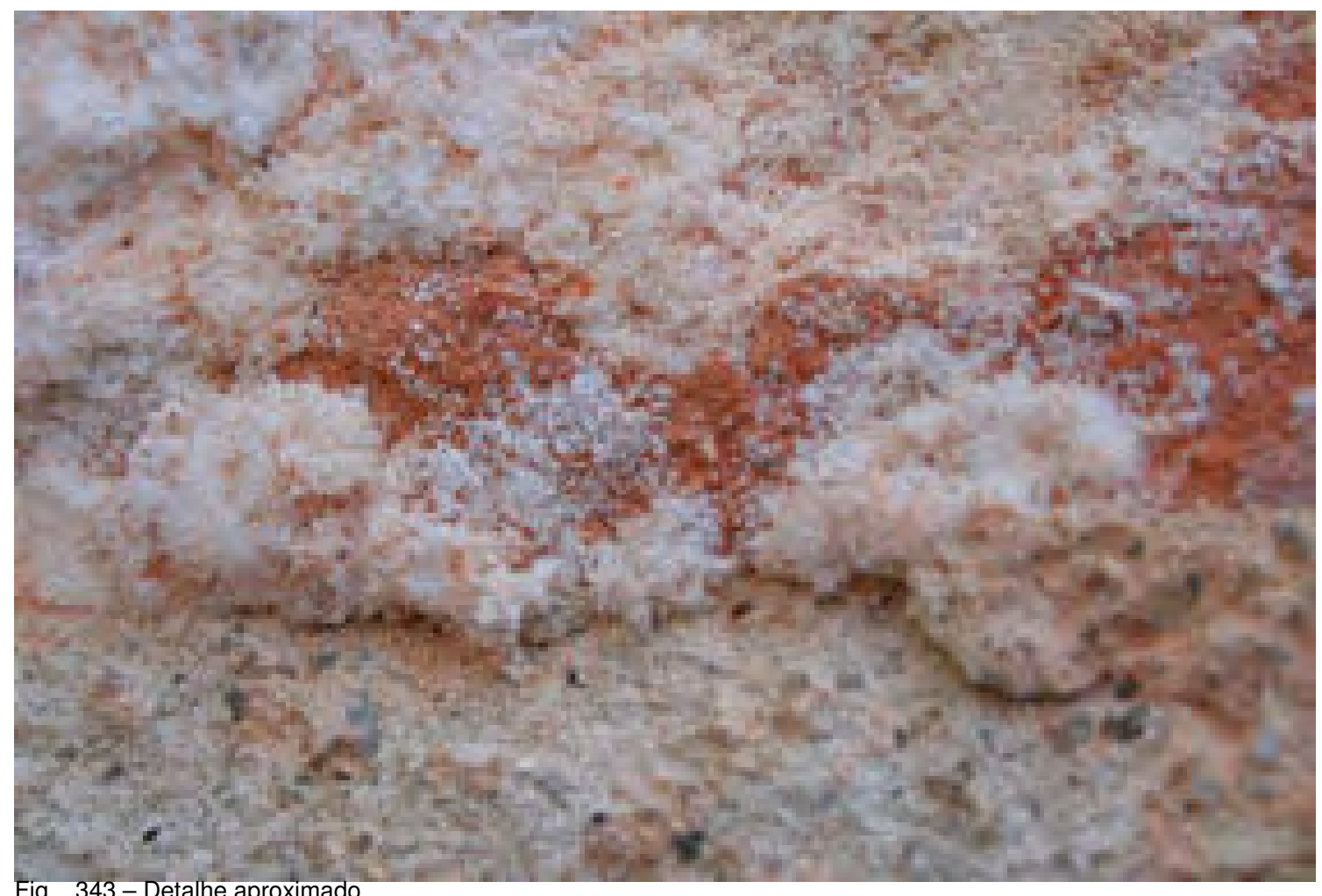

Fig. 343 - Detalhe aproximado

As patologias que apresentaram o revestimento interno das paredes do mirante, é um exemplo de umidade descendente, em que a água de chuva penetrava através de rachaduras na parte superior das paredes, e atingia o revestimento de argamassa de dentro para fora. Como foi apresentado nas intervenções de 2002, este reboco foi extraído e refeito.

O desprendimento do reboco ocorre quando os sais cristalizados alojados nos poros dos materiais, dilatam-se produzindo um impulso perpendicular ao plano de interface, entre as camadas, e este impulso supera a capacidade de aderência, produzindo 0 desprendimento até chegar ao rompimento de fragmentos e cair.
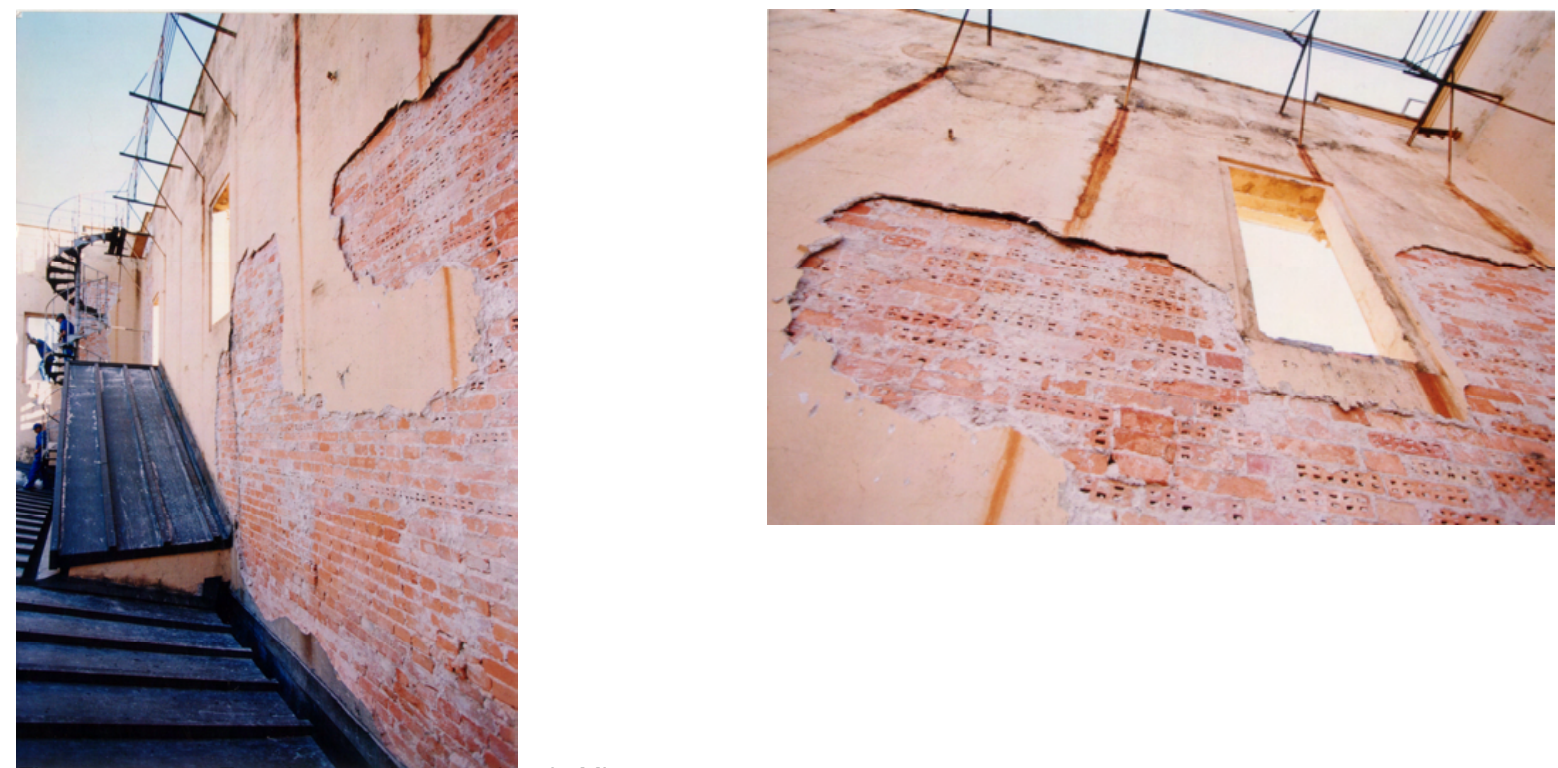

Fig. 344, 345 - Face interna das paredes do Mirante 
Outra manifestação de deterioração, é a perda de coesão ou desagregação, da argamassa de revestimento. Ocorre em todas as fachadas, sendo mais acentuada na face sul, devido a maior umidade e menor insolação.

São várias as causas destas anomalias, mas se pode considerar como a presença prolongada de umidade, à recristalização de sais, a presença de microrganismos.

Neste edifício, como as paredes são completamente ornamentadas, a desagregação das argamassas é um fato que chama atenção, pois ao perder a consistência, a forma dos ornamentos se desfaz, e a restauração desses será bastante trabalhosa.

Observa-se que este dano ocorre em fissuras horizontais, com muita freqüência. Os exemplos apresentados a seguir apresentam a mesma localização, sobre uma moldura curva. Foi verificado que esta moldura tem uma camada muita espessa de argamassa e de pouca resistência mecânica.

Estas fissuras também podem surgir nos cantos de ornamentos nas paredes, onde pode haver movimentos diferentes entre o suporte e o revestimento. Criam lacunas ocas e constitui um adequado abrigo para diversos insetos e microrganismos.

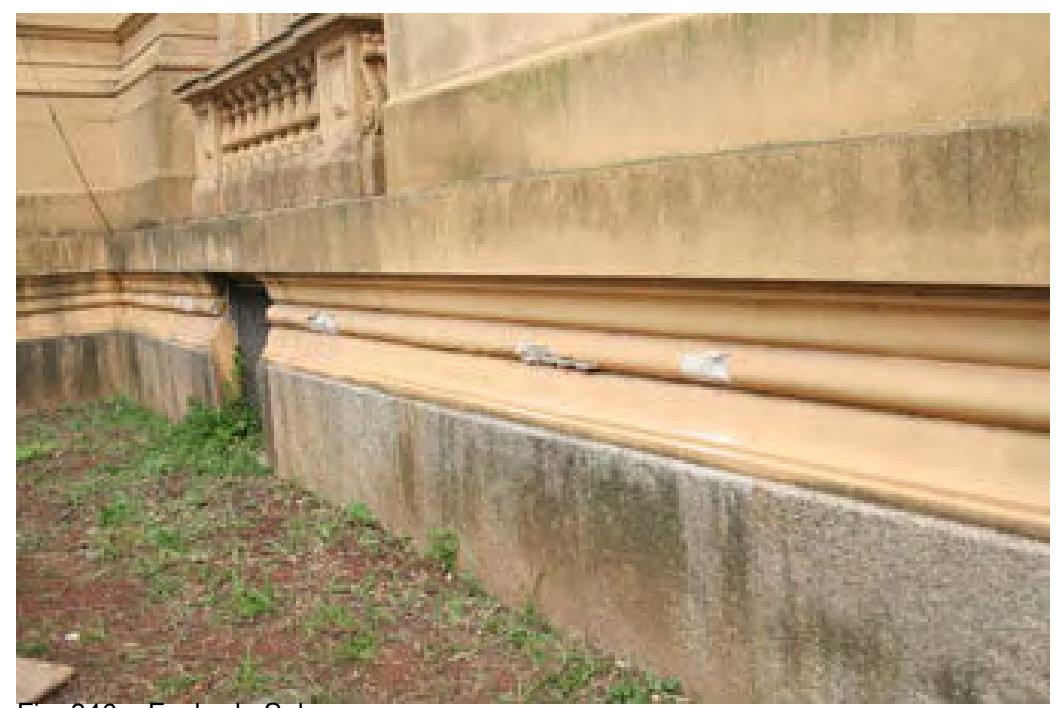

Fig. 346 - Fachada Sul
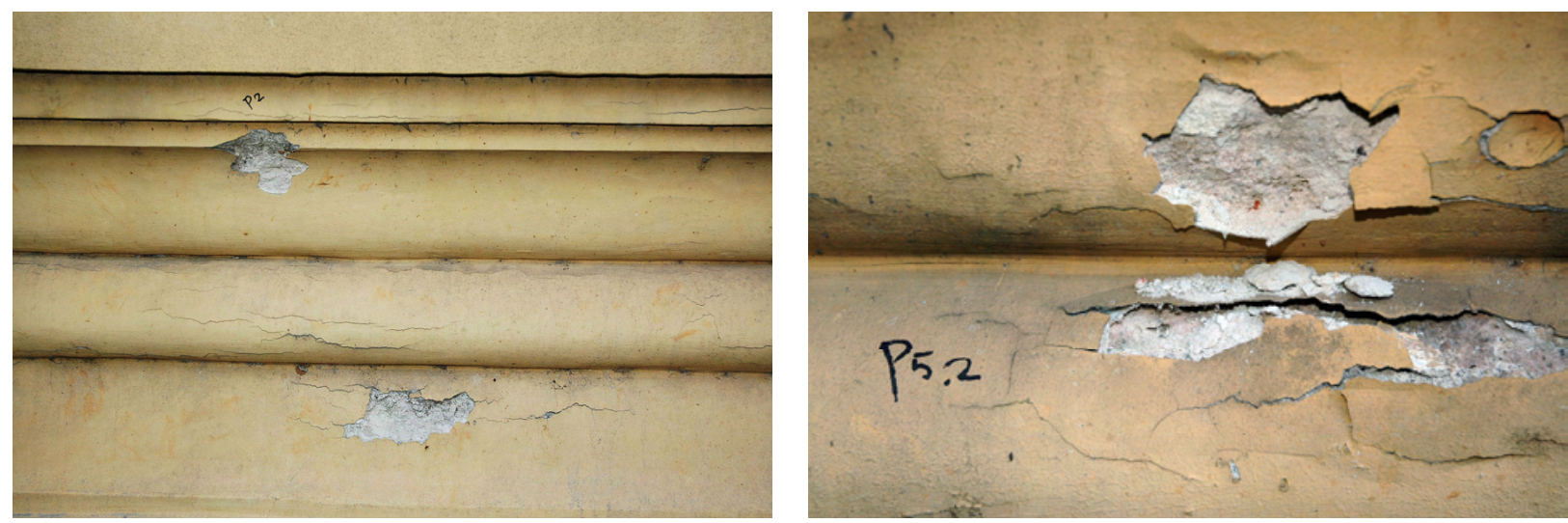

Fig. 347,348 
Foi verificado, ao coletar material para os ensaios, que ao redor da abertura sob a camada de tinta, os danos vão se ampliando e a argamassa desagregada apresenta sujidade e insetos, que sob a espessa película da tinta encontra-se um ambiente propício à proliferação

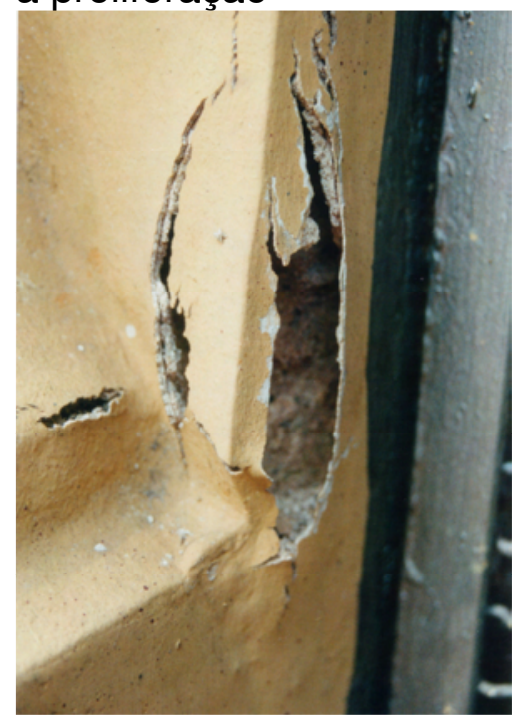

Fig. 349, 350 Desagregação nos cantos de ornamentos na parede

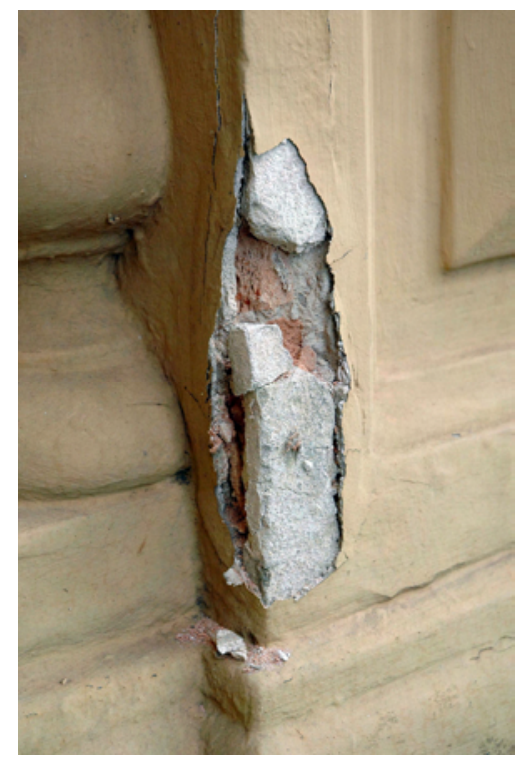

Outra forma de manifestação de patologia é a provocada por intervenções localizadas, utilizando argamassa rica em cimento. Sempre ocorrem da mesma forma. Assim que é empregada a argamassa a parede já inicia o processo.

Este exemplo, foi acompanhado num período aproximado de quatro anos, em que houve duas intervenções e o processo se deu da mesma forma.

A observação foi iniciada, quando a argamassa já apresentava rachaduras e desprendimento. Evoluiu até eliminar toda argamassa.

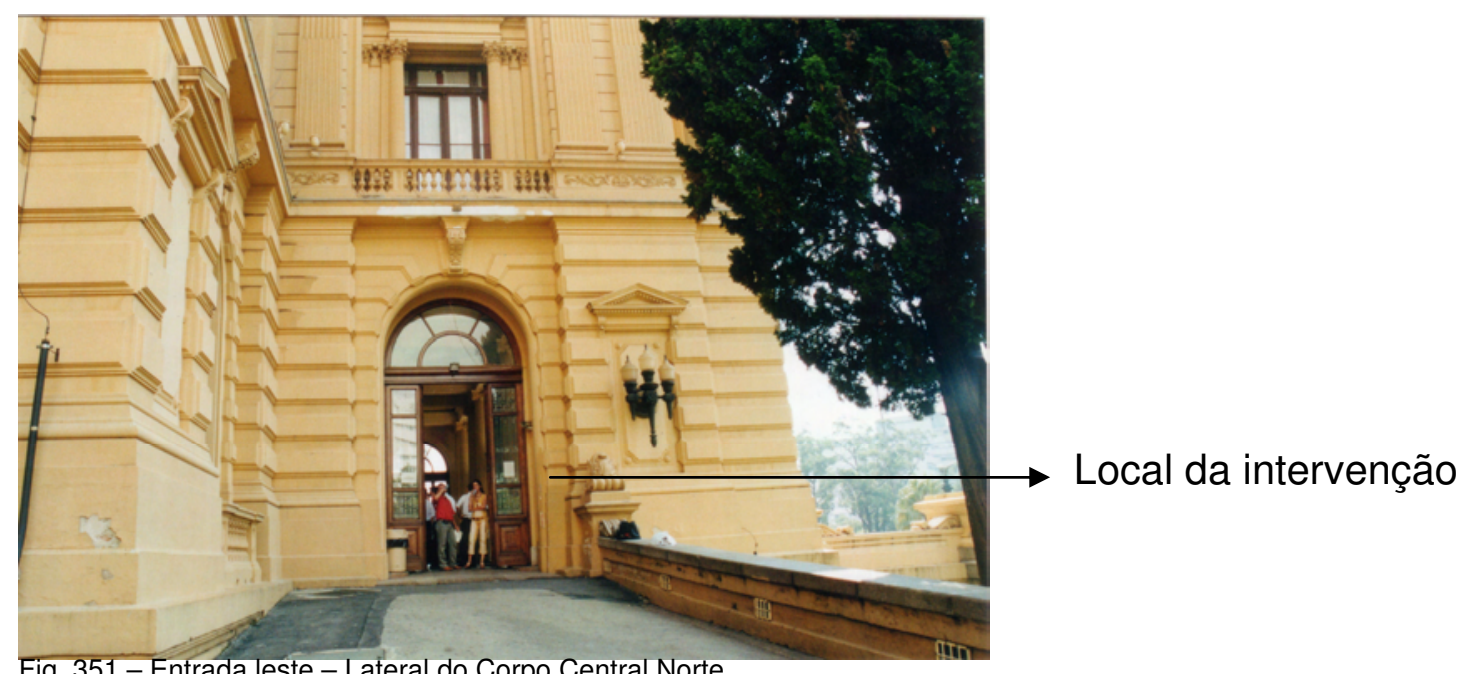

Fig. 351 - Entrada leste - Lateral do Corpo Central Norte 

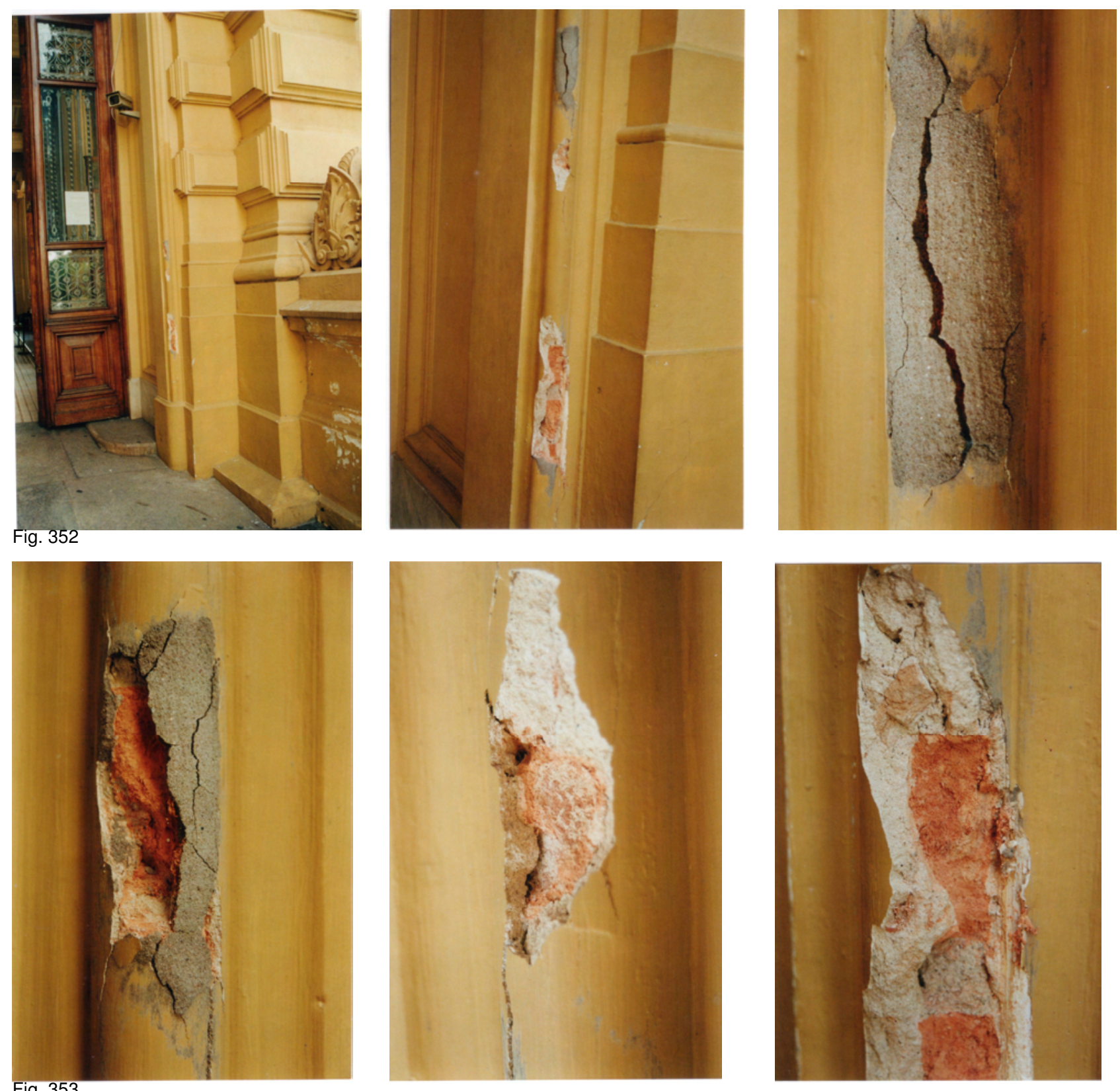

Fig. 353 


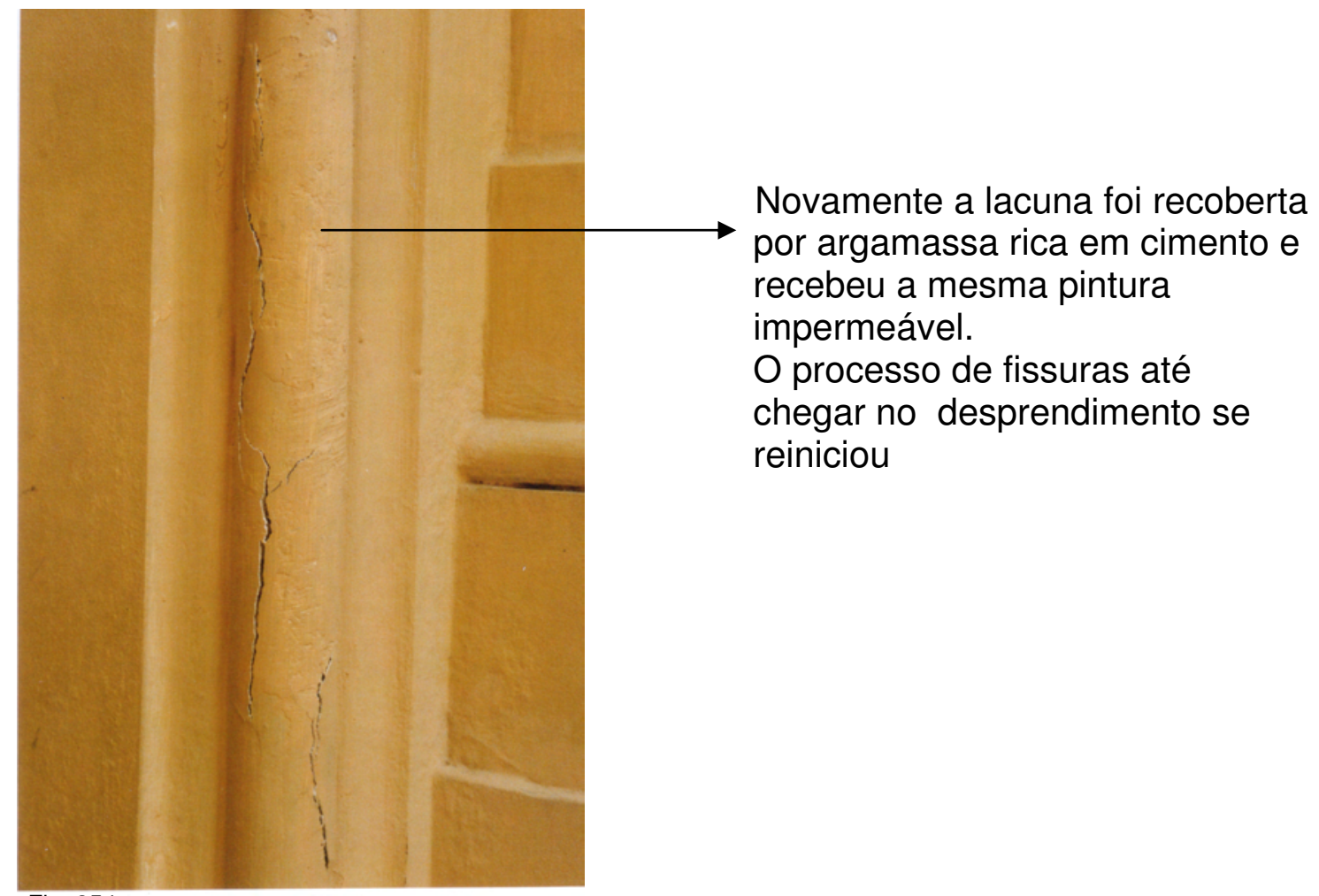

Fig. 354

Na segunda intervenção ocorre novamente o mesmo processo.
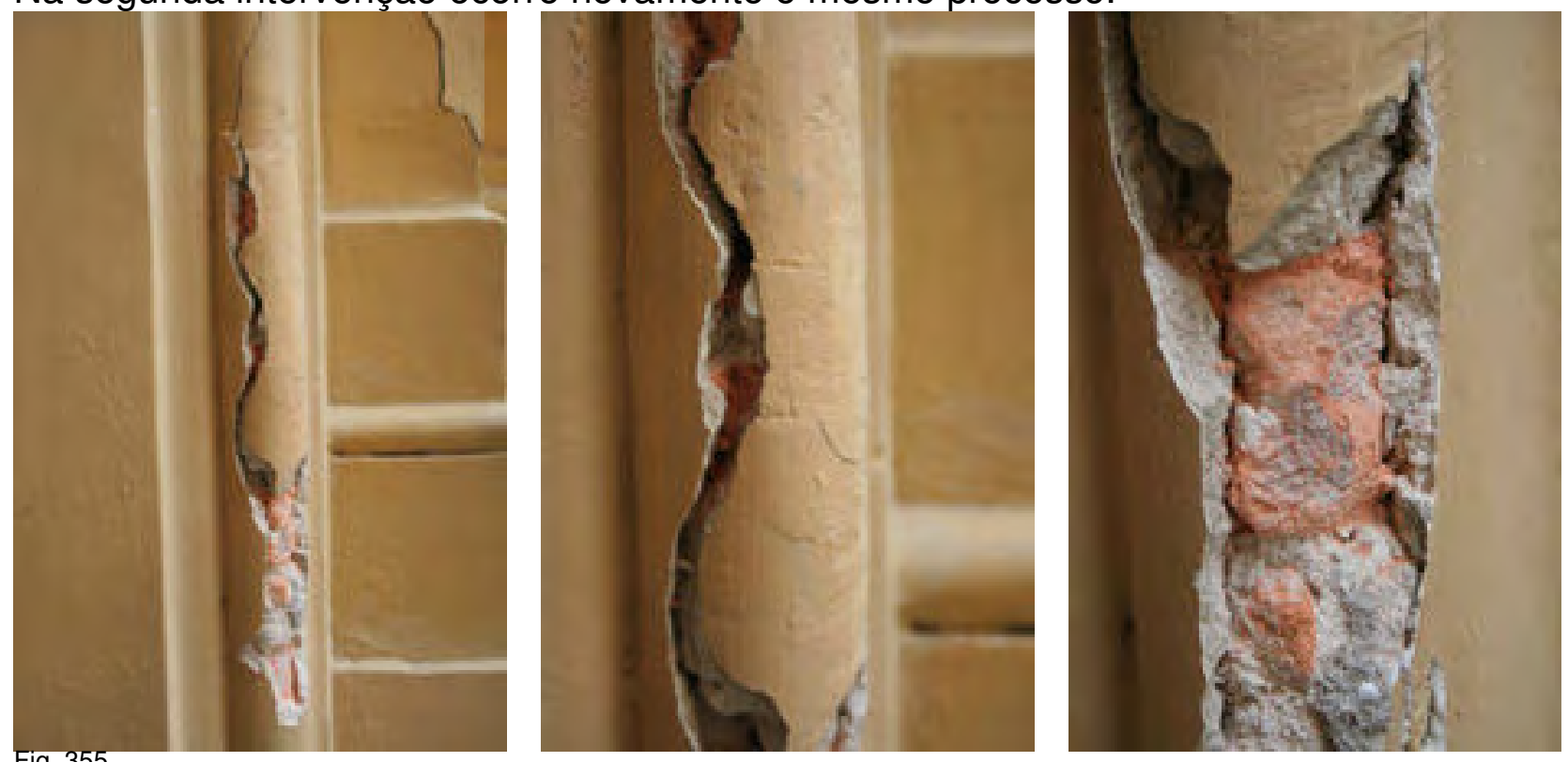

Novamente, o aumento progressivo das rachaduras, até ocorrer o desprendimento da argamassa.

Para este tipo de intervenção a solução não é simples. Inicia-se pela identificação do traço da argamassa original, para se adotar na argamassa de reposição.

A tinta precisa ser extraída para a parede voltar às suas características físicas e químicas. A fonte de umidade também é outro fator importante. Deve-se buscar a sua origem e as possíveis soluções ou pelo menos amenizá-las. 


\section{TINTAS PARA EDIFÍCIOS HISTÓRICOS}

A escolha do tipo de tinta para um edifício histórico deve considerar as características da técnica construtiva e de seus materiais.

A ausência de impermeabilização das fundações, é um aspecto fundamental que vai ter como conseqüência a constante presença da umidade em suas paredes e a necessidade da evaporação, como ocorria com a pintura à base de cal utilizada na época de sua construção.

No Documento 237, Bezzi especifica na página 8, \$16:

A primeira pintura que o edifício do Museu Paulista recebeu foi à base de cal mas não define a cor que será empregada

Pintura a fresco:

Art. $1^{\circ}-\mathrm{A}$ pintura a fresco exterior será feita a gosto do engenheiro chefe, e com as cores que depois serão escolhidas, [...] tintas de primeira qualidade.

Art. $2^{\circ}$ - Pintura a fresco interior com cornijas e filetes muito simples formando painéis e 0 todo muito simples. [...]

Como vimos, quanto mais espessa a parede, mais umidade absorve, do solo ou das águas superficiais das chuvas.

A tinta então não deve ser uma barreira à evaporação da água, para que a umidade e os sais solúveis não sejam causas de danos na estrutura dos materiais, alterando a sua consolidação.

As tintas produzidas hoje são de alta qualidade e desempenho, mas não consideram as características dos edifícios de técnica construtiva tradicional, e sua aplicação causa muitas vezes danos irreparáveis aos revestimentos e à alvenaria.

Através do levantamento documental a partir de 1911, várias vezes são citadas as pinturas realizadas mas não informam se as fachadas ou as áreas internas foram pintadas, e muito menos a cor usada e o tipo de tinta.

Como foi apresentado, as pinturas realizadas em 1972 e 1990 são melhores documentadas.

\section{OS TIPOS DE TINTA}

As tintas podem ser divididas em dois grupos em função do mecanismo que define o tipo de revestimento:

- Aquela que numa reação química se cristaliza permeando o suporte

- E as que formam uma película que adere sobre a superfície.

No primeiro grupo estão a tinta à base de cal e à base de silicato.

A tinta à base de cal - o material é principalmente constituído de hidróxido de cálcio que combina com dióxido de carbono, para formar a cristalização do carbonato de cálcio. Esta estrutura cristalina é que define a porosidade da tinta e sua permeabilidade

A tinta à base de silicato, conforme fabricantes consultados, deve ser aplicada sobre argamassa livre de resíduos. Isto significa, que as camadas de pintura anteriores deverão ser totalmente extraídas.

A reação que ocorre na superfície é a transformação do carbonato de cálcio do substrato em silicato, quando em contato com a anidrido carbônico do ar.

A tinta sílico mineral penetra com profundidade no substrato, cristaliza as substâncias minerais, melhora a sua coesão e consistência.

A cristalização é um processo lento, assim as características da tinta melhoram com o passar do tempo. 
Em relação à pintura à base de cal, a tinta silicática tem a vantagem de ter maior resistência à água e agressão química do meio ambiente.

Assim, a tinta à base de cal e à base de silicato, são permeáveis devido à cristalização que forma nas superfície.

No segundo grupo estão as tintas de materiais filmogênicos, aquelas que formam uma película impermeável e que adere à superfície. Inicialmente eram à base de óleo e depois de resinas sintéticas.

\section{A EVOLUÇÃO DA FABRICAÇÃO DAS TINTAS}

Segundo, Dr. Jorge Fazenda da ABRAFATI, (Associação Brasileira dos Fabricantes de Tinta)

durante o século XIX a indústria química era incipiente e só a partir de meados do século XIX começa a introduzir as resinas sintéticas, derivadas do petróleo.

Até 1900 as tintas eram à base de óleos cozidos, isto é, polimerizados com calor, misturados com resinas naturais como copal, âmbar, gelatina de clara de ovo

A primeira resina sintética surgiu em 1910 - a fenólica baquelite

$\mathrm{Na}$ década de 20 surgem as resinas alquídicas; na década de 30 a melanímica, durante a guerra as resinas epóxi, acrílicas com solventes e na década de 50 a emulsão aquosa.

Relata que em 1972, foi utilizada na pintura das fachadas do Museu Paulista a Tinta Coralmur, látex PVA - emulsão aquosa de copolímero de acetato de vinila com dibutil maleato, provavelmente na Cor Corsário, um tom róseo.

Em 1972 não existia a emulsão acrílica.

Foi utilizado para a reparação da parede um aglutinante de argamassa e uniformidade do acabamento na superfície - Líquido Preparador de Superfície, a base de óleo vegetal muito diluído com água raz mineral, solvente derivado do petróleo, que se define como óleo polimerizado com resina fenólica.

Em alguns pontos foi aplicada massa corrida para corrigir a superfície.

Sobre os caixilhos de madeira, foi utilizada em 1972 tinta em base alquídica - um polímero de anidrido fetálico, glicerina e óleo vegetal.

Em 1990, foi utilizada tinta a base de emulsão acrílica na amarela como está até hoje.

\section{A COR ORIGINAL}

E ainda Dr. Jorge Fazenda relatou que no século XIX os pigmentos disponíveis, eram os pigmentos naturais:

Óxido de ferro amarelo

Óxido de ferro vermelho

Óxido de zinco - alguns Azuis Ultramar

Sulfato de bário - branco (minérios naturais - barita)

Pó de sapato - Preto

Alvaiade de Chumbo - branco

Um dos poucos sintéticos: Azul da Prússia - ferro cianeto

No século XX o primeiro importante pigmento foi o dióxido de titânio - a cor branca. 
Muito se fala em cor original quando se vai pintar um edifício histórico. Mas não podemos deixar de verificar que o uso das cores e seus respectivos pigmentos, num determinado momento histórico, são determinados também segundo o desenvolvimento da indústria química, e os que eram disponibilizados no comércio da época. Este é um fato simples e prático que deve ser somado aos significados históricos e estilísticos do edifício.

Tão importante quanto resgatar a cor original , é a escolha do tipo de tinta compatível com o substrato, e que não altere suas características originais para não causar danos.

KÜHL (2004 p-309-330) observa que

"Em muitas intervenções recentes, porém, volta-se de modo imponderado ao uso das cores originais, convertendo essa volta num álibi cômodo, como se as cores (supostamente) originais, tivessem por si só uma autoridade irrefutável, e subtraíssem a intervenção da responsabilidade, por uma proposta fundamentada de qualquer julgamento crítico, resultando em renovações inconsideradas e o mais das vezes mal executadas, ademais com materiais inapropriados"

O encaminhamento de uma pesquisa responsável pode ser trabalhosa e envolver custos financeiros, mas é totalmente possível e viável conhecer as particularidades do edifício, e introduzir materiais compatíveis com sua natureza.

O que fará a diferença para que haja preservação do bem histórico, na sua total integridade, é se observar as diferenças de comportamento dos materiais com a argamassa original, de forma que combinem na aplicação de uma técnica correta e eficiente. 


\section{COLETA DE AMOSTRAS PARA ENSAIOS EXPLORATÓRIOS}

Foram realizados alguns ensaios exploratórios para caracterização dos materiais e identificação de evidências nos processos de danos.

Adotou-se como critério de trabalho, realizar os ensaios com as mesmas amostras para estabelecer comparações dos resultados.

As amostras foram coletadas em locais onde se manifestavam danos com características diferentes, em que salientava um aspecto determinado.

Foram coletadas amostras de:

ARGAMASSAS

- Amostra P1 - foi escolhida na fachada sul, no primeiro pavimento. É uma argamassa íntegra que foi adotada como referência.

- Amostras P2, P3, P5.2 - são argamassas desagregadas num local atingido por umidade ascendente.

- Amostra $S$ - se localiza próximo às amostras desagregadas, porém foi extraída sob película de pintura sem fissuras.

- Amostra Mirante - amostra integra, com desprendimento da alvenaria.

- Amostra Cimento Romano - de ornamentos pré-moldados em diversos locais.

\section{TIJOLOS}

- Foram examinados tijolos com desagregação e eflorescência na entrada leste.

- Fragmentos coletados em escavação.

\section{EFLORESCÊNCIA}

- Eflorescência sobre tijolos sem revestimento na entrada leste.

- Eflorescência sob vesícula.

\section{CAMADA DE TINTA}

- Na fachada sul, sobre guarda-corpo.

- Na entrada leste.

\section{MICRORGANISMO}

- Ensaios com as amostras P2, P3, P5.2 e S. 


\section{ENSAIOS / AMOSTRAS UTILIZADAS / LABORATÓRIOS}

\begin{tabular}{|c|c|c|c|}
\hline LOCALIZAÇÃO & AMOSTRA & DESCRIÇÃO & ENSAIO \\
\hline Cobertura & Mirante & $\begin{array}{l}\text { Íntegra / desprendida da } \\
\text { alvenaria }\end{array}$ & $\begin{array}{l}\text { Análise Química e } \\
\text { Reconst. de Traço - IPT } \\
\text { DRX - LCT }\end{array}$ \\
\hline Diversas & $\begin{array}{l}\text { Ornamento Cimento } \\
\text { Romano }\end{array}$ & Pré-moldado Íntegro & $\begin{array}{l}\text { Análise Química e } \\
\text { Reconst. de Traço - IPT } \\
\text { DRX - LCT }\end{array}$ \\
\hline Fachada Sul & P1 - Emboço e Reboco & $\begin{array}{l}\text { Íntegra (referência) } \\
\text { Camada de Tinta+Argam. }\end{array}$ & $\begin{array}{l}\text { Análise Química e } \\
\text { Reconst. de Traço - IPT } \\
\text { DRX - LCT } \\
\text { MEV - LCT } \\
\text { IPT - pH }\end{array}$ \\
\hline \multirow[t]{7}{*}{ Fachada Sul } & P2, P3 & $\begin{array}{l}\text { Desagregada } \\
\text { Vesícula / fissuras }\end{array}$ & $\begin{array}{l}\text { IPT- Análise Química e } \\
\text { Reconst. de Traço }\end{array}$ \\
\hline & $\mathrm{P} 2$ & & DRX - LCT \\
\hline & $\mathrm{P} 2+\mathrm{P} 3$ & & $\mathrm{IPT}-\mathrm{pH}$ \\
\hline & P3, P5.2 & & MEV - Microbiologia \\
\hline & P3,P5.2 & & EDS - Microbiologia \\
\hline & P2, P3,P5.2 & & $\begin{array}{l}\text { Cultivo de } \\
\text { microrganismos }\end{array}$ \\
\hline & $S$ & Sob película íntegra & $\begin{array}{l}\text { Cultivo de } \\
\text { microrganismos }\end{array}$ \\
\hline $\begin{array}{l}\text { Fachada Sul (guarda } \\
\text { corpo) }\end{array}$ & Camada de Tinta & (rósea e amarela) & IQ \\
\hline \multirow[t]{8}{*}{ Entrada Leste } & Eflorescência & cristais & DRX - Geociências \\
\hline & Tijolo+Eflorescência & Pó & IPT- Análise Química \\
\hline & Tijolo & Esfoliado & DRX - Geociências \\
\hline & $\begin{array}{l}\text { Eflorescência/ Vesícula } \\
\text { (empolamento- sob } \\
\text { tinta) }\end{array}$ & Pó branco & $\begin{array}{l}\text { IPT- Análise Química } \\
\text { IQ }\end{array}$ \\
\hline & $\begin{array}{l}\text { Argamassa de } \\
\text { Revestimento }\end{array}$ & & DRX - Geociências \\
\hline & $\begin{array}{l}\text { Argamassa de } \\
\text { Assentamento }\end{array}$ & & DRX - Geociências \\
\hline & Fragmentos de tijolos & & IPT- Análise Química \\
\hline & Camada de Tinta & & $\begin{array}{l}\text { MEV - Geociências } \\
\text { EDS - Geociências }\end{array}$ \\
\hline
\end{tabular}




\section{LABORATÓRIOS}

DRX - DIFRAÇÃO DE RAIOS-X

LCT - Laboratório de Caracterização Tecnológica

Departamento de Engenharia de Minas e de Petróleo - Escola Politécnica da Universidade de São Paulo

Rui Barbosa de Souza

- Ornamento pré-moldado em Cimento Romano

- Amostra P1 Íntegra - Fachada Sul $1^{\circ}$ andar

- Amostra Mirante - paredes internas, cobertura

- Amostra P2 - ornamento moldado in loco.Fachada sul, paredes do embasamento. Desagregada

MEV - MICROSCOPIA ELETRÔNICA DE VARREDURA

LCT - Laboratório de Caracterização Tecnológica

Departamento de Engenharia de Minas e de Petróleo - Escola Politécnica da Universidade de São Paulo

Liz Zanchetta D'Agostino

- Amostra P1 Íntegra - camada de tinta e argamassa

DRX - DIFRAÇÃO DE RAIOS-X

Instituto de Geociências da Universidade de São Paulo

Eliane Del Lama

Amostras Entrada Leste, Primeiro Pavimento:

- Eflorescência sobre Tijolo

- Argamassa de Assentamento

- Argamassa de Revestimento

- Tijolo

MEV- MICROSCOPIA ELETRÔNICA DE VARREDURA

Instituto de Geociências da Universidade de São Paulo

Eliane Del Lama

Amostra entrada Leste, Primeiro Pavimento:

- Amostra com camada de tinta e argamassa

ANÁLISE QUÍMICA

Instituto de Pesquisas Tecnológicas

Laboratório de Materiais de Construção Civil - CT-Obras

EQUIIPE TÉCNICA:

Daniel Martins Aleixo - Químico

Fabiano Ferreira Chotoli - Químico

José Francisco de Paula - Técnico Químico

Eduardo Brandau Quitete - Geólogo

Mirian Cruxem Barros de Oliveira - Geóloga

Valdecir Ângelo Quarcioni - Químico

- $\quad$ P2+P3 - Ornamento no embasamento, Fachada Sul- Amostra Desagregada

- Amostra P1 - emboço e reboco $-1^{\circ}$ andar, Fachada Sul - Amostra Íntegra

- Eflorescência no reboco, vesícula - Pavimento térreo, Entrada Leste Eflorescência no tijolo - Pavimento térreo, Entrada Leste

- Amostra Mirante - Cobertura, revestimento parede interna

- Amostra Ornamento de Cimento Romano

- Fragmentos de tijolos - escavação, entulho da obra

- $\quad \mathrm{pH}$ das Amostras P1 e P2+P3

\section{ESPECTROSCOPIA RAMAN}

Instituto de Química da Universidade de São Paulo

Dalva Lúcia de Faria

- Camadas de Tinta: rósea e duas amarelas

- Camadas de Tinta: duas amarelas

- Pó branco sob película da tinta - Entrada Leste, Pavimento Térreo, sobre a lacuna onde ocorre a Eflorescência

\section{ANÁLISE MICROBIOLÓGICA - BIODETERIORAÇÃO}

MEX DRX

Laboratório de Microbiologia -Departamento de Engenharia Civil Escola Politécnica da Universidade de São Paulo

Márcia Shirakawa

- $\quad$ Amostras: P2, P3, P5.2, S

LCT - Laboratório de Caracterização Tecnológica

Departamento de Engenharia de Minas e de Petróleo - Escola Politécnica da Universidade de São Paulo Liz Zanchetta D'Agostino

- Amostras: P3, P5.2, 


\section{AMOSTRA P1 - ÍNTEGRA}

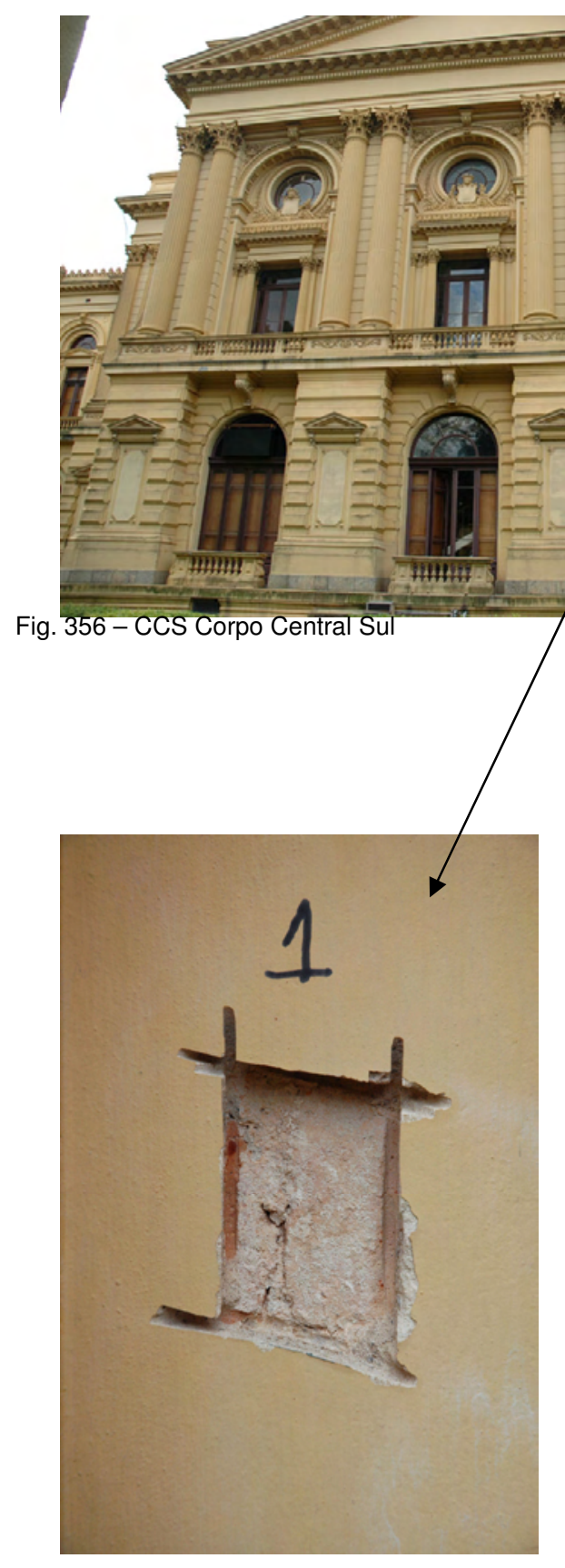

Fig. 357 Local da extração

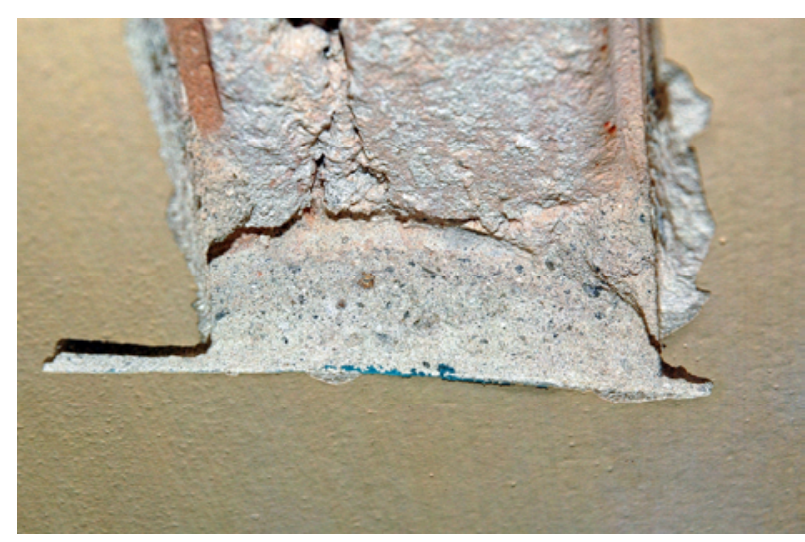

Fig 358 - Detalhe: duas camadas - emboço e reboco

Amostra extraída com auxílio de serra Makita, por estar endurecida e íntegra.

Pode-se observar duas camadas: Emboço e Reboco 


\section{AMOSTRAS P2, P3, P52 AMOSTRA S}

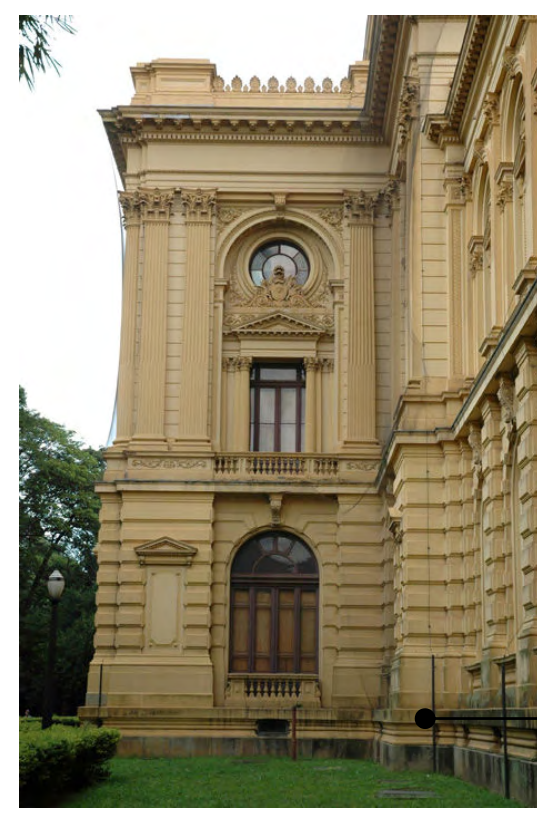

As Amostras P2, P3 e P5.2 - vesículas com fissuras, argamassa em desagregação.

Presença de sais e umidade

Amostra S - extraída sob película de tinta sem fissuras

Fachada Sul - Parede do Embasamento

Fig. 359 - Fachada sul -- Lateral do Corpo Central

Localização da extração das amostras.

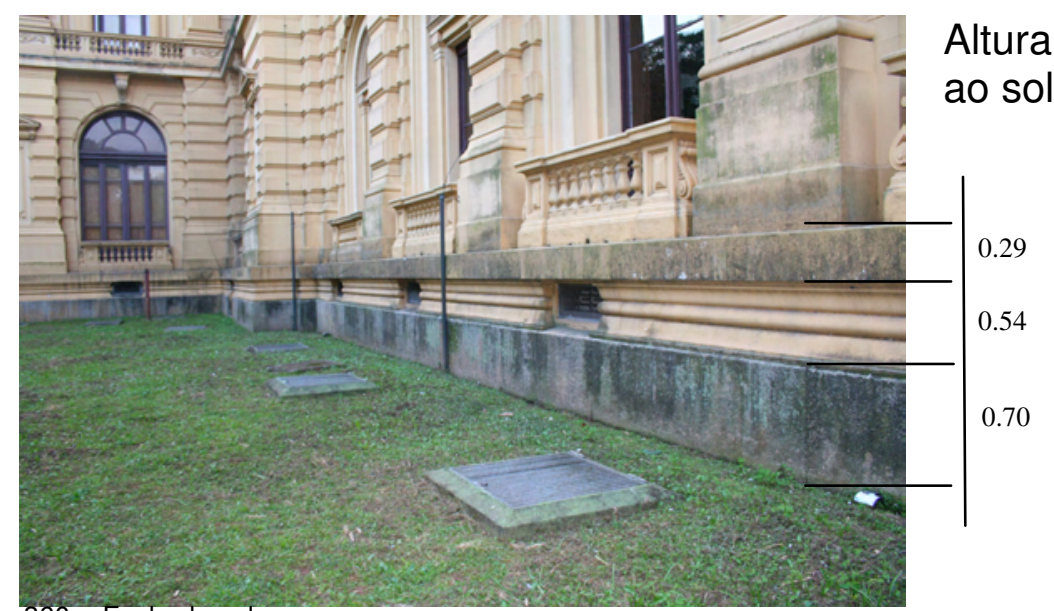

Fig. 360 - Fachada sul

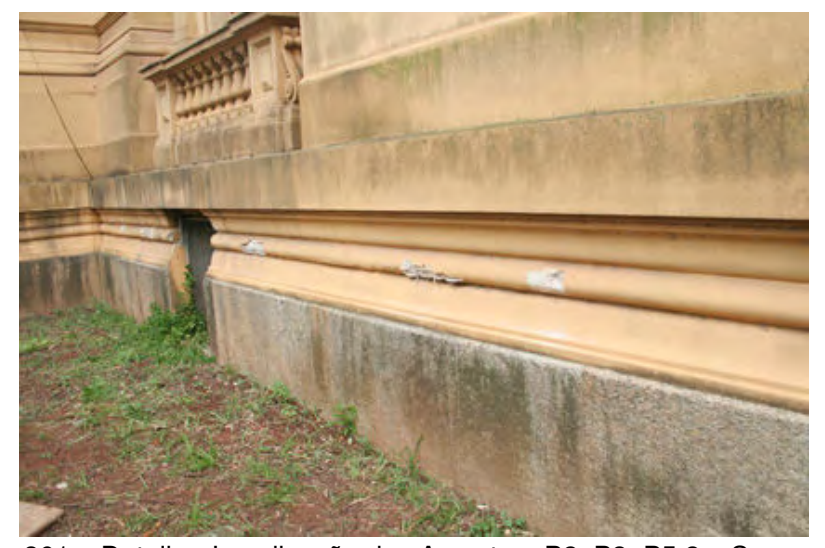

Fig. 361 - Detalhe: Localização das Amostras P2, P3, P5.2 e S

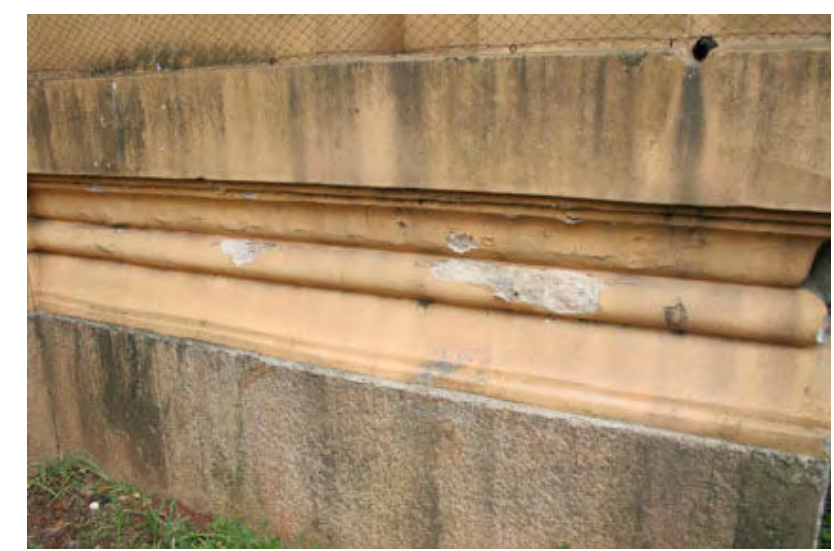

Fig. 362 - detalhe 
AMOSTRA P2

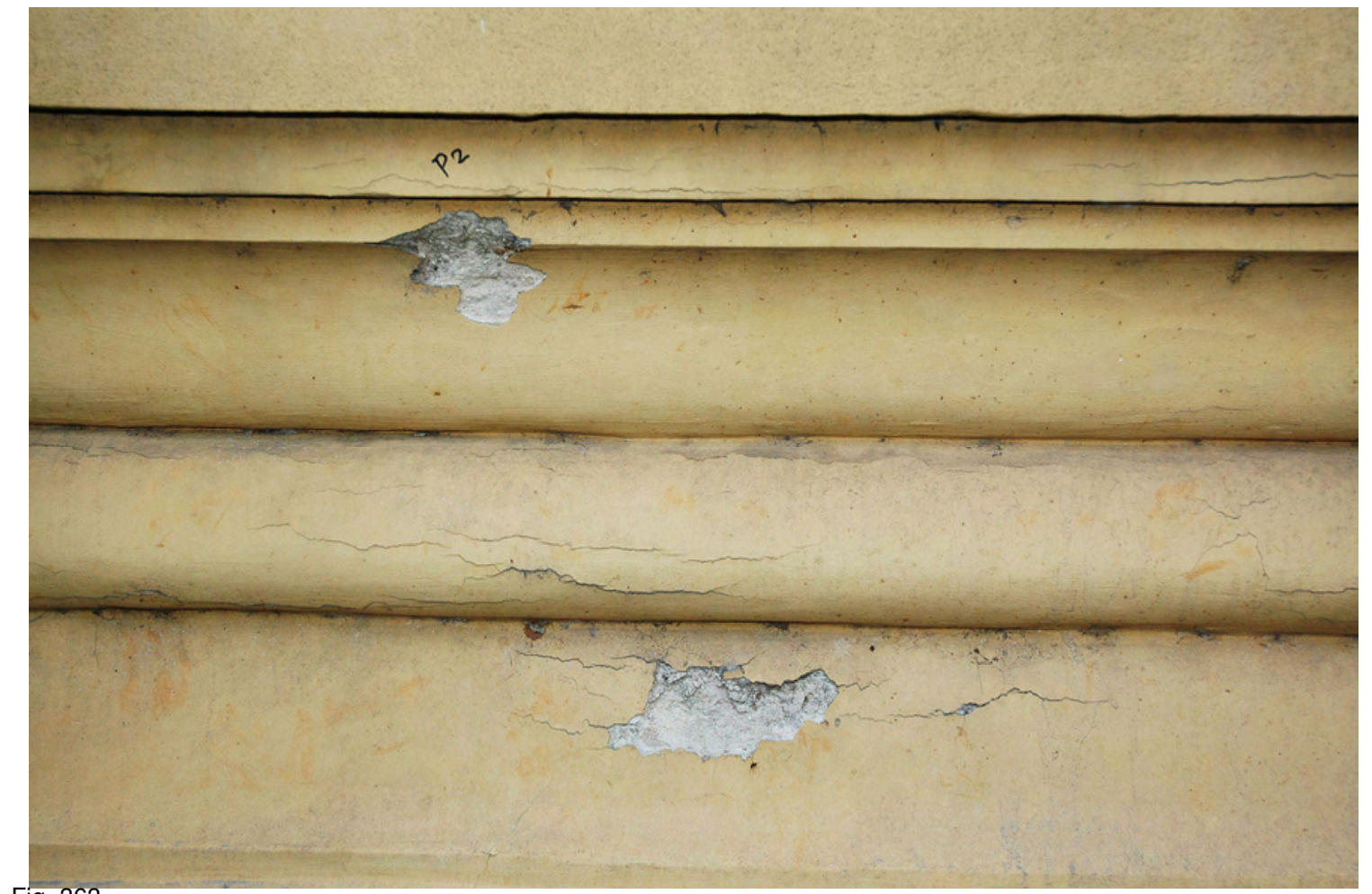

Fig. 363

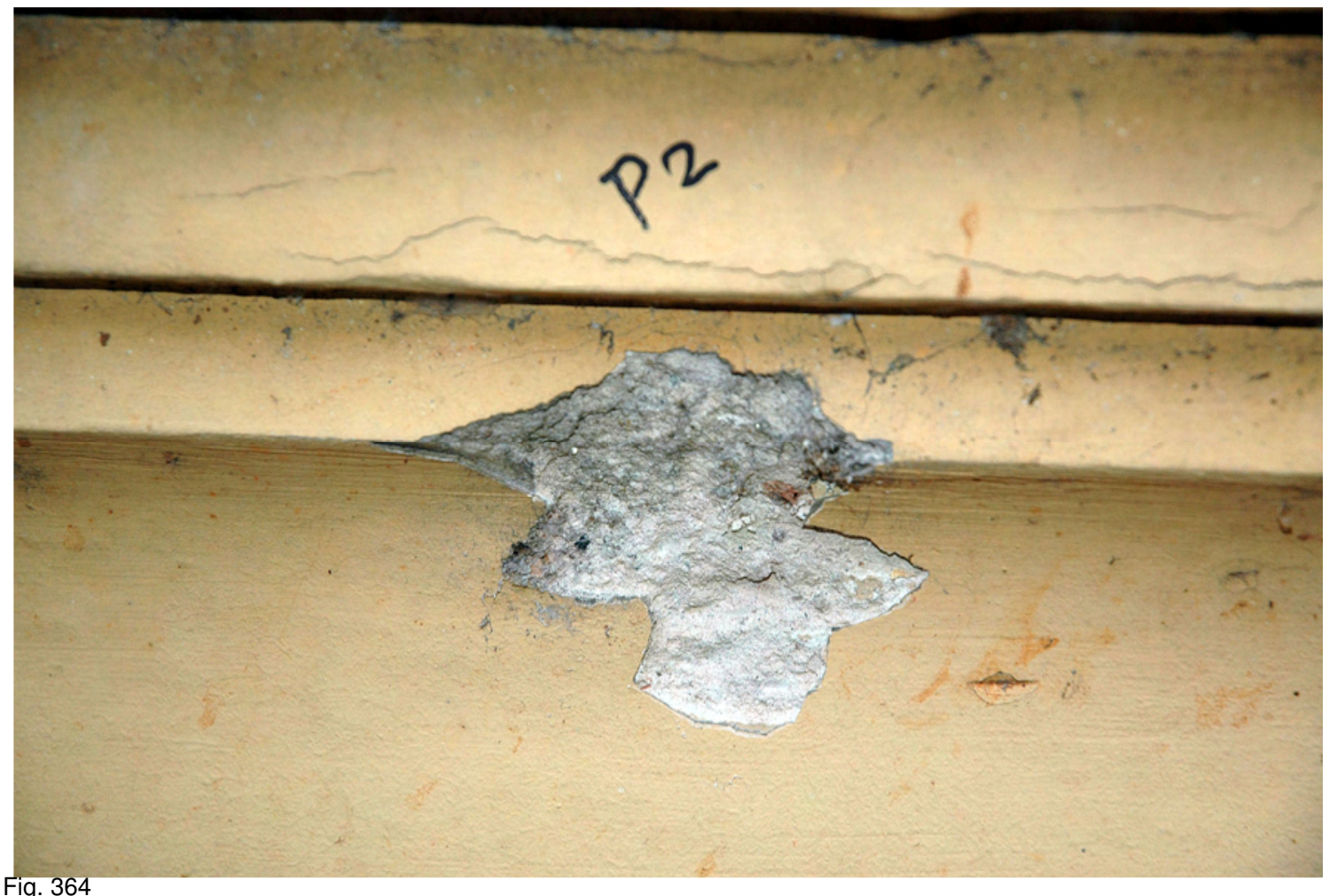

Fig. 364 
AMOSTRA P3

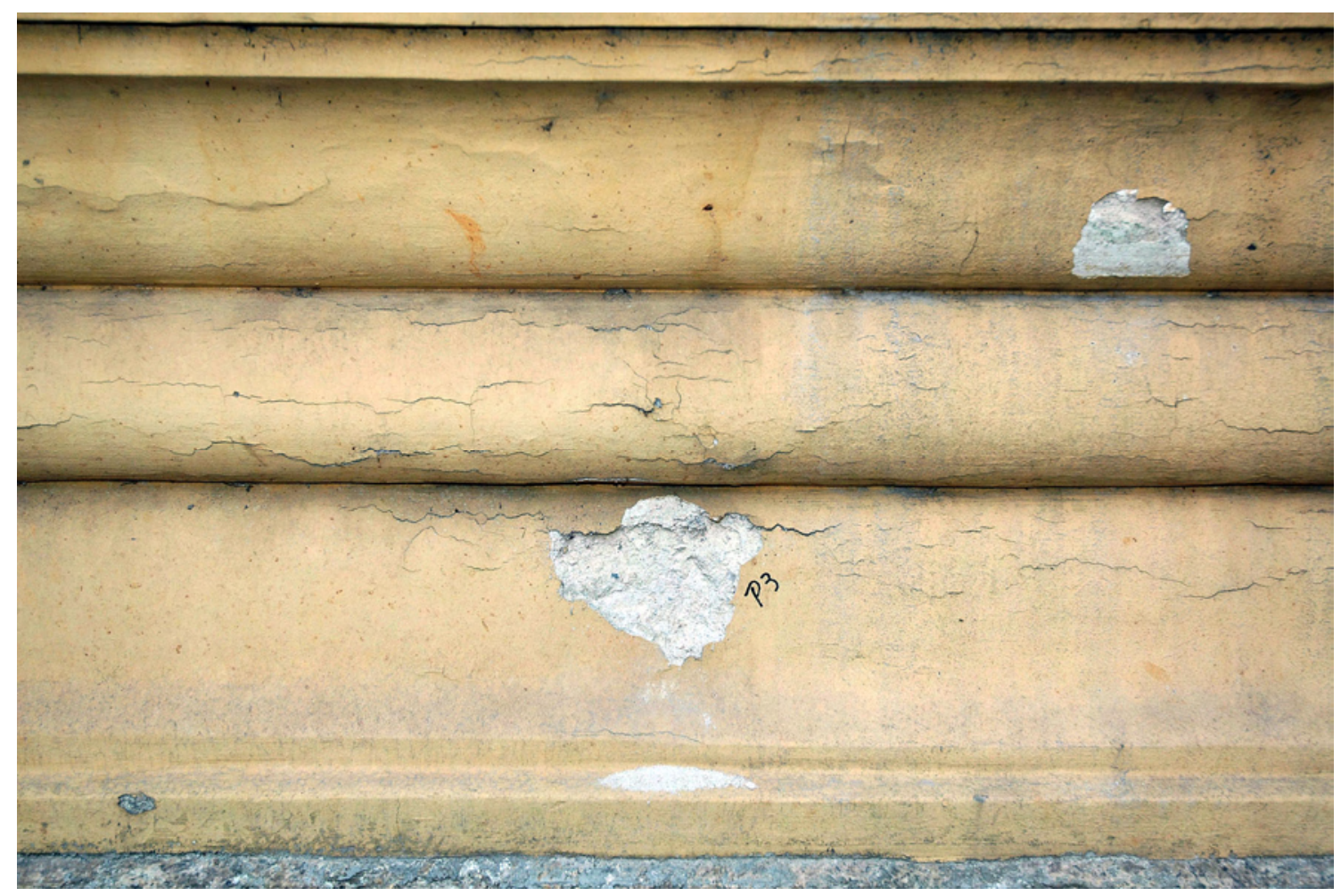

Fig. 365

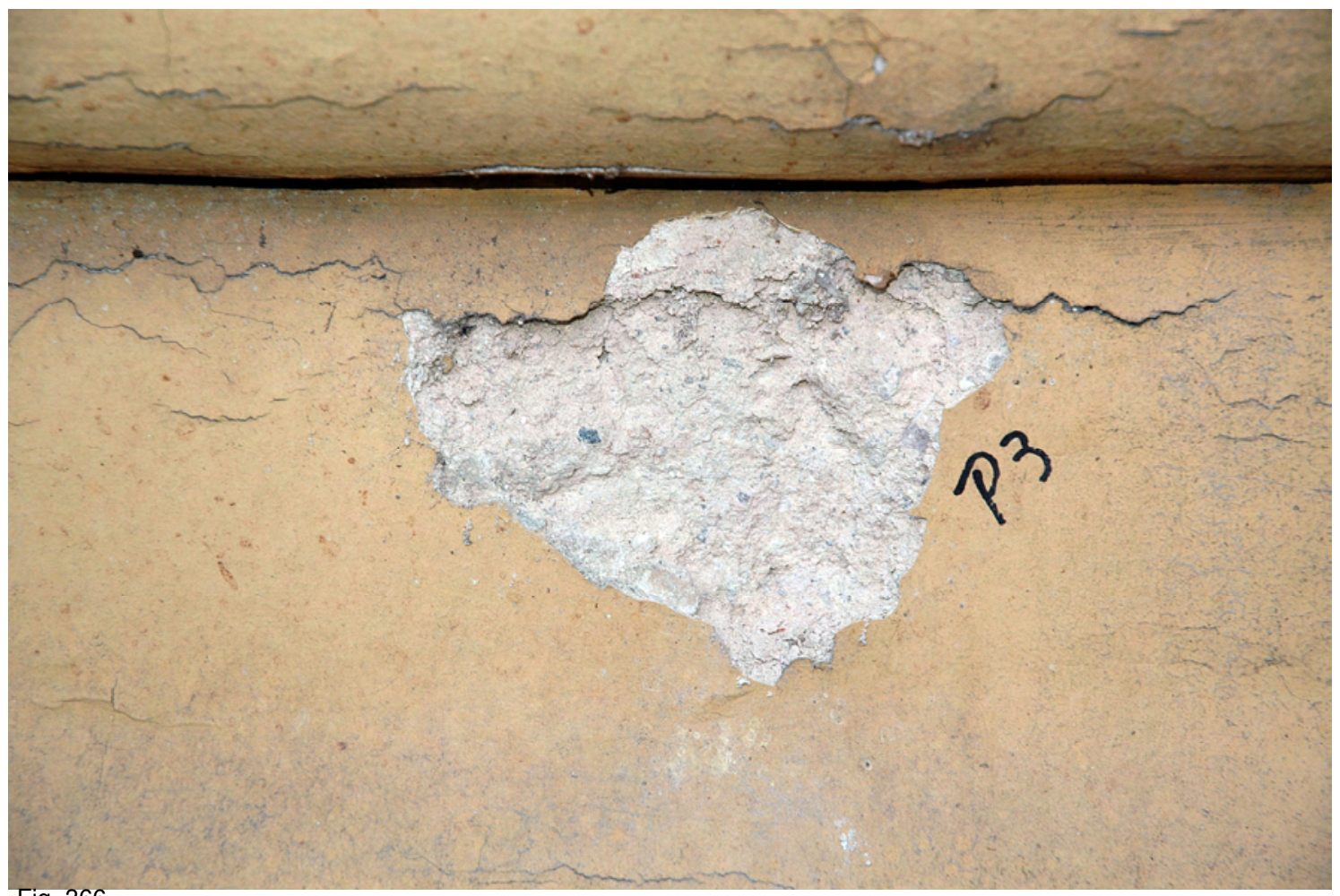

Fig. 366 


\section{AMOSTRA P5.2}
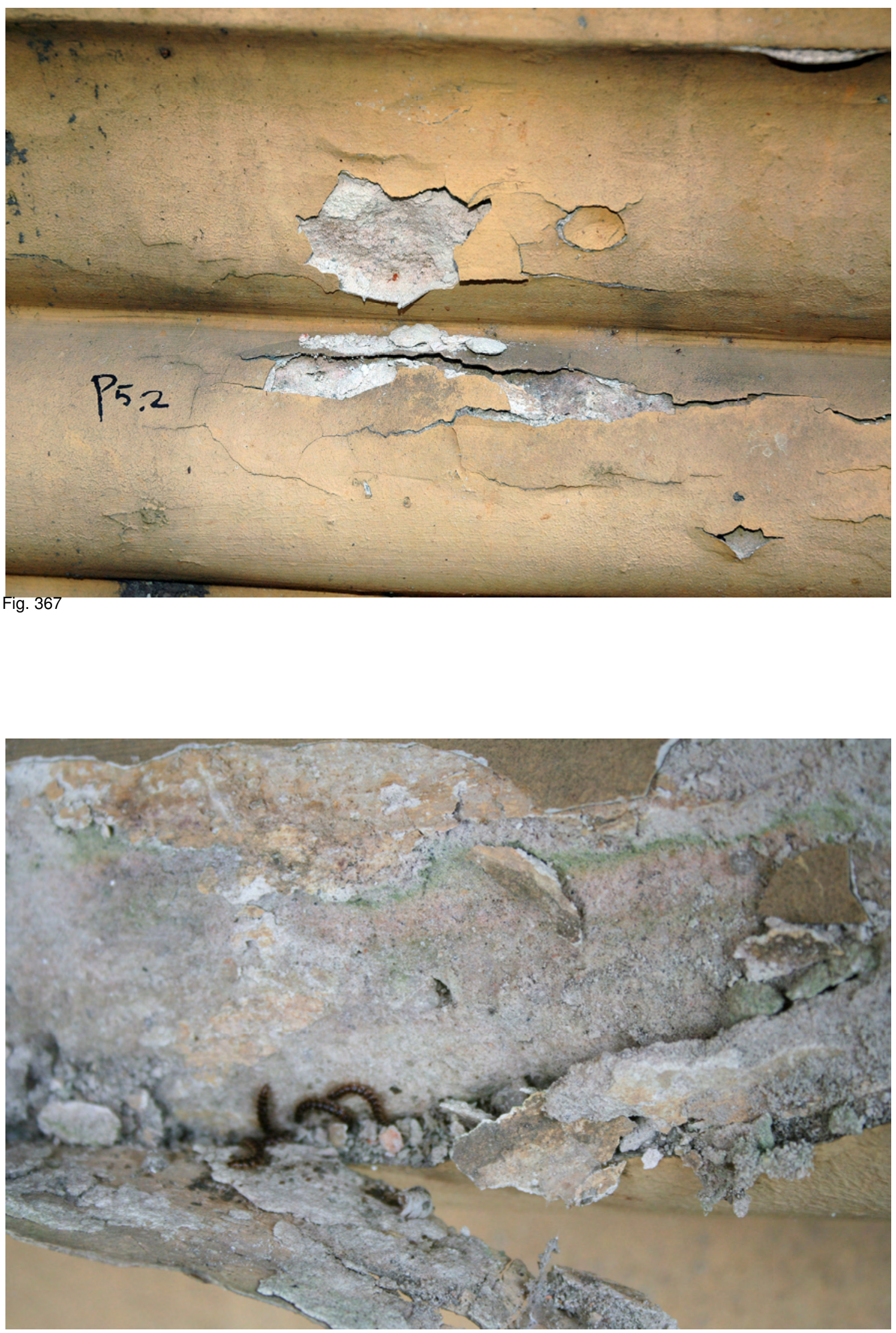

Fig. 368 


\section{AMOSTRA S}

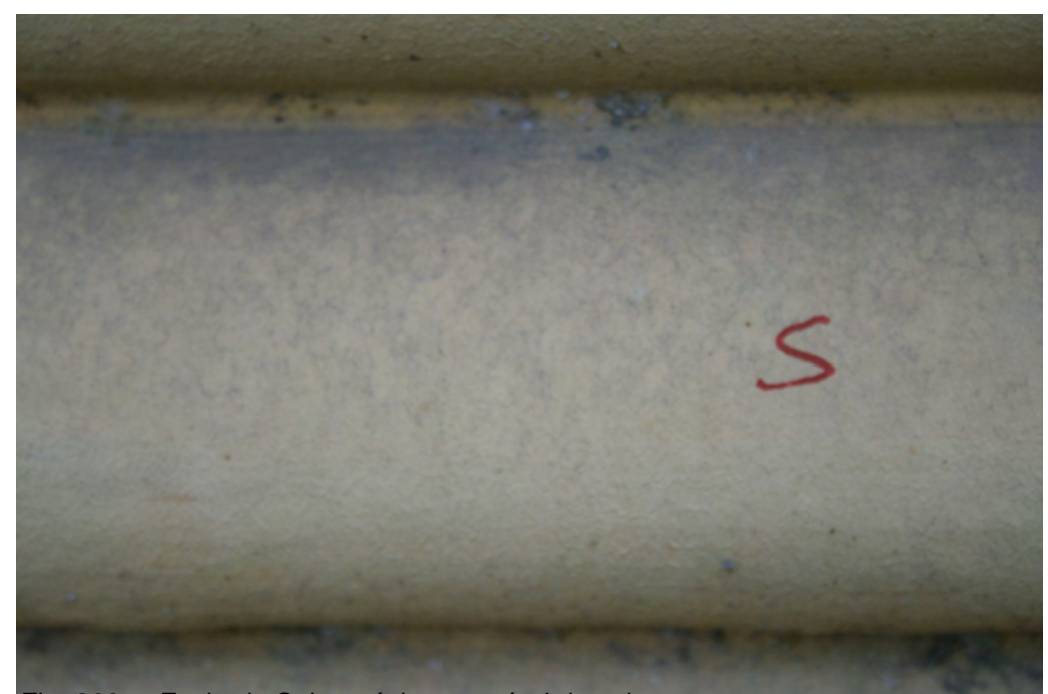

\section{Fachada Sul}

Local da extração: com a película da tinta sem danos aparentes, em região atingida pela umidade ascendente

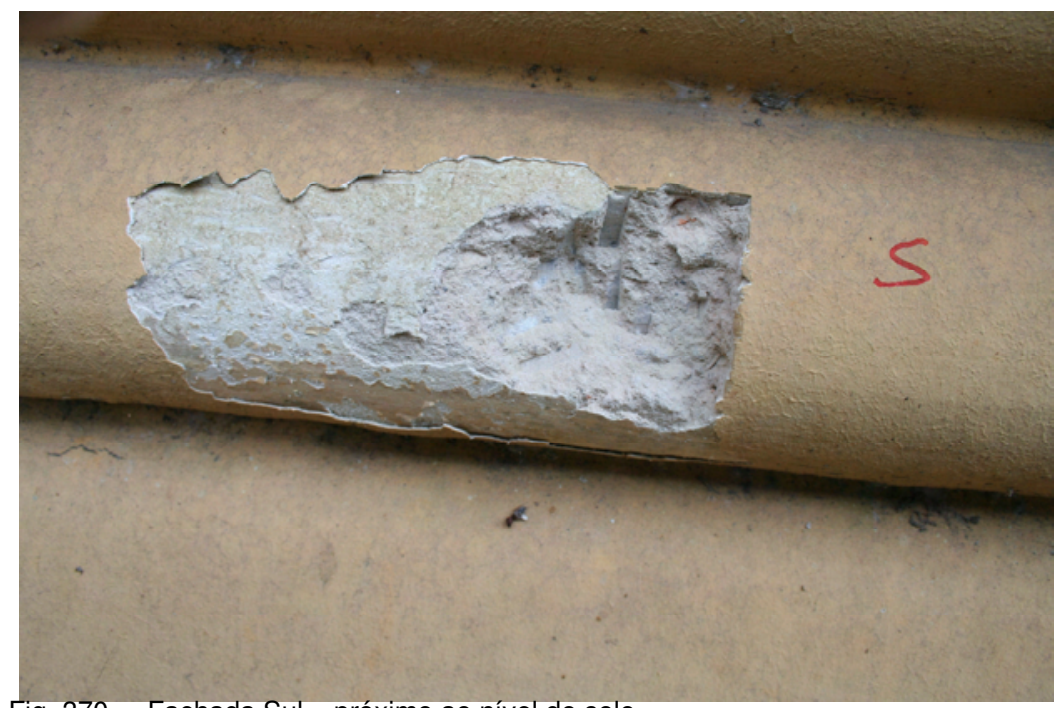

Extração da argamassa

Fig. 370 - Fachada Sul - próximo ao nível do solo

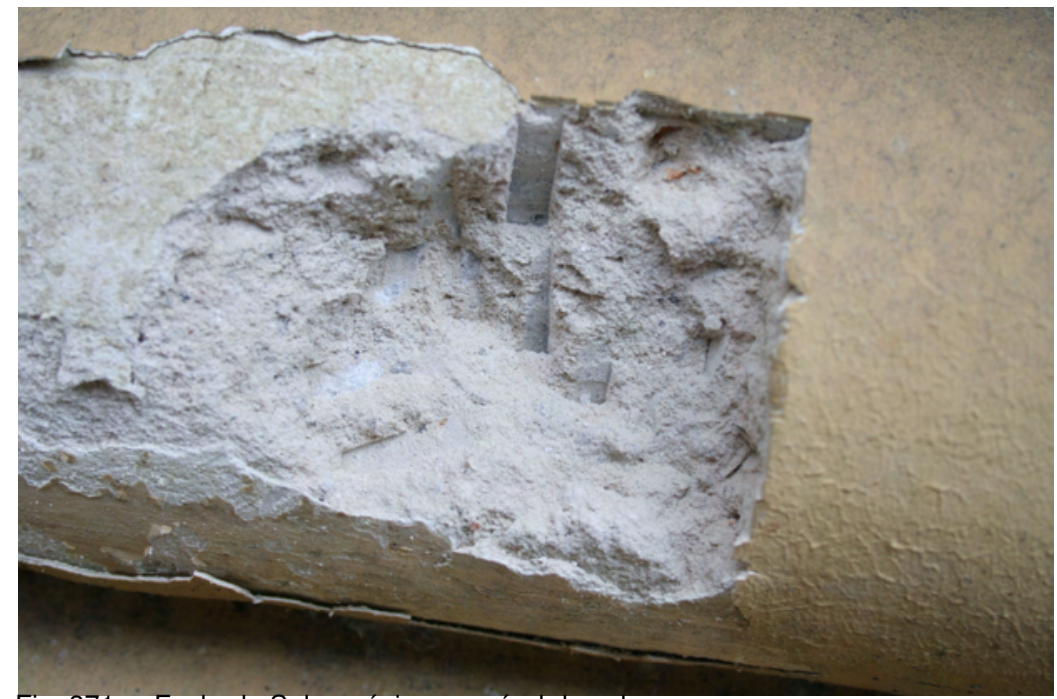

Argamassa com grande espessura - até esta profundidade a alvenaria não foi observada

Fig. 371 - Fachada Sul - próximo ao nível do solo 


\section{AMOSTRA MIRANTE}

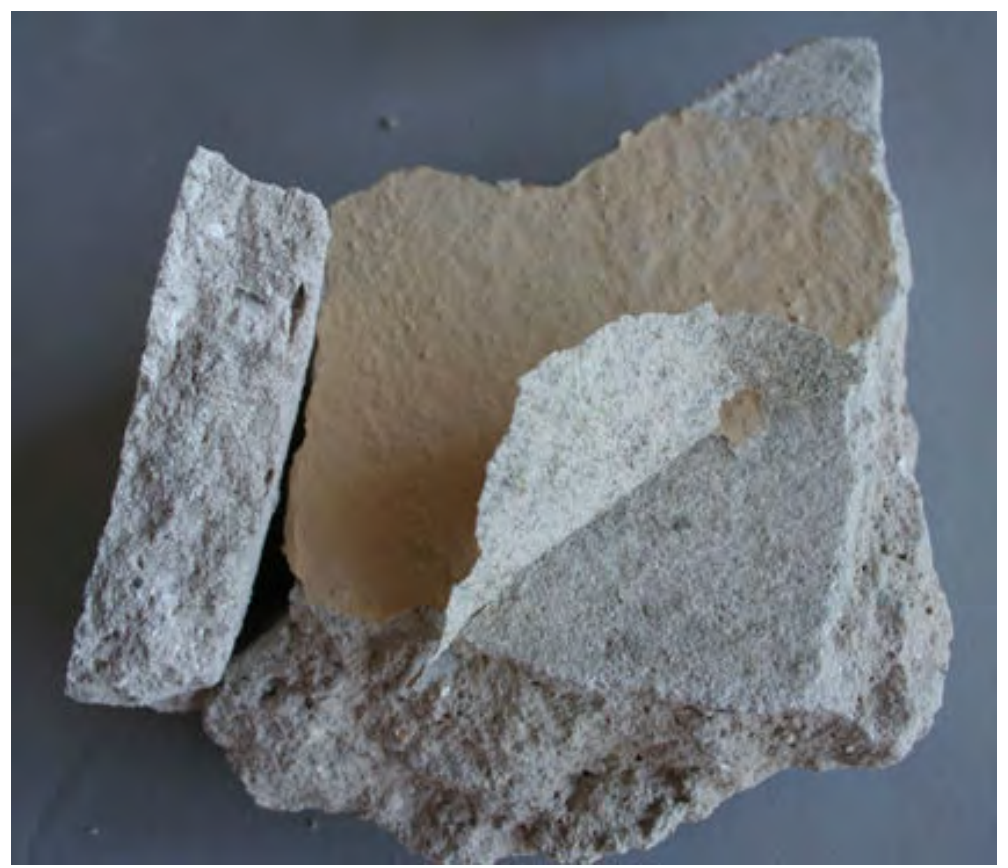

\section{COBERTURA}

A argamassa apresenta apenas uma camada - não se observa emboço e reboco.

Não apresenta desagregação

A película de tinta se desprende da argamassa com facilidade - já estava descolada

Fig. $372-$
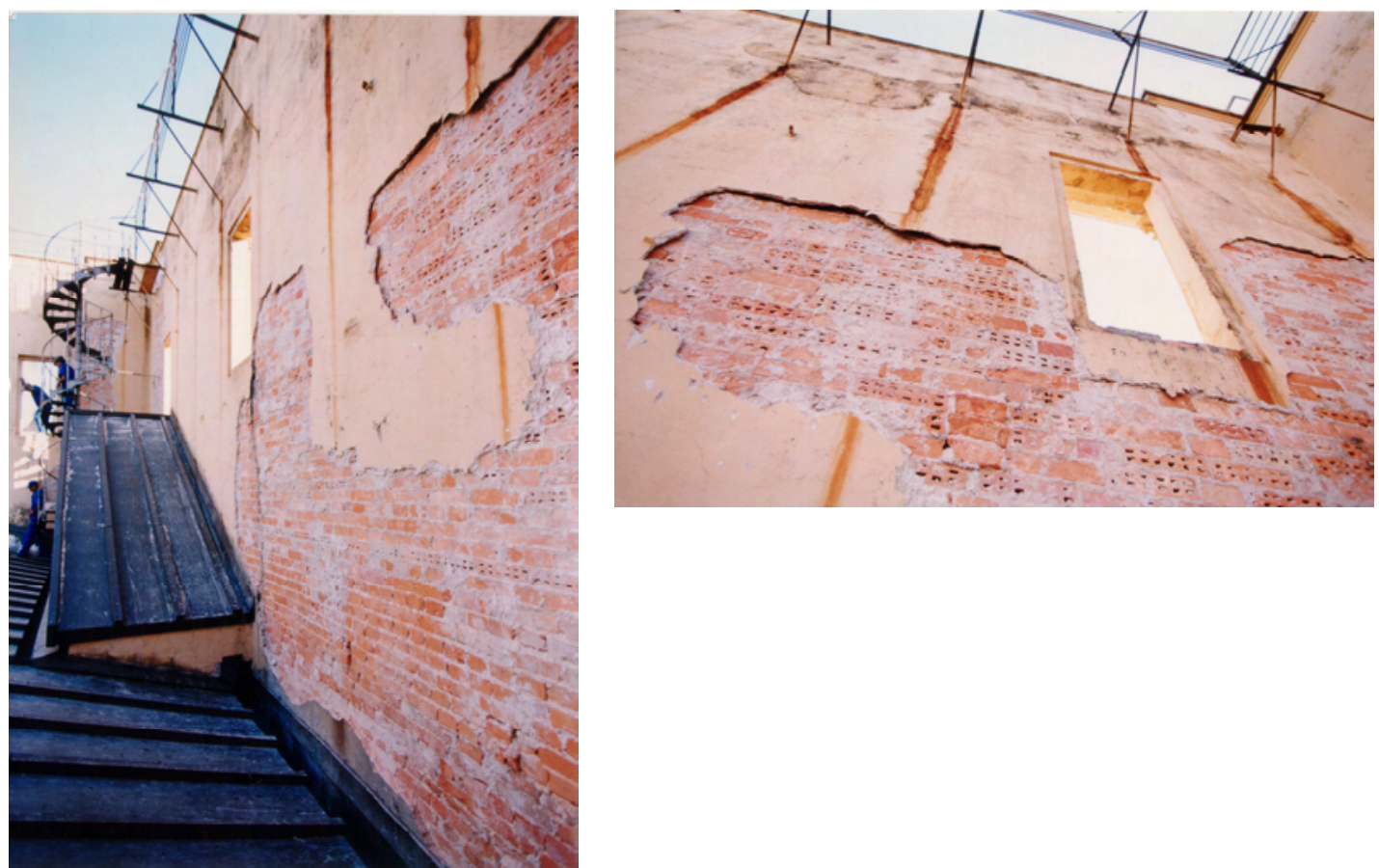

Fig. 373-Argamassa de revestimento das paredes internas do Mirante 


\section{AMOSTRA CIMENTO ROMANO}
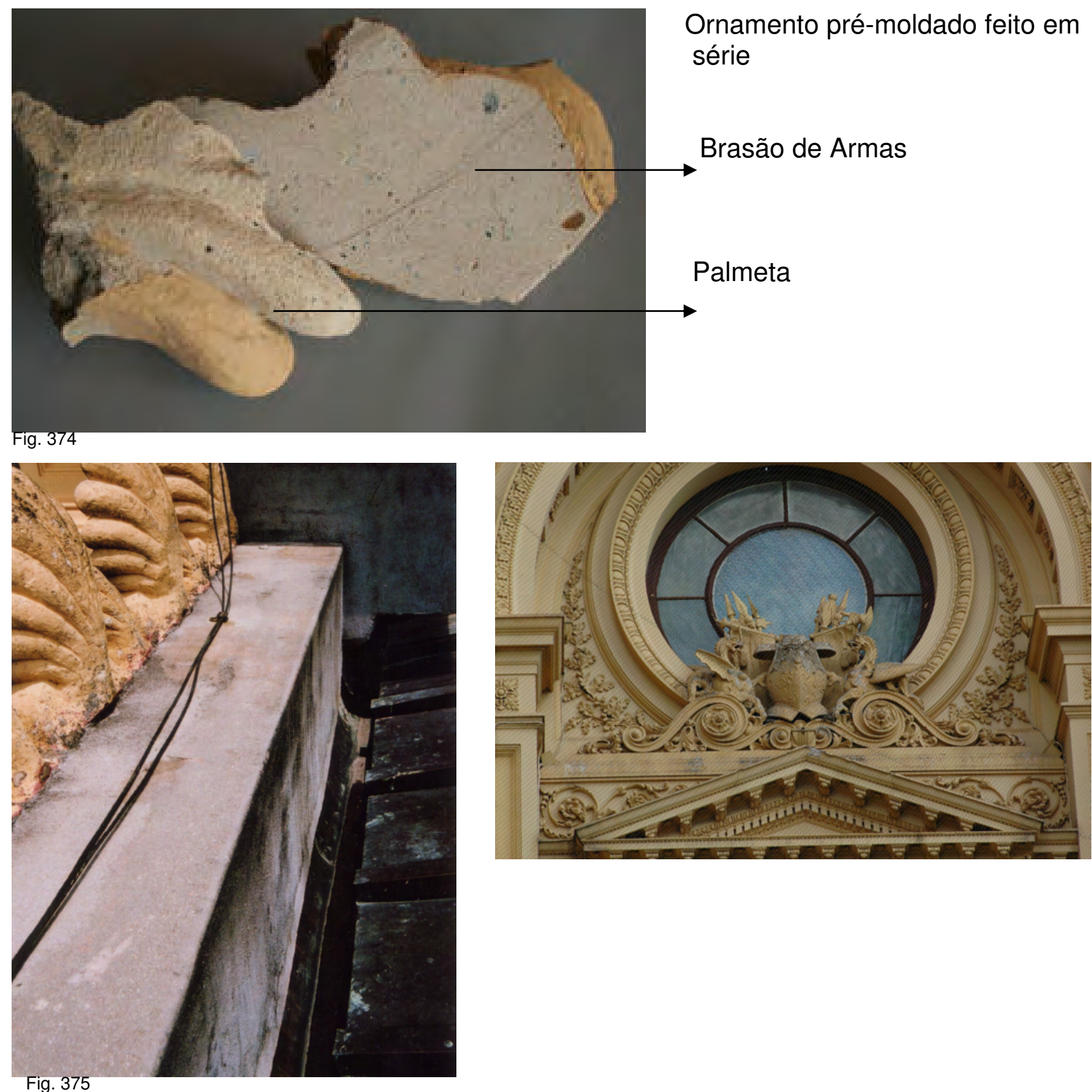

Palmeta

Brasão de Armas 


\section{TIJOLOS}

ORIGEM : Coletados nas escavações arqueológicas históricas realizadas no subsolo do Museu Paulista (área sob o Corpo Central) em 1994, sob a coordenação da Profa. Dra. Margarida Davina Andreatta

\section{FRAGMENTOS}

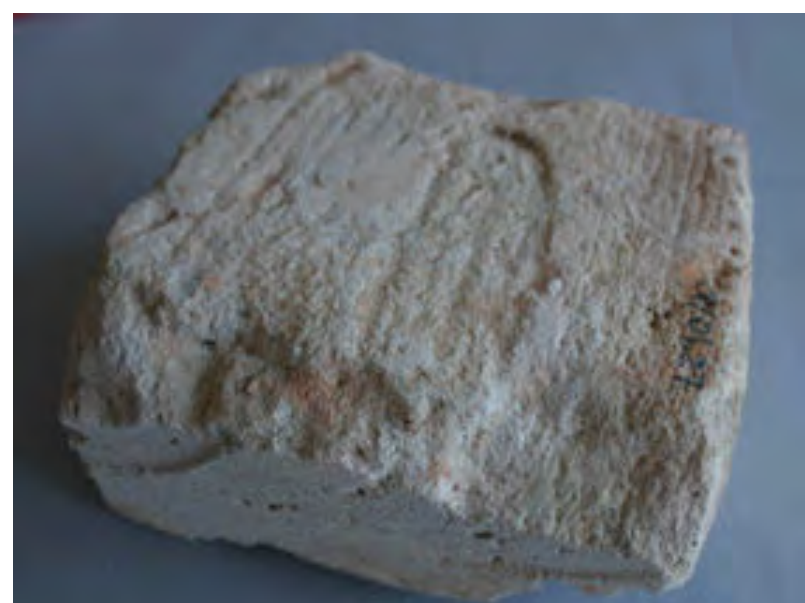

\section{Fragmento}

Tijolo de Barro Cozido $M \& B$

- mm X 125mm X 63mm

Comp. X Larg X Epes

MY 01.27

Fig. 376 - Fragmento de Tijolo MY 01.27 - Acervo Museu Paulista

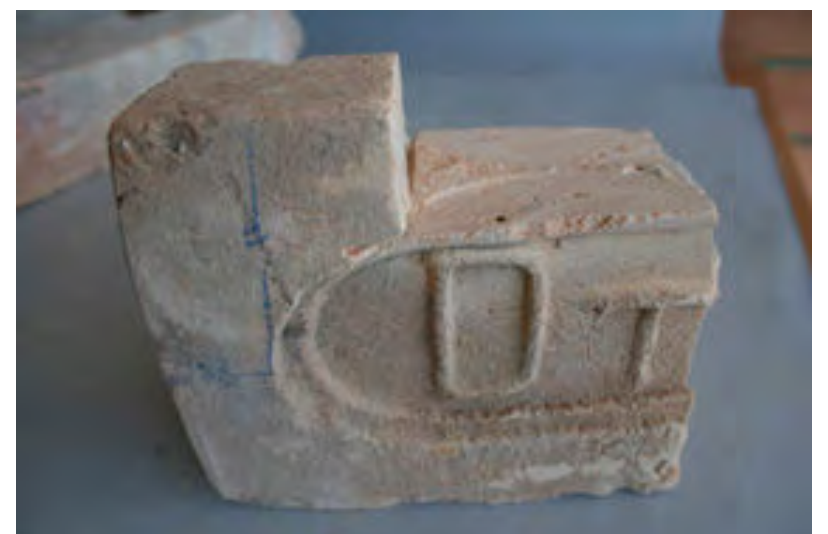

Fragmento

Tijolo de Barro Cozido

D T M

$-m m \times 115 m m \times 55 m m$

MY 01.06

Fig. 377 - Fragmento de tijolo MY 01.06 - Acervo Museu Paulista 


\section{TIJOLOS INTEIROS}

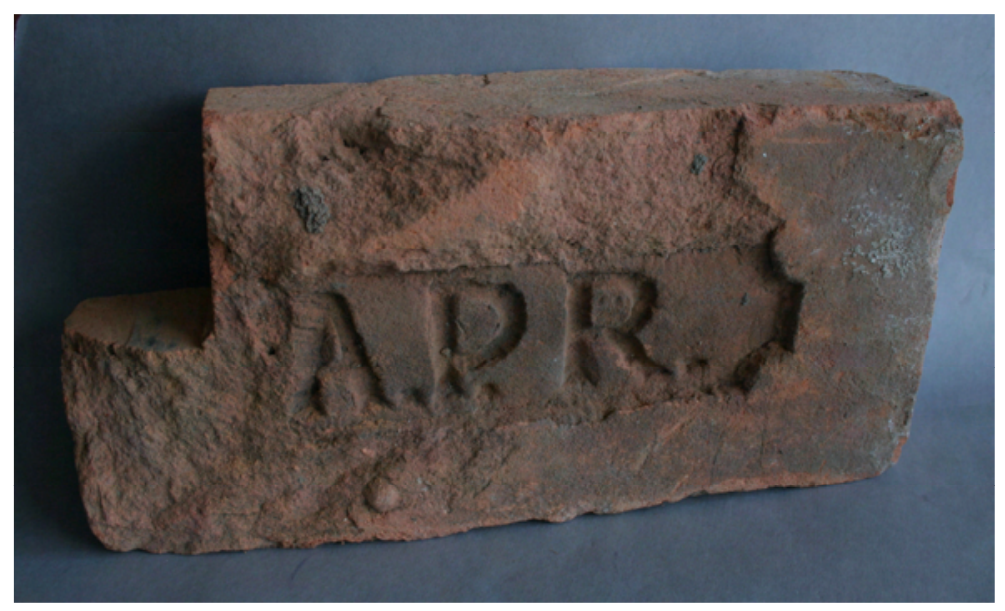

Fig. 378 - MY 01.02 - Acervo Museu Paulista

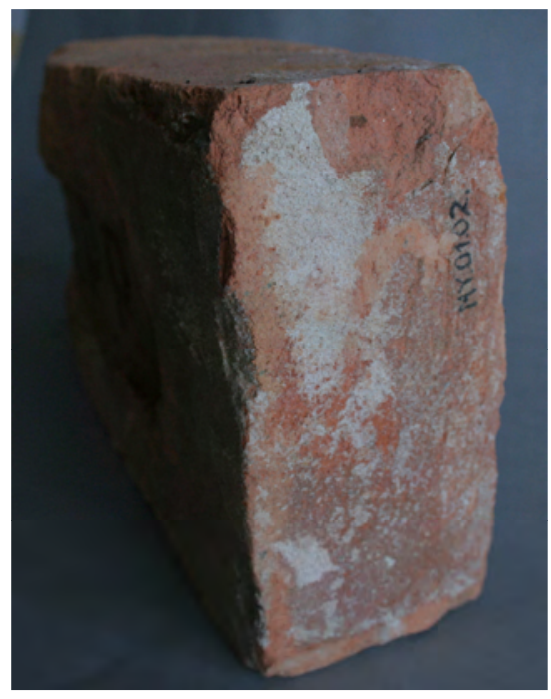

APR - $287 \times 142 \times 70$
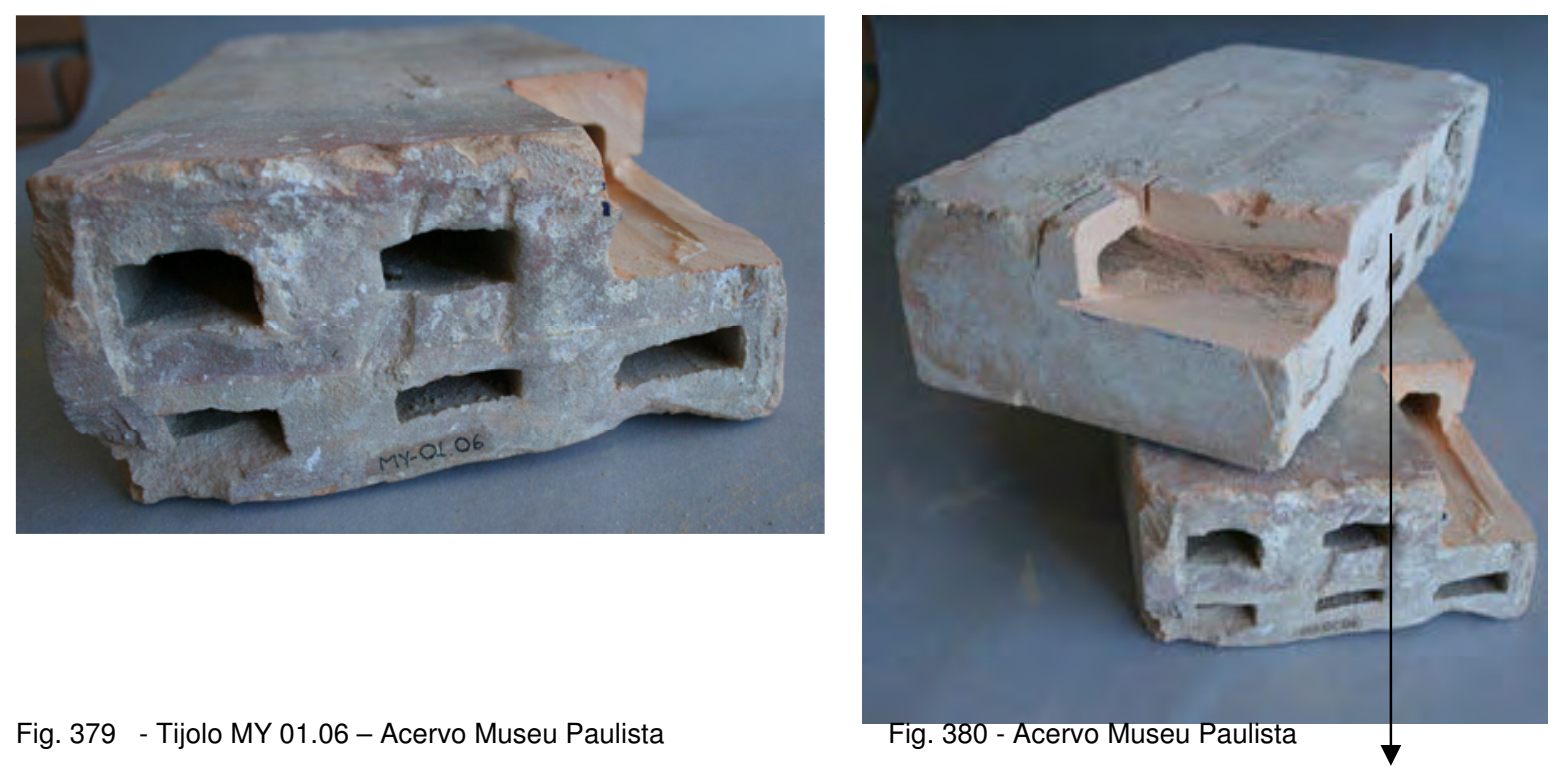

Fig. 379 - Tijolo MY 01.06 - Acervo Museu Paulista TIJOLO BAHIANO SEIS FUROS LONGITUDINAIS $270 \times 130 \times 63 \mathrm{~mm}$ Fig. $X$ - Tijolos doze furos e seis furos - Acervo Museu Paulista TRANSVERSAIS $290 \times 140 \times 70 \mathrm{~mm}$ 


\section{AMOSTRA EFLORESCÊNCIA DE SAIS SOLÚVEIS AMOSTRAS DA LACUNA E DO SEU ENTORNO}

\section{ENTRADA LESTE - FACE NORTE}

Amostras da lacuna e no seu entorno: camada de tinta, argamassa de revestimento, argamassa de assentamento, tijolo, tijolo desagregado juntamente com sais cristalizados

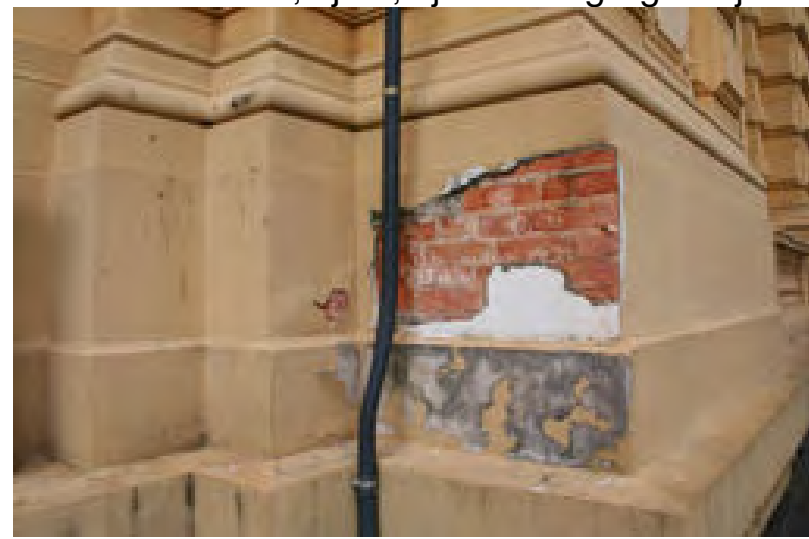

Fig 381 - Entrada Leste

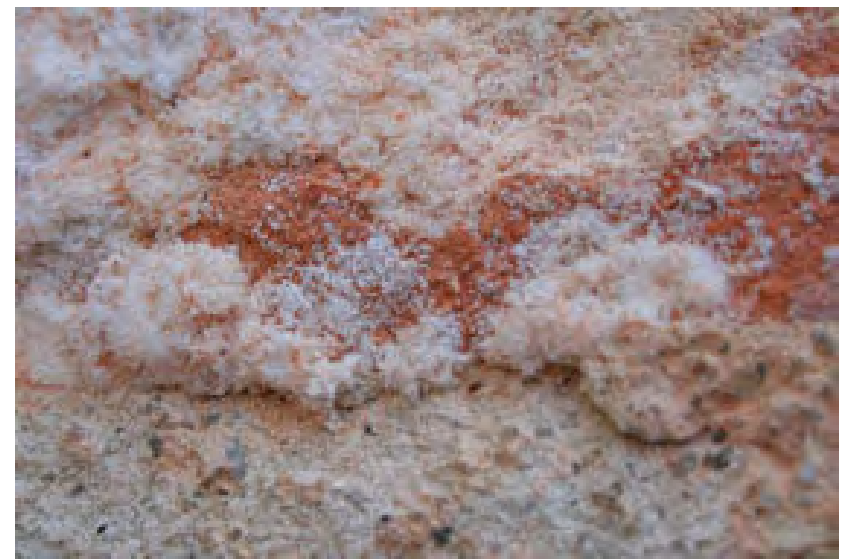

Fig. 383 - Eflorescência sobre tijolo

Eflorescência de sais sobre tijolos sem revestimento

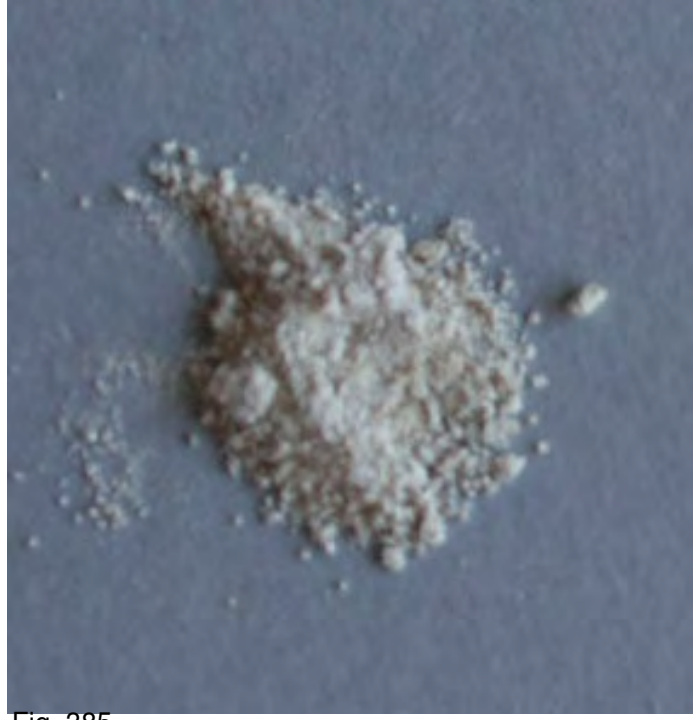

Fig. 385

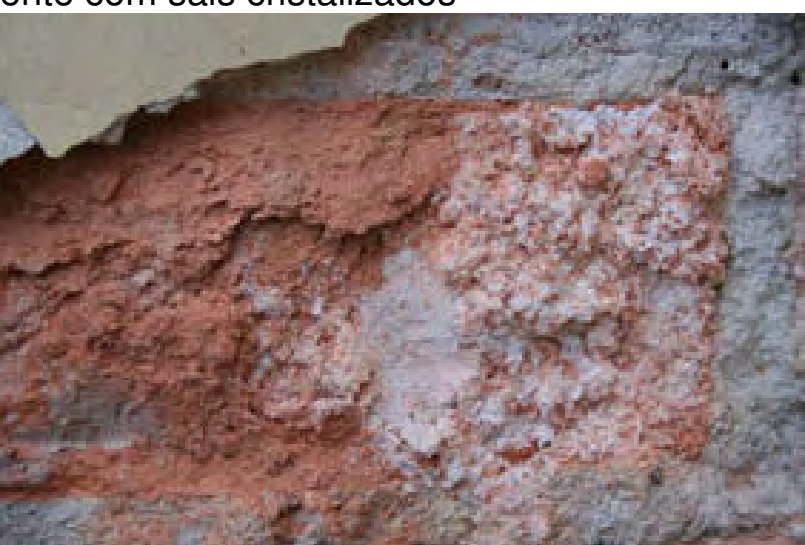

Fig 382

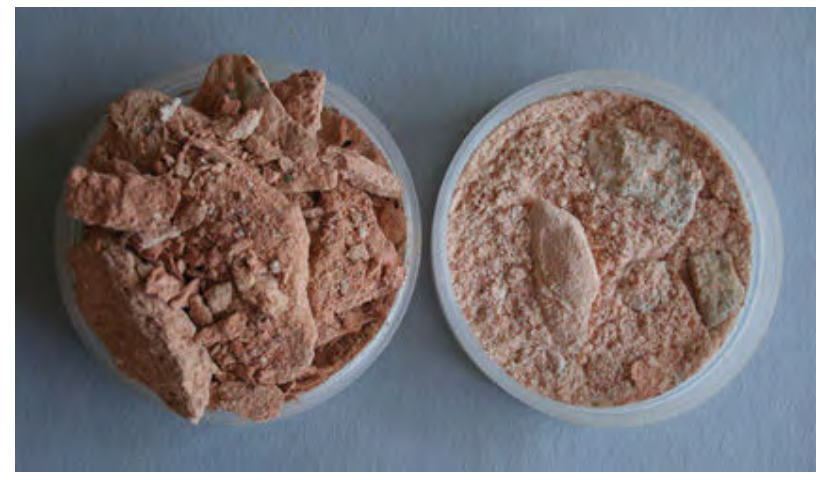

Fig 384

Tijolo esfoliado

Tijolo desagregado e sais

Argamassa desagregada em vesícula fechada

Entrada Leste no entorno da lacuna com eflorescência 
ANÁLISE QUÍMICA E RECONSTITUIÇÀO DE TRAÇO

Laboratório de Materiais de Construção Civil (LMCC)/CT- Obras

IPT - Instituto de Pesquisas Tecnológicas

\section{MATERIAIS - Museu Paulista/USP}

Argamassas

(Tabela 1)

\begin{tabular}{|c|c|c|c|}
\hline Identificação & Local de coleta & Massa de amostra (g) & N.․ \\
\hline $\begin{array}{c}\text { Amostra P2+P3 } \\
\text { Emboço e Reboco } \\
\text { desagregado }\end{array}$ & $\begin{array}{l}\text { Fachada Sul - } \\
\text { Ornamento no } \\
\text { embasamento }\end{array}$ & 60 & 21.509 \\
\hline $\begin{array}{c}\text { Amostra P1 - Emboço } \\
\text { Íntegra }\end{array}$ & \multirow{2}{*}{$\begin{array}{c}\text { Fachada Sul - } \\
1^{\circ} \text { Andar }\end{array}$} & 31 & 21.510 \\
\hline $\begin{array}{c}\text { Amostra P1 - Reboco } \\
\text { Íntegra }\end{array}$ & & 32 & 21.511 \\
\hline $\begin{array}{c}\text { Amostra Mirante } \\
\text { Íntegra }\end{array}$ & $\begin{array}{l}\text { Parede interna do } \\
\text { Mirante - } \\
\text { Cobertura }\end{array}$ & 233 & 21.639 \\
\hline
\end{tabular}

Eflorescência

\begin{tabular}{c|c|c|c}
\hline $\begin{array}{c}\text { Eflorescência em reboco } \\
\text { (vesícula) }\end{array}$ & $\begin{array}{c}\text { Pavimento Térreo - } \\
\text { Entrada Leste }\end{array}$ & 1 & 21.634 \\
\cline { 1 - 1 } Eflorescência em tijolo & & 8 & 21.635 \\
\hline
\end{tabular}

Tijolos

\begin{tabular}{|c|c|c|c|}
\hline Tijolo-Fragmento MY 0102 & $\begin{array}{c}\text { Coleta entulho } \\
\text { subsolo }\end{array}$ & 222 & 21.732 \\
\hline Tijolo-Fragmento MY 0106 & $\begin{array}{l}\text { Coleta entulho } \\
\text { subsolo }\end{array}$ & 78 & 21.733 \\
\hline Tijolo-Fragmento MY 0108 & $\begin{array}{c}\text { Coleta entulho } \\
\text { subsolo }\end{array}$ & 120 & 21.734 \\
\hline Tijolo-Fragmento MY 0127 & $\begin{array}{c}\text { Coleta entulho } \\
\text { subsolo }\end{array}$ & 101 & 21.735 \\
\hline Tijolo- Fragmento My & $\begin{array}{l}\text { Coleta entulho } \\
\text { subsolo }\end{array}$ & 75 & 21.736 \\
\hline
\end{tabular}




\section{MÉTODOS UTILIZADOS}

\subsection{Argamassas}

- Umidade, perda ao fogo, resíduo insolúvel, anidrido silícico $\left(\mathrm{SiO}_{2}\right)$, óxido de cálcio (CaO), óxido de magnésio $(\mathrm{MgO})$, óxidos de ferro e alumínio $\left(\mathrm{R}_{2} \mathrm{O}_{3}\right)$ e anidrido sulfúrico ( $\left.\mathrm{SO}_{3}\right)$ : Procedimento CT-OBRAS-LMCC-Q-PE-042 "Concreto e Argamassa - Reconstituição de traço", com base em diretrizes gerais do método de ensaio apresentado em QUARCIONI, V. A. Reconstituição de traço de argamassas: atualização do Método IPT. Dissertação de Mestrado da Escola Politécnica da Universidade de São Paulo. São Paulo, 1998, 188 p.;

- Anidrido carbônico $\left(\mathrm{CO}_{2}\right)$ : Procedimento CT-OBRAS-LMCC-Q-PE-011 "Determinação de anidrido carbônico $\left(\mathrm{CO}_{2}\right)$ por gasometria", com base em diretrizes gerais da NBR NM 20:2004;

- Análise sob estereomicroscópio: metodologia a ser detalhada.

\section{2 "Eflorescências"}

- Sais, cloreto $(\mathrm{Cl})$ e sulfato $\left(\mathrm{SO}_{4}{ }^{2-}\right)$ solúveis: Procedimento CT-OBRAS-LMCC-QPE-044 "Agregado para concreto - Determinação de sais, cloretos e sulfatos solúveis": com base na NBR 9917/87 e procedimento CT-OBRAS-LMCC-Q-PE-064 "Determinação de ĺons cloreto e fluoreto por potenciometria com eletrodo de ĺons seletivo - Procedimento de leitura", com base em diretrizes gerais da NBR 13737/96 e ASTM D 512/04;

Nota 1: O ataque da amostra foi executado seguindo diretrizes gerais da publicação de QUARCIONI et al. ${ }^{(1)}$, como adequação do procedimento indicado pela NBR 9917/87, a saber: em um béquer, adicionou-se $20 \mathrm{~g}$ de agregado e $100 \mathrm{~mL}$ de água à temperatura ambiente, agitando-se por aproximadamente 10min em agitador magnético; filtrou-se a suspensão em papel de filtração média, recolhendose o filtrado em balão volumétrico de $500 \mathrm{~mL}$.

Nota 2: Para a determinação semiquantitativa de cloreto ( $\mathrm{Cr}$ ) foi utilizado Kit de Teste de Cloreto (Método Colorimétrico) Microquant, Merck, faixa de 3 a $300 \mathrm{mg} / \mathrm{L}$ de $\mathrm{Cl}$ - Lote 90332884.

- Sódio, ( $\mathrm{Na}$ ), potássio (K) e magnésio (Mg): Procedimento CT-OBRAS-LMCC-Q$P E-061$ "Determinação de metais por espectrofotometria de absorção atômica Procedimento de leitura", com base em diretrizes gerais da NBR 13810/97.

Nota 3: Ensaios realizados no filtrado obtido na determinação de cloreto e sulfato.

\section{Fragmentos de tijolos}

- Sais, cloreto $(\mathrm{Cl})$ e sulfato $\left(\mathrm{SO}_{4}{ }^{2-}\right)$ solúveis: Procedimento CT-OBRAS-LMCC-QPE-044 "Agregado para concreto - Determinação de sais, cloretos e sulfatos solúveis": com base na NBR 9917/87 e procedimento CT-OBRAS-LMCC-Q-PE-064 "Determinação de Íons cloreto e fluoreto por potenciometria com eletrodo de Íons seletivo - Procedimento de leitura", com base em diretrizes gerais da NBR 13737/96 e ASTM D 512/04;

Nota 4: idem notas 1 e 2.

${ }^{1}$ QUARCIONI, V.A., CHOTOLI, F.F., ALEIXO, D.M. Proposta de método para determinação de sais solúveis em argamassas endurecidas. In: SIMPÓSIO BRASILEIRO DE TECNOLOGIA DAS ARGAMASSAS, 5, 2003. São Paulo. Anais... São Paulo: USP/ANTAC, pág. 647-662. 
- Sódio, (Na), potássio (K) e magnésio (Mg): Procedimento CT-OBRAS-LMCC-QPE-061 "Determinação de metais por espectrofotometria por absorção atômica Procedimento de leitura", com base em diretrizes gerais da NBR 13810/97.

Nota 5: idem nota 3.

- Simulação laboratorial para verificação da formação de eflorescência de sais: seguindo diretrizes gerais da publicação QUARCIONI et al. ${ }^{(2)}$.

\section{RESULTADOS}

\subsection{Preparação de amostra}

As argamassas foram moídas manualmente em almofariz de porcelana, até totalmente passante em peneira ABNT N.․ $20(0,84 \mathrm{~mm})$.

As "eflorescências" foram ensaiadas tal qual recebidas no laboratório.

Os fragmentos foram recortados diretamente dos tijolos no laboratório, sendo parte recortada e moída manualmente em almofariz de porcelana até passante totalmente em peneira ABNT N. $50(0,300 \mathrm{~mm})$ e o restante foi de cada fragmento foi embutido na tampa de recipiente cilíndrico (de volume aproximado de $500 \mathrm{~mL}$ ), de plástico, e fixado com silicone neutro até a meia altura do fragmento, de forma que a parte superior permaneceu exposta e a parte inferior imersa parcialmente em água deionizada, conforme ilustrado na Figura 1. O sistema foi mantido em estufa a $65^{\circ} \mathrm{C}$ durante 24 horas e, após esse período, em ambiente de laboratório por 07 dias.

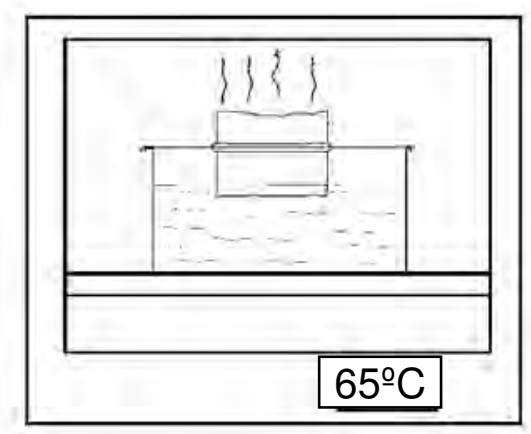

Figura 1: Vista frontal esquemática das condições de ensaio

\subsection{Resultados de análise química e reconstituição de traço das argamassas}

Os resultados obtidos nas análises químicas das argamassas e os respectivos traços calculados estão apresentados nas Tabelas de 2 a 5 .

${ }^{2}$ QUARCIONI, V. A., CHOTOLI, F. F., ALEIXO, D. M. Ensaio acelerado para simular eflorescência de sais solúveis em argamassas endurecidas. In: SIMPÓSIO BRASILEIRO DE TECNOLOGIA DAS ARGAMASSAS, 5, 2003. São Paulo. Anais...São Paulo: USP/ANTAC. p. 595-604. 
ANÁLISE QUÍMICA - ARGAMASSAS

\begin{tabular}{|c|c|c|c|c|c|c|}
\hline \multirow{3}{*}{ Determinações } & \multicolumn{4}{|c|}{ Resultados, em \% } & \multirow{2}{*}{\multicolumn{2}{|c|}{\begin{tabular}{|c|} 
Tabela 2 \\
Argamassa \\
P1 - Reboco \\
\end{tabular}}} \\
\hline & \multicolumn{2}{|c|}{$\begin{array}{c}\text { Argamassa } \\
\text { Amostra P2+P3) }\end{array}$} & \multicolumn{2}{|c|}{$\begin{array}{c}\text { Argamassa } \\
\text { P1 - Emboço }\end{array}$} & & \\
\hline & $\left|\begin{array}{c}\text { Base } \\
\text { original }\end{array}\right|$ & \begin{tabular}{|c|} 
Base \\
não \\
volátil \\
\end{tabular} & $\begin{array}{c}\text { Base } \\
\text { original }\end{array}$ & $\begin{array}{c}\text { Base } \\
\text { não } \\
\text { volátil } \\
\end{array}$ & $\begin{array}{c}\text { Base } \\
\text { original }\end{array}$ & \begin{tabular}{|c|} 
Base \\
não \\
volátil
\end{tabular} \\
\hline Umidade & 1,13 & - & 0,56 & - & 0,64 & - \\
\hline Perda ao fogo & 6,58 & - & 6,78 & 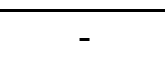 & 8,65 & - \\
\hline Resíduo insolúvel & 83,3 & 90,3 & 84,3 & 91,0 & 79,1 & 87,2 \\
\hline Anidrido silícico $\left(\mathrm{SiO}_{2}\right)$ & 0,77 & 0,83 & 0,60 & 0,65 & 0,70 & 0,77 \\
\hline Óxidos de ferro e alumínio $\left(\mathrm{R}_{2} \mathrm{O}_{3}\right)$ & 1,08 & 1,17 & 0,54 & 0,58 & 0,52 & 0,57 \\
\hline Óxido de cálcio (CaO) & 5,77 & 6,25 & 5,72 & 6,17 & 9,08 & 10,0 \\
\hline Óxido de magnésio (MgO) & 1,11 & 1,20 & 1,61 & 1,74 & 1,27 & 1,40 \\
\hline Anidrido sulfúrico $\left(\mathrm{SO}_{3}\right)$ & 0,67 & 0,73 & 0,05 & 0,05 & 0,10 & 0,11 \\
\hline Anidrido carbônico $\left(\mathrm{CO}_{2}\right)$ & 4,59 & - & 5,03 & - & 6,89 & - \\
\hline
\end{tabular}

\begin{tabular}{l|c|c|c|c}
\hline \multirow{2}{*}{ Determinações } & \multicolumn{3}{c}{ Resultados, em \% - } & \multicolumn{2}{c}{ Tabela 4 } \\
\cline { 2 - 5 } & \multicolumn{2}{|c|}{ Amostra Mirante } & \multicolumn{2}{c}{$\begin{array}{c}\text { Rmomano Cimento } \\
\text { Romano }\end{array}$} \\
\cline { 2 - 5 } & $\begin{array}{c}\text { Base } \\
\text { original }\end{array}$ & $\begin{array}{c}\text { Base não } \\
\text { volátil }\end{array}$ & $\begin{array}{c}\text { Base } \\
\text { original }\end{array}$ & $\begin{array}{c}\text { Base não } \\
\text { volátil }\end{array}$ \\
\hline \hline Umidade & 0,69 & - & 4,07 & - \\
\hline Perda ao fogo & 7,97 & - & 23,9 & - \\
\hline Resíduo insolúvel & 79,0 & $\mathbf{8 6 , 5}$ & 29,9 & $\mathbf{4 1 , 5}$ \\
\hline Anidrido silícico $\left(\mathrm{SiO}_{2}\right)$ cimento & 1,52 & $\mathbf{1 , 6 6}$ & 4,60 & $\mathbf{6 , 3 9}$ \\
\hline Óxidos de ferro e alumínio $\left(\mathrm{R}_{2} \mathrm{O}_{3}\right)$ & 1,14 & 1,25 & 5,79 & 8,04 \\
\hline Óxido de cálcio $(\mathrm{CaO})$ & 6,61 & 7,24 & 29,5 & 41,0 \\
\hline Óxido de magnésio $(\mathrm{MgO})$ & 3,22 & 3,53 & 0,80 & 1,11 \\
\hline $\begin{array}{l}\text { Anidrido sulfúrico }\left(\mathrm{SO}_{3}\right) \text { Sulfato de } \\
\text { Magnésio }\end{array}$ & 0,06 & $\mathbf{0 , 0 7}$ & 1,20 & $\mathbf{1 , 6 7}$ \\
\hline Anidrido carbônico $\left(\mathrm{CO}_{2}\right)$ & 4,80 & - & 18,3 & - \\
\hline
\end{tabular}




\section{RECONSTITUIÇÃO DA COMPOSIÇÃO (TRAÇO)}

()

\begin{tabular}{|c|c|c|c|c|}
\hline Identificação & $\begin{array}{l}\text { Parâmetros } \\
\text { calculados }\end{array}$ & Cal hidratada & Agregado & $\begin{array}{c}\text { Tabela } 3 \\
\text { Rel. } \\
\text { Aglo/Agre }\end{array}$ \\
\hline \multirow{3}{*}{$\begin{array}{c}\text { Argamassa } \\
\text { Amostra P2+P3 }\end{array}$} & Constituintes (\%) & 12,9 & 87,1 & \multirow{2}{*}{$1: 6,8$} \\
\hline & Traço, em massa & 1 & 6,8 & \\
\hline & Traço, em volume & 1 & 3,8 & $1: 3,8$ \\
\hline \multirow{3}{*}{$\begin{array}{c}\text { Argamassa } \\
\text { Amostra P1 } \\
\text { Emboço }\end{array}$} & Constituintes (\%) & 12,0 & 88,0 & \multirow{2}{*}{$1: 7,3$} \\
\hline & Traço, em massa & 1 & 7,3 & \\
\hline & Traço, em volume & 1 & 4,1 & $1: 4,1$ \\
\hline \multirow{3}{*}{$\begin{array}{c}\text { Argamassa } \\
\text { Amostra P1 } \\
\text { Reboco }\end{array}$} & Constituintes (\%) & 16,8 & 83,2 & \multirow{2}{*}{$1: 5,0$} \\
\hline & Traço, em massa & 1 & 5,0 & \\
\hline & Traço, em volume & 1 & 2,8 & $1: 2,8$ \\
\hline
\end{tabular}

\begin{tabular}{c|c|c|c|c|c}
\hline \multirow{2}{*}{ Identificação } & $\begin{array}{c}\text { Parâmetros } \\
\text { calculados }\end{array}$ & Cimento & Cal hidratada & Agregado & $\begin{array}{c}\text { Tabela 5 } \\
\text { Rel. } \\
\text { Aglo/Agre }\end{array}$ \\
\hline \multirow{3}{*}{ Amostra Mirante } & Constituintes (\%) & 8,9 & $\mathbf{2 , 2}$ & 88,9 & \multirow{1}{*}{$\mathbf{7 , 4}$} \\
\cline { 2 - 6 } & Traço, em massa & 1 & 0,3 & 9,6 & \\
\cline { 2 - 6 } & Traço, em volume & 1 & 0,5 & 9,6 & $1: 6,4$ \\
\hline \hline \multirow{2}{*}{$\begin{array}{c}\text { Amostra Cimento } \\
\text { Romano }\end{array}$} & Constituintes (\%) & 34,2 & $\mathbf{2 3 , 6}$ & 42,2 & \multirow{2}{*}{$\mathbf{1}: \mathbf{0 , 6}$} \\
\cline { 2 - 6 } & Traço, em massa & 1 & 0,9 & 1,2 & $1: 0,5$ \\
\cline { 2 - 6 } & Traço, em volume & 1 & 1,6 & 1,2 & $1: 2$ \\
\hline
\end{tabular}




\section{ANÁLISE DOS RESULTADOS}

\section{ANÁLISE QUÍMICA - IPT Laboratório de Química dos Materiais}

O objetivo da análise química, é determinar a composição química para cálculo da proporção de mistura aglomerante-agregado das argamassas, com dois objetivos:

- Avaliar a alteração na composição por comparação entre argamassas sadias e deterioradas

- Conhecendo a composição das argamassas sadias possibilitar o reparo com argamassas análogas ou compatíveis.

A amostra é dissolvida em ácido clorídrico para separar a fração aglomerante do agregado.

Quanto maior o teor do agregado, mais pobre de aglomerante, e a argamassa será mais frágil.

A relação aglomerante / agregado indica também a porosidade da argamassa. Quanto maior a porosidade na estrutura do material, mais frágil será a argamassa.

A porosidade elevada facilita a ascensão da água por capilaridade devido à pressão hidrostática. Nos poros se alojam a água e os sais solúveis. Mesmo havendo somente água, se houver de forma intermitente umedecimento/ secagem, já causará danos na estrutura do material. Se houver sais solúveis e se estes recristalizarem no interior da argamassa, por aumento de volume produzirá a perda da coesão do material, ou a desagregação, agravando-se os danos.

Método de Reconstituição de Traço desenvolvido pelo IPT, baseia-se no princípio de que a argamassa ao ser atacada com ácido clorídrico, dá origem a duas frações distintas: uma solúvel e uma insolúvel.

- A fração insolúvel é constituída pelo agregado

- A fração solúvel é composta essencialmente pelos aglomerantes

O método prevê as determinações quantitativas na forma dos óxidos correspondentes:

Anidrido Silícico - $\mathrm{SiO}_{2}$, procedente do cimento;

Óxido de Cálcio - $\mathrm{CaO}$, procedente da cal e do cimento;

Óxido de Magnésio - MgO, procedente do cimento e, quando em teor elevado indica a presença de cal dolomítica.

Óxidos de Ferro e Alumínio $\mathrm{R}_{2} \mathrm{O}_{3}$, procedentes do cimento.

É também determinado o teor de anidrido sulfúrico $\left(\mathrm{SO}_{3}\right)$ que, se em teor elevado, indica alteração da argamassa por efeito do meio ambiente.

Há ainda uma terceira, a fração volátil, determinada a $1000{ }^{\circ} \mathrm{C}$.

Nessa fração determina-se:

A umidade - (UM), determinada por secagem da amostra em estufa, a $100{ }^{\circ} \mathrm{C}$.

Perda ao fogo - (PF), que indica o teor de água combinada no cimento

hidratado ou na cal hidratada ainda não totalmente carbonatada e da fração

carbonatada. Como o resultado apresentado é a soma da água combinada e do anidrido carbônico, o teor de água combinada é dado pele diferença: perda ao fogo - anidrido carbônico.

Anidrido Carbônico - $\mathrm{CO}_{2}$, determinada gasometricamente. 
Como a fração volátil é variável, dependendo do grau de hidratação da cal e do cimento, e também da carbonatação da argamassa, os resultados são calculados para uma mesma base, eliminando-se os voláteis.

\section{RESULTADOS DA ANÁLISE QUÍMICA E RECONSTITUIÇÃO DO TRAÇO}

Dos resultados da análise química fazem-se as observações que se seguem, por argamassa coletada.

\section{Amostra P1 - Emboço e Reboco (Tabela 2)}

$\mathrm{Na}$ Amostra P1 o emboço, tem maior teor de agregado do que o reboco, a saber, $91,0 \%$ e $87,2 \%$ respectivamente.

O traço calculado (Tabela 3 ) para o emboço é relação aglomerante/ agregado de 1:7,4 e de 1:5,0 para o reboco, indicando que o reboco tem menor quantidade de agregado em relação ao aglomerante.

\section{Amostra Mirante e Amostra Cimento Romano (Tabela 4)}

A análise química indica o teor de resíduo insolúvel, isto é, de agregado, de $86,5 \%$ na amostra do Mirante e bem menor, de $41,5 \%$ para o Cimento Romano. Em ambas pelo teor de anidrido silícico conclui-se que contêm cimento.

A reconstituição de traço indica uma relação cimento:cal:agregado, em massa, de 1: 0,3: 9,6 e 1: 0,9:1,2, respectivamente, para o Mirante e Cimento romano. A relação aglomerante/ agregado a partir destes valores é de 1:7,4 da Amostra Mirante e de 1:0,5 para o Cimento Romano.; 7,4 é um alto valor de agregado e indica menor resistência mecânica do que a amostra de Cimento Romano. Uma diferença significativa.

De fato, o resultado encontrado para Cimento Romano é compatível com a resistência que os ornamentos devem ter. Apresenta também um elevado teor de cal, que se destaca na Tabela 5 , necessário para dar a plasticidade requerida para a moldagem.

O Emboço na Tabela 5, apresenta a maior porcentagem de agregado $=88,9$ para 2,2 de cal, resultando na proporção aglomerante/ agregado 1:7,3, que caracteriza uma argamassa com pouca resistência mecânica e muito porosa.

O Anidrido Sulfúrico do Cimento Romano é alto $=1,67$ o que indica ter ao longo do tempo assimilado $\mathrm{SO}_{3}$ do ambiente, poluição atmosférica ou água de chuva, dada a sua permanente exposição ao ar. Pelo elevado teor de cal esse sulfato deve estar na forma de gipsita $\left(\mathrm{CaSO}_{4} 2 \mathrm{H}_{2} \mathrm{O}\right)$. Isto explica a fissuração observada e o desprendimento dos fragmentos ..

\section{AÇÃO DA UMIDADE SOBRE O EMBOÇO E REBOCO}

A identificação do traço e a relação aglomerante / agregado da Amostra 1, indica que o Emboço tem mais agregado do que o Reboco, e assim a argamassa é mais frágil.

Esta informação possibilita a compreensão, pelo menos de uma das causas, que faz parte do processo de dano que ocorre com a argamassa de revestimento nas fachadas do edifício. 
Considerando-se que a presença da umidade e de sais solúveis, ocorrem constantemente, como uma característica deste edifício, estas irão interferir na conservação do emboço e reboco.

A umidade ascendendo pelo interior da parede através da porosidade dos tijolos, se encaminhará até à superfície para se evaporar, assim atingirá primeiro o emboço e depois o reboco. Como o emboço é mais frágil se ressentirá com intensidade maior do que o reboco. O reboco poderá se manifestar com alguma movimentação devido às alterações no emboço e poderão assim surgir minúsculas fissuras e se iniciar um processo que atingirá maiores dimensões.

Os danos podem se manifestar pela perda de coesão do emboço e também poderá se constituir em uma das causas do desprendimento do reboco da parede.

Este desprendimento poderá ter outras causas no que diz respeito da execução deste revestimento. Tudo indica, que não foi utilizado chapisco para criar maior aderência do reboco à parede. Poderia ainda haver algum resíduo de pó no tijolo, ou a parede não ter sido umedecida o suficiente para também possibilitar a aderência. 
Tabela 8: Resultados de ensaios químicos nas "eflorescências"

\begin{tabular}{c|c|c|c|c|c|c}
\hline \multirow{2}{*}{ Material } & \multicolumn{7}{c}{ Base original (\%) } \\
\cline { 2 - 7 } & $\begin{array}{c}\text { Sais } \\
\text { solúveis }\end{array}$ & $\begin{array}{c}\text { Sódio } \\
(\mathrm{Na})\end{array}$ & $\begin{array}{c}\text { Potássio } \\
(\mathrm{K})\end{array}$ & $\begin{array}{c}\text { Magnésio } \\
(\mathrm{Mg})\end{array}$ & $\begin{array}{c}\text { Cloreto } \\
(\mathrm{Cl}-)\end{array}$ & $\begin{array}{c}\text { Sulfato } \\
\left(\mathbf{S O}_{4}^{2-}\right)\end{array}$ \\
\hline $\begin{array}{c}\text { Eflorescência em } \\
\text { reboco (vesícula) }\end{array}$ & 4,06 & 0,02 & 0,01 & $\mathbf{0 , 1 3}$ & $<0,1$ & $\mathbf{n . d .}$ \\
\hline $\begin{array}{c}\text { Eflorescência em } \\
\text { tijolo }\end{array}$ & 18,9 & 0,04 & 0,04 & $\mathbf{2 , 2 5}$ & 0,1 & $\mathbf{9 , 8 5}$ \\
\hline
\end{tabular}

n.d.: não detectado.

Tabela 9: Resultados de ensaios químicos nas "eflorescências"

\begin{tabular}{|c|c|c|c|c|c|c|}
\hline \multirow[b]{2}{*}{ Material } & \multicolumn{6}{|c|}{ Base original (\%) } \\
\hline & $\begin{array}{c}\text { Sais } \\
\text { solúveis }\end{array}$ & $\begin{array}{l}\text { Sódio } \\
\text { (Na) }\end{array}$ & $\begin{array}{l}\text { Potássio } \\
\text { (K) }\end{array}$ & $\begin{array}{c}\text { Magnésio } \\
\text { (Mg) }\end{array}$ & $\begin{array}{c}\text { Cloreto } \\
\text { (Cl-) }\end{array}$ & $\begin{array}{l}\text { Sulfato } \\
\left(\mathrm{SO}_{4}{ }^{2-}\right)\end{array}$ \\
\hline Fragmento MY 0102 & 0,05 & $<0,01$ & $<0,01$ & $<0,01$ & $<0,01$ & 0,02 \\
\hline Fragmento MY 0106 & 0,13 & $<0,01$ & $<0,01$ & $<0,01$ & $<0,01$ & 0,03 \\
\hline Fragmento MY 0108 & 0,11 & $<0,01$ & $<0,01$ & $<0,01$ & $<0,01$ & 0,01 \\
\hline Fragmento MY 0127 & 0,40 & 0,02 & 0,02 & 0,02 & 0,05 & 0,08 \\
\hline Fragmento My & 0,05 & $<0,01$ & $<0,01$ & $<0,01$ & $<0,01$ & 0,04 \\
\hline
\end{tabular}

n.d.: não detectado.

A Tabela 9 apresenta os dados da avaliação visual qualitativa do volume de eflorescência gerado nos fragmentos de tijolos ensaiados, no âmbito do ensaio de simulação laboratorial para a formação de eflorescência de sais. As Fotos 1 a 5 ilustram os fragmentos, após o ensaio. 


\section{ENSAIOS QUÍMICOS NAS EFLORESCÊNCIAS - IPT}

\section{EFLORESCÊNCIA NA SUPERFÍCIE DOS TIJOLOS}

Após alguns dias, já havia diminuído a camada de sais cristalizados, e ao coletar este material se misturou com o tijolo em desagregação

Os resultados obtidos confirmaram o DRX - apresentado a seguir:

Sulfato $-9,85 \%$

Magnésio 2,25\%

O magnésio não é um elemento encontrado facilmente na natureza, e que possa impurificar materiais de construção, a não ser que a cal da argamassas de assentamento seja dolomítica e tenha o magnésio dissolvido por lixiviação; mas se provem da cal, deveria também apresentar calcita, uma vez que o teor de cálcio é maior do que o magnésio.

Outra fonte possível é a areia empregada ter sido procedente de praia, mas não está indicada na documentação da obra.

Outra fonte ainda pode ser a cal produzida de marisco. se ele não foi lavado antes da calcinação. A cal virgem pode conter magnésio, na forma de sulfato ou de cloreto. O teor de cloreto da análise química indica baixo teor de cloreto. Por exclusão a impureza deve ser de sulfato de magnésio, lixiviado para a superfície da alvenaria. 


\section{DRX - DIFRAÇÃO DE RAIOS-X}

Instituto de Geociências da Universidade de São Paulo

Departamento de Mineralogia e Geotectônica

Eliane Del Lama

- Amostras Entrada Leste, Primeiro Pavimento:

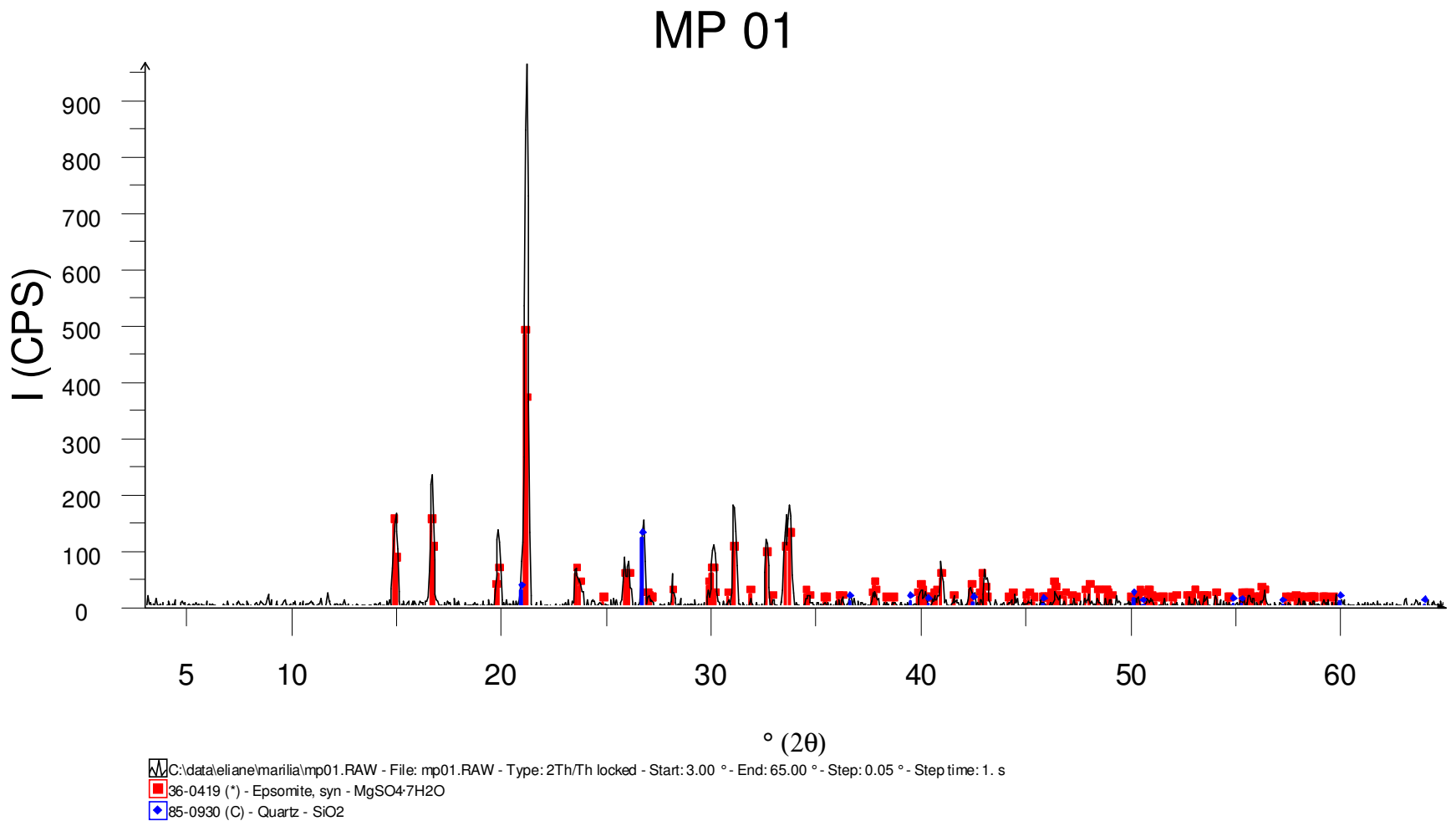

DIFRATOGRAMA - EFLORESCÊNCIA - MINERAIS: Quartzo e Epsomita

EPSOMITA = Sulfato de Magnésio $\mathrm{MgSO}_{4} 7 \mathrm{H}_{2} \mathrm{O}$

A amostra utilizada nesta análise, provém do mesmo material identificado como Eflorescência em tijolo, e que foi utilizado nos Ensaios Químicos pelo IPT. 
Tabela 10: Dados da avaliação qualitativa do volume de eflorescência na superfície dos fragmentos, após o ensaio de simulação

\begin{tabular}{|c|c|}
\hline Material & Cor da eflorescência \\
\hline Fragmento "MY 0102" (LMCC-Q N. 21.732) & $\begin{array}{c}\text { Amarela esbranquiçada } \\
\text { (discretas manchas dispersas) }\end{array}$ \\
\hline Fragmento "MY 0106" (LMCC-Q № 21.733) & Branca (pontos dispersos) \\
\hline Fragmento "MY 0108" (LMCC-Q N.- 21.734) & Branca (pontos dispersos) \\
\hline Fragmento "MY 0127" (LMCC-Q N. 21.735) & $\begin{array}{l}\text { Amarela esbranquiçada (arestas } \\
\text { do topo) }\end{array}$ \\
\hline Fragmento "My" (LMCC-Q N. 21.736) & Amarela (arestas do topo) \\
\hline
\end{tabular}

Legenda: Escala qualitativa de ocorrência de eflorescência de sais: 0: nenhuma; 1: muito pouca; 2: pouca; 3: média; 4: elevada; 5: muito elevada. O símbolo + acrescido na escala qualitativa indica tratar-se de ocorrências intermediárias entre o respectivo número e o número superior.

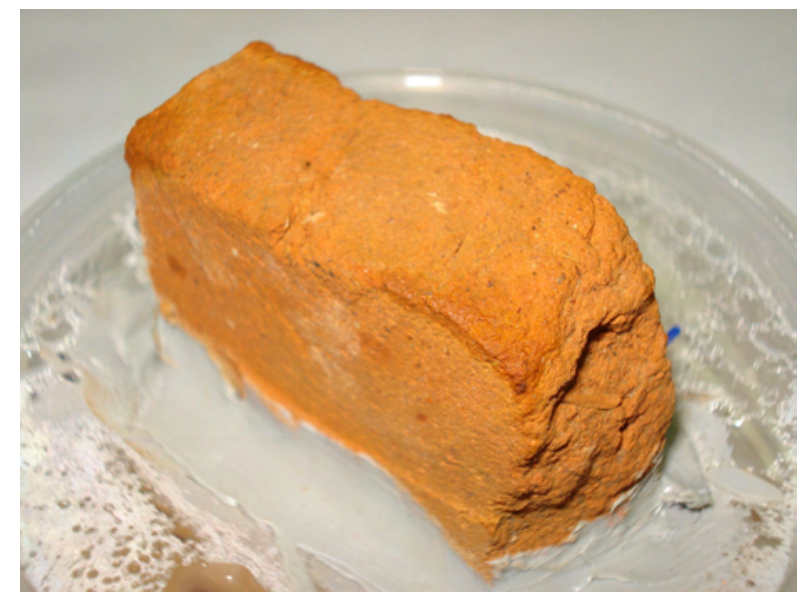

Foto 5: Aspecto do fragmento "MY 0102" (LMCC-Q N. 21.732), após o ensaio

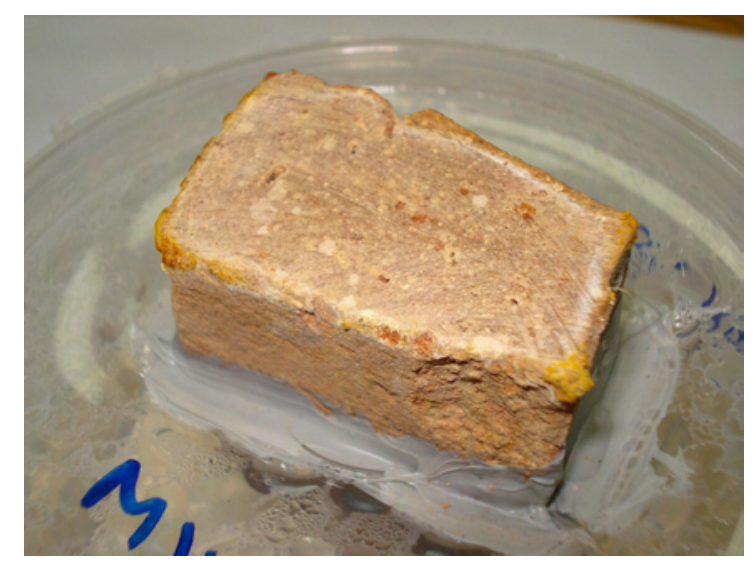

Foto 7: Aspecto do fragmento "MY 0108" (LMCC-Q N.o 21.734), após 0 ensaio

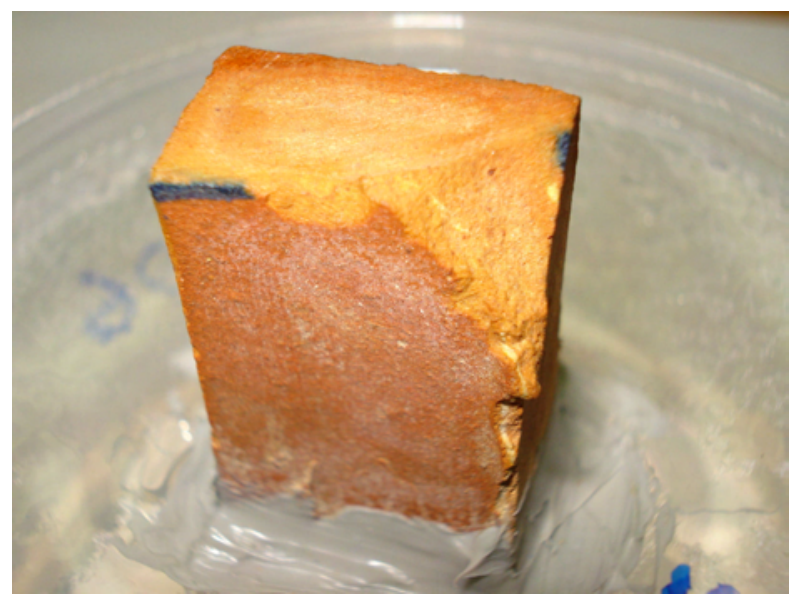

Foto 6: Aspecto do fragmento "MY 0106" (LMCC-Q N. 21.733), após o ensaio

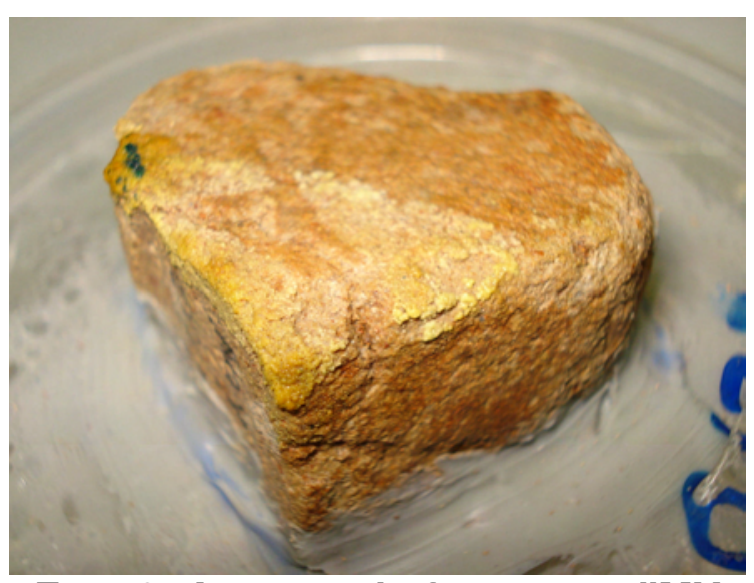

Foto 8: Aspecto do fragmento "MY 0127" (LMCC-Q N. 21.735), após o ensaio 


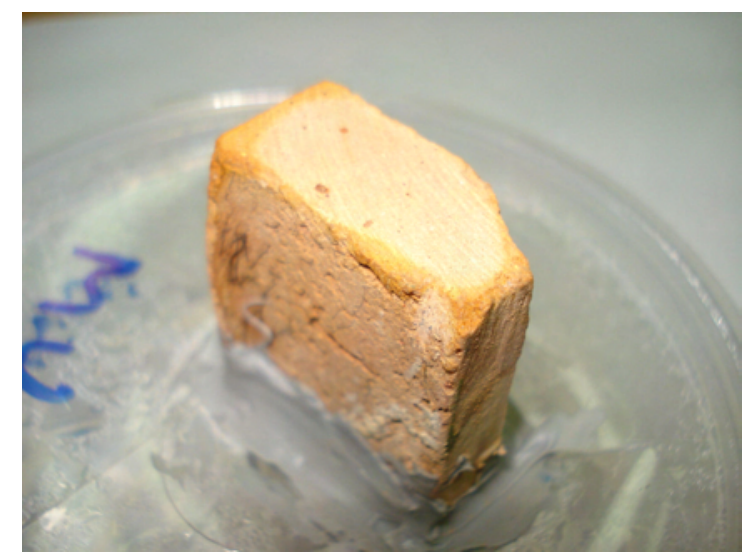

\section{Foto 9: Aspecto do fragmento "MU" (LMCC-Q N. 21.736), após 0 ensaio}

No período em que as amostras permaneceram em estufa houve discreta formação visível de eflorescência, sendo mais pronunciada nos fragmentos "MY 0108" (LMCC-Q N.․21.734) e "MY 0127" (LMCC-Q N.ำ 21.735). Após a exposição dos fragmentos em ambiente de laboratório, observou-se um aumento da formação de eflorescências nas arestas de alguns fragmentos "MY 0108" (LMCC-Q N. 21.734) e "MY 0127" (LMCC-Q N. 21.735) e manutenção de discreta formação nos demais fragmentos (Tabela 2).

São Paulo, 14 de dezembro de 2.007.

\section{EQUIPE TÉCNICA}

Daniel Martins Aleixo - Químico

Fabiano Ferreira Chotoli - Químico

José Francisco de Paula - Técnico Químico

Eduardo Brandau Quitete - Geólogo

Mirian Cruxem Barros de Oliveira - Geóloga

Valdecir Ângelo Quarcioni - Químico 


\title{
ANÁLISES LABORATORIAIS e ANÁLISE DOS RESULTADOS
}

\author{
DRX - DIFRAÇÃO DE RAIOS-X \\ LCT - Laboratório de Caracterização Tecnológica \\ Departamento de Engenharia de Minas e de Petróleo \\ Escola Politécnica da Universidade de São Paulo
}

Rui Barbosa de Souza

\section{IDENTIFICAÇÃO POR DIFRAÇÃO DE RAIOS-X DOS COMPOSTOS PRESENTES EM AMOSTRAS DE ARGAMASSAS DE CIMENTO PORTLAND E CIMENTO ROMANO}

\section{FERRAMENTA DE INTERPRETAÇÃO DAS DIFRAÇÕES}

A identificação das fases cristalinas foi obtida utilizando o software Philips X'Pert HighScore versão $1.0 \mathrm{~b}$, por comparação do difratograma das amostras com o banco de dados do ano de 2003 do ICDD - International Centre for Diffraction Data.

\section{Identificação das Amostras Tabela 1 - Identificação das amostras interpretadas}

\begin{tabular}{|c|c|c|c|}
\hline código & identificação & estado & descrição \\
\hline $0639 / 07$ & Ornamento & Íntegra & $\begin{array}{c}\text { Argamassa com Cimento Romano, de } \\
\text { ornamento pré-moldado }\end{array}$ \\
\hline $0640 / 07$ & P1 - Referência & Íntegra & $\begin{array}{c}\text { Argamassa de revestimento retirada da } \\
\text { fachada sul, no primeiro andar }\end{array}$ \\
\hline $0641 / 07$ & Mirante & Íntegra & $\begin{array}{c}\text { Argamassa de revestimento retirada do } \\
\text { Mirante, no último andar do edifício, em área } \\
\text { descoberta, desprendida da alvenaria }\end{array}$ \\
\hline $0768 / 07$ & $\begin{array}{c}\text { P2 - Ornamento de } \\
\text { cimento Portland }\end{array}$ & Desagregada & $\begin{array}{c}\text { Argamassa com Cimento Portland, de } \\
\text { ornamento moldado in loco }\end{array}$ \\
\hline
\end{tabular}

\section{COMENTÁRIOS E DISCUSSÕES SOBRE OS RESULTADOS}

Todas as amostras de argamassas (ornamentos e revestimento), listadas no item anterior (item 4.1.), foram interpretadas, constando da interpretação a identificação dos compostos cristalinos presentes nas amostras ensaiadas.

As amostras fazem parte de um estudo de diagnóstico das manifestações patológicas observadas no edifício do Museu Paulista da Universidade de São Paulo, sendo como objetivo a identificação das causas do processo deletério causador de grandes manifestações patológicas nas argamassas de revestimento, ornamentos e na própria alvenaria.

Das amostras estudadas, as variáveis são:

- Estado de degradação da amostra - desagregada ou íntegra

- Tipo de argamassa - argamassa de ornamento com cimento Romano ou argamassa com Cimento Portland; Exposição à umidade - maior ou menor exposição à umidade da chuva, ou ascendente do solo.

Para facilitar a identificação dos compostos cristalinos presentes nas amostras, foram adotadas siglas como abreviação dos nomes dos compostos. A Tabela 2 expõe os significados das siglas. 
Tabela 2 - Legenda das siglas utilizadas nos difratogramas.

\begin{tabular}{|c|c|c|}
\hline sigla & composto cristalino & fórmula química \\
\hline $\mathrm{P}$ & Portlandita & $\mathrm{Ca}(\mathrm{OH})_{2}$ \\
\hline $\mathrm{C} 1$ & $\mathrm{C}-\mathrm{S}-\mathrm{H}$ & $x \mathrm{CaO} \cdot y \mathrm{SiO}_{2} \cdot \mathrm{zH}_{2} \mathrm{O}$ \\
\hline $\mathrm{Q}$ & Quartzo & $\mathrm{SiO}_{2}$ \\
\hline $\mathrm{C}$ & Calcita & $\mathrm{CaCO}_{3}$ \\
\hline $\mathrm{CS}$ & Carbossilicato de cálcio & $\mathrm{Ca}_{5} \mathrm{Si}_{2} \mathrm{O}_{7}\left(\mathrm{CO}_{3}\right)_{2}$ \\
\hline $\mathrm{G}$ & Gipsita & $\mathrm{CaSO}_{4} \cdot 2 \mathrm{H}_{2} \mathrm{O}$ \\
\hline $\mathrm{Mv}$ & Muscovita & $(\mathrm{K}, \mathrm{Na})\left(\mathrm{Al}, \mathrm{Mg}, \mathrm{Fe}_{2}\left(\mathrm{Si}_{3.1} \mathrm{Al} \mathrm{O}_{0.9}\right) \mathrm{O}_{10}(\mathrm{OH})_{2}\right.$ \\
\hline $\mathrm{SA}$ & Silicoaluminato de potássio & $3 \mathrm{Sl}_{2} \mathrm{O}_{3} \cdot 2 \mathrm{SiO}_{3}$ \\
\hline $\mathrm{Mu}$ & Mulita & $\mathrm{Fe}_{2} \mathrm{O}_{3}$ \\
\hline $\mathrm{H}$ & Hematita & $\mathrm{Fe}_{3} \mathrm{O}_{4}$ \\
\hline $\mathrm{Ma}$ & Magnetita & \\
\hline
\end{tabular}

\section{AMOSTRA P1 - ÍNTEGRA - AMOSTRA DE REFERÊNCIA}

Os compostos cristalinos do cimento Portland hidratado, normalmente identificados em amostras de materiais cimentícios, são: portlandita; C-S-H; aluminatos de cálcio hidratados; carboaluminato de cálcio hidratado; monossulfoaluminato; até mesmo os anidros $C_{2} S$; $C_{3} S$ e $C_{4} A F$.

Para facilitar a interpretação, a amostra de referência foi comparada com uma amostra qualquer de pasta de cimento Portland tipo 1 (sem adições minerais). Os difratogramas das amostras estudadas não mostram a presença destes compostos relativos ao cimento hidratado. Como pode ser visto na Figura 1, onde o difratograma da amostra de referência está sobreposto ao difratograma de uma amostra de cimento Portland CP-I, o pico de intensidade $100 \%$ referente à portlandita (em torno de $18^{\circ}{ }^{2}$ Theta) não aparece no difratograma da amostra de referência. Através da Figura 1 se observa que também não há indicação de presença de C-S-H na amostra de referência. O halo amorfo do C$\mathrm{S}-\mathrm{H}$, que é o principal indicativo de sua presença, e os picos referentes a este composto hidratado, não aparece no difratograma da amostra de referência.

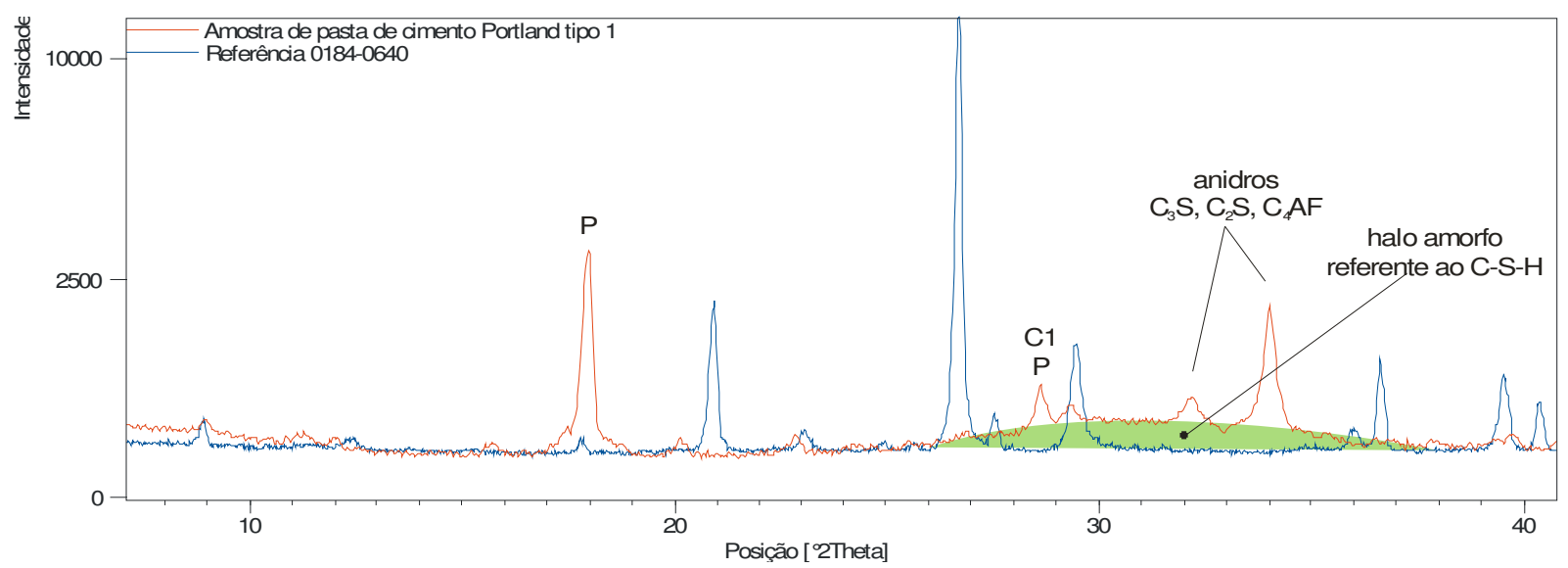

Figura 1 - Difratograma da amostra de referência comparada com uma amostra de pasta de cimento Portland tipo 1. 
A Figura 1 demonstra que:

Os compostos cristalinos do cimento Portland hidratado ${ }^{1}$, comumente são:

Portlandita - hidróxido de cálcio $(\mathrm{CH}), \mathrm{C}-\mathrm{S}-\mathrm{H}$ - silicato de cálcio hidratado, Aluminatos de cálcio hidratado, Carboaluminato de cálcio hidratado, Monossulfoaluminato de cálcio, ou ainda, os compostos anidros do cimento C2S, C3S e C4AF. Ao lado dos constituintes do aglomerante, a difração de raios $X$ indica também os minerais presentes no agregado (quartzo, muscovita, mulita, hematita e magnetita).

O primeiro pode ocorrer em rochas graníticas ou em outras rochas metamórficas, enquanto que o segundo (muscovita) é um mineral comum, em rochas tais como gnaisses, xistos, granitos, arenitos e pegmatitos, onde forma cristais grandes, atingindo dimensões métricas. Em virtude do que foi mencionado, e considerando a grande quantidade de agregado da amostra, conclui-se que a fonte destes dois compostos cristalinos é do agregado.

Foram também identificados picos de muscovita, procedente do agregado.

A Figura 2 mostra o difratograma da amostra de referência. - Amostra P1

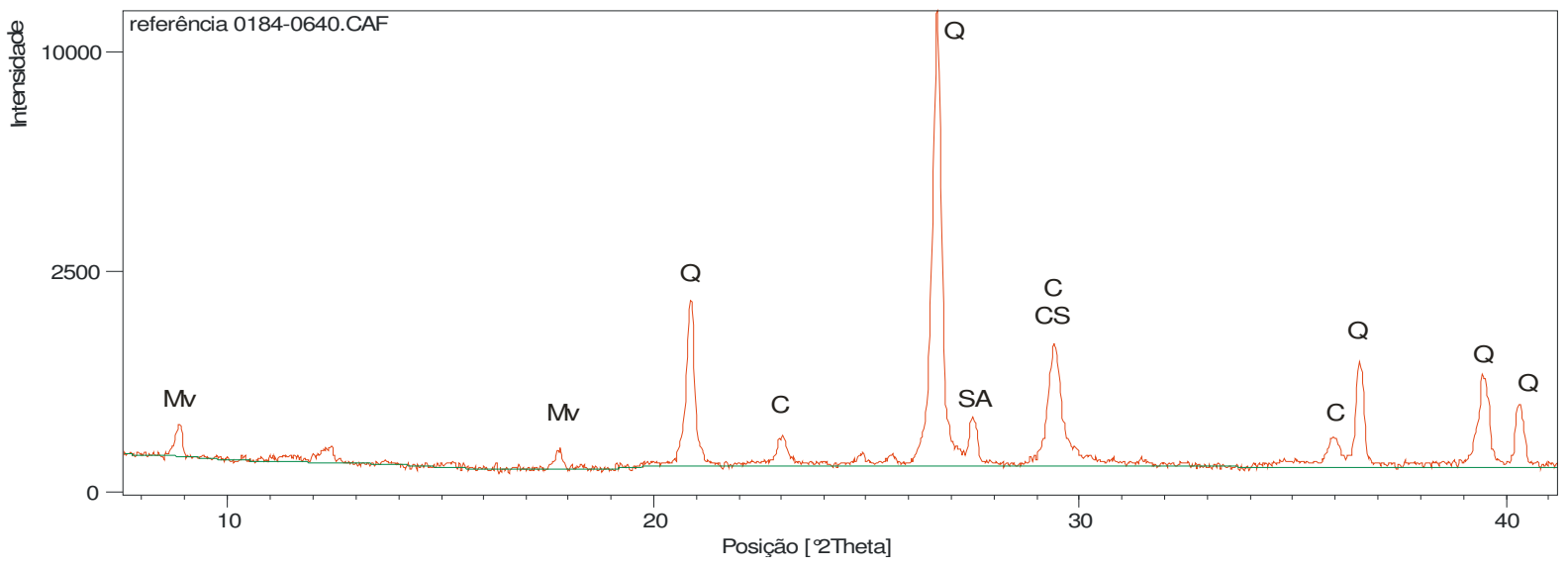

Figura 2 - Difratograma da AMOSTRA P1 (argamassa íntegra, com cimento Portland, retirada da fachada sul do prédio).

\section{Amostra Mirante}

A amostra apresentava descolamento da parede. Esta amostra ficava sujeita à umidade das chuvas e da infiltração que ocorria pelas rachaduras na parte superior destas paredes, isto é, de dentro para fora.

Apesar das diferentes condições frente à umidade da Amostra do Mirante e da Amostra P 1, que só recebe umidade de chuva, o resultado da DRX foi idêntico para as duas amostras, como pode ser visto pela Figura 4.

${ }^{1} \mathrm{~S}-\mathrm{SiO}_{2} ; \mathrm{C}-\mathrm{CaO} ; \mathrm{A}-\mathrm{Al}_{2} \mathrm{O}_{3} ; \mathrm{F}-\mathrm{Fe}_{2} \mathrm{O}_{3} ; \mathrm{H}-\mathrm{H}_{2} \mathrm{O}$. 


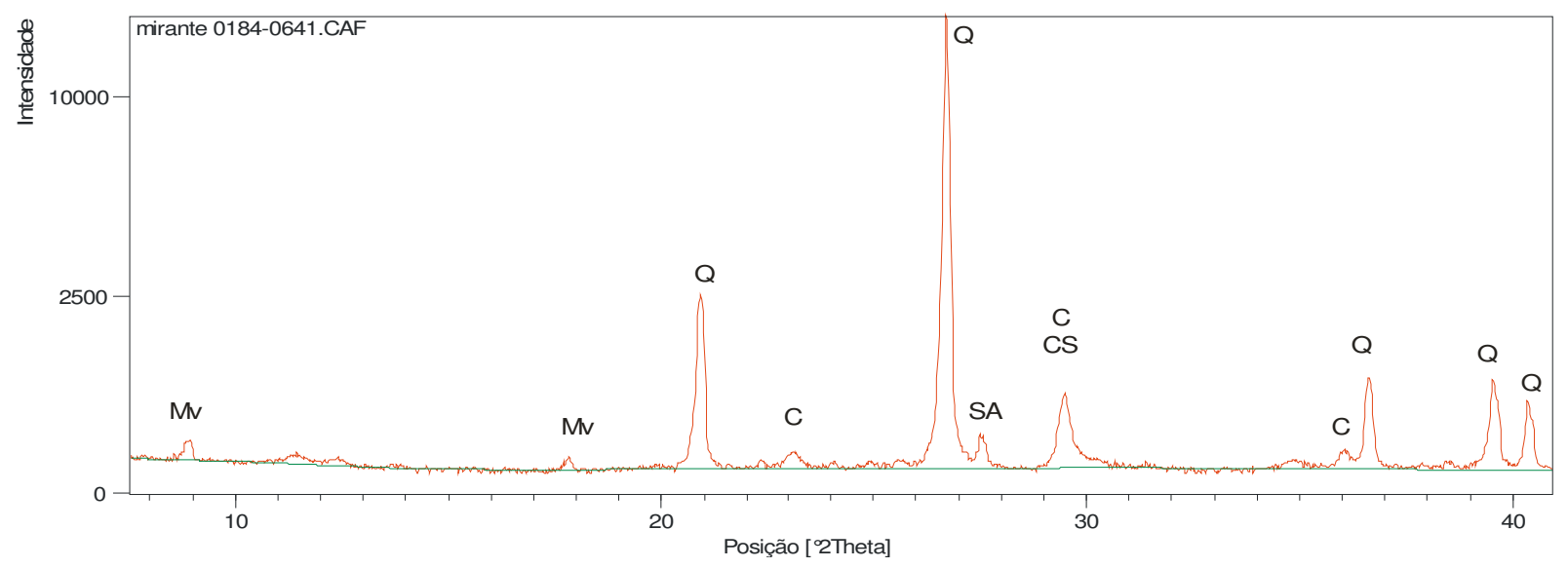

Figura 3 - Difratograma da AMOSTRA DO MIRANTE (argamassa íntegra, com cimento Portland, retirada do revestimento do mirante, no alto do prédio).

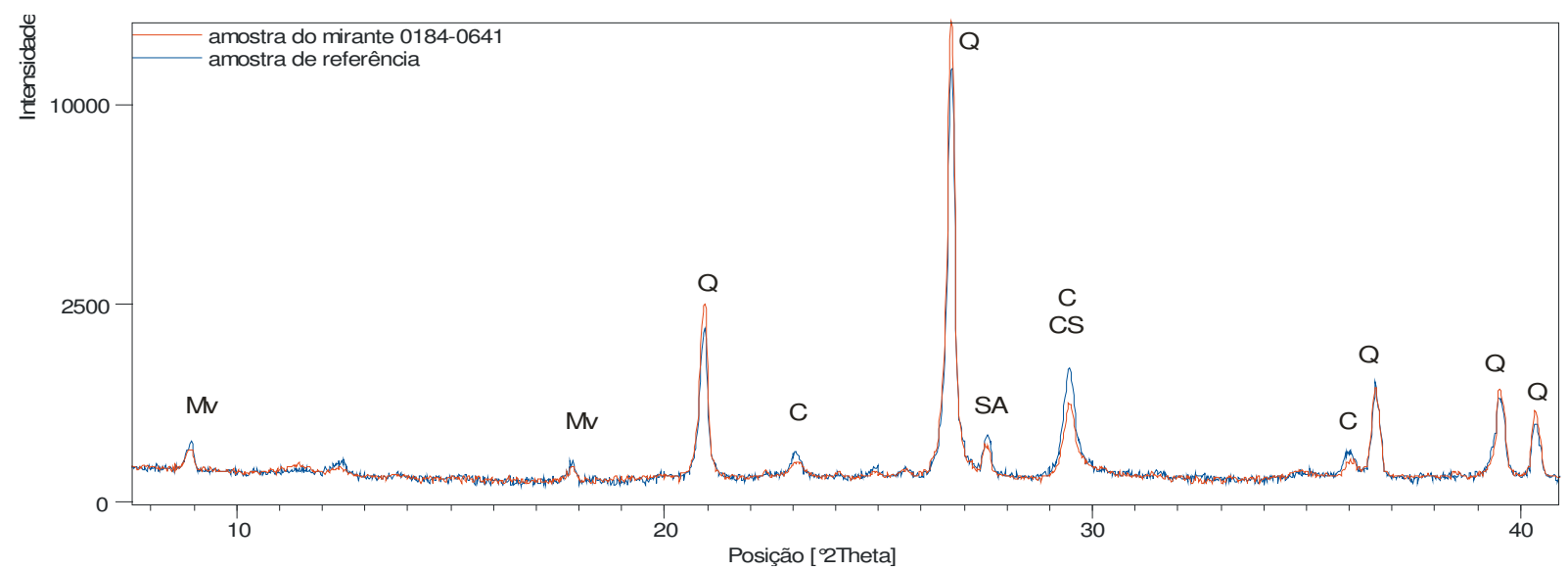

Figura 4 - Difratograma da AMOSTRA DO MIRANTE comparada com a AMOSTRA DE REFERENCIA.

Os resultados apresentados nas Figura 3 e Figura 4, apresentam resultados semelhantes. Quanto ao descolamento da argamassa da alvenaria, tem-se que considerar duas possibilidades. Pela análise química verifica-se que a argamassa do mirante, é porosa, tem pouca resistência mecânica e suscetível à umidade, resultando em dilatação, contração em função dos ciclos de umidecimento/ secagem, provocando o descolamento da alvenaria. Pode-se ainda considerar a presença de sais e sua cristalização, tendo a sua origem em outro material, como os tijolos.

A agravante é a ausência de chapisco.

\section{AMOSTRA DE ORNAMENTO - CIMENTO ROMANO}

A amostra retirada de ornamentos pré-moldados é diferente das demais, uma vez que a matériaprima deste é o cimento Romano, ao invés do cimento Portland. O difratograma desta amostra apresentou algumas diferenças com relação às argamassas de cimento Portland, a começar pela ausência de muscovita e silicoaluminato de potássio, indicando não haver a mesma fonte de potássio observado nas amostras anteriores. Também não houve nenhuma indicação de presença de monossulfoaluminato de cálcio hidratado. Ao invés disso, observou-se a presença de gipsita, sendo identificados por picos isolados no difratograma, como mostram a Figura 5 e Figura 6. 


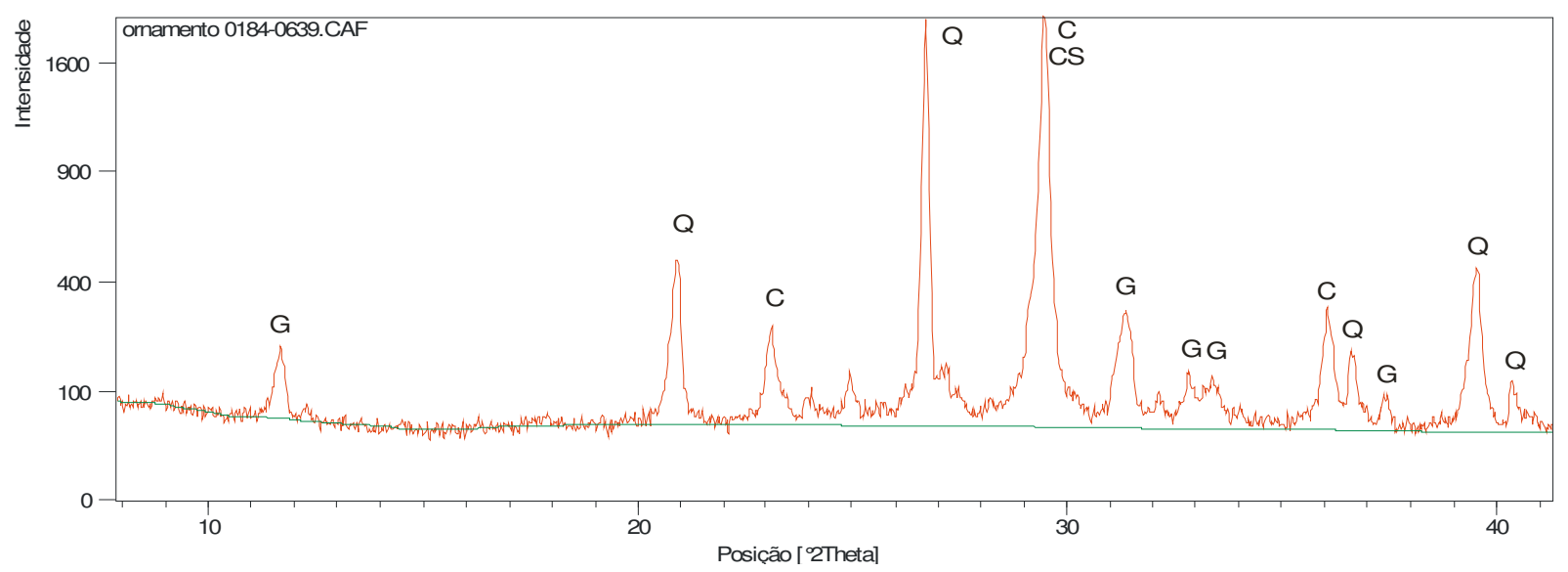

Figura 5 - Difratograma da amostra do ornamento com CIMENTO ROMANO, retirada de ornamentos prémoldados).

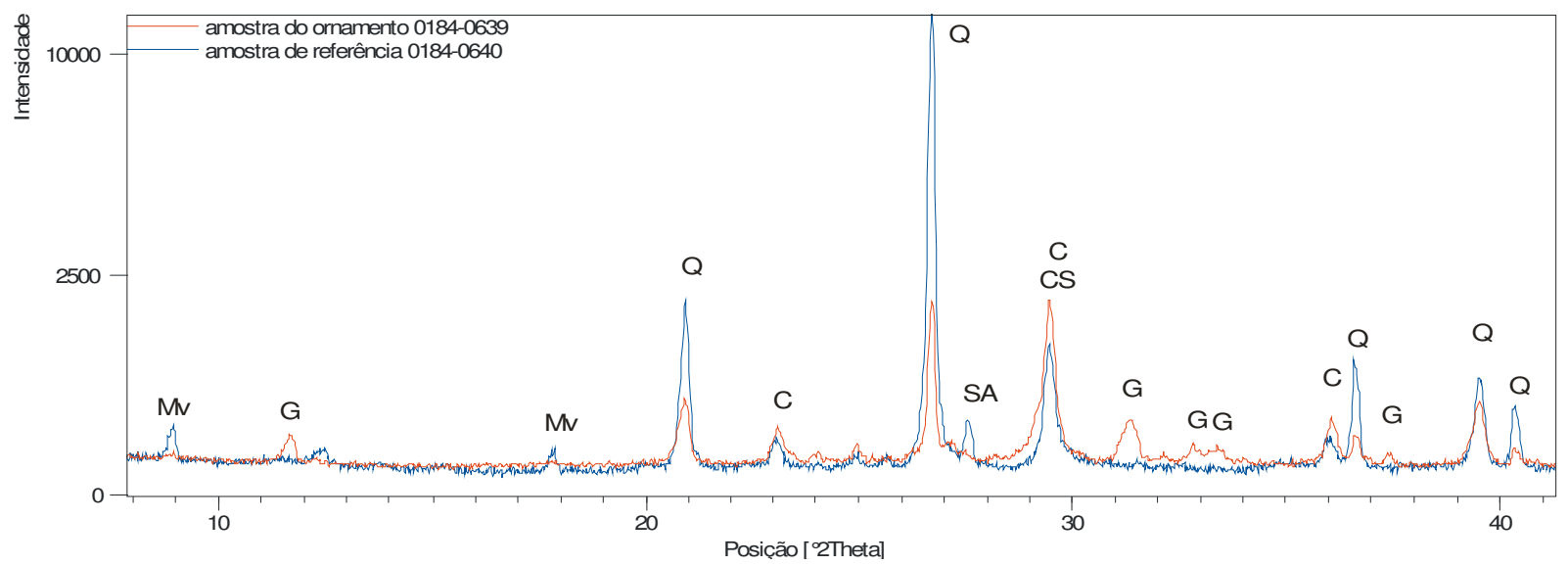

Figura 6 - Difratograma da amostra de ornamento CIMENTO ROMANO comparada com a AMOSTRA P1

O cimento Romano é a mistura de cinza volante e cal. Compostos cristalinos normalmente presentes na cinza volante são: mulita, hematita e magnetita. Verificando a presença destes compostos cristalinos na amostra, observou-se que a presença no difratograma não é conclusiva, com os picos principais aparecendo sobrepostos a outros picos mais intensos ou em pequenos ombros. Assim, não se pode afirmar que há ou não há cada um destes compostos cristalinos (Figura 7). 


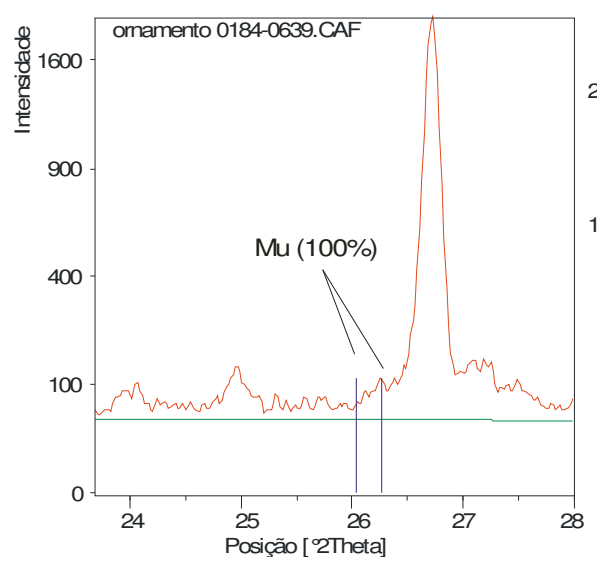

(a)

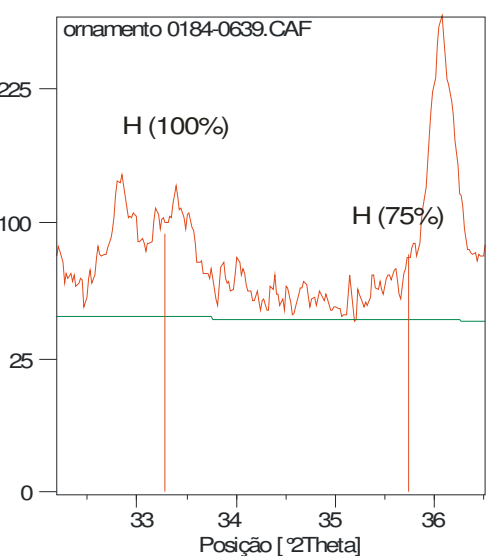

(b)

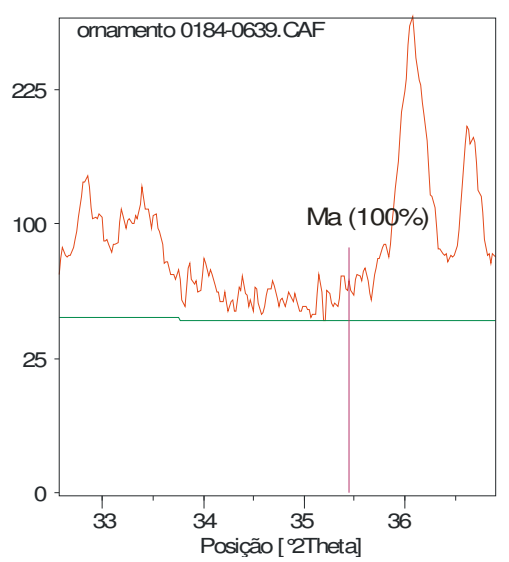

(c)

Figura 7 - Detalhes do difratograma da amostra do ornamento (com cimento Romano, retirada de ornamentos prémoldados). (a) picos de intensidade 100\% da Mulita; (b) picos de intensidade $100 \%$ e $75 \%$ da Hematita; (c) pico de intensidade $100 \%$ da Magnetita.

\section{AMOSTRA P2 - ORNAMENTO DE CIMENTO PORTLAND}

A quarta amostra estudada é de argamassa de cimento Portland de ornamentos moldados in loco e apresenta desagregação. Esta amostra não contém cimento Romano. O difratograma foi bastante próximo da amostra de referência, com a única diferença sendo a presença de gipsita, podendo ser oriunda do ataque por sulfato de magnésio.

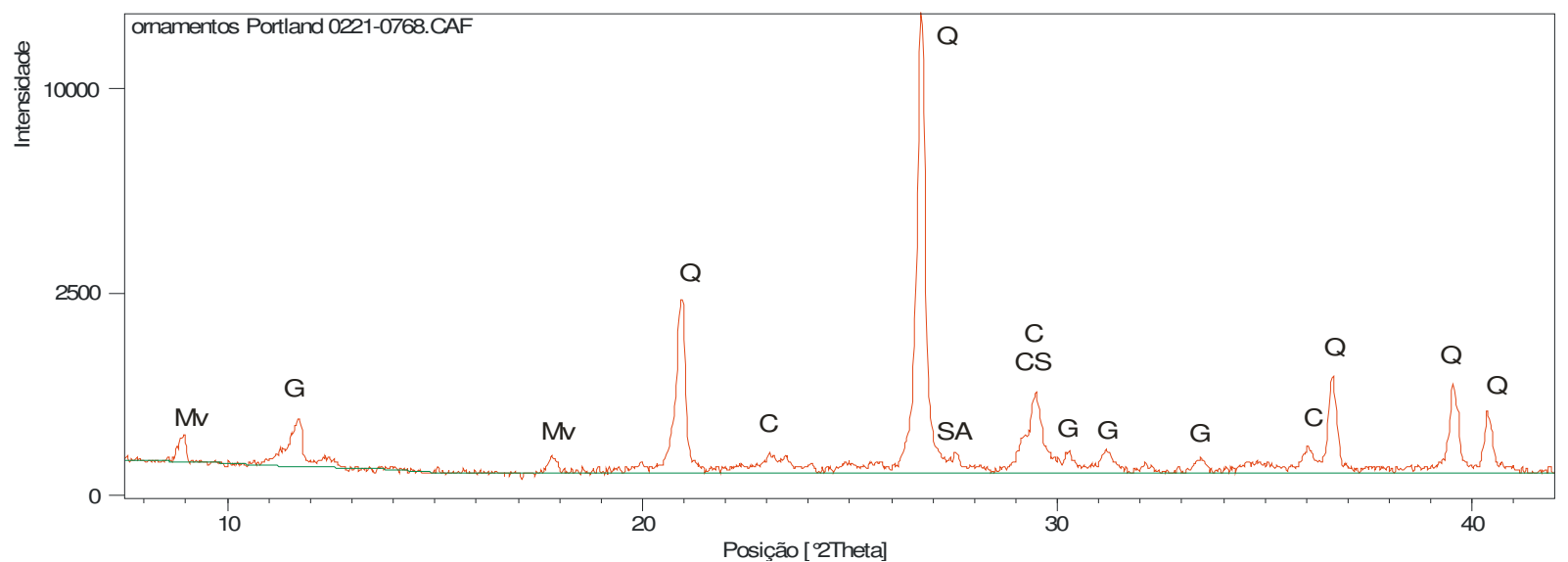

Figura 8 - Difratograma da AMOSTRA P2 do ornamento moldado in loco (argamassa degradada, com cimento Portland). 


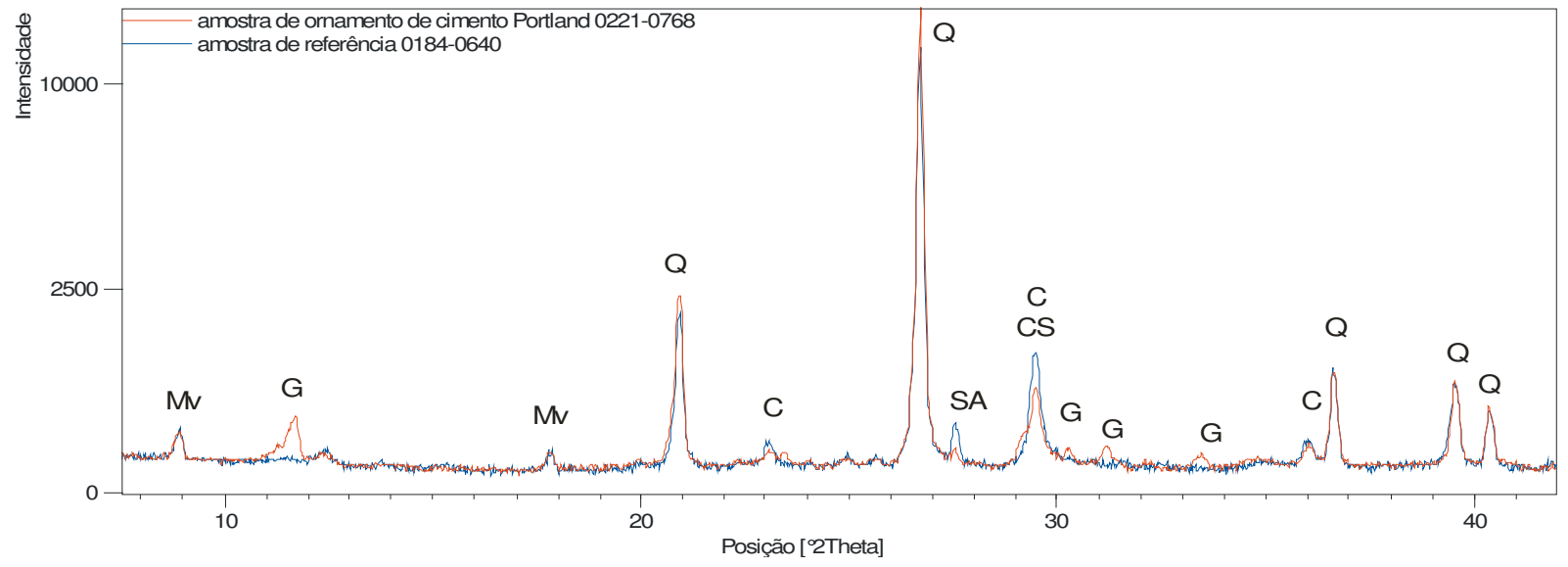

Figura 9 - Difratograma da amostra de ornamento de cimento Portland comparada com a amostra de referência.

Foi observado - Gipsita, confirmando o teor de anidrido sulfúrico determinado na análise química.(dado da análise química realizada pelo IPT).

A amostra P2 extraída de uma vesícula com fissuração e desagregada, se diferiu do difratograma da P1 pela presença de Gipsita, o que explica a sua desagregação. Não foi indicada a presença de gipsita na amostra P1.

Esta informação indica a presença de sais como uma das causas da desagregação da argamassa P2.

\section{CONCLUSÕES}

Dos compostos cristalinos identificados nos difratogramas, observou-se que poucas alterações ocorreram entre as amostras, com as maiores diferenças entre a amostra de ornamento de cimento romano e as demais amostras. As diferenças são oriundas da argamassa de cimento Romano, além da possível adição de gipsita para o controle da pega destes artefatos pré-moldados. Entretanto, as argamassas de revestimento e artefatos moldados in loco, são de cimento Portland, e possivelmente com menor consumo de cimento (menor quantidade de agregados nas argamassas). Não foram detectados picos relativos aos compostos hidratados comuns do cimento. Os compostos identificados sempre estavam carbonatados, ou eram produto da reação com sulfatos. Isso ocorre devido a dois fatores: o primeiro, a amostra é de argamassa, contendo agregados de quartzo, altamente cristalino, sobrepondo-se aos picos dos demais compostos; o segundo, a idade avançada da amostra, que ficou exposta muitos anos às ações deletérias de carbonatação, e ataques químicos do meio ambiente.

Em virtude dos resultados apresentados, a ação de molhagem e secagem é a causa mais provável da degradação das argamassas. Produziu o descolamento da argamassa da alvenaria, a desagregação da argamassa, fissuras e desprendimento dos ornamentos, que foi agravado pela cristalização de sais solúveis. A expansão foi de tal forma, que rompeu as argamassas, resultando nas manifestações patológicas existentes hoje na edificação. 


MEV - MICROSCOPIA ELETRÔNICA DE VARREDURA
EDS - ESPECTRO DE ENERGIA DISPERSIVA
LCT - Laboratório de Caracterização Tecnológica
Departamento de Engenharia de Minas e de Petróleo - Escola Politécnica da
Universidade de São Paulo

\section{Liz Zanchetta D'Agostino}

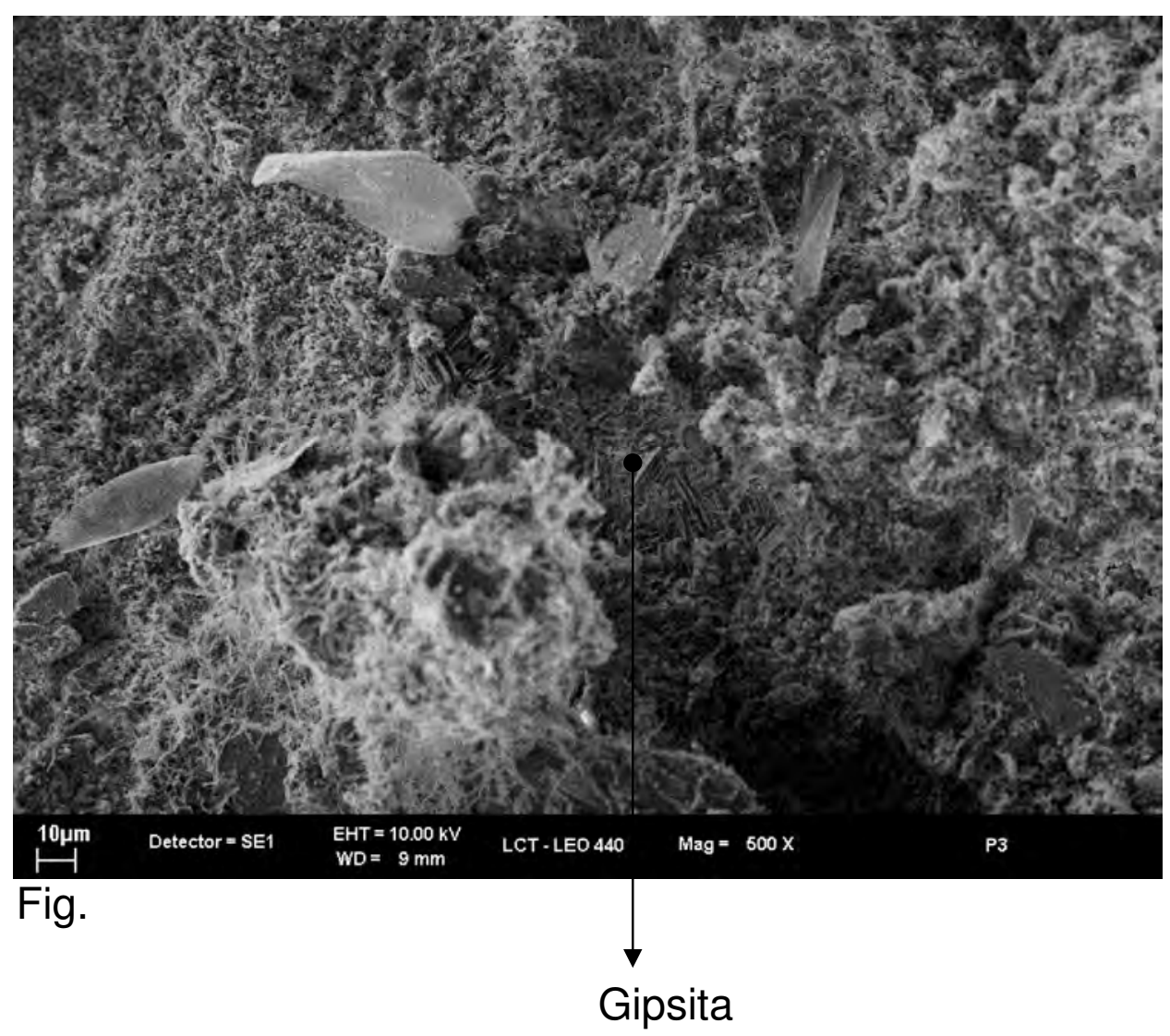

Esta análise utilizou a Amostra P3, na mesma região que a P2, nas mesmas condições. A imagem do MEV focaliza atrás de uma camada de tinta com argamassa aderida. Visualiza uma estrutura cristalina, identificada como Gipsita, considerada como uma das causas da desagregação da argamassa. Confirma o resultado do DRX na Amostra P2. 


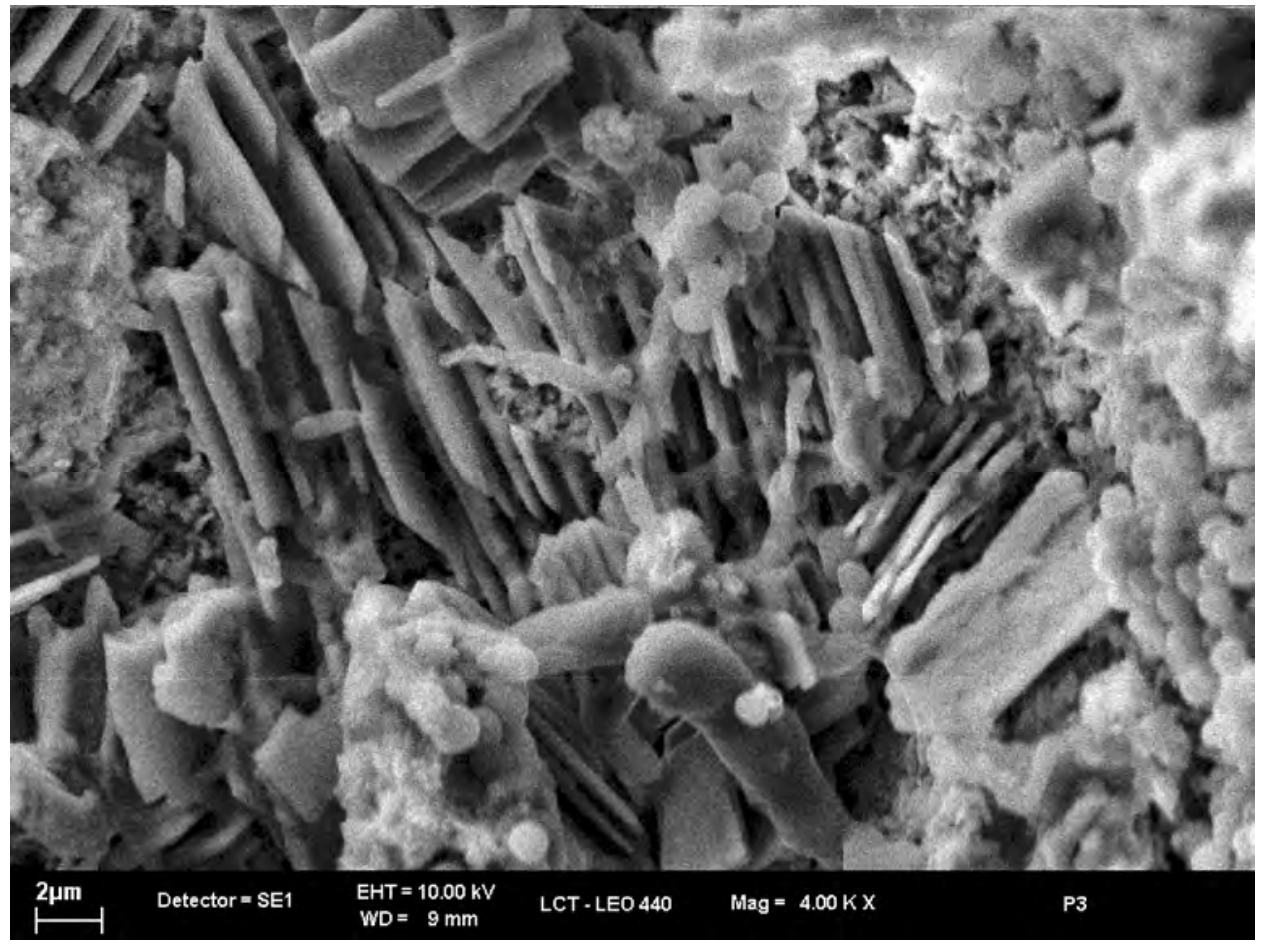

Fig.

Detalhe: Gipsita (sais cristalizados)

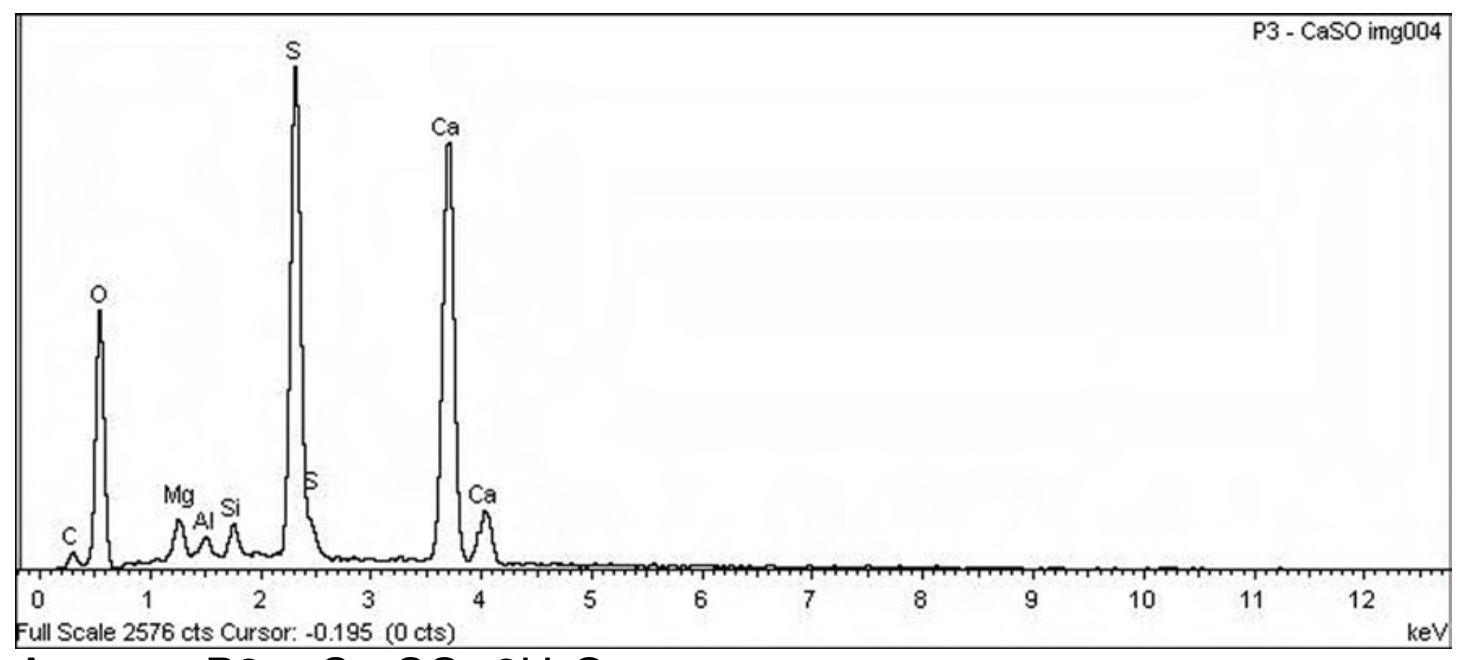
Amostra P3 - $\mathrm{Ca}_{5} \mathrm{SO}_{4} .2 \mathrm{H}_{2} \mathrm{O}$ 


\section{ENSAIOS EM AMOSTRA: CAMADA DE TINTA}

Foram realizados dois Ensaios em Amostra de Camada de Tinta:

- A Espectroscopia Raman, com amostra extraída da lateral superior do guardacorpo de uma sacada na fachada sul

- MEV de uma coletada na lateral da lacuna na parede onde ocorreu eflorescência sobre tijolo sem revestimento, na Entrada Leste.

Os dois ensaios captaram imagens em corte estratigráfico, onde o resultado foi semelhante: duas camadas de tinta amarela e uma rósea.

Esta camada rósea pode ser observada em alguns locais nas paredes do edifício.

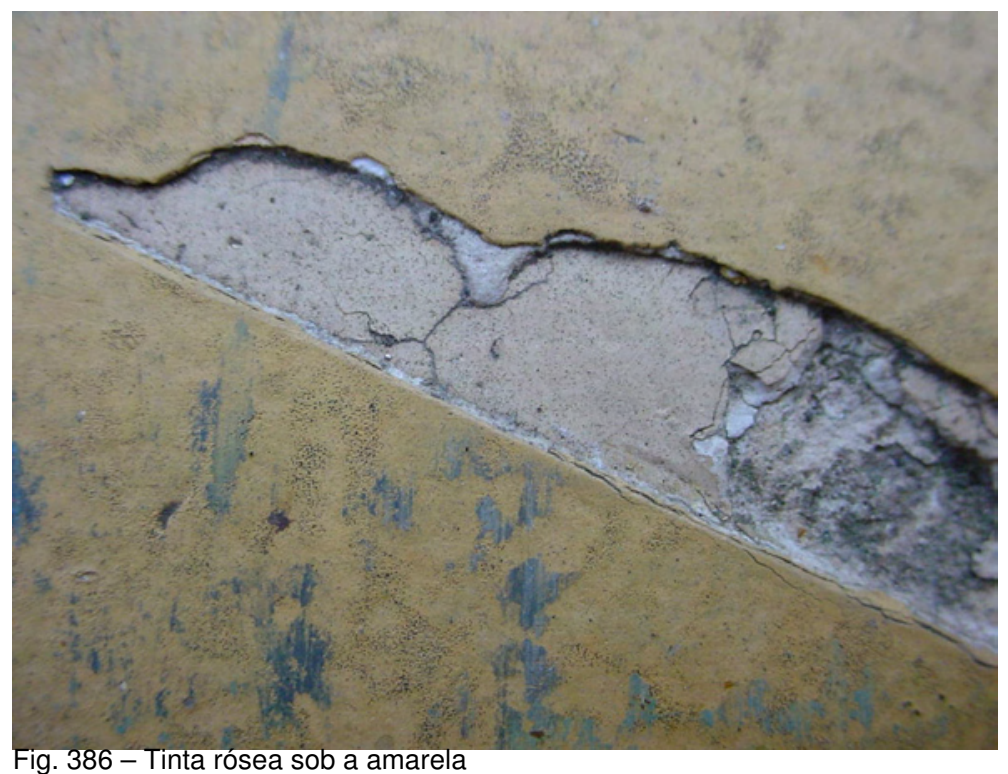

Foram realizados algumas prospecções e os resultados não foram conclusivos. Cada local apresentava uma situação diferente.

Supõe-se que não existam mais todas as camadas de tinta, devido às preparações que eram feitas em cada pintura. E foi possível observar, que não há uma uniformidade de camadas de tinta. Varia em função das intervenções, pois quando era necessário aplicavam massa corrida, ou não. Assim não prepararam as superfícies das paredes sempre da mesma forma. Hoje não é mais possível fazer prospecções com um resultando que seja completamente satisfatório.

Pelos dois ensaios, com amostras de locais diferentes, mostraram que sob a camada rósea, há uma camada de preparação, possivelmente uma massa corrida e a argamassa da parede.

Foi utilizado um Líquido Preparador de superfície na pintura de 1972 à base de óleo e assim deve ter impregnado a tinta. É possível que hoje este óleo tenha sido identificado na tinta rósea, através da Espectroscopia Raman.

Pela consulta feita a Coral, as informações obtidas indicam a possibilidade da pintura realizada em 1972 , ter sido esta tinta rósea - a cor mais próxima existente em catálogo é a Corsário e a tinta Coralmur.

A Fig. 3 da Espectroscopia Raman, apresenta um outro local onde não ha tinta rósea, somente as duas amarelas. Este fato pode ocorrer em outros locais. 


\section{ESPECTROSCOPIA RAMAN Instituto de Química da Universidade de São Paulo}

\section{Dalva Lúcia de Faria}

\section{O que é}

Dentre as técnicas de caracterização de substâncias os métodos espectroscópicos ocupam posição destacada por permitirem a obtenção de uma quantidade muito grande de informação sobre as amostras de modo minimamente invasivo ou, eventualmente, não invasivo. Essas técnicas estão baseadas na interação de algum tipo de radiação eletromagnética (radiação visível, no infravermelho, no ultravioleta, no infravermelho próximo, microondas etc) com a matéria, causando absorção, emissão ou espalhamento de radiação.

De particular interesse é a espectroscopia Raman porque possibilita a investigação sem a necessidade de retirar fragmento do objeto ou de manipulá-la através da trituração, solubilização, deposição de filmes em sua superfície etc.

A técnica utiliza um feixe de radiação laser (geralmente de comprimento de onda no visível ou no infravermelho próximo) focalizado em um ponto da amostra e um conjunto de lentes que coletam a radiação que é inelasticamente espalhada por ela, ou seja, a radiação que tem energia (freqüência) diferente da incidente. Um espectro Raman é uma representação gráfica da intensidade da radiação espalhada em função da energia (expressa em número de onda em $\left.\mathrm{cm}^{-1}\right)$. Através desses espectros podem ser obtidas informações sobre as vibrações dos átomos existentes área analisada e como essas vibrações são características das substâncias, permitem a identificação inequívoca dos compostos presentes. Caso um microscópio seja usado acoplado a um espectrômetro Raman tem-se a vantagem adicional da possibilidade de analisar heterogeneidades da ordem de poucos micrometros $\left(10^{-6} \mathrm{~m}\right)$ de diâmetro, sem que seja necessário qualquer tipo de manipulação da amostra.

Além de ser uma técnica não destrutiva ou minimamente invasivo (também chamada de virtualmente não destrutiva), outras vantagens da espectroscopia Raman é o fato de permitir a identificação de substâncias e não apenas elementos químicos, como no caso do EDX e da fluorescência de raios-X; substâncias amorfas podem também ser identificada, ao contrário da difração de raios- $X$, uma vez que a espectroscopia Raman é uma técnica de curto alcance.

Uma das restrições mais sérias à espectroscopia Raman é a luminescência apresentada pela amostra ou por alguma impureza ou contaminação nela presentes, porque essa emissão é muito mais intensa que o espalhamento inelástico. Para viabilizar a obtenção de espectros Raman desse tipo de amostra, geralmente utiliza-se uma radiação laser de menor comprimento de onda (no infravermelho próximo, NIR) no lugar de utilizar uma radiação no visível. Equipamentos que usam esse tipo de radiação são equipamentos interferométricos, sendo portanto chamados de FTRaman (Fourier Transform Raman).

\section{Equipamentos}

As amostras dos fragmentos de tinta foram analisadas em um microscópio Raman Renishaw, modelo System 3000, dotado de detector CCD (Charge Coupled Device) e acoplado a microscópio óptico metalúrgico Olympus $\mathrm{BH} 2-\mathrm{UMA}$. Na obtenção dos espectros foi utilizada a linha em 632,8 nm de um laser de He-Ne (Spectra Physics).

Quando a luminescência da amostra impossibilitou o uso desse equipamento utilizou-se um espectrômetro Raman Bruker RFS-100/S, dotado de detector de germânio refrigerado por nitrogênio líquido e operando com a linha em $1064 \mathrm{~nm}$ de um laser de $\mathrm{Nd}^{3+} / \mathrm{YAG}$.

\section{Amostras}

Foram estudados fragmentos de tinta removidos das paredes da edificação em pontos selecionados e um pó branco formado em grande quantidade em locais nos quais a camada de tinta se desprendeu do substrato formando bolhas que eventualmente se rompiam. 
Como já foi dito, a Microscopia Raman não necessita que amostra seja destruída ou manipulada, entretanto, devido à natureza da informação que se pretende da análise (camadas anteriores de tinta) os fragmentos de tinta foram seccionados usando lâmina cirúrgica de aço e analisados de dois modos diferentes: como corte estratigráfico ou na face mais próxima à alvenaria para permitir a identificação da primeira camada de tinta; neste último caso, a camada pictórica foi ligeiramente lixada para remover sujidades e contaminações antes da obtenção do espectro.

No caso do pó branco, uma pequena quantidade do sólido foi compactada em um orifício de $1 \mathrm{~mm}$ de diâmetro no centro de um disco de alumínio e estudado em equipamento FT-Raman.

Nota: A Amostra Pó Branco - é o mesmo material utilizado no Ensaio Químico pelo IPT, o qual chamou de Eflorescência em reboco (vesícula). Ver p.270 Tabela 8.

\section{Resultados e discussões}

As fotografias abaixo mostram cortes estratigráficos de fragmentos de tinta evidenciando duas camadas de tinta amarela e uma camada rósea, esta mais próxima á parede.
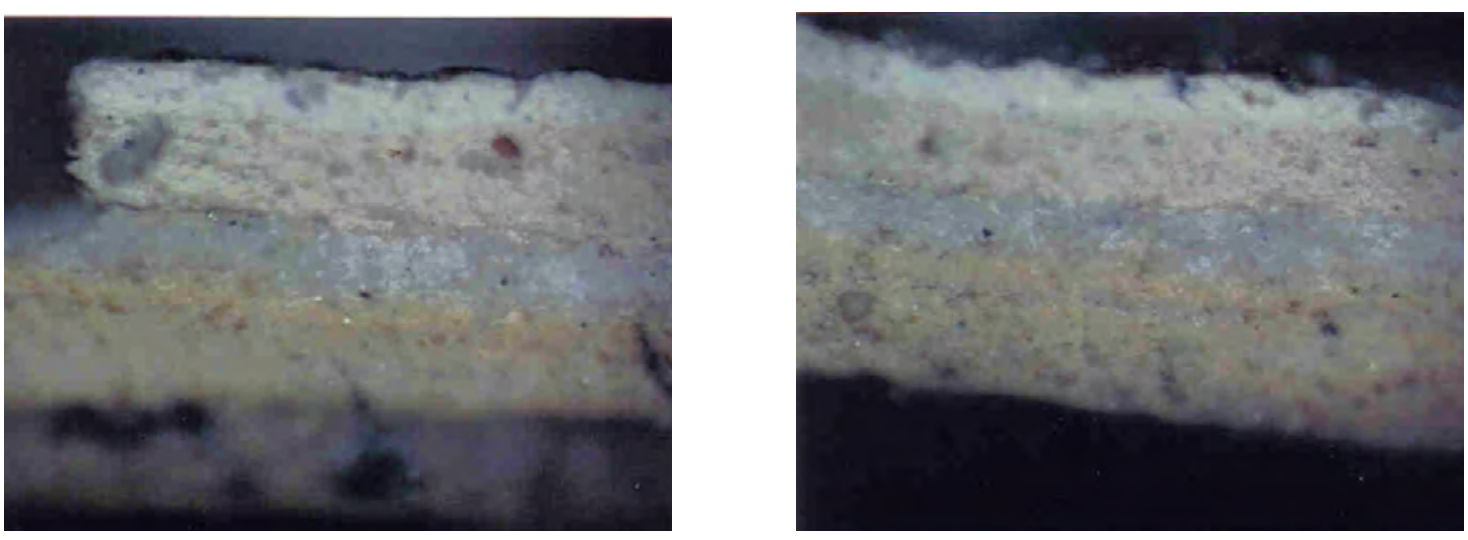

Figura 1:- Fotografia de corte estratigráfico de fragmento de tinta.

A camada rósea tem espessura de 60 a $70 \mu \mathrm{m}$ e as amarelas têm espessura de 20 a 30 $\mu \mathrm{m}$ nesses fragmentos. O espectro mostrado na figura seguinte foi obtido da camada rósea após limpeza para remoção de restos de alvenaria e outras contaminações.

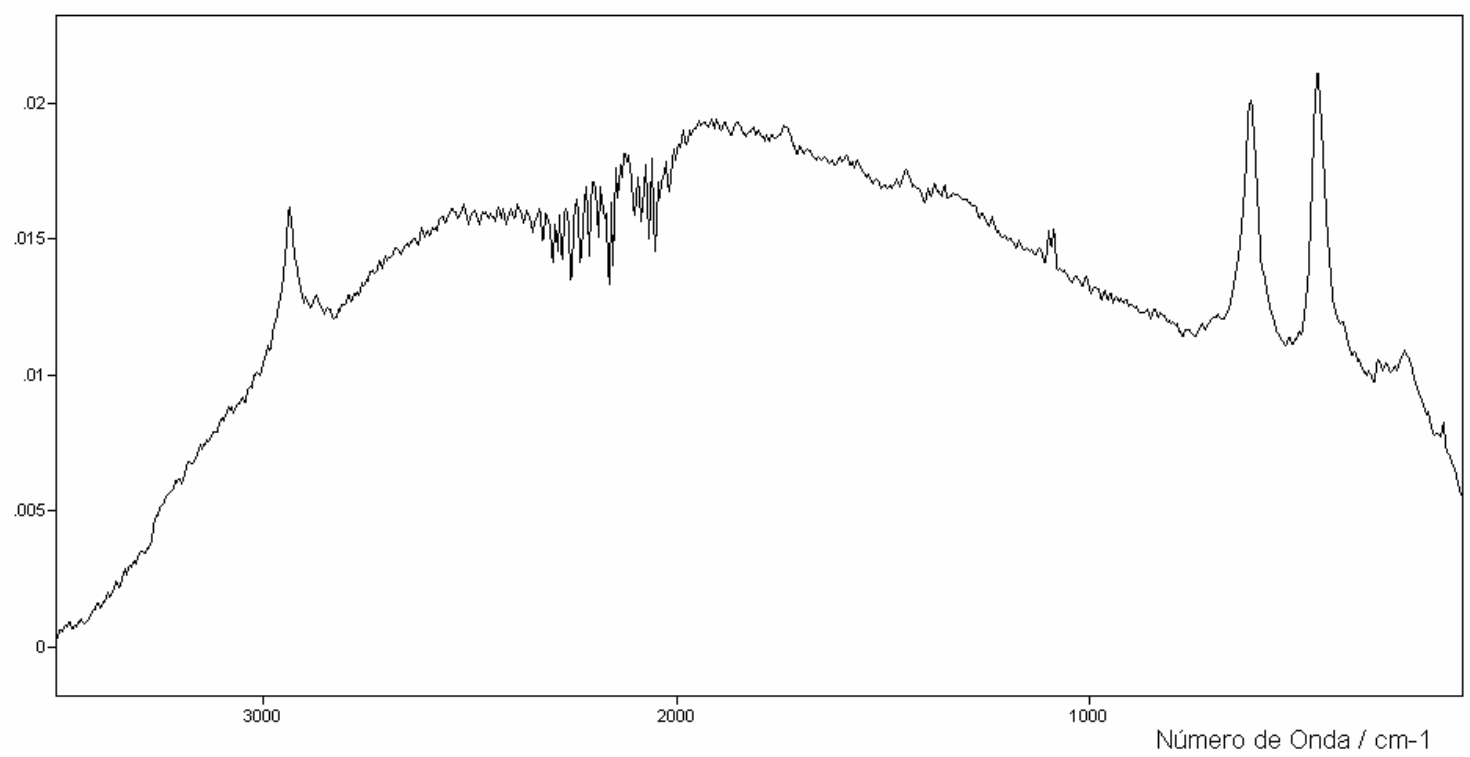

Figura 2:- Espectro FT-Raman da camada de tinta rósea. 
Nele podem ser observadas bandas referentes a compostos orgânicos $(2938,1735,1443$ e $1098 \mathrm{~cm}^{-1}$ ) e inorgânicos $\left(1087,611,448,386,236\right.$ e $\left.142 \mathrm{~cm}^{-1}\right)$, sendo que as duas bandas mais intensas do espectro $\left(611\right.$ e $\left.448 \mathrm{~cm}^{-1}\right)$ são linhas de fluorescência de íons terras raras presentes; das bandas restantes, a mais relevante é a em $1087 \mathrm{~cm}^{-1}$ referente a carbonato de cálcio, que se forma em decorrência da reação entre o gás carbônico $\left(\mathrm{CO}_{2}\right)$ do ar com a água rica em íons cálcio da umidade presente na parede. No caso do composto orgânico as posições das bandas mais relevantes (2938 e $1735 \mathrm{~cm}^{-1}$ ) são compatíveis com as existentes em resinas alquídicas (poliéster) das tintas a óleo.

Quando as camadas brancas e amarelas do corte estratigráfico são examinadas (Fig. 3), registram-se os espectros mostrados nas figuras 4 (amarelo) e 5 (branco); a identificação de cada camada é dada na Fig. 3.

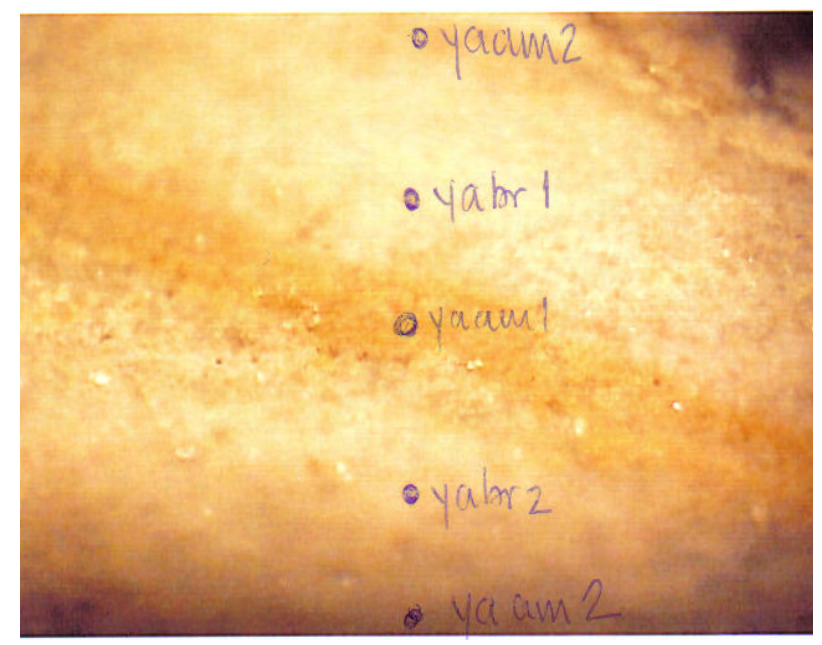

Figura 3:- Fotografia de corte estratigráfico evidenciando as camadas brancas amarelas.

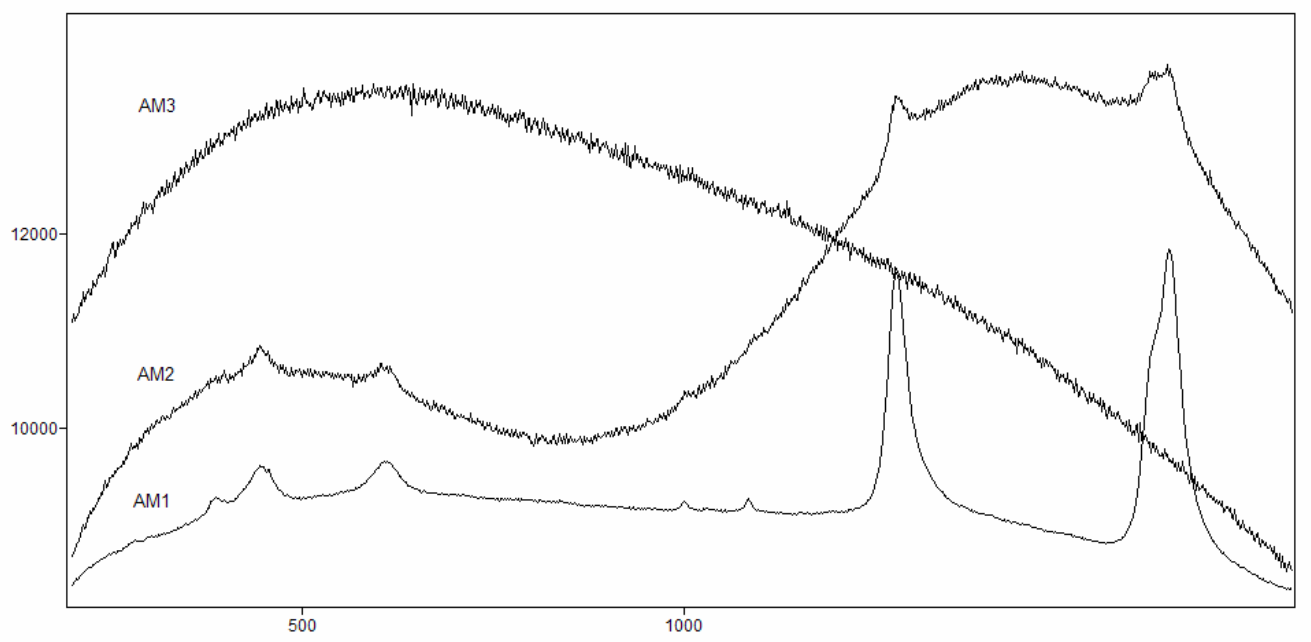

Figura 4:- Espectros Raman das camadas amarelas. 


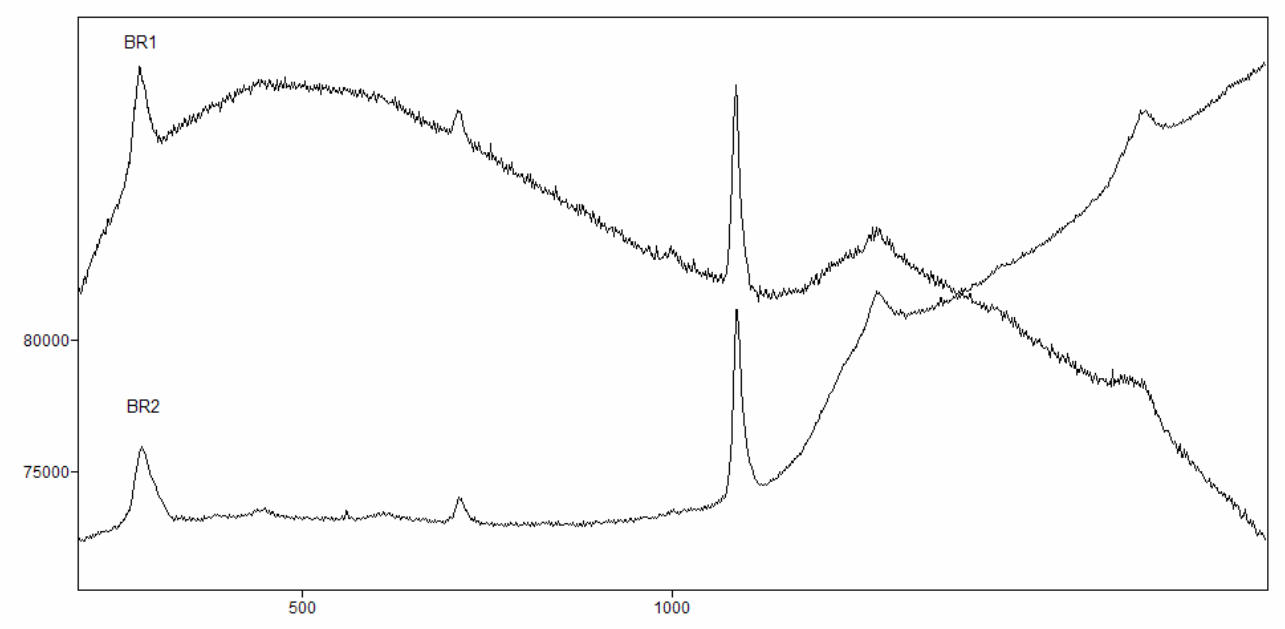

Figura 5:- Espectros Raman das camadas brancas.

Outra amostra mostra comportamento semelhante, como apresentado na figura abaixo:

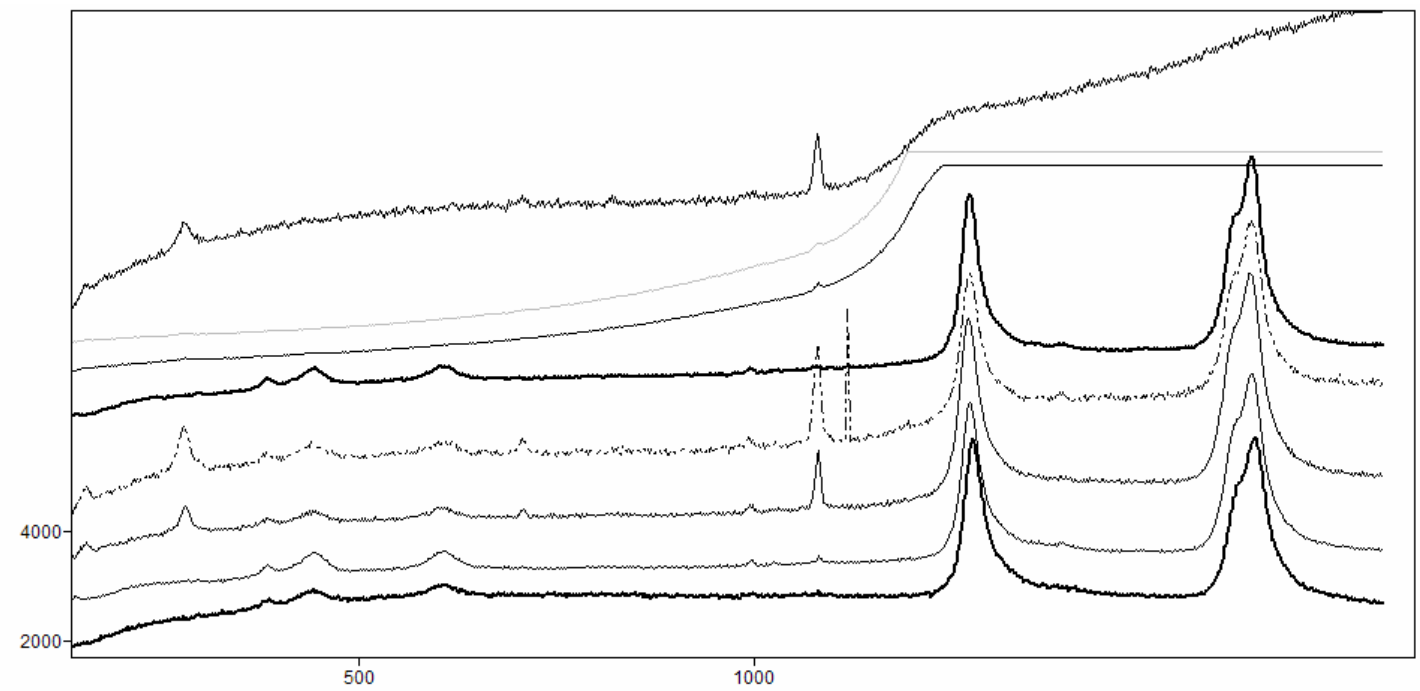

Figura 6:- Espectros Raman (633 nm) feitos de corte estratigráfico. O espectro inferior e 0 tracejado referem-se a camadas amarelas sendo que o primeiro é o da camada mais externa.

Como há ocorrência de luminescência em maior ou menor grau nos espectros e a natureza das duas bandas mais intensas dos espectros mostrados eram incertos (pela intensidade poderia ser emissão de terra rara) foram feitos também os espectros FT-Raman, com excitação em 1064 $\mathrm{nm}$, mostrados na figura abaixo. 


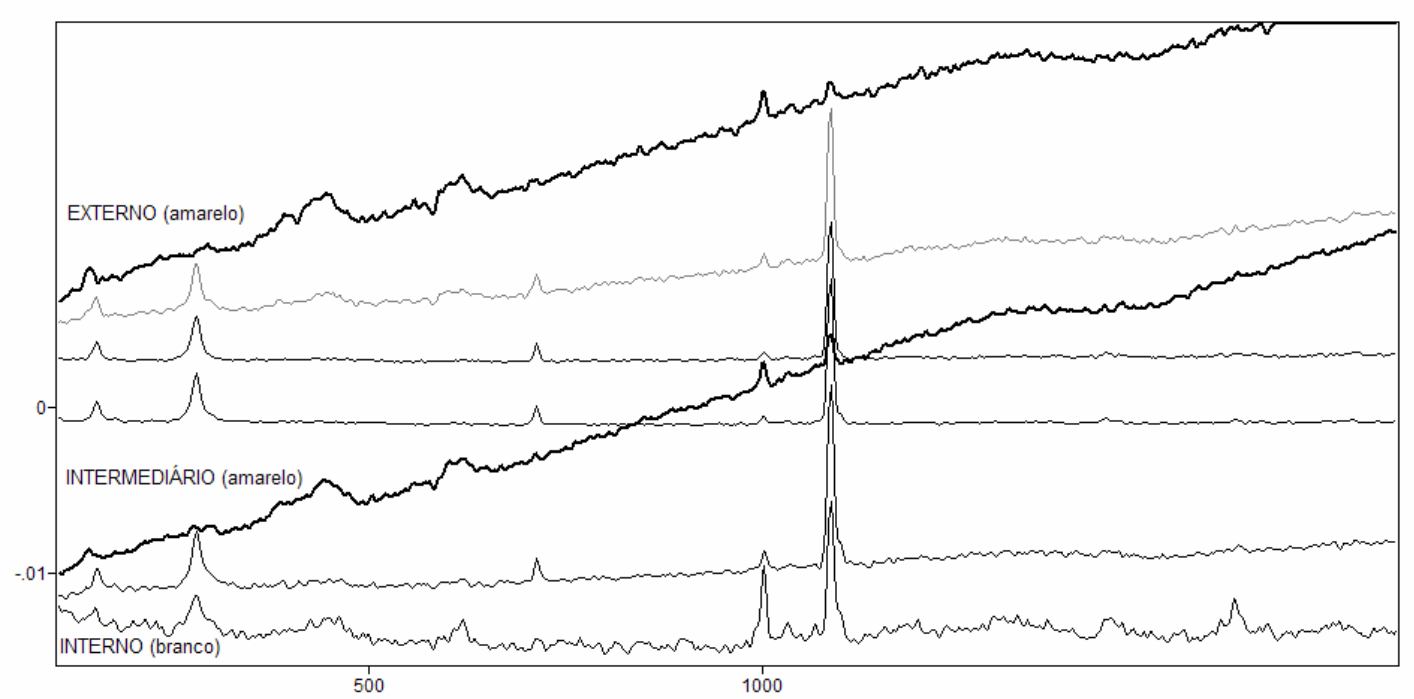

Figura 7:- Espectros FT-Raman de corte estratigráfico de fragmento de tinta. O espectro superior é da camada externa de tinta amarela.

As duas bandas intensas no espectro feito em $633 \mathrm{~nm}$ não estão presentes nos espectros feitos em $1064 \mathrm{~nm}$ (figura acima), mostrando que se trata efetivamente de emissão fluorescente de íons de terras raras presentes na amostra.

Os espectros mostrados na figura a seguir foram obtidos do pó branco que se forma sob a película de tinta. As bandas são observadas em 1160, 1141, 1086, 1054, 1008, 784, 710, 465, 400, 394, 355, 282, 264, 207, 154, 145 e $128 \mathrm{~cm}^{-1}$ e representam diversas substâncias químicas, como será abordado a seguir. Essas bandas estão presentes em todos os espectros obtidos apresentando intensidades diferentes devido ao fato do sólido ser heterogêneo e ter composição variável.

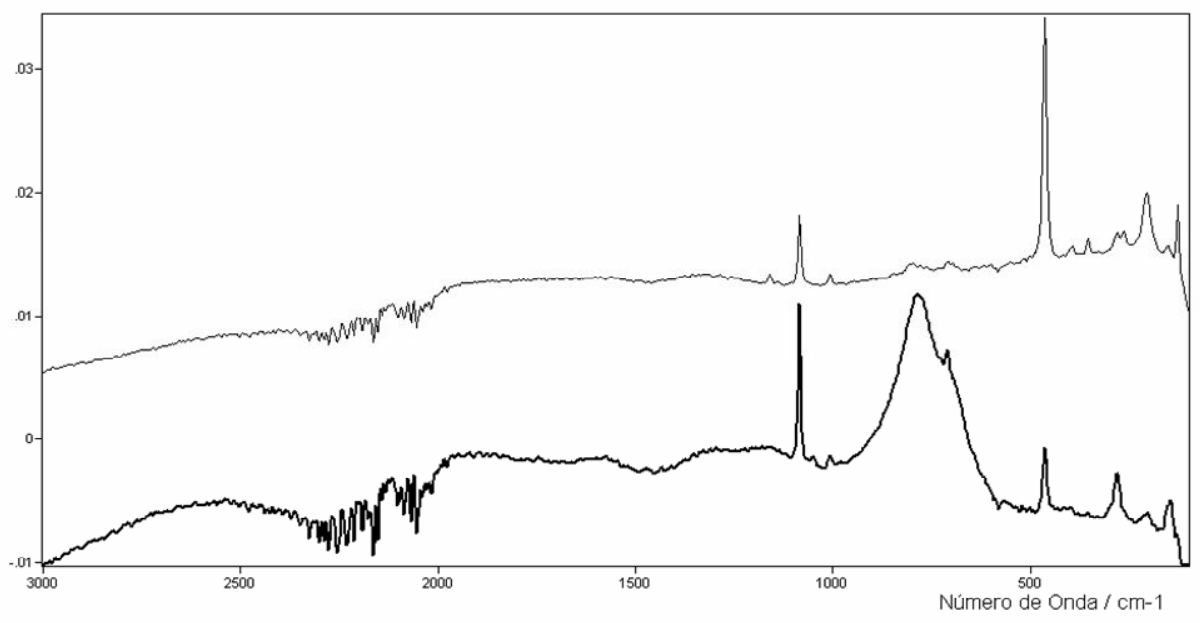

Figura 8:- Espectro FT-Raman de sólido branco formado entre a parede e a película de tinta.

Na figura acima as bandas registradas no espectro superior são devidas majoritariamente a carbonato de cálcio (banda mais representativa em $1086 \mathrm{~cm}^{-1}$ ) e $\alpha$-quartzo (banda intensa em $465 \mathrm{~cm}^{-1}$ ), ao passo que no espectro na parte inferior da figura além dessas substâncias é nítida a presença de hidróxido de cálcio $\left(784 \mathrm{~cm}^{-1}\right)$. Quantidades mínimas de sulfato de magnésio (1008 $\mathrm{cm}^{-1}$ ) e nitratos $\left(1054 \mathrm{~cm}^{-1}\right)$ são também observadas. Essa região do espectro é detalhada na figura abaixo: 


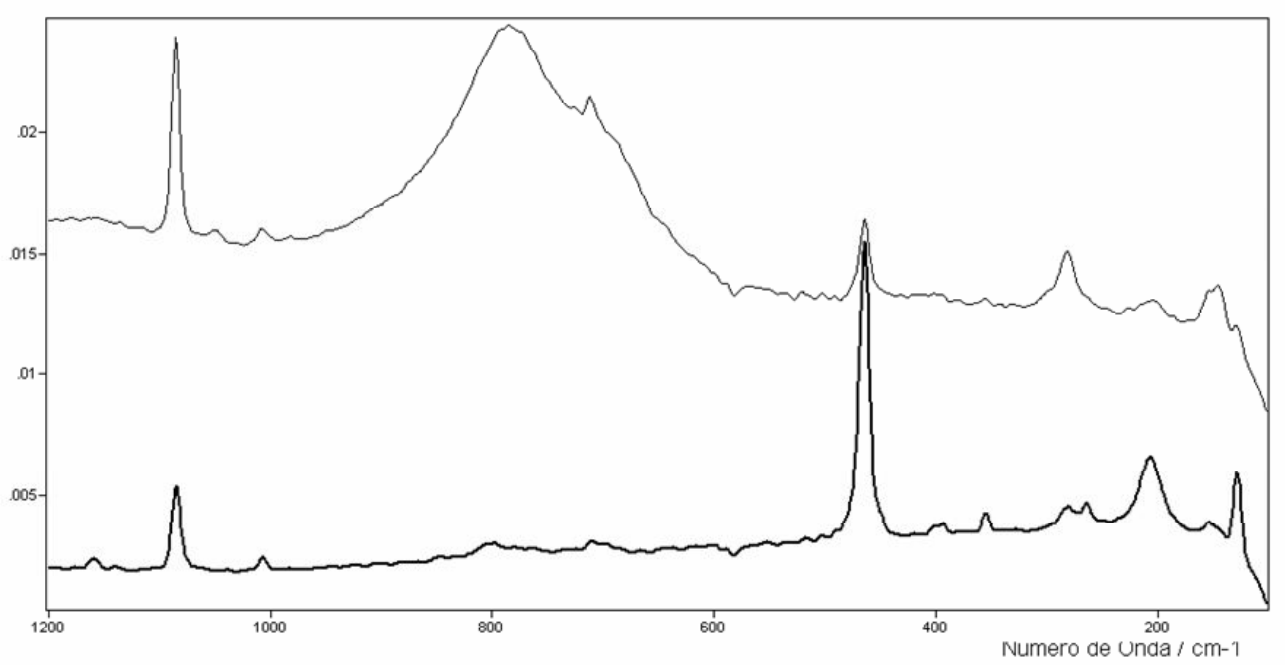

Figura 9:- Espectro FT-Raman de sólido branco formado entre a parede e a película de tinta na região entre 100 e $1200 \mathrm{~cm}^{-1}$.

\section{Conclusões}

- Não há diferença perceptível entre as tintas amarelas observadas ns diferentes camadas (pigmento amarelo, carbonato de cálcio, sulfato de magnésio e algum sal de terra rara responsável pela emissão acima de $1200 \mathrm{~cm}^{-1}$ ).

- As camadas brancas analisadas no corte estratigráfico contêm majoritariamente carbonato de cálcio.

- O sólido que se forma entre a película de tinta e a parede, é constituído principalmente de carbonato de cálcio. 


MEV - MICROSCOPIA ELETRÔNICA DE VARREDURA
EDS - ESPECTRO DE ENERGIA DISPERSIVA - ANÁLISE QUÍMICA
QUALITATIVA
Instituto de Geociências da Universidade de São Paulo
Departamento de Mineralogia e Geotectônica

Eliane Del Lama

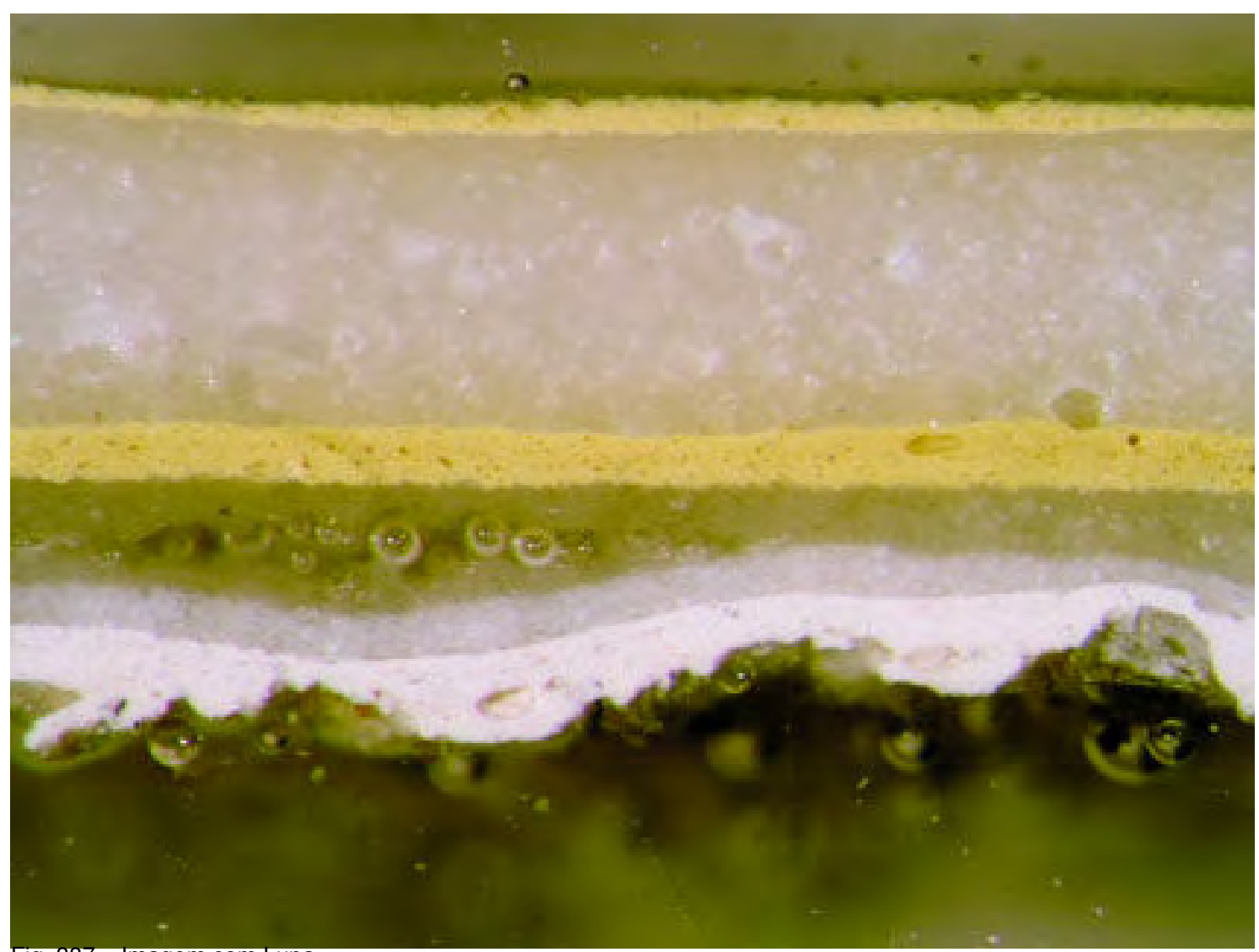

Fig. 387 - Imagem com Lupa

Película de tinta: Todas camadas

Local: Entrada leste, face norte. Junto da lacuna: Eflorescência 


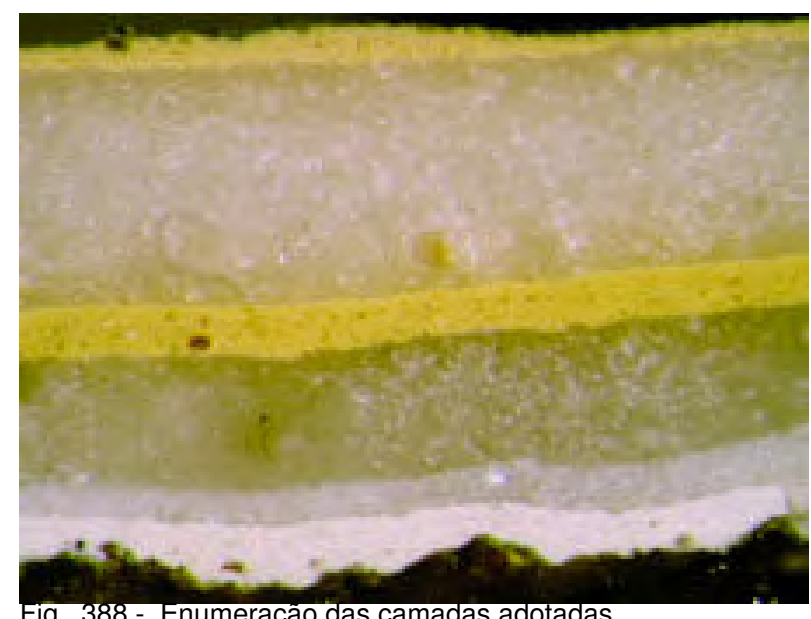

Fig . 388 - Enumeraçao das camadas adotadas
Camada 1: Tinta amarela

Camada 2: Preparação

Camada 3: Tinta amarela

Camada 4: Preparação

Camada 5: Tinta rósea

Camada 6: Preparação

PAREDE - ARGAMASSA

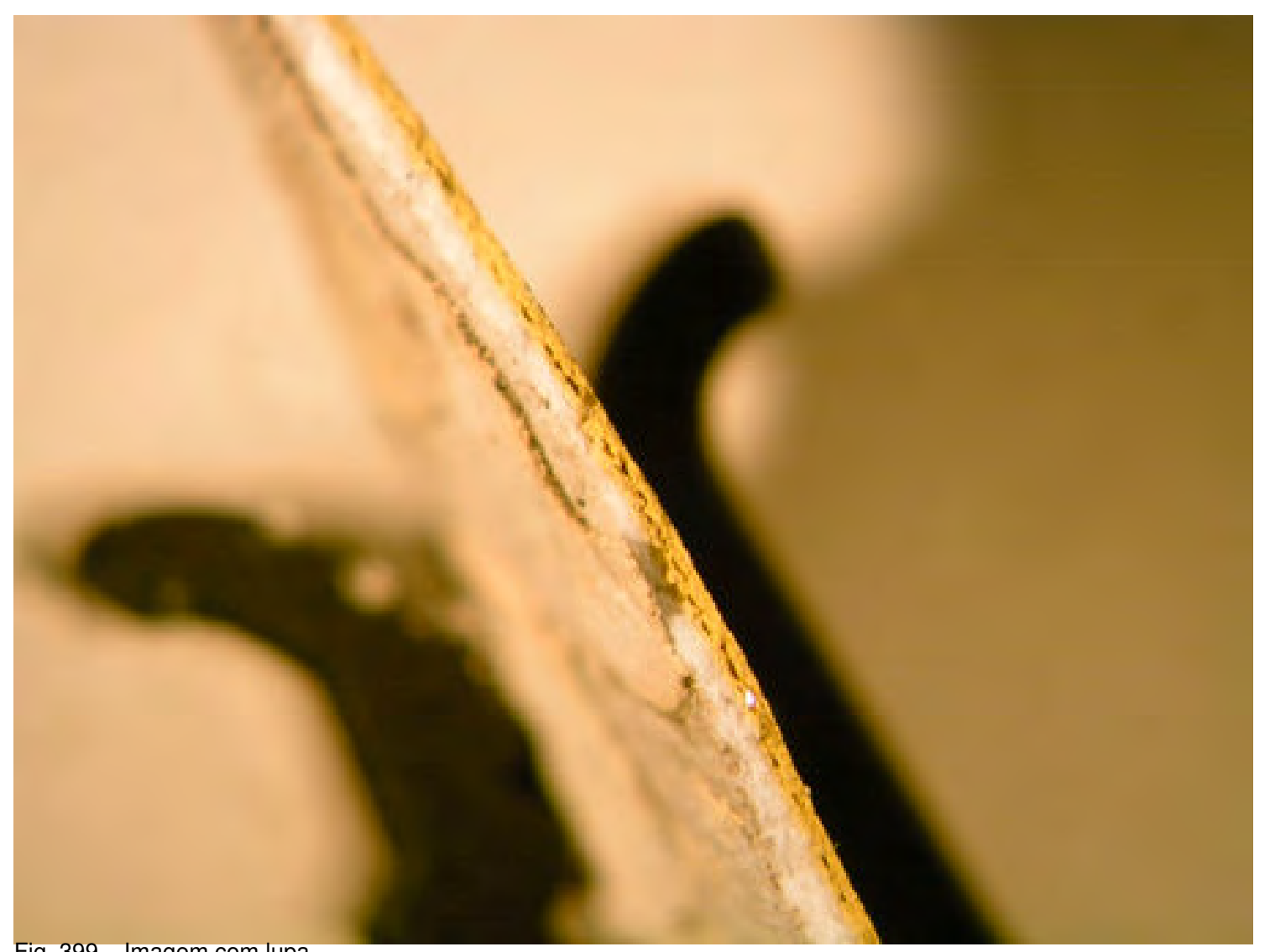

Fig. 399 - Imagem com lupa

Película de tinta: camada de tinta amarela, massa corrida, camada de tinta rósea 


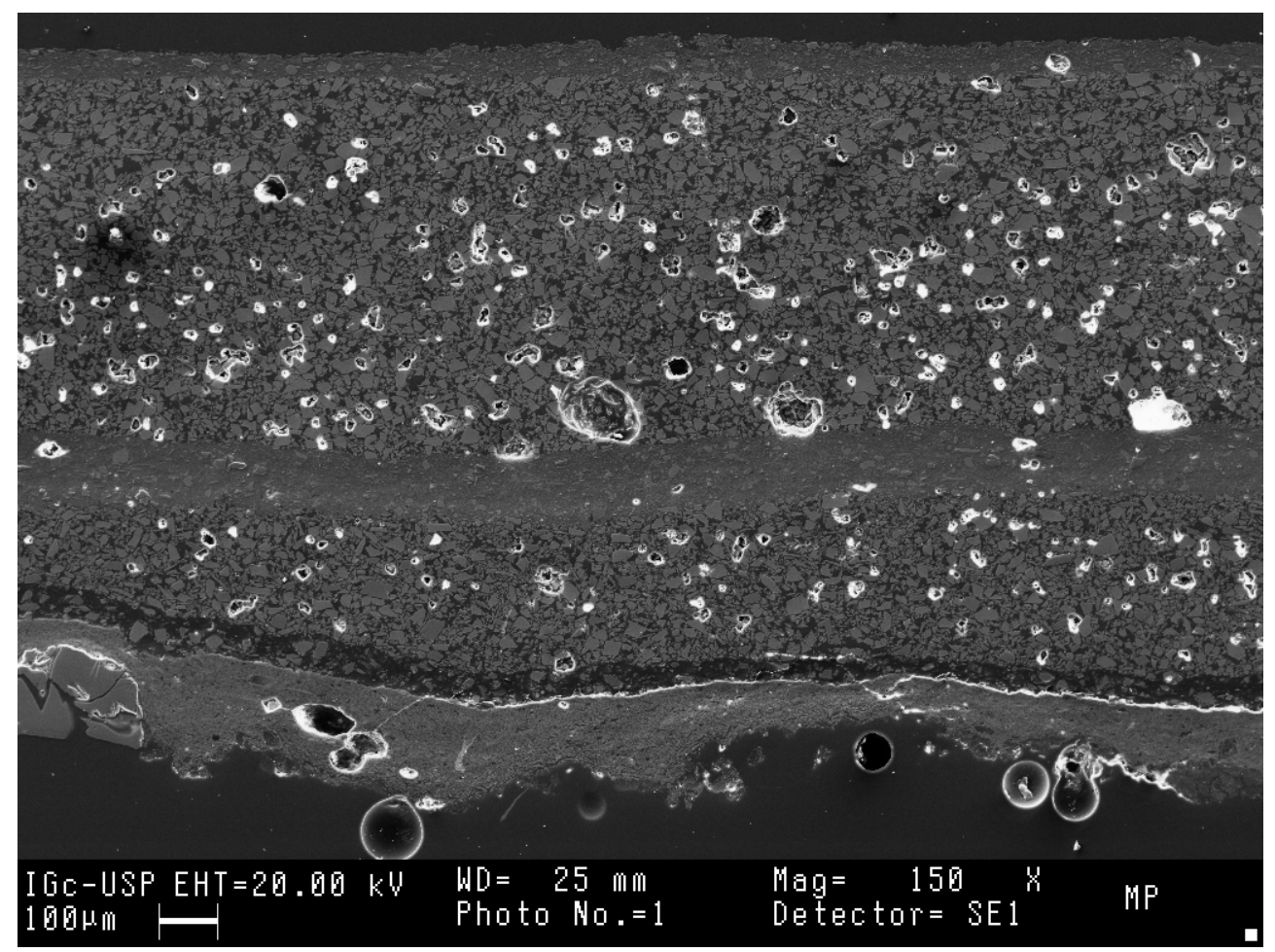

Photo N. 1 - Todas camadas - Corte estratigráfico Imagem de Elétrons Secundários 


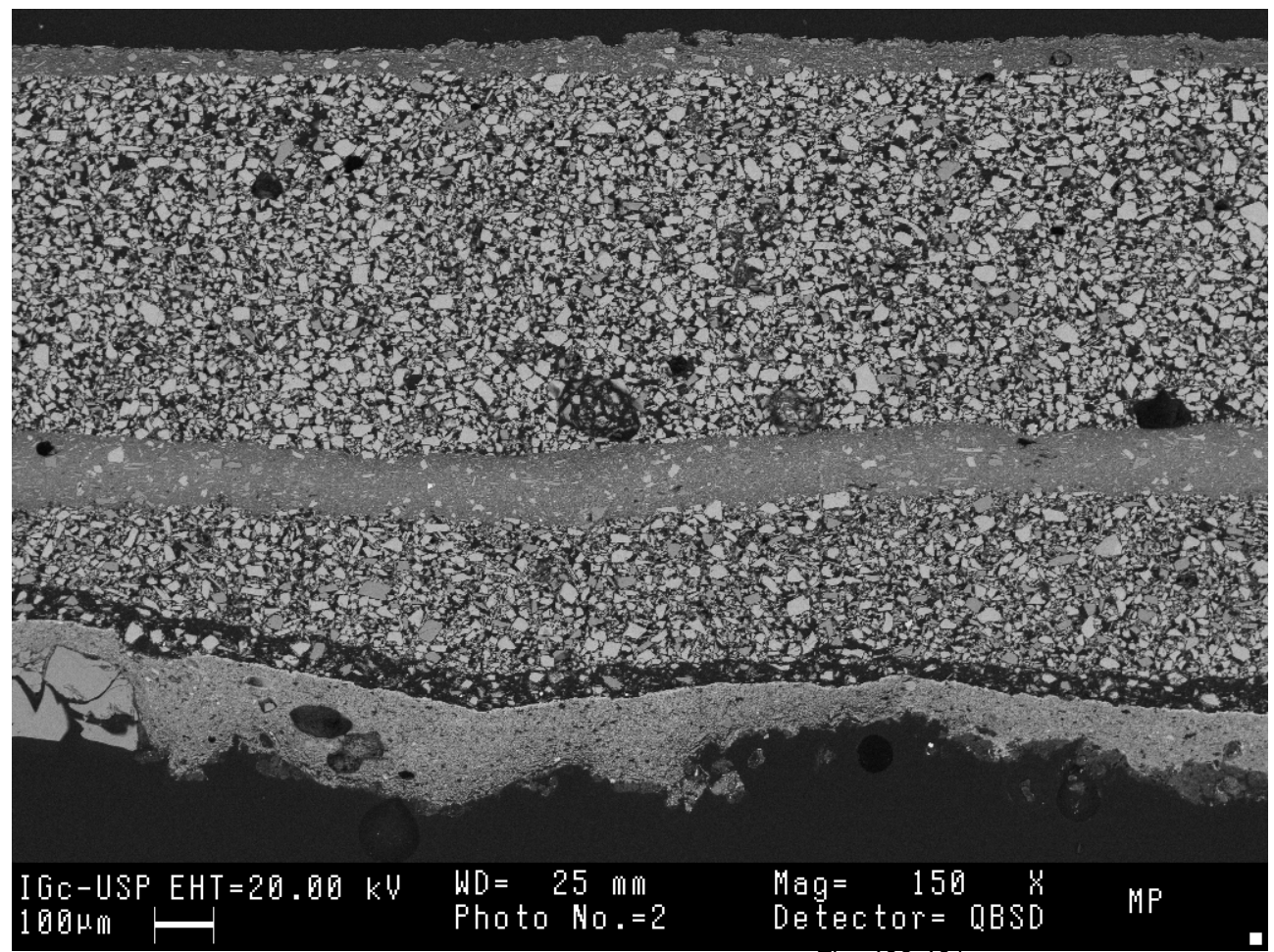

Photo N.2 - Todas camadas - Corte estratigráfico

Imagem de Elétrons retroespalhados 
MEV - MICROSCOPIA ELETRÔNICA DE VARREDURA

LCT - Laboratório de Caracterização Tecnológica

Departamento de Engenharia de Minas e de Petróleo - Escola Politécnica da

Universidade de São Paulo

Liz Zanchetta D’Agostino

- Amostra P1 Íntegra - camada de tinta e argamassa

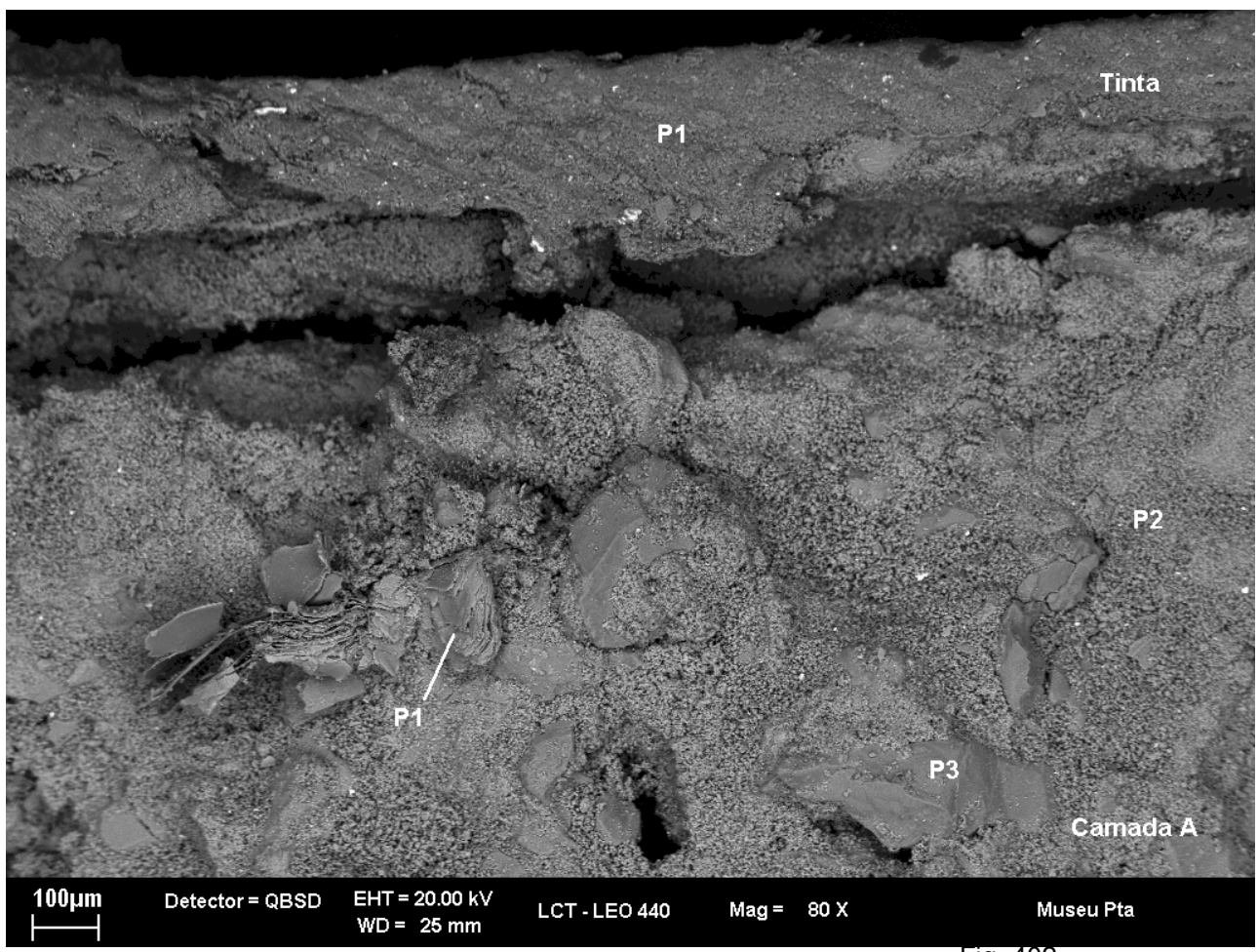

MuseuPta 001.tif

Fig. 402

Camada de Tinta e a superfície da argamassa

Observa-se nesta imagem o descolamento da camada de tinta da argamassa, que já foi constatado em outros locais. Esta Amostra P1 - íntegra, não apresentava danos. Isto provavelmente ocorre por ser uma tinta resistente aplicada sobre argamassa porosa, mais frágil. 


\section{BIODETERIORAÇÃO}

A BIODETERIORAÇÃO se refere a fenômenos devidos à presença de macrorganismos ou microrganismos vivos: algas, musgos, liquens, fungos, plantas diversas, entre outros - que de alguma forma deterioram as superfícies dos revestimentos, quer por sua simples presença ou das espécies químicas que secretam produtos do metabolismo, é suficiente para causar danos.

Com origens variadas, provenientes do solo, do ar ou transportados pelo vento, insetos, aves, etc., os microrganismos depositam-se nas superfícies dos revestimentos, bem como nas fendas, fissuras e vazios ali existentes, e multiplicam-se conforme seu metabolismo, conforme a disponibilidade dos nutrientes, e ainda em função das condições climáticas da zona do edifício. Para que a adesão dos microrganismos seja favorecida, é necessário que ocorram algumas condicionantes físico-químicas e ambientais, das quais se destacam: $\mathrm{pH}$ do substrato, umidade, temperatura, iluminação, oxigênio, etc.

Como conseqüência da atividade humana, industrial e urbana (tráfego), é liberada na atmosfera diariamente produtos da queima de combustão, uma grande quantidade de poluentes como, por exemplo, o dióxido de enxofre, o nitrogênio, derivados do petróleo, etc. Estes poluentes, quando em presença de umidade, podem favorecer o crescimento e a proliferação de diversos microrganismos, contribuindo significativamente para sua deterioração.

Assim, as causas que favorecem a ocorrência de biodeterioração são:

- Presença prolongada de umidade

- Falta de ventilação

- lluminação

- Acumulação de pó, terra e sujidade na superfície do revestimento

- Acumulação de poluentes resultantes da atividade industrial

- Porosidade elevada do revestimento. (MAGALHÃES, 2002, p.77-78)

A biodeterioração é considerada nesta pesquisa, em uma abordagem preliminar a um conhecimento vasto e especializado, mas que mesmo numa avaliação enquanto rotina , permitiu-se observar a sua importância na participação dos processos e danos que ocorrem neste edifício histórico.

A presença de água, existente nas paredes, é o maior agente de deterioração dos rebocos antigos, e que possibilita as condições propícias ao desenvolvimento de diversos agentes biológicos (referencia).

Como afirma SOUSA (2005,p.9), "os rebocos constituem um meio propício ao desenvolvimento de diversas comunidades de seres vivos com graus de desenvolvimento variado. Os seres vivos mais simples são responsáveis por deteriorações químicas e/ou mecânicas, entre eles se encontram as algas, as bactérias, os liquens, os fungos, etc. No entanto, há ainda que ter em conta as degradações causadas por algumas plantas superiores, principalmente através do desenvolvimentos de suas raízes, e animais como os pombos, principalmente pelas suas fezes. Estas, além de serem uma importante fonte de sais e de matéria orgânica para as comunidades que povoam os revestimentos, atacam quimicamente os rebocos e provocam anomalias estéticas importantes"

Quanto aos fungos, tem-se ampliado o interesse no seu estudo, tanto que foi criada uma ramificação da micologia, a Micologia das Edificações. A sua ocorrência em edificações em ambientes internos e externos, afeta os materiais de construção, estrutura e também a saúde de seus habitantes quando no ambiente.

A Biodeterioração das Edificações requer equipe multidisciplinar envolvendo pesquisadores em microbiologia, engenharia civil, arquitetura e química dos materiais de construção. Esta multidisciplinaridade é essencial para um correto diagnóstico, além da 
determinação de diretrizes para controle, prevenção e remediação deste fenômeno (SINGH in SHIRAKAWA, 1999)

Geralmente os fungos causam manchas escuras, interferindo na estética do edifício..Quando o bolor se desenvolve em ambientes internos, além da questão estética, pode desencadear alergias respiratórias em indivíduos que freqüentam esse ambientes (GAMBALE in SHIRAKAWA, 1999)

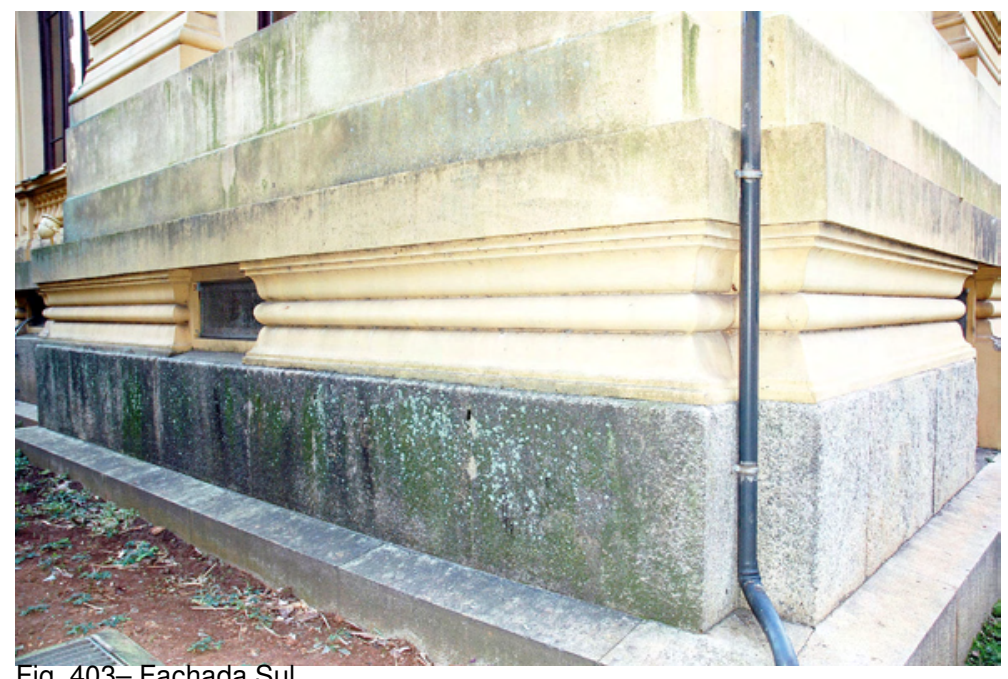

As manchas verdes com aparência de fungos e liquens aparecem na fachada sul e aumentam no período de frio e chuvas. Se fixam acentuadamente nas rugosidades da pedra de revestimento do embasamento

Muitas vezes se formam sobre os caminhos da água de chuva - sobre as molduras e os frisos.
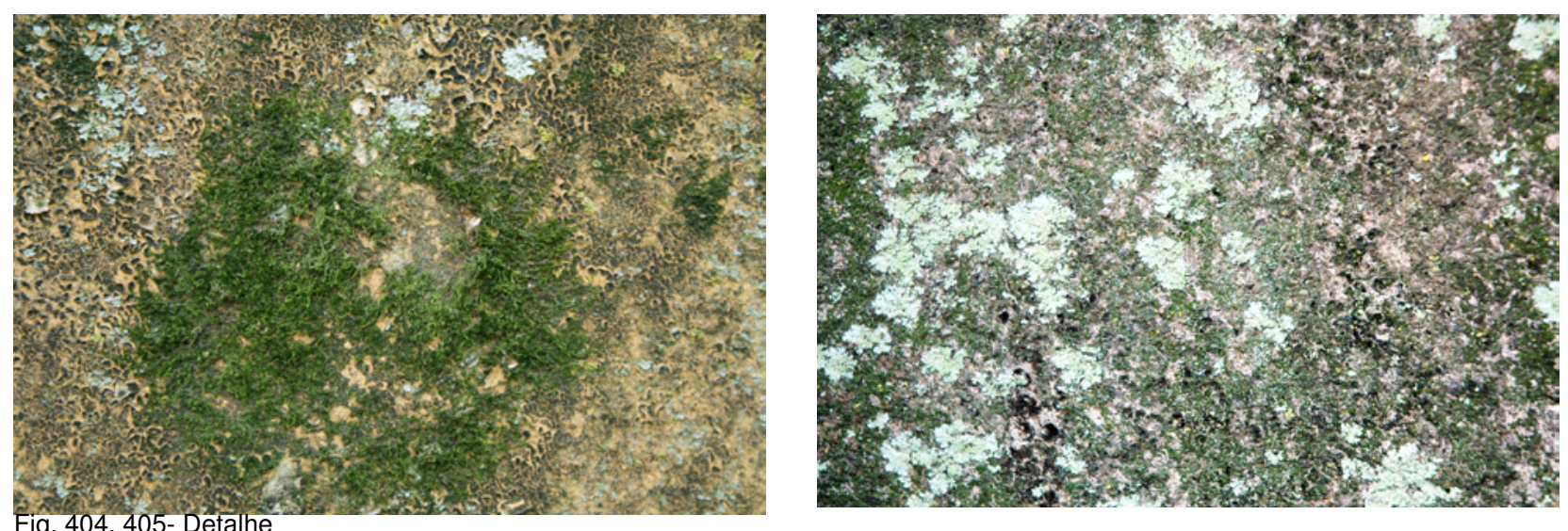

No entorno da fachada sul, além de menor insolação, com a proximidade da vegetação do parque, é formado um micro clima diferente da face norte. Como as paredes da fachada sul não recebem sol, o ambiente é mais escuro, e mais úmido criando assim condições para a proliferação de microrganismos. 


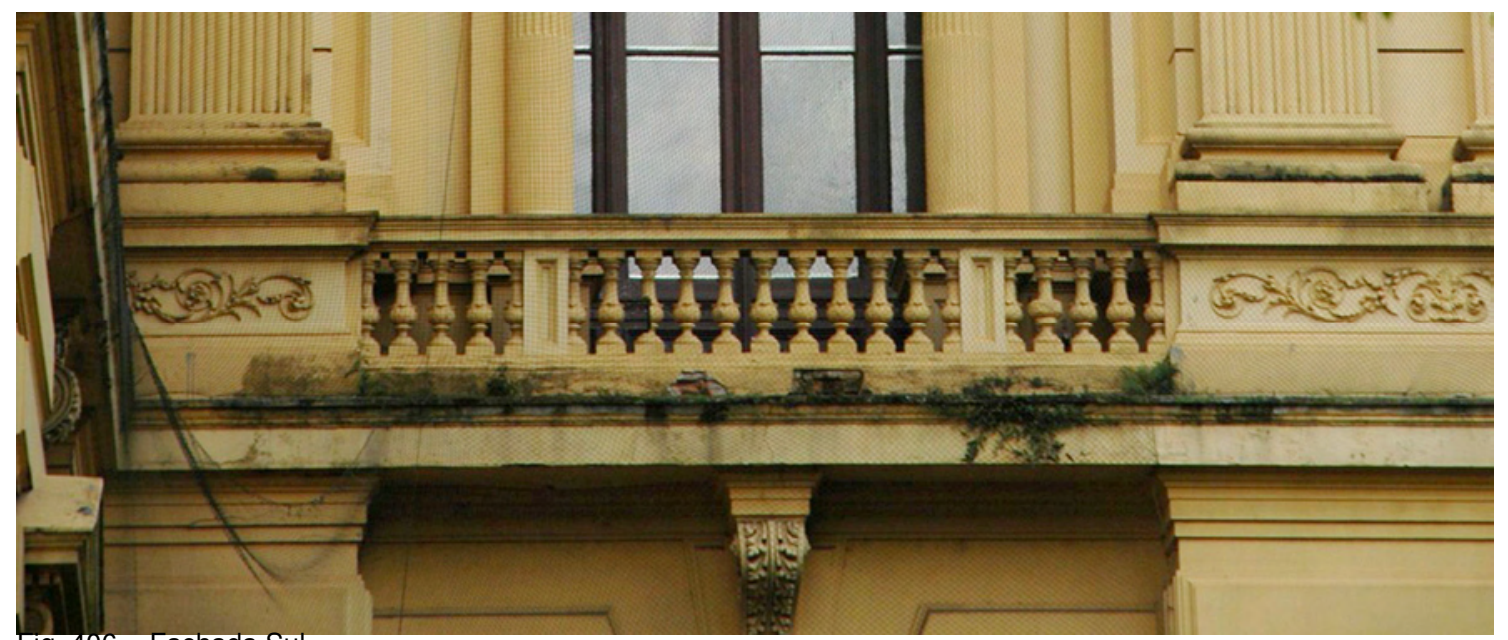

Fig. 406 - Fachada Sul Presença de planta, sujidade e manchas esverdeadas

$\mathrm{Na}$ fachada sul também são encontrados sinais de biodeterioração devido à presença de vegetação crescendo nas cornijas das varandas além de manchas e sujidades

As bactérias são microrganismos unicelulares mais simples encontrados na maioria dos ambientes naturais. Elas podem ter diferentes morfologias com células esféricas (cocos), espiraladas, ramificadas ou em forma de bastonetes (bacilos) curtos ou com comprimentos variados. $O$ diâmetro das bactérias em forma de cocos é da ordem de $0,5 \mathrm{a}$ 1,0 microns $(\mu \mathrm{m})$. Os bastonetes podem ter cerca de $0,5(\mu \mathrm{m})$. de diâmetro a 1 a $3(\mu \mathrm{m})$. de comprimento Os rebocos constituem um meio propício para seu desenvolvimento, principalmente depois de ocorrer carbonatação da cal acompanhada pela diminuição do $\mathrm{pH}$. Em geral o desenvolvimento de seres vivos é inibido em $\mathrm{pH}$ elevado.

Algumas bactérias produzem ácidos orgânicos que atacam quimicamente os compostos do reboco.[...]

Os fungos para se desenvolverem precisam de matéria orgânica, depositada por outros seres e/ou transportada pelo vento - e preferencialmente em comunidades [...]

Os fungos filamentosos com conjunto de hifas, penetram na estrutura do reboco causando danos mecânicos, que podem ser mínimos, mas a degradação química é bem mais significativa. Diversos produtos resultantes da atividade metabólica dos fungos são coloridos e comprometem a estética, pelo que se estendem à superfície dos rebocos podem ser conseqüência do desenvolvimento de fungos.(SOUSA, 2005, p.10,14)

Para um diagnóstico ideal é necessário identificar diferentes grupos desses organismos com características fisiológicas distintas, conhecer o metabolismo, e as conseqüências ao meio em que se encontram. Nesta etapa do projeto foram realizados cultivo de fungos e bactérias heterotróficas e microscopia eletrônica de varredura (MEV) evidenciaram a predominância de bactérias.

\section{CULTIVO DE BACTÉRIAS E FUNGOS}

Laboratório de Microbiologia- Departamento de Engenharia Civil-POLI USP Márcia Shirakawa

A análise microbiológica foi realizada com as Amostras:

- P2, P3 e P5.2 de argamassas extraídas de vesículas, desagregadas, com fissuração da camada da pintura , interagem com o meio ambiente, sofrendo ação dos ventos, chuvas, poluição e diversos insetos que se alojam nos vazios 
- Amostra S, argamassa sob película fechada da pintura, com aparência compacta. Foram efetuadas suspensões com as argamassas em água destilada estéril (1:1) e submetidas à agitação em vortex (marca Phoenix). A suspensão foi diluída em água estéril atingindo diluições decimais

Um volume de $100 \mu \mathrm{L}$ da suspensão inicial e das subseqüentes diluições serviram de inoculo para análise de bactérias heterotróficas ${ }^{1}$ em Agar Nutriente (Difco) e os fungos em Agar Sabouraud Dextrose (Acumedia). As leituras das concentrações de unidades formadoras de colônias (UFC) foram feitas após 24 e 48 horas de incubação a $28^{\circ} \mathrm{C}$ para as bactérias e 72 horas para contagens de UFC de fungos.

\begin{tabular}{|c|c|c|}
\hline \multirow{2}{*}{ AMOSTRAS } & \multicolumn{2}{|l|}{$\begin{array}{l}\text { Concentração de microrganismos (Unidade Formadora de } \\
\text { Colônias) }\end{array}$} \\
\cline { 2 - 3 } & Fungos & Bactérias heterotróficas \\
\hline P2 & $2,0 \times 10^{3}$ & Colonização da ordem de10 \\
\hline P3 & $3,0 \times 10^{4}$ & $5,0 \times 10^{5}$ \\
\hline P5.2 & $5,0 \times 10^{4}$ & $1,2 \times 10^{5}$ \\
\hline S & $7,3 \times 10^{3}$ & Não foi possível quantificar \\
\hline
\end{tabular}

\section{OBSERVAÇÕES}

O gênero fúngico predominante foi Penicillium nas amostras P3 e P2 . A amostra P5.2 apresentou outros gêneros não identificados. Na amostra $S$ houve colonização por fungos do gênero Cladosporium.

Ressalta-se que a amostragem efetuada não tem significado estatístico, mas pode-se assumir que os microrganismos encontrados estão fazendo parte do processo de deterioração uma vez que as amostras analisadas por MEV apresentam elevadas concentrações de bactérias. Ao se comparar o pH das amostras P3 e P2 com a amostra sadia $\mathrm{P} 1$, observa-se que há tendência de diminuição do $\mathrm{pH}$, indicando produção de ácido das regiões com maiores concentrações de microrganismos (estes dados são apenas indicativos, não podem ser conclusivos uma vez que não foi feita análise estatística). $O$ $\mathrm{pH}$ da amostra sadia indica, como era de se esperar após quase 1 século, a carbonatação de Portlandita.

As figuras ilustram o crescimento de Fungos em Agar Sabouraud Dextrose (ASD) nas amostras P2, P3 e P5.3 respectivamente

As figuras que ilustram o crescimento de bactérias em Agar nutriente

\section{MEV- MICROSCOPIA ELETRÔNICA DE VARREDURA \\ Especificações: \\ MEV - foi utilizado LEO Stereoscan 440}

EDS com detector de Ge, marca Oxford, com software também da Oxford chamado INCA.

As amostras receberam filme de Carbono para condução de elétrons

As amostras foram mantidas em temperatura ambiente até o cobrimento

Os resultados das análises pelo MEV evidenciaram intensa colonização por microrganismos nas amostras de argamassa desagregadas P3 e P52 .

Embora através de método de cultivo tenham também sido encontradas razoáveis concentrações de fungos. As análises por MEV evidenciaram predominância de bactérias

As figuras 407 a 420 ilustram os resultados obtidos por MEV

\footnotetext{
${ }^{1}$ Bactérias Heterotróficas são aquelas que necessitam componentes orgânicos como fonte de carbono.
} 
Fig.407 AMOSTRA P2 - Inoculo de Fungos Suspensão 1:1: Penicillium

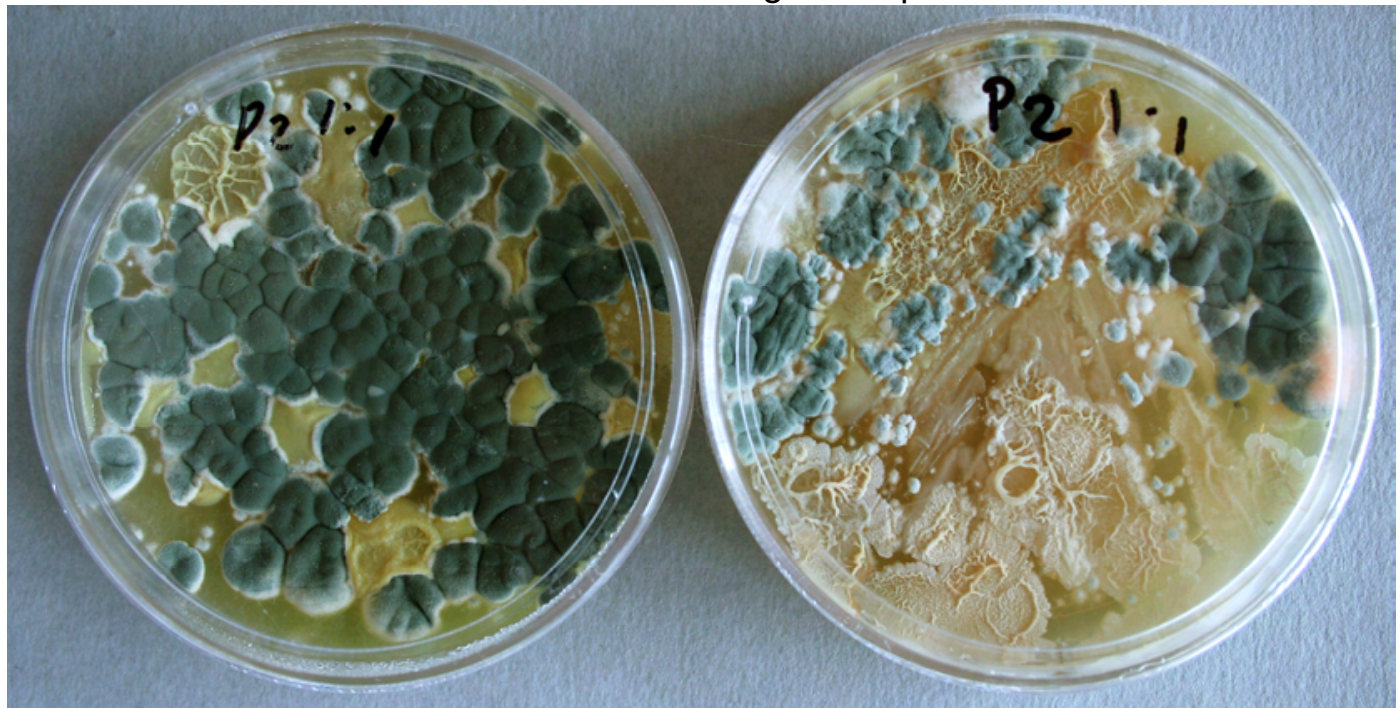

Fig.408 Inoculo de Fungos Suspensão $10-^{-1}$ Penicillium

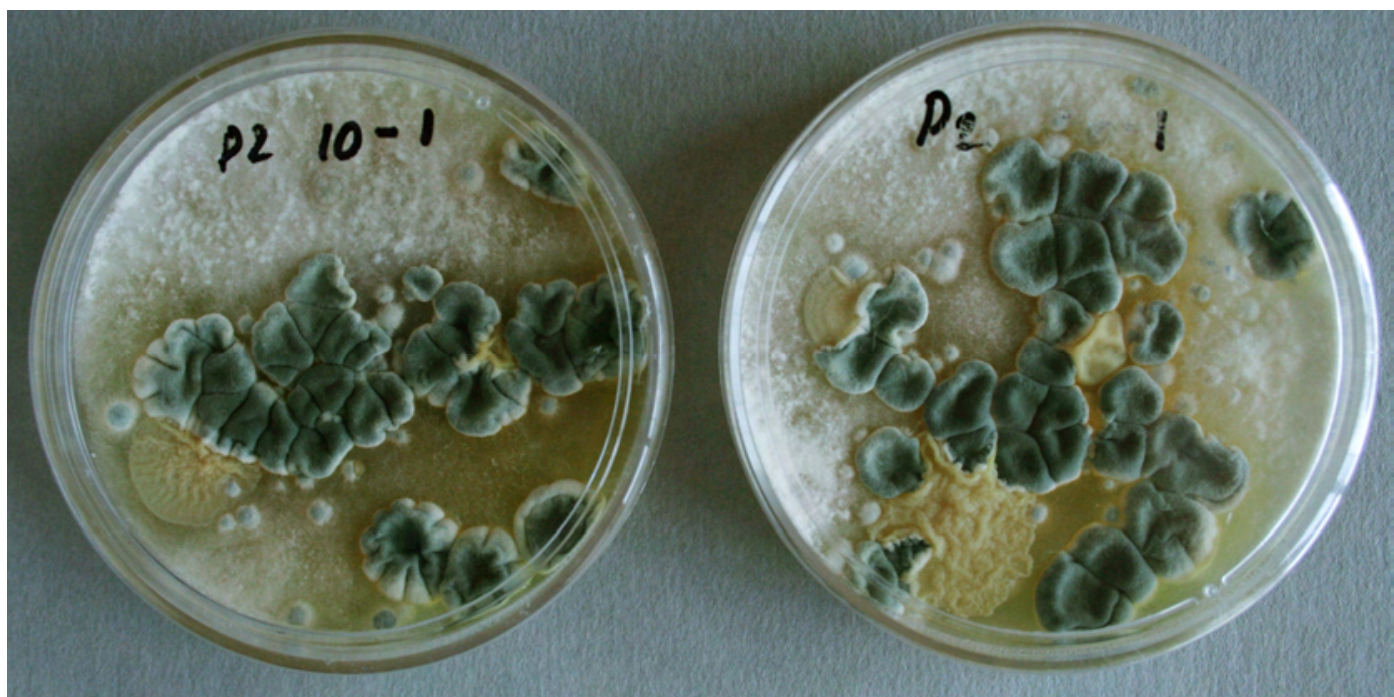

Fig.409 Innouln do Funnne Cucnancãn 10_2: Panicillium

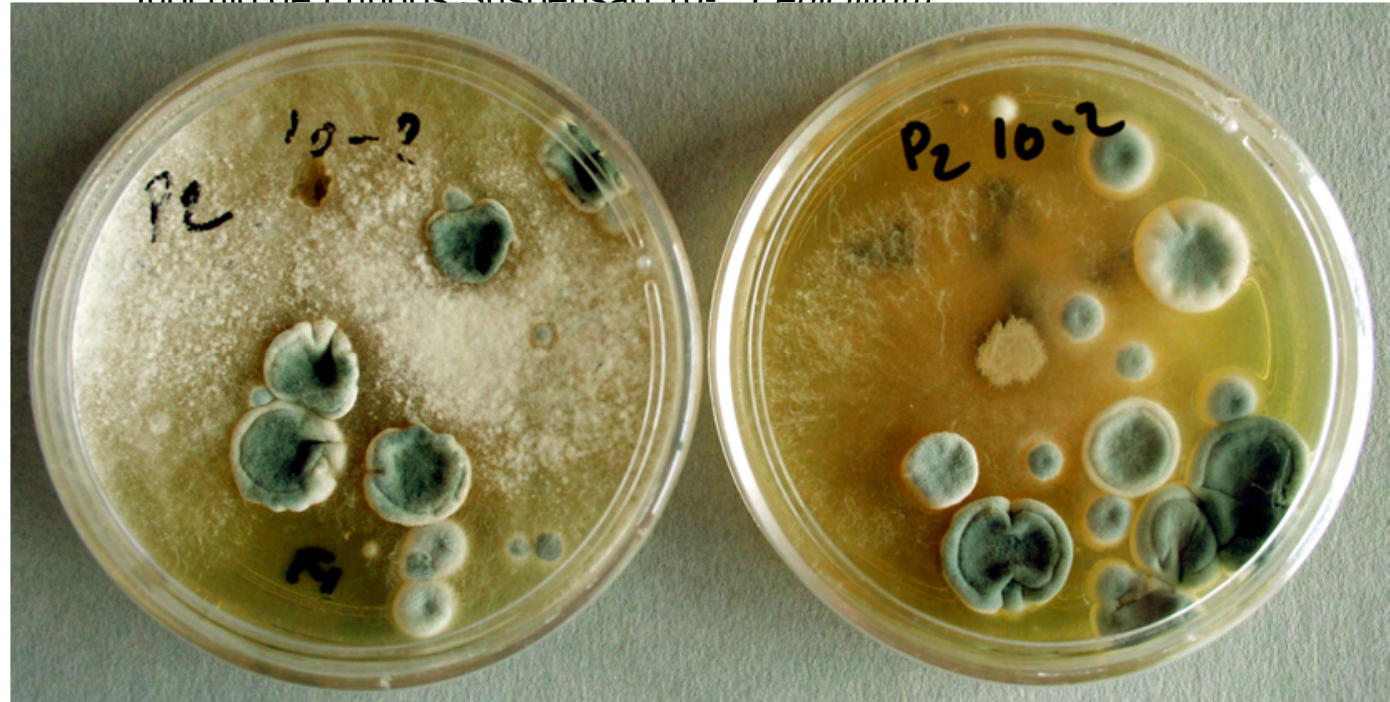

Crescimento de fungo em Agar Sabouraud Dextrose Predominância de Penicillium 
Fig 410 AMOSTRA P3- Inoculo de Fungos Suspensão 1:1: Penicillium

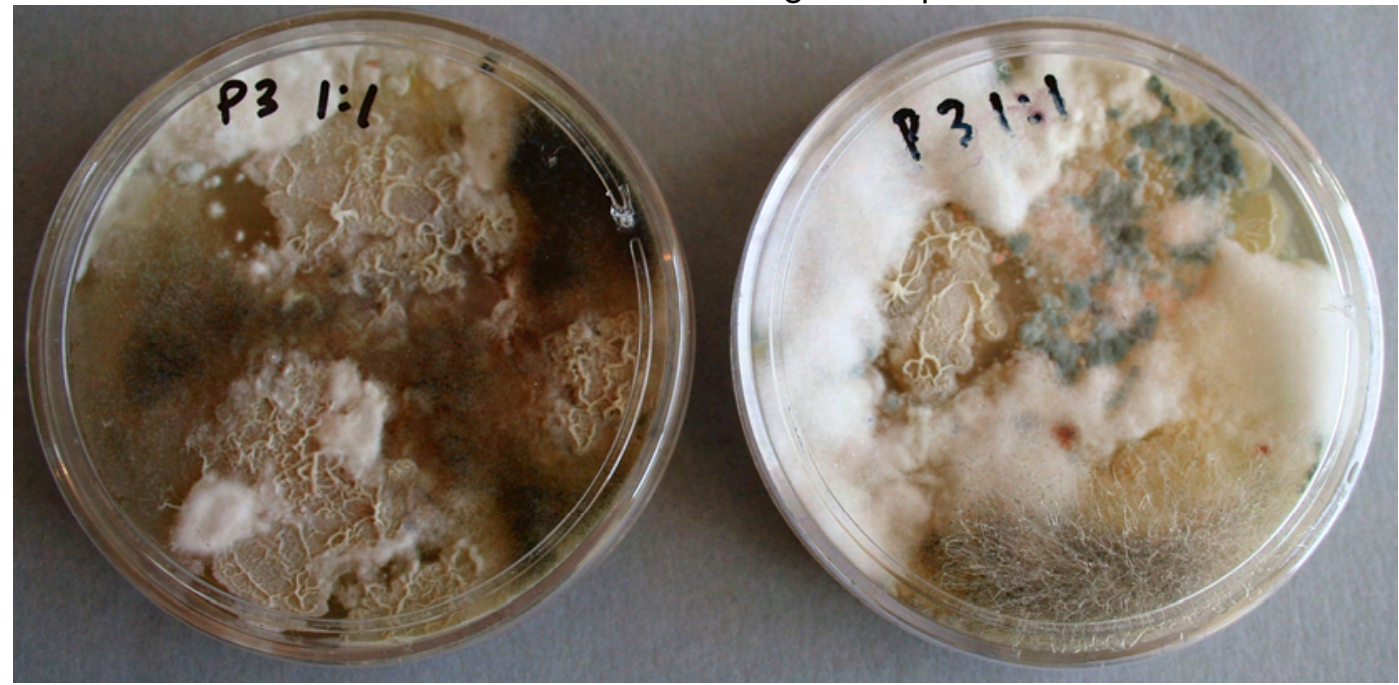

Fig. 411 Inoculo de Fungos Suspensão $10^{-1}$ : Penicillium

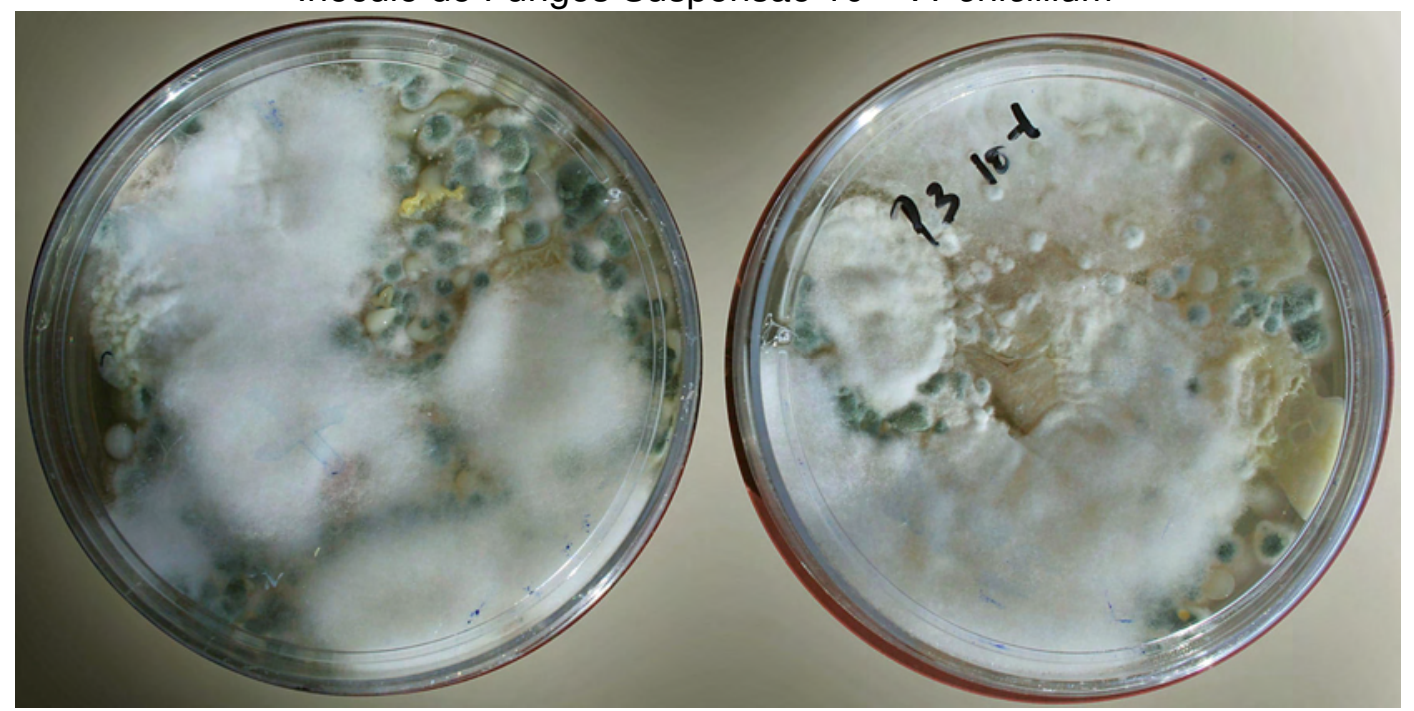

Fig. 412

Inoculo de Fungos Suspensão 10-2: Penicillium

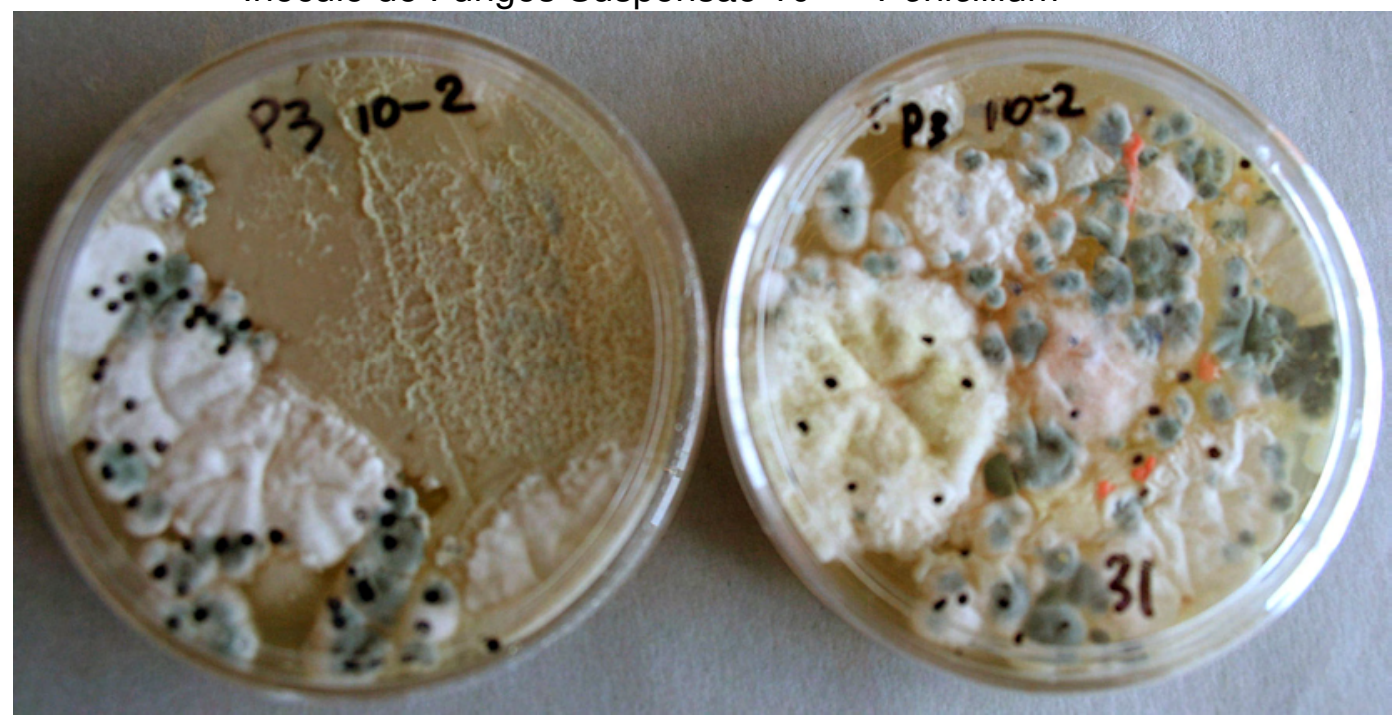

Crescimento de fungo em Agar Sabouraud Dextrose

Predominância de Penicillium 

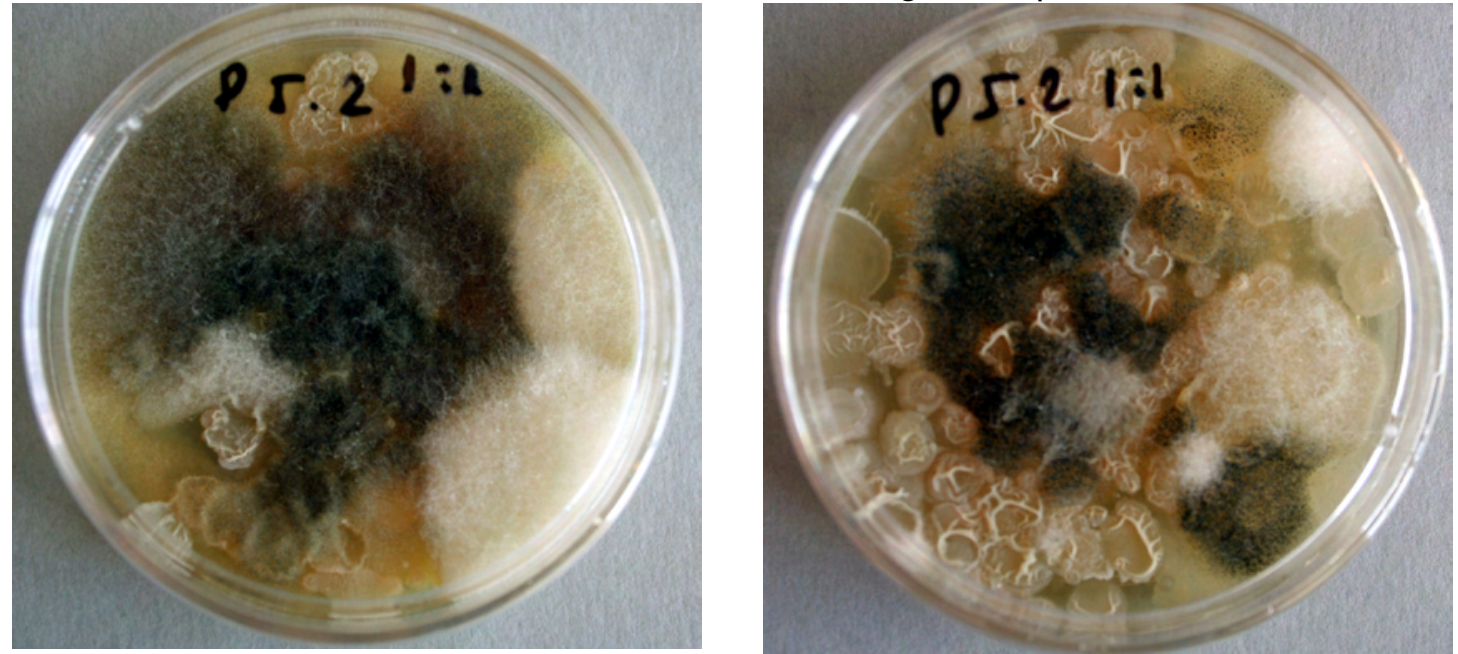

Fig. 414 Inoculo de Fungos Suspensão $10-^{1}$ Penicillium

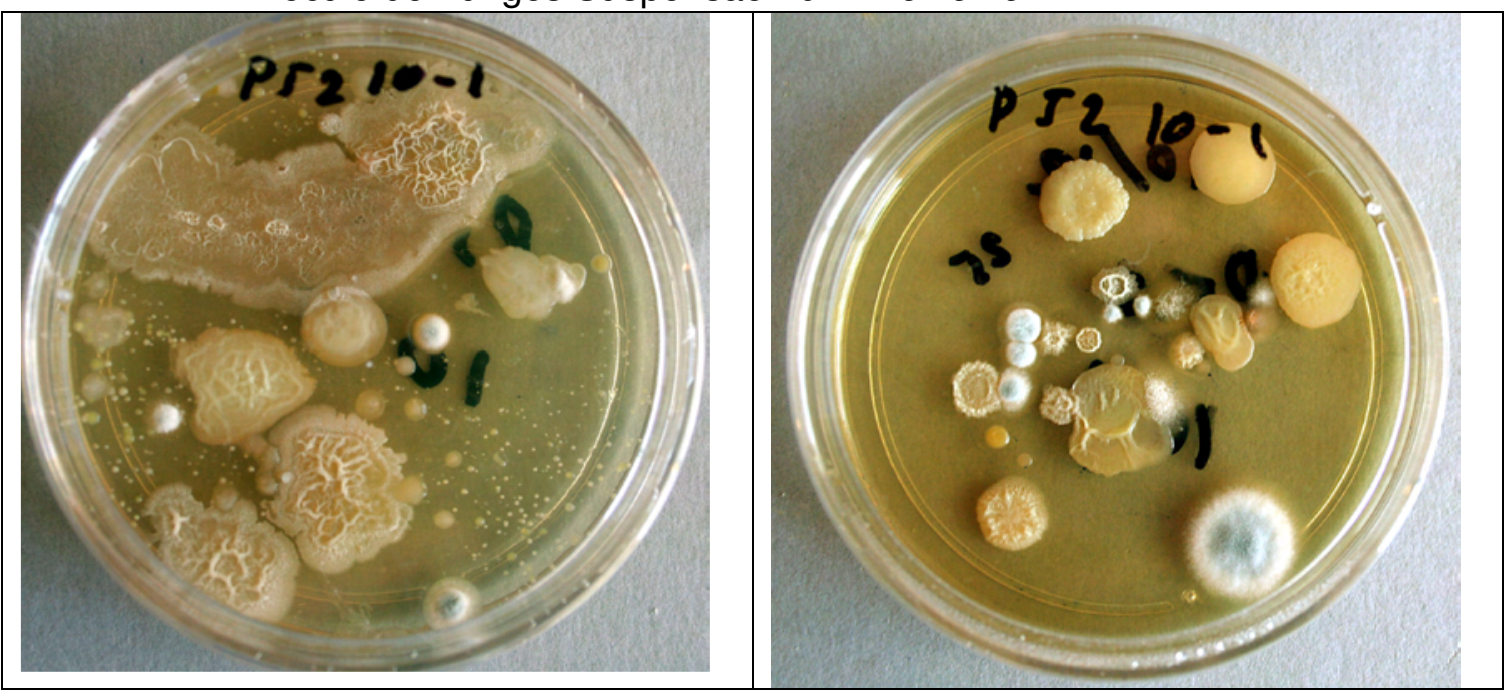

Fig. 415 Inoculo de Fungos Suspensão 10- ${ }^{2:} \quad$ Penicillium
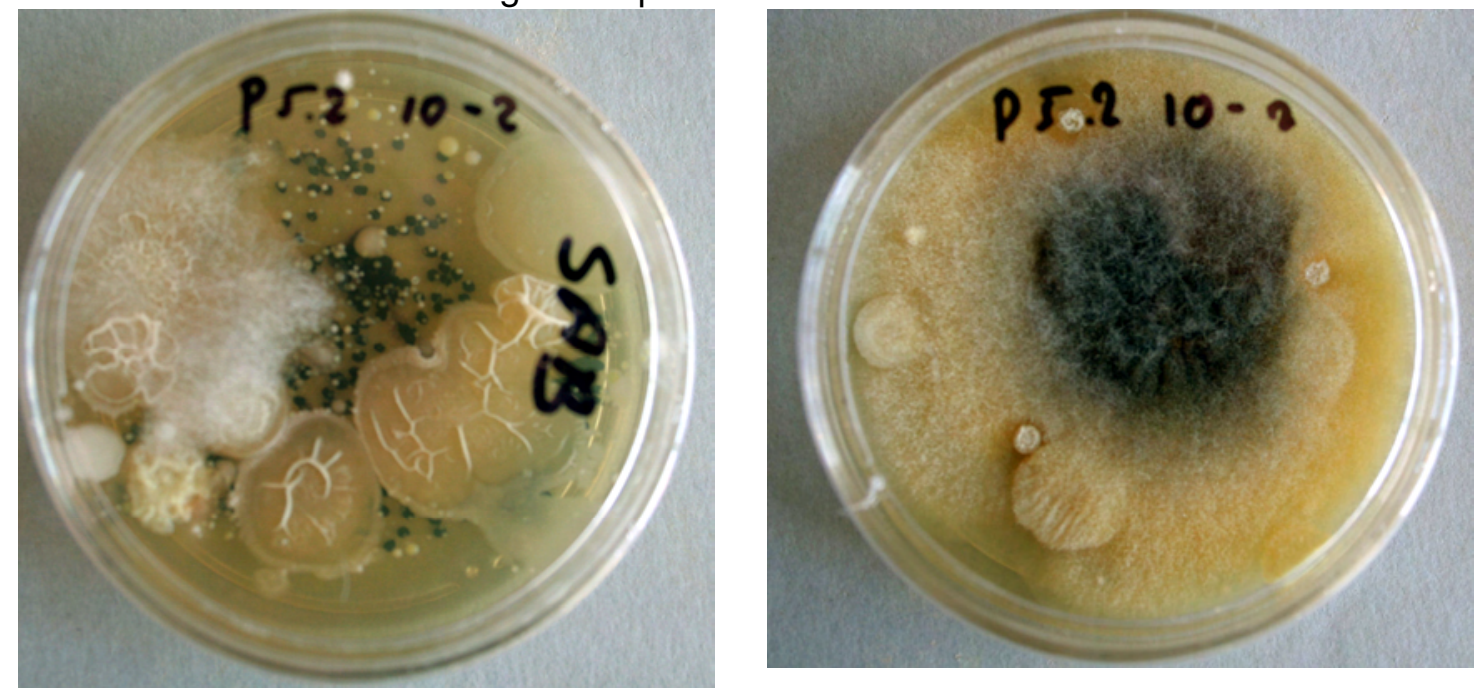

Crescimento de fungo em Agar Sabouraud Dextrose Predominância de Penicillium 
AMOSTRA S - Inoculo de Fungos Suspensão 1:1: Cladosporium.

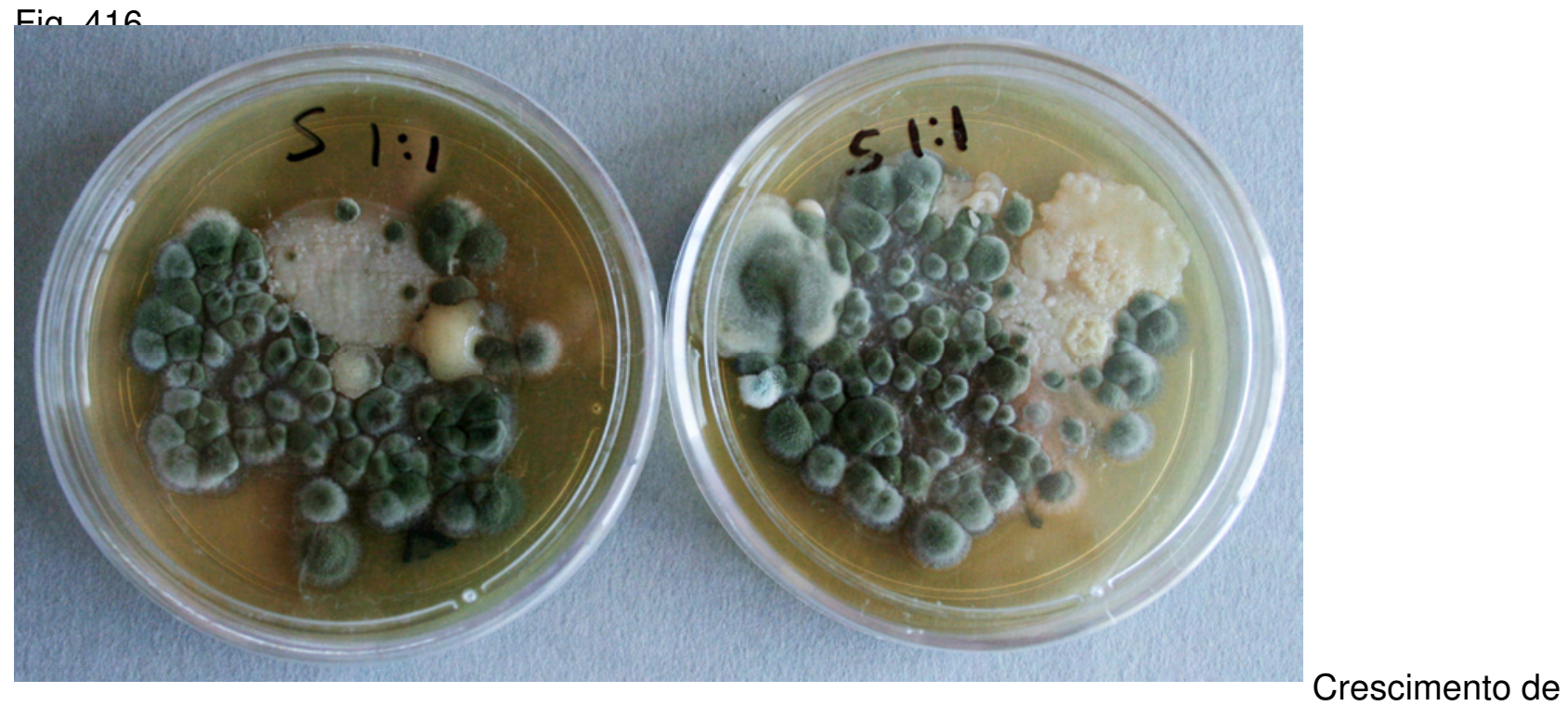

fungo em Agar Sabouraud Dextrose

Predominância de Cladosporium

Foi extraída sob película de pintura sem fissuras. Nesta Amostra, houve colonização por fungo do gênero Cladosporium. 


\section{Fig. 417 AMOSTRA P2 -}

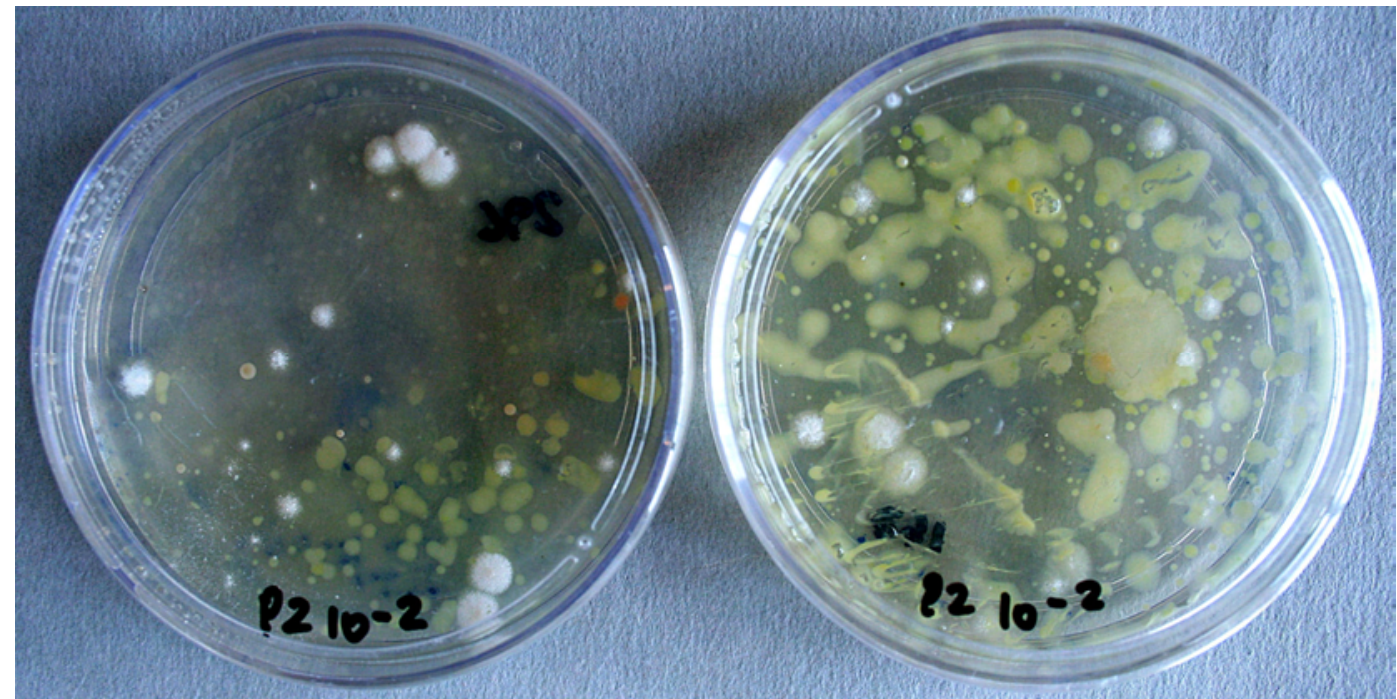

Fig. 418

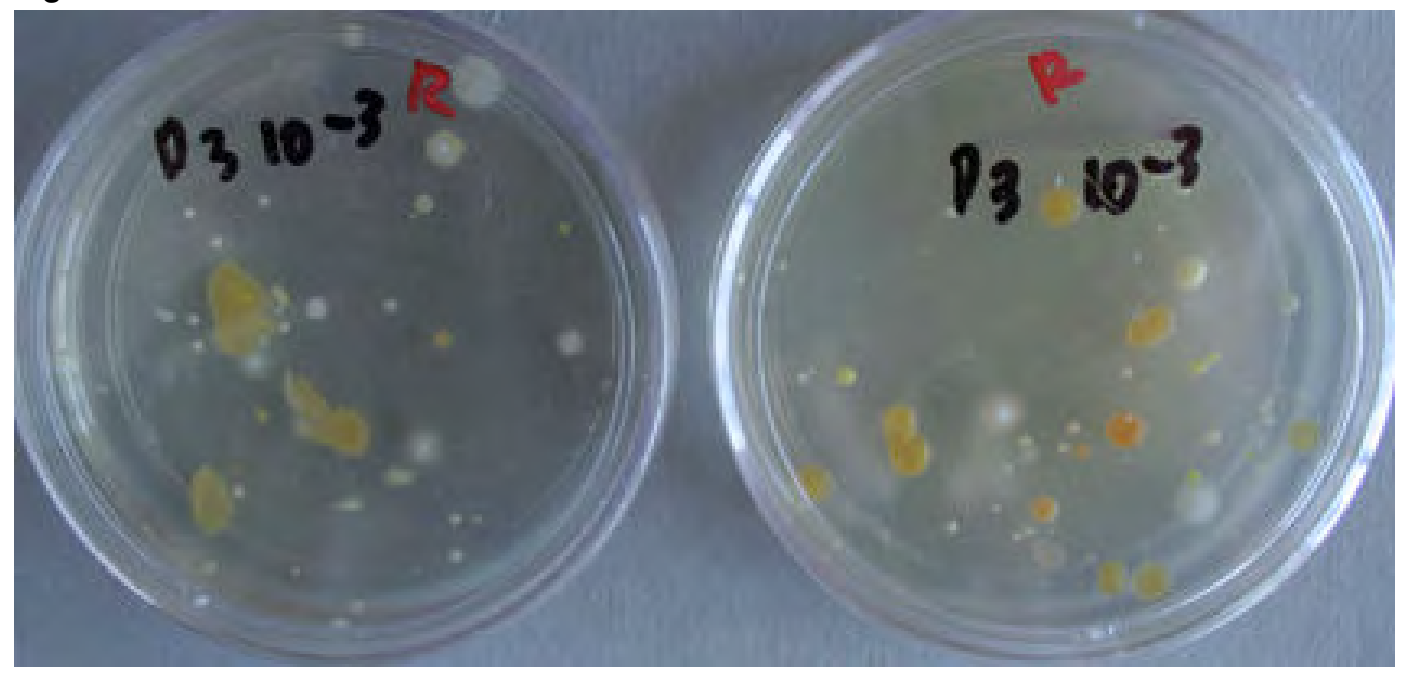

Fig. 419

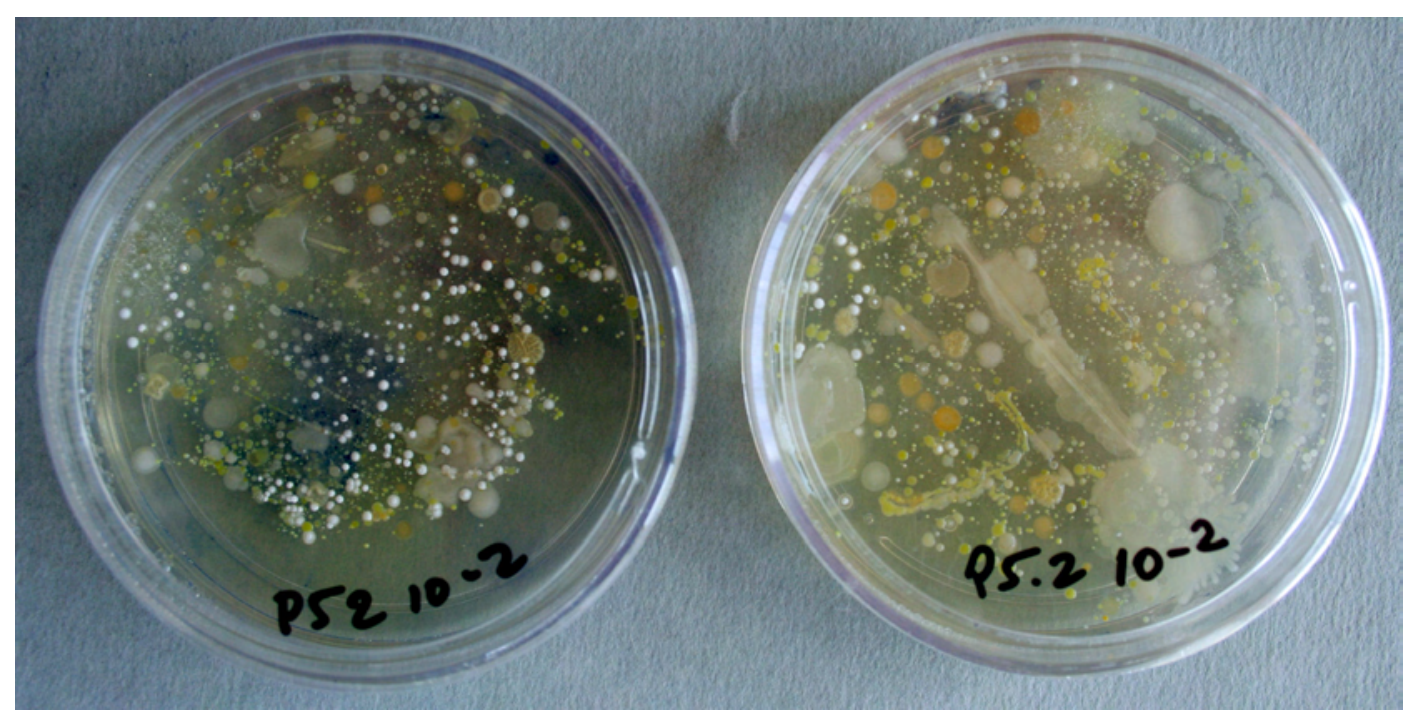

Amostra P2, P3 e P5.2

Crescimento de Aga Nutriente para bactéria heterotróficas 
MEV - MICROSCOPIA ELETRÔNICA DE VARREDURA

EDS - ESPECTRO DE ENERGIA DISPERSIVA

LCT - Laboratório de Caracterização Tecnológica

Departamento de Engenharia de Minas e de Petróleo - Escola Politécnica da

Universidade de São Paulo

Liz Zanchetta D’Agostino - operação

Márcia Shirakawa - interpretação

\section{MEV - MICROSCOPIA ELETRÔNICA DE VARREDURA}

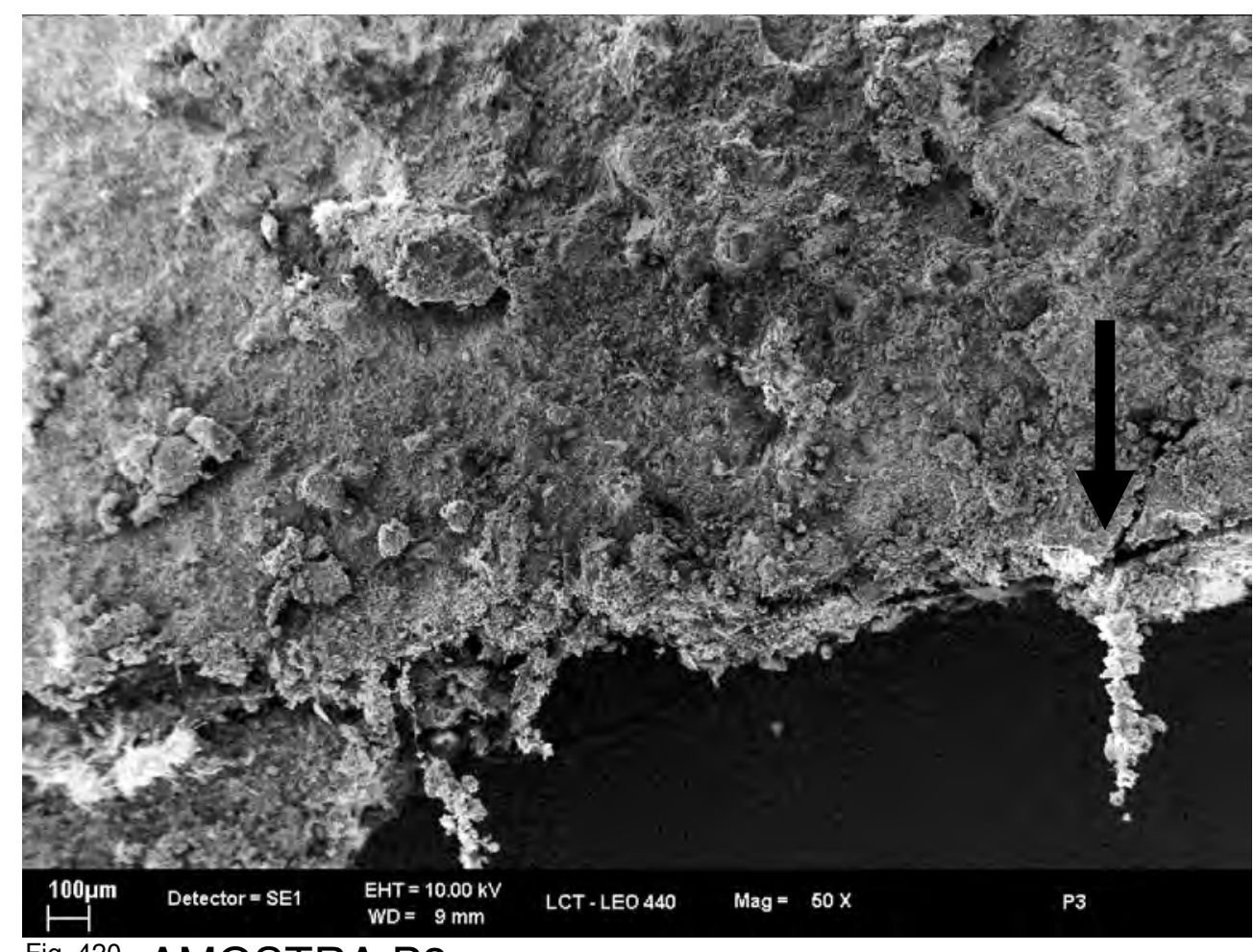

Fig. 420 AMOSTRA P3

Com fissura na película da pintura 


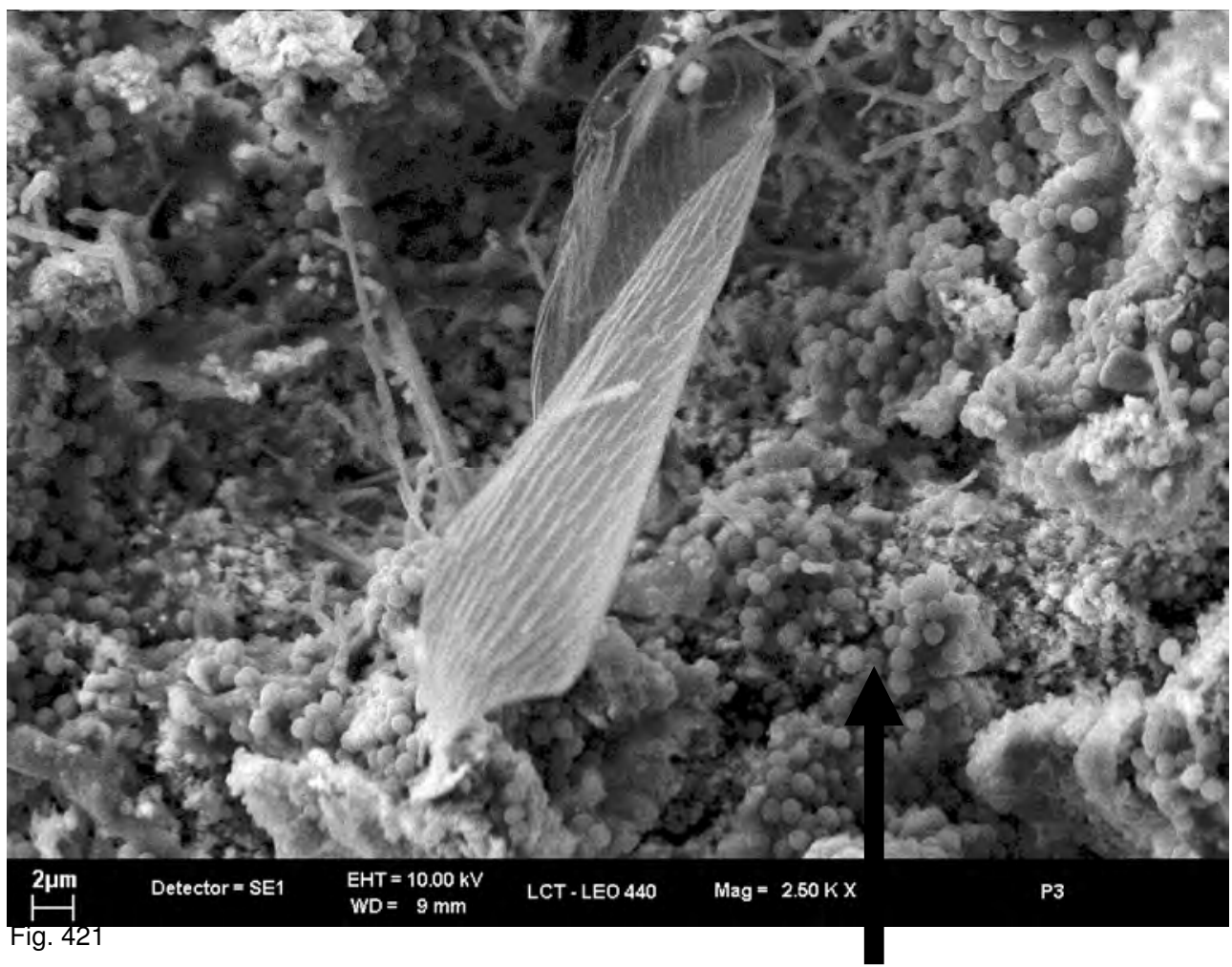

\section{Bactérias em forma de Cocos}

V

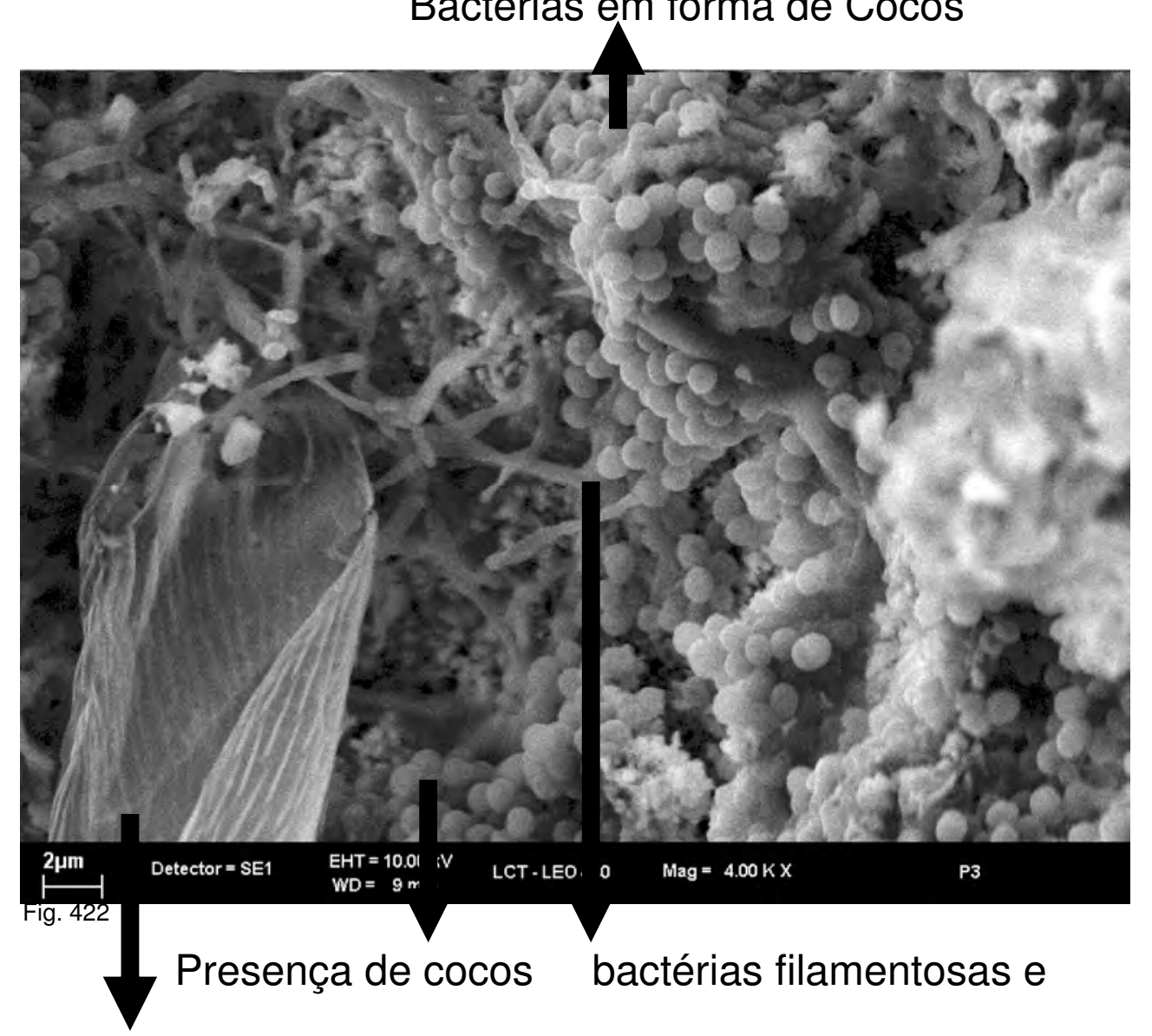

estrutura semelhante à asa de insetos 


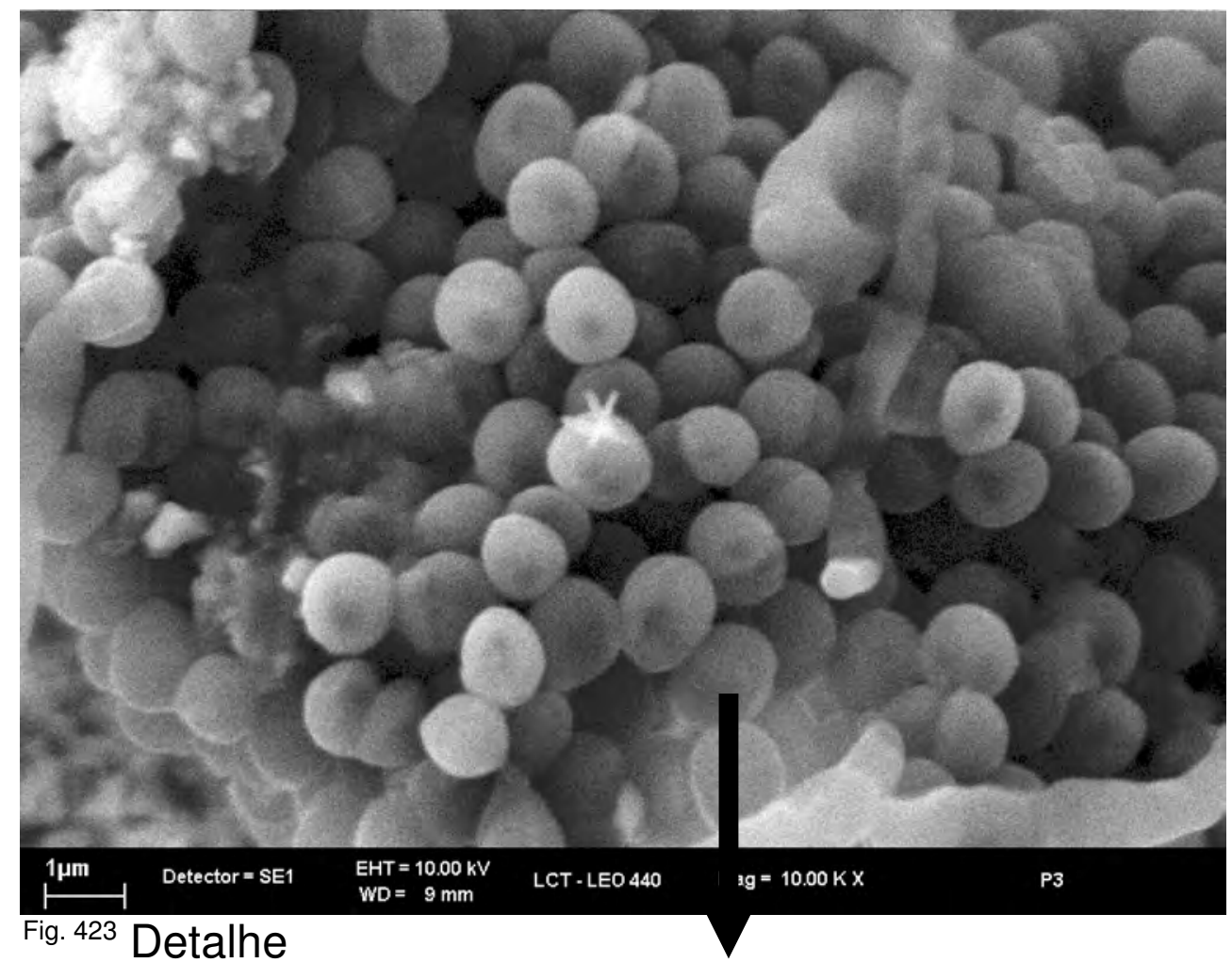

Bactérias em forma de Cocos: em grande quantidade Bactérias Filamentosas : em grande quantidade

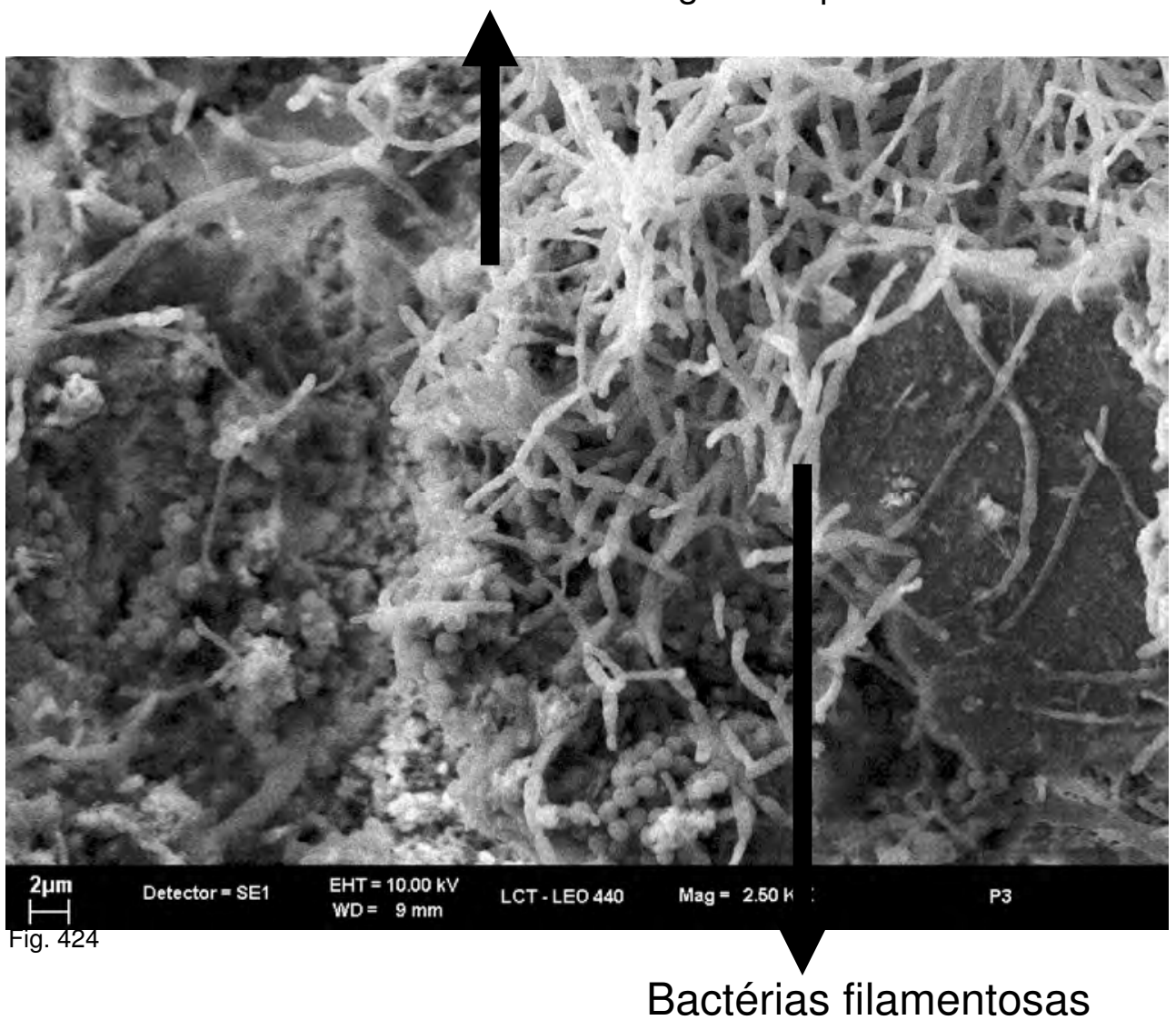



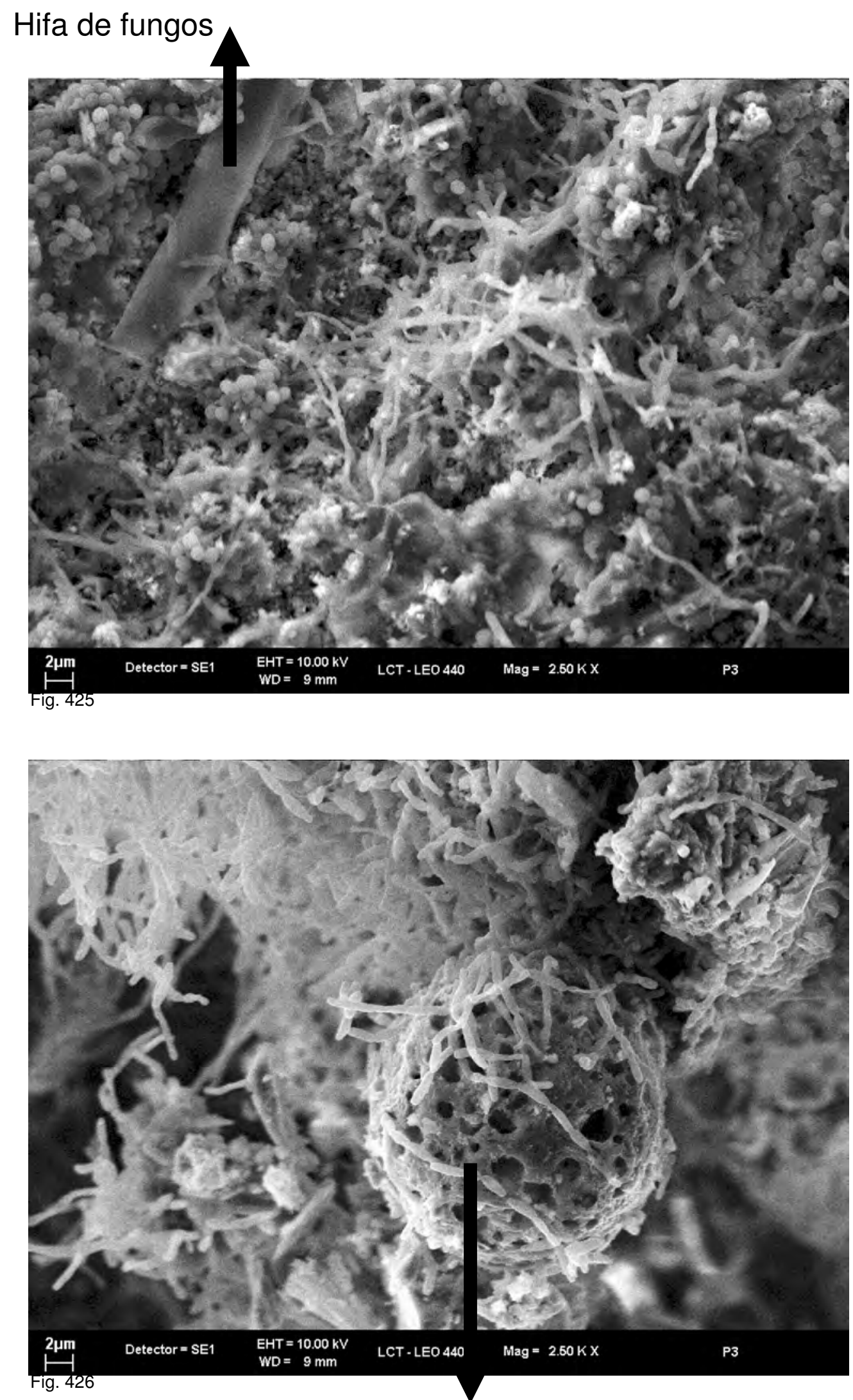

Estrutura atípica em argamassa, colonizada Por Bactérias Filamentosas 


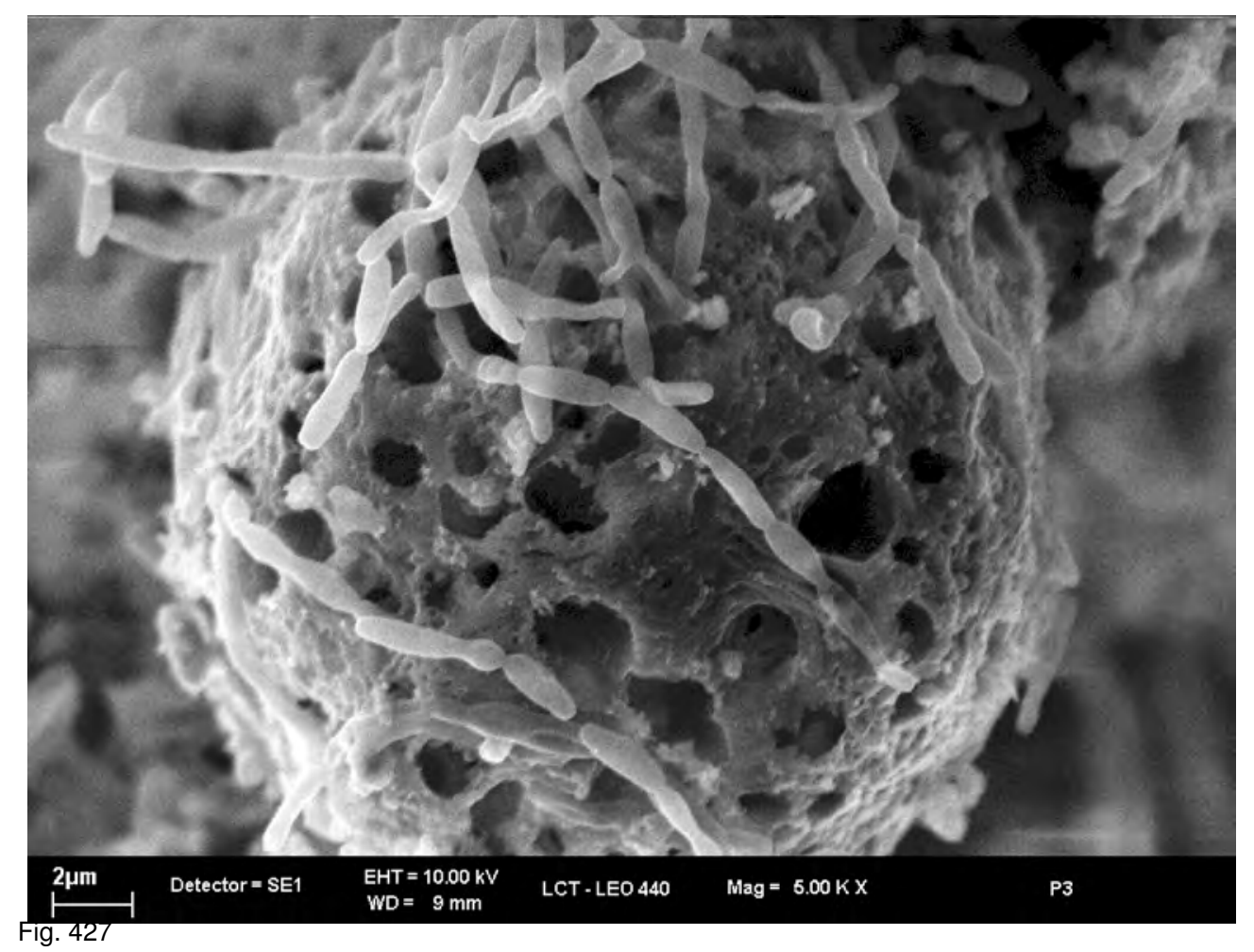

Detalhe

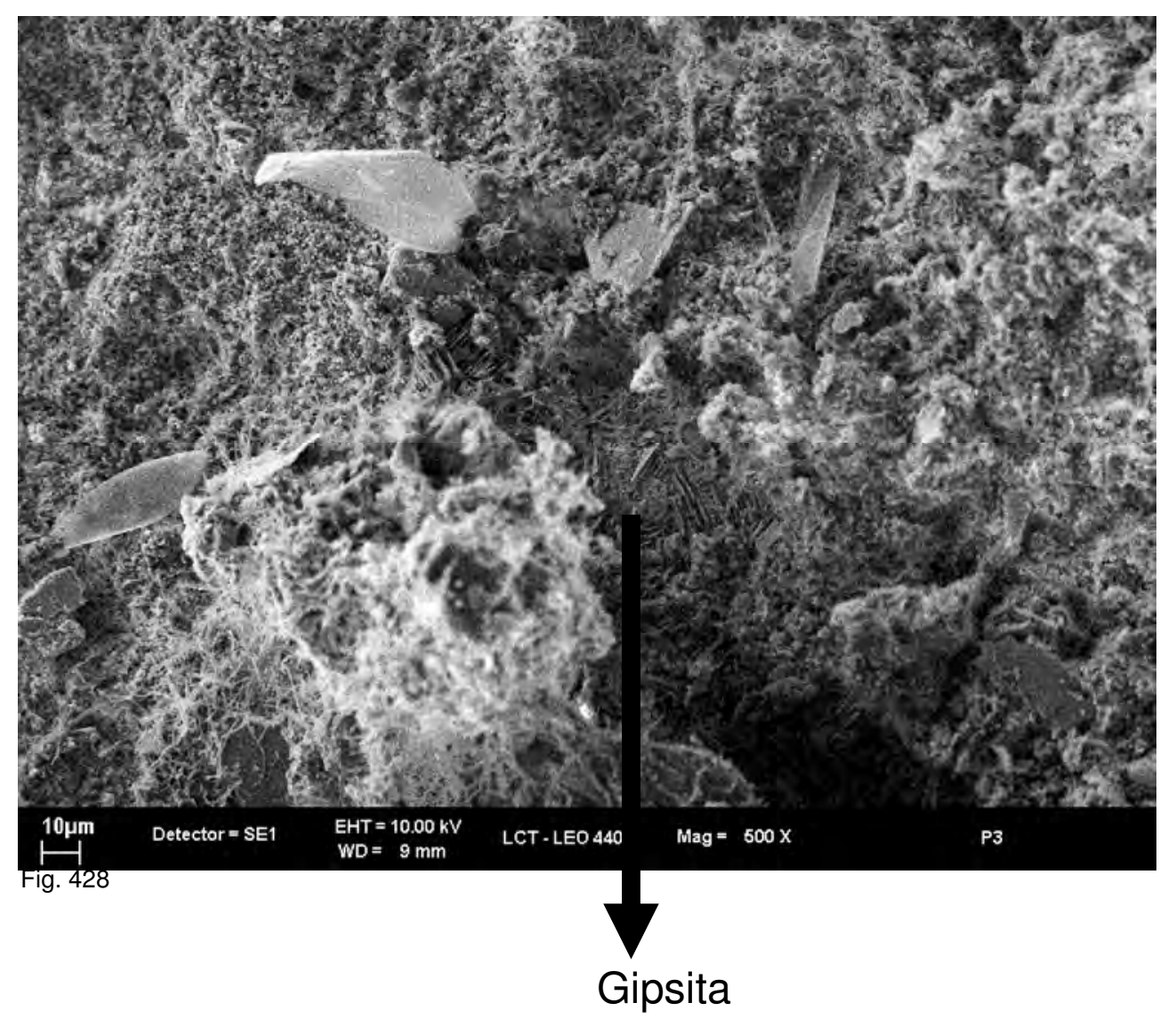




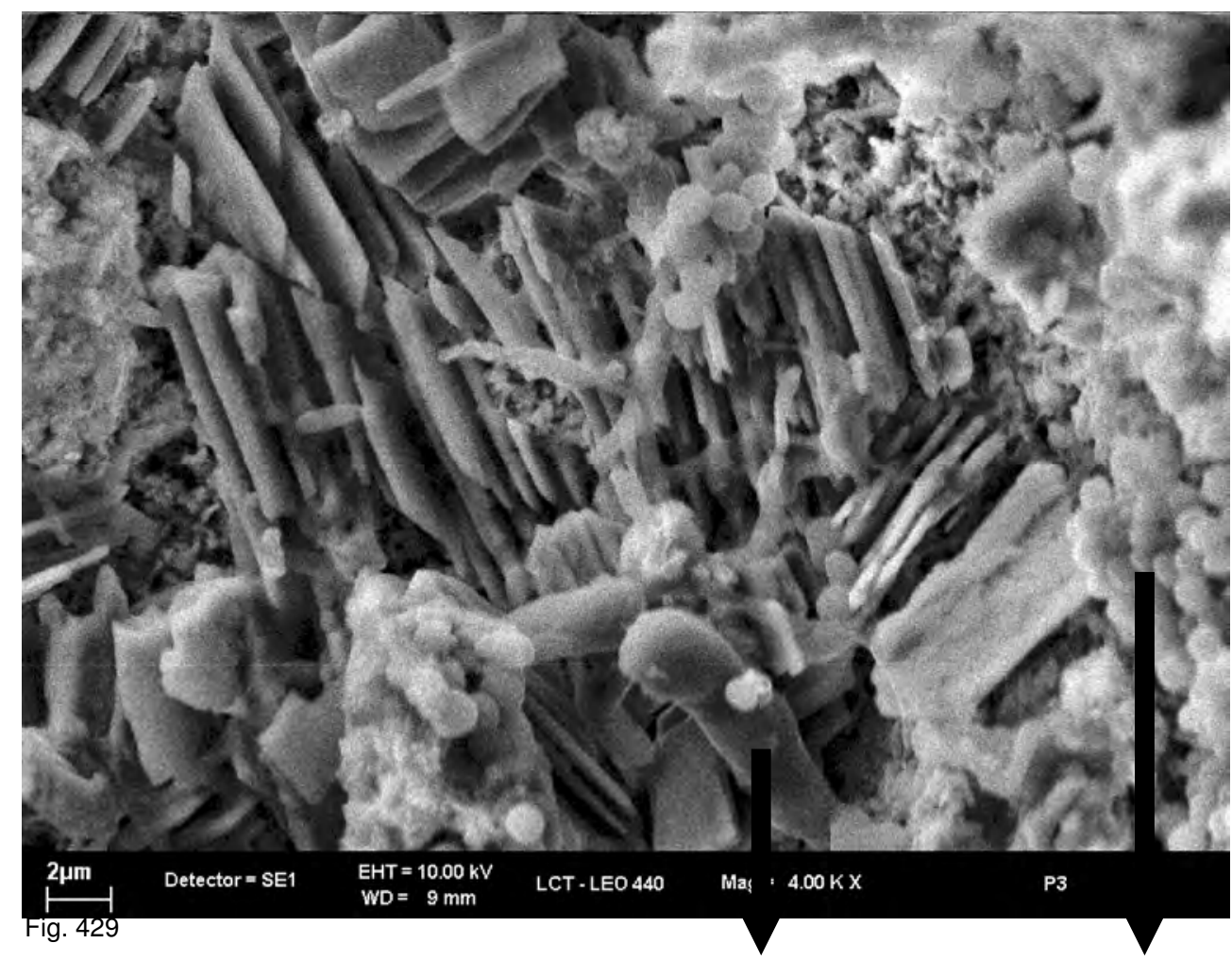

Detalhe: Gipsita (sais cristalizados) Hifas bactérias em cocos

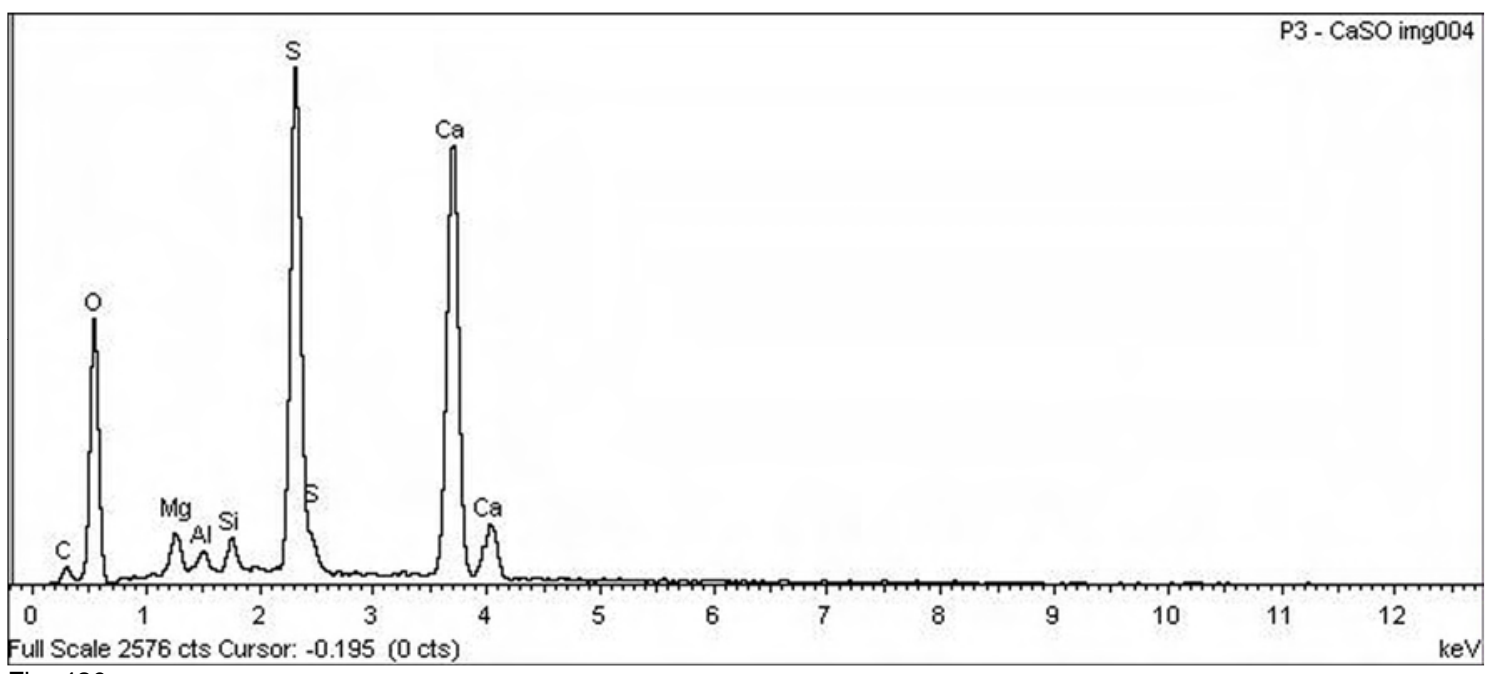

Fig. $430 \quad$ Amostra P3 CaSO - EDS

Presença de enxofre, cálcio e oxigênio evidenciando presença de gipsita 


\section{AMOSTRA P5.2}

MEV

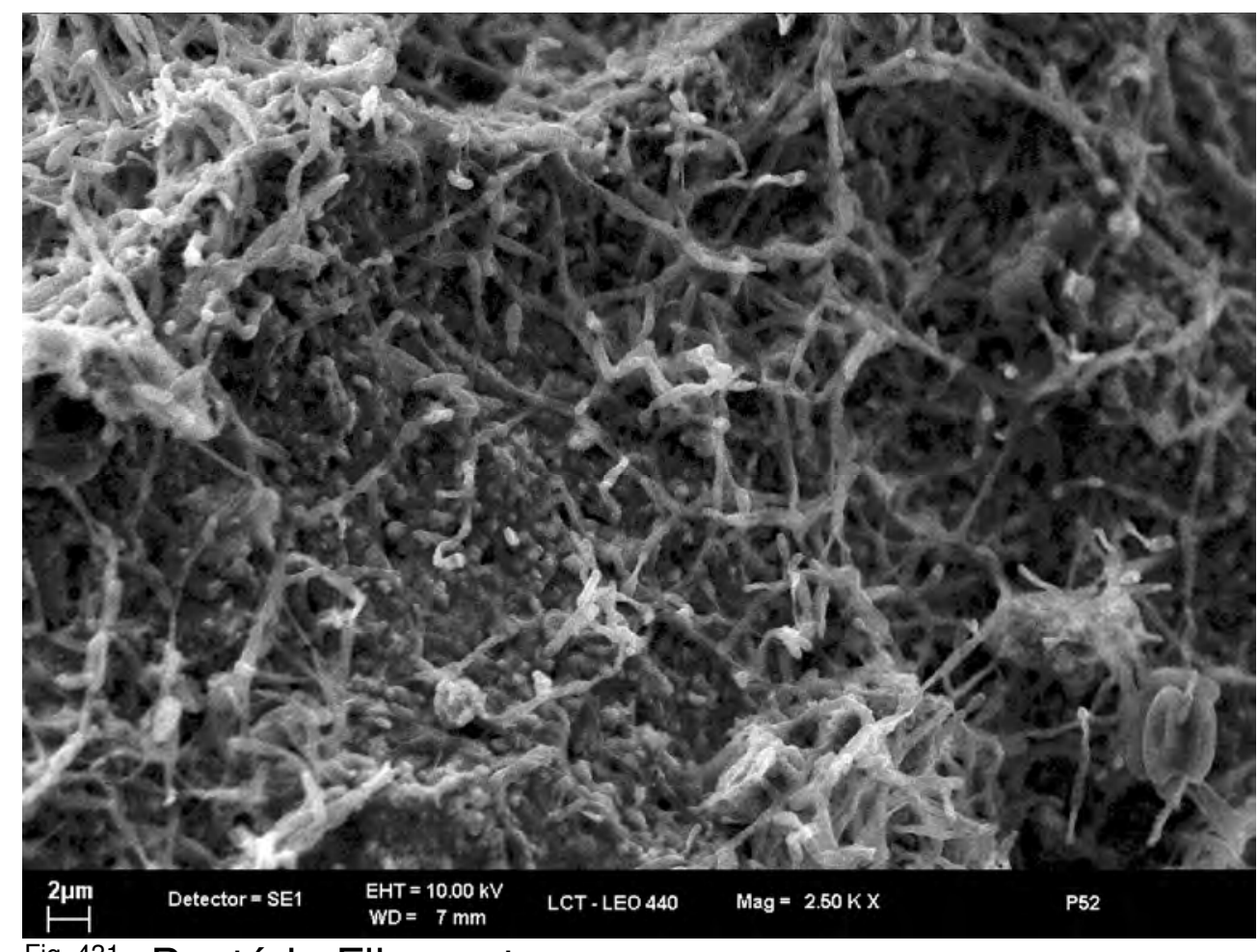

Fig. 431 Bactéria Filamentosa

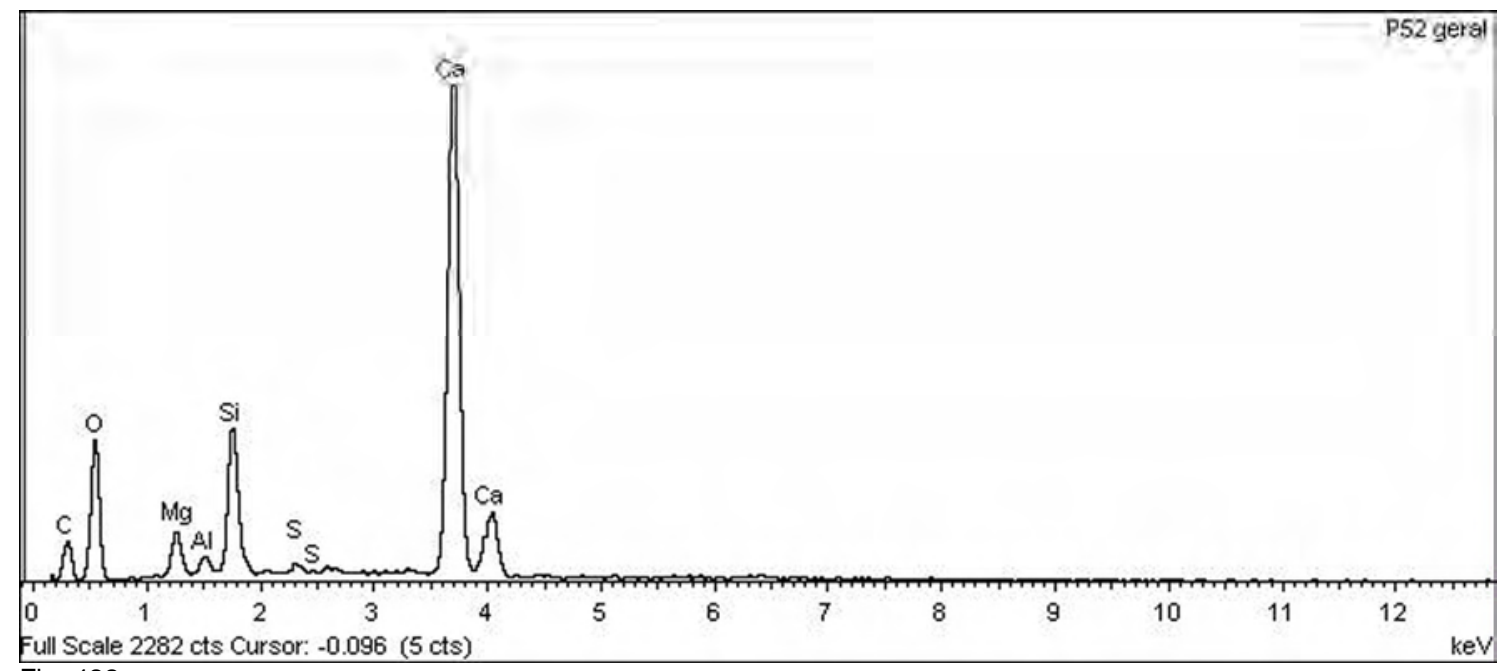

Fig. 432 AMOSTRA P52 - EDS Geral - confirmação de argamassa aderida na película da tinta 

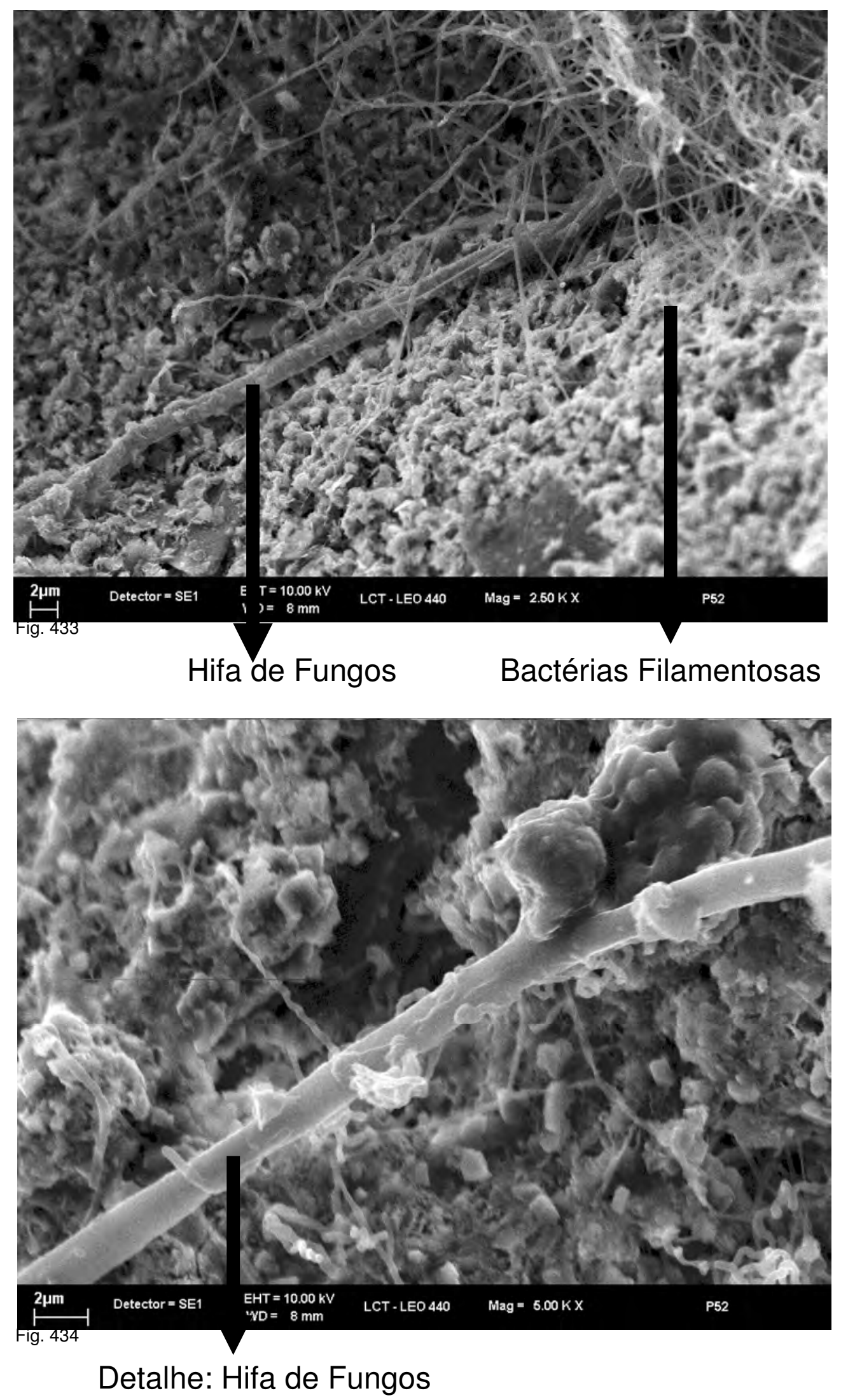


\section{CONCLUSÕES}

\section{VALORES}

Diversos valores são atribuídos ao edifício do Museu Paulista, mas esta pesquisa, tem como objetivo destacar e agregar mais um valor, o de sua técnica construtiva.

O que se pretende, é que este edifício seja apreciado, não só pela sua estética como manifestação do Ecletismo, mas pela sua técnica construtiva e as soluções específicas ornamentais e estruturais, que aqui foi citada repetidamente como Técnica Tradicional de Construção de Alvenarias. Este título foi inspirado no livro do restaurador, pesquisador, Eng. João Mascarenhas Mateus, no qual estabelece importantes referências.

\section{METODOLOGIA}

O método adotado para a realização da pesquisa foi:

- A pesquisa bibliográfica, arquivística e iconográfica, focalizando as questões da técnica construtiva e dos materiais.

- A observação do edifício com registro fotográfico, orientada por embasamento teórico e técnico a respeito da técnica construtiva.

- Os ensaios exploratórios de alguns materiais: argamassa, tijolo, camada de tinta.

Os passos que foram seguidos no estudo, contribui com reflexões na elaboração de uma metodologia de pesquisa, e podem ser avaliadas as fontes em que se basearam e como vieram a ser aplicadas.

Através dos resultados dos ensaios exploratórios, verifica-se as causas de danos, e como se processam em relação às circunstâncias criadas em desacordo com sua natureza, e características do edifício.

\section{HIPÓTESE}

Esta pesquisa teve como hipótese, que as intervenções realizadas no edifício, não consideraram que este difere fundamentalmente de um edifício moderno.

Não consideraram as características da técnica tradicional de construção de alvenarias, quanto à natureza de seus materiais e suas funções na estrutura do edifício.

As intervenções acabaram por se constituir como causa de sérios danos, com algumas raras exceções.

Esta hipótese pode ser confirmada, através da avaliação do histórico das intervenções e das patologias que apresentam nos dias de hoje.

Através dos estudos e ensaios exploratórios foram esclarecidas as causas de danos e como se processam.

O conhecimento sobre a técnica construtiva é absolutamente indispensável para ser observada nas futuras intervenções, com o fim de não mais provocar danos ao Patrimônio

\section{AVALIAÇÃO DAS INTERVENÇÕES}

Observou-se que no Histórico das Intervenções, referente a aproximadamente 112 anos de vida do edifício, não há referências quanto aos critérios adotados no planejamento e de uma etapa de investigação antecedendo a execução. Não é mencionado que um edifício de alvenaria tem peculiaridades, e que a estrutura, as paredes e seus revestimentos, devam ser considerados para que as intervenções fossem compatíveis, e que alcançassem o objetivo que é a preservação do edifício.

Esta constatação produziu um sólido embasamento para a formulação da hipótese, e que foi o que despertou a princípio, o interesse desta pesquisa. 
Como exceções, são apontadas as intervenções realizadas no período de 1995 / 1997.

Uma delas foi a intervenção do Eng. Péricles Fusco, na estrutura do piso do segundo pavimento da torre oeste, que levou em consideração, as soluções estruturais concebidas por Bezzi, para melhor se adequar.

Analisou também a estrutura do edifício como um todo, ao avaliar os cortes realizados nas fundações a partir de 1931, para a abertura de novo espaço no subsolo (ver FUSCO, 1997, p.55-102). Este fato, segundo o engenheiro, causou rachaduras e movimentação, principalmente nos arcos transversais das galerias do primeiro pavimento, porque comprometeram a rigidez dos elementos da fundação. $\mathrm{E}$ o maior dano à estrutura foram os cortes em diversas paredes transversais, para aberturas de portas de acesso às novas salas. Com isso a parede longitudinal frontal precisou se reequilibrar por conta própria, em virtude da menor colaboração das sapatas transversais, que funcionavam como vigas alavancas mantendo a rigidez dos grandes maciços da fundação.

Outras exceções se referem à execução de novo telhado com placas de cobre, da substituição dos vidros das clarabóias, e os reparos na estrutura de metal que até hoje permanecem estáveis, sem apresentar vazamentos.

O documento apresentado na p. 204, no qual o engenheiro fiscal da Secretaria dos Serviços e Obras Públicas (hoje CPOS), a respeito da pintura das fachadas realizada em 1972, preconiza acertadamente, que a restauração futura dos ornatos seria muito mais trabalhosa, pelo fato de não executar uma restauração como deveria naquele momento. Faz comentários que muito se aproximam da problemática que envolve a pintura, mas que assim mesmo, ela é executada num prazo exíguo e de forma inadequada. Suas observações são parcialmente corretas, mas não se aprofundou nos conceitos quanto à técnica de alvenaria, e não conseguiu convencer para mudar os planos das intervenções. Os ornatos com rugosidades que o engenheiro se refere, tudo indica que sejam as palmetas na platibanda, que até hoje permanecem com estas rugosidades, com rachaduras nas espessas camadas de tinta com colorações diferentes, com sujidades e a presença de microrganismos, como exemplifica a imagem abaixo.
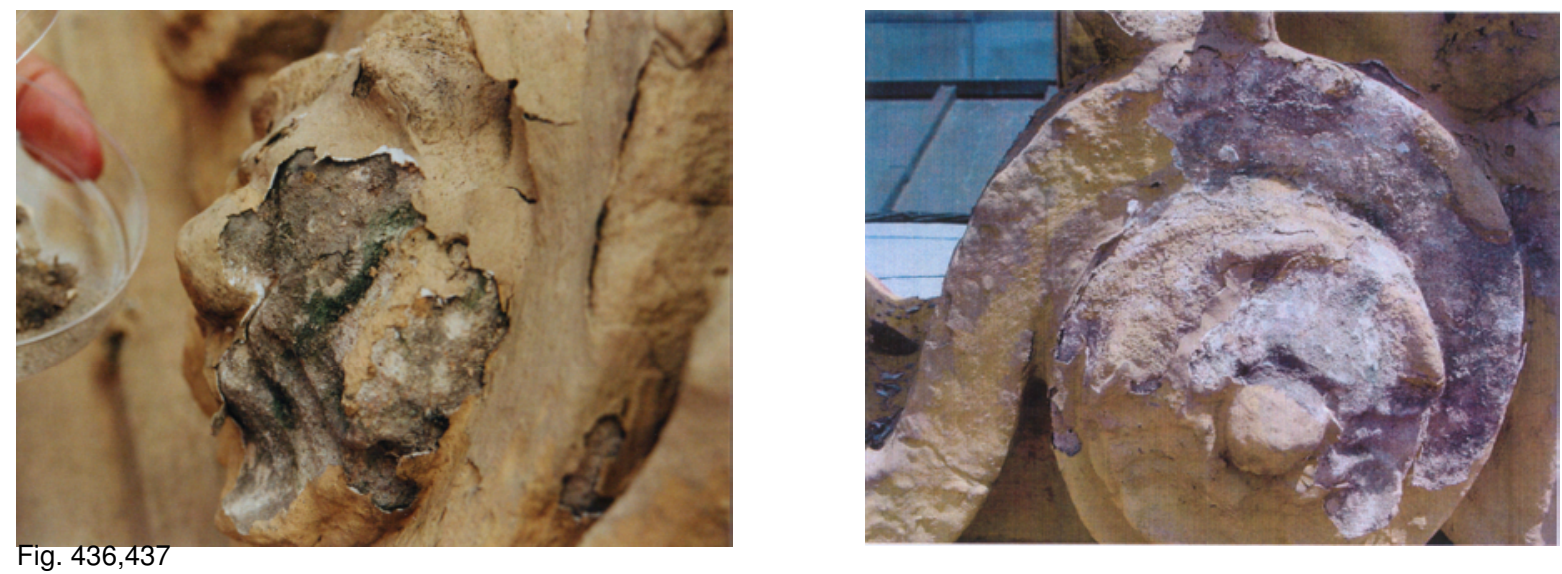

Camadas de tinta sobrepostas, com desprendimento da argamassa, com fissuras e perdas. Na imagem da direita, as formas e desenhos superficiais estão desaparecendo.

Estes danos são devidos ao procedimento inadequado da pintura, sendo executada sobre superfícies sem a devida restauração dos ornamentos, da extração das camadas de tinta e sujidades, e principalmente pela utilização do tipo de tinta filmogênica que impede a 
evaporação, e também pela água de chuva, que penetrando pelas fissuras, vai danificando cada vez mais a argamassa.

Outro aspecto relevante, constatado pelas conseqüências de uma intervenção executada isoladamente e sem considerar o edifício como um todo, ou mesmo as áreas vizinhas, afetou e provocou diferentes danos. (veja fig. 446 a 449).

Para exemplificar, focalizaremos dois casos.

Nesta mesma região da platibanda, no entablamento onde se apóiam as palmetas, em 1990 apresentava empolamentos no friso liso e foi tratada com impermeabilizante, massa e pintura acrílicas. Em 2002 na parte interna deste entablamento, foi novamente impermeabilizada, e assim tanto a faixa externa e as palmetas, como a faixa interna, ficaram impermeabilizadas com pintura acrílica. Mas, a umidade continuou a penetrar e os danos nas palmetas se acentuaram, os empolamentos do friso voltaram a surgir. A umidade penetra na base das palmetas, e pelas fissuras das camadas de tinta. Assim, intervenções realizadas em dois momentos, não se compatibilizaram e os danos foram mais acentuados.

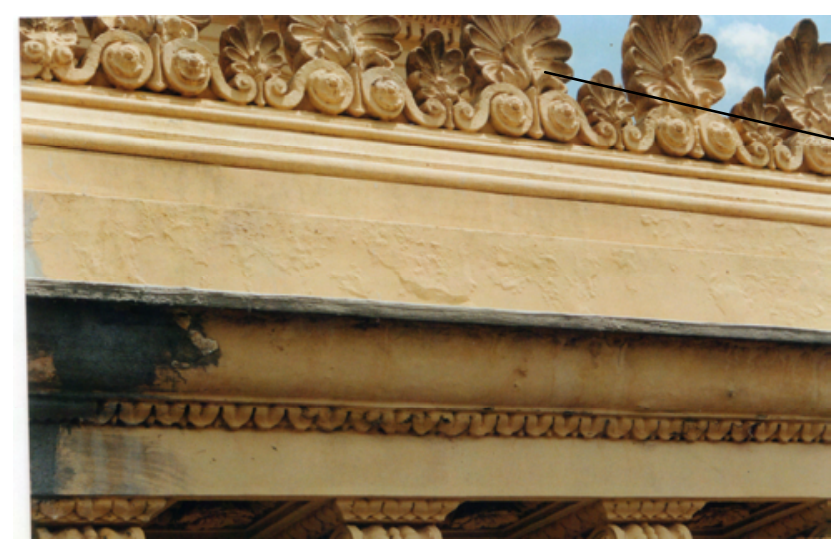

Empolamento da pintura sobre o friso liso Fig. 438,439

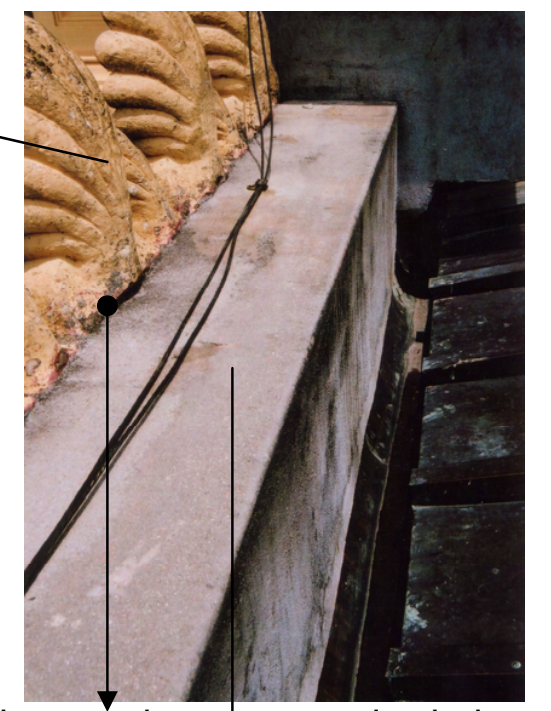

Fissuras junto ao apoio da base Faixa interna împermeabilizada

Outro exemplo, é a iluminação das fachadas, realizada em 1999. Ela em si, trouxe benefício ao edifício, destacando-o na paisagem urbana noturna. Mas ao se observar de cima para baixo no edifício, vemos o "avesso" e as conseqüências, como ilustram as imagens, dos feixes de fios interligando-se às luminárias nas fachadas, sobre as saliências das cornijas. Acumulam sobre estes fios, sujidade e transmitem umidade para as paredes próximas, danificando a argamassa de revestimento. 

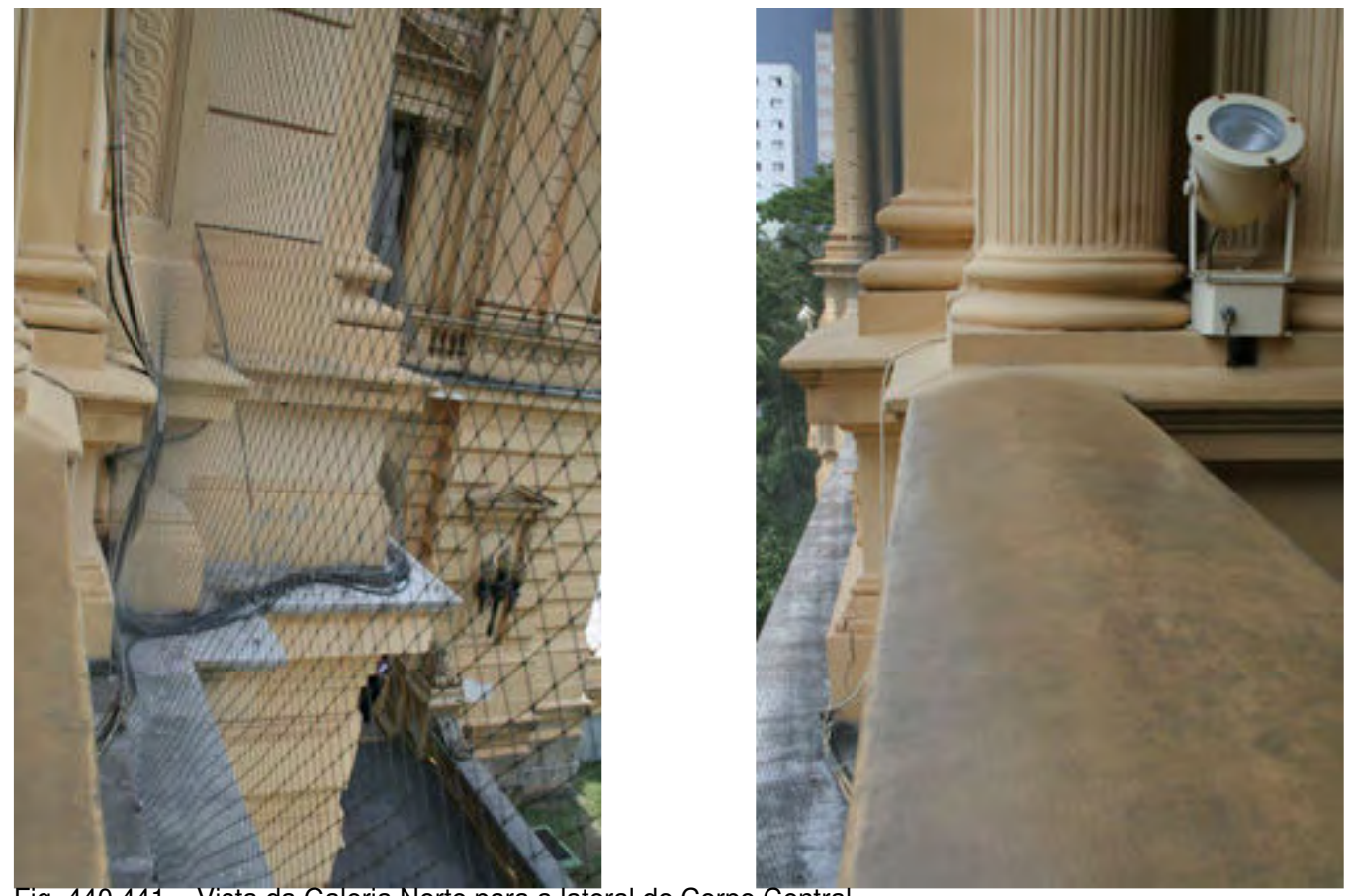

A enfiação é interligada às luminárias externamente às paredes das fachadas e quando possível apóiam-se nas saliências das cornijas.

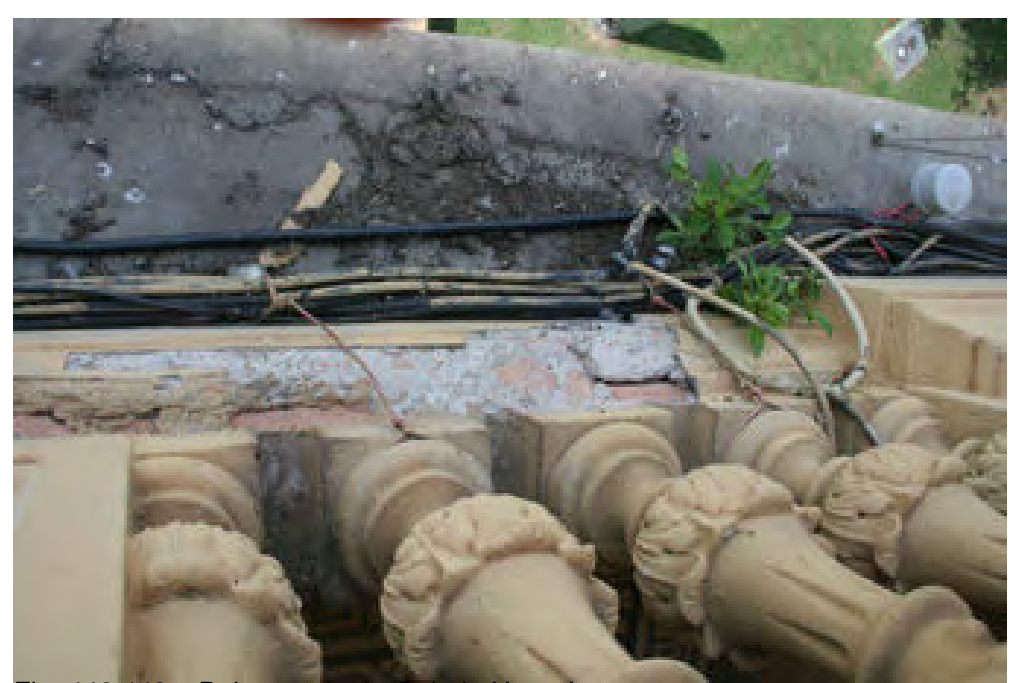

Fig. 442,443 - Balaustrada da Galeria Norte-Leste

Acumulação de sujidade, umidade, vegetação, criando danos na argamassa da base da balaustrada 

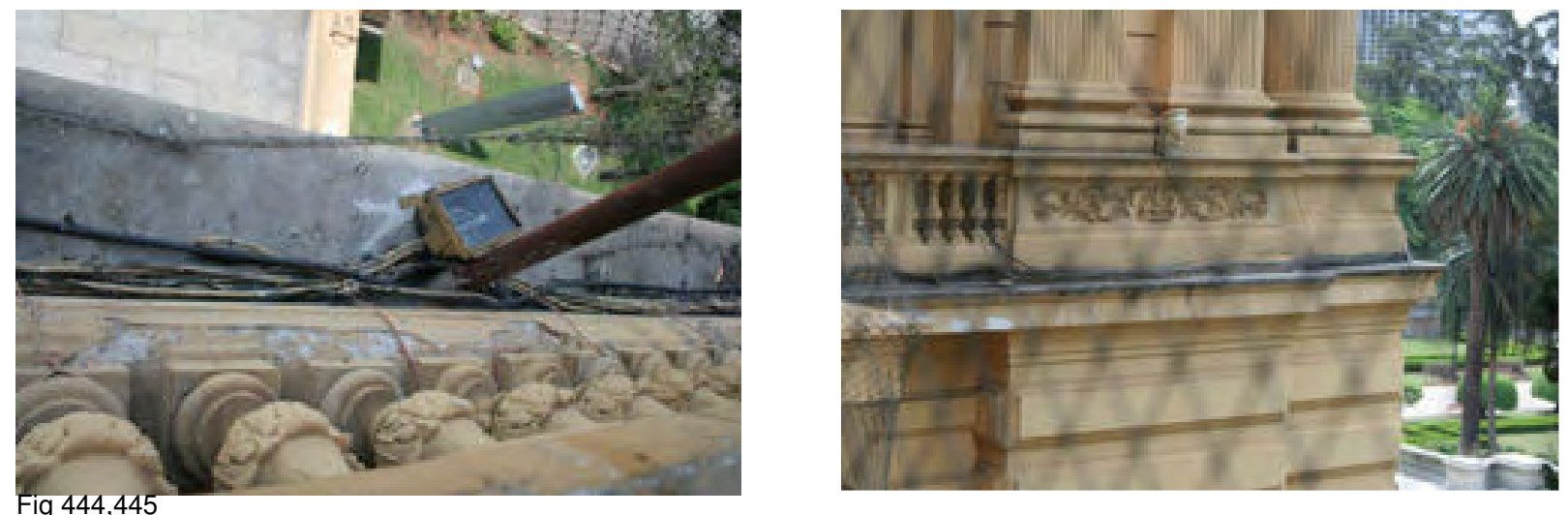

Foram ainda utilizados na iluminação das fachadas, holofotes instalados em caixas enterradas no solo. A execução das caixas e transmissão da enfiação causou cortes e emendas no cimentado do piso externo. Os desníveis e fissuras nessas emendas facilitam a infiltração de água, pois as conseqüências da umidade podem ser observadas nas paredes próximas ao seu redor.

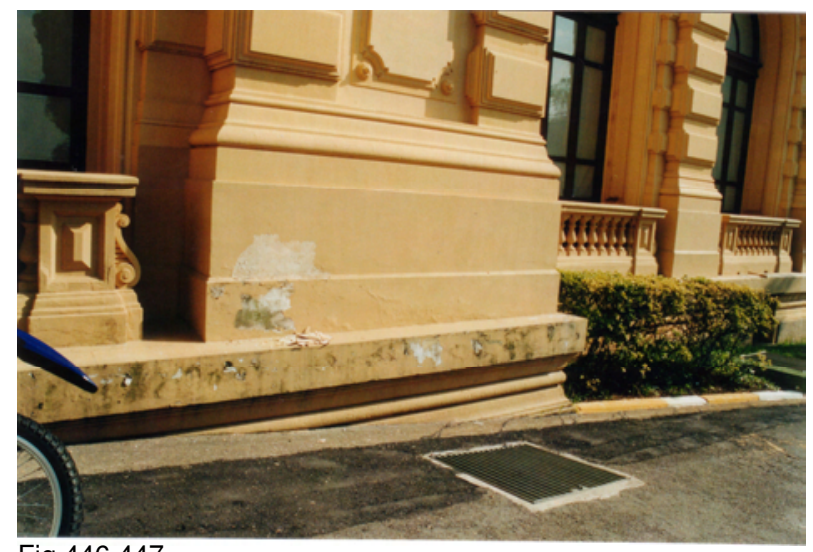

Fig 446,447

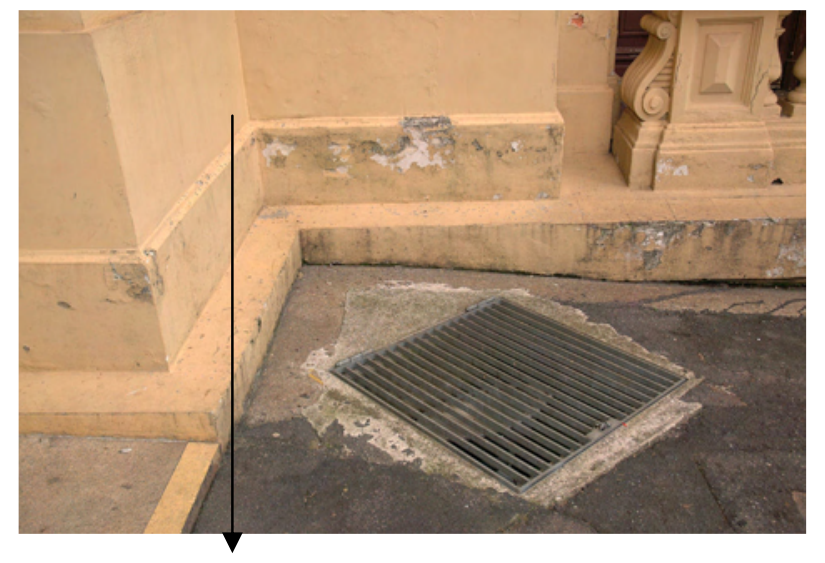

Do lado interno, parede atrás do Bandeirante

Manchas esverdeadas .

Manchas esverdeadas nas paredes externas, empolamentos e desprendimento da película da pintura, como mostram as figuras acima, progrediram nos últimos anos. Nessa parede do lado interno, há empolamento na pintura, também, atrás da escultura do Bandeirante no saguão de entrada. E no subsolo, a umidade se torna visível na alvenaria sem revestimento do embasamento.

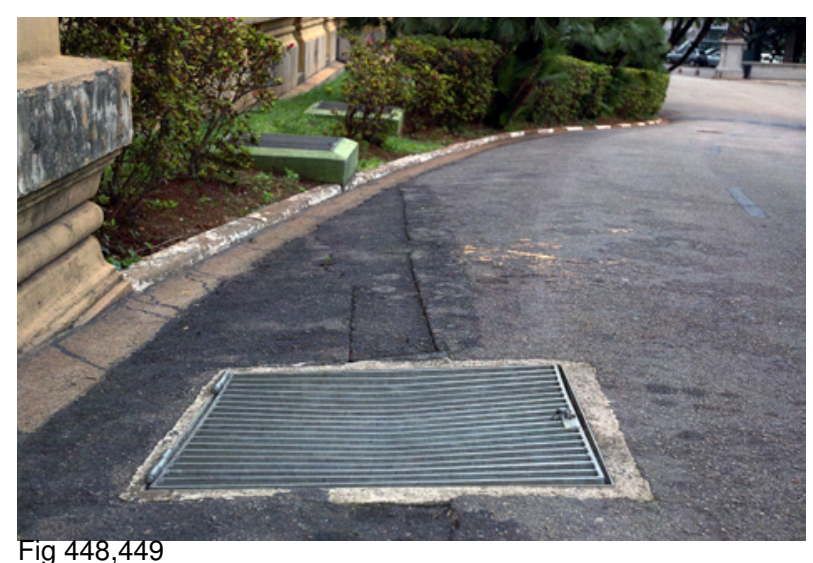

Fig 448,449

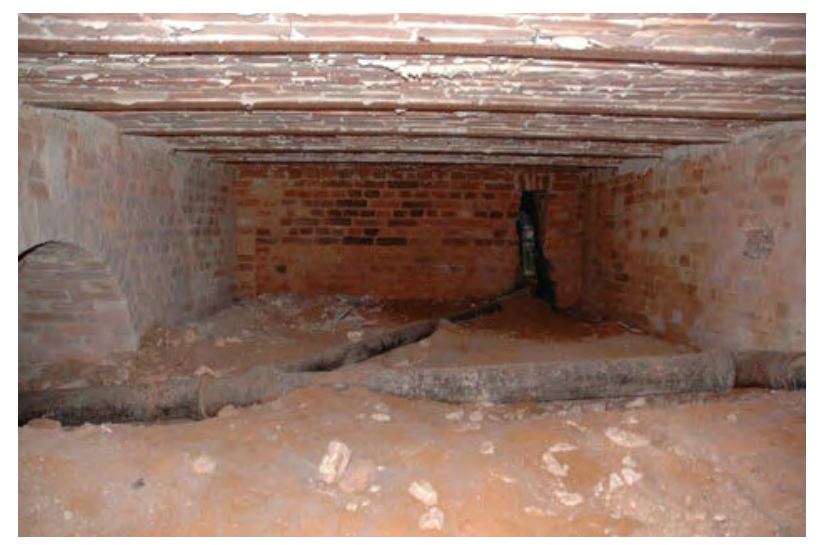


Portanto, como já mencionado, uma intervenção mesmo que seja valorizada, executada individualmente, pode acarretar danos às outras partes do edifício e aos seus diferentes materiais.

Nota-se que entre as maiores intervenções, não há programas de atividades intermediários de conservação. Não há principalmente uma Política de Conservação, que estabeleça critérios e procedimentos básicos, para que haja continuidade em todas as ações, de forma a complementar uma à outra, com coerência e clareza de objetivos, compatíveis à técnica construtiva do edifício e aos materiais originais.

\section{EDIFÍCIO DE TÉCNICA CONSTRUTIVA TRADICIONAL / EDIFÍCIO HISTÓRICO}

Um edifício de técnica construtiva tradicional se diferencia de um edifício moderno:

- O edifício moderno tem as fundações impermeabilizadas, seus materiais são bem menos porosos e suas paredes podem receber tintas altamente impermeáveis e resistentes.

- Já o de técnica tradicional não tem impermeabilização nas fundações, sofre a ação da umidade ascendente e da descendente. A umidade que atinge as paredes, pode se originar de águas freáticas, de águas superficiais, de dentro das paredes e sob o edifício, devido aos danos nos condutores de águas pluviais e tubulação de esgoto.

Seus materiais são porosos e facilitam a percolação da água pelos condutores capilares, onde dissolve e carrega substâncias e assim vai provocando reações químicas.

A umidade ascendente é um fato irrefutável no edifício objeto do estudo, pelas diversas manifestações no revestimento das fachadas, na faixa próxima ao solo, de desagregação da argamassa, vesículas, empolamento da pintura e argamassa de revestimento, manchas esverdeadas. $\mathrm{E}$ também na umidade descendente, nas áreas próximas à cobertura, também com empolamento, erosão nos ornamentos, fissuras, desprendimento da argamassa da alvenaria

É de fundamental importância, eliminar as barreiras impostas à evaporação da umidade, que é permanente e imutável, com a extração extremamente criteriosa das películas de tinta, permitindo que as paredes retornem às suas condições originais.

A umidade, tem que ser evaporada constantemente, para não causar danos à alvenaria $e$ aos revestimentos.

Como Bezzi indicou no Documento 237, a primeira pintura foi utilizada a cal, uma tinta permeável aos vapores de água, devido ao processo de cristalização que ocorre com a carbonatação. Assim, o edifício concebido por Bezzi, permitia uma adequada convivência com a umidade ascendente, ou descendente, com este tipo de tinta.

O tipo de tinta não permeável, começa ser utilizada por volta de 1910,1912, quando foi experimentada uma tinta a óleo nas partes mais sujeitas ao tempo. Este fato demonstra que neste momento, o conceito de tinta mais resistente às intempéries, do que a primeira pintura à cal, já existia.

Quando se encontra referências à execução de pinturas no edifício, muitas destas informações estão incompletas, como por exemplo se a pintura geral realizada em 1922, para comemoração do centenário da Independência. Não especifica qual o tipo de tinta, a cor, e quais as áreas que de fato foram trabalhadas. 
As pinturas realizadas em 1972 e 1990 são documentadas, e a principal informação é a utilização de tinta látex e acrílica, de grande resistência às agressões do meio ambiente, mas totalmente impermeáveis aos vapores de água.

Com essa barreira criada à evaporação da umidade, durante anos, está havendo um extenso processo de danos nas argamassas de revestimento e assentamento, nas superfícies dos tijolos, mas estes não são sempre visíveis.

As paredes das fachadas estão mascaradas por uma espessa camada de tinta e somente nos locais onde esta se rompe em forma de fissuras, é que torna aparente a desagregação da argamassa, o desprendimento dos materiais. Mesmo em locais onde a pintura está íntegra, pode ocorrer a perda de aderência do reboco da alvenaria, ou da camada de tinta do reboco.

Outro recurso que contribuía com a evaporação da umidade, é o emprego do porão de ventilação, ou caixa de ar, que além de distanciar o primeiro pavimento da umidade originada no solo, tinha a importante função de evaporar a umidade ascendente, tal como se pode observar neste edifício. Esta umidade manifestava-se livremente através da porosidade dos tijolos sem revestimento, pedras e argamassa de cal de assentamento. Esta evaporação ocorria através de um sistema de ventilação natural e permanente, na direção transversal e longitudinal sob o edifício, pelas aberturas nas fachadas comunicando-se com as diversas aberturas, em arcos semicirculares, nas paredes internas do embasamento. Uma parcela da umidade era assim eliminada por esta ventilação e a restante que ainda pudesse ascender pelas paredes até atingir o primeiro pavimento, evaporava-se nas superfícies externas das fachadas, sem dificuldades.

Estas características originais foram drasticamente alteradas na intervenção realizada a partir de 1931, quando o porão de ventilação se transformou em mais um pavimento, com salas de trabalho e área expositiva.

Para se adaptar os espaços criados, diversos arcos nas paredes internas, por onde circulava ar constantemente, foram fechados para abrigar salas e banheiros, e assim a ventilação deixou de existir de forma completa. Além disso as paredes internas receberam uma pintura com tinta impermeável, sendo aplicada uma camada sobre a outra.

As fundações em alvenaria de pedra, as paredes do embasamento em alvenaria de tijolos, originalmente não tinham revestimento, e a umidade ascendente tinha a facilidade de se evaporar através da porosidade dos materiais.

Assim, as alvenarias de pedra e tijolos, do novo pavimento, o subsolo, foram rebocadas e pintadas.

No início da utilização deste espaço, notou-se uma grande umidade, que ascendia na alvenaria de pedra, e se transmitia aos ambientes internos. Então foram recobertas com uma fiada de tijolos em espelho, distanciados $15 \mathrm{~cm}$ do alinhamento da fundação, para que a umidade se tornasse imperceptível.

As paredes do subsolo receberam pintura com tinta impermeável e permanecem até hoje, sendo comum a repintura, uma camada sobre a outra, quando é considerado necessário preparar estes espaços para exposições de acervo. Nessas paredes quando há empolamento na pintura, sinais de umidade com bolor, descascamento da tinta, são retocadas com os mesmos tipos de materiais, e a situação permanece inalterada.

As paredes internas e externas se tornaram totalmente impermeabilizadas, e a tendência da umidade ascendente é aumentar a altura, procurando de alguma forma atingir a superfície das paredes externas para se evaporar. 
Os danos nas paredes das fachadas somente podem ser observados onde a película de tinta se rompeu, devido ao completo mascaramento da pintura sobre o reboco. Mas se pode constatar que uma faixa de parede a 1 metro do solo, em toda volta do edifício, apresenta descolamento da argamassa da alvenaria, que só pode ser percebida com percussão e pelo som cavo que emite. Aparentemente, numa simples observação, na maioria dos locais, a argamassa e a tinta estão planas, não indicam o dano que está ocorrendo.

Os tijolos, nas superfícies onde podem ser vistos nas vesículas ou nas perdas da camada de tinta, apresentam esfoliamento, desagregação. Não se conhece o estado que se encontram os tijolos no interior das paredes das fachadas, como do embasamento. Não se conhece se a sua resistência mecânica permanece em bom estado, e isto deve ser levado em conta na sua preservação futura.

A umidade é considerada o maior agente de deterioração, e a causa primeira de outros processos de danos. A ação mecânica e química da água nos materiais se torna bastante acentuada com a presença de sais solúveis e com a proliferação de microrganismos, os quais foram confirmados através dos resultados dos ensaios.

A presença dos sais solúveis pode ser observado na lacuna, que chamamos de Entrada Leste, onde numa área sem reboco e pintura, houve uma intensa eflorescência, e foi identificado como sulfato de magnésio.

Através dos resultados dos ensaios, pode-se confirmar a presença de sais e como se manifestam nas patologias.

A análise de DRX realizado na Amostra P2, com argamassa desagregada, apresentado na pg. 280, identificou a presença de sal, a Gipsita, e que é uma das causas de sua desagregação.

Na Amostra P1, que é íntegra, não foi encontrado nenhum sal. O local desta Amostra não é atingido pela umidade ascendente, como ocorre com a Amostra P2. Este sal pode ter sido carreado de outros materiais ou do solo.

Através do MEV, realizado na amostra P3, de idênticas condições da P2, pode ser visualizada a mesma Gipsita.

É importante notar que a Amostra de Cimento Romano, dos ornamentos pré-moldados, apresenta também Gipsita e os danos nesses ornamentos se manifestam com outras características. O Cimento Romano tem maior resistência mecânica e com a presença de sal, produzem fissuras e desprendimento de partes dos ornamentos, como se observa por exemplo, nos Brasões de Armas, na moldura da cornija do frontão. Nas palmetas da platibanda, sob a espessa camada de tinta com fissuras, a superfície dos ornamentos sofre uma erosão, um desgaste superficial, no qual perde o relevo das formas e desenhos, mas o ornamento permanece com sua estrutura. Um dano bem diferente da desagregação das argamassas das Amostras P2, P3, onde há perda do material, aparecendo vazios sob a película de tinta..

Não se conhece exatamente a origem dos sais. Pode vir do solo ou dos materiais. Mas o que importa para a conservação do edifício, é se ter a certeza que eles existem e que agravam os danos

Como vimos no capítulo primeiro sobre a história da cidade de São Paulo, era comum na época correspondente à construção do edifício do Museu Paulista, o emprego de materiais de má qualidade, como a cal de marisco, mais barata e que vinha de Santos. Era observado pelos higienistas do século XIX, a umidade nas construções provenientes da presença de sais. 
Os sais existentes nos materiais podem permanecer por tempo indeterminado e se mantiverem sua forma cristalizada, não produzirá nenhum dano.

Se a umidade ascendente, solubilizar os sais e os encaminhar em direção à superfície, ao evaporar a água, estes tornarão a se cristalizar. Neste processo, provocam dilatação dentro dos poros dos materiais, e a conseqüente perda de coesão ou desagregação, principalmente se ocorrer de forma intermitente.

Outra característica significativa é a porosidade na estrutura dos materiais, e sim uma elevada capilaridade.

Esta característica dos materiais está intimamente relacionada com a umidade, pois a água poderá migrar por entre seus poros, ascendendo pelos canais capilares, impulsionada pela pressão hidrostática, atingindo uma altura que é maior quanto menor for o diâmetro dos poros dos materiais. A umidade atingirá uma altura até o ponto de equilíbrio em que a quantidade de água absorvida do solo seja igual à água evaporada. Se houver barreiras a essa evaporação, com algum tipo de impermeabilização, a umidade ascenderá a uma altura mais elevada, até atingir um novo ponto de equilíbrio.

Pela Análise Química e Reconstituição do Traço, verificou-se que o emboço, é uma argamassa de pouca resistência mecânica e muito porosa, mais suscetível à umidade do que o reboco.

A umidade atinge em primeiro lugar o emboço, e devido à sua fragilidade se ressente com maior intensidade, com tensões em sua estrutura, provocando fissuras, desprendimento da alvenaria. O reboco, mais resistente, poderá produzir também fissuras e abaulamentos, devido às alterações do emboço.

Este fato, pode justificar o descolamento da argamassa da alvenaria, em toda faixa próxima ao solo onde é atingida pela umidade ascendente.

Este estudo se baseou no conceito, de que para cada patologia, há diversas causas, que são interdependentes e concomitantes.

Assim, a deterioração ocorre em função da composição da argamassa e do emprego de tintas impermeáveis. A argamassa se caracteriza pela porosidade e baixa resistência mecânica, principalmente aquela que tem como aglutinante somente a cal, sem o cimento Portland.

O emprego da tinta impermeável, por longo tempo, impediu que não atendesse à necessidade da constante evaporação da umidade contida nas paredes. Esta umidade, quando dissolve e transporta substâncias, como sais solúveis e higroscópicos, e alguns poluentes, provoca a eflorescência dos sais e a proliferação de microrganismos. Acentuam as patologias, com os empolamentos e desagregação da argamassa dos ornamentos, em todas as fachadas do edifício, na faixa de parede atingida pela umidade ascendente, próxima ao solo. 


\section{BIBLIOGRAFIA}

\section{DICIONÁRIO E PUBLICAÇÕES DE REFERÊNCIA}

ÁVILA, Afonso (org.). Barroco: teoria e análise. São Paulo/Belo Horizonte: Perspectiva/Cia. Brasileira de Metalurgia e Mineração, 1997.

ÁVILA, Afonso; GONTIJO, João Marcos Machado; MACHADO, Reinaldo Guedes. Barroco mineiro: glossário de arquitetura e ornamentação. São Paulo: Cia. Melhoramentos de São Paulo, 1980.

BURDEN, Ernest. Illustrated dictionary of architectural preservation. New York:The McGraw-Hill Companies, 1976.

CHING, Francis. Dicionário visual de arquitetura. São Paulo: Martins Fontes, 2003.

CORONA \& LEMOS. Dicionário de arquitetura brasileira. São Paulo: EDART/São Paulo Livraria Editora Ltda, 1972.

COSTA, Lúcio. Arquitetura. Rio de Janeiro: Bloch/Fename, 1980.

DUCHER, Robert. Características dos estilos. São Paulo: Martins Fontes, 2001.

HOUAISS, Antônio; VILLAR, Mauro de Salles. Dicionário Houaiss de Língua Portuguesa. Rio de Janeiro:

Objetiva, 2001.

KOCH, Wilfried. Dicionário dos estilos arquitetônicos. São Paulo: Martins Fontes, 2004.

SILVA, Jorge Henrique Pais da; CALADO, Margarida. Dicionário de termos de arte e arquitetura. Lisboa: Editorial Presença, 2005.

TEIXEIRA, Luiz Manoel. Dicionário Ilustrado de Belas Artes. Lisboa: Editorial Presença.

\section{TRATADOS / MANUAIS}

ANDRADE, José Calheiros de Magalhães e. Regras das cinco ordens de architectura segundo os princípios de Vignhola. Lisboa: Em Casa da Viúva Bertrand \& C. ${ }^{-a}, 1872$.

BORGES, Alberto de Campos. Prática das pequenas construções. Cidade? Editora Edgard Blucher Ltda.

COUTINHO, Francisco de L.de F.P.(estampas). Regras das cinco ordens de architectura segundo princípios de Vinhola. Lisboa: Em Casa da Viúva Bertrand \& Cª 1872.

GUIMARÃES, José Epitácio Passos; GOMES, Rubens Donizeti; SEABRA, Mauro Adamo. Guia das Argamassas nas Construções. Associação Brasileira de Produtores de Cal, 3르 ed., 2004.

LÉVEIL, J.A. Tratado prático elementar de architectura ou estudo das cinco ordens de Jacques Barozzio de Vinhola . Paris/ Rio de Janeiro: Livraria Garnier.

MAZZOCCHI, Luigi. Calce e Cementi. Milano: Editore Libraio Della Real Casa, 1915. 
MILANI,G.B. L'Ossatura murale, Parte I: La Stabilita. Torino: C.Crudo \& C, 1920.

L'Ossatura murale, Parte II: L'Estetica .Torino: C.Crudo \& C, 1920.

.L'Ossatura murale, Partelll: La Costruzione.Torino:C.Crudo \&C, 1920.

PALLADIO, Andrea. The four books of architecture. New York: Dover Publications, 1965

(Vitrúvio) POLIÃO, Marco. Da Arquitetura. São Paulo: Hucitec/Annablume, 2002.

RONDELET, L'Art de Batir. Paris: Chez Firmin Didot Freres, Fils et C, 1867.

SEGURADO, João Emílio dos Santos. Biblioteca de Instrução Profissional: edificações. Lisboa: Livraria Bertrand, s/d.

,João Emílio dos Santos. Biblioteca de Instrução Profissional: encanamentos e salubridade das habitações. Lisboa: Typographia de A. Editora, s/d.

João Emílio dos Santos. Biblioteca de Instrução Profissional: terraplanagens e alicerces. Lisboa: Livraria Bertrand, s/d.

João Emílio dos Santos. Biblioteca de Instrução Profissional: acabamentos das construções. Lisboa: Diário de Notícias, s/d.

João Emílio dos Santos. Biblioteca de Instrução Profissional: materiais de construções. Lisboa: Livraria Bertrand, s/d.

Bertrand, s/d.

João Emílio dos Santos. Biblioteca de Instrução Profissional: alvenaria e cantaria Lisboa: Livraria

SEQUEIRA, José da Costa. Noções theoricas de architectura civil, seguidas de um breve tractado das cinco ordens de J. B. de Vinhola. Lisboa: Academia das Bellas Artes de Lisboa, 1858.

\section{HISTÓRIA / HISTÓRIA DA ARQUITETURA / HISTÓRIA DA CIDADE DE SÃO PAULO}

ANGOTTI SALGUEIRO, Heliana. La Casaque d'Arlequin: Belo horizonte, une capitale écletique au 19 siècle. Paris: Ed. de L'École dês Hautes Études en Sciences Sociales, 1997.

ARGAN, Giulio Carlo. História da arte como história da cidade. São Paulo: Martins Fontes, 1995.

BREFE, Ana Claudia Fonseca. O Museu Paulista - Affonso de Taunay e a memória nacional, 1917-1945. São Paulo: Editora UNESP/Museu Paulista, 2005.

BRUNO, Ernani Silva (dir.). História e tradições da cidade de São Paulo: arraial de sertanistas (1554-1828), Rio de Janeiro: José Olympio, 1953, v.1.

de Janeiro: José Olympio, 1953, v.2. História e tradições da cidade de São Paulo: burgo de estudantes (1828-1872), Rio Janeiro: José Olympio, 1954, v.3. História e tradições da cidade de São Paulo: metrópole do café (1872-1918), Rio de História e tradições da cidade de São Paulo: São Paulo de agora (1918-1954), Rio de Janeiro: José Olympio, 1954, v.4. 
CAMPOS JUNIOR, Eudes de Mello. A arquitetura paulistana sob o império: aspectos da formação da cultura burguesa em São Paulo. Tese de doutorado apresentado à Faculdade de Arquitetura e Urbanismo da USP, 1997.

CAMPOS JÚNIOR, Eudes de Mello. A cidade de São Paulo e a era dos 'melhoramentos materiaes': obras públicas e arquitetura vistas por meio de fotografias de autoria de Militão Augusto de Azevedo, datadas do período 1862-1863. In: Anais do Museu Paulista, v.15, n.1, jan/jun 2007.

CAMPOS JUNIOR, Eudes de Mello. São Paulo: desenvolvimento urbano e arquitetura sob o Império. In: PORTA, Paula (org). História da cidade de São Paulo: A Cidade no Império 1823-1889. São Paulo: Paz e Terra, 2004, v.2.

CATÀLOGO Às margens do Ipiranga 1890-1990. Catálogo da Exposição do Centenário do Edifício do Museu Paulista da USP. Patrocínio Cultural Bradesco S/A. Museu Paulista - USP, 1990.

D' ALAMBERT, Clara Correia. O tijolo nas construções paulistanas do século XIX. Dissertação de Mestrado apresentada à Faculdade de Arquitetura e Urbanismo da USP, 1993.

ELIAS, Maria José. Museu Paulista: memória e história. Tese de Doutorado apresentada ao Departamento de Historia da Faculdade de Filosofia, Letras e Ciências Humanas da USP, 1996.

ELIAS, Maria José. O Museu Paulista. In: O Museu Paulista da Universidade de São Paulo. São Paulo: Banco Safra, 1984.

ELIAS, Maria José. Revendo o nascimento dos museus no Brasil. Revista do Museu de Arqueologia e Etnologia. São Paulo (2): 139-145, 1992.

FABRIS, Annateresa (org.). Ecletismo na arquitetura brasileira. São Paulo: Nobel/EDUSP, 1987.

FLYNN, Maria Helena de Moraes Barros. Concursos públicos para o monumento do Ipiranga. In: margens do Ipiranga 1890-1990. Catálogo da Exposição do Centenário do Edifício do Museu Paulista da USP. Patrocínio Cultural Bradesco S/A. Museu Paulista - USP, 1990.

Policromia Arquitetônica. São Paulo: FAU, 1980.

IHERING, Rodolpho von. Guia das exposições do Museu Paulista. São Paulo: Imprensa Oficial do Estado, 1900.

KÜHL, Beatriz Mugayar. A preservação da arquitetura de ferro em São Paulo. Tese de doutorado apresentada à Faculdade de Arquitetura e Urbanismo da USP, 1996.

LEMOS, Carlos Alberto Cerqueira. Alvenaria burguesa: breve história da arquitetura residencial de tijolos em São Paulo a partir do ciclo econômico liderado pelo café. São Paulo: Nobel, 1985.

LEMOS, Carlos Alberto Cerqueira. Ecletismo em São Paulo. In: FABRIS, Annateresa (org.). Ecletismo na arquitetura brasileira. São Paulo: Nobel/ EDUSP, 1987.

LEMOS, Carlos. O Projeto de Bezzi e a Arquitetura do séc. XIX em São Paulo. In: Às Margens do Ipiranga 1890-1990. Catalogo da Exposição do Centenário do Edifício do Museu Paulista da USP. Patrocínio Cultural Bradesco S/A. Museu Paulista - USP, 1990

LOUREIRO, Maria Amélia Salgado. Evolução da casa paulistana. São Paulo: Secretaria de Estado da Cultura, 1981.

MACAMBIRA, Yvoty de Macedo Pereira. Os mestres da fachada. São Paulo: C.C.S.P. - Divisão de Pesquisas, 1985. 
MACHADO, Lourival Gomes. Barroco mineiro. São Paulo: Perspectiva, 2003.

MATOS, Odilon Nogueira de. Afonso de Taunay, historiador de São Paulo e do Brasil: perfil biográfico e ensaio bibliográfico. São Paulo: Coleção Museu Paulista, Série Ensaios, v.11, 1977.

v.10, jan./jun. 1955, pp. 89-125.

A cidade de São Paulo no século XIX. Revista de História, ano VII, nํos 21 e 22,

MENESES, Ulpiano T. Bezerra de. Do Teatro da Memória ao Laboratório da História: a Exposição Museológica e o Conhecimento Histórico. Anais do Museu Paulista, v.2, jan./dez. 1994, pp. 9-42.

MORSE, Richard. Formação Histórica de São Paulo. São Paulo: Difel, 1970.

OLIVEIRA, Cecília Helena de Salles. Museu Paulista: espaço celebrativo e memória da Independência. In:

BRESCIANI, Stella; NAXARA, Márcia (org.). Memória e (res)sentimentos. Campinas: UNICAMP, 2001, pp. 197222.

OLIVEIRA, Cecília Helena de Salles. O Espetáculo do Ipiranga: mediações entre historia e memória. Tese de livre-docência, Museu Paulista, USP, São Paulo, 2000.

OLIVEIRA, Cecília Helena de Salles. O Espetáculo do Ipiranga: reflexões preliminares sobre o imaginário da independência. Anais do Museu Paulista. Revista de Historia e Cultura Material, Nova Série, São Paulo, n.3, 1995.

OLIVEIRA, Cecília Helena de Salles. O Museu Paulista e o imaginário da Independência. In OLIVEIRA, Cecília Helena de Salles (org.). Museu Paulista: novas leituras. São Paulo: Museu Paulista, 1995, pp. 1-4.

OLIVEIRA, Cecília Helena de Salles (org.). Museu Paulista: novas leituras. São Paulo: Museu Paulista da USP, 1995.

PATETTA, Luciano. Considerações sobre o Ecletismo na Europa. In: FABRIS, Annateresa, (org.). Ecletismo na Arquitetura Brasileira. São Paulo: Nobel/ EDUSP, 1987.

PAULA, Eurípedes Simões de. A segunda Formação de São Paulo. Revista de História, ano V, n. 17, jan./mar. 1954, pp. 167-179.

PINHEIRO, Maria Lúcia Bressan. A história da arquitetura brasileira e a preservação do patrimônio cultural. Revista CPC, São Paulo, v.1, no1, nov. 2005/abr. 2006, pp.41-74.

PORTA, Paula (org.). História da cidade de São Paulo: a cidade no Império 1823-1889, v.2, São Paulo: Paz e Terra, 2004.

RAMALHO, Maria Lúcia Pinheiro. Da beux-arts ao bangalow. Dissertação de mestrado apresentada à Faculdade de Arquitetura e Urbanismo da USP, 1989.

REIS FILHO, Nestor Goulart. Quadro da arquitetura no Brasil. São Paulo: Editora Perspectiva,1970.

REIS FILHO, Nestor Goulart. Arquitetura residencial brasileira no Século XIX. Anais do Museu Paulista, tomo XIX, 1965.

REVISTA RAíZES. Fundação Pró-memória de São Caetano do Sul, dezembro de 2001, ano XII, n. 24.

SAIA, Luis. Morada paulista. São Paulo: Pespectiva, 1995. 
SCHMIDT, Carlos Borges. Construções de taipa: alguns aspectos do seu emprego e de sua técnica. Boletim da Agricultura São Paulo, 1949.

SILVA, Raul de Andrade e. São Paulo nos tempos coloniais. Revista de História, ano VII, №s. 21 e 22, v. 10, jan./jun. 1955. pp. 55-87.

SUMMERSON, John. A linguagem clássica da arquitetura. São Paulo: Martins Fontes, 1999.

TAUNAY, Afonso de. Comemoração do cincoentenário da solene instituição do Museu Paulista no Palácio do Ipiranga. São Paulo: Imprensa Oficial do Estado, 1937.

1937. Guia da Secção Histórica do Museu Paulista. São Paulo: Imprensa Oficial do Estado,

TELLES, Carlos Queiroz. A indústria de tintas no Brasil: cem anos de cor e história. São Paulo: CL-A Comunicações S/C Ltda/ABRAFATI - Associação brasileira dos fabricantes de tintas, 1989.

TOLEDO, Benedito Lima de. São Paulo: três cidades em um século. São Paulo: Cosacnaify Livraria Duas Cidades, 1934.

VAUTHIER, L. L. Casas de residência no Brasil. Introdução de Gilberto Freyre. São Paulo: IPHAN/FAU, 1975.

\section{TEORIAS DE CONSERVAÇÃO E RESTAURAÇÃO}

ANDRADE, Antônio Luiz Dias de. Um estado completo que pode jamais ter existido. Tese de doutorado apresentada à Faculdade de Arquitetura e Urbanismo da Universidade de São Paulo, 1993.

BOITO, Camillo. Os Restauradores. Tradução de Beatriz Mugayar Kühl. São Paulo: Artes \& Ofícios, 2003.

Restaurar ou conservar?. In: Questioni pratiche di belle arti. Milão: Ulrico Moepli, 1893.

BRANDI, Cesari. Teoria da Restauração. Madrid: Alianza Editorial, 1995.

BRANDI, Cesari. Teoria da Restauração. Cotia, SP: Ateliê Editorial, 2004.

CARBONARA, Giovanni. Restauro dei monumenti: guida agli elaborati grafici. Napoli: Liguori, 1990.

CHOAY, Françoise. A alegoria do patrimônio. Tradução de Luciano Vieira Machado. São Paulo: Ed. UNESP, 2001.

CHOAY, Françoise. Sete proposições sobre o conceito de autenticidade e uso nas práticas do patrimônio histórico in Conference de Nara sur l'Authenticité. Paris, Unesco, 1955, pp.101-120 Tradução Beatriz Mugayar Kuhl.

FIELDEN, Bernard M. Conservation of historic buildings. Butterworths: Grã-Bretanha, 1982.

KÜHL, Beatriz Mugayar. História e ética na conservação e na restauração de monumentos históricos. Revista CPC, São Paulo, v.1, no 1, nov. 2005/abr. 2006, pp. 16-40.

Questões teóricas relativas à preservação da arquitetura industrial. Revista Desígnio, 1, mar. 2004, pp.101-128.

Beatriz Mugayar. O tratamento das superfícies arquitetônicas como problema teórico da restauração. $\overline{\text { Anais }}$ do Museu Paulista, v.12, jan./dez., 2004, pp. 309-330. 
Beatriz Mugayar. Quatremère de Quincy e os verbetes Restauração, Restaurar, Restituição e Ruína in sua Encyclopédie méthodique, Architecture.

LEMAIRE, Raymond. Autenticidade e Patrimônio Monumental. Restauro, №129, Napoli: 1994. Tradução de Beatriz Mugayar Kuhl, pp. 7-24.

PINHEIRO, Maria Lúcia Bressan. A história da arquitetura brasileira e a preservação do patrimônio cultural. São Paulo: CPC, v.1, no 1, nov. 2005/ abr. 2006, pp .41-74.

PINHEIRO, Maria Lúcia Bressan. William Morris e a SPAB.

RIEGL, Aloïs. Monumentos: valores atribuídos e sua evolução histórica. IN: Revista de Museologia, v. 1, ㄲo1, ㄴo semestre de 1989, pp.17-23.

RUSKIN, John. Siete lamparas de la arquitectura. Buenos Aires: Ateneo, 1956.

VIOLLET-LE-DUC, Eugène Emmanuel. Restauração. Tradução de Beatriz Mugayar Kühl. São Paulo: Artes \& Ofícios, 2000.

\section{ESTUDOS TÉCNICO-CIENTÍFICOS / ESTUDOS TÉCNICOS DE CONSERVAÇÃO E RESTAURAÇÃO}

ANAIS do V Simpósio brasileiro de tecnologia das argamassas. SP: EPUSP-Pcc/Antac, 2003.

CADERNO EDIFÍCIOS: revestimentos de paredes em edifícios antigos, n.2, out. 2002.

CADERNOS TÉCNICOS DO INSTITUTO PORTUGUÊS DE CONSERVAÇÃO E RESTAURO, ano 1, no. 1 e 2, 2002.

CATARINO, Joana; ESTEVES, Ana Maria. Caracterização de sais solúveis em monumentos antigos.

CAVANI, Gilberto de Renieri; QUARCIONI, Valdecir Ângelo; NASCIMENTO, Cláudia Bastos do. Formulação e avaliação de argamassa de revestimento para restauração de fachada: estudo de caso. In: III Simpósio brasileiro de tecnologia das argamassas, Vitória, Espírito Santo, 22 e 23 de Abril de 1999.

CINCOTTO, Maria Alba. Definições, terminologia, normalização. Manuscrito.

Patologia das argamassas. Revista da Associaçãao Brasileira dos Produtores de Cal. SP, 1985.

Patologia das argamassas de revestimento: análise e recomendações. $2^{\underline{a}}$ ed., São Paulo: Instituto de Pesquisas Tecnológicas, 1989.

CINCOTTO, M. A.; UEMOTO, K. L. Patologia das argamassas de revestimento: aspectos químicos. In: Anais do III Simpósio Nacional de Tecnologia de Tecnologia da Construção: Patologia das Edificações, São Paulo: EPUSP, 1988, pp. 77-85.

CINCOTTO, Maria Alba; SHIRAKAWA, Márcia Aiko. Restauro das fachadas: relatório técnico de vistoria. Museu Paulista da USP, 2003.

DAVIES, Gareth. Tintas permeáveis ao vapor de água. The building conservation directory.

D’ÁVILA, Ana paula R.T.; D’ÁVILA, Carlos A. C.; FABREGA, Pere Roca y. Consideraciones sobre las patologías de la Iglesia de San Francisco de Assis, proyecto de Niemeyer, em Belo Horizonte, MG, Brasil. In: $V$ Congresso iberoamericano de patología de las construcciones. Montevideo, Uruguai, 18 a 21 de outubro de 1999. 


\section{DIAGNÓSTICO DE CONSERVAÇÃO: MODELO PROPOSTO PARA AVALIAR AS NECESSIDADES DE}

GERENCIAMENTO AMBIENTAL EM MUSEUS

DINIZ, Silvana Sousa Nilo Bahia. Taipa de pilão: uma aproximação tecnológica através de exemplos em S. Paulo. Dissertação de mestrado apresentada à Faculdade de Arquitetura e Urbanismo da USP, 2000.

EASTON, David. Como construir paredes de taipa: folheto desenvolvido a partir do workshop sobre paredes de taipa ministrado pelo arquiteto D. Easton e equipe para protótipo habitacional em Pindamonhangaba, SP, 1994.

FUSCO, Péricles Brasiliense. A estrutura do edifício. In: WITTER, Jose Sebastião; BARBUY, Heloisa (org.). Um monumento no Ipiranga: história de um edifício centenário e sua recuperação. São Paulo:FIESP,1 997.p.54101.

GONÇALVES, Teresa. Pesquisa de mercado sobre revestimentos para paredes sujeitas à acção de sais solúveis. Cadernos edifícios: revestimentos de paredes em edifícios antigos. Lisboa: Laboratório Nacional de Engenharia Civil, no 2, out. 2002, pp.175-189.

GRIMMER, Anne E. Perigos da limpeza abrasiva aos edifícios históricos. Tradução de António de Borja Araújo. The building conservation directory, 1996.

Preservação e reparação de 'stucco' histórico. Preservation Briefs, technical preservation Services, National Park Service,1990.

GUIMARÃES, José Epitácio Passos. A cal: fundamentos e aplicações na engenharia civil. São Paulo: Pini, 1997.

HENRIQUES, Fernando A. M. Conservação de revestimentos exteriores do Palácio Nacional de Sintra. In: Cadernos edifícios: revestimentos de paredes em edifícios antigos. Lisboa: Laboratório Nacional de Engenharia Civil, ํㅡㄹ 2, out. 2002.

Humidade em paredes. Lisboa: Laboratório Nacional de Engenharia Civil, 2001

KANAN, Maria Isabel. Manual de argamassas, rebocos e tintas para uso em conservação. Mimeografado.

. Materiais à base de cal: argamassas e rebocos. In: An analytical study of earth and lime based building materials in the Blumenau regions, southern Brazil. Tese de PhD, 1995.

. Materiais à base de cal: caiação. In: An analytical study of earth and lime based building materials in the Blumenau regions, southern Brazil. Tese de PhD, 1995.

1996.

Notas da oficina de arquitetura: argamassas, rebocos e tintas à base de cal, 7 a 9 de Outubro de

Restoration and conservation of architectural surfaces: experiences of the Terracal Project.

LABORATÓRIO DE ENSAIO DE MATERIAES DA ESCOLA POLYTECHNICA DE SÃO PAULO. Estudo sobre os tijolos communs. Boletim n. 7, 1932.

LABORATÓRIO DE ENTRANAMIENTO MULTIDISCIPLINÁRIO PARA LA INVESTIGACIÓN TECNOLÓGICA (LEMIT). Colonização biológica em construcciones de valor histórico. In: $V$ Congresso iberoamericano de patología de las construcciones. Montevideo, Uruguai, 18 a 21 de outubro de 1999.

LOPES, Claudemira V. G.; CARVALHO, Francisco J. P. de Campos; KRIEGER, Nadia. Biodeterioração: ataque de microrganismos a monumentos históricos. In: Ciência hoje, v. 34, № 200, dezembro de 2003, pp.35-39. 
MacDONALD, Mary Lee. Reparação do estuque liso histórico: paredes e tectos. Tradução de António da Borja Araújo. Preservation Briefs, technical preservation Services, National Park Service, 1989.

MAEKAWA, Shin. Controlled ventilation and heating to preserve collections in historic buildings in hot and humid regions.

MAEKAWA, Shin; TOLEDO, Franciza. Sustainable climate control for historic buildings in hot and humid regions. In: The 18' conference on passive and low energy architecture, Florianópolis, Brasil, 7 a 9 de novembro de 2001.

MAGALHÃES, Ana Cristian. Patologia de rebocos antigos. Cadernos edifícios: revestimentos de paredes em edifícios antigos. Lisboa: Laboratório Nacional de Engenharia Civil, n.2, out. 2002, pp.69-85.

MAIER, Luigia Binda; ANTI, Laura; BARONIO, Giulia. Durabilità delle murature in ambiente agressivo e delle tecniche di conservazione e protecione. In: Atti del Corso di Aggiornamento in Ingegneria Sísmica, Augusta, março a maio, 1991, pp. 799-869.

MALDONADO, Noemí Graciela; MICHELINI, Rufino Júlio. Técnicas aplicadas para la restauración de construcciones antigüas de Mamposteriã em zona de elevado riesgo sísmico. In: $V$ Congresso iberoamericano de patología de las construcciones. Montevideo, Uruguai, 18 a 21 de outubro de 1999.

MATEUS, João Mascarenhas. Técnicas tradicionais de construção de alvenarias: a literatura técnica de 1750 a 1900 e o seu contributo para a conservação de edifícios históricos. Lisboa: Livros Horizonte, 2002.

NAPPI, Sérgio. Salinidade em Edifícios Históricos.

Umidade em Paredes.

NAPPI, Sérgio; MATOS, Karine. A ação dos sais em argamassas.

NAPPI, Sérgio, PELUSO, Simone, TONERA, Roberto. Tintas para edifícios históricos Universidade Federal de Santa Catarina.

Estudo comparativo da resistência de rebocos à salinidade.

NAPPI, Sérgio, TONERA, Roberto. Rebocos de recuperação. Universidade Federal de Santa Catarina.

. Rebocos de recuperação e processo de dessalinização por eletrólise.

NAPPI, Sergio, TONERA, Roberto Recuperação de danos em edifícios históricos. Universidade Federal de Santa Catarina.

NAPPI, Sergio; MEYER, Tatiana. Influência da granulometria do pó de tijolo nas características de uma argamassa à base de cal para utilização em obras de restauro.

NASCIMENTO, Cláudia B. Deterioração de forro em estuque reforçado com ripas vegetais: o caso "Vila Penteado" - FAUUSP. Dissertação de mestrado apresentada à Escola Politécnica da USP, 2002.

NASCIMENTO, Claudia B. et alii. Caracterização da Argamassa do forro visando restauro da edificação histórica Vila Penteado. In: V Congresso iberoamericano de patología de las construcciones. Montevideo, Uruguai, 18 a 21 de outubro de 1999.

OLIVEIRA, Mario Mendonça Tecnologia da conservação e restauração: materiais, estrutura, roteiro. Dissertação de mestrado em Arquitetura e Urbanismo apresentada à UFBA / PNUD / UNESCO, 1995. 
OLIVEIRA, M. C. B. de; NASIMENTO, C. B. do; CINCOTTO, M. A. Microestrutura de argamassas endurecidas: uma contribuição da petrografia. In: $V$ Congresso iberoamericano de patología de las construcciones. Montevideo, Uruguai, 18 a 21 de outubro de 1999.

PETRELLA, Yara Lígia M.M. Conservação e Restauração das Pnturas da Sanca. In: WITTER, Jose Sebastião; BARBUY, Heloisa (org.). Um monumento no Ipiranga: história de um edifício centenário e sua recuperação. São Paulo: FIESP, 1997.p.106-165.

QUARCIONI, Valdecir A; CHOTOLI, Fabiano; ALEIXO, Daniel M. Proposta de método para determinação de sais solúveis em argamassas endurecidas. In: Simpósio Brasileiro de Tecnologia de Argamassas, São Paulo, 11 a 13 de junho de 2003.

Ensaio acelerado para simular a formação de eflorescência em argamassas endurecidas. Simpósio Brasileiro de Tecnologia de Argamassas, São Paulo, 11 a 13 de junho de 2003.

QUARCIONI, Valdecir Ângelo; CINCOTTO, Maria Alba; CHOTOLI, Fabiano Ferreira. Caracterização da composição de argamassas de assentamento e de revestimento: diretrizes para normalização.

QUARCIONI, Valdecir Ângelo. Reconstituição de Argamassas: atualização do Método IPT. Dissertação de Mestrado, POLI, 1998, 188p.

RATCLIFFE, Tim. O emprego de estuques de gesso. Tradução de António da Borja Araújo. The building conservation directory, 2003.

REBELLO, Yaponan C.P. A Concepção Estrutural e a arquitetura. São Paulo: Zigurate Editora, 2006.

RIBEIRO, Alejandro França Gomes. Tintas inorgânicas: tintas de cal e de silicatos in Cadernos edifícios: revestimentos de paredes em edifícios antigos. Lisboa: Laboratório Nacional de Engenharia Civil, ํo 2, out. 2002, pp.117-137.

SANTIAGO, Manuel Olivares; OSTERET, José Laffarga. Introducción al control de calidad en restauración: limpieza y restauración de fachadas. Instituto Universitário de Ciências de la Conservacción, Escuela Técnica Superior de Arquitetura Universidad de Sevilla, 1998.

SHIRAKAWA, Márcia Aiko. Biodeterioração de argamassas por fungos - desenvolvimento de teste acelerado para avaliação da bio-receptividade. Tese apresentada ao Instituto de Ciências Biomédicas da USP, São Paulo, 1999.

SILVA, Antonio Santos. Caracterização de argamassas antigas: casos paradigmáticos. In: Cadernos edifícios: revestimentos de paredes em edifícios antigos. Lisboa: Laboratório Nacional de Engenharia Civil, ํㅡㄴ 2, out. 2002, pp. 87-101.

SILVEIRA, Paulo Malta da; VEIGA, Rosário; BRITO, Jorge de. Eflorescências em estuques antigos.

SOUSA, Vitor; PEREIRA, Fernando Dias; BRITO, Jorge de. Rebocos tradicionais: principais causas de degradação. Engenhara civil, Portugal, no 23, 2005, pp. 5-18.

TAVARES, Martha Lins. Revestimentos por pintura para edifícios antigos: um estudo experimental sobre caiações e as tintas de silicatos. Cadernos edifícios: revestimentos de paredes em edifícios antigos. Lisboa: Laboratório Nacional de Engenharia Civil, no 2, out. 2002, pp. 139-151.

TAYLOR, Jonathan. Lime: the basics. The building conservation directory. What is lime?. The building conservation directory, 1999.

VADSTRUP. Soren. Caiação sobre alvenaria. Tradução de António de Borja Araújo. 
Reparações em alvenaria e rebocos. Tradução de António da Borja Araújo.

VEIGA, Maria do Rosário. Intervenções em revestimentos antigos: conservar, substituir ou... destruir.

Argamassas compatíveis para intervenção em edifícios antigos. In: Oficina: técnicas tradicionais de revestimento, CENFIC, 2007.

VEIGA, M. Rosário, CARVALHO, Fernanda. Argamassas de reboco para paredes de edifícios antigos: requisitos e características a respeitar. Cadernos edifícios: revestimentos de paredes em edifícios antigos. Lisboa: Laboratório Nacional de Engenharia Civil, no 2, out. 2002, pp.39-55.

VELOSA, Ana Luísa Influência das adições pozolânicas em argamassas de cal para conservação de edifícios antigos. Cadernos edifícios: revestimentos de paredes em edifícios antigos. Lisboa: Laboratório Nacional de Engenharia Civil, № 2, out. 2002, pp. 103-115.

WEAVER, Mantin: MATERO, F.G. E. Conserving buildings: a manual of techniques and materials. New York: John Wiley \& Sons INC,1997.

\section{CARTAS PATRIMONIAIS}

LE CORBUSIER. A carta de Atenas. São Paulo: Hucitec/Edusp, 1993.

CURY, Isabelle (org.). Cartas Patrimoniais. Rio de Janeiro: IPHAM, 2000.

DECLARAÇÃO de São Paulo (1989)

DECLARAÇÃO de São Paulo II (1996)

BENS imóveis tombados ou em processo de tombamento da USP. São Paulo: EDUSP/Imprensa Oficial do Estado, 2002.

INTERVENÇÕES no patrimônio, 1995-2000: nova política. Instituto Português do Patrimônio Arquitetônico.

\section{DOCUMENTOS IMPRESSOS E ARQUIVÍSTICOS}

ARQUIVO Intermediário do Fundo Museu Paulista, 1963-2007.

BEZZI, Tommaso Gaudenzio. Especificações, preços e condições para a construção das obras do Monumento do Ypiranga, São Paulo, 2 de fevereiro de 1885.

CÓDIGO de posturas dp Município de São Paulo: 6 de outubro de 1886. São Paulo: Departamento de Cultura, 1940; (arq mun - DPH)

COLECÇÃO de leis e posturas municipaes promulgadas pela Assembléia Legislativa Provincial de S. Paulo no anno de 1875. São Paulo: Typographia do Diário, 1875.

COLEÇÃO CPOS, 1931 a 1972, Museu Paulista.

EGAS, Eugenio. Galeria dos presidentes de São Paulo: periodo monarchico, 1822-1889; Publicação official do Estado de São Paulo commemorativa do $1^{\circ}$ centenario da Independencia do Brazil, v.1. São Paulo: Secção de Obras d' Estado de São Paulo; 1926, p. 913.

Galeria dos presidentes de São Paulo: periodo republicano, 1889-1920; publicação official do Estado de São Paulo commemorativa do $1^{\circ}$ centenario da Independencia do Brazil, v.2. São Paulo: Secção de Obras d' Estado de São Paulo; 1927.p. 71, 152. 
Galeria dos presidentes de São Paulo: periodo republicano 1920-1924; publicação official do Estado de São Paulo commemorativa do $1^{\circ}$ centenario da Independencia do Brazil, v.3. São Paulo: Secção de Obras d' Estado de São Paulo; 1927. pp.138-139; 152; 218-220; 248.

EXPOSIÇÃO com que o Exmo. Sr. Dr. Pedro Vicente de Azevedo passou a administração da provincia de São Paulo ao Exmo. Sr. Dr. Barão de Jaragua no dia 11 de abril de 1889. São Paulo: Typografia a vapor de Jorge Seckler \& comp. Anexos-Leis não sancionadas, 1889. p.33.

FUNDO Tommaso Gaudenzio Bezzi, Museu Paulista.

MEMORANDUM explicativo dos direitos do engenheiro Thomaz G. Bezzi oriundos da rescisão dos contratos do Monumento do Ypiranga. Rio de janeiro: Typographia Leuzinger, 1905.

RELATÓRIO em que o Exmo. Sr. Dr. Francisco Antonio de Souza Queiroz Filho, vice- presidente da provincia de São Paulo, passou a administração ao vice-presidente, Exmo. Sr. Dr. Elias Antonio Pacheco e Chaves. São Paulo: Typographia do Correio Paulistano, 1885. p.32.

RELATÓRIO com que o Exmo. Sr. Dr. Jose Luiz de Almeida Couto, presidente da provincia de São Paulo, passou a administração ao $1^{\circ}$ Vice- Presidente, Exmo. Sr. Dr.Francisco Antônio de Souza Queiroz Filho. São Paulo: Typographia do Correio Paulistano, 1886. p.36.

RELATÓRIO com que o Exmo. Sr. Dr. Francisco de Paula Rodriguez Alves passou a administração da província de São Paulo ao Exmo. Sr. Francisco Antonio Dutra Rodrigues $1^{\circ}$ Vice-Presidente no dia 27 de Abril de 1888. São Paulo: Typographia a vapor de Jorge Seckler \& com., 1888. p. 48.

IHERING, Hermann von. História do monumento do Ypiranga e do Museu Paulista. Revista do Museu Paulista, v.1. São Paulo: Typ. A vapor de Hennies Irmãos, 1895.

O Museu Paulista em 1901 e 1902. Revista do Museu Paulista, v. 6. São Paulo: 1904, pp. 1-22. O Museu Paulista nos anos de 1903 a 1905. Revista do Museu Paulista, v. 7. São Paulo, 1907. Reclamações do ex-diretor Dr. Ihering. Revista do Museu Paulista, v. 11. São Paulo, pp. 921-927. $\overline{1895, p 10 .}$ (publicação). Revista do Museu Paulista, v.1. São Paulo: typographia a vapor de Hennies Irmãos, (publicação). Revista do Museu Paulista, v.5. São Paulo: Typographia do Diario Official; 1902., p.11. (publicação). Revista do Museu Paulista, v.6. São Paulo: Typographia do Diario Official; 1904, p.3.

IHERINHG, Rodolpho von (publicação). Revista do Museu Paulista, v.7, publicada por Rodolpho von Ihering, Director Interino do Museu Paulista, São Paulo: Typografia Cardoso, Filho \& Cia.; 1907, p.10. (publicação). Revista do Museu Paulista, v.8. São Paulo: Typographia do Diario Official; 1911, p.4. p.14. (publicação). Revista do Museu Paulista, v.9. São Paulo: Typographia do Diario Official; 1914,

Revista do Museu Paulista , v.10 publicada por H. von Ihering, dir. Med. et Phil., São Paulo: Typographia do Diario Official; 1918, p.25 